\title{
CONTEMPORARY
}

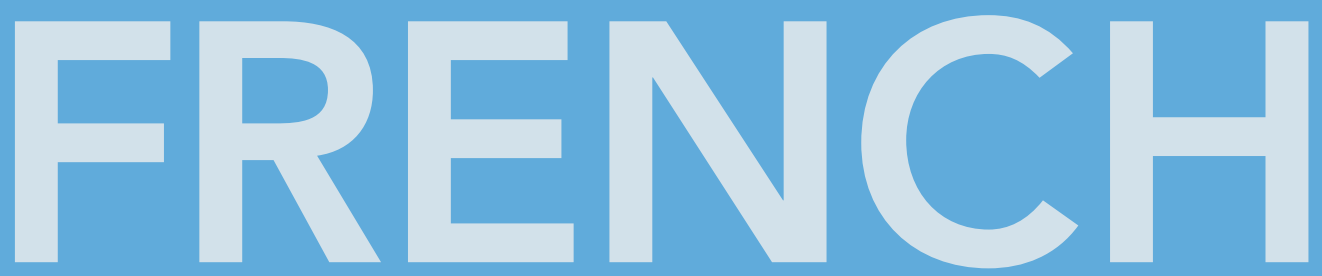

\section{ADMINISTRATIVE LAW}

\section{John Bell and François Lichère}

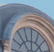

(1)

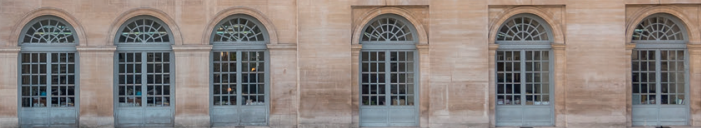




\section{CONTEMPORARY FRENCH ADMINISTRATIVE LAW}

Despite the growing scholarly interest in comparative public law, there remain relatively few works on the subject. Contemporary French Administrative Law aims to redress that imbalance, offering English-language readers an authoritative introduction to the key features of French administrative law and its institutions. The French legal system is among the most well-developed and influential in the world, and, as procedures continually adapt to European and international influences, it has never been more worthy of research, study and interrogation. This book employs a wide range of recent, illustrative cases to demonstrate how French administrative law works both in theory and in practice. Using a systematic approach and covering everything from judicial review to public contracts, this is a highly valuable text for any student or researcher with an interest in French law. The book is also available as Open Access.

John Bell QC (hon.), FBA is a retired professor of law at the University of Cambridge. Previously, he worked at the Universities of Oxford and Leeds. He has been Visiting Professor at the Universities of Paris 1 and Paris 2, Aix-Marseille 3, and the Université du Maine.

François Lichère is Professor of public law at the University of Jean Moulin Lyon 3. He has taught administrative law since 1995. He has published numerous books and articles, mainly in the field of administrative law and public contracts law in French and English. He is also a consultant to law firms and the founder and head of the Chaire de droit des contrats publics. 


\title{
Contemporary French Administrative Law
}

\author{
JOHN BELL \\ University of Cambridge \\ FRANÇOIS LICHÈRE \\ Université Jean Moulin Lyon 3
}

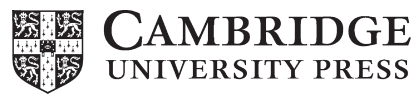




\section{CAMBRIDGE UNIVERSITY PRESS}

University Printing House, Cambridge св2 8вs, United Kingdom

One Liberty Plaza, 2oth Floor, New York, NY 10006, USA

477 Williamstown Road, Port Melbourne, vIC 3207, Australia

314-321, 3rd Floor, Plot 3, Splendor Forum, Jasola District Centre, New Delhi - 110025, India

103 Penang Road, \#05-06/07, Visioncrest Commercial, Singapore 238467

Cambridge University Press is part of the University of Cambridge.

It furthers the University's mission by disseminating knowledge in the pursuit of education, learning, and research at the highest international levels of excellence.

www.cambridge.org

Information on this title: www.cambridge.org/9781316511169

DOI: $10.1017 / 9781009057127$

(C) John Bell and François Lichère 2022

This work is in copyright. It is subject to statutory exceptions and to the provisions of relevant licensing agreements; with the exception of the Creative Commons version the link for which is provided below, no reproduction of any part of this work may take place without the written permission of Cambridge University Press.

An online version of this work is published at doi.org/10.1017/9781009057127 under a Creative Commons Open Access license CC-BY-NC 4.0 which permits re-use, distribution and reproduction in any medium for non-commercial purposes providing appropriate credit to the original work is given and any changes made are indicated. To view a copy of this license visit https://creativecommons.org/licenses/by-nc/4.०

All versions of this work may contain content reproduced under license from third parties.

Permission to reproduce this third-party content must be obtained from these thirdparties directly.

When citing this work, please include a reference to the DOI 10.1017/9781009057127

First published 2022

A catalogue record for this publication is available from the British Library.

ISBN 978-1-316-51116-9 Hardback

ISBN 978-1-009-05666-3 Paperback

Cambridge University Press has no responsibility for the persistence or accuracy of URLs for external or third-party internet websites referred to in this publication and does not guarantee that any content on such websites is, or will remain, accurate or appropriate. 


\section{Contents}

Preface

page xiii

List of Abbreviations

XV

Table of Cases by Date

xvii

Table of Cases by Name

1 Introduction

1.1 French Administrative Law in British Scholarship

1.2 What Is 'Droit administratif?

1.3 The Shaping of Droit administratif

1.4 The Influence of French Constitutional Law

1.5 The Influence of EU Law: French Administrative Law and the Supremacy of EU Law

1.6 The Influence of the European Convention on Human Rights

1.7 Reform of the Administration

1.8 A Note about Case Citation

2 The Institutional and Legal Context of Administrative Law 26

2.1 The Central Organs of the State 26

2.1.1 The Executive 27

2.1.2 The Legislature 28

2.2 The Local Organs of the State 30

2.2.1 Regional Administration $\quad 30$

2.2.2 Département 32

2.2.3 The Commune 32

2.2.4 The Big Cities: Paris, Lyon, Marseille (PLM) 33 
2.2.5 The Prefect

2.3 Elected Local Authorities 34

2.3.1 Region $\quad 35$

2.3.2 Département 36

2.3.3 The Commune $\quad 36$

2.3.4 The Big Cities: Paris, Lyon, Marseille 37

2.4 Independent Administrative Authorities (AAIs) 38

2.4.1 Regulation 39

2.4.2 Decision 40

2.4 .3 Independence 40

2.5 Défenseur(e) des droits 41

2.6 Sources of Administrative Law 43

2.6.1 The Constitution 44

2.6.2 Codes and Legislation $\quad 46$

2.6.3 EU Law 47

2.6.4 European Convention on Human Rights 51

2.6.5 General Principles of Law 53

2.6.6 Case Law (La jurisprudence) 55

2.6.7 Legal Scholarship (La doctrine) 57

2.7 Conclusion 59

3 Courts and Judges 61

3.1 Historical Context 61

3.2 Administrative Courts 65

3.3 General Courts 65

3.3.1 Tribunaux administratifs 66

3.3.2 Cours administratives d'appel 68

3.3.3 Conseil d'Etat 69

3.3.3.1 The Judicial Role $\quad 70$

3.3.3.2 The Consultative Role 72

3.3.3.3 Section du rapport et des études $\quad 76$

3.3.4 Cour nationale du droit d'asile 78

3.3.5 Cour des comptes and Other Financial Courts 80

3.3.6 Other Administrative Courts 82

3.4 Administrative Judges 83

3.4.1 Corps of Judges of the Tribunaux administratifs and the Cours administratives d'appel 84

3.4.2 Corps of the Conseil d'Etat 85

3.4.3 Corps of Financial Judges 88

3.5 Conclusion 88 
4 The Procedure for Making Claims against Public Authorities

4.1 Principles of the Administrative Court Process 90

4.1.1 The Right to Effective Redress (Le droit au recours) 91

4.1.2 The Principle of Contradiction (Le principe du contradictoire)

4.1.3 The Principle of Openness (Le principe de la publicité)

4.1.4 The Principle of a Decision within a Reasonable Time (La durée raisonnable de la procédure)

4.1.5 The Principle of the Written Nature of Proceedings (Le caractère principalement écrite de la procédure) 95

4.1.6 The Principle of the Inquisitorial Character of Proceedings (Le caractère inquisitoire de la procédure)

4.1.7 The Principle of Collegiality (Le principe de la collégialité)

4.2 How Is a Claim Made?

4.2.1 Prior Administrative Redress

4.2.2 Alternative Dispute Resolution

4.2.3 Obligatory Legal Representation

4.3 Interim Measures (Le référé)

4.4 The Investigation (L'instruction)

4.4.1 Request for Information

4.4.2 Expert Report (L'expertise)

4.4.3 Site Visit (La visite des lieux)

4.4.4 Witness Hearing (L'enquête)

4.4.5 Amicus Curiae

4.6 Preliminary References $\quad 118$

4.7 The Hearing 120

4.8 The Deliberation 122

4.9 Enforcement 123

$\begin{array}{ll}4.10 & \text { Conclusion } \\ \end{array}$

5 The Distinction between Public Law and Private Law 128

5.1 The Subject Matter of Litigation at the Constitutional Level

5.1.1 Illegality

5.1.2 Exceptions to the Separation of Administrative and Ordinary Judicial Authorities 
5.1.2.1 The Defence of Illegality before the Civil Courts

5.1.2.2 Criminal Proceedings

5.1.2.3 Protection of Civil Liberties and Private Property

5.1.2.4 The Good Administration of Justice

5.1.2.5 Legislative Exceptions

5.2 Other Categories of Litigation

5.2.1 Contracts and Commercial Activities 139

5.2.2 Property

5.2.3 Liability of Public Bodies 140

$5 \cdot 3$ Voie de fait

5.4 Public Persons

144

5.5 General Criteria for Identifying Public Law Matters 147

5.6 Mechanisms for Handling Conflicts over Jurisdiction 150 5.6.1 Positive Conflict 150

5.6.2 Negative Conflict $\quad 151$

5.6.3 Preliminary Reference by a Court 151

5.6.4 Conflict of Decisions $\quad 152$

$5 \cdot 7$ Conclusion 152

6 Judicial Review of Administrative Action: Procedure 154

6.1 Who Can Challenge an Administrative Decision? 155

6.2 What Kinds of Decisions Can Be Challenged? 158

6.2.1 The Need for a Prior Decision 158

6.2.2 Circulars and Soft Law 159

6.2.2.1 Circulars 159

6.2.2.2 Guidelines 160

6.2.2.3 Other Soft Law and Information $\quad{ }_{161}$

6.2.3 Internal Measures $\quad 162$

6.2.4 Actes de gouvernement $\quad 164$

6.3 Is Judicial Review Inappropriate? 166

6.4 Time Limits $\quad{ }^{167}$

6.5 Can Judicial Review Be Excluded? 168

6.6 Remedies 169

6.6.1 Nullity 169

6.6.1.1 What Is the Effect of Nullity? 169

6.6.2 Can Nullity Be Avoided? 170

6.6.3 Injunctions (Injonctions) 172 
$\begin{array}{lll}\text { 6.6.4 Declaratory Judgments } & 173\end{array}$

6.6.5 Correcting a Decision 174

$\begin{array}{lll}6.7 \text { Costs } & 174\end{array}$

6.8 Penalties 175

6.9 Conclusion 176

7 Maintaining Legality: The Grounds of Review $\quad 178$

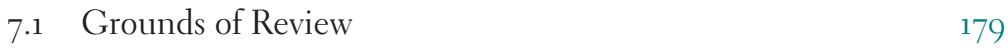

$\begin{array}{lll}\text { 7.1.1 Non-existence (Inexistence) } & 179\end{array}$

7.1.2 Lack of Competence (Incompétence) 181

7.1.3 Breach of an Essential Procedural Requirement (Vice de procédure et vice de forme) 182

7.1.4 Abuse of Power (Détournement de pouvoir) 185

$\begin{array}{ll}7.1 .5 & \text { Illegality } \\ & 188\end{array}$

7.1.5.1 Error of Fact $\quad 188$

7.1.5.2 Error of Law (Erreur de droit) 190

7.1.5.3 Manifest Error in Evaluation (Erreur manifeste d'appréciation) $\quad 191$

7.1.5.4 Proportionality 195

7.1.5.5 The Sliding Scale for Review 199

7.2 Values Enforced through Judicial Review 203

7.3 Fundamental Rights 203

7.3.1 Constitutional Rights 204

7.3.2 European Convention on Human Rights 208

7.3.3 General Principles of Law 210

7.3.4 Modern Emerging Principles 219

7.4 Principles of Good Administration 221

7.4.1 The Conduct of Public Officials 222

7.4.2 Transparency and Data Protection 224

7.4.3 The Handling of Requests from the Public 225

7.4.4 Time Limits and Appeals 227

7.4.5 Principles Governing the Decision Taken 228

7.4.6 Legitimate Expectations and Legal Certainty 228

7.4.7 Duty to Give Reasons 230

7.5 Conclusion 231

8 State Liability 233

8.1 Introduction 233

8.2 Theories of Liability 234 
8.3 Liability for Public Works (Responsabilité pour les travaux publics)

8.4 Fault Liability

8.4.1 The Nature of Fault 239

8.4.2 Faute de service 240

8.4.3 Faute personnelle 242

8.4.4 Faute simple and Faute lourde 245

8.4.5 Fault and Unlawfulness 248

8.4.6 Fault in Regulation 250

8.4.7 Types of Fault 251

8.5 No-Fault Liability 252

8.5.1 Liability for Exceptional Risks 252

8.5.2 Assistance to the Public Service 256

8.5.3 Equality before Public Burdens 257

8.5.4 Other No-Fault Compensation 261

8.6 Controls on Liability 263

8.6.1 Categories of Harm 263

8.6.2 Causation 264

8.6.3 Measure of Damages 266

8.7 Conclusion 268

9 Claims Relating to Public Contracts 270

9.1 What is a Public Law Contract? 270

9.1.1 Criteria Laid Down by Administrative Courts 272

9.1.1.1 Criteria Linked to a Public Service Mission 272

9.1.1.2 Criteria Based on a Clause Unusual in Private Law 273

9.1.2 Criteria Laid Down by the Legislator 275

9.2 Specific Rules Applicable to Public Law Contracts 278

9.2.1 Rules Applicable to the Formation of the Contract 278

9.2.1.1 Validity of the Contractual Consent 279

9.2.1.2 Validity of the Contractual Content 281

9.2.2 Rules Applicable to the Performance of the

Contract

9.2.2.1 Exceptions to the Binding Force of

Contracts Benefiting Public Authorities 284

9.2.2.2 Exceptions to the Binding Force of Contracts

Benefiting Private Contractors 287

9.3 Remedies for Public Law Contracts 289

9.3.1 Remedies for Third Parties to Public Law Contracts 290 
9.3.2 Remedies for Parties to Public Law Contracts 291 9.4 Concluding Remarks 293

10 Conclusion 299

10.1 Path Dependence 299

10.2 The Constitutional Turn 301

10.3 The European Environment 303

$\begin{array}{ll}10.4 & \text { Social Change } \\ & 305\end{array}$

10.5 Renvoi 306

$\begin{array}{ll}\text { Index } & 307\end{array}$ 


\section{Preface}

There have been many presentations of French administrative law to an English-speaking audience since Dicey wrote more than 135 years ago. The most comprehensive coverage was last written more than twenty years ago. One of the co-authors was an author of that edition of Brown and Bell, French Administrative Law (5th edition). A lot has changed in that time, not least the importance of the European dimension in French law (and its decline in English law). It seemed best to both of the present authors to start a contemporary presentation of French administrative law from a clean slate.

As we explain in Chapter 1, the importance of French constitutional law, European Union law and the European Convention on Human Rights has reshaped French administrative law in the past fifty years. In their turn, French administrative lawyers have also contributed to shaping these influential sources of law. French administrative law is less a self-standing branch of law than it once was.

The aim of this work is to provide an introduction to French administrative law, so it is necessarily limited in length. Although Legifrance and the Conseil d'Etat websites provide some translations of legislation and case law, they are limited. In order to go further, the reader really does have to make use of French-language sources, many of which are available electronically.

We have worked together on the different chapters. Our aim has been to blend French rigour, system and principle with English attention to cases and empiricism. We hope we have taken the best of both pedagogical traditions and made them into a coherent whole. We also hope that this collaboration will encourage similar collaborations between colleagues from different jurisdictions in the future.

We each owe debts of gratitude to various individuals. We both took part in a number of meetings over the best part of a decade in which French judges 
and academics met with British judges and academics, often supplemented by members of the European courts and some national jurisdictions. These meetings enabled us to test out the extent of differences between the different legal traditions and to understand contemporary points of convergence and divergence. We are grateful in particular to the former president of the Section du Contentieux, Bernard Stirn, who made possible these meetings. Particularly important in organising those meetings and in shaping our ideas were Mattias Guyomar (now of the European Court of Human Rights) and Duncan Fairgrieve. Among the active participants was Lord Reed, whose insights into British and European laws was particularly helpful.

John Bell owes a particular debt of gratitude to Neville Brown, who gave a young academic opportunities to work on French law, and who was a cheerful and supportive collaborator. We shared membership of Pembroke College Cambridge. Roger Errera gave an opportunity to be a stagiaire in the Conseil d'Etat for six months in 1986, which provided the chance to understand how French administrative law operates in practice. Tony Bradley gave the first chance to write on comparative administrative law, bringing contacts with French lawyers and judges.

François Lichère owes debt to the members of the Conseil d'Etat just quoted, who embody French administrative law and helped him to better understand the rationale of French administrative law. He is also indebted to John Bell and Duncan Fairgrieve for introducing him to English administrative law, which in turn helped him to better understand French administrative law.

We have tried to make the text accurate up to 1 May 2021. The production process in the period of the Covid-19 pandemic has inevitably been longer than usual, but we hope this has not affected the currency of what we have written. 


\section{Abbreviations}

\begin{tabular}{|c|c|}
\hline AJDA & Actualité Juridique Droit Administratif \\
\hline App. & $\begin{array}{l}\text { Application (to the European Court of Human } \\
\text { Rights) }\end{array}$ \\
\hline Brown and Bell & $\begin{array}{l}\text { L. N. Brown and J. Bell, French Administrative } \\
\text { Law, 5th ed. (Oxford: Oxford University Press, } \\
1998 \text { ) }\end{array}$ \\
\hline Cass ch. mixte & Cour de cassation, chambre mixte \\
\hline Cass.civ. & $\begin{array}{l}\text { Cour de cassation, chambre civil (with a number } \\
\text { indicating which chamber) }\end{array}$ \\
\hline CC & Conseil constitutionnel \\
\hline CCP & Code de la commande publique \\
\hline CCSDN & $\begin{array}{l}\text { Commission consultative du secret de la défense } \\
\text { nationale }\end{array}$ \\
\hline $\mathrm{CDBF}$ & Cour de discipline budgétaire et financière \\
\hline CE & Conseil d'Etat \\
\hline CE Ass. & Conseil d'Etat, Assemblée du Contentieux \\
\hline CE ord. & Conseil d’Etat, ordonnance de référé \\
\hline CE Sect. & Conseil d'Etat, Section du Contentieux \\
\hline Ceseda & $\begin{array}{l}\text { Code de l'entrée et du séjour des étrangers et du } \\
\text { droit de l'asile }\end{array}$ \\
\hline CESER & $\begin{array}{l}\text { Conseil économique, social et environnemental } \\
\text { régional }\end{array}$ \\
\hline CGCT & Code général des collectivités territoriales \\
\hline CGPPP & $\begin{array}{l}\text { Code général de la propriété des personnes } \\
\text { publiques }\end{array}$ \\
\hline Chr. & Chronique \\
\hline CJA & Code de la Justice Administrative \\
\hline CNDA & Cour nationale du droit d'asile \\
\hline
\end{tabular}


CNIL

concl.

Crim.

CRPA

C. santé pub.

D

DC

DDHC

EDCE

GPA

Grands Arrêts

Guyomar and Seiller

JCP

$\mathrm{L}$

Leb.

MPO

OFPRA

QPC

RAPO

RDP

Rec.

RFDA

Rfdc

$\mathrm{S}$

TC
Conseil national de l'informatique et des libertés conclusions (of a Rapporteur Public or (earlier)

Commissaire du gouvernement)

Cour de cassation, chambre criminelle

Code des Relations entre le Public et l'Administration

Code de la santé publique

Recueil Dalloz

Décision de Conformité (Conseil constitutionnel)

Déclaration des Droits de l'Homme (1789)

Etudes et Documents du Conseil d'Etat

World Trade Organization Agreement on

Government Procurement

P. Delvolvé, M. Long, P. Weil, G. Braibant and B.

Genevois, Les Grands Arrêts de la Jurisprudence

Administratif, 22nd ed. (Paris: Dalloz, 2019)

M. Guyomar and B. Seiller, Contentieux administratif, 5th ed. (Paris: Dalloz, 2019)

Juris-Classeur Périodique : Semaine Juridique

Décision de déclassement (Conseil constitutionnel)

Recueil Lebon (decisions of the Conseil d'Etat)

Médiation préalable obligatoire

Office français de protection des réfugiés et apatrides

Question préalable de constitutionalité (Conseil constitutionnel)

Recours administratif préalable obligatoire

Revue de Droit Public

Recueil des décisions du Conseil constitutionnel

Revue française de droit administratif

Revue française de droit constitutionnel

Recueil Sirey

Tribunal des Conflits 


\title{
Table of Cases by Date
}

\author{
FRENCH ADMINISTRATIVE LAW CASES (INCLUDING TRIBUNAL \\ DES CONFLITS)
}

\begin{tabular}{|c|c|c|c|c|}
\hline 1838 & 11 January & $\mathrm{CE}$ & Duchâtellier & 259 \\
\hline \multirow[t]{3}{*}{1873} & 8 February & $\mathrm{TC}$ & Blanco & $\begin{array}{l}24,140,148,234,236, \\
251,268\end{array}$ \\
\hline & 30 July & $\mathrm{TC}$ & Pelletier & 241,242 \\
\hline & 26 November & $\mathrm{CE}$ & Pariset & 187 \\
\hline 1889 & 13 December & $\mathrm{CE}$ & Cadot & 64,89 \\
\hline 1895 & 21 June & $\mathrm{CE}$ & Cames & 256 \\
\hline \multirow[t]{2}{*}{1899} & 5 May & $\mathrm{CE}$ & Cook et Fils & 156 \\
\hline & 9 December & $\mathrm{TC}$ & $\begin{array}{l}\text { Association syndicale du } \\
\text { Canal de Grignac }\end{array}$ & 144 \\
\hline 1900 & 4 May & $\mathrm{CE}$ & Héritiers du sieur Gouy & 281 \\
\hline 1901 & 29 March & $\mathrm{CE}$ & Casanova & 157 \\
\hline 1902 & 10 January & $\mathrm{CE}$ & $\begin{array}{l}\text { Compagnie nouvelle du } \\
\text { Gaz de Deville-lès- } \\
\text { Rouen }\end{array}$ & 286 \\
\hline \multirow{2}{*}{1903} & 6 February & $\mathrm{CE}$ & Terrier & 139,148 \\
\hline & 11 December & $\mathrm{CE}$ & Lot & 155 \\
\hline 1904 & 30 November & $\mathrm{CE}$ & Allarousse & 94 \\
\hline 1905 & 20 January & $\mathrm{CE}$ & $\begin{array}{l}\text { Compagnie } \\
\text { départementale des eaux }\end{array}$ & 286 \\
\hline \multirow[t]{2}{*}{1906} & 21 December & $\mathrm{CE}$ & $\begin{array}{l}\text { Syndicat des propriétaires } \\
\text { et contribuables du } \\
\text { Quartier de Croix-de- } \\
\text { Seguey-Tivoli }\end{array}$ & 156,290 \\
\hline & 28 December & $\mathrm{CE}$ & $\begin{array}{l}\text { Syndicat des Patrons- } \\
\text { Coiffeurs de Limoges }\end{array}$ & 157 \\
\hline 1908 & 29 February & $\mathrm{TC}$ & Feutry & 241,243 \\
\hline \multirow[t]{2}{*}{1909} & 19 February & $\mathrm{CE}$ & Abbé Olivier & 196,198 \\
\hline & 23 July & $\mathrm{CE}$ & Fabrègue & 186 \\
\hline \multirow[t]{2}{*}{1910} & 4 March & $\mathrm{CE}$ & Théron & 272 \\
\hline & 11 March & $\mathrm{CE}$ & $\begin{array}{l}\text { Compagnie générale } \\
\text { française des tramways }\end{array}$ & 284 \\
\hline
\end{tabular}


(continued)

\begin{tabular}{|c|c|c|c|c|}
\hline \multirow[t]{2}{*}{1911} & 3 February & CE & Anguet & 242 \\
\hline & 29 December & $\mathrm{CE}$ & Chomel & 214 \\
\hline \multirow[t]{3}{*}{1912} & 10 January & $\mathrm{CE}$ & Ville de Saint-Étienne & 280 \\
\hline & 10 May & $\mathrm{CE}$ & Abbé Boutèyre & 212,219 \\
\hline & 31 July & $\mathrm{CE}$ & $\begin{array}{l}\text { Société des granits } \\
\quad \text { porphyroïdes des Vosges }\end{array}$ & 273,275 \\
\hline 1913 & 9 May & $\mathrm{CE}$ & Préfet de l'Eure & 166 \\
\hline 1914 & 4 April & $\mathrm{CE}$ & Gomel & 189,201 \\
\hline \multirow[t]{2}{*}{1916} & 14 January & $\mathrm{CE}$ & Camino & $93,188-9$ \\
\hline & 30 March & $\mathrm{CE}$ & $\begin{array}{l}\text { Compagnie générale } \\
\text { d'éclairage de Bordeaux }\end{array}$ & 287 \\
\hline 1917 & 28 December & CE & Belmont & 280 \\
\hline \multirow[t]{2}{*}{1918} & 28 June & CE & Heyriès & 8 \\
\hline & 26 July & $\mathrm{CE}$ & Epoux Lemonnier & 242 \\
\hline \multirow[t]{2}{*}{1919} & 28 March & $\mathrm{CE}$ & Regnault-Desroziers & 253 \\
\hline & 8 August & $\mathrm{CE}$ & Labonne. & 105,217 \\
\hline 1922 & 5 May & $\mathrm{CE}$ & Sieur Fontan & 213 \\
\hline \multirow[t]{4}{*}{1923} & 26 January & $\mathrm{CE}$ & De Robert Lafrégeyre & 273 \\
\hline & 16 June & $\mathrm{TC}$ & Septfonds & 131 \\
\hline & 30 November & $\mathrm{CE}$ & Couitéas & 257 \\
\hline & ${ }_{14}$ December & $\mathrm{CE}$ & $\begin{array}{l}\text { Société des grands moulins } \\
\text { de Corbeil }\end{array}$ & 280 \\
\hline \multirow[t]{2}{*}{1925} & 4 December & CE & Charton & 212 \\
\hline & 26 December & $\mathrm{CE}$ & Rodière & 155,170 \\
\hline \multirow[t]{2}{*}{1928} & 10 February & $\mathrm{CE}$ & $\begin{array}{l}\text { Chambre syndicale des } \\
\text { propriétaires de } \\
\text { Marseille }\end{array}$ & 214 \\
\hline & 27 July & $\mathrm{CE}$ & SA des usines Renault & 212 \\
\hline 1929 & 5 July & $\mathrm{CE}$ & Ministre de travail & 195 \\
\hline 1932 & 9 December & $\mathrm{CE}$ & $\begin{array}{l}\text { Compagnie des tramways } \\
\text { de Cherbourg }\end{array}$ & 288 \\
\hline \multirow[t]{2}{*}{1933} & 8 May & TC & Rosay & $15^{2}$ \\
\hline & 19 May & $\mathrm{CE}$ & Benjamin & $196,198,202$ \\
\hline 1934 & 14 March & $\mathrm{CE}$ & Rault & 186 \\
\hline 1935 & 8 April & $\mathrm{TC}$ & Action française & 142 \\
\hline \multirow[t]{3}{*}{1936} & 1 May & CE Sect. & Couespel de Mesnil & 96 \\
\hline & 3 July & $\mathrm{CE}$ & Bobard & 213 \\
\hline & 23 November & CE & Abdoulhoussan & 213 \\
\hline \multirow[t]{2}{*}{$193^{8}$} & 14 January & $\mathrm{CE}$ & $\begin{array}{l}\text { S.A. des Produits Laitiers } \\
\text { 'La Fleurette' }\end{array}$ & 259,263 \\
\hline & 13 May & CE Ass. & $\begin{array}{l}\text { Caisse primaire "Aide et } \\
\text { Protection } ~\end{array}$ & 145 \\
\hline 1941 & 16 May & $\mathrm{CE}$ & Commune de Vizille & 285 \\
\hline 1942 & 31 July & CE Ass. & Montpeurt & 145 \\
\hline \multirow[t]{2}{*}{1943} & 2 April & CE Ass. & Bouguen & 146 \\
\hline & 9 July & CE Ass. & Tabouret and Laroche & $190-1$ \\
\hline
\end{tabular}


(continued)

\begin{tabular}{|c|c|c|c|c|}
\hline \multirow[t]{2}{*}{1944} & 4 February & $\mathrm{CE}$ & Guiyesse & 214 \\
\hline & 5 May & CE Sect. & $\begin{array}{l}\text { Trompier-Gravier (Dame } \\
\text { Veuve) }\end{array}$ & 225 \\
\hline \multirow[t]{2}{*}{1945} & 4 May & CE & $\begin{array}{l}\text { Syndicat des entrepreneurs } \\
\text { des transports de la } \\
\text { Riviera }\end{array}$ & 212 \\
\hline & 26 October & CE Ass. & Aramu & 210 \\
\hline 1946 & 22 November & CE Ass. & $\begin{array}{l}\text { Commune de Saint-Priest- } \\
\text { La-Plaine }\end{array}$ & 256 \\
\hline \multirow[t]{3}{*}{1947} & 21 February & CE Sect. & Guillemet & 188 \\
\hline & 20 October & $\mathrm{TC}$ & Barinstein & 132 \\
\hline & 18 December & $\mathrm{TC}$ & Hilaire & 134 \\
\hline \multirow[t]{4}{*}{1949} & 24 June & CE Ass. & Daramy & 254 \\
\hline & 24 June & CE Ass. & Lecomte & 254 \\
\hline & 18 November & CE Ass. & Carlier & 143 \\
\hline & 18 November & CE & $\begin{array}{l}\text { Mimeur, Defaux and } \\
\text { Besthelsemer }\end{array}$ & 243 \\
\hline \multirow[t]{6}{*}{1950} & 2 February & $\mathrm{TC}$ & Radiodiffusion Française & 151 \\
\hline & 17 February & CE Ass. & $\begin{array}{l}\text { Ministre de l'Agriculture c } \\
\text { Dame Lamotte }\end{array}$ & $91,168,227$ \\
\hline & 22 February & $\mathrm{CE}$ & Société des ciments français & 212 \\
\hline & 3 March & CE Sect. & Jamet & 219 \\
\hline & 26 April & $\mathrm{CE}$ & Domergue & 281 \\
\hline & 7 July & CE Ass. & Dehaene & 217 \\
\hline \multirow[t]{4}{*}{1951} & 9 March & CE Sect. & $\begin{array}{l}\text { Société des concerts du } \\
\text { conservatoire }\end{array}$ & 215 \\
\hline & 27 April & CE Ass. & Toni & 199 \\
\hline & 5 July & $\mathrm{TC}$ & Avranches et Desmarets & 133 \\
\hline & 28 July & CE Ass. & Laruelle and Delville & 244 \\
\hline 1952 & 30 May & CE Ass. & Kirkwood (Dame) & 164 \\
\hline 1953 & 13 November & $\mathrm{CE}$ & Denizet & 192 \\
\hline \multirow[t]{4}{*}{1954} & 29 January & CE Ass. & $\begin{array}{l}\text { Institution Notre-Dame du } \\
\quad \text { Kreisker }\end{array}$ & 161 \\
\hline & 28 May & CE Ass. & Barel & $\begin{array}{l}96,112,190,191,210 \\
\quad 212,230\end{array}$ \\
\hline & 24 June & $\mathrm{TC}$ & Société Trystram & 142 \\
\hline & 20 October & $\mathrm{CE}$ & Chapou & 163 \\
\hline 1955 & 11 March & $\mathrm{CE}$ & Coulon & 93 \\
\hline \multirow[t]{5}{*}{1956} & 3 February & CE Ass. & Keddar & 188 \\
\hline & 3 February & CE Sect. & Thouzellier & 254 \\
\hline & 20 April & CE Sect. & Époux Bertin & 272 \\
\hline & 20 April & CE Sect. & Consorts Grimouard & 273 \\
\hline & 11 July & CE Ass. & $\begin{array}{l}\text { Amicale des Annamites de } \\
\quad \text { Paris }\end{array}$ & 205 \\
\hline
\end{tabular}


(continued)

\begin{tabular}{|c|c|c|c|c|}
\hline \multirow[t]{9}{*}{1957} & 4 January & $\mathrm{CE}$ & $\begin{array}{l}\text { Syndicat autonome du } \\
\text { personnel }\end{array}$ & 302 \\
\hline & 11 January & $\mathrm{CE}$ & Louvard & 186 \\
\hline & 8 March & CE Sect. & Jalenques de Labeau & 273 \\
\hline & 20 March & $\mathrm{CE}$ & $\begin{array}{l}\text { Société des Établissements } \\
\text { thermaux d'Ussat-les- } \\
\text { Bains }\end{array}$ & 285 \\
\hline & 22 March & CE Sect. & Commune de Grigny & 257 \\
\hline & 27 March & $\mathrm{CE}$ & Carsalade & 285 \\
\hline & 27 May & $\mathrm{CE}$ & Artaud & 275 \\
\hline & 31 May & CE Ass. & Rosan Girard & 180 \\
\hline & 10 July & $\mathrm{CE}$ & Gervaise & 15 \\
\hline \multirow[t]{2}{*}{$195^{8}$} & ${ }_{14}$ February & $\mathrm{CE}$ & Abisset & 156 \\
\hline & 2 May & CE Ass. & $\begin{array}{l}\text { Distilleries de Magnac- } \\
\quad \text { Laval }\end{array}$ & 286 \\
\hline \multirow[t]{2}{*}{1959} & 26 June & CE Sect. & $\begin{array}{l}\text { Syndicat général des } \\
\text { ingénieurs-conseils }\end{array}$ & 54,211 \\
\hline & 18 December & $\mathrm{CE}$ & Films Lutetia & 217 \\
\hline 1960 & 12 February & $\mathrm{CE}$ & Société Eky & 205 \\
\hline \multirow[t]{4}{*}{1961} & 15 February & CE Sect. & Lagrange & $191-2$ \\
\hline & 12 May & CE Sect. & Société La Huta & 92 \\
\hline & 13 July & $\mathrm{CE}$ & Demoiselle Achart & 192 \\
\hline & 24 November & CE Ass. & Epoux Letisserand & 264,267 \\
\hline \multirow[t]{4}{*}{1962} & 2 March & CE Ass. & Rubin de Servens & 164 \\
\hline & 2 July & $\mathrm{TC}$ & Consorts Cazautets & 274 \\
\hline & 13 July & CE Ass. & Bréart de Boisanger & 187 \\
\hline & 19 October & CE Ass. & Brocas & 164 \\
\hline \multirow[t]{3}{*}{1963} & 22 February & CE Sect. & Commune de Gavarnie & $25^{8}$ \\
\hline & 28 June & CE Sect. & Narcy & 145 \\
\hline & 8 July & $\mathrm{TC}$ & Société Entreprise Peyrot & 237 \\
\hline 1965 & 22 January & CE Sect. & $\begin{array}{l}\text { Société des établissements } \\
\text { Michel Aubrun }\end{array}$ & 286 \\
\hline \multirow[t]{2}{*}{1967} & 16 January & $\mathrm{TC}$ & $\begin{array}{l}\text { Société du vélodrome du } \\
\quad \text { Parc des Princes }\end{array}$ & 274 \\
\hline & 22 November & CE & AGAP de Paris c Chevreau & 196 \\
\hline \multirow[t]{6}{*}{1968} & 12 January & CE Ass. & $\begin{array}{c}\text { Ministre de l'Economie et } \\
\text { des Finances c Perrot }\end{array}$ & 172 \\
\hline & 15 January & $\mathrm{TC}$ & $\begin{array}{l}\text { Compagnie Air France c } \\
\text { Barbier }\end{array}$ & 147 \\
\hline & 26 January & CE Sect. & Société Maison Genestal & 231 \\
\hline & 1 March & CE Sect. & $\begin{array}{l}\text { Syndicat général des } \\
\text { fabricants de semoules } \\
\text { de France }\end{array}$ & 10 \\
\hline & 29 March & CE Ass. & $\begin{array}{l}\text { Société du Lotissement de } \\
\text { la Plage de Pamplonne }\end{array}$ & 192 \\
\hline & 24 June & $\mathrm{TC}$ & $\begin{array}{l}\text { Société Distilleries } \\
\text { bretonnes }\end{array}$ & 273 \\
\hline
\end{tabular}


(continued)

\begin{tabular}{|c|c|c|c|c|}
\hline 1969 & 12 July & CE Ass. & L'Etang & 247 \\
\hline \multirow[t]{3}{*}{1970} & 27 February & CE Ass. & Commune de Bozas & 55 \\
\hline & 25 September & CE Sect. & $\begin{array}{l}\text { Commune de Batz-sur-Mer } \\
\text { c Tesson }\end{array}$ & 257 \\
\hline & 27 November & CE Ass. & $\begin{array}{l}\text { Agence maritime Marseille- } \\
\text { Fret }\end{array}$ & 230 \\
\hline \multirow[t]{3}{*}{1971} & 19 March & CE Sect. & Mergui & 102 \\
\hline & 21 May & $\mathrm{CE}$ & La cellulose d'Aquitaine & 281 \\
\hline & 28 May & CE Ass. & Ville Nouvelle Est & 192 \\
\hline \multirow[t]{3}{*}{1972} & 21 July & CE Sect. & Legros & 166 \\
\hline & 13 October & CE Sect. & $\begin{array}{l}\text { SA de banque "Le Crédit } \\
\text { du Nord» }\end{array}$ & 280 \\
\hline & 20 October & CE Ass. & Ste Marie de l'Assomption & 195 \\
\hline \multirow[t]{8}{*}{1973} & 26 January & CE Sect. & Lang & 230 \\
\hline & 26 January & CE Sect. & Ville de Paris c Driancourt & 248,263 \\
\hline & 16 February & CE & $\begin{array}{c}\text { Ministre de l'équipement et } \\
\text { du logement c Baron }\end{array}$ & 187 \\
\hline & 8 June & CE Ass. & Peynet (Dame) & 216,273 \\
\hline & 6 July & CE Ass. & $\begin{array}{l}\text { Ministre de l'équipement et } \\
\text { logement c Dalleau }\end{array}$ & 253 \\
\hline & 26 October & CE Ass. & Sadoudi & 254 \\
\hline & 26 October & CE Sect. & Grassin & 194 \\
\hline & 2 November & CE Ass. & Librairie François Maspero & 208 \\
\hline \multirow[t]{3}{*}{1974} & 22 February & CE Ass. & Adam & 194 \\
\hline & $\begin{array}{l}\mathrm{CE}_{4} \\
\quad \text { October }\end{array}$ & $\mathrm{CE}$ & David (Dame) & 53 \\
\hline & 20 November & $\mathrm{CE}$ & $\begin{array}{l}\text { Epoux Thony and Epoux } \\
\text { Hartman-Six }\end{array}$ & 194 \\
\hline \multirow[t]{3}{*}{1975} & 13 June & CE Sect. & Adrasse & 116 \\
\hline & 17 October & CE Sect. & Commune de Canari & 289 \\
\hline & 22 October & $\mathrm{CE}$ & Bergon & 248 \\
\hline \multirow[t]{4}{*}{1976} & 5 May & CE Ass. & $\begin{array}{l}\text { SAFER d'Auvergne c } \\
\text { Bernette }\end{array}$ & 200 \\
\hline & 23 July & $\mathrm{CE}$ & $\begin{array}{c}\text { Secrétaire d'Etat aux Postes } \\
\text { et Télécommunications }\end{array}$ & 205 \\
\hline & 29 October & CE Sect. & $\begin{array}{l}\text { Ministre des affaires } \\
\text { étrangères c Burgat }\end{array}$ & 259 \\
\hline & 12 November & $\mathrm{CE}$ & $\begin{array}{l}\text { Syndicat unifié de } \\
\text { radiodiffusion et de } \\
\text { télévision CFDT }\end{array}$ & 218 \\
\hline \multirow[t]{3}{*}{1978} & 9 June & CE Sect. & Lebon & 202 \\
\hline & 27 October & CE Sect. & Debout & 52 \\
\hline & 8 December & CE Ass. & $\begin{array}{l}\text { Groupe d'Information et de } \\
\text { Soutien des Travailleurs } \\
\text { Immigrés }\end{array}$ & 207,211 \\
\hline
\end{tabular}


(continued)

\begin{tabular}{|c|c|c|c|c|}
\hline & 22 December & CE Ass. & $\begin{array}{l}\text { Ministre de l'Intérieur c } \\
\text { Cohn-Bendit }\end{array}$ & $10-11,12,4^{8}$ \\
\hline & 29 December & CE Ass. & Darmont & 247 \\
\hline 1979 & 23 May & $\mathrm{CE}$ & $\begin{array}{l}\text { Commune de Fontenay-le- } \\
\text { Fleury }\end{array}$ & 292 \\
\hline 1980 & 7 July & TC & $\begin{array}{c}\text { Peschaud c Groupement du } \\
\text { Football professionnel }\end{array}$ & 146 \\
\hline 1981 & 19 June & CE Sect. & Carliez & 249 \\
\hline \multirow[t]{3}{*}{1982} & 23 April & CE Sect. & $\begin{array}{l}\text { Ville de Toulouse c } \\
\text { Aragnou }\end{array}$ & 216,273 \\
\hline & 7 July & CE Sect. & $\begin{array}{l}\text { Commune de Guidel c } \\
\text { Mme Courtet }\end{array}$ & 57 \\
\hline & 5 November & CE Sect. & Société Propétrol & 288 \\
\hline 1983 & 2 February & $\mathrm{CE}$ & $\begin{array}{l}\text { Union des transports } \\
\text { publics urbains et } \\
\text { régionaux }\end{array}$ & 284 \\
\hline \multirow[t]{3}{*}{1984} & 22 June & $\mathrm{CE}$ & Sealink U.K. Ltd. & $25^{8}$ \\
\hline & 22 June & CE & $\begin{array}{l}\text { Société Jokelson et } \\
\text { Handstaem }\end{array}$ & 258 \\
\hline & 23 November & CE Ass. & Association 'Les Verts' & 165 \\
\hline 1985 & 6 May & $\mathrm{CE}$ & Association Eurolat & 284 \\
\hline \multirow[t]{5}{*}{1986} & 28 February & CE Sect. & Akhras & 122 \\
\hline & 28 February & CE Sect. & Bouhanna & 122,190 \\
\hline & 12 March & $\mathrm{CE}$ & $\begin{array}{l}\text { Ministre de la culture c } \\
\text { Mme Cusenier }\end{array}$ & 158 \\
\hline & 9 June & $\mathrm{TC}$ & $\begin{array}{l}\text { Commissaire de la } \\
\text { République pour la } \\
\text { région d'Alsace }\end{array}$ & 143 \\
\hline & 10 December & $\mathrm{CE}$ & Lorédon & 201 \\
\hline \multirow[t]{5}{*}{1987} & 13 March & CE Sect. & $\begin{array}{l}\text { Société albigeoise de } \\
\text { spectacles }\end{array}$ & 155 \\
\hline & 20 March & $\mathrm{CE}$ & Gambus & 201 \\
\hline & 27 April & $\mathrm{CE}$ & $\begin{array}{c}\text { Comité interprofessionnel } \\
\text { du Gruyère de Comté }\end{array}$ & 212 \\
\hline & 29 April & $\mathrm{CE}$ & $\begin{array}{c}\text { Garde des Sceaux c Banque } \\
\text { Populaire de Strasbourg }\end{array}$ & 255 \\
\hline & 24 June & $\mathrm{CE}$ & Bes & 187 \\
\hline \multirow[t]{5}{*}{1988} & 27 January & $\mathrm{CE}$ & Giraud & 251 \\
\hline & 1 April & CE Ass. & Bereciartua-Echarri & 211 \\
\hline & 18 May & $\mathrm{CE}$ & Ville de Toulouse & 166 \\
\hline & 21 October & CE Ass. & $\begin{array}{l}\text { Fédération des parents } \\
\text { d'élèves de } \\
\text { l'enseignement public }\end{array}$ & 218 \\
\hline & 23 November & $\mathrm{CE}$ & Dumont & 157 \\
\hline
\end{tabular}


(continued)

\begin{tabular}{|c|c|c|c|c|}
\hline & 19 December & $\mathrm{CE}$ & Pascau & 146 \\
\hline & 23 December & CE Sect. & $\begin{array}{c}\text { Banque de France c } \\
\text { Huberschwiller }\end{array}$ & 92 \\
\hline \multirow[t]{4}{*}{1989} & 3 February & CE Ass. & Compagnie Alitalia & $11,50,223$ \\
\hline & 20 February & $\mathrm{CE}$ & Allain & 165 \\
\hline & 21 July & $\mathrm{CE}$ & $\begin{array}{l}\text { Commune de Noisy-le- } \\
\text { Grand }\end{array}$ & 166 \\
\hline & 20 October & CE Ass. & Nicolo & $11,47,119,165$ \\
\hline \multirow[t]{7}{*}{1990} & 6 April & $\begin{array}{r}\text { CE Ass. } \\
\quad(\text { avis })\end{array}$ & $\begin{array}{l}\text { Compagnie financière et } \\
\text { industrielle des } \\
\text { autoroutes } \\
\text { (COFIROUTE) }\end{array}$ & 258 \\
\hline & 9 May & $\mathrm{CE}$ & $\begin{array}{l}\text { Commune de Lavaur c } \\
\quad \text { Lozar }\end{array}$ & 180 \\
\hline & 29 June & CE Ass. & GISTI & 14,164 \\
\hline & 20 July & CE & $\begin{array}{l}\text { Ville de Melun et } \\
\text { Association « Melun- } \\
\text { culture-loisirs » c Vivien }\end{array}$ & 146,148 \\
\hline & 19 October & CE Sect. & Ingremeau & 255 \\
\hline & 26 October & CE Ass. & $\begin{array}{c}\text { Fédération nationale du } \\
\text { commerce extérieur des } \\
\text { produits alimentaires }\end{array}$ & 119 \\
\hline & 28 December & CAA Lyon & Fauvry & 250 \\
\hline \multirow[t]{2}{*}{1991} & 19 April & CE Ass. & Babas and Belgacem & 198 \\
\hline & 26 July & $\mathrm{CE}$ & $\begin{array}{l}\text { Fédération nationale des } \\
\text { syndicats de producteurs } \\
\text { autonomes d'électricité }\end{array}$ & 199 \\
\hline \multirow[t]{6}{*}{1992} & 17 January & CE Sect. & $\begin{array}{l}\text { Université de Dijon c } \\
\text { Picard et Brachet }\end{array}$ & 191 \\
\hline & 10 April & CE Ass. & Époux $V$ & $245-6,268$ \\
\hline & 11 May & $\mathrm{TC}$ & $\begin{array}{l}\text { Société Office Maraîcher } \\
\quad \text { fruitier }\end{array}$ & 274 \\
\hline & 23 September & $\mathrm{CE}$ & GISTI and MRAP & 165 \\
\hline & 2 November & $\mathrm{CE}$ & Kherouaa & 162 \\
\hline & 18 December & CE Ass. & $\begin{array}{l}\text { Préfet de la Gironde c } \\
\text { Mahmedi }\end{array}$ & 165 \\
\hline \multirow[t]{4}{*}{1993} & 1 February & $\mathrm{CE}$ & Guillec ( $\mathrm{M}$ et $\mathrm{Mme})$ & 186 \\
\hline & 9 April & CE Ass. & Bianchi & 256,268 \\
\hline & 9 April & CE Ass. & M.D. & 251,252 \\
\hline & 15 October & CE Ass. & $\begin{array}{l}\text { Royaume-Uni et } \\
\text { Gouverneur de la } \\
\text { Colonie Royale de Hong } \\
\text { Kong }\end{array}$ & 166 \\
\hline 1994 & 1 April & CE & Commune de Menton & 283 \\
\hline
\end{tabular}


(continued)

\begin{tabular}{|c|c|c|c|c|}
\hline & 29 April & CE Ass. & Colombani & 286 \\
\hline & 29 July & $\mathrm{CE}$ & Sanimam & 166 \\
\hline \multirow[t]{5}{*}{1995} & 17 February & CE Ass. & Hardouin and Marie & $162-3$ \\
\hline & 24 March & $\mathrm{CE}$ & Nice Hélicoptères & 263 \\
\hline & 31 March & CE Sect. & Lavaud & 258 \\
\hline & 29 September & $\mathrm{CE}$ & $\begin{array}{l}\text { Association Greenpeace } \\
\text { France }\end{array}$ & 165 \\
\hline & 29 December & $\mathrm{CE}$ & Beucher & 157 \\
\hline \multirow[t]{8}{*}{1996} & 6 February & CAA Paris & $\begin{array}{l}\text { Société de Promotion et de } \\
\text { Distribution Touristique }\end{array}$ & 182 \\
\hline & 25 March & $\mathrm{TC}$ & $\begin{array}{l}\text { Préfet de la région Rhône- } \\
\quad \text { Alpes }\end{array}$ & 273 \\
\hline & 3 July & CE Ass. & Koné & $21,45,208$ \\
\hline & 10 July & CE Ass. & Cayzeele & 289 \\
\hline & 31 July & $\mathrm{CE}$ & $\begin{array}{c}\text { Société des téléphériques du } \\
\text { massif du Mont-Blanc }\end{array}$ & 286 \\
\hline & 30 October & CE Ass. & SA Dangeville & 167 \\
\hline & 30 October & CE Ass. & Waijs (Mme) et Monnier & 156 \\
\hline & 6 December & CE Ass. & Société Lambda & 47 \\
\hline \multirow[t]{9}{*}{1997} & 28 March & CE Ass. & $\begin{array}{l}\text { Association contre le projet } \\
\text { autoroute } \\
\text { transchablaisienne }\end{array}$ & 195 \\
\hline & 28 March & CE Ass. & $\begin{array}{l}\text { Fédération des comités de } \\
\text { défense contre le tracé de } \\
\text { l'autoroute } A_{2} 8\end{array}$ & 194 \\
\hline & 28 March & CE Ass. & Société Baxter & 214 \\
\hline & 12 May & $\mathrm{TC}$ & $\begin{array}{l}\text { Préfet de police de Paris c } \\
\text { Tribunal de grande } \\
\text { instance de Paris }\end{array}$ & 134,160 \\
\hline & 2o June & CE Sect. & Theux & 246 \\
\hline & 9 July & CE Sect. & Société Ekin & $53,208-9$ \\
\hline & 20 October & $\mathrm{TC}$ & $\begin{array}{l}\text { Paris Racing I c Fédération } \\
\text { française de football }\end{array}$ & 151 \\
\hline & 3 November & CE Sect. & Société Million et Marais & 47 \\
\hline & 29 December & $\mathrm{CE}$ & $\begin{array}{l}\text { Société civile des Néo- } \\
\text { Polders }\end{array}$ & 288 \\
\hline \multirow[t]{5}{*}{1998} & 11 March & $\mathrm{CE}$ & $\begin{array}{l}\text { Ministre de l'Intèrieur c } \\
\text { Auger (Mme) }\end{array}$ & $180-1$ \\
\hline & 13 March & CE Sect. & Améon & 246 \\
\hline & 27 March & CE Sect. & $\begin{array}{l}\text { Société d'assurances la } \\
\text { Nantaise et l'Angevine } \\
\text { réunies }\end{array}$ & 284 \\
\hline & 29 April & $\mathrm{CE}$ & Commune de Hannapes & 246 \\
\hline & 20 May & $\mathrm{CE}$ & $\begin{array}{l}\text { Communauté de } \\
\text { communes du Piémont } \\
\text { de Barr }\end{array}$ & 296 \\
\hline
\end{tabular}


(continued)

\begin{tabular}{|c|c|c|c|c|}
\hline & 25 May & $\mathrm{CE}$ & $\begin{array}{l}\text { Fédération française } \\
\text { d'haltérophilie, } \\
\text { musculation et } \\
\text { disciplines associées }\end{array}$ & 186 \\
\hline & 22 June & $\mathrm{TC}$ & $\begin{array}{l}\text { Agent judiciaire du Trésor c } \\
\text { Miglierina }\end{array}$ & 274 \\
\hline & 3 July & $\mathrm{CE}$ & $\begin{array}{l}\text { Association de défense et de } \\
\text { protection de } \\
\text { l'environnement de } \\
\text { Saint-Come-d'Olt }\end{array}$ & 172 \\
\hline & 3 July & CE Ass. & $\begin{array}{l}\text { Syndicat des médecins de } \\
\text { l'Ain }\end{array}$ & 182 \\
\hline & 29 July & CE & Esclatine & 92 \\
\hline & 29 July & $\mathrm{CE}$ & $\begin{array}{l}\text { Syndicat des avocats de } \\
\quad \text { France }\end{array}$ & 91 \\
\hline & 25 September & CE Sect. & Mégret & 164 \\
\hline & 30 October & CE Sect. & Lorenzi & 52 \\
\hline & 30 October & CE Sect. & Ville de Lisieux & 290 \\
\hline & 7 December & $\mathrm{TC}$ & $\begin{array}{l}\text { District urbain de } \\
\text { l'agglomération rennaise } \\
\text { c Société des } \\
\text { automobiles Citroën }\end{array}$ & 132 \\
\hline 1999 & 3 December & CE Ass. & Didier & 52 \\
\hline & 3 December & CE Sect. & $\begin{array}{l}\text { Association ornithologique } \\
\text { et mammalogique de } \\
\text { Saône-et-Loire }\end{array}$ & 47 \\
\hline 2000 & 23 February & $\mathrm{CE}$ & L'Hermite & $5^{2}$ \\
\hline & 20 March & $\mathrm{CE}$ & Mayer et Richer & 271 \\
\hline & 3 May & $\mathrm{CE}$ avis & Martaux (Mlle) & 206 \\
\hline & 14 June & $\mathrm{CE}$ & Commune de Staffelfelden & 288 \\
\hline & 6 October & $\mathrm{CE}$ & $\begin{array}{l}\text { Ministre de l'Intérieur c } \\
\text { Commune de St-Florent }\end{array}$ & 251 \\
\hline & 29 December & $\mathrm{CE}$ & Beule & 282 \\
\hline 2001 & 16 February & $\mathrm{CE}$ & $\begin{array}{l}\text { Centre du château de } \\
\quad \text { Gleteins }\end{array}$ & 114 \\
\hline & 29 June & CE Ass. & Berton & 216 \\
\hline & 26 October & CE Ass. & Ternon & 223 \\
\hline & 30 November & CE Ass. & Kechichian & $250,263,265$ \\
\hline & 30 November & CE Ass. & $\begin{array}{l}\text { Ministre de la Défense c } \\
\text { Diop }\end{array}$ & 51 \\
\hline 2002 & 16 January & $\mathrm{CE}$ & Stiegler & 157 \\
\hline & 12 April & CE Ass. & Papon & 244 \\
\hline & 17 May & $\mathrm{CE}$ & Epoux Hofmann & 157 \\
\hline
\end{tabular}


(continued)

\begin{tabular}{|c|c|c|c|c|}
\hline & 28 June & CE Ass. & $\begin{array}{l}\text { Garde des Sceaux c } \\
\quad \text { Magiera }\end{array}$ & $95,227,247$ \\
\hline & 1 July & TC & Labrousse c Gaz de France & 149 \\
\hline & 2 October & $\mathrm{CE}$ & CCI de Meurthe et Moselle & 216 \\
\hline & 6 November & CE Ass. & Moon sun myung & 93 \\
\hline & 6 December & CE Ass. avis & $\begin{array}{l}\text { Syndicat intercommunal } \\
\text { des Etablissements du } \\
\text { second cycle du second } \\
\text { degré du District de } \\
\text { L'Hay-Les-Roses }\end{array}$ & 103 \\
\hline & 6 December & CE Ass. & Trognon & 82 \\
\hline & 18 December & CE Sect. & Duvignères (Mme) & 159 \\
\hline & 28 December & $\mathrm{CE}$ & $\begin{array}{l}\text { Société Valeo équipements } \\
\text { électriques }\end{array}$ & 174 \\
\hline \multirow[t]{10}{*}{2003} & 5 March & CE & UNSPIC & 295 \\
\hline & 18 June & $\mathrm{CE}$ & $\begin{array}{l}\text { Groupement d'entreprises } \\
\text { solidaires ETPO } \\
\text { Guadeloupe }\end{array}$ & 291 \\
\hline & 30 June & CE & $\begin{array}{l}\text { Section française de } \\
\text { l'observation } \\
\text { internationale des } \\
\text { prisons }\end{array}$ & 164 \\
\hline & 4 July & CE Ass. & Moya-Caville & 256 \\
\hline & 30 July & CE Sect. & $\begin{array}{l}\text { Association pour le } \\
\text { développement de } \\
\text { l'aquaculture en région } \\
\text { Centre }\end{array}$ & 259 \\
\hline & 30 July & $\mathrm{CE}$ & Commune de Lens & 289 \\
\hline & 10 October & $\mathrm{CE}$ & Cohen & 252,256 \\
\hline & 17 October & CE Sect. & Bouhsane & 201 \\
\hline & 3 December & CE Sect. & $\begin{array}{l}\text { Préfet Seine-maritime c El } \\
\quad \text { Bahi }\end{array}$ & 171 \\
\hline & 30 December & $\mathrm{CE}$ & $\begin{array}{l}\text { Comité contre la Guerre en } \\
\text { Iraq }\end{array}$ & 165 \\
\hline \multirow[t]{3}{*}{2004} & 8 October & $\mathrm{CE}$ & $\begin{array}{l}\text { Union française pour la } \\
\text { cohésion nationale }\end{array}$ & 206 \\
\hline & 29 October & $\mathrm{CE}$ & Sueur & 171 \\
\hline & 29 December & $\mathrm{TC}$ & Préfet des Deux-Sèvres & 135 \\
\hline \multirow[t]{6}{*}{2005} & 11 February & CE Sect. & Cie Axa Courtage & 255 \\
\hline & 11 May & CE Ass. & Association AC! and others & 126,170 \\
\hline & 25 May & $\mathrm{CE}$ & $\begin{array}{l}\text { Associations Reporters sans } \\
\quad \text { frontières }\end{array}$ & 112 \\
\hline & 1 July & CE Sect. & Abgrall & 113 \\
\hline & 27 July & $\mathrm{CE}$ & Département d'Essonne & 154 \\
\hline & 18 November & CE Sect. & $\begin{array}{l}\text { Société fermière de } \\
\text { Campoloro }\end{array}$ & 124 \\
\hline
\end{tabular}


(continued)

\begin{tabular}{|c|c|c|c|c|}
\hline & 5 December & CE & Mann Singh & 181,191 \\
\hline & 12 December & $\mathrm{TC}$ & $\begin{array}{l}\text { EURL Croisières lorraines } \\
\text { «La Bergamote } c \text { Voies } \\
\text { Navigables de France }\end{array}$ & 144 \\
\hline \multirow[t]{8}{*}{2006} & 25 January & $\mathrm{CE}$ & Marc-Antoine & $15,115,118$ \\
\hline & 1 February & CE Sect. & $\begin{array}{l}\text { Garde des Sceaux c } \\
\text { Mutuelle des instituteurs } \\
\text { de France }\end{array}$ & 255 \\
\hline & 13 March & $\mathrm{CE}$ & $\begin{array}{l}\text { Bayrou and Association de } \\
\text { défense des usagers des } \\
\text { autoroutes publiques de } \\
\text { France }\end{array}$ & 91 \\
\hline & 22 March & $\mathrm{CE}$ & SAJEGA & 214 \\
\hline & 24 March & CE Ass. & KPMG & 51,229 \\
\hline & 10 July & $\mathrm{CE}$ & Jacques A & 175 \\
\hline & 27 September & $\mathrm{CE}$ & Commune de Baalon & 246 \\
\hline & 16 October & TC & $\begin{array}{l}\text { Caisse centrale de } \\
\text { réassurance }\end{array}$ & 278 \\
\hline \multirow[t]{13}{*}{2007} & 8 February & CE Ass. & Gardedieu & 261 \\
\hline & 8 February & CE Ass. & $\begin{array}{l}\text { Société Arcelor Atlantique } \\
\text { et Lorraine }\end{array}$ & $12,4^{8}$ \\
\hline & 2 March & $\mathrm{CE}$ & $\begin{array}{l}\text { Société Banque française } \\
\text { commerciale de l'Océan } \\
\text { Indien }\end{array}$ & 243 \\
\hline & 6 April & CE Sect. & $\begin{array}{l}\text { Commune d'Aix-en- } \\
\text { Provence }\end{array}$ & 146 \\
\hline & 4 June & $\mathrm{CE}$ avis & Lagier, Consorts Guigon & 267 \\
\hline & 11 June & CAA Paris & $\mathrm{n}^{\circ}$ o6PAo1579 & 267 \\
\hline & 22 June & CE Sect. & Arfi & 202 \\
\hline & 9 July & $\mathrm{CE}$ & $M D$ & 246,251 \\
\hline & 16 July & CE Ass. & $\begin{array}{l}\text { Société Tropic Travaux } \\
\text { Signalisation }\end{array}$ & 291 \\
\hline & 26 September & $\mathrm{CE}$ & OPDHLM du Gard & 282 \\
\hline & 19 December & $\mathrm{CE}$ & $\begin{array}{l}\text { Société Campenon- } \\
\text { Bernard }\end{array}$ & 280 \\
\hline & 21 December & $\mathrm{CE}$ & $\begin{array}{l}\text { Centre hospitalière de } \\
\text { Vienne }\end{array}$ & 266 \\
\hline & 28 December & $\mathrm{CE}$ & Texier c Le Bail & 93 \\
\hline \multirow[t]{4}{*}{2008} & 15 February & $\mathrm{CE}$ & $\begin{array}{l}\text { Commune de La-Londe-lès- } \\
\text { Maure, }\end{array}$ & 282 \\
\hline & 20 February & $\mathrm{CE}$ & $\begin{array}{l}\text { Office National de la } \\
\text { Chasse et de la faune } \\
\text { sauvage }\end{array}$ & 282 \\
\hline & 20 February & $\mathrm{TC}$ & Verrière & 274 \\
\hline & 10 April & CE Sect. & $\begin{array}{l}\text { Société Jean-Claude } \\
\text { Decaux }\end{array}$ & 292 \\
\hline
\end{tabular}


(continued)

\begin{tabular}{|c|c|c|c|c|}
\hline & 18 June & $\mathrm{CE}$ & Gestas & 249,267 \\
\hline & 7 August & CE & $\begin{array}{l}\text { Ministre de l'agriculture et } \\
\text { de la pêche }\end{array}$ & 246 \\
\hline & 7 August & $\mathrm{CE}$ & SAGEP & 278 \\
\hline & 29 December & $\mathrm{CE}$ & OPHLM de Puteaux & 285 \\
\hline \multirow[t]{9}{*}{2009} & 8 April & $\mathrm{CE}$ & Laruelle & 251 \\
\hline & 6 May & $\mathrm{CE}$ & Khan & 104 \\
\hline & 15 May & CE & $\begin{array}{l}\text { Société France } \\
\text { conditionnement }\end{array}$ & 199 \\
\hline & 1 July & $\mathrm{CE}$ & Kohumoetini & 157 \\
\hline & 6 July & $\mathrm{TC}$ & Mario Bonato c APELIOR & 152 \\
\hline & 30 October & CE Ass. & Perreux & $13,4^{8}, 96$ \\
\hline & 25 November & $\mathrm{CE}$ & Association Promouvoir & 185 \\
\hline & 4 December & $\mathrm{CE}$ & $\begin{array}{l}\text { Minister of Immigration c } \\
\text { Hammou }\end{array}$ & 91 \\
\hline & 28 December & CE Ass. & Commune de Béziers & 293 \\
\hline \multirow[t]{5}{*}{2010} & 12 May & $\mathrm{CE}$ & Alberigo & 143 \\
\hline & 14 May & $\mathrm{CE}$ & Rujovic & $4^{8}$ \\
\hline & 9 September & CE & Société Babel & 289 \\
\hline & 13 December & $\mathrm{TC}$ & Société Greenyellow & 277 \\
\hline & 15 December & CE ord. & $\begin{array}{l}\text { Ministre de l'Education } \\
\text { Nationale c Pehrilhé }\end{array}$ & 220 \\
\hline \multirow[t]{10}{*}{2011} & 11 January & $\mathrm{CE}$ & Manoukian & 293 \\
\hline & 2 February & $\mathrm{CE}$ & Gérard A & 246 \\
\hline & 9 February & $\mathrm{CE}$ & Piazza & 200 \\
\hline & 14 March & $\mathrm{CE}$ & Ahmad & 92 \\
\hline & 21 March & CE Sect. & Christian Krupa & 246 \\
\hline & 21 March & CE Sect. & Commune de Béziers & 292 \\
\hline & 19 July & CE Ass. & $\begin{array}{l}\text { Commune de Montpellier, } \\
\text { Communauté urbaine } \\
\text { du Mans; Fédération de } \\
\text { la libre pensée du } \\
\text { Rhône; Commune de } \\
\text { Trélazé }\end{array}$ & 219 \\
\hline & ${ }_{14}$ October & CE Sect. & Commune de Valmeinier & 173 \\
\hline & 17 October & $\mathrm{TC}$ & $\begin{array}{l}\text { SCEA de Chéneau c } \\
\text { Interprofessional } \\
\text { nationale porcine } \\
\text { (INAPORC) and Centre } \\
\text { national } \\
\text { interprofessionnel de } \\
\text { l'économie laitière } \\
\text { (CNIEL) }\end{array}$ & 137 \\
\hline & 26 October & CE Ass. & $\begin{array}{l}\text { Association pour la } \\
\text { promotion de l'image }\end{array}$ & 196 \\
\hline
\end{tabular}


(continued)

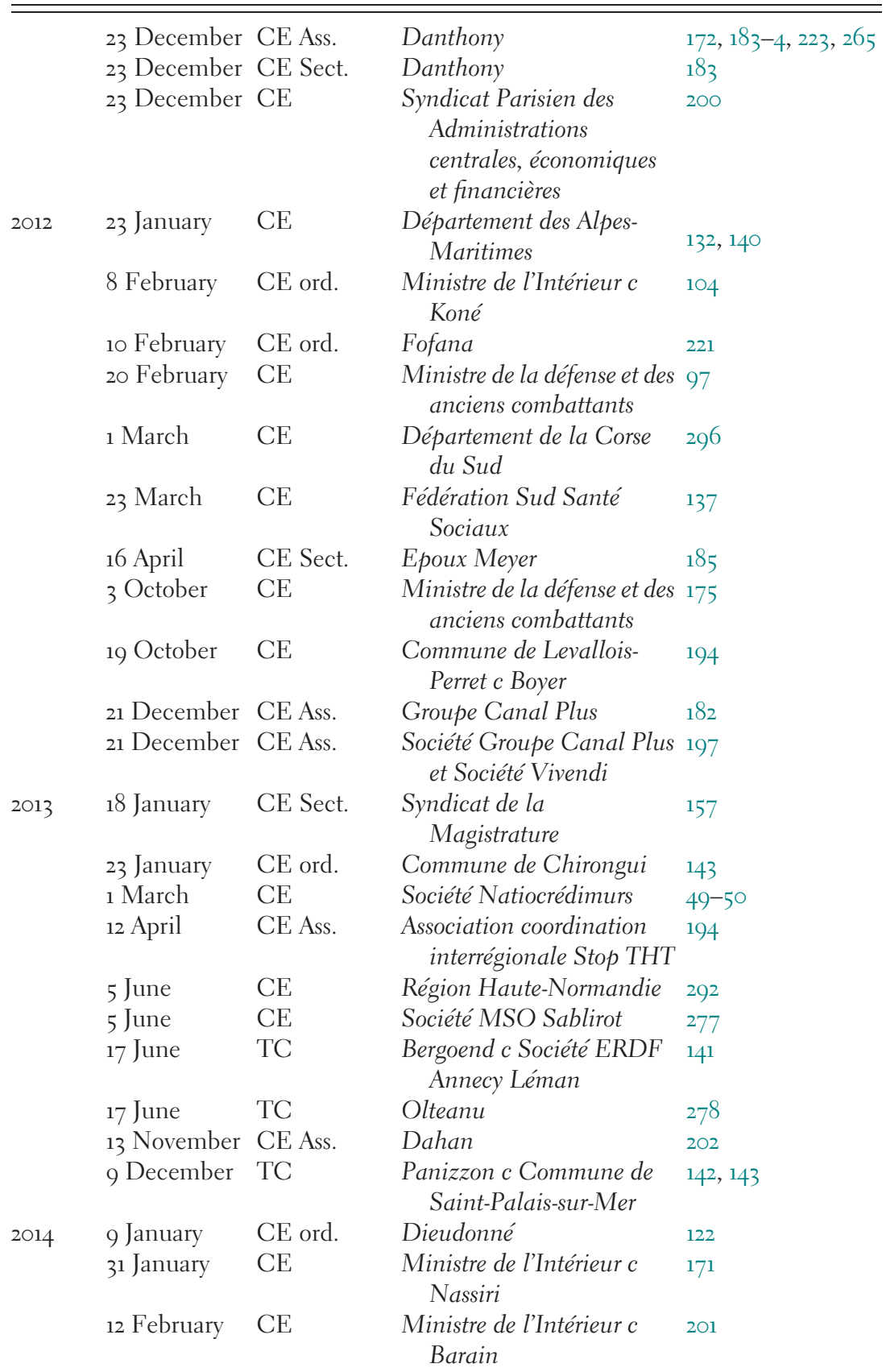


(continued)

\begin{tabular}{|c|c|c|c|c|}
\hline & 4 April & CE Ass. & $\begin{array}{l}\text { Département du Tarn-et- } \\
\text { Garonne }\end{array}$ & 291,293 \\
\hline & 4 April & CE Ass. & $\begin{array}{l}\text { Ministre de l'Ecologie, du } \\
\text { développement durable } \\
\text { et de l'énergie }\end{array}$ & 113 \\
\hline & 7 April & $\mathrm{TC}$ & $\begin{array}{c}\text { Société Services d'édition et } \\
\text { de ventes publicitaires }\end{array}$ & 278 \\
\hline & 24 June & CE Ass. & $\begin{array}{l}\text { Lambert (Mme Rachel), } \\
\text { Lambert (M. François) } \\
\text { ङ Centre hospitalier de } \\
\text { Reims }\end{array}$ & $\begin{array}{c}108-9,112-3 \\
114,209\end{array}$ \\
\hline & 1 October & CE Sect. & Erden & 111 \\
\hline & 8 October & $\mathrm{CE}$ & Société Grenke location & 286 \\
\hline & 13 October & TC & Société Axa France IARD & 274 \\
\hline & 22 October & $\mathrm{CE}$ & $\begin{array}{l}\text { Société Métropole } \\
\text { Télévision (M6) }\end{array}$ & 261 \\
\hline 2015 & 4 February & CE Sect. & $\begin{array}{l}\text { Ministre de l'Intérieur c } \\
\text { Cortes Ortiz }\end{array}$ & 161 \\
\hline & 6 May & $\mathrm{CE}$ & $\begin{array}{l}\text { Association tutélaire d'Ille- } \\
\text { et-Vilaire }\end{array}$ & 115 \\
\hline & 1 June & $\mathrm{CE}$ & Boromée & 203 \\
\hline & 9 June & TA Nice & $D$ & 206 \\
\hline & 9 July & $\mathrm{CE}$ & $\begin{array}{l}\text { Football Club des } \\
\text { Girondins de Bordeaux }\end{array}$ & 283 \\
\hline & 9 November & $\mathrm{CE}$ & $D$ and $B$ & 163 \\
\hline & 12 November & $\mathrm{CE}$ & $\begin{array}{l}\text { Société Le Jardin } \\
\text { d'acclimatation }\end{array}$ & 286 \\
\hline & 7 December & CE & $\begin{array}{l}\text { Syndicat Mixte de } \\
\quad \text { Pierrefonds }\end{array}$ & 294 \\
\hline 2016 & 24 February & $\mathrm{CE}$ & Département de l'Eure & 292 \\
\hline & 21 March & CE Ass. & $\begin{array}{l}\text { Société Fairvesta } \\
\quad \text { International GmbH }\end{array}$ & 41,161 \\
\hline & 21 March & CE Ass. & Société NC Numéricable & 161 \\
\hline & 3 May & $\mathrm{CE}$ & Lourdjane & 167 \\
\hline & 11 May & $\mathrm{CE}$ & $\begin{array}{l}\text { Commune de Levallois- } \\
\text { Perret }\end{array}$ & 194 \\
\hline & 6 June & TC & Commune d'Aragnouet & 274 \\
\hline & 8 June & $\mathrm{CE}$ & $\begin{array}{l}\text { Association française des } \\
\text { entreprises privées }\end{array}$ & 160 \\
\hline & 8 June & CE Ass. & Prats & 200 \\
\hline & 20 June & $\mathrm{CE}$ & $\begin{array}{l}\text { Association citoyenne } \\
\text { intercommunale des } \\
\text { populations concernées } \\
\text { par le projet d'aéroport } \\
\text { de Notre-Dame-des- } \\
\text { Landes }\end{array}$ & $76,226-7$ \\
\hline
\end{tabular}


(continued)

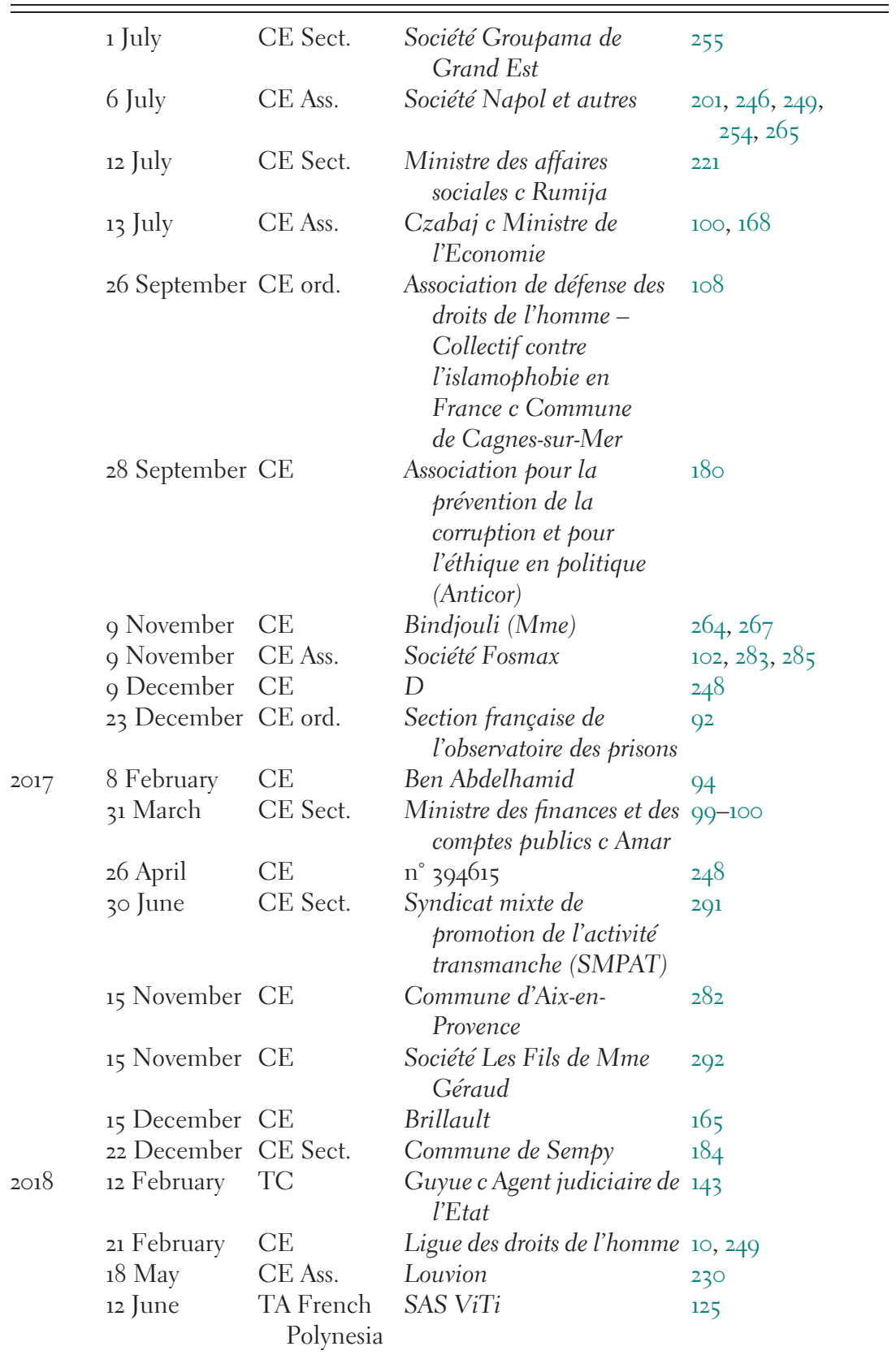


(continued)

\begin{tabular}{|c|c|c|c|c|}
\hline & 4 July & CE & $\begin{array}{l}\text { Association pour la } \\
\text { neutralité de } \\
\text { l'enseignement de } \\
\text { l'histoire turque dans les } \\
\text { programmes scolaires }\end{array}$ & 201 \\
\hline & 18 July & $\mathrm{CE}$ & Chennouf & 248 \\
\hline & 18 July & TA Paris & $V, W, X$ & 248 \\
\hline & 26 September & $\mathrm{CE}$ & Joublot & 201 \\
\hline & 5 October & $\mathrm{CE}$ & Société Edilys & 189 \\
\hline & 12 October & $\mathrm{CE}$ & Boutin & 217 \\
\hline & 3 December & CE Sect. & Bermond & 264 \\
\hline & 19 December & TA Poitiers & $n^{\circ} 1800409$ & 112 \\
\hline \multirow[t]{24}{*}{2019} & 1 February & $\mathrm{CE}$ & $L$ & 218 \\
\hline & 13 March & $\mathrm{CE}$ & $\begin{array}{c}\text { Syndicat intercommunale } \\
\text { pour l'aménagement } \\
\text { hydraulique du bassin } \\
\text { de la Berre et du Rieu }\end{array}$ & 238,265 \\
\hline & 18 March & $\mathrm{CE}$ & Commune de Chambéry & 238 \\
\hline & 27 March & TA Lyon & $B$ & 103 \\
\hline & 28 March & $\mathrm{CE}$ & Consorts Bendjebel & 118 \\
\hline & 10 April & $\mathrm{CE}$ & Cie nationale du Rhône & 237 \\
\hline & 23 April & CE ord. & $\mathrm{C}(\mathrm{Mme})$ and $\mathrm{D}(\mathrm{Mme})$ & 165 \\
\hline & 30 April & CE & $\begin{array}{l}\text { Société Total Marketing } \\
\text { France }\end{array}$ & 290 \\
\hline & 5 June & $\mathrm{CE}$ & Centre hospitalier de Sédan & 103 \\
\hline & 27 June & $\mathrm{CE}$ & SNESUP-FSU & 219 \\
\hline & 28 June & $\mathrm{CE}$ & $n^{\circ} 415863$ & 242 \\
\hline & 15 July & TA Bordeaux & Bordeaux Métropole & 103 \\
\hline & 19 July & CE Ass. & $\begin{array}{l}\text { Association des Américains } \\
\text { accidentels }\end{array}$ & 223 \\
\hline & 31 July & CE & Cimade & $4^{8}$ \\
\hline & 30 September & CE & $\begin{array}{l}\text { Compagnie méridionale de } \\
\text { navigation }\end{array}$ & 258 \\
\hline & 9 October & $\mathrm{CE}$ & $n^{\circ} 428634$ & 213 \\
\hline & 8 November & $\mathrm{CE}$ & $B A$ & 251 \\
\hline & 22 November & $\mathrm{CE}$ & $\begin{array}{l}\text { Centre hospitalier de } \\
\text { Vienne }\end{array}$ & 266 \\
\hline & 3 December & $\begin{array}{l}\text { CAA } \\
\text { Versailles }\end{array}$ & $n^{\circ} 16 \mathrm{VEO} 365$ & 231 \\
\hline & 6 December & CE Sect. & $\begin{array}{c}\text { Société des copropriétaires } \\
\text { de Montecarlo Hill }\end{array}$ & 292 \\
\hline & 9 December & $\mathrm{TC}$ & $\mathrm{C}$ & 247 \\
\hline & 24 December & CE Ass. & Laillat & 260 \\
\hline & 24 December & CE Ass. & Paris Eiffel Suffren & $260,261,263,265$ \\
\hline & 24 December & CE Ass. & Société Paris Clichy & 260 \\
\hline
\end{tabular}


(continued)

\begin{tabular}{|c|c|c|c|c|}
\hline \multirow[t]{22}{*}{2020} & 7 February & $\mathrm{CE}$ & $B$ & 223 \\
\hline & 10 February & $\mathrm{CE}$ & SAEM & 294 \\
\hline & 20 February & $\mathrm{CE}$ & $\begin{array}{l}\text { Elections municipals } \\
\text { Saint-Elie }\end{array}$ & 174 \\
\hline & 28 February & $\mathrm{CE}$ & Stassen & 223 \\
\hline & 22 March & CE ord. & Syndicat Jeunes Médecins & 108 \\
\hline & 27 March & $\mathrm{CE}$ & Société Géomat & 289 \\
\hline & 17 April & CE ord. & Commune de Sceaux & 37,181 \\
\hline & 30 April & CE ord. & $\begin{array}{l}\text { Fédération française des } \\
\text { usagers de la bicyclette }\end{array}$ & $104-5$ \\
\hline & 18 May & CE ord. & $\begin{array}{l}\text { Association «La } \\
\quad \text { Quadrature du Net» }\end{array}$ & $105-6$ \\
\hline & 18 May & CE ord. & $\begin{array}{l}\text { W and others (Church } \\
\text { Gatherings) }\end{array}$ & $\begin{array}{l}106,124,125,127 \\
\quad 170,173,197,207\end{array}$ \\
\hline & 22 May & CE ord. & Syndicat Jeunes Médecins & 107 \\
\hline & 12 June & CE Sect. & GISTI & $108,160,162$ \\
\hline & 19 June & $\mathrm{CE}$ & Société Google LLC & 39 \\
\hline & 10 July & CE & $\begin{array}{l}\text { Société comptoir Négoce } \\
\text { Equipement }\end{array}$ & 286,293 \\
\hline & 10 July & $\mathrm{CE}$ & $\begin{array}{l}\text { Société Lacroix } \\
\text { signalisation c Seine- } \\
\text { Maritime }\end{array}$ & 114,280 \\
\hline & 9 October & $\mathrm{CE}$ & Lectalis Ingredients SNC & 250 \\
\hline & 19 October & $\mathrm{CE}$ & M. B. & 202 \\
\hline & 19 November & $\mathrm{CE}$ & $\begin{array}{l}\text { Commune de Grande- } \\
\text { Synthe }\end{array}$ & 264 \\
\hline & 20 November & $\mathrm{CE}$ & $n^{\circ} 431508$ & 213 \\
\hline & 29 November & CE ord. & $\begin{array}{l}\text { Association Civitas, } \\
\text { Conférence des Evêques } \\
\text { de France }\end{array}$ & 173,206 \\
\hline & 11 December & $\mathrm{CE}$ & $\begin{array}{l}\text { Commune de Chalons-sur- } \\
\text { Saône }\end{array}$ & 215 \\
\hline & 23 December & $\mathrm{CE}$ & Association Autisme & 161 \\
\hline \multirow[t]{7}{*}{2021} & 26 January & $\mathrm{CE}$ & $n^{\circ} 431494$ & 215 \\
\hline & 3 February & TA Paris & $n^{\circ} 1904968$ & 264 \\
\hline & 15 April & $\mathrm{CE}$ & $\begin{array}{c}\text { Fédération Forestiers privés } \\
\text { de France (Fransylva) }\end{array}$ & 120 \\
\hline & 21 April & CE Ass. & La Quadrature du Net & 13,306 \\
\hline & 21 April & TA Paris & no. $1823994 / 2-2$ & 249 \\
\hline & 10 June & $\mathrm{CE}$ & $\begin{array}{l}\text { Syndicat national des } \\
\quad \text { journalistes }\end{array}$ & 208 \\
\hline & 28 June & CE & $\begin{array}{l}\text { Département des Alpes- } \\
\text { Maritimes }\end{array}$ & 195 \\
\hline
\end{tabular}


FRENCH CONSEIL CONSTITUTIONNEL CASES

\begin{tabular}{|c|c|c|c|c|}
\hline 1969 & 26 June & $\begin{array}{l}\text { Protection of } \\
\quad \text { Monuments }\end{array}$ & $n^{\circ} 69-55 \mathrm{~L}$ & 55 \\
\hline 1969 & 24 October & $\begin{array}{c}\text { Repayment of Fees } \\
\text { at the Ecole } \\
\text { Polytechnique }\end{array}$ & $n^{\circ} 69-57 \mathrm{~L}$ & 55 \\
\hline 1971 & 16 July & Associations Law & $n^{\circ} 71-44 \mathrm{DC}$ & 45,205 \\
\hline 1972 & 21 December & $\begin{array}{c}\text { Administrative } \\
\text { procedure }\end{array}$ & $\mathrm{n}^{\circ}{ }_{72-75} \mathrm{~L}$ & 55 \\
\hline 1973 & 28 November & $\begin{array}{l}\text { Criminal Penalties } \\
\text { (Rural Code) }\end{array}$ & $n^{\circ} 73-80 \mathrm{~L}$ & 205 \\
\hline 1977 & 23 November & $\begin{array}{l}\text { Freedom of } \\
\text { Education }\end{array}$ & $n^{\circ} 77-87 \mathrm{DC}$ & 45 \\
\hline 1979 & 25 July & $\begin{array}{l}\text { Strikes in Radio } \\
\text { and Television }\end{array}$ & $n^{\circ} 79-105$ DC & 45,218 \\
\hline 1980 & 22 July & $\begin{array}{l}\text { Validation of } \\
\text { Administrative } \\
\text { Decisions }\end{array}$ & $n^{\circ} 80-119$ DC & 9,128 \\
\hline 1981 & $\begin{array}{l}19 \& 20 \\
\text { January }\end{array}$ & $\begin{array}{l}\text { Security and } \\
\text { Liberty }\end{array}$ & $n^{\circ} 80-127 \mathrm{DC}$ & 198,205 \\
\hline \multirow[t]{2}{*}{1982} & 16 January & Nationalisations & $n^{\circ} 81-132$ DC & 44 \\
\hline & 22 October & $\begin{array}{l}\text { Trades Union } \\
\text { Immunity }\end{array}$ & $n^{\circ} 82-144$ DC & 239 \\
\hline 1985 & $\begin{array}{l}13 \text { December } \\
1985\end{array}$ & $\begin{array}{l}\text { Eiffel Tower } \\
\text { Amendment }\end{array}$ & $n^{\circ} 85-198 \mathrm{DC}$ & 136 \\
\hline \multirow[t]{2}{*}{1986} & $25 \& 26$ June & Privatisations & $n^{\circ} 86-207$ DC & 217 \\
\hline & 18 September & $\begin{array}{l}\text { Commission } \\
\text { Nationale de la } \\
\text { Communication } \\
\text { et des Libertés } \\
\text { (CNCL) }\end{array}$ & $n^{\circ} 86-217$ DC & $39 \cdot 40$ \\
\hline 1987 & 23 January & Competition Law & $n^{\circ} 86-224$ DC & $\begin{array}{c}9,45,128,131,138 \\
144,147,275\end{array}$ \\
\hline 1988 & 21 October & $\begin{array}{c}5 e \text { circonscription } \\
\text { du Val d'Oise }\end{array}$ & $\begin{array}{l}\mathrm{n}^{\circ} 88-1082 / \\
1107 \mathrm{AN}\end{array}$ & 11 \\
\hline \multirow[t]{3}{*}{1989} & 17 January & $\begin{array}{l}\text { Conseil Supérieur } \\
\text { de } \\
\text { l'Audiovisuel } \\
\text { (CSA), }\end{array}$ & $n^{\circ} 88-268 \mathrm{DC}$ & 39 \\
\hline & 25 July & TGV Nord & $n^{\circ} 89-256 \mathrm{DC}$ & 136 \\
\hline & 28 July & $\begin{array}{l}\text { Entry and } \\
\text { Residence of } \\
\text { Foreigners }\end{array}$ & $n^{\circ} 89-261$ DC & $91,131,135$ \\
\hline
\end{tabular}


(continued)

\begin{tabular}{|c|c|c|c|c|}
\hline & 29 December & $\begin{array}{l}\text { Finance Law for } \\
\qquad 1990\end{array}$ & $n^{\circ} 89-268 \mathrm{DC}$ & 92 \\
\hline 1990 & 29 May & Housing Law & $n^{\circ} 90-274$ DC & 220 \\
\hline \multirow[t]{2}{*}{1994} & 21 January & $\begin{array}{l}\text { Planning and } \\
\text { Construction }\end{array}$ & $\mathrm{n}^{\circ} 93-335 \mathrm{DC}$ & 168 \\
\hline & 27 July & Bioethics & $\begin{array}{c}\mathrm{n}^{\circ \mathrm{s}} 343 \text { and } \\
344 \text { DC }\end{array}$ & 45 \\
\hline 1997 & 18 December & Family Allowances & $n^{\circ} 97-393 \mathrm{DC}$ & 44 \\
\hline \multirow[t]{2}{*}{1998} & 6 March & $\begin{array}{l}\text { The Functioning of } \\
\text { Regional } \\
\text { Councils }\end{array}$ & $n^{\circ} 98-397$ DC & 34 \\
\hline & 29 July & $\begin{array}{l}\text { Fight against } \\
\text { Exclusions }\end{array}$ & $n^{\circ} 98-403 \mathrm{DC}$ & $25^{8}$ \\
\hline \multirow[t]{2}{*}{1999} & 15 June & $\begin{array}{l}\text { European Charter } \\
\text { of Regional and } \\
\text { Minority } \\
\text { Languages }\end{array}$ & $n^{\circ} 99-412 \mathrm{DC}$ & 35 \\
\hline & 16 December & Codification & $n^{\circ} 99-421$ DC & 229 \\
\hline 2002 & 17 January & Corsica & $n^{\circ} 2001-454$ DC & 34 \\
\hline 2003 & 13 March & $\begin{array}{l}\text { Internal } \\
\quad \text { Security Law }\end{array}$ & $n^{\circ} 2003-467$ DC & 135 \\
\hline \multirow[t]{2}{*}{2004} & 10 June & $\begin{array}{l}\text { Confidence in the } \\
\text { Digital } \\
\text { Economy }\end{array}$ & $n^{\circ} 2004-496 \mathrm{DC}$ & 49 \\
\hline & 12 August & $\begin{array}{l}\text { Law on the } \\
\text { Freedoms and } \\
\text { Responsibilities } \\
\text { of Local } \\
\text { Authorities }\end{array}$ & $n^{\circ} 2004-503$ DC & 220 \\
\hline 2006 & 28 December & $\begin{array}{l}\text { Workers' } \\
\quad \text { Participation }\end{array}$ & $\mathrm{n}^{\circ} 2006-545 \mathrm{DC}$ & 137 \\
\hline \multirow[t]{2}{*}{2008} & 21 February & $\begin{array}{l}\text { Detention for } \\
\text { Security }\end{array}$ & $n^{\circ} 2008-562 \mathrm{DC}$ & 197 \\
\hline & 21 February & $\begin{array}{l}\text { Indefinite } \\
\text { Sentences }\end{array}$ & $n^{\circ} 2008-562 \mathrm{DC}$ & 197,198 \\
\hline 2010 & 26 November & Danielle S & $n^{\circ} 2010-71$ QPC & 135 \\
\hline 2011 & $\begin{array}{l}11 \text { February } \\
25 \text { March } \\
8 \text { April }\end{array}$ & $\begin{array}{l}\text { Viviane L } \\
\text { Jean-Pierre B }\end{array}$ & $\begin{array}{l}n^{\circ} 2010-102 \text { QPC } \\
n^{\circ} 2010-110 \text { QPC } \\
n^{\circ} 2011-116 \text { QPC }\end{array}$ & $\begin{array}{l}229 \\
82 \\
264\end{array}$ \\
\hline 2012 & 27 January & $\begin{array}{l}\text { Société } \\
\quad \text { COVED SA }\end{array}$ & $n^{\circ} 2011-214$ QPC & 10 \\
\hline 2013 & $\begin{array}{l}8 \text { June } \\
1 \text { August }\end{array}$ & $\begin{array}{l}\text { Christian G } \\
\text { Société Natixis } \\
\text { Asset } \\
\text { Management }\end{array}$ & $\begin{array}{l}n^{\circ} 2012-250 \text { QPC } \\
n^{\circ} 2013-336 \text { QPC }\end{array}$ & $\begin{array}{l}82 \\
260\end{array}$ \\
\hline
\end{tabular}


(continued)

\begin{tabular}{|c|c|c|c|c|}
\hline & 4 December & Fiscal Fraud & $n^{\circ} 2013-679$ DC & 135 \\
\hline & 19 December & $\begin{array}{l}\text { Finance Law for } \\
\text { Social Security } \\
\quad \text { for } 2014\end{array}$ & $n^{\circ} 2013-682$ DC & 229 \\
\hline 2014 & 14 November & $\begin{array}{l}\text { Special Tax on Fire } \\
\text { Insurance }\end{array}$ & $n^{\circ} 2014-425$ QPC & 213 \\
\hline 2015 & 22 December & Cédric D & $\mathrm{n}^{\circ} 2015-527$ QPC & 135 \\
\hline 2016 & 19 February & $\begin{array}{l}\text { Ligue des droits de } \\
\text { l'homme }\end{array}$ & $n^{\circ} 2016-536$ QPC & 249 \\
\hline 2017 & 28 December & $\begin{array}{l}\text { Finance Law for } \\
2018\end{array}$ & $\mathrm{n}^{\circ} 2017-758 \mathrm{DC}$ & 213 \\
\hline 2018 & 1 June & $\begin{array}{l}\text { Section française de } \\
\text { l'observatoire } \\
\text { international des } \\
\text { prisons }\end{array}$ & $n^{\circ} 2018-709$ QPC & 169 \\
\hline 2019 & 21 March & Justice Reform & $\mathrm{n}^{\circ} 2019-778 \mathrm{DC}$ & 76 \\
\hline \multirow[t]{3}{*}{2020} & 28 February & Raphaël S. & $\begin{array}{c}n^{\circ} 2019-828 / \\
829 \text { QPC }\end{array}$ & 260 \\
\hline & 28 May & Force 5 & $n^{\circ} 2020-843$ QPC & 29 \\
\hline & 9 July & $\begin{array}{l}\text { Deconfinement } \\
\text { Law }\end{array}$ & $\mathrm{n}^{\circ} 2020-803$ DC & 198 \\
\hline
\end{tabular}

\section{COUR DE CASSATION CASES}

\begin{tabular}{llll}
\hline \hline 1967 & 17 July 1967 & Cass. $2^{\mathrm{e}}$ civ. & 241 \\
1975 & 24 May 1975 & Cass ch. mixte & 11 \\
1986 & 10 June 1986 & Cass. 1re civ & 253 \\
2000 & 22 December 2000 & Cass. Ass. plén. & 82 \\
2015 & 11 March 2015 & Cass. 3 civ. & 142 \\
2016 & 13 December 2016 & Crim. & 134 \\
2019 & 29 January 2019 & Crim. & 133 \\
\hline \hline
\end{tabular}




\section{EUROPEAN UNION CASES}

\begin{tabular}{|c|c|c|c|}
\hline 1960 & 15 July & $\begin{array}{l}\text { Präsident Ruhrkolen- } \\
\quad \text { Verkaufsgesellschaft mbH }\end{array}$ & 211 \\
\hline 1962 & 6 April & $\begin{array}{l}\text { Kledingverkoopbedriif De Geus en } \\
\text { Uitdenbogerd v Bosch Gmbh }\end{array}$ & 228 \\
\hline 1974 & 14 May & Nold v Commission & 45 \\
\hline 1975 & 28 October & Rutili & 11 \\
\hline 1981 & 5 May & $\begin{array}{l}\text { Firma Anton Dürbeck v Hauptzollamt } \\
\text { Frankfurt am Main-Flughafen }\end{array}$ & 228 \\
\hline 1986 & 15 May & $\begin{array}{l}\text { Johnston } v \text { Chief Constable of Northern } \\
\text { Ireland }\end{array}$ & 91,169 \\
\hline 2001 & 22 March & France v Commission & 160 \\
\hline \multirow[t]{2}{*}{2003} & 20 May & Österreichischer Rundfunck & 197 \\
\hline & 30 September & Köbler v Austria & 250 \\
\hline 2006 & 5 October & Commission v France & 167 \\
\hline \multirow[t]{2}{*}{2008} & 19 June & Pressetext Nachrichtenagentur & 297 \\
\hline & 16 December & $\begin{array}{l}\text { Société Arcelor Atlantique et Lorraine v } \\
\text { Premier ministre }\end{array}$ & 12 \\
\hline 2012 & 29 March & SAG ELV Slovensko a.s. & 296 \\
\hline \multirow[t]{2}{*}{2016} & 14 July & Promoimpresa Srl. & 279 \\
\hline & 7 September & Finn Frogne A/S & 297 \\
\hline 2018 & 4 October & Commission v France & 119 \\
\hline 2020 & 6 October & La Quadrature du Net & 13 \\
\hline
\end{tabular}

\section{EUROPEAN COURT OF HUMAN RIGHTS CASES}

\begin{tabular}{llll}
\hline \hline 1979 & 13 June & Marckx and Marckx v Belgium & 228 \\
1986 & 18 December & Bozano & 135 \\
1991 & 30 October & Borgers v Belgium & 16 \\
1995 & 28 September & Procola v Luxembourg & 15,76 \\
1996 & 20 February & Lobo Machado v Portugal & 16 \\
1998 & 31 March & Reinhardt and Slimane Kaïd v France & 16,18 \\
2001 & 7 June & Kress v France & $16,17,72,95,118$ \\
2005 & 10 November & Leyla Shahin v Turkey & 206,209 \\
2006 & 12 April & Martinie v France & 18,19 \\
& 15 June & Lykourezos v Greece & 228 \\
2008 & 4 December & S and Marper v UK & 197 \\
2013 & 4 December & Marc-Antoine v France & $15,115,118$ \\
2014 & 1 July & SAS v France & 206 \\
2015 & 5 June & Lambert v France & 109,209 \\
\hline \hline
\end{tabular}




\section{Table of Cases by Name}

\section{FRENCH ADMINISTRATIVE LAW CASES (INCLUDING TRIBUNAL DES CONFLITS)}

Cases are listed by surnames of individuals, not by title (Consorts, Dame, Epoux, M, Mlle, Mme), except for Abbé.

\begin{tabular}{|c|c|c|}
\hline Abbé Boutèyre & CE 10 May 1912 & 212,219 \\
\hline Abbé Olivier & CE 19 February 1909 & 196,198 \\
\hline Abdoulhoussan & CE 23 November 1936 & 213 \\
\hline Abgrall & CE Sect. 1 July 2005 & 113 \\
\hline Abisset & CE 14 February $195^{8}$ & 156 \\
\hline Achart (Demoiselle) & CE 13 July 1961 & 192 \\
\hline Action française & TC 8 April 1935 & 142 \\
\hline Adam & CE Ass. 22 February 1974 & 194 \\
\hline Adrasse & CE Sect. 13 June 1975 & 116 \\
\hline AGAP de Paris c Chevreau & CE 22 November 1967 & 196 \\
\hline $\begin{array}{l}\text { Agence maritime Marseille- } \\
\text { Fret }\end{array}$ & CE Ass. 27 November 1970 & 230 \\
\hline $\begin{array}{l}\text { Agent judiciaire du Trésor c } \\
\text { Miglierina }\end{array}$ & TC 22 June 1998 & 274 \\
\hline Ahmad & CE 14 March 2011 & 92 \\
\hline \multicolumn{3}{|l|}{$\begin{array}{l}\text { Aide et Protection see Caisse } \\
\quad \text { primaire }\end{array}$} \\
\hline Akhras & CE Sect. 28 February 1986 & 122 \\
\hline Alberigo & CE 12 May 2010 & 143 \\
\hline Allain & CE 20 February 1989 & 165 \\
\hline Allarousse & CE 30 November 1904 & 94 \\
\hline Améon & CE Sect. 13 March 1998 & 246 \\
\hline
\end{tabular}


(continued)

Amicale des Annamites de Paris

Anguet

Aramu

Arfi

Artaud

Association AC! and others

Association autisme

Association citoyenne intercommunale des populations concernées par le projet d'aéroport de NotreDame-des-Landes

Association Civitas, Conférence des Evêques de France

Association contre le projet autoroute transchablaisienne

Association coordination interrégionale Stop THT

Association de défense des droits de l'homme Collectif contre l'islamophobie en France c Commune de Cagnessur-Mer

Association de défense et de protection de l'environnement de SaintCome-d'Olt

Association des Américains accidentels

Association Eurolat

Association française des entreprises privées

Association Greenpeace France

Association La Cimade

Association «La Quadrature du Net»

Association 'Les Verts'

Association ornithologique et mammalogique de Saône-etLoire
CE Ass. 11 July 1956

CE 3 February 1911

242

CE Ass. 26 October 1945

CE Sect. 22 June $2007 \quad 202$

CE 27 May 1957

CE Ass. 11 May 2005 126, 170

CE 23 December $2020 \quad 161$

CE 20 June $2016 \quad 76,226-7$

CE ord. 29 November $2020 \quad$ 173, 206

CE Ass. 28 March $1997 \quad 195$

CE Ass. 12 April 2013

CE ord. 26 September $2016 \quad 108$

CE 3 July 1998

172

CE Ass. 19 July 2019

223

CE 6 May $1985 \quad 284$

CE 8 June 2016

CE 29 September $1995 \quad 165$

CE 31 July 2019

$4^{8}$

CE ord. 18 May 2020

$105-6$

CE Ass. 23 November $1984 \quad 165$

CE Sect. 3 December $1999 \quad 47$ 
(continued)

Association pour la neutralité

de l'enseignement de

l'histoire turque dans les

programmes scolaires

Association pour la prévention

CE 28 September 2016

180

de la corruption et pour

l'éthique en politique

(Anticor)

Association pour la promotion de l'image

Association pour le développement de

CE 4 July 2018

201

l'aquaculture en région

Centre

Association Promouvoir

CE 25 November 2009

185

Association syndicale du

Canal de Grignac

Association tutélaire d'Ille-et-

Vilaire

CE Ass. 26 October $2011 \quad 196$

CE Sect. 30 July $2003 \quad 259$

TC 9 December 1899

144

CE 6 May 2015

115

CE 25 May 2005

112

$$
\text { frontières }
$$

Avranches et Desmarets

$B$

$B$

TC 5 July 1951

133

CE 7 February 2020

223

TA Lyon 27 March $2019 \quad 103$

$B A$

CE 8 November $2019 \quad 251$

Babas and Belgacem

CE Ass. 19 April 1991

198

Banque de France $c$

Huberschwiller

CE Sect. 23 December 1988

92

CE Ass. 28 May 1954

96, 112, 190, 191,

$210,212,230$

TC 20 October 1947

132

CE 13 March 2006

91

défense des usagers des autoroutes publiques de France

Belmont

Ben Abdelhamid

Bendjebel (Consorts)

Benjamin

Bereciartua-Echarri

Bergoend c Société ERDF

Annecy Léman

Bergon

Bermond

CE 28 December $1917 \quad 280$

CE 8 February $2017 \quad 94$

CE 28 March $2019 \quad 118$

CE 19 May 1933

CE Ass. 1 April 1988

TC 17 June 2013

CE 22 October 1975

CE Sect. 3 December 2018
$196,198,202$

211

141

248

264 
(continued)

\begin{tabular}{|c|c|c|}
\hline Bertin (Epoux) & CE Sect. 20 April 1956 & 272 \\
\hline Berton & CE Ass. 29 June 2001 & 216 \\
\hline Bes & CE 24 June 1987 & 187 \\
\hline Beucher & CE 29 December 1995 & 157 \\
\hline Beule & CE 29 December 2000 & 282 \\
\hline \multicolumn{3}{|l|}{$\begin{array}{l}\text { Béziers I see Commune de } \\
\text { Béziers (2009) }\end{array}$} \\
\hline \multicolumn{3}{|l|}{$\begin{array}{l}\text { Béziers II see Commune de } \\
\text { Béziers (2011) }\end{array}$} \\
\hline Bianchi & CE Ass. 9 April 1993 & 256,268 \\
\hline \multicolumn{3}{|l|}{$\begin{array}{l}\text { Bicycles see Fédération } \\
\text { française des usagers }\end{array}$} \\
\hline Bindjouli (Mme) & CE 9 November 2016 & 264,267 \\
\hline Blanco & TC 8 February 1873 & $\begin{array}{l}24,140,148,234 \\
236,251,268\end{array}$ \\
\hline Bobard & CE 3 July 1936 & 213 \\
\hline Bordeaux Métropole & TA Bordeaux 15 July 2019 & 103 \\
\hline Boromée & CE 1 June 2015 & 203 \\
\hline Bouguen & CE Ass. 2 April 1943 & 146 \\
\hline Bouhanna & CE Sect. 28 February 1986 & 122,190 \\
\hline Bouhsane & CE Sect. 17 October 2003 & 201 \\
\hline Bouteyre & CE 10 May 1912 & 212,219 \\
\hline Boutin & CE 12 October 2018 & 217 \\
\hline Bréart de Boisanger & CE Ass. 13 July 1962 & 187 \\
\hline Brillault & CE 15 December 2017 & 165 \\
\hline Brocas & CE Ass. 19 October 1962 & 164 \\
\hline $\mathrm{C}$ & TC g December 2019 & 247 \\
\hline $\mathrm{C}(\mathrm{Mme})$ and $\mathrm{D}(\mathrm{Mme})$ & CE ord. 23 April 2019 & 165 \\
\hline Cadot & CE 13 December 1889 & 64,89 \\
\hline Caisse centrale de réassurance & TC 16 October 2006 & 278 \\
\hline $\begin{array}{l}\text { Caisse primaire "Aide et } \\
\quad \text { Protection }\end{array}$ & CE Ass. 13 May $193^{8}$ & 145 \\
\hline Cames & CE 21 June 1895 & 256 \\
\hline Camino & CE 14 January 1916 & $93,188-9$ \\
\hline Carlier & CE Ass. 18 November 1949 & 143 \\
\hline Carliez & CE Sect. 19 June 1981 & 249 \\
\hline Carsalade & CE 27 March 1957 & 285 \\
\hline Casanova & CE 29 March 1901 & 157 \\
\hline Cayzeele & CE Ass. 10 July 1996 & 289 \\
\hline Cazautets (Consorts) & TC 2 July 1962 & 274 \\
\hline CCI de Meurthe et Moselle & $\mathrm{CE}_{2}$ October 2002 & 216 \\
\hline Centre du château de Gleteins & CE 16 February 2001 & 114 \\
\hline Centre hospitalier de Sédan & CE 5 June 2019 & 103 \\
\hline Centre hospitalier de Vienne & CE 22 November 2019 & 266 \\
\hline $\begin{array}{l}\text { Chambre syndicale des } \\
\text { propriétaires de Marseille }\end{array}$ & CE 10 February 1928 & 214 \\
\hline Chapou & CE 20 October 1954 & 163 \\
\hline
\end{tabular}


(continued)

\begin{tabular}{|c|c|c|}
\hline Charton & $\mathrm{CE}_{4}$ December 1925 & 212 \\
\hline Chennouf & CE 18 July 2018 & 248 \\
\hline Chomel & CE 29 December 1911 & 214 \\
\hline Christian Krupa & CE Sect. 21 March 2011 & 246 \\
\hline \multicolumn{3}{|l|}{$\begin{array}{l}\text { Church Gatherings see W } \\
\text { and others }\end{array}$} \\
\hline Cie Axa Courtage & CE Sect. 11 February 2005 & 255 \\
\hline Cie nationale du Rhône & CE 10 April 2019 & 237 \\
\hline Cimade & CE 31 July 2019 & $4^{8}$ \\
\hline Cohen & CE 10 October 2003 & 252,256 \\
\hline Colombani & CE Ass. 29 April 1994 & 286 \\
\hline $\begin{array}{l}\text { Comité contre la Guerre en } \\
\text { Iraq }\end{array}$ & CE 30 December 2003 & 165 \\
\hline $\begin{array}{l}\text { Comité interprofessionnel du } \\
\text { Gruyère de Comté }\end{array}$ & CE 27 April 1987 & 212 \\
\hline $\begin{array}{l}\text { Commissaire de la République } \\
\text { pour la région d'Alsace }\end{array}$ & TC 9 June 1986 & 143 \\
\hline $\begin{array}{l}\text { Communauté de communes } \\
\text { du Piémont de Barr }\end{array}$ & CE 20 May $199^{8}$ & 296 \\
\hline Commune d'Aix-en-Provence & CE 15 November 2017 & 282 \\
\hline Commune d'Aix-en-Provence & CE Sect. 6 April 2007 & 146 \\
\hline Commune d'Aragnouet & TC 6 June 2016 & 274 \\
\hline Commune de Baalon & CE 27 September 2006 & 246 \\
\hline $\begin{array}{l}\text { Commune de Batz-sur-Mer c } \\
\text { Tesson }\end{array}$ & CE Sect. 25 September 1970 & 257 \\
\hline Commune de Béziers & CE Ass. 28 December 2009 & 293 \\
\hline Commune de Béziers & CE Sect. 21 March 2011 & 292 \\
\hline Commune de Bozas & CE Ass. 27 February 1970 & 55 \\
\hline Commune de Canari & CE Sect. 17 October 1975 & 289 \\
\hline $\begin{array}{l}\text { Commune de Chalons-sur- } \\
\text { Saône, }\end{array}$ & CE 11 December 2020 & 215 \\
\hline Commune de Chambéry & CE 18 March 2019 & 238 \\
\hline Commune de Chirongui & CE ord. 23 January 2013 & 143 \\
\hline $\begin{array}{l}\text { Commune de Fontenay-le- } \\
\text { Fleury }\end{array}$ & CE 23 May 1979 & 292 \\
\hline Commune de Gavarnie & CE Sect. 22 February 1963 & 258 \\
\hline Commune de Grande-Synthe & CE 19 November 2020 & 264 \\
\hline Commune de Grigny & CE Sect. 22 March 1957 & 257 \\
\hline $\begin{array}{l}\text { Commune de Guidel c Mme } \\
\text { Courtet }\end{array}$ & CE Sect. 7 July 1982 & 57 \\
\hline Commune de Hannapes & CE 29 April 1998 & 246 \\
\hline $\begin{array}{l}\text { Commune de La-Londe-lès- } \\
\text { Maure }\end{array}$ & CE 15 February 2008 & 282 \\
\hline Commune de Lavaur c Lozar & CE 9 May 1990 & 180 \\
\hline Commune de Lens & CE 30 July 2003 & 289 \\
\hline
\end{tabular}


(continued)

\begin{tabular}{|c|c|c|}
\hline Commune de Levallois-Perret & CE 11 May 2016 & 194 \\
\hline $\begin{array}{l}\text { Commune de Levallois-Perret c } \\
\text { Boyer }\end{array}$ & CE 19 October 2012 & 194 \\
\hline Commune de Menton & CE 1 April 1994 & 283 \\
\hline $\begin{array}{l}\text { Commune de Montpellier, } \\
\text { Communauté urbaine du } \\
\text { Mans; Fédération de la libre } \\
\text { pensée du Rhône; } \\
\text { Commune de Trélazé }\end{array}$ & CE Ass. 19 July 2011 & 219 \\
\hline Commune de Noisy-le-Grand & CE 21 July 1989 & 166 \\
\hline $\begin{array}{l}\text { Commune de Saint-Priest-La- } \\
\text { Plaine }\end{array}$ & CE Ass. 22 November 1946 & 256 \\
\hline Commune de Sceaux & CE ord. 17 April 2020 & 37,191 \\
\hline Commune de Sempy & CE Sect. 22 December 2017 & 184 \\
\hline Commune de Staffelfelden & CE 14 June 2000 & 288 \\
\hline Commune de Valmeinier & CE Sect. 14 October 2011 & 173 \\
\hline Commune de Vizille & CE 16 May 1941 & 285 \\
\hline $\begin{array}{l}\text { Compagnie Air France c } \\
\text { Barbier }\end{array}$ & TC 15 January 1968 & 147 \\
\hline Compagnie Alitalia & CE Ass. 3 February 1989 & $11,50,223$ \\
\hline $\begin{array}{l}\text { Compagnie départementale } \\
\text { des eaux }\end{array}$ & CE 20 January 1905 & 286 \\
\hline $\begin{array}{l}\text { Compagnie des tramways de } \\
\text { Cherbourg }\end{array}$ & CE 9 December 1932 & 288 \\
\hline $\begin{array}{l}\text { Compagnie financière et } \\
\text { industrielle des autoroutes } \\
\text { (COFIROUTE) }\end{array}$ & CE Ass. (avis) 6 April 1990 & 258 \\
\hline $\begin{array}{l}\text { Compagnie générale } \\
\text { d'éclairage de Bordeaux }\end{array}$ & CE 30 March 1916 & 287 \\
\hline $\begin{array}{l}\text { Compagnie générale française } \\
\text { des tramways }\end{array}$ & CE 11 March 1910 & 284 \\
\hline $\begin{array}{l}\text { Compagnie méridionale de } \\
\text { navigation }\end{array}$ & CE 30 September 2019 & 258 \\
\hline $\begin{array}{l}\text { Compagnie nationale du } \\
\text { Rhone }\end{array}$ & CE 10 April 2019 & 237 \\
\hline $\begin{array}{l}\text { Compagnie nouvelle du Gaz } \\
\text { de Deville-lès-Rouen }\end{array}$ & CE 10 January 1902 & 286 \\
\hline Cook et Fils & CE 5 May 1899 & 156 \\
\hline Couespel de Mesnil & CE Sect. 1 May 1936 & 96 \\
\hline Couitéas & CE 30 November 1923 & 257 \\
\hline Coulon & CE 11 March 1955 & 93 \\
\hline $\begin{array}{l}\text { Czabaj c Ministre de } \\
\text { l'Economie }\end{array}$ & CE Ass. 13 July 2016 & 100,168 \\
\hline$D$ & TA Nice 9 June 2015 & 206 \\
\hline$D$ & CE 9 Dec 2016 & 248 \\
\hline$D$ and $B$ & CE 9 November 2015 & 163 \\
\hline
\end{tabular}


(continued)

\begin{tabular}{|c|c|c|}
\hline Dahan & CE Ass. 13 November 2013 & 202 \\
\hline Danthony & CE Ass. 23 December 2011 & $172,183-4,223,265$ \\
\hline Danthony & CE Sect. 23 December 2011 & 183 \\
\hline Daramy & CE Ass. 24 June 1949 & 254 \\
\hline Darmont & CE Ass. 29 December 1978 & 247 \\
\hline David (Dame) & $\mathrm{CE}_{4}$ October 1974 & 53 \\
\hline De Robert Lafrégeyre & CE 26 January 1923 & 279 \\
\hline Debout & CE Sect. 27 October 1978 & 52 \\
\hline Dehaene & CE Ass. 7 July 1950 & 217 \\
\hline Denizet & CE 13 November 1953 & 192 \\
\hline Département d'Essonne & CE 27 July 2005 & 154 \\
\hline Département de l'Eure & CE 24 February 2016 & 292 \\
\hline $\begin{array}{l}\text { Département de la Corse } \\
\quad \text { du Sud }\end{array}$ & CE 1 March 2012 & 296 \\
\hline $\begin{array}{l}\text { Département des Alpes- } \\
\quad \text { Maritimes }\end{array}$ & CE 23 January 2012 & 132,140 \\
\hline $\begin{array}{l}\text { Département des Alpes- } \\
\text { Maritimes }\end{array}$ & CE 28 June 2021 & 195 \\
\hline $\begin{array}{l}\text { Département du Tarn-et- } \\
\text { Garonne }\end{array}$ & CE Ass. 4 April 2014 & 291,293 \\
\hline Didier & CE Ass. 3 December 1999 & 52 \\
\hline Dieudonné & CE ord. 9 January 2014 & 122 \\
\hline Distilleries de Magnac-Laval & CE Ass. 2 May $195^{8}$ & 286 \\
\hline $\begin{array}{l}\text { District urbain de } \\
\text { l'agglomération rennaise c } \\
\text { Société des automobiles } \\
\text { Citroën }\end{array}$ & TC 7 December 1998 & 132 \\
\hline Domergue & CE 26 April 1950 & 281 \\
\hline Duchâtellier & CE 11 January 1838 & 259 \\
\hline Dumont & CE 23 November 1988 & 157 \\
\hline Duvignères (Mme) & CE Sect. 18 December 2002 & 159 \\
\hline $\begin{array}{l}\text { Elections municipals Saint- } \\
\quad \text { Elie }\end{array}$ & CE 20 February 2020 & 174 \\
\hline Erden & CE Sect. 1 October 2014 & 111 \\
\hline Esclatine & CE CE 29 July 1998 & 92 \\
\hline $\begin{array}{l}\text { EURL Croisières lorraines } \\
\text { «La Bergamote »c Voies } \\
\text { Navigables de France }\end{array}$ & TC 12 December 2005 & 144 \\
\hline Fabrègue & CE 23 July 1909 & 186 \\
\hline Fauvry & CAA Lyon 28 December 1990 & 250 \\
\hline $\begin{array}{l}\text { Fédération des comités de } \\
\text { défense contre le tracé de } \\
\text { l'autoroute A } 28\end{array}$ & CE Ass. 28 March 1997 & 194 \\
\hline $\begin{array}{c}\text { Fédération des parents d'élèves } \\
\text { de l'enseignement public }\end{array}$ & CE Ass. 21 October 1988 & 218 \\
\hline
\end{tabular}


(continued)

\begin{tabular}{|c|c|c|}
\hline $\begin{array}{l}\text { Fédération Forestiers privés de } \\
\text { France (Fransylva) }\end{array}$ & CE 15 April 2021 & 120 \\
\hline $\begin{array}{l}\text { Fédération française } \\
\text { d'haltérophilie, } \\
\text { musculation et disciplines } \\
\text { associées }\end{array}$ & CE 25 May 1998 & 186 \\
\hline $\begin{array}{l}\text { Fédération française des } \\
\text { usagers de la bicyclette }\end{array}$ & CE ord. 30 April 2020 & $104-5$ \\
\hline $\begin{array}{l}\text { Fédération nationale des } \\
\text { syndicats de producteurs } \\
\text { autonomes d'électricité }\end{array}$ & CE 26 July 1991 & 199 \\
\hline $\begin{array}{l}\text { Fédération nationale du } \\
\text { commerce extérieur des } \\
\quad \text { produits alimentaires }\end{array}$ & CE Ass. 26 October 1990 & 119 \\
\hline Fédération Sud Santé Sociaux & CE 23 March 2012 & 137 \\
\hline Feutry & TC 29 February 1908 & 241,243 \\
\hline Films Lutetia & CE 18 December 1959 & 217 \\
\hline Fofana & CE ord. 10 February 2012 & 221 \\
\hline Fontan (Sieur) & CE 5 May 1922 & 213 \\
\hline $\begin{array}{l}\text { Football Club des Girondins } \\
\text { de Bordeaux }\end{array}$ & CE 9 July 2015 & 283 \\
\hline Gambus & CE 20 March 1987 & 201 \\
\hline $\begin{array}{l}\text { Garde des Sceaux c Banque } \\
\text { Populaire de Strasbourg }\end{array}$ & CE 29 April 1987 & 255 \\
\hline Garde des Sceaux c Magiera & CE Ass. 28 June 2002 & $95,227,247$ \\
\hline $\begin{array}{c}\text { Garde des Sceaux c Mutuelle } \\
\text { des instituteurs de France }\end{array}$ & CE Sect. 1 February 2006 & 255 \\
\hline Gardedieu & CE Ass. 8 February 2007 & 261 \\
\hline Gérard A & CE 2 February 2011 & 246 \\
\hline Gervaise & CE 10 July 1957 & 15 \\
\hline Gestas & CE 18 June 2008 & 249,267 \\
\hline Giraud & CE 27 January 1988 & 251 \\
\hline GISTI & CE Ass. 29 June 1990 & 14,164 \\
\hline GISTI & CE Sect. 12 June 2020 & $108,160,162$ \\
\hline GISTI and MRAP & CE 23 September 1992 & 165 \\
\hline \multicolumn{3}{|c|}{$\begin{array}{l}\text { GISTI see Groupe d'Information } \\
\text { et de Soutien des Travailleurs } \\
\text { Immigrés }\end{array}$} \\
\hline Gomel & $\mathrm{CE}_{4}$ April 1914 & 189,201 \\
\hline Grassin & CE Sect. 26 October 1973 & 194 \\
\hline Grimouard (Consorts) & CE Sect. 20 April 1956 & 273 \\
\hline Groupe Canal Plus & CE Ass. 21 December 2012 & 182 \\
\hline $\begin{array}{l}\text { Groupe d'Information et de } \\
\text { Soutien des Travailleurs } \\
\text { Immigrés }\end{array}$ & CE Ass. 8 December 1978 & 207,211 \\
\hline
\end{tabular}


(continued)

\begin{tabular}{|c|c|c|}
\hline $\begin{array}{l}\text { Groupement d'entreprises } \\
\text { solidaires ETPO } \\
\text { Guadeloupe }\end{array}$ & CE 18 June 2003 & 291 \\
\hline Guillec (M et Mme) & CE 1 February 1993 & 186 \\
\hline Guillemet & CE Sect. 21 February 1947 & 188 \\
\hline Guiyesse & $\mathrm{CE}_{4}$ February 1944 & 214 \\
\hline $\begin{array}{l}\text { Guyue c Agent judiciaire de } \\
\text { l'Etat }\end{array}$ & TC 12 February 2018 & 143 \\
\hline Hardouin and Marie & CE Ass. 17 February 1995 & $162-3$ \\
\hline Héritiers du sieur Gouy & $\mathrm{CE}_{4}$ May 1900 & 281 \\
\hline Heyriès & CE 28 June 1918 & 8 \\
\hline Hilaire & TC 18 December 1947 & 134 \\
\hline Hofmann (Epoux) & CE 17 May 2002 & 157 \\
\hline Ingremeau & CE Sect. 19 October 1990 & 255 \\
\hline $\begin{array}{l}\text { Institution Notre-Dame du } \\
\quad \text { Kreisker }\end{array}$ & CE Ass. 29 January 1954 & 161 \\
\hline Jacques A & CE 10 July 2006 & 175 \\
\hline Jalenques de Labeau & CE Sect. 8 March 1957 & 273 \\
\hline Jamet & CE Sect. 3 March 1950 & 219 \\
\hline Joublot & CE 26 September 2018 & 201 \\
\hline Kechichian & CE Ass. 30 November 2001 & $250,263,265$ \\
\hline Keddar & CE Ass. 3 February 1956 & 188 \\
\hline Khan & CE 6 May 2009 & 104 \\
\hline Kherouaa & CE 2 November 1992 & 162 \\
\hline Kirkwood (Dame) & CE Ass. 30 May 1952 & 164 \\
\hline Kohumoetini & CE 1 July 2009 & 157 \\
\hline Koné & CE Ass. 3 July 1996 & $21,45,208$ \\
\hline KPMG & CE Ass. 24 March 2006 & 51,229 \\
\hline$L$ & CE 1 February 2019 & 218 \\
\hline L'Etang & CE Ass. 12 July 1969 & 247 \\
\hline L'Hermite & CE 23 February 2000 & 52 \\
\hline $\begin{array}{l}\text { La Bergamote see EURL } \\
\text { Croisières }\end{array}$ & & \\
\hline La cellulose d'Aquitaine & CE 21 May 1971 & 281 \\
\hline La Quadrature du Net & CE Ass. 21 April 2021 & 13,306 \\
\hline Labonne & CE 8 August 1919 & 105,217 \\
\hline Labrousse c Gaz de France & TC 1 July 2002 & 149 \\
\hline Lagier, Consorts Guigon & CE avis 4 June 2007 & 267 \\
\hline Lagrange & CE Sect. 15 February 1961 & 205 \\
\hline Laillat & CE Ass. 24 December 2019 & 260 \\
\hline $\begin{array}{l}\text { Lambert (Mme Rachel), } \\
\text { Lambert (M. François) ङ } \\
\text { Centre hospitalier de Reims }\end{array}$ & CE Ass. 24 June 2014 & $\begin{array}{c}108-9,112-3 \\
114,209\end{array}$ \\
\hline
\end{tabular}


(continued)

\begin{tabular}{|c|c|c|}
\hline Lang & CE Sect. 26 January 1973 & 230 \\
\hline Laruelle & CE 8 April 2009 & 251 \\
\hline Laruelle and Delville & CE Ass. 28 July 1951 & $243-4$ \\
\hline Lavaud & CE Sect. 31 March 1995 & 258 \\
\hline Lebon & CE Sect. 9 June 1978 & 202 \\
\hline Lecomte & CE Ass. 24 June 1949 & 254 \\
\hline Lectalis Ingredients SNC & CE 9 October 2020 & 250 \\
\hline Legros & CE Sect. 21 July 1972 & 166 \\
\hline Lemonnier (Epoux) & CE 26 July 1918 & 242 \\
\hline Letisserand (Epoux) & CE Ass. 24 November 1961 & 264 \\
\hline Librairie François Maspero & CE Ass. 2 November 1973 & 208 \\
\hline Ligue des droits de l'homme & $\mathrm{CE}_{21}$ February 2018 & 10 \\
\hline Lorédon & CE 10 December 1986 & 201 \\
\hline Lorenzi & CE Sect. 30 October 1998 & 52 \\
\hline Lot & CE 11 December 1903 & 155 \\
\hline Lourdjane & $\mathrm{CE}_{3}$ May 2016 & 167 \\
\hline Louvard & CE 11 January 1957 & 186 \\
\hline Louvion & CE Ass. 18 May 2018 & 230 \\
\hline M. B. & CE 19 October 2020 & 202 \\
\hline M. D. & CE Ass. 9 April 1993 & 251,252 \\
\hline \multicolumn{3}{|l|}{$\begin{array}{l}\text { Magiera see Garde des } \\
\text { Sceaux c Magiera }\end{array}$} \\
\hline Mann Singh & CE 5 December 2005 & 181,191 \\
\hline Manoukian & CE 11 January 2011 & 293 \\
\hline Marc-Antoine & CE 25 January 2006 & $15,115,118$ \\
\hline Mario Bonato c APELIOR & TC 6 July zoo9 & 152 \\
\hline Martaux (Mlle) & $\mathrm{CE}$ avis 3 May 2000 & 206 \\
\hline Mayer et Richer & CE 20 March 2000 & 271 \\
\hline MD & CE 9 July 2007 & 246,251 \\
\hline Mégret & CE Sect. 25 September 1998 & 164 \\
\hline Mergui & CE Sect. 19 March 1971 & 102 \\
\hline Meyer (Epoux) & CE Sect. 16 April 2012 & 185 \\
\hline $\begin{array}{l}\text { Mimeur, Defaux and } \\
\text { Besthelsemer }\end{array}$ & CE 18 November 1949 & 243 \\
\hline $\begin{array}{l}\text { Ministre des affaires étrangères } \\
\text { c Burgat }\end{array}$ & CE Sect. 29 October 1976 & 259 \\
\hline $\begin{array}{l}\text { Ministre des affaires sociales } c \\
\quad \text { Rumija }\end{array}$ & CE Sect. 12 July 2016 & 221 \\
\hline $\begin{array}{l}\text { Ministre de l'agriculture c } \\
\text { Dame Lamotte }\end{array}$ & CE Ass. 17 February 1950 & $91,168,227$ \\
\hline $\begin{array}{l}\text { Ministre de l'agriculture et de } \\
\text { la pêche }\end{array}$ & CE 7 August 2008 & 246 \\
\hline $\begin{array}{l}\text { Ministre de la culture c Mme } \\
\text { Cusenier }\end{array}$ & CE 12 March 1986 & 158 \\
\hline
\end{tabular}


(continued)

\begin{tabular}{|c|c|c|}
\hline Ministre de la Défense c Diop & CE Ass. 30 November 2001 & 51 \\
\hline $\begin{array}{l}\text { Ministre de la Défense et des } \\
\text { Anciens combattants }\end{array}$ & $\mathrm{CE}_{3}$ October 2012 & 175 \\
\hline $\begin{array}{l}\text { Ministre de la Défense et des } \\
\text { Anciens combattants }\end{array}$ & CE 20 February 2012 & 97 \\
\hline $\begin{array}{l}\text { Ministre de l'Ecologie, du } \\
\text { développement durable et de } \\
\text { l'énergie }\end{array}$ & CE Ass. 4 April 2014 & 113 \\
\hline $\begin{array}{l}\text { Ministre de l'Economie et des } \\
\text { Finances c Perrot }\end{array}$ & CE Ass. 12 January 1968 & 172 \\
\hline $\begin{array}{l}\text { Ministre de l'Education } \\
\text { Nationale c Pehrilhé }\end{array}$ & CE ord. 15 December 2010 & 220 \\
\hline $\begin{array}{l}\text { Ministre de l'équipement et du } \\
\text { logement c Baron }\end{array}$ & CE 16 February 1973 & 187 \\
\hline $\begin{array}{l}\text { Ministre de l'équipement et } \\
\text { logement c Dalleau }\end{array}$ & CE Ass. 6 July 1973 & 253 \\
\hline $\begin{array}{l}\text { Ministre des finances et des } \\
\text { comptes publics c Amar }\end{array}$ & CE Sect. 31 March 2017 & $99-100$ \\
\hline $\begin{array}{l}\text { Ministere de l'immigration c } \\
\text { Hammou }\end{array}$ & $\mathrm{CE}_{4}$ December 2009 & 91 \\
\hline Ministre de l'Intérieur c Barain & CE 12 February 2014 & 201 \\
\hline $\begin{array}{l}\text { Ministre de l'Intérieur c Cohn- } \\
\text { Bendit }\end{array}$ & CE Ass. 22 December 1978 & $10-11,4^{8}$ \\
\hline $\begin{array}{l}\text { Ministre de l'Intérieur c } \\
\text { Commune de St-Florent }\end{array}$ & CE 6 October 2000 & 251 \\
\hline $\begin{array}{l}\text { Ministre de l'Intérieur c Cortes } \\
\text { Ortiz }\end{array}$ & CE Sect. 4 February 2015 & 161 \\
\hline Ministre de l'Intérieur c Koné & CE ord. 8 February 2012 & 104 \\
\hline $\begin{array}{l}\text { Ministre de l'Intérieur c Mme } \\
\text { Auger }\end{array}$ & CE 11 March 1998 & $180-1$ \\
\hline Ministre de l'Intérieur c Nassiri & CE 31 January 2014 & 171 \\
\hline Ministre de travail & CE 5 July 1929 & 195 \\
\hline Montpeurt & CE Ass. 31 July 1942 & 145 \\
\hline Moon sun myung & CE Ass. 6 November 2002 & 93 \\
\hline Moya-Caville & CE Ass. 4 July 2003 & 256 \\
\hline Narcy & CE Sect. 28 June 1963 & 145 \\
\hline Nice Hélicoptères & CE 24 March 1995 & 263 \\
\hline Nicolo & CE Ass. 20 October 1989 & $11,47,119,165$ \\
\hline $\begin{array}{l}\text { Office National de la Chasse et } \\
\text { de la faune sauvage }\end{array}$ & CE 20 February 2008 & 282 \\
\hline Olteanu & TC 17 June 2013 & 278 \\
\hline OPDHLM du Gard & CE 26 September 2007 & 282 \\
\hline OPHLM de Puteaux & CE 29 December 2008 & 285 \\
\hline $\begin{array}{l}\text { Panizzon c Commune de } \\
\text { Saint-Palais-sur-Mer }\end{array}$ & TC 9 December 2013 & 142,143 \\
\hline
\end{tabular}


(continued)

\begin{tabular}{|c|c|c|}
\hline Papon & CE Ass. 12 April 2002 & 244 \\
\hline Paris Eiffel Suffren & CE Ass. 24 December 2019 & $260,261,263,265$ \\
\hline $\begin{array}{l}\text { Paris Racing I c Fédération } \\
\text { française de football }\end{array}$ & TC 20 October 1997 & 151 \\
\hline Pariset & CE 26 November 1873 & 187 \\
\hline Pascau & CE 19 December 1988 & 146 \\
\hline \multicolumn{3}{|l|}{$\begin{array}{l}\text { Pehrilhé see Ministre de } \\
\text { l'Education Nationale }\end{array}$} \\
\hline Pelletier & TC 30 July 1873 & 241,242 \\
\hline Perreux & CE Ass. 30 October 2009 & $13,48,96$ \\
\hline $\begin{array}{l}\text { Peschaud c Groupement du } \\
\text { Football professionnel }\end{array}$ & TC 7 July 1980 & 146 \\
\hline Peynet (Dame) & CE Ass. 8 June 1973 & 216,273 \\
\hline Piazza & CE 9 February 2011 & 200 \\
\hline Prats & CE Ass. 8 June 2016 & 200 \\
\hline Préfet de l'Eure & CE 9 May 1913 & 166 \\
\hline $\begin{array}{l}\text { Préfet de la Gironde c } \\
\text { Mahmedi }\end{array}$ & CE Ass. 18 December 1992 & 165 \\
\hline Préfet de la région Rhône-Alpes & TC 25 March 1996 & 273 \\
\hline $\begin{array}{l}\text { Préfet de police de Paris c } \\
\text { Tribunal de grande instance } \\
\text { de Paris }\end{array}$ & TC 12 May 1997 & 134,160 \\
\hline Préfet des Deux-Sèvres & TC 29 December 2004 & 135 \\
\hline $\begin{array}{l}\text { Préfet Seine-maritime c El } \\
\quad \text { Bahi }\end{array}$ & CE Sect. 3 December 2003 & 171 \\
\hline Radiodiffusion Française & TC 2 February 1950 & 151 \\
\hline Rault & CE 14 March 1934 & 186 \\
\hline Région Haute-Normandie & CE 5 June 2013 & 292 \\
\hline Regnault-Desroziers & CE 28 March 1919 & 253 \\
\hline Rodière & CE 26 December 1925 & 155,170 \\
\hline Rosan Girard & CE Ass. 31 May 1957 & 180 \\
\hline Rosay & TC 8 May 1933 & 152 \\
\hline $\begin{array}{l}\text { Royaume-Uni et Gouverneur } \\
\text { de la Colonie Royale de } \\
\text { Hong Kong }\end{array}$ & CE Ass. 15 October 1993 & 166 \\
\hline Rubin de Servens & CE Ass. 2 March 1962 & 164 \\
\hline Rujovic & CE 14 May 2010 & $4^{8}$ \\
\hline SA Dangeville & CE Ass. 30 October 1996 & 167 \\
\hline $\begin{array}{l}\text { SA de banque "Le Crédit du } \\
\quad \text { Nord» }\end{array}$ & CE Sect. 13 October 1972 & 280 \\
\hline $\begin{array}{l}\text { SA des Produits Laitiers 'La } \\
\text { Fleurette' }\end{array}$ & CE 14 January 1938 & 259,263 \\
\hline SA des usines Renault & CE 27 July 1928 & 212 \\
\hline Sadoudi & CE Ass. 26 October 1973 & 254 \\
\hline
\end{tabular}


(continued)

\begin{tabular}{|c|c|c|}
\hline SAEM & CE 10 February 2020 & 294 \\
\hline SAFER d'Auvergne c Bernette & CE Ass. 5 May 1976 & 200 \\
\hline SAGEP & CE 7 August 2008 & 278 \\
\hline SAJEGA & CE 22 March 2006 & 214 \\
\hline Sanimam & CE 29 July 1994 & 166 \\
\hline SAS ViTi & $\begin{array}{l}\text { TA French Polynesia } 12 \text { June } \\
\quad 2018\end{array}$ & 125 \\
\hline $\begin{array}{l}\text { SCEA de Chéneau c } \\
\text { Interprofessional nationale } \\
\text { porcine (INAPORC) and } \\
\text { Centre national } \\
\text { interprofessionnel de } \\
\text { l'économie laitière } \\
\text { (CNIEL) }\end{array}$ & TC 17 October 2011 & 137 \\
\hline Sealink U.K. Ltd. & CE 22 June 1984 & 258 \\
\hline $\begin{array}{l}\text { Secrétaire d'Etat aux Postes et } \\
\text { Télécommunications }\end{array}$ & CE 23 July 1976 & 205 \\
\hline $\begin{array}{l}\text { Section française de } \\
\text { l'observation internationale } \\
\text { des prisons }\end{array}$ & CE 30 June 2003 & 164 \\
\hline $\begin{array}{l}\text { Section française de } \\
\quad \text { l'observatoire des prisons }\end{array}$ & CE ord. 23 December 2016 & 92 \\
\hline Septfonds & TC 16 June 1923 & 131 \\
\hline SNESUP-FSU & CE 27 June 2019 & 219 \\
\hline Société albigeoise de spectacles & CE Sect. 13 March 1987 & 155 \\
\hline $\begin{array}{l}\text { Société Arcelor Atlantique et } \\
\text { Lorraine }\end{array}$ & CE Ass. 8 February 2007 & $12,4^{8}$ \\
\hline Société Axa France IARD & TC ${ }_{13}$ October 2014 & 274 \\
\hline Société Babel & CE 9 September 2010 & 289 \\
\hline $\begin{array}{l}\text { Société Banque française } \\
\text { commerciale de l'Océan } \\
\text { Indien }\end{array}$ & CE 2 March 2007 & 243 \\
\hline Société Baxter & CE Ass. 28 March 1997 & 214 \\
\hline Société Campenon-Bernard & CE 19 December 2007 & 280 \\
\hline Société civile des Néo-Polders & CE 29 December 1997 & 288 \\
\hline $\begin{array}{l}\text { Société comptoir Négoce } \\
\text { Equipement }\end{array}$ & CE 10 July 2020 & 286,293 \\
\hline $\begin{array}{l}\text { Société d'assurances la } \\
\text { Nantaise et l'Angevine } \\
\text { réunies }\end{array}$ & CE Sect. 27 March 1998 & 284 \\
\hline Société des ciments français & CE 22 February 1950 & 212 \\
\hline $\begin{array}{l}\text { Société des concerts du } \\
\quad \text { conservatoire }\end{array}$ & CE Sect. 9 March 1951 & 215 \\
\hline Société Distilleries bretonnes & TC 24 June 1968 & 273 \\
\hline
\end{tabular}


(continued)

\begin{tabular}{|c|c|c|}
\hline $\begin{array}{l}\text { Société des établissements } \\
\text { Michel Aubrun }\end{array}$ & CE Sect. 22 January 1965 & 286 \\
\hline $\begin{array}{l}\text { Société des établissements } \\
\text { thermaux d'Ussat-les-Bains }\end{array}$ & CE 20 March 1957 & 285 \\
\hline $\begin{array}{l}\text { Société des grands moulins de } \\
\text { Corbeil }\end{array}$ & CE 14 December 1923 & 280 \\
\hline $\begin{array}{l}\text { Société des granits } \\
\quad \text { porphyroïdes des Vosges }\end{array}$ & CE 31 July 1912 & 273,275 \\
\hline $\begin{array}{l}\text { Société du Lotissement de la } \\
\text { Plage de Pamplonne }\end{array}$ & CE Ass. 29 March 1968 & 192 \\
\hline $\begin{array}{l}\text { Société de Promotion et de } \\
\text { Distribution Touristique }\end{array}$ & CAA Paris 6 February 1996 & 182 \\
\hline $\begin{array}{l}\text { Société des téléphériques du } \\
\text { massif du Mont-Blanc }\end{array}$ & CE 31 July 1996 & 286 \\
\hline $\begin{array}{l}\text { Société du vélodrome du Parc } \\
\text { des Princes }\end{array}$ & TC 16 January 1967 & 274 \\
\hline Société Edilys & CE 5 October 2018 & 189 \\
\hline Société Ekin & CE Sect. 9 July 1997 & $53,208-9$ \\
\hline Société Eky & CE 12 February 1960 & 205 \\
\hline Société Entreprise Peyrot & TC 8 July 1963 & 237 \\
\hline $\begin{array}{l}\text { Société Fairvesta International } \\
\mathrm{GmbH}\end{array}$ & CE Ass. 21 March 2016 & 41,161 \\
\hline Société fermière de Campoloro & CE Sect. 18 November 2005 & 124 \\
\hline Société Fosmax & CE Ass. 9 November 2016 & $102,283,285$ \\
\hline $\begin{array}{l}\text { Société France } \\
\text { conditionnement }\end{array}$ & CE 15 May 2009 & 199 \\
\hline Société Géomat & CE 27 March 2020 & 289 \\
\hline Société Google LLC & CE 19 June 2020 & 35 \\
\hline Société Greenyellow & TC 13 December 2010 & 277 \\
\hline Société Grenke location & CE 8 October 2014 & 286 \\
\hline $\begin{array}{l}\text { Société Groupama de } \\
\text { Grand Est }\end{array}$ & CE Sect. 1 July 2016 & 255 \\
\hline $\begin{array}{l}\text { Société Groupe Canal Plus et } \\
\text { Société Vivendi }\end{array}$ & CE Ass. 21 December 2012 & 197 \\
\hline Société Jean-Claude Decaux & CE Sect. 10 April 2008 & 292 \\
\hline Société Jokelson et Handstaem & CE 22 June 1984 & 258 \\
\hline Société La Huta & CE Sect. 12 May 1961 & 92 \\
\hline $\begin{array}{l}\text { Société Lacroix signalisation c } \\
\text { Seine-Maritime }\end{array}$ & CE 10 July 2020 & 114,280 \\
\hline Société Lambda & CE Ass. 6 December 1996 & 47 \\
\hline $\begin{array}{l}\text { Société Le Jardin } \\
\text { d'acclimatation }\end{array}$ & CE 12 November 2015 & 286 \\
\hline $\begin{array}{l}\text { Société Les Fils de Mme } \\
\text { Géraud }\end{array}$ & CE 15 November 2017 & 292 \\
\hline
\end{tabular}


(continued)

\begin{tabular}{|c|c|c|}
\hline Société Maison Genestal & CE Sect. 26 January 1968 & 231 \\
\hline $\begin{array}{l}\text { Société Métropole } \\
\text { Télévision (M6) }\end{array}$ & CE 22 October 2014 & 261 \\
\hline Société Million et Marais & CE Sect. 3 November 1997 & 47 \\
\hline Société MSO Sablirot & $\mathrm{CE}_{5}$ June 2013 & 277 \\
\hline Société Napol et autres & CE Ass. 6 July 2016 & $\begin{array}{c}201,246,249 \\
254,265\end{array}$ \\
\hline Société Natiocrédimurs & CE 1 March 2013 & $49-50$ \\
\hline Société NC Numéricable & CE Ass. 21 March 2016 & 161 \\
\hline $\begin{array}{l}\text { Société Office Maraîcher } \\
\text { fruitier }\end{array}$ & TC 11 May 1992 & 274 \\
\hline Société Paris Clichy & CE Ass. 24 December 2019 & 260 \\
\hline Société Propétrol & CE Sect. 5 November 1982 & 288 \\
\hline $\begin{array}{l}\text { Société Services d'édition et de } \\
\text { ventes publicitaires }\end{array}$ & TC 7 April 2014 & 278 \\
\hline $\begin{array}{l}\text { Société Total Marketing } \\
\text { France }\end{array}$ & CE 30 April 2019 & 290 \\
\hline $\begin{array}{l}\text { Société Tropic Travaux } \\
\text { Signalisation }\end{array}$ & CE Ass. 16 July 2007 & 291 \\
\hline Société Trystram & TC 24 June 1954 & 142 \\
\hline $\begin{array}{l}\text { Société Valeo équipements } \\
\text { électriques }\end{array}$ & CE 28 December 2002 & 174 \\
\hline Stassen & CE 28 February 2020 & 223 \\
\hline Ste Marie de l'Assomption & CE Ass. 20 October 1972 & 195 \\
\hline Stiegler & CE 16 January 2002 & 157 \\
\hline Sueur & CE 29 October 2004 & 171 \\
\hline Syndicat de la Magistrature & CE Sect. 18 January 2013 & 157 \\
\hline Syndicat des avocats de France & CE 29 July 1998 & 91 \\
\hline $\begin{array}{l}\text { Syndicat des entrepreneurs des } \\
\text { transports de la Riviera }\end{array}$ & CE 4 May 1945 & 212 \\
\hline Syndicat des médecins de l'Ain & CE Ass. 3 July 1998 & 182 \\
\hline $\begin{array}{l}\text { Syndicat des Patrons-Coiffeurs } \\
\text { de Limoges }\end{array}$ & CE 28 December 1906 & 157 \\
\hline $\begin{array}{c}\text { Syndicat des propriétaires et } \\
\text { contribuables du Quartier } \\
\text { de Croix-de-Seguey-Tivoli }\end{array}$ & CE 21 December 1906 & 156,290 \\
\hline $\begin{array}{l}\text { Syndicat général des fabricants } \\
\text { de semoules de France }\end{array}$ & CE Sect. 1 March 1968 & 10 \\
\hline $\begin{array}{l}\text { Syndicat général des } \\
\text { ingénieurs-conseils }\end{array}$ & CE Sect. 26 June 1959 & 54,211 \\
\hline $\begin{array}{l}\text { Syndicat intercommunal des } \\
\text { Etablissements du second } \\
\text { cycle du second degré du } \\
\text { District de L'Hay-Les-Roses }\end{array}$ & CE Ass. Avis 6 December 2002 & 103 \\
\hline
\end{tabular}


(continued)

\begin{tabular}{|c|c|c|}
\hline $\begin{array}{l}\text { Syndicat intercommunale pour } \\
\text { l'aménagement hydraulique } \\
\text { du bassin de la Berre et du } \\
\text { Rieu }\end{array}$ & CE 13 March 2019 & 238,265 \\
\hline Syndicat Jeunes Médecins & CE ord. 22 March 2020 & 108 \\
\hline Syndicat Jeunes Médecins & CE ord. 22 May 2020 & 107 \\
\hline Syndicat Mixte de Pierrefonds & CE 7 December 2015 & 294 \\
\hline $\begin{array}{l}\text { Syndicat mixte de promotion } \\
\text { de l'activité transmanche } \\
\text { (SMPAT) }\end{array}$ & CE Sect. 30 June 2017 & 291 \\
\hline $\begin{array}{l}\text { Syndicat Parisien des } \\
\text { Administrations centrales, } \\
\text { économiques et financières }\end{array}$ & CE 23 December 2011 & 200 \\
\hline $\begin{array}{l}\text { Syndicat unifié de } \\
\text { radiodiffusion et de } \\
\text { télévision CFDT }\end{array}$ & CE 12 November 1976 & 218 \\
\hline Tabouret and Laroche & CE Ass. 9 July 1943 & $190-1$ \\
\hline Ternon & CE Ass. 26 October 2001 & 223 \\
\hline Terrier & CE 6 February 1903 & 139,148 \\
\hline Texier c Le Bail & CE 28 December 2007 & 93 \\
\hline Théron & $\mathrm{CE}_{4}$ March 1910 & 272 \\
\hline Theux & CE Sect. 20 June 1997 & 246 \\
\hline $\begin{array}{l}\text { Thony (Epoux) and Hartman- } \\
\text { Six (Epoux) }\end{array}$ & CE 20 November 1974 & 194 \\
\hline Thouzellier & CE Sect. 3 February 1956 & 254 \\
\hline Toni & CE Ass. 27 April 1951 & 199 \\
\hline Trognon & CE Ass. 6 December 2002 & 82 \\
\hline $\begin{array}{l}\text { Trompier-Gravier (Dame } \\
\text { Veuve) }\end{array}$ & CE Sect. 5 May 1944 & 225 \\
\hline $\begin{array}{l}\text { Union des transports publics } \\
\text { urbains et régionaux }\end{array}$ & CE 2 February 1983 & 284 \\
\hline $\begin{array}{l}\text { Union française pour la } \\
\text { cohésion nationale }\end{array}$ & CE 8 October 2004 & 206 \\
\hline $\begin{array}{l}\text { Université de Dijon c Picard et } \\
\text { Brachet }\end{array}$ & CE Sect. 17 January 1992 & 191 \\
\hline UNSPIC & CE 5 March 2003 & 295 \\
\hline$V($ Époux $)$ & CE Ass. 10 April 1992 & $245-6,268$ \\
\hline$V, W, X$ & TA Paris 18 July 2018 & 248 \\
\hline Verrière & TC 20 February 2008 & 274 \\
\hline Ville de Lisieux & CE Sect. 30 October 1998 & 290 \\
\hline $\begin{array}{l}\text { Ville de Melun et Association } \\
\text { "Melun-culture-loisirs } c c \\
\text { Vivien }\end{array}$ & CE 20 July 1990 & 146,148 \\
\hline
\end{tabular}


(continued)

\begin{tabular}{lll}
\hline Ville de Paris c Driancourt & CE Sect. 26 January 1973 & 248,263 \\
Ville de Saint-Étienne & CE 10 January 1912 & 280 \\
Ville de Toulouse & CE 18 May 1988 & 166 \\
Ville de Toulouse c Aragnou & CE Sect. 23 April 1982 & 216,273 \\
Ville Nouvelle Est & CE Ass. 28 May 1971 & 192 \\
W and others & CE ord. 18 May 2020 & $106,124,125,127$, \\
& & $170,173,197,207$ \\
Waijs (Mme) et Monnier & CE Ass. 30 October 1996 & 156 \\
\hline \hline
\end{tabular}

FRENCH CONSEIL CONSTITUTIONNEL CASES

\begin{tabular}{|c|c|c|c|}
\hline $\begin{array}{l}\text { 5e circonscription du Val } \\
\text { d'Oise }\end{array}$ & 21 October 1988 & $n^{\circ} 88-1082 / 1107 \mathrm{AN}$ & 11 \\
\hline Administrative procedure & 21 December 1972 & $\mathrm{n}^{\circ} 72-75 \mathrm{~L}$ & 55 \\
\hline Associations Law & 16 July 1971 & $n^{\circ} 71-44 \mathrm{DC}$ & 45,205 \\
\hline Bioethics & 27 July 1994 & $n^{\circ \mathrm{s}} 343$ and 344 DC & 45 \\
\hline Cédric D & 22 December 2015 & $n^{\circ} 2015-527$ QPC & 135 \\
\hline Christian G & 8 June 2012 & $n^{\circ} 2012-250$ QPC & 82 \\
\hline Codification & 16 December 1999 & $n^{\circ} 99-421 \mathrm{DC}$ & 229 \\
\hline $\begin{array}{l}\text { Commission Nationale } \\
\text { de la Communication } \\
\text { et des Libertés } \\
\text { (CNCL) }\end{array}$ & 18 September 1986 & $n^{\circ} 86-217 \mathrm{DC}$ & 39,40 \\
\hline Competition Law & 23 January 1987 & $n^{\circ} 86-224 \mathrm{DC}$ & $\begin{array}{c}9,45,128,131,138, \\
144,147,275\end{array}$ \\
\hline $\begin{array}{l}\text { Confidence in the } \\
\text { Digital Economy }\end{array}$ & 10 June 2004 & $n^{\circ} 2004-496 \mathrm{DC}$ & 49 \\
\hline $\begin{array}{l}\text { Conseil Supérieur de } \\
\text { l'Audiovisuel (CSA) }\end{array}$ & 17 January 1989 & $n^{\circ} 88-268 \mathrm{DC}$ & 39 \\
\hline Corsica & 17 January 2002 & $n^{\circ} 2001-454$ DC & 34 \\
\hline $\begin{array}{l}\text { Criminal Penalties } \\
\text { (Rural Code) }\end{array}$ & 28 November 1973 & $n^{\circ} 73-80 \mathrm{~L}$ & 209 \\
\hline Danielle S & 26 November 2010 & $n^{\circ} 2010-71$ QPC & 135 \\
\hline Deconfinement Law & 9 July 2020 & $\mathrm{n}^{\circ} 2 \mathrm{O} 2 \mathrm{O}-8 \mathrm{O} 3 \mathrm{DC}$ & 198 \\
\hline Detention for Security & 21 February 2008 & $n^{\circ} 2008-562$ DC & 197 \\
\hline Eiffel Tower Amendment & 13 December 1985 & $n^{\circ} 85-198 \mathrm{DC}$ & 136 \\
\hline
\end{tabular}


(continued)

\begin{tabular}{|c|c|c|c|}
\hline $\begin{array}{l}\text { Entry and Residence of } \\
\quad \text { Foreigners }\end{array}$ & 28 July 1989 & $n^{\circ} 89-261 \mathrm{DC}$ & $91,131,135$ \\
\hline $\begin{array}{l}\text { European Charter of } \\
\text { Regional and } \\
\text { Minority Languages }\end{array}$ & 15 June 1999 & $\mathrm{n}^{\circ} 99-412 \mathrm{DC}$ & 35 \\
\hline Family Allowances & 18 December 1997 & $n^{\circ} 97-393 \mathrm{DC}$ & 44 \\
\hline Fight against Exclusions & 29 July 1998 & $n^{\circ} 98-403$ DC & $25^{8}$ \\
\hline Finance Law for 1990 & 29 December 1989 & $n^{\circ} 89-268$ DC & 92 \\
\hline Finance Law for 2018 & 28 December 2017 & $\mathrm{n}^{\circ} 2017-75^{8} \mathrm{DC}$ & 213 \\
\hline $\begin{array}{l}\text { Finance Law for Social } \\
\text { Security for } 2014\end{array}$ & 19 December 2013 & $n^{\circ} 2013-682 \mathrm{DC}$ & 229 \\
\hline Fiscal Fraud & 4 December 2013 & $\mathrm{n}^{\circ} 2013-679 \mathrm{DC}$ & 135 \\
\hline Force 5 & 28 Мау 2020 & $n^{\circ} 2020-843$ QPC & 29 \\
\hline Freedom of Education & 23 November 1977 & $\mathrm{n}^{\circ} 77-87 \mathrm{DC}$ & 45 \\
\hline Housing Law & 29 May 1990 & $n^{\circ} 90-274$ DC & 220 \\
\hline Indefinite Sentences & 21 February 2008 & $n^{\circ} 2008-562$ DC & 197,198 \\
\hline Internal Security Law & 13 March 2003 & $n^{\circ} 2003-467$ DC & 135 \\
\hline Jean-Pierre B & 25 March 2011 & $n^{\circ} 2010-110$ QPC & 82 \\
\hline Justice Reform & 21 March 2019 & $\mathrm{n}^{\circ} 2019-778 \mathrm{DC}$ & 76 \\
\hline $\begin{array}{l}\text { Law on the Freedoms } \\
\text { and Responsibilities of } \\
\text { Local Authorities }\end{array}$ & 12 August 2004 & $\mathrm{n}^{\circ} 2004-503 \mathrm{DC}$ & 220 \\
\hline $\begin{array}{l}\text { Ligue des droits de } \\
\text { l'homme }\end{array}$ & 19 February 2016 & $n^{\circ} 2016-536$ QPC & 10,249 \\
\hline Nationalisations & 16 January 1982 & $n^{\circ} 81-132$ DC & 44 \\
\hline $\begin{array}{l}\text { Planning and } \\
\text { Construction }\end{array}$ & 21 January 1994 & $\mathrm{n}^{\circ} 93-335 \mathrm{DC}$ & 168 \\
\hline Privatisations & 25 \& 26 June 1986 & $n^{\circ} 86-207 \mathrm{DC}$ & 217 \\
\hline Protection of Monuments & 26 June 1969 & $n^{\circ} 69-55 \mathrm{~L}$ & 55 \\
\hline Raphaël S. & 28 February 2020 & $\begin{array}{c}n^{\circ} 2019-828 / \\
829 \text { QPC }\end{array}$ & 260 \\
\hline $\begin{array}{l}\text { Repayment of Fees at the } \\
\text { Ecole Polytechnique }\end{array}$ & 24 October 1969 & $n^{\circ} 69-57 \mathrm{~L}$ & 55 \\
\hline $\begin{array}{l}\text { Section française de } \\
\text { l'observatoire } \\
\text { international des } \\
\text { prisons }\end{array}$ & 1 June 2018 & $n^{\circ}$ 2018-709 QPC & 169 \\
\hline Security and Liberty & $\begin{array}{c}19 \& 20 \text { January } \\
1981\end{array}$ & $n^{\circ} 80-127$ DC & 198,205 \\
\hline Société COVED SA & 27 January 2012 & $n^{\circ} 2011-214$ QPC & 10 \\
\hline $\begin{array}{l}\text { Société Natixis Asset } \\
\text { Management }\end{array}$ & 1 August 2013 & $n^{\circ} 2013-336$ QPC & 260 \\
\hline $\begin{array}{l}\text { Special Tax on Fire } \\
\text { Insurance }\end{array}$ & 14 November 2014 & $n^{\circ} 2014-425$ QPC & 213 \\
\hline
\end{tabular}


(continued)

\begin{tabular}{|c|c|c|c|}
\hline $\begin{array}{l}\text { Strikes in Radio and } \\
\text { Television }\end{array}$ & 25 July 1979 & $n^{\circ} 79-105$ DC & 45,218 \\
\hline TGV Nord & 25 July 1989 & $n^{\circ} 89-256 \mathrm{DC}$ & 126 \\
\hline $\begin{array}{l}\text { The Functioning of } \\
\text { Regional Councils }\end{array}$ & 6 March 1998 & $n^{\circ} 98-397$ DC & 34 \\
\hline Trades Union Immunity & 22 October 1982 & $n^{\circ} 82-144$ DC & 239 \\
\hline $\begin{array}{l}\text { Validation of } \\
\text { Administrative } \\
\text { Decisions }\end{array}$ & 22 July 1980 & $n^{\circ} 80-119$ DC & 9,128 \\
\hline Viviane L & 11 February 2011 & $n^{\circ} 2010-102$ QPC & 229 \\
\hline Workers' Participation & 28 December 2006 & $\mathrm{n}^{\circ} 2006-545 \mathrm{DC}$ & 137 \\
\hline
\end{tabular}

EUROPEAN UNION CASES

\begin{tabular}{|c|c|c|c|}
\hline Commission v France & 5 October 2006 & Case C-232/05 & 167 \\
\hline Commission v France & 4 October 2018 & Case C-416/17 & 119 \\
\hline Finn Frogne A/S & $\begin{array}{l}7 \text { September } \\
2016\end{array}$ & Case C-549/14 & 297 \\
\hline $\begin{array}{l}\text { Firma Anton Dürbeckv } \\
\text { Hauptzollamt } \\
\text { Frankfurt am Main- } \\
\text { Flughafen }\end{array}$ & 5 May 1981 & Case 112/80 & 228 \\
\hline France v Commission & 22 March 2001 & Case $17 / 99$ & 160 \\
\hline $\begin{array}{l}\text { Johnston v Chief } \\
\text { Constable of } \\
\text { Northern Ireland }\end{array}$ & 15 May 1986 & Case 22/84 & 91,169 \\
\hline $\begin{array}{l}\text { Kledingverkoopbedriif } \\
\text { De Geus en } \\
\text { Uitdenbogerd v } \\
\text { Bosch Gmbh }\end{array}$ & 6 April 1962 & Case $13 / 61$ & 228 \\
\hline Köbler v Austria & $\begin{array}{l}30 \text { September } \\
2003\end{array}$ & Case C-224/o1 & 250 \\
\hline La Quadrature du Net & 6 October 2020 & $\begin{array}{l}\text { Cases C-511/18 and } \\
512 / 18\end{array}$ & 13 \\
\hline Nold v Commission & 14 May 1974 & Case $4 / 73$ & 45 \\
\hline $\begin{array}{l}\text { Österreichischer } \\
\text { Rundfunck }\end{array}$ & 20 May 2003 & $\begin{array}{c}\text { Cases C-465/oo, } \\
\text { C-138/o1 and } \\
\text { C-139/o1 }\end{array}$ & 197 \\
\hline
\end{tabular}


(continued)

\begin{tabular}{llll}
\hline \hline $\begin{array}{l}\text { Präsident Ruhrkolen- } \\
\begin{array}{l}\text { Verkaufsgesellschaft } \\
\text { mbH }\end{array}\end{array}$ & 15 July 1960 & $\begin{array}{c}\text { Cases 37, 38, 39 \& } \\
40 / 59\end{array}$ & 211 \\
$\begin{array}{l}\text { Pressetext } \\
\text { Nachrichtenagentur }\end{array}$ & 19 June 2008 & Case C-454/06 & 297 \\
$\begin{array}{l}\text { Promoimpresa Srl. } \\
\text { Rutili }\end{array}$ & 14 July 2016 & Case C-458/14 & 279 \\
$\begin{array}{l}\text { SAG ELV Slovensko } \\
\text { a.s. }\end{array}$ & 29 March 2012 & Case 36/75 C-599/10 & 11 \\
$\begin{array}{l}\text { Société Arcelor } \\
\text { Atlantique et } \\
\begin{array}{l}\text { Lorraine v Premier } \\
\text { ministre }\end{array}\end{array}$ & 16 December & Case C-127/07 & 12 \\
\hline \hline
\end{tabular}

EUROPEAN COURT OF HUMAN RIGHTS CASES

\begin{tabular}{lll}
\hline \hline Borgers v Belgium & 30 October 1991 & 16 \\
Bozano & 18 December 1986 & 135 \\
Kress v France & 7 June 2001 & 16,17 \\
Lambert v France & 5 June 2015 & 109,209 \\
Leyla Şahin v Turkey & 10 November 2005 & 206,209 \\
Lobo Machado v Portugal & 20 February 1996 & 16 \\
Lykourezos v Greece & 15 June 2006 & 228 \\
Marc-Antoine v France & 4 December 2013 & 115,118 \\
Marckx and Marckx v Belgium & 13 June 1979 & 228 \\
Martinie v France & 12 April 2006 & $18-9$ \\
Procola v Luxembourg & 28 September 1995 & $15-6$ \\
Reinhardt and Slimane Kaid v France & 31 March 1998 & 18 \\
S and Marper v UK & 4 December 2008 & 197 \\
SAS v France & 1 July 2014 & 206 \\
\hline \hline
\end{tabular}




\section{OTHER JURISDICTIONS}

\begin{tabular}{lll}
\hline \hline Airedale NHS Trust v Bland & {$[1993]$ A.C. 789} & 109 \\
CCSU v Minister for the Civil Service & {$[1985]$ A.C. 374} & 8 \\
$\begin{array}{l}\text { Gillick v Norfolk and Wisbech AHA } \\
\text { R (on the application of Miller) v Secretary of } \\
\quad \text { State for exiting the European Union }\end{array}$ & {$[1986]$ A.C. 112} & 176 \\
R $v$ Secretary of State for Transport, & [1991] 1 A.C. 603 & 8 \\
$\quad \begin{array}{l}\text { ex parte Factortame (No. 2) } \\
\text { Rev. Dr J.U. Philip and others }\end{array}$ & {$[2021]$ CSOH 32 } & 173 \\
Weiss & 2 BvR $859 / 15$ & 13 \\
\hline \hline
\end{tabular}




\section{Introduction}

\subsection{FRENCH ADMINISTRATIVE LAW IN BRITISH SCHOLARSHIP}

French droit administratif has been a subject of fascination for British lawyers since the late nineteenth century. Although, on first reading, Dicey's An Introduction to the Study of the Law of the Constitution, first published in 1885, might appear to have rejected droit administratif as contrary to the British understanding of the 'rule of law', John Allison has admirably demonstrated that Dicey's subsequent writing (often unpublished) reveals a detailed understanding of and admiration for the achievement of droit administratif. ${ }^{2}$ In those writings, he explains that it is a misconception not to consider droit administratif as law. ${ }^{3}$ He also explains how French administrative judges have become not just officials who judge cases, but almost equivalent to judges. ${ }^{4}$ His particular concern remained that relations between the citizen and the state were governed by different principles to private law relations between citizens and that adjudication was not determined in the ordinary courts. ${ }^{5}$ These were key tenets of the British conception of the rule of law which differed from the French and which excluded the existence of administrative law in England.

The published (and less subtle) views Dicey expressed reverberated for most of the following century. Later generations of scholars who sought to establish

1 See A. V. Dicey, Lectures Introductory to the Study of the Law of the Constitution, edited by J. W. F. Allison (Oxford: Oxford University Press, 2013), especially chapter 12.

2 Ibid., 'Editor's Introduction' and J. W. F. Allison, A Continental Distinction in the Common Law (Oxford: Oxford University Press, 1996).

3 See A. V. Dicey, Comparative Constitutionalism, edited by J. W. F. Allison (Oxford: Oxford University Press, 2013), p. 304.

4 Ibid., Notes X ('English Misconceptions as to Droit Administratif) and XI ('The Evolution of Droit Administratif).

5 Ibid., pp. 304-5. 
administrative law as a subject used French droit administratif as a positive benchmark of what the common law could achieve. Port in 1929 was one of the first writers of a treatise on 'administrative law' in the UK. ${ }^{6}$ Port described French administrative law, discussing the theories of Hauriou, Jèze and Duguit. ${ }^{7}$ He then used French categories to describe American administrative law. Even if neither he nor the other main UK writer on administrative law at the time, Robson, ${ }^{8}$ subscribed to Dicey's approach to administrative law, they retained his idea that France was the primary reference point for conceptual ideas, a point supported by the content of contemporary journal articles and by the contributions of Robson and Laski to the Donoughmore Committee. ${ }^{9}$ This continued after the Second World War with the work particularly of Hamson in his Hamlyn lectures in $1954^{10}$ and of J. D. B. Mitchell in Scotland. ${ }^{11}$ But it would be fair to say that the apogee of French droit administratif as the benchmark of a developed administrative law was reached in 1956 when the Vice President of the Conseil d'Etat was invited to give evidence to the Franks inquiry into the control of ministers' powers. But that committee did not choose to recommend any features of the French model. ${ }^{12}$ The American model, especially as it developed with the Administrative Law Procedure Act 1945, became too alluring for the common lawyer. ${ }^{13}$ Nevertheless, the publication of a textbook on French administrative law by Neville Brown and Jack Garner provided the English-speaking lawyer with

7 He cites Duguit's works translated in English: 'French Administrative Courts' (1914) Political Science Quarterly $390 \mathrm{ff}$., and Law in the Modern State, translated by F. and H. Laski (London: Allen and Unwin, 1921). He also cites J. Brissaud, A History of French Public Law, translated by J. W. Garner (London: John Murray, 1915).

8 W. A. Robson, Justice and Administrative Law: A Study of the British Constitution, ist ed. (London: Macmillan, 1928).

9 See A. Mestre, 'Droit administratif (1929) 3 C.L.J. 355; Committee on Ministers' Powers, Cmd. 406o, London, 1932.

10 J. Hamson, Executive Discretion and Judicial Control: An Aspect of the French Conseil d'Etat (London: Stevens, 1954).

${ }^{11}$ 'The State of Public Law in the U.K.' (1966) 15 International and Comparative Law Quarterly 133.

12 Report of the Committee on Administrative Tribunals and Enquiries (Cmnd. 218;1957).

13 See already W. I. Jennings, W. A. Robson and E. C. S. Wade, 'Administrative Law and the Teaching of Public Law' (1938) J. S. P. T. L. 10 and B. Schwartz, Law and the Executive in Britain (New York: New York University Press, 1949) before the publication of the first major textbook, J. A. G. Griffith and H. Street, Principles of Administrative Law (London: Pitman, 1952). Also later authors such as P. P. Craig, Public Law and Democracy in the United Kingdom and the United States of America (Oxford: Oxford University Press, 1990); I. Harden and N. Lewis, The Noble Lie: The British Constitution and the Rule of Law (London: Hutchinson, 1988). 
a good insight into droit administratif just as administrative law was beginning to take shape in Britain. ${ }^{14}$

The theme of the twentieth-century works on French droit administratif were both that France had a sophisticated and effective set of legal principles to review the exercise of power by the executive and that it was distinctively French in terms of its organisation and sources. No doubt this theme was encouraged by the talks and writings of members of the Conseil d'Etat and French academics. Indeed, that distinctiveness may well have been the reason why the American model was more attractive to the British common lawyers (apart from the linguistic accessibility of its judicial decisions and scholarly writings).

The theme of this book is different. In the long period since Hamson, Brown and Garner wrote their works, France has changed, and French administrative law has changed. The most important change has been the active participation of France in the European Union (EU) and in the Council of Europe with its European Convention on Human Rights. France helped to found the European Coal and Steel Community in 1951, and it ratified the Treaty of Rome founding the European Economic Community (EEC) in 1957, which was opposed by the Gaullists who came to power in 1958 and created the Fifth Republic. Arguably, France was not reconciled to the EEC until at least De Gaulle's abdication of power in 1969, if not until the election of Giscard d'Estaing as President in 1974. France did not ratify the European Convention of 1950 until 1974 and did not allow direct petition until 1981. But once France did ratify these treaties, the primacy given to treaties over national legislation under the Constitutions of the Fourth and Fifth Republics gave a strong impetus to the influence of these agreements on subsequent French domestic law, including administrative law.

The relationship between French administrative law and principles of EU or European Convention law has not always been easy. Two topics illustrate this point: the recognition of the supremacy of EU law over national law and the right to a fair trial as it affected long-established procedures in the administrative courts. These topics will be discussed in some depth in Sections 5 and 6 of this chapter.

14 L. N. Brown and J. F. Garner (with the help of N. Questiaux), French Administrative Law, ist ed. (London: Butterworths, 1967). The most recent edition of this work is L. N. Brown and J. Bell (with J.-L. Galabert), French Administrative Law, 5th ed. (Oxford: Oxford University Press, 1998). 


\subsection{WHAT IS ‘DROIT ADMINISTRATIF’?}

In many ways, Dicey understood droit administratif very well. He wrote:

Droit administratif, as it exists in France, is not the sum of the powers possessed, or of the functions discharged by the administration, it is rather the sum of the principles which govern the relationship between French citizens, as individuals, and the administration as the representative of the state. $^{15}$

There are clearly two dimensions. On the one hand there is the internal dimension of administrative law as the principles which govern the division of tasks within the administration, whether this be civil service employment, or the power to delegate functions, or the supervision of the functions of specific administrations by a ministry or a prefect. On the other hand, there are the external relations of the administration towards citizens (or, as the French more correctly call them, 'the administered'). As Dicey rightly saw, the French believe that the relations between the citizen and the state should be governed by different principles from those governing relations between citizens. The state is acting in the public interest and so is given special powers to achieve that objective, whereas private citizens act in their own interest and have less justification for interfering with the interests of others.

So the distinctiveness of droit administratif does not lie in the distinctive character of the judges, their formation and careers (which will be seen in Chapter 3). Nor does it lie in the procedure which has been aligned increasingly to that in private law and in other European Convention countries (as will be seen in Chapter 4). Instead, the distinctiveness lies in the powers and responsibilities which attach to the state in its relationship with the citizen. The mission to fulfil the general interest (l'intérêt général, as the French put it) confers on the state extraordinary powers (pouvoirs exorbitants) which no citizen could exercise over another - for example, expropriating the property of an individual to build a new TGV line. Furthermore, unlike the private individual, the state has the authority to act without consent (un pouvoir unilatéral) - for example, to impose a curfew or to terminate a contract. On the other hand, the state has special responsibilities. The first is that it has to justify its actions in a way a private individual does not. The state has to show that its actions are authorised (the issue of compétence), that they will lead to a permitted objective, and that they are not excessive in the burdens they impose (absence of mesure excessive: see Chapter 7, Sections 1.5.3 and 1.5.4). 
A private individual can buy a house on a whim and need not give reasons why they do not wish to continue negotiations (unless the conduct is in very bad faith). The state cannot act on a whim because that would be an abuse of power (un détournement de pouvoir). It has to act for lawful reasons and, these days, it has to provide those reasons to the person affected. As a result, distinctive rules apply to public procurement that do not apply to private procurement (see Chapter 9). Despite the emphasis of Dicey, the state is not subject to the same rules of contract as private individuals. Furthermore, the rules of competition that apply to private individuals are weaker. The private individual is required not to make agreements with others that distort competition and not to abuse a dominant position. The state is almost assumed to be occupying a dominant position and is strictly controlled in the way it chooses its contracting partner. As regards liability to private citizens, the Revolution recognised the principle of the equality of public burdens in art. 13 of the Declaration of the Rights of Man, and so where one citizen suffers an excessive detriment from a policy, then the state has to compensate them (see Chapter 8). This is different from a private individual who normally only has to pay compensation for a wrongful harm. The state also has to pay when it has done a wrong. But the fault of the public service extends to a failure to deliver the service which should be expected by the user - for example, the failure to provide lessons in particular subjects at school. This would be treated in England more as maladministration than fault. This is in addition to liability to compensate citizens for excessive detriments suffered as a result of (lawful) public policies. The distinction between public and private law is difficult to make in some instances (see Chapter 5), but the overarching idea that Dicey spotted is that the state is not just one subject of the law like any other subject of the law. In the French sense, the state under law (l'Etat de droit or le Règne du droit) means that the actions of the state are governed and controlled by law. But, unlike Dicey's conception of the rule of law, that does not mean that the state or its officials are subject to the same rules as the private individual. The scrutiny of whether an act is lawful is more stringent, and the rules of liability to compensate are more extensive.

\subsection{THE SHAPING OF DROIT ADMINISTRATIF}

As will be seen in Chapter 2, the general principles of droit administratif - the review of administrative decisions, liability in contract and extra-contractually, and administrative procedure were not codified at the same time as private and criminal law were in the Napoleonic period. As a result, droit administratif was largely the creation of the administrative judges, who were, for the first 150 
years, just the members of the Conseil d'Etat. They shaped the subject not only through judgments, but also through the arguments of the commissaire du gouvernement (now called the rapporteur public) and through the textbooks and scholarly articles which individual members wrote extrajudicially. In that way, it was more like the common law in which case law, rather than statute, has set out major principles for judicial review of administrative action, contract and tort. In many ways, one of the high points of this process of developing administrative law occurred just after the Liberation in 1944. In the absence of binding legal statements of fundamental rights, the Conseil d'Etat developed a set of legally binding 'general principles of law' which bound the administration, even if they could not limit the sovereignty of the legislature, except by way of interpretation (see Chapter 2, Section 6.3). These principles consolidated the understandings of democratic liberal principles as developed in the Third Republic (1870-1940) and taken forward in the Fourth Republic (1946-58).

The full importance of the administrative judiciary and scholarly writers in shaping the French droit administratif will be explored in Chapter 2. But it is important to understand that contemporary French public law is shaped not only by the administrative judges and scholars. Since $195^{8}$, three sources of influence have emerged which are very significant in shaping the general principles and sometimes the rules that govern the relationship between the state and those it administers. The first is purely internal - the Constitution and the Conseil constitutionnel, which has emerged as a constitutional court. The second and third are shared with other European countries, but also have a direct influence on domestic administrative law through provisions within the 1958 Constitution - membership of the European Union and the ratification of the European Convention on Human Rights. Certainly, until after the second edition of Brown and Garner was published in $1973,{ }^{16}$ the Conseil d'Etat with its droit administratif was supreme in shaping public law in general and the law relating to the administration in particular. But since the 1970s, first the Conseil constitutionnel, then the Court of Justice of the European Union (CJEU) in Luxembourg and the Court of Human Rights in Strasbourg have exercised influence over the general principles of administrative law, and sometimes over its detail. We therefore need to be aware of these other factors which create the climate in which droit administratif now operates.

16 French Administrative Law, 2nd ed. (London: Butterworths, 1973). 


\subsection{THE INFLUENCE OF FRENCH CONSTITUTIONAL LAW}

In Chapter 2, we will look in more detail at the place of constitutional law among the sources of French law in general and of administrative law in particular. The Constitution of the Fifth Republic in 1958 did not set out any new constitutional principles relating to fundamental rights and did not create a constitutional court. It is quite clear that the provisions on fundamental rights mentioned in the Preamble to the 1958 Constitution were originally intended to be conventional, not legal. When asked specifically whether the provisions of the Preamble were to be of constitutional value, the commissaire du gouvernement, Janot, replied, 'Certainly not!' They were to be binding on the Government, but not on Parliament. ${ }^{17}$ In other words, they would be legally enforceable on the Government by the administrative courts, but only politically enforceable on Parliament, a solution which some found unacceptable. ${ }^{18}$ As art. 5 of the Constitution made clear, the President of the Republic, not the Conseil constitutionnel, was to be the guardian of the Constitution, much as had been the role of the President in the Third and Fourth Republics. On this view, the President is not amenable to legal sanction for his interpretations of the Constitution, but these therefore fall into the area of conventional constitutional obligations, rather than legal obligations. ${ }^{19}$ This initial understanding of the Constitution has changed radically. It is very clear that it contains legally binding principles which affect the administration.

In the middle of the twentieth century, there was a dispute between two of the titans of French public law at the time, Vedel and Eisenmann, as to whether there were constitutional foundations. ${ }^{20}$ Vedel argued that the Constitution is the necessary foundation of the rules which together make up droit administratif. ${ }^{21}$ The actions of the executive in exercising special

17 Comité consultatif constitutionnel, Travaux préparatoires de la Constitution du 4 octobre 1958: Avis et débats du Comité consultatif constitutionnel (Paris: La Documentation Française, 1960, hereafter 'Avis et débats'), p. 101. See generally F. Luchaire, La protection constitutionelle des droits et des libertés (Paris: Economica, 1987), pp. 14-16.

18 See Coste-Floret, Avis et débats, p. 102.

19 See R. Romi, 'Le Président de la République, interprète de la Constitution', RDP 1987, 1265.

2o X. Magnon, 'Commentaire sous les bases constitutionnelles du droit administratif, la controverse G. Vedel/Ch. Eisenmann', in W. Mastor, P. Egéa and X. Magnon, eds., Les grands discours de la culture juridique (Paris: Dalloz, 2017), nº 68. The key articles were G. Vedel, 'Les bases constitutionnelles du droit administratif, EDCE, 1954, no. 8, pp. 21-53; G. Vedel, 'Les bases constitutionnelles du droit administratif, in P. Amsalek, ed., La pensée de Charles Eisenmann (Paris: Economica, 1986), pp. 133-45; and C. Eisenmann, 'La théorie des "bases constitutionnelles du droit administratif", RDP 1972, 1345-1441.

21 Vedel, 'Les bases constitutionnelles du droit administratif, p. 21. 
public powers that exceeded those of private individuals was acknowledged in certain constitutional texts, especially those of the Fourth and Fifth Republics, and in certain case law of the Third Republic. The texts conferring powers on the President of the Republic and on the Prime Minister presupposed that there was a domain in which the executive exercised sole competence. Furthermore, the 1958 Constitution specifically gave autonomous legislative powers to the executive in art. 37. This seemed to confirm the areas of sole administrative competence. Eisenmann took the view that no constitutional text clearly set out the powers of the executive. In any case, the consequence of administrative law being grounded in the Constitution would be that it could vary from one constitution to another, whereas the experience of the Conseil d'Etat was of a continuity of administrative law principles despite changes in the Constitution, particularly in 1946 and 1958 . He saw administrative law as grounded in the sovereignty of Parliament. By that he meant that the powers the Constitution granted to the state were to execute the laws enacted by Parliament and the courts had the function of giving the correct interpretation of the powers given to the state. In essence, Vedel was keen to argue that the Constitution conferred a special position on the state to exercise extraordinary and unilateral powers to fulfil its mission. This included legislative powers, as is shown by art. 37 of the Constitution and by the First World War case law of the Conseil d'Etat on the inherent powers of the President to maintain public order and to manage the public service. ${ }^{22}$ (We see here echoes of the discussion in the UK of the nature of the prerogative over the civil service in CCSU $v$ Minister for the Civil Service. ${ }^{23}$ ) On the other hand, Eisenmann argued that the scope of executive action depended on what Parliament authorised the executive to do.

To an important extent, Vedel had the final word, not as a scholar, but as a judge of the Conseil constitutionnel. As a former President of the Section du Contentieux of the Conseil d'Etat and himself a leading administrative law scholar, Bernard Stirn, remarked 'through its case law, the Conseil constitutionnel has enriched "the constitutional sources of administrative law"' ${ }^{24}$ In the period up to 1970, the Conseil d'Etat had been central in shaping the protection of fundamental rights through its notion of 'general principles of law', often based on the Declaration of the Rights of Man of 1789, itself not seen at the time as having legally binding status. But it refused explicitly to

22 See, for example, CE 28 June 1918, Heyriès, no. 63412, S. 1922.3.49 note Hauriou.

$23 \quad[1985]$ A.C. 374 .

24 B. Stirn, 'Constitution et droit administratif (2012) Nouveaux Cahiers du Conseil constitutionnel no. 37 (Le Conseil constitutionnel et le droit administratif), p. 1. 
challenge the legality of legislation. Vedel was reporting judge for two key decisions of the Conseil constitutionnel which gave constitutional force to key principles of administrative law. In 1980, ${ }^{25}$ the Conseil constitutionnel endorsed the independence of the administrative courts as a fundamental principle recognised by the laws of the Republic. In 1987, it found that the judicial review of decisions of bodies exercising executive power belonged to the administrative courts, thereby consecrating the separation of administrative and ordinary courts by way of a fundamental principle recognised by the laws of the Republic (even if the best statement was in a law of the Bourbon monarchy in 1790). ${ }^{26}$ So a law conferring such powers on the ordinary courts was unconstitutional. Rather than focusing on the rules concerning the powers of the administration, these decisions focus on the control of administrative powers, appealing to the idea of the separation of powers, rather than the rule of law (as UK courts would have done). It is the control of the administration that was the object of constitutional attention in 1641, 1790, 1799,1872 and 1945, albeit not all in texts that are these days considered legally binding.

But, as Stirn pointed out, ${ }^{27}$ particularly in the past decade or so, there is a spirit of cooperation between the Conseil constitutionnel and the Conseil d'Etat in developing the constitutional principles that underpin droit administratif. The reform of the Constitution in 2008 created the possibility for the first time that laws which had already been enacted could be challenged for unconstitutionality. Previously, the Conseil constitutionnel was only concerned with laws before they were promulgated. Now it is possible for a litigant in a civil or administrative case to challenge the effect of a law on the ground that it is unconstitutional. In this process, the top court in each system acts as the gatekeeper to ensure only serious issues are submitted to the Conseil constitutionnel. The Conseil constitutionnel deals with the constitutional question by way of a reference from the administrative or ordinary courts - hence it is called a preliminary question, the question préalable de constitutionnalité (QPC). This innovation has changed the role of the Conseil constitutionnel. In the years since 1 March 2010, when the QPC came into force, the Conseil constitutionnel has typically dealt with references from parliamentarians on between twenty-five and thirty laws a year prior to promulgation, but between seventy and eighty QPC references. Of the references received in 2019, 46 per cent were from the Conseil d'Etat. The Conseil d'Etat

25

26

27

CC decision no. 80-119 DC, 22 July 1980, Validation of Administrative Acts, Rec. 46, para. 6.

CC decision no. 86-224 DC, 23 January 1987, Competition Law, Rec. 8, para. 15.

Stirn, 'Constitution et droit administratif, p. 6. 
can act as gatekeeper. For example, in 2018 , it refused to submit a law on terrorism to the Conseil constitutionnel because it did not think the complaint of unconstitutionality was sufficiently serious. In its view, the legislator had provided sufficient safeguards for fundamental rights that no breach of constitutional values was arguable. ${ }^{28}$ On the other hand, the decisions of the Conseil constitutionnel on a QPC reference can lead to changes in the way the administration or the administrative courts work. A good example will be seen in Chapter 4, Section 2.7, on the composition of specialised administrative courts (what the UK knows as tribunals). There the decision of the Conseil constitutionnel led to a restructuring of the membership of these bodies and the transfer of much of their work to the generalist administrative courts.

The constitutional principles requiring a hearing before a sanction is imposed is recognised both by the Conseil d'Etat and by the Conseil constitutionnel. ${ }^{29}$ That affects the way the administration behaves, as well as how the legislature drafts the powers it confers on the administration.

\subsection{THE INFLUENCE OF EU LAW: FRENCH ADMINISTRATIVE LAW AND THE SUPREMACY OF EU LAW}

Entry into the European Economic Community (as it then was called) in 1957 was politically divisive in France. Both the communists and the Gaullists were against it. De Gaulle, who returned to power in 1958, blocked much activity through his 'empty chair' policy in 1965 at a time when the EEC had to act by unanimity. It is therefore not surprising that the Conseil d'Etat did not accept the supremacy of EEC law over domestic law when the issue was raised before it in 1968. In Semoules de France, there was a clear conflict between an EEC regulation and a French Law. ${ }^{30}$ The Conseil held that it had no power to ignore a constitutionally valid law, and so it refused to give effect to the EEC regulation because the law was posterior to the regulation and therefore expressed the last will of the sovereign Parliament, despite art. 55 of the Constitution according to which a regularly adopted treaty must prevail over a law. When a similar issue returned ten years later, the response was much the same with regard to the effect of a directive towards an administrative act. In Cohn-Bendit, a German leader, brought up in France, of the May 1968 student protests was subject to

28

29 tion de l'administration des douanes), Rec. 94, para. 6.

30 CE Sect. 1 March 1968, Syndicat général des fabricants de semoules de France, no. 62814, Leb. 149; AJDA 1968, 235 concl. Questiaux. 
an expulsion order imposed in $1968.3^{31}$ In 1976, he requested the Minister of the Interior to revoke the expulsion in conformity with art. 6 of an EEC directive of 1964. On the Minister's refusal without reasons (as required by the 1964 directive), Cohn-Bendit challenged the decision and the tribunal administratif referred the matter to the European Court of Justice (ECJ). The Minister appealed successfully to the Conseil d'Etat. Despite the clear ruling of the ECJ on the direct effect of art. 6 of the 1964 directive in relation to France, ${ }^{32}$ the Conseil d'Etat held that, even if Member States were obliged to legislate to implement a directive, 'these authorities alone remain competent to decide the form in which to implement directive and to determine themselves ... the appropriate means to give effect to it in internal law'. This contrasted with approach of the Cour de cassation, which had already decided in 1975 to give priority to EEC law over a conflicting national law. ${ }^{33}$ To be fair to the Conseil d'Etat, it was not the only national court which took this approach to the idea that directives might be directly effective - indeed in 1981, the Bundesfinanzhof expressly agreed with the Conseil. But there was clearly a generational problem among the judges in attitudes towards EU law. Indeed, the commissaire du gouvernement Bruno Genevois had taken the opposite view with his famous claim that 'At the European community level, there should be neither a judges' government nor a judges' war, there must be room for a dialogue between judges.' In 1988, the Conseil constitutionnel, sitting as an election court, held that EEC law had to prevail over an inconsistent national law. ${ }^{34}$ In two decisions in 1989, the Conseil d'Etat followed suit. In Compagnie Alitalia, it held that there was a principle under which an administrative authority was obliged to withdraw an illegal decision at the request of its addressee (abrogation). ${ }^{35}$ This principle applied not only to decisions contrary to national law, but also to those contrary to European law. In this case, the Minister was obliged to withdraw national regulations in the General Tax Code which were inconsistent with the sixth EEC VAT directive. This was followed by Nicolo in which an individual challenged a 1977 French law on European elections on the ground that it gave voting rights to citizens of France's overseas

${ }^{31}$ CE Ass. 22 December 1978, Ministre de l'Intérieur c Cohn-Bendit, no. 11604, Leb 524; D 1979, 155 concl. Genevois.

32 ECJ, 28 October 1975, Case 36/75, Rutili [1975] E.C.R. 1219.

33 Cass ch. mixte, 24 May 1975, Administration des Douanes c Société Cafés Jacques Vabre, no. 73-13556, D. 1975, 505; [1975] 2 C.M.L.R. 336.

34 CC decision no. 88-1082/1107 AN, 21 October 1988, 5 e circonscription du Val d'Oise, AJDA 1989, 128 note Wachsmann.

35 CE Ass. 3 February 1989, Compagnie Alitalia, no. 70452, Leb. 44; AJDA 1989, 387 note Fouquet. 
départements and territories on the ground that this was contrary to art. 227-1 of the EEC Treaty. ${ }^{36}$ The Conseil held that the 1977 law was perfectly compatible with art. 227-1, but in so doing, it recognised (albeit obliquely) the superiority of EEC law, a point made clear in the conclusions of the commissaire du gouvernement Frydman.

The Conseil's slowness to recognise the supremacy of EEC law (as it then was) was matched by that of the House of Lords, which came to a similar decision in the same year in the Factortame decision. ${ }^{37}$ The position of both courts took place against the background of the creation of the Single Market from 1986 to 1992, which gave a new impetus to the EEC. It reveals that courts at the time were reluctant to be at the forefront of greater transfers of sovereignty to the EEC, and that they relied on constitutional reform which came with the constitutional amendments of 1992, including art. 88-1 of the Constitution, which gives explicit priority to EU law (as it was called after the Maastricht Treaty of 1992).

Two decisions in the zooos show the sincere adhesion of the Conseil d'Etat to EU law. In the Arcelor case of 2007 , it had to deal with the issue of competition between a European rule, in this case a directive setting up the system of greenhouse gas quotas but only for certain industries, and the Constitution. Since plastic industries were not concerned by this new regulation, unlike steel industries, Arcelor challenged it on the ground the decree transposing the directive was contrary to the constitutional principle of equality. The Conseil d'Etat ruled that, since there was an equivalent principle at the EU level, it should decide on the basis of EU rather than on constitutional principle, which the commissaire du gouvernement Guyomar called an 'opération de translation'. ${ }^{3}$ The Conseil d'Etat asked the ECJ for a preliminary ruling, which eventually ruled that the breach of equality was justified on the ground that it was a complex system which must be put in place step by step. ${ }^{39}$ However, it remains possible, in theory, that EU law may not offer an equivalent principle to a French constitutional one - one may think of secularism - which may lead to the Constitution to prevail over EU law.

In 2009, the Conseil d'Etat overturned the Cohn-Bendit case law, regarding the directive no 2000/78/CE not transposed at the time of the litigation, which imposes Member States to secure a reverse burden of proof whenever an

$37 R v$ Secretary of State for Transport, ex parte Factortame (No. 2) [1991] 1 A.C. 603.

$3^{8}$ CE Ass. 8 February 2007, Société Arcelor Atlantique et Lorraine, no. 287110.

39 ECJ 16 December 2008, C-127/07, Société Arcelor Atlantique et Lorraine v Premier ministre [2008] ECR I-9895. 
individual presents in court facts from which it may be presumed that there has been direct or indirect discrimination. ${ }^{40}$ The Conseil d'Etat applied this to a civil law judge who challenged her rejection as a professor in the Ecole Nationale de la Magistrature, which she claimed was based on her trade union membership. Although the Conseil d'Etat admitted that certain facts might raise a presumption of a potential discrimination, her claim was dismissed on the ground that the woman nominated instead of the claimant had better qualifications for the position, based on various evaluations of the two as well as the linguistic capacity of the nominee.

It is significant that, when faced with a French government claim that the CJEU had interpreted EU law in a way which was contrary to the French Constitution, the Conseil d'Etat did not rise to the bait, but sought to diffuse the problem by aligning EU law with domestic constitutional law. Its reaction was unlike that of the German Constitutional Court in Weiss. ${ }^{41}$ The decision of the Conseil d'Etat in La Quadrature du Net carefully negotiated the French policy of wishing to have access to mobile telephony data in the fight against terrorism with the EU legislation on data retention. ${ }^{42}$ Guided by a reference to the CJEU, it found lawful most of what the government wished to ensure for its antiterrorism policy, but required the retention to be reviewed more frequently than the government planned. In interpreting the French legislation, it ensured respect for the French constitutional objective of protecting public order and respect for privacy within EU data protection law. The Prime Minister argued that the requirements of the European Court of Justice in its reply to the reference from the Conseil d'Etat conflicted with the constitutional objectives of protecting public order and the investigation of crime. The decision of the CJEU had been that the EU directives on data protection 'must be interpreted as precluding legislative measures which, for the purposes laid down in Article 15(1), provide, as a preventive measure, for the general and indiscriminate retention of traffic and location data. ${ }^{43}$ But the reply of the CJEU went on to state that general and indiscriminate requirements to hand over data would be allowed for the purposes of safeguarding national security, recourse to an instruction requiring providers of electronic communications services to retain, generally and

$4^{\circ}$ CE Ass. 30 October 2009, Perreux, no. 298348.

${ }^{41}$ BVerfG 5 May 2020, Weiss, 2 BvR 859/15, ECLI:DE:BVerfG:2020:rs20200505.2bvro85915.

42 CE Ass. 21 April 2021, La Quadrature du Net, no. 393099.

43 CJEU Grand Chamber, 6 October 2020, Cases C-511/18 and 512/18, La Quadrature du Net, ECLI:EU:C:2020:791. 
indiscriminately, traffic and location data in situations where the Member State concerned is confronted with a serious threat to national security that is shown to be genuine and present or foreseeable, where the decision imposing such an instruction is subject to effective review, either by a court or by an independent administrative body whose decision is binding, the aim of that review being to verify that one of those situations exists and that the conditions and safeguards which must be laid down are observed, and where that instruction may be given only for a period that is limited in time to what is strictly necessary, but which may be extended if that threat persists.

The Conseil d'Etat found that the French situation fitted within the exception and so there was no clash between EU law and domestic constitutional requirements.

\subsection{THE INFLUENCE OF THE EUROPEAN CONVENTION ON HUMAN RIGHTS ${ }^{44}$}

Article 6 (1) of the European Convention on Human Rights provides 'In the determination of his civil rights and obligations or of any criminal charge against him, everyone is entitled to a fair and public hearing within a reasonable time by an independent and impartial tribunal established by law.' It is the concept of 'an independent and impartial tribunal' that caused the greatest difficulty for French administrative law in relation to the role of the commissaire du gouvernement.

The commissaire du gouvernement was a long-established part of French administrative court procedure. ${ }^{45}$ Created in 1831 , the commissaire du gouvernement had as his function to present arguments to the court in the interests of the law, and not in the interests of any of the parties, either the government or

44 See J. Bell, "The Role of the Commissaire du gouvernement and the European Convention on Human Rights' (2003) 9 European Public Law 309; id. 'Interpretative Resistance Faced with the Case-Law of the Strasbourg Court' (2008) 14 European Public Law 137; id. 'From "Government Commissioner" to "Public Reporter": A Transformation in French Administrative Court Procedure?' (2010) 16 European Public Law 533. For a further example of long-standing administrative court practice being overturned under the influence of the European Convention, see, for example, in 1990, the Conseil d'Etat overturned the practice adopted since 1823 that, when it was faced with an issue about the interpretation of a treaty, it asked for an opinion from the Ministry of Foreign Affairs and applied its interpretation: CE Ass. 29 June 1990, GISTI, no. 78519 , AJDA 1990, 621 concl. Abraham.

45 See L. N. Brown and J. Bell, French Administrative Law, $5^{\text {th }}$ ed. (Oxford: Oxford University Press, 1998), pp. 49 and 104-6; J. Bell, French Legal Cultures (London: Butterworths, 2001), pp. $183-4$ and $186-7$. 
the citizen. He is conceived as part of the judicial function and he is a judge. ${ }^{46}$ As the Conseil put it in 1957: ${ }^{47}$

Considering that the commissaire du gouvernement in litigation before the Conseil is not the representative of the administration; . . . as his mission is to search out and present to the Conseil the issues to be resolved in each case and to make known his views, formulated completely independently, his assessment, which should be impartial, of the facts of the case and the applicable rules, as well as on the solutions which, according to his own opinion, are required.

His role is to advise the court neutrally and to maintain a degree of continuity within the case law of the court. An experienced commissaire described the role as one of 'forging the case-law' as well as publicising it to the wider world. ${ }^{4}$ He was able to agree to the order of hearing of cases and to decide the importance of a case and request a hearing before a more solemn formation of the court. In this respect, as guardian of the case law, he performed a role close to that of the Advocate General before the European Court of Justice, which was modelled on the procedure in the French courts. The commissaire enjoyed independence in formulating his arguments and, despite the name, was never subjected to orders from the government.

But two features of the Conseil d'Etat procedure (and that of other countries which followed its procedure) attracted adverse comment from the European Court of Human Rights in the 1990s, years during which judicial independence was a particular concern, both in relation to the investigation of political corruption and in establishing democracy in Central and Eastern Europe following the fall of the Iron Curtain. The first of these was the connection between the advisory and the adjudicatory functions of members of the Conseil d'Etat. As will be seen in Chapter 3, the Conseil d'Etat has long had a function as legal advisor to the government, as well as of judge of governmental actions. In Procola v Luxembourg, the European Court of Human Rights ruled that judges who had advised the government on the legality of legislative or administrative instruments could not then adjudicate on cases

$4^{6}$ The commissaire is hierarchically subordinate to the senior judges in his court and may be subjected to disciplinary action by them for his conduct in court: see CE 25 January 2006, Marc-Antoine, no. 275070, AJDA 2006, 997 note Markus. The note points out that no sanction can interfere with the proper independence of the commissaire in formulating his opinion.

47 CE 10 July 1957, Gervaise, no. 26517, Leb. 365. The arguments of the commissaire were considered distinct from those of the parties: N. Rainaud, Le commissaire du gouvernement par le Conseil d'Etat (Paris: LDGJ, 1996), p. 47.

$4^{8}$ B. Genevois, 'Conserver l'apport du commissaire du gouvernement tout en prenant compte de la jurisprudence européenne’, AJDA 2006, 900 at p. 901. 
involving their application. ${ }^{49}$ The Luxembourg Conseil d'Etat had so few members that it was difficult to avoid a situation in which those who had advised on draft legislation would not also be needed to make up a judicial panel adjudicating on issues connected with the legality of the measure in question. The French took the view that this problem would not affect them, because there were far more members of the French body, so a separation of functions could be maintained.

A greater challenge to the French conception of judicial independence and of a fair trial came in a series of cases questioning the role of the commissaire du gouvernement. Although the function (like that of the avocat général in the ordinary courts) was to be the neutral advisor of the court, a number of procedural aspects of the role attracted criticism from the European Court of Human Rights. There were two main concerns. The first was that the conclusions presented by the commissaire du gouvernement were not open to challenge by the parties. The second was that the commissaire du gouvernement participated in the deliberations of the court. As we will see in Chapter 4, the commissaire (now called the rapporteur public) speaks after the parties have made their submissions.

In Kress v France, a claimant in a damages action against the state complained about a number of breaches of art. 6 of the European Convention in relation to the hearing of her case before the Conseil d'Etat. ${ }^{\circ}$ The first was that she did not have access to the opinion of the commissaire du gouvernement. This was rejected. Before the administrative courts, the parties could make observations on his remarks by way of a short, written submission to the court, known as a note en délibéré. This was different from other cases in which European Court of Human Rights had sanctioned civil and criminal procedure in Belgium and France because the parties did not have access to the conclusions of the avocat général, but had no way of rebutting points before the judges deliberated..$^{51}$ In administrative court procedure, the claimant's avocat was permitted to ask the commissaire du gouvernement for an indication of the line of his arguments before the hearing and could send in a note before the judges deliberated. This made the procedure different from that of the Cour de cassation and saved this aspect of the procedure from censure. All the

ECHR 28 September 1995, Procola v Luxembourg, Application 14570/89 (1995) 22 EHRR 193. ECHR 7 June 2001, Kress v France, Application no. 39594/98, AJDA 2001, 675. Bell, "The Role of the Commissaire du gouvernement and the European Convention on Human Rights'.

See ECHR 30 October 1991, Borgers v Belgium, Application no. 12005/86 (1993) 15 EHRR 92; also ECHR 20 February 1996, Lobo Machado v Portugal, Application no. 15764/89 (1996) 23 EHRR 79; ECHR 31 March 1998, Reinhardt and Slimane Kaid v France, Application nos. $23043 / 93$ and 22921/93 [1998] ECHR 23. 
same, the European Court of Human Rights still declared the role of the commissaire $d u$ gouvernement incompatible with art. 6 of the Convention. It simply adopted a different perspective from the French courts based on the idea that justice must not only be done, but must be seen to be done. In essence, it considered the commissaire du gouvernement as an amicus curiae, someone offering impartial advice to the court, not part of the judicial team who decides the case. The analogy with the Advocate General in the European Court of Justice in Luxembourg was only too obvious. ${ }^{52}$

The key problem with the role of the commissaire du gouvernement was that, in status, he was a judge and considered by the French as part of the judicial team dealing with the case. Indeed, the commissaire du gouvernement had actually read the full file and worked on the cases attached to it. Only the rapporteur in the judicial team had done as much work. As will be seen when discussing court procedure in Chapter 4, the other deciding judges will not necessarily have read the case file in anything like such depth. Furthermore, the commissaire had access to the draft judgment prepared by the rapporteur before the oral hearing. Indeed, one of the authors had the experience in the 1980 of reading case files on the day before the hearing and could compare the draft judgment of the rapporteur with the draft conclusions of the commissaire du gouvernement on the same cases. A particular problem was the practice of the administrative courts that the commissaire retired with the deciding judges and was present during their deliberations. He was allowed to speak, but not to vote. One of the authors was allowed to be present during the deliberation phase of cases in both the Conseil d'Etat and in some tribunaux administratifs during the 1980s and can vouch for the fact that the commissaire did indeed speak during the deliberations at the invitation of the deciding judges and there was often a debate with him..$^{53}$ This aspect of the commissaire's role was considered unacceptable by the European Court of Human Rights. It relied on the theory of appearances, so beloved of the common law approach to natural justice. The Court thought that the litigant was entitled to be assured that the very presence of the commissaire du gouvernement could not exercise and influence on the outcome of the court's deliberations. On a French analysis, this argument was stupid. If the commissaire du gouvernement was part of the judicial team, then of course he ought to be able to influence the decision, even if he does not have a vote. On the other hand, the European Court was fixated with an analysis of the judicial bench,

52 See para. 86 of the Kress judgment.

53 See J. Bell, 'Reflections on the Procedure of the Conseil d'Etat', in G. Hand and J. McBride, eds., Droit sans frontières (Birmingham: Faculty of Law, 1991), p. 211. 
more familiar in the common law, where there is a clear separation between advocates (representing the parties or the public interest) on the one hand, and judges sitting on the bench on the other. Only if the reasonable litigant's perspective adopted such a strict separation and treated the commissaire as an advocate and not a judge did this appearance seem problematic. No one practising in the French system would adopt such a perspective. But the alternative view prevailed. The French administrative judicial establishment reacted badly to this.

Not surprisingly, the initial reaction of the French administrative judges was to stick as far as possible to their traditional practices and to make minimal changes - for example, by ensuring the parties were aware of the 'sense' (but not the detail) of the commissaire's arguments in advance of the hearing. By contrast, the Cour de cassation had decided to comply with Strasbourg court ruling against it, ${ }^{54}$ and no longer to allow the avocat général to be present at the private deliberation phase with the deciding judges. The position of the administrative courts came under further scrutiny from the European Court of Human Rights in Martiniev France. ${ }^{55}$ Here the issue was the compatibility of the procedure before the Cour des comptes (the audit court judging public accounts and disciplining public accountants, see Chapter 3) with art. 6 of the Convention. The procedure of the Cour des comptes was similar to that of the general administrative courts, except that it was purely a written procedure. The majority of the Grand Chamber found that the procedure violated art. 6 , despite a vigorous defence led by the French judge (who was also a member of the Conseil d'Etat). Two grounds of the decision were significant for all French administrative courts. France was condemned because the procureur général (the equivalent of the commissaire du gouvernement in the general administrative courts) was present during the deliberation, even though he did not in fact participate. In addition, the report of the reporter judge (i.e. the draft judgment) was communicated to the procureur before the hearing, but not to the parties, so he had privileged access. The principle that justice must be seen to be done prevailed, even if there is no evidence of any actual prejudice to litigants. Although he had been a dissenter in the Kress decision, the President of the European Court of Human Rights, Wildhaber, joined the majority in Martinie, refusing to overturn its previous case law.

54 Reinhardt and Slimane Kaid; see note 51.

55 ECHR Grand Chamber, 12 April 2006, Application no. 58675/00, AJDA 2006, 986, (2007) 45 EHRR 15 . 
The reaction of the Conseil is shown by an interview given by its then chief, Vice President Genevois. ${ }^{56}$ He did not hide his view that the Strasbourg court made the wrong decision. The minority of the court in Martinie explicitly made the argument 'if it ain't broke, don't fix it' to argue that a practice that had secured justice for more than 170 years should not be overturned simply because it might be misunderstood or because it did not fit a 'purist' conception of a fair procedure..$^{57}$ All the same, the approach of the Conseil d'Etat was been described aptly as "partly submission and partly interpretative resistance..$^{8}$ In part it changed its procedure, as did the Cour de cassation, to encourage greater communication of the commissaire's arguments to the lawyers before the hearing; it also accepted changes in the rules of procedure that allow a party to object to the presence of the commissaire at the deliberation among the judges. But the resistance has come in the interpretation of 'participation'. Contrary to the view of the majority in Martinie, the Conseil does not consider 'presence' synonymous with 'participation'. As will be seen in Chapter 4, although the rapporteur public (as he is now called) in the tribunal administratif or in the Cour administrative d'appel does not retire with the judges, he is entitled to be present in the Conseil d'Etat unless the parties object (and their lawyers never do!). The final element in this saga was the relabelling of the commissaire du gouvernement as 'rapporteur public' in 2009 and a number of changes in procedure, allowing the parties to respond orally to the arguments of the rapporteur public. Increasingly, the rapporteur public mirrored the Advocate General in the Court of Justice of the European Union. Distinctive traditional French conceptions of fair procedure have had to change to meet contemporary European conceptions of what a fair procedure now demands. Whereas for Hamson in 1954 'this autonomy [of the Conseil d'Etat is] self-evident', conceptions of transparency have moved on. ${ }^{59}$ As an occasional additional judge of the European Court of Human Rights, Pacteau is sensitive to how the French system looks from the outside. He noted in 2009 that:

It is true that it seems bizarre to see the Government, largely master of the composition of the Conseil d'Etat, not to mention that its president is the Prime Minister (albeit as a matter of protocol, but all the same....). Indeed

Genevois, 'Conserver l'apport du commissaire du gouvernement tout en prenant compte de la jurisprudence européenne', AJDA 2006, 900. A good statement of the French perspective can be found in I. Pingel and F. Sudre, eds., Le ministère public et le procès equitable (Brussels: Bruylant, 2003).

57 Dissenting opinion of Judges Costa, Caflisch and Jungwiert, in Martinie, para. 9.

$5^{8}$ F. Rolin in AJDA 2006, 989 .

59 Hamson, Executive Discretion and Judicial Control, p. 75. 
notably, because it is highlighted, many administrative judges pass through mixed and subtle careers. Not least, there is the duality of its functions, with that other original feature, at least to external eyes, that litigation on decrees or ministerial decisions made after consultation with it is reserved to [the Conseil d'Etat] ..., remembering the ambiguous care with which the Conseil d'Etat ensures that consulting it has been genuine, effective and without abuse, over and above the normal requirements for consultations. ${ }^{60}$

Commentators have perceived a much deeper change resulting from the European Convention. Madiot argued in 1991 that French society was 'dominated by an administrative law subordinated to a mythical and indefinable public interest which only operates for the almost exclusive interest of the administration and which, too often, reduces the individual to the level of a subject'. ${ }^{61}$ Braconnier argues that the Convention's emphasis on the individual, his claims against the state, and the subordination of the state and its discretionary power to the law undermines the authoritarian aspects of the French public law tradition. ${ }^{62}$ For the French, the Convention also does not respect the public law/private law distinction, which is central to their conception of administrative law - for example, in relation to the application of art. 6(1) on a fair judicial process, or on principles of liability. In the case of the latter, the Strasbourg court takes the view that interference with individual rights requires a minimum standard of protection whether the interference results from the act of an individual or of a public body. ${ }^{6} 3$ This clashes with the French tradition of seeing public law issues as conceptually distinct because the reconciliation of the interests of the public and an individual is not the same as the reconciliation of two competing individual interests. With some exaggeration, Braconnier argues that the focus on the protection of individual rights constitutes 'a legal earthquake' which requires the French to reassess both their conceptual structures and values and their organisation in public law. ${ }^{64}$ Lasser also viewed the debate about the commissaire du gouvernement as a challenge to the traditional French conception of public law. ${ }^{65}$ The Republican tradition focused on the public interest as determined by the

B. Pacteau, 'La justice administrative française désormais en règle avec la Cour européenne des droits de l'homme?', RFDA 2009, 885, at p. 886 (our translation and introduction of punctuation into a sentence 120 words long!).

61 Cited in S. Braconnier, Jurisprudence de la Cour européenne des droits de l'homme et droit administratif français (Brussels: Bruylant, 1997) at p. 318.

62 Ibid.

63 See Chapter 7, Section 3.2.

64 Braconnier, Jurisprudence de la Cour européenne, p. 505.

65 M. De S.-O.l'E. Lasser, Judicial Transformations (Oxford: Oxford University Press, 2009), pp. $265 \mathrm{ff}$. 
general will of the people expressed through the legislature and the executive. Administrative law structured and facilitated this. By contrast, the European Convention represents, in his view, a more 'liberal' model of competing individual interests and entitlements which the law has to regulate. Administrative law is no longer naturally aligned with the state, albeit as a moderating and supervising influence. It is much more a neutral arbiter where the state has no particular special position.

Braconnier also argued that the Convention enriches administrative law by providing a new source of general principles of law and this leads to a decline in importance of the administrative judge in protecting rights. As will be seen in Chapter 3, the Conseil d'Etat had a very distinguished role in developing 'general principles of law' as the foundation for the protection of fundamental rights, especially in the 1950s. But the Conseil constitutionnel (set up in 1958) and the European Court of Human Rights (since direct petition was allowed by France in 1981) have become major judicial forces in defining standards for the protection of human rights in France. This has inevitably reduced the role of the Conseil d'Etat, which is effectively (though not formally) a hierarchically inferior court. French administrative law has to look to constitutional law and European laws for authoritative statements. Although it can still act innovatively in declaring new principles, but it is no longer the principal driving force. ${ }^{66}$

\subsection{REFORM OF THE ADMINISTRATION}

France may be distinctive in the organisation of its administration and in its administrative law, but it is not unusual among developed countries. Particularly since the Second World War, France has been subject to what Christopher Hood called 'megatrends' in government. ${ }^{67}$ In the immediate post-war period, France centralised rebuilding its economy and society through the Plan, but in the 1980s, this gave way to reliance on the free market. Nationalisation of key public services and, in the early 1980s, of the "heights of the economy' spawned a large number of public enterprises and publicly owned private law enterprises. But from the Chirac government of 1986 , privatisation became a major way of organising public services, not least under the influence of European Union law which wished to avoid some Member States closing off sectors of their economies to competition coming from other Member States. A further trend was the introduction of new public

66 For example, CE Ass. 3 July 1996, Koné, no. 169219, Chapter 7 note 100 and text thereto.

67 C. Hood, 'A Public Management for All Seasons?' (1991) 69 Public Administration 3. 
management. Hood ${ }^{68}$ points to changes in the technologies of government and of delivering public services, changes in social expectations and changes in the operation of political parties as some of the reasons for changes in government which occurred across a range of developed countries. The Organisation for Economic Co-operation and Development (OECD) has been a major location for the exchange of ideas among the administrations of many developed countries. Its location in Paris has been helpful for providing the French administration, among others with intelligence on what has worked in other countries and what are the best ideas. It has monitored developments in a large number of countries on themes such as 'the modernising of the state', a label and a theme which has dominated French government discourse for the past forty years. ${ }^{69}$ The themes have involved control and reduction of budgets, accountability for results and a different kind of face for public administration towards the citizen. These trends in public administration also fitted into the changes in social expectations following the protests of May 1968. The demand for a more democratic, responsive and accountable government gave particularly French impetus to the general trend to a more consumer-like relationship between the users and providers of public services. 'History, culture and the level of development give different characteristics and priorities to governments. ${ }^{30}$

Through the modernisation programme, the face of the administration has changed increasingly because of technology. The rather authoritarian, bureaucratic and anonymous face has given way to trends of more open government. Technology enabled greater accessibility of the administration to the public. Information could be provided by the administration to the public and the public could interact more easily with the administration. France was idiosyncratic in developing Minitel for this purpose, before migrating to the Internet. This was combined with a more personalised interaction. There has long been a requirement that the administrator making a decision should sign the document. So it was relatively straightforward to ensure that the citizen knew the name of the administrator dealing with their case.

Transparency was an early requirement of the modernising French state. The Law of 17 July 1978 gave any person the right of access on demand to files, reports, minutes, statistics, decrees and circulars held by the administration. It also gave individuals the right to request documents concerning them individually. These rights were enforced by the creation of a commission for access

\footnotetext{
Ibid., pp. 7-8.

69 See, for example, OECD, Moderniser l'État: la Route à Suivre (Paris: OECD, 2005).

70 Ibid., p. 12.
} 
to public documents (the CADA; see Chapter 2, Section 4.1). The Law of 11 July 1979 introduced obligations for the administration to give reasons for its decisions affecting individuals unfavourably. In particular, reasons have to be given where civil liberties are restricted, penalties imposed, conditions are imposed on an authorisation, existing rights are restricted or withdrawn, time limits set or benefits refused when the requisite conditions are met. This reversed the normal expectation in administrative law that there was no requirement to give reasons without a specific text requiring this.

Accountability was among the earliest issues in France after 1968. Changes in complaints were introduced in 1973 when the Médiateur, the French ombudsman (now called the Défenseur des droits) was introduced. Whereas the administrative courts were concerned with the legality of administrative decisions, the Médiateur added a further level of accountability in terms of failure to fulfil its mission or unfairness in the results achieved. (We will return to this office, which became a constitutional office in 2008 , in more depth in Chapter 2, Section 5.) The extension of scope and the lack of charge for this service provided an independent check on the administration, alongside the judicial controls.

Holistic approaches to the procedures of public administration have been slow to emerge. Unlike the United States and Germany, which enacted comprehensive legislation on administrative procedure in 1945 and 1976, France did not have a comprehensive text on non-litigation administrative procedure until the Code on the Relations between the Public and the Administration (CRPA) was enacted in 2015. Even then, this is a compilation of texts, rather than a systematic framework for these relations. The first stage was the decree of 28 November 1983 on the relations between 'the administration and its users'. This clarified the status of documents such as governmental circulars (on which users were entitled to rely) and the duty of the administration to withdraw unlawful decisions (without waiting for a court order). It set out a number of rules on administrative procedure. In particular, it required the administration to acknowledge receipt of correspondence, to identify the civil servant responsible for the file and to initiate the transfer of an incorrectly addressed request to the right administration. It also set out a right for a user to make observations before a decision was made. It also set out procedures for consultative bodies, thus enabling the public to participate more effectively in decision-making. The next stage was the circular of Prime Minister Rocard of 23 February 1989 on the 'renewal of the public service'. It sought to empower civil servants by imposing fewer controls and allowing them more initiative, having better dialogue between staff unions and the administration, and encouraging a more welcoming culture towards those 
using a public service. In its fourth section, the circular tried to foster a service culture within the public service. Here technology, personalisation and treating users of a service as partners, rather than the objects of administration were seen as keys. The mood of approach continued in the following decade, leading to the Law of 12 April 2000 on 'the rights of citizens in their relations with the administration'. There is already a change of terminology - the talk of 'rights', the use of the word 'citizen', rather than 'the administered' and the reversal of the order of the citizen and the administration. The vision was that the citizen was not just the passive recipient of benevolent administrative largesse, but an active participant in shaping an appropriate public service. In terms of content, in particular, it re-enacted the provisions of the decree of 1983, and improved the role of the Médiateur.

Initiatives on the 'modernisation' of the public service have been found in all governments since the 1990s. The CRPA of 2015 came as the culmination of attempts to make public administration adapt to the requirements of a changing society. In trying to change the culture, there was a deliberate attempt to reduce grounds of complaint against the administration. Although this work concentrates on the methods of judicial redress against administrative action, that is inevitably only a pathological view of administrative law. The success of administrative law is that it provides a framework of procedures, rules and authority which enables the public to be served in an appropriate way by the administration. That relies on the success of the non-litigation parts of the system which form a background to the system of administrative litigation. More of this will be seen in the discussion on standards of good administration in Chapter 7 .

\subsection{A NOTE ABOUT CASE CITATION}

This book, like most French administrative law textbooks and articles, refers to parties by name. So we talk about leading cases such as Blanco or Nicolo. This remains the tradition of printed French case reports. Alas, French courts have taken the decision that the names of parties are personal data which are protected from online dissemination without their consent. As a result, the online Legifrance website and other similar official websites have anonymised the names of parties in cases, even in old cases. In addition, art. 33 of the Law of 23 March 2019 prohibits the reuse of data on the identity of judges and registrars in cases. So it is not possible to undertake the classic English approach of analysing the decisions or opinions of different judges. All the online reader will get is the number of the case. Accordingly, this book gives the official numbers of every case. French lawyers have as much trouble with 
this as do British readers. British jurists are unlikely to remember 'House of Lords, 5 May 1932' instead of 'Donoghue v Stevenson'!

All the same, the availability of French cases free and online is a great benefit. There are two collections. Legifrance provides access to legislation and judicial decisions of all French courts. The Conseil d'Etat's ArianeWeb is accessible from the Conseil d'Etat website and it provides more precise searching of administrative law decisions, conclusions of the rapporteur public, as well as to consultative opinions. This website provides links to the archive of Conseil d'Etat decisions back to 1821. 


\section{The Institutional and Legal Context of Administrative Law}

Administrative law is the law that defines and regulates the administration. The administration exists as an organisational and a political reality. It is there to serve the political process, but also to provide a reality check on political ambitions - political ideas have to be made to work in the practical world. Compared with other democracies, France has traditionally been a rather centralised state, but it also has deep-rooted local loyalties. As a result, national politicians have often wanted to retain a local power base as the mayor of a specific town or commune, in a way which is not found in the United Kingdom. Only since 2014 has it been unlawful to have both national or European parliamentary mandates and occupy an office in local government. Until then more than 80 per cent of members of the national parliament had some form of local role, such as mayor or deputy mayor of their local commune. The relationship between the central government (Section 2.1) and local administrations is worked out in relation both to the administrations (Section 2.2) and to elected bodies (Section 2.3). As in many contemporary European democracies, governmental power is exercised not only through central and local governments, but also through independent regulatory bodies (Section 2.4). The control and review of the exercise of governmental power operates within the different organs of government and through the law and complaint mechanisms, notably the ombudsman function (Section 2.5). In order to complete the legal context, this chapter presents an overview of the sources of administrative law (Section 2.6).

\subsection{THE CENTRAL ORGANS OF THE STATE}

The French state under the Constitution of the Fifth Republic has strong centralised organs. 


\subsubsection{The Executive}

The distinctive feature of the Fifth Republic is the role of the President. In the Third (1870-1940) and Fourth Republics (1946-58), the President of the Republic was largely a figurehead chosen by Parliament who performed a useful role in appointing the Prime Minister in the frequent changes of government. As Weiss remarked in 1885 , "The fundamental principle of the Constitution is, or ought to be, that the President hunts rabbits and does not govern.' It was the result of a political clash that took place in 1877 at a time when republicans were not certain to impose the Republic. President MacMahon, a royalist, nominated a royalist as the head of government, but after the elections saw the victory of republicans, their leader Léon Gambetta asked the President to dismiss the head of government or to resign ('se soumettre ou se démettre'), which he did. After that, the President chaired the Council of Ministers, but not the cabinet, which junior ministers attended. The President in the Fifth Republic is radically different. Since 1962, the President is directly elected and effectively directs the policy of government (except in times of cohabitation). The President chooses and dismisses the Prime Minister, accepts (and often influences) the Prime Minister's choice of ministers, is the head of defence and foreign relations, assents to legislation and, in name at least, makes many senior administrative and judicial appointments.

As a consequence of the direct election of the President, political parties are shaped as the majority for the President. In 2002 and 2017, new parties were created for the presidential election and in 2002, the successful party's name was 'Union for the Presidential Majority', which indicated the centrality of the leader over the party. Since 1981, every presidential election has been followed by elections to the National Assembly. This reinforces the idea that Parliament should provide the President with the means to carry out his mandate. Until the reform of the President's term of office in 2000, the length of the President's mandate (seven years) was longer than that of the National Assembly (five years). As a result, midterm elections could sometimes generate a majority in the National Assembly that was from a party opposed to the President. In such cases, a prime minister will be effectively forced on the President from the parliamentary majority party. This is described as a situation of 'cohabitation'. Such cohabitation governments operated in 1986-8 (Mitterand as President and Chirac as Prime Minister), in 1993-5

1 Cited in P. M. Williams, Crisis and Compromise: Politics in the Fourth Republic, $3^{\text {rd }}$ ed. (London: Longman, 1964), p. 185. 
(Mitterrand as President and Balladur as Prime Minister) and in 1997-2002 (Chirac as President and Jospin as Prime Minister).

Another significant difference from the Third and Fourth Republics is that ministers are not members of Parliament. If members of Parliament are chosen as ministers, they must hand over their parliamentary seat to a party colleague for the duration of their service. The result is that the Prime Minister can be chosen from people with no strong party background, such as Raymond Barre (1976-81), or even from a party different from the President or the parliamentary majority, for example Edouard Philippe (2017-20), who was, however, excluded from his political party as a consequence. This arrangement was designed to enable the government to be drawn from people with expertise, rather than simply from those with political followings. Ministers are thus dependent on the President and the Prime Minister for their tenure. As a minister put it in 2013 in a less elegant way than Gambetta, 'a minister either keeps his mouth shut or steps down'.

\subsubsection{The Legislature}

The executive holds strong power over Parliament. Under the Fifth Republic, Parliament and its activities have been rationalised, arguably with the result that it is more effective. Parliament meets for specified periods in the year totalling 120 days, and outside those periods (sessions extraordinaires, which are becoming more frequent) meets only on an agenda determined by the government. Within the ordinary legislative period, the government has the right to determine two weeks out of four for the discussion of its legislative proposals (projets de loi), and one week in four is dedicated to the exercise of control by Parliament over the government. Since the 2008 constitutional reform, the powers of Parliament have been enhanced in this regard. In addition, one day a week is given to questions to ministers and one day a month to parliamentary initiatives, including legislative proposals (propositions de loi). Parliamentary committees can question ministers and officials about the conduct of particular policies. These committees tend to be large and are less effective than those in the UK Parliament. However, the 2008 reform extended their powers to investigate similar to the US model, and these have become a new means to control the government as shown on several occasions, including the handling of the Covid-19 pandemic.

The government not only has powers to ensure its business is discussed by Parliament, it also has powers to ensure that it is passed. Finance laws must be considered within seventy days or else they become law all the same (art. 47 of the Constitution). Laws for the financing of social security must be decided 
within fifty days (art. 47-1 of the Constitution). More generally, the government can insist that the Senate or the National Assembly vote on a text as a whole, rather than on individual articles one by one (art. 44-3 of the Constitution). This is often combined with making the vote a matter of confidence in the government. Under art. 49-3, when a vote is declared a matter of confidence, then only votes in favour of the no-confidence motion are counted and, to succeed, the motion must be passed by more than half of the members of the relevant parliamentary assembly. In consequence, abstentions count in favour of the government. Between 1959 and 2018, the government declared eighty-nine issues a matter of confidence, especially when a government did not have an absolute majority as with the Rocard government (1988-90). These attracted fifty-three no-confidence motions, of which the government lost only one (in 1962). Since the 2008 reform, there is a limitation in the number of uses of art. 49-3.

The most important function of the 1958 Constitution was to rationalise the relative competences of the government and Parliament in relation to legislation. Rather than give Parliament competence to vote laws on everything, it has limited competence and the rest is left to the executive to make legislation by decree. Article 34 of the Constitution establishes that, in certain matters such as education and health, the law establishes the principles and then the executive is free to establish the rules by decree. But in certain more fundamental matters such as nationality, crimes and taxes, laws should determine the rules as well as the principles. Article 37 then gives the executive power to legislate by decree on the remaining matters. In addition, the government may be authorised by law to legislate by way of ordonnance in areas that normally fall within the competence of Parliament under art. 34. Such rules come into force by executive decision, but eventually have to be ratified by Parliament and become law. The Conseil constitutionnel recently decided that, if not ratified in the given time, the articles pertaining to the competence of the legislator become law after the expiry date. ${ }^{2}$ An example would be the reform of the Civil Code on contract law which covered more than two hundred articles and was made by ordonnance in 2016 and then ratified (with amendments) in 2018. Decrees of regulatory kind and ordonnances come into force without the approval of Parliament and, unlike in the United Kingdom, are not subject to scrutiny or disapproval by Parliament but can be subject to judicial review before they become law. Each of these forms of legislation presented by the government must first be considered by the consultative procedure in the Conseil d'Etat (see Chapter 3.3.3.2). The balance between

2 CC decision no. 2020-843 QPC of 28 May 2020, Force 5. 
these different forms of legislation can be seen if we take a single recent year. In 2018, there were 45 Laws voted by Parliament, 28 Ordonnances and 1,267 Decrees. ${ }^{3}$ This number is significantly smaller than in the previous year following presidential and parliamentary elections. But the new Prime Minister reintroduced a guideline that one new piece of legislation had to replace two old ones (circular of 26 July 2017).

In such ways, the Constitution of the Fifth Republic formalises the control of the executive over Parliament that exists in many countries. The reforms of 2008 aimed to rebalance this. One-fifth of parliamentarians supported by onetenth of electors can call a referendum (art. 11 of the Constitution). Threefifths of parliamentarians in the relevant committee can reject presidential nominations to senior public posts (art. 13). Parliament was given the right to debate before the deployment of French forces abroad (art. 35) and delegated legislation (ordonnance) has to be ratified expressly, rather than being continued in force by the failure of Parliament to vote positively against it (art. 38).

\subsection{THE LOCAL ORGANS OF THE STATE}

France has been a centralised state certainly since the Revolution of 1789 , if not since unification in 1589 . The French kings had their local administrators, the intendants, and the Revolution carried on the pattern of state officials running decentralised strategic administrations alongside elected bodies providing services which were valued locally. This pattern continues today.

The state's administration broadly follows the pattern of region, département and arrondissement/commune, with increasing diversity for big conurbations.

\subsubsection{Regional Administration}

The region emerged gradually throughout the twentieth century as a vehicle for decentralising the state and making public policy more responsive to local needs. The number, structure and functions of regions were reformed by the law of 7 August 2015 (the Loi NOTRe (Nouvelle Organisation Territoriale de la République)) in order to regroup some of the pre-existing regions. Since 1 January 2016, thirteen regions have been established in metropolitan France and five overseas. The region takes the lead in commenting on and funding initiatives which are particularly relevant to its area. A major function is the

3 For comparison, in 2018, the UK Parliament passed 34 public and general acts and the UK government made 1,128 statutory instruments. 
coordination of economic initiatives with respect to the competence of the government. The region is responsible for economic development and planning. Here it will engage with public and private organisations. In addition, it has specific areas of competence, such as regional transport and professional training. For example, the region of Pays de la Loire has 3.7 million people mainly clustered around big centres such as Nantes, Le Mans and Angers. In 2020 , it had a budget of $€_{135} .6$ million.

The decentralised authority in relation to secondary, further and higher education is the académie, headed by a rector nominated by the government. ${ }^{4}$ Metropolitan France has twenty-six académies, so many regions have more than one académie. They are under the Ministry of Education. The Rectorat de l'académie is responsible for education policy, the appointment of teaching staff and researchers, and the running of schools, technical colleges and universities. The Rectorate is thus a very large regional employer with a very large budget. For example, the Académie of Nantes, which covers the whole of the region of Pays de la Loire, in 2019 had a budget of $€_{3.452}$ billion for its population of 3.7 million. It had 874,800 pupils, students and apprentices in 3,600 education institutions and a staff of 63,600 people.

As will be seen, the political decisions on the development of a region are taken by elected councils and officials within their spheres of competence. Alongside these local policy decisions is a decentralised administration of the state run by the prefect of the region. Essentially, a ministry may choose to confer powers on a prefect rather than to operate a policy centrally from Paris. Article 1 of decree no 2015-510 of 7 May 2015 proclaims decentralisation (déconcentration) to be the default organisation of public administration of the central government. So, if the latter defines, facilitates and evaluates the general policy framework, then the 'facilitation, coordination and implementation' of the policy at the local level is the remit of the prefect. All the same, the ministry retains a role in coordinating the various local administrations of the state. In addition, the Secretary General of the government chairs the National Conference of Local Administration, which brings together the regional prefects and others to ensure the effective articulation of the state's local and central services.

The prefect of the region is first among equals within the prefectoral corps. ${ }^{5}$ That said, he or she has authority over the prefects of the départements of the

4 The French term is retained to avoid confusion with the very different use of 'academy' as a description of a type of school in England.

5 At the time of writing, it has been announced that the prefectoral corps will be abolished, but the prefect role will continue. 
region in most matters. He or she has authority to give instructions on how to carry out government policies and to supervise their implementation. The three main exceptions are the supervision of départements, communes and local public bodies in their area, public order and security within their area, and the entry and residence of foreigners.

\subsubsection{Département}

Départements are local divisions of France that date from the Revolution (law of 22 December 1789-8 January 1790), based on the principle that one could ride on horseback from the capital to any location within the territory in a day. Metropolitan France consists of ninety-six départements. They have both a local authority with elected representatives - political decentralisation and a local state governmental structure - administrative decentralisation called déconcentration. Article 6 of the decree on déconcentration provides that, unless otherwise prescribed, the département is legally the normal territorial unit for the implementation of national and EU policies. It has been the principal beneficiary of policies of political decentralisation started in 1982.

The département is further decentralised to the level of an arrondissement. This is not the same as the arrondissements of cities like Paris, Lyon and Marseille as shown in what follows, which is convenient for running government services under the authority of sub-prefects (sous-préfets).

Services are also operated on a level between départements - for example, water and forests - which are best run at a level below that of a region.

\subsubsection{The Commune}

Communes are the very local unit of administration. The commune was created in order to impose uniformity in the treatment of towns and cities across the country. There are now about thirty-five thousand communes. Many are very small and there have been attempts to encourage mergers in recent years. On 1 January 2018 , 91 per cent of communes $(32,148)$ in metropolitan France had fewer than thirty-five hundred inhabitants, and they accounted for only 33 per cent of the population. But they had a budget of $€_{21} .8$ billion. Each commune has a mayor who holds administrative roles such as serving as the officier of the état civil (registrar of births, marriages and deaths) and being responsible for local public health and order. The mayor is thus the very local representative of the state - for example, at a marriage - as well as politically, the representative of the local area to the state and, in many cases, the person who endorses a candidacy for the presidency of the Republic. 


\subsubsection{The Big Cities: Paris, Lyon, Marseille (PLM)}

The tripartite division of region, département and commune has long been inappropriate for the big conurbations of Paris, Lyon and Marseille. Since 1982, they have formed administrative units within communes (arrondissements), but with their own mayor and assembly in addition to those existing at the city level.

Since 2019, the Ville de Paris is a unitary public authority that is a commune and a département with legal personality, an elected mayor and a significant budget.

The city of Marseille is part of a joint organisation of communes called the Métropole, as are almost all communes (which can also take other forms and names) with specific competences transferred from the communes. The Métropole of Lyon is unique in France since it also holds the competence of the département of Rhône, but only for the communes belonging to this Métropole.

\subsubsection{The Prefect}

The prefect is an office created by Napoleon Bonaparte, and prefects are consequently sometimes nicknamed the empereurs aux petits pieds. The prefect is a senior civil service role. The Prime Minister selects members of the corps of prefects from those who succeed in the competition at the civil service college, the École nationale de l'administration (ENA), or from civil servants who enter the corps by way of competitive examination.

In 2013 , there were 250 prefects for the whole of France; 127 of them held posts in regions and départements and 75 were at a senior level. Many of those who were not in local territories worked either for the President of the Republic or for the Ministry of the Interior. They are obliged to operate with strict and transparent neutrality, unless they are formally given leave of absence. When assigned to a territorial post, prefects are obliged to live in that area. They rarely become politically eminent with the exception of Sadi Carnot, the President of the Republic assassinated by an Italian anarchist in 1894 in Lyon. However, they may attract attention due to their important role, as did Baron Haussman, who refurbished the city of Paris in the mid nineteenth century, or Jean Moulin, whose first act of resistance was in his capacity of prefect. He refused - under torture - to endorse false accusations against black people launched in 1940 by German troops of occupation.

The prefect is the sole representative of the state in the local area. The prefect represents the Prime Minister or other ministers and ensures the 
implementation of regulations and government decisions. For example, the prefect is entitled to speak to the Conseil régional either by agreement with the chair of the Conseil or at the insistence of the Prime Minister (art. L4132-35 of the Code général des collectivités territoriales (CGCT)). During the Covid-19 crisis, the prefect was in charge of ensuring that confinement rules were enforced (and sometimes to adapt them locally). That is because state arrangements on security belong to the prefect. The prefect is also the supervisor over local authorities. Until 1982, the local authorities had to submit decisions to the prefect and he or she was able to prevent them coming into force. Today, the prefect can only refer a decision to the tribunal administratif once received by him or her. In practice this happens in about 1,500 cases out of about 6 million decisions submitted to prefects every year. ${ }^{6}$ The prefect also monitors local financial decisions and may refer matters to the chambres régionales des comptes. The prefect is thus the state monitor of local authorities in a way that is only exercised centrally in England.

\subsection{ELECTED LOCAL AUTHORITIES}

Elected authorities are established at the levels of region, département and commune. They are institutions of local democracy and have their own local administrations, policies and resources. The Constitution of 1958 recognises the principle of the free administration of local authorities (arts. 34 and 72). That free administration involves the guarantee of sufficient powers, the guarantee of proportionate interference by the state and the guarantee of resources. The guarantee that the local authorities will have enough power to carry out their mission is recognised by art. $72(2)$ of the Constitution, which states that 'local authorities are called to take decisions on the totality of the competences which can be best implemented at their level'. But there are few inherent powers, and most are conferred by the legislator. The Conseil constitutionnel tends to operate with minimum scrutiny over the discretion exercised by the legislature in whether to allocate powers to local authorities. $^{7}$ At the same time, article 1 of the Constitution entrenches the important principle of the indivisibility of the Republic. That has as a consequence that local authorities cannot be given powers to develop special treatment in their area which affects fundamental rights. ${ }^{8}$ Thus the conditions for local special treatment have to be carefully circumscribed. The freedom of

6 www.vie-publique.fr/fiches/20169-role-du-prefet-departement (visited 26 April 2021).

7 CC decision no. 98-397 DC of 6 March 1998, The Functioning of Regional Councils, Rec. 186.

8 CC decision no. 2001-454 DC of 17 January 2002, Corsica, AJDA 2002, 100 note Schoettl. 
local authorities to govern their territory needs to be balanced against the basic equality of all French citizens in their rights and in the public services they receive. A peculiar French approach to this uniformity is shown in the treatment of local languages. The Conseil constitutionnel ruled that conferring rights on a local community - for example, the Bretons - to exercise their local language would infringe the unity of the Republic around one language (the principle of the unity of the French people). ${ }^{9}$ However, the legislator tends to increase more indirectly the use of local languages to be in conformity with the European charter of local languages.

\subsubsection{Region}

The region is governed by the Conseil régional as the deliberative organ, which elects the President of the region, and by a consultative organ, the Conseil économique, social et environnemental régional (CESER).

The Conseil régional is directly elected for six years in two rounds by a list system. ${ }^{10}$ In the first round, electors vote for a list of candidates by party grouping. In the second round, only those lists having obtained at least 10 per cent of votes in the first round are able to present lists for which candidates are chosen. These lists can be combined between the rounds with any list having obtained 5 per cent of the votes in the first round. After the second round, seats are allocated according to a 'proportionalised majority' system. The winning party list obtains a quarter of the seats, and the parties obtaining less than 5 per cent of the votes are eliminated. The remaining threequarters of seats are then distributed in proportion to the votes cast for each party list in the second round of voting. The councillors then meet and elect the President of the region. In terms of policy areas, the Conseil régional has a broad remit. For example, the Conseil régional for the Pays de la Loire developed policies in 2020 for a regional train network, for providing career advice, for promoting summer tourism after the Covid-19 confinement, and for investing in medical research within the region.

The CESER is a consultative body. It advises on the economic, social and environmental consequences of regional policies; it is consulted on such policies and it contributes to the assessment of their effectiveness (art. 4134-1 CGCT). The aim is to get a spread of civil society interests. This Conseil operates mainly through thematic committees. For example, the CESER of

9 CC decision no. 99-412 DC of 15 June 1999, European Charter of Regional and Minority Languages, AJDA 1999, 573 note Schoettl.

10 Art. L338 Code électoral. 
the Pays de la Loire is composed of 120 members appointed for six years. One group comprises representatives of local employees, another group includes representatives of employers and the self-employed, a third group consists of representatives of associations - for example, from environmental associations or youth associations - and a small fourth group is made up of individuals appointed by the prefect. The CESER operates through seven standing committees. In 2019, the CESER produced opinions on the future of regional transport and the future of industrial strategy and professional education, as well as giving its opinion on the regional budget for the coming year. Its advice is not binding on the Conseil régional.

\subsubsection{Département}

The département is the typical unit for developing local policies. It is led by a Conseil départemental elected by constituencies called 'cantons'. For example, the Conseil for the Sarthe département consists of forty-two members, one man and one woman elected from each of twenty-one cantons on a majority, two-round basis since the 2008 constitutional reform imposed parity in political institutions. These councillors in turn elect a president of the département. The full Conseil meets four times a year and an executive committee, the Commission permanente, transacts most business. Specialist committees also feed into the decision-making process. Their remit covers tourism, culture, social housing, local transport infrastructure and skills development. The Département de la Sarthe has a budget of $€_{101}$ million for a population of 566,506 inhabitants. A lot of important decisions are taken at this level. For example, secondary schools (collèges) are run by the département when it comes to the construction and maintenance of buildings, whereas lycées are run at the regional level and primary schools at the city level.

\subsubsection{The Commune}

The commune is a very small unit for local decisions on areas like urban planning, kindergartens, primary schools and tourism. The small size is illustrated by the fact that the Département de la Sarthe had, in 2020, 354 communes, but only 21 cantons electing its Conseil départemental. In the 2017 census, only 9 of these communes had more than 5,000 inhabitants, and 122 had fewer than 500 inhabitants. The smallest (Nauvay) had a population of 11. It is not surprising that some communes have been merged in recent years and that some find it very difficult to field candidates for elected offices such as 
the mayor. More than 100 communes failed to have candidates in the 2020 municipal elections. ${ }^{11}$ In those elections in the Département de la Sarthe, only a quarter of the mayors elected were women.

The number of services provided directly by a commune depends on its size. Many services are provided by joint organisations between communes (établissements publics de coopération intercommunale which have legal personality). A larger commune like the town of Laval has elementary schools, planning, sports and cultural centres, tourism and social welfare provision. With a population of 52,359, Laval had a budget of $€ 88,225,000$ in 2020 . A smaller commune like Mamers with just over 5,000 inhabitants had a budget of just over $€_{12}$ million. Spending per head of population is actually not very different between small and big communes, but the former can do very little on their own. Democracy needs to adjust to the effectiveness of public services.

The local mayor has powers over public order and public health. But these are subject to strict justifications and also to the pre-eminent competences of state specialised authorities. For example, when the mayor of Sceaux decided at the beginning of the Covid-19 crisis that masks must be worn in public, the Conseil d'Etat struck down the public health order on the ground that the legislator had conferred the control of the epidemic to the state and its officials and there was no imperative local reason for departing from the coherence of national measures. ${ }^{12}$ Of course, subsequently the mayor's idea became national policy when masks were widely available.

\subsubsection{The Big Cities: Paris, Lyon, Marseille}

Under the PLM Law of 1982, these three major conurbations are divided into electoral sectors. (In Paris, these sectors are called arrondissements, though the central arrondissements are grouped together. The sectors in Lyon are also called arrondissements.) The voters in each sector elect councillors on a party list basis and these in turn elect one of their members to be their sector mayor. In proportion to their populations, a number of the sector councillors also sit as city councillors for the Ville. The councillors for the city plus the mayors of the sectors form an electoral college which elects the city mayor. Particularly in Paris, which has the powers of a département as well as those of a commune, the position of the mayor is significant. Unlike the mayors of large English cities such as Manchester

11 Le Monde, 13 March 2020.

12 CE ord. 17 avril 2020, Commune de Sceaux, no. 440057, AJDA 2020, 1013. 
and London, the mayors of these big French cities do not have authority over the state police or the fire service, but they have greater power in the provision of services and head the local police called police municipale which has limited powers.

The budget of these large cities is substantial. Lyon in 2020 had a budget of $€_{79} 8$ million (and the Métropole of Lyon $€_{4}$ billion). Of the expenditure on particular directly provided services, 45 per cent went to children and education and 30 per cent to culture and sport.

\subsection{INDEPENDENT ADMINISTRATIVE AUTHORITIES (AAIS)}

Modern administration has given rise to a range of bodies which are neither government departments or local state administrations nor elected bodies. At one time, there were nationalised industries (entreprises publiques), but these were largely privatised in the last part of the twentieth century. A number of large public enterprises remain, such as the state train company SNCF and the rail track company RFF. Much of the activity of such bodies is governed by private law in relation to customers and subsidy arrangements with public authorities. In more recent times, the state has been concerned less with the direct delivery of services than with the regulation of private actors involved in an activity to achieve public interest objectives. A variety of these bodies grew up over the years, and the Law of 20 January 2017 has attempted to give coherence to the rules governing the most important regulatory bodies, the so-called Independent Administrative Authorities (autorités administratives indépendantes (AAIs)). These twentysix bodies are a small but important subset UK scholars would call 'quangos' or 'Executive Non-departmental Public Bodies' (ENDPBs). Examples of those included are the authority controlling airport noise, the authority regulating online gambling, the commission for access to public documents, the national commission on election expenses and the financing of politics, the commission responsible for assessing research and universities and the Défenseur des droits (the ombudsman).

Some AAIs are called autorités publiques indépendantes (APIs) because they have legal personality in their own right conferred by the law which created them. This has been particularly the case of some of the financial regulators. For example, the Autorite des marches financiers and the Commission de contrôle des assurances, des mutuelles et des institutions de prévoyance were given legal personality to regulate respectively the financial and insurance markets. Having separate legal personality reinforced their independence in relation to public bodies. 
Although the Law of 2017 does not provide a general definition of AAIs and merely lists the bodies to which it applies, there are a number of typical features: regulation, a power of decision and independence from government.

\subsubsection{Regulation}

The purpose of these different bodies is to regulate the conduct of individuals, groups and companies in a particular sphere of activity. Some regulate the actions of the public administration - for example, the commission for access to public documents (CADA) or the commission responsible for assessing research and universities (HCERES). Some regulate the activities of commercial entities which are public (e.g. the authority controlling airport noise (ACNUSA)) or private (e.g. the authority regulating online gambling (ARJEL)). They assess and rule on the conduct in their domain. This might be by dealing with complaints of individuals or it may be by setting standards. In either case, they exercise normative power which governs the way in which particular activities are carried out.

A particular concern relates to the rule-making powers of AAIs. In the Constitution, legislative power is conferred either on Parliament (art. 34) or on the Prime Minister (art. 21). So how can AAIs make rules that directly regulate the conduct of citizens and companies? The Conseil constitutionnel has had two responses. First, the regulatory power of an AAI is not superior to that of the Prime Minister. Thus, a legislative provision was struck down which subordinated the rules laid down in decrees to general rules produced by an AAI. ${ }^{13}$ Secondly, the measures must be limited in scope both in terms of their field of application and by their content. ${ }^{14}$ The rules produced by AAIs are soft law rather than hard law like the decrees promulgated by the government. So, for example, they cannot create a total ban on 'cookie walls' within soft law guidelines on the protection of personal data. Such a generalised and absolute ban would require hard law, and the Conseil national de l'informatique et des libertés (CNIL) could not create such hard law. ${ }^{15}$

13 CC Decision no. 86-217 DC of 18 September 1986, Commission Nationale de la Communication et des Libertés (CNCL), AJDA 1987, 162 note Wachsmann.

14 CC Decision no. 88-268 DC of 17 January 1989, Conseil Supérieur de l'Audiovisuel (CSA), Rec. 18: no general power of regulation permitted over publicity, sponsorship and institutional communication.

15 CE 19 juin 2020, Société Google LLC, no. 430810. 


\subsubsection{Decision}

The key difference between these and many other public bodies is that they have power to make decisions rather than to be consulted. So they are genuinely executive bodies with powers to enforce their decisions either directly or indirectly (e.g. by bringing prosecutions). In particular, many of these bodies have the power to sanction the actions of the persons they regulate. The sanctions can be substantial.

\section{4 .3 Independence}

The key feature of the AAIs is their independence from the government. This feature gives them both status and legitimacy. For example, because the CNIL is independent of the government, the public will have confidence in its view about whether 'Stop-Covid', a contact-tracing application downloaded onto the phones of individual citizens, would sufficiently protect their privacy. ${ }^{16}$ In that case, the CNIL set out guidelines for the operation of such applications so individual freedoms could be protected.

The independence of AAIs is not clearly regulated in the Constitution. Article 20 of the Constitution puts the administration at the disposal of the government. So, on first reading of this very hierarchical provision, it might appear that AAIs are subordinated to the government. In 1987, the Conseil d'Etat remarked in its advisory capacity that they are 'a category for which the constituent did not provide and which is difficult to reconcile with the balance of powers which it put in place'. ${ }^{17}$ But case law of the Conseil constitutionnel sees the independence of AAIs as a permitted exception. ${ }^{18}$

The status and powers of such bodies rests on statute. Only the Défenseur des droits is a constitutionally defined authority and even then she does not make legally binding decisions.

It may be that, in some cases, these AAIs do not have an independent budget (e.g. the CADA's budget is simply part of the Prime Minister's budget) or their power to issue guidelines is subordinated to approval by the Prime Minister. It will also be true that the decisions and sanctions will be subject to judicial review by the administrative courts, including soft ones such as "naming and

www.cnil.fr/en/publication-cnils-opinion-french-contact-tracing-application-known-stop covid (visited 2 July 2020).

17 Etudes et Documents du Conseil d'Etat, 1987, p. 53.

18 See CC decision no. 86-217 DC of 18 September 1986, CNCL, note 13; C. Teitgen-Colly, 'Les instance de régulation et la Constitution', RDP 1990, 153. 
shaming' or public advice. ${ }^{19}$ Some features of independence are common, such as the non-renewable tenure of members (so as to avoid the need to maintain the favour of someone who might reappoint them).

\subsection{DÉFENSEUR(E) DES DROITS}

Like many democracies in the second half of the twentieth century, France adopted the institution of the ombudsman in 1973. The proponents of the institution argued that this would provide a protection to the citizens against an aloof bureaucracy. For example, Poniatowski declared:

The French administration is often heartless, haughty, and convinced that it embodies the sovereign. Sprung directly from the past and having largely taken shape under the monarchy, it is riddled with monarchical attitudes. It does not regard itself as a public service but as a master ordering subjects about. ${ }^{20}$

The Médiateur, as he was then called, offered a simple and accessible remedy that was not limited to the scope of judicial review and could examine the merits of a decision for unfairness.

The constitutional reforms of 2008 gave the Défenseur des droits, as he then became, a constitutional foundation. Article $71-1$ of the Constitution gives the Défenseur the mission of ensuring that individual rights are respected by public bodies and those delivering public services. This is clarified by Art. 4 of the Organic Law of 29 March 2011. That law also gives him the mission of protecting the internationally defined rights of the child or rights against direct or indirect discrimination, as well as the promotion of equality. He is also responsible for ensuring compliance with the code of ethics for the security forces and for directing whistle-blowers on violations of rights to an appropriate authority. Any person who considers that they have been harmed by a public service can bring a complaint, and the Défenseur can begin an investigation on his own initiative. For example, in January 2020, the Défenseur and former minister of justice, Jacques Toubon, opened an inquiry on his own initiative into the death of a delivery driver of North African origin at the hands of the police. ${ }^{21}$ In 2019, he began eleven such inquiries, also under his own initiative. Associations protecting people against discrimination also have standing to make complaints.

19 CE Ass. 21 March 2016, Société Fairvesta international, no. 368082.

20 Cited in L. N. Brown and P. Lavirotte, 'The Mediator: A French Ombudsman?' (1974) 90 L.Q.R. 212; L. N. Brown and J. Bell (with J.-L. Galabert), French Administrative Law, 5th ed.

(Oxford: Oxford University Press, 1998), pp. 32-4.

21 Le Monde, 9 January 2020. 
The Défenseur thus has a wider remit in some respects than the parliamentary and health ombudsman in the United Kingdom. His work also covers the work of the Equal Opportunities Commission, the local government ombudsman and the Independent Office for Police Conduct. On the other hand, the Défenseur does not have responsibility for the French equivalent of the British National Health Service. In May 2021, the new Défenseure, Claire Hédon, reported very critically on more than nine hundred complaints about breaches of fundamental rights in care homes received by her office since 2014, notably during Covid-19 confinement. ${ }^{22}$

The independence of the Défenseur is ensured by his non-renewable term of office for six years, by the prohibition on anyone giving him instructions, and by his immunity from suit in relation to his work. Tenure of this role is incompatible with any other public role, either elective or administrative.

Because it is a national institution covering the full range of central and local government, the Défenseur des droits has a substantial workload. In 2019, the Défenseur received 103,066 complaints and his offices received a further 48,183 telephone enquiries. The institution has 510 local representatives and 874 local offices. ${ }^{23}$ The advantage of local offices is that complainants can appear in person, which 77 per cent did in 2019. ${ }^{24}$ By contrast, the central office received more than 60 per cent of its complaints online. In 2019, the institution closed 99,095 complaints with 80 per cent of cases settled informally thanks to the Défenseur's intervention. There were 304 formal decisions with nearly 700 recommendations. In terms of areas of work, in 2019, 24 per cent of cases related to social security and welfare, 11.2 per cent to road traffic, 10 per cent to migrants and 9.4 per cent to the courts and prisons system, half of which related to prisons. ${ }^{25}$

The Défenseur can make reports to the President on particular topics, give advice on pending legislation or recommend legislative reform. In 2019, he made 180 recommendations for legislative reform. He also gave advice on legislation to deal with the Covid-19 pandemic. ${ }^{26}$

During the Covid-19 pandemic, the Défenseur received 1,424 complaints, more than 870 of which related to restrictions on individual freedoms imposed by the confinement measures. ${ }^{27}$ He created a special hotline for prisoners to

22 Défenseur des droits, Les droits fondamentaux des personnes âgés accueillis en EHPAD (Paris, 2021).

23 Défenseur des droits, Rapport annuel d'activité 2019 (Paris, 2020), p. 12.

24 Ibid., p. 16.

25 Ibid.

26 Défenseur des droits, Synthèse urgence sanitaire (Paris, 2020), pp. 16-17.

27 Ibid., p. 6. 
complain about their conditions and received 2,000 calls. Such calls led to discussions with the Ministry of Justice and the prison authorities and prompted action to reduce the risks to prisoners from the disease. ${ }^{28} \mathrm{He}$ produced a decision (report $\mathrm{n}^{\circ}$ 2020-100) which found that the closure of offices for the registration of asylum seekers was required neither by the Covid19 legislation nor by the threat of infection, and it severely prejudiced their rights. He also intervened with supermarkets to end the practice of refusing to let handicapped children accompany their parents on shopping trips and requiring them to be left at the door. ${ }^{29}$

A good example of the role of the Défenseur in the area of discrimination is in dealing with complaints relating to the mistreatment of Moslem women because of their attire out of a misguided understanding of the requirements of the neutrality of the state in matters of religious belief. Examples related to applicants for housing (report $n^{\circ}$ 2018-070), students sitting university examinations (report n²016-299), swimmers wearing the 'burkini' on the beach or mothers accompanying classes on a school outing. In this area, the Défenseur worked in line with the advisory opinions of the Conseil d'Etat. ${ }^{30}$

The role of the Défenseur(e) is an important alternative to the courts. It is free and speedy. But there are limitations. As art. 25 of the Organic Law of 2011 makes clear, the Défenseur(e) may make recommendations and may suggest a fair settlement of a grievance, but he has no powers of enforcement. The public authorities are merely bound to explain what they have done in relation to his recommendations. All the same, the high level of settlements makes this a very important kind of alternative dispute resolution.

\subsection{SOURCES OF ADMINISTRATIVE LAW}

Although codes govern a large number of areas of administrative activity, these 'codes' are much more like consolidating acts of Parliament than the broad general principles of the French Code civil. Like the common law, the general rules and principles of French administrative law, especially those relating to judicial review, are laid down not in codes or legislation, but in the case law of the courts, systematised by legal scholarship. Although the French talk about the hierarchy of rules (la hiérarchie des normes), the interaction between the different levels in providing legal solutions is more complex. All the same, this

\footnotetext{
8 Ibid., pp. $7-8$.

Ibid., p. 11.

Ibid., pp. 35-6.
} 
presentation of sources will follow the pattern of the classical hierarchy of norms.

\subsubsection{The Constitution}

The French Constitution of 1958 is not a complete statement of the rules and principles of the Constitution. The Constitution has to be sought in a variety of locations, not all of them written texts.

The text of the $195^{8}$ Constitution contains most of the core institutional rules on the powers of the President, of Parliament, of the executive and of the judiciary, as well as rules on constitutional amendment. In a number of areas, these rules are supplemented by Organic Laws - for example, the ordonnance of 2 January 1959 on finance laws and the Organic Law of 26 July 1996 on social security budgets, as well as the Organic Law of 29 March 2011 on the Défenseur des droits. The rules of procedure in each chamber of the Parliament are also approved by the Conseil constitutionnel.

The 1958 Constitution did not try to set out a new set of rights. Rather it merely took over the statements in previous constitutions. In 1946, there were problems in obtaining popular approval for a new statement of fundamental rights. The eventual compromise was to reaffirm the Declaration of the Rights of Man and of the Citizen of 1789 together with a set of 'principles particularly necessary for our times'. The 1958 Constitution simply endorsed both these documents. There is clearly a problem of priority between the two sets of fundamental rights. The Conseil constitutionnel had to resolve this in relation to the nationalisation of various key industries in $1982 .{ }^{31}$ The Conseil used historical arguments to justify the priority of the 1789 text because the Preamble to the 1946 Constitution specifically endorsed that earlier set of principles, but now it tends to make compromises between the two of them.

The Preamble to the 1946 Constitution also states that it affirms 'the fundamental principles recognized by the laws of the Republic'. But it fails to state which laws or, indeed, which Republic. It was understood to apply essentially to the fundamental values recognised by the laws of the Third Republic. ${ }^{32}$ That Republic never had a single constitutional text, but gradually built up a set of

${ }^{31}$ CC decision no. 81-132 DC of 16 January 1982, Nationalisations, Rec. 18; J. Bell, French Constitutional Law (Oxford: Oxford University Press, 1992), DECISION 2.

32 The Conseil appears to endorse principles adopted in legislation up until the adoption of the 1946 Constitution. Thus, in CC decision no. 97-393 DC of 18 December 1997, Family Allowances, Rec. 320 , the Conseil was prepared to consider that an ordonnance of the provisional government from 4 October 1945 and a loi of 22 August 1946 could be the basis for such a fundamental principle. 
fundamental constitutional principles through legislation, much like the British Constitution. The decisive decision establishing constitutional review, the Associations Law decision, was based on the right to association that was a fundamental principle recognised by the laws of the Republic, notably the loi of 1901. ${ }^{33}$ The process of determining whether a contested value is a fundamental principle recognised by the laws of the Republic involves a number of stages. Firstly, the Conseil identifies a text which talks about the value in question. In doing this, the Conseil needs a prior conception of which right is at issue and whether it is possibly fundamental. Typically, the authors of the reference will cite texts. The texts will either be whole laws, or even disparate provisions, as will be seen in the case of the freedom of education which was 'discovered' in Article 91 of the Finance Law of 31 March 1931. ${ }^{34}$ Secondly, the Conseil looks not so much at the precise words of the text as at the fundamental value it expresses, a general principle underlying its specific provisions. Thirdly, it has to be permanently confirmed - that is, it must not have been repealed at some point by a law of a Republic. Finally, having elicited a principle of general import, like the freedom of association, it has to produce a specific rule capable of resolving the question before it, such as the rule against prior restraint. In performing this task, the Conseil is at its most creative. Apart from the freedom of association, the Conseil has also declared as fundamental a number of principles in administrative law such as the independence of administrative judges and the separation of public and private law courts, ${ }^{35}$ the continuity of public services ${ }^{36}$ and human dignity. ${ }^{37}$ The Conseil constitutionnel has abandoned the search for specific texts in more recent years. Since 1976, the Conseil constitutionnel has typically referred to 'principles having constitutional value' (principes à valeur constitutionnelle), frequently without mentioning a specific source. This phrase includes both the written texts and other materials drawn from fundamental principle recognised by the laws of the Republic, some general principles of law and some objectives of constitutional value. ${ }^{38}$ The Conseil constitutionnel is not the only body to identify such principles. The Conseil d'Etat has also done so. ${ }^{39}$

33 CC decision no. 71-44 DC of 16 July 1971, Associations Law, Rec. 29; Bell, French Constitutional Law, DECISION 1.

34 CC decision no. 77-87 DC of 23 November 1977, Freedom of Education, Rec. 42; Bell, French Constitutional Law, DECISION 21.

35 CC decision no. 86-224 DC of 23 January 1987, Competition Law, Rec. 8.

36 CC decision no. 79-105 DC of 25 July 1979, Strikes on Radio and TV, Rec. 33; Bell, French Constitutional Law, DECISION 23.

37 CC decision nos. 343 and 344 DC of 27 July 1994, Bioethics, Rec. 100; GD no. 47.

$3^{8}$ See J.-P. Costa, 'Principes fondamentaux, principes généraux, principes à valeur constitutionnelle', Conseil constitutionnel et Conseil d'Etat (Paris: LGDJ, 1988), p. 133.

39 CE Ass. 3 July 1996, Koné, nos. 394399 and 400328, Leb. 355. 
In addition to these fundamental principles which leave scope for interpretation, the Conseil has set out a number of 'objectives having constitutional value'. ${ }^{\circ}$ They are means for implementing constitutional values. As Genevois states, "the objective of constitutional value appears as the necessary corollary of the implementation of a constitutionally recognized value'. ${ }^{41}$ Although these are matters of means rather than ends, the Conseil constitutionnel has been reluctant to leave Parliament with total liberty in this area. If an objective is identified as of 'constitutional value', it has a special status as a means by which the legislature must realise a fundamental constitutional value. The law cannot be changed in such a way as to weaken the constitutional protection afforded to individual rights. In this way, the objectives restrict the freedom of action of the legislature.

\subsubsection{Codes and Legislation}

As has been mentioned, a large number of very specific 'codes' regulate much of the activity of the administration. The code général des collectivités territoriales (CGCT), the code de l'entrée et du séjour des étrangers et du droit de l'asile (Ceseda), the code de la commande publique (CCP) and the code général des impôts are all consolidated collections of legal rules applicable to major areas of administrative activity. But there are no general codes. The nearest is the code des relations entre le public et l'administration (CRPA) of 2015, which deals with the non-litigation aspects of administrative procedure. In 2000, the rules of administrative court procedure were consolidated into the code de la justice administrative (CJA) and these come close to the codes of civil and criminal procedure. Key legislation established the role of the Conseil d'Etat, such as the Law of 24 May 1872 or the ordonnance of 31 July 1945 and regularly gives powers to government and other public bodies. But there is no code or legislative provision which sets out the principles on which judicial review and state liability are based. In addition to these codes and legislation specific to the administration, the Conseil d'Etat accepts that any law is 'opposable' to the administration. For instance, a nomination of a high civil servant to a private undertaking was ruled out as contrary to the famous criminal offence of pantouflage which banned any civil servant from being employed by a firm over which he or she had exercised supervision in

40 See B. Faure, 'Les objectifs de valeur constitutionnelle: une nouvelle catégorie juridique?' (1995) 21 Rfdc 47.

41 B. Genevois, La Jurisprudence du Conseil constitutionnel (Paris: Editions STH, 1988), $\$ 342$. He draws a parallel with Nold v Commission [1974] ECR 491 (European Court of Justice). 
the previous five years (art. $43^{2-13}$ of the criminal code $)^{42}$. Competition law which sanctions abuses of dominant position and illicit collusion can be also be opposed against any administrative act whether unilateral or contractual which has the potential effect of placing a firm in a situation to infringe these rules. Therefore, a long duration of a contract giving exclusive rights may be deemed as placing the benefitting firm into an automatic abuse of dominant position. $^{43}$

\subsubsection{EU Law}

European Union law is a major source of French law. As noted in Chapter 1, Section 5, the French administrative courts were much slower than the ordinary courts in recognising the supremacy of EU law over national laws. The position was clarified first by the Nicolo decision of the Conseil d'Etat in $1989,{ }^{44}$ and then by an amendment to the Constitution in 1992 such that its art. 88-1 now provides:

The Republic shall participate in the European Union made up of states which have freely chosen to exercise certain of their competences in common by virtue of the Treaty on European Union and the Treaty on the Functioning of the European Union as they result from the treaty signed in Lisbon on 13 December 2007. ${ }^{45}$

Situations in which a French court has to declare a French law incompatible with EU law are very rare. The approach of the Conseil d'Etat is shown by Association ornithologique et mammalogique de Saône-et-Loire. ${ }^{46}$ In the first decision, the Prime Minister was requested to declassify a Law of 15 July 1994 under which the date for the opening of the hunting season for migratory birds was fixed in a way that was incompatible with a recent decision of the ECJ interpreting a directive of 1979 on the protection of wild birds. The Conseil d'Etat did not quash his refusal. It noted that the Prime Minister had an obligation to implement EU law and to draw the consequences of the incompatibility of the law with the 1979 directive as interpreted by the ECJ. But the Prime Minister had wide discretion about how to do this, and his failure to choose a particular route could not be challenged. On the other hand, in

42 CE Ass. 6 Décember 1996, Société Lambda, no. 167502.

43 CE Sect. 3 nov. 1997, Société Million et Marais, no. 169907.

44 CE Ass. 20 October 1989, Nicolo, no. 108243, Leb. 190 concl. Frydman.

45 See more generally S. Boyron, "The "New" French Constitution and the European Union' (2009) 11 Cambridge Yearbook of European Legal Studies 321.

$4^{6}$ CE Sect. 3 December 1999, nos. 164789, 165122, RFDA 2000, 59 concl. Lamy. 
the second decision, the Conseil d'Etat quashed the refusal of the minister to fix dates for the season for hunting waterfowl. He claimed that he was prevented from doing so by a law of 1998 which had a formula for setting dates which was earlier than 1 September. But the Conseil d'Etat held that this law was incompatible with the 1979 directive and so the minister could not refuse to exercise his general powers under the Rural Code to set the start of the hunting season.

The discretion to keep an unlawful provision in force is very limited. In Association La Cimade, a decree provided for the automatic loss of benefits from migrants with an irregular immigration status. ${ }^{47}$ The Conseil d'Etat held this to be incompatible with an EU directive of 2013 which only permitted withdrawal of benefits in limited circumstances and which required attention to the individual circumstances of the person in question. Despite the claims of administrative difficulties from the Minister of the Interior, the Conseil d'Etat refused to delay the quashing of the provision in the decree. A delay in annulling the illegal provision could only be used in exceptional cases in the face of an imperative necessity.

In a situation where it is possible to challenge the domestic implementation of a directive on grounds of incompatibility both with EU law and with the French Constitution, the Conseil d'Etat has taken the view that it should refer the issue by way of a preliminary reference to the CJEU in case there is an equivalent principle at the EU level such as the principle of equality.$^{8}$ In that case, the challenge to the domestic legislation involved an allegation that the directive itself was invalid because it treated similar industries differently with regard to quotas on greenhouse gas emissions, an issue which might infringe both general principles of EU law and French constitutional values. Since the entry into force of the QPC, the priority is for the constitution unless the issue raises an urgent question justifying a preliminary ruling to the ECJ. ${ }^{49}$

A normal situation is when the French courts apply EU law either because it is directly applicable - for example, a regulation - or because it has been transposed into domestic law - for example, a directive. If the delay to transpose a directive is expired (or the directive badly transposed) and the directive clear and unconditional, the Conseil took thirty-one years to recognise its direct effect. ${ }^{50}$ Substantial amounts of French legislation implement

47 CE 31 July 2019, no. 428530 , Leb. 334 concl. Odinet.

$4^{8}$ CE Ass. 8 February 2007, Société Arcelor Atlantique et Lorraine, no. 287110, Leb. 55 concl. Guyomar.

49 CE 14 May 2010, Rujovic, no. 312305.

$5 \circ$ CE Ass. 30 October 2009, Perreux, no. 298348, overturning CE Ass. 22 December 1978, CohnBendit, no. 11604. 
EU law. Major areas such as VAT and agricultural law, as well as many provisions on consumer and environmental law, have their origins in EU law or have been modified by EU law, such as public contracts. The function of the courts here is to interpret national law consistently with EU law. In its annual report for 2007, the Conseil d'Etat examined the relations of the French administration with the European Union and noted the large number of directives which France had not implemented on time. ${ }^{5^{1}}$ The transposition of directives into domestic law was declared a constitutional objective by the Conseil constitutionnel in 2004 and by a circular from the Prime Minister in the same year. ${ }^{2}$ The efforts have been rewarded since France moved from twenty-third place out of twenty-eight Member States in 2007 in its efficiency of implementing directives on time to eighth place in 2019. ${ }^{53}$

The French administrative courts are under an obligation to provide effective remedies for the breach of EU law. Under art. 19 TEU, 'Member States shall provide remedies sufficient to ensure effective legal protection in the fields covered by Union law.' Furthermore, art. 47 of the Charter of Fundamental Rights provides:

Everyone whose rights and freedoms guaranteed by the law of the Union are violated has the right to an effective remedy before a tribunal in compliance with the conditions laid down in this Article. Everyone is entitled to a fair and public hearing within a reasonable time by an independent and impartial tribunal previously established by law.

Those effective remedies involve not only disapplying incompatible legislation and annulling incompatible administrative decisions, but also interpreting domestic law to make it compatible with EU law. An example is Société Natiocrédimurs, in which an EU directive on waste required that the producer of waste or the owner of the land on which it is found be responsible for clearing it up. ${ }^{54}$ The French implementing legislation empowered the local authority to require the producer and the landowner to pay for the cost of removing waste. After a fire at a factory, toxic waste was left which the local mayor ordered the landowner to remove. The landowner contested the order on the ground that the primary person responsible should have been the

${ }^{51}$ Rapport annuel 2007: L'administration française et l'Union européenne: Quelles influences? Quelles stratégies? (Paris, 2007), pp. $321 \mathrm{ff}$.

52 CC decision no. 2004-496 DC of 10 June 2004, Confidence in the Digital Economy, RFDA 2004, 651.

53 European Commission, Commission Staff Working Document Part I: General Statistical Overview Accompanying the Document 'Monitoring the Application of European Union Law 2019 Annual Report' (Brussels, 2020), p. 26.

54 CE 1 March 2013, no. 354188. 
operator of the factory. The Conseil d'Etat upheld the landowner's claim and annulled the mayor's order. Whereas the French legislation seemed to give the mayor a choice of whom he might order to clear up the waste, the preparatory works of the directive were clear that the landowner was only liable in a subsidiary position - for example, when the producer could not be identified. The Conseil d'Etat thus used interpretation to align the domestic legislation with the directive. In addition, the French state will be liable in damages for the unlawful effects of a failure to implement EU law correctly, as will be seen in Chapter 8, Section 4.5.

The obligations of EU law do not fall principally on the judicial branch of government, but on the executive. Thus, as was seen in Chapter 1, Section 5 , in Compagnie Alitalia, the Conseil d'Etat held that the principle under which an administrative authority was obliged to withdraw an illegal decision applied not only to decisions contrary to national law, but also to those contrary to European Union law. ${ }^{55}$ In this case, the minister was obliged to withdraw national regulations in the General Tax Code which were inconsistent with the sixth EEC VAT directive.

A permanent unit in the Section du Rapport et des Etudes of the Conseil d'Etat monitors developments in European law..$^{56}$ This délégation au droit européen produces monthly electronic newsletters which provide the Conseil d'Etat with updates on cases and legislation on the European Union and the European Convention. There are also regular alerts and bulletins on legislative developments, enabling not only the judicial section, but also the administrative sections to keep abreast of forthcoming developments as well as actual court decisions. This unit can answer questions posed by members of the Conseil d'Etat during their work. Under art. R123-6 CJA, the unit can also appear as an advisor to an administrative section in its consideration of forthcoming legislation. The unit is thus part of a proactive attempt by the Conseil d'Etat to ensure that it implements EU law correctly. The unit also takes part in international gatherings outside Europe within its wider mission to integrate international law with national law.

The influence of EU law is not confined to situations where the rules and principles of EU law are directly applicable. There may also be 'spillover' effects in that ideas developed in EU law are applied more generally in domestic law. Whether a 'spillover' occurs is a matter of choice. As will be

55 CE Ass. 3 February 1989, Compagnie Alitalia, no. 70452, Leb. 44; AJDA 1989, $3^{8} 7$ note Fouquet.

${ }^{5}$ See Conseil d'Etat, Rapport public: L'activité juridictionnelle et consultative des juridictions administratives en 2019 (Paris, 2020), p. 381. 
seen in Chapter 7, the Conseil d'Etat has refused to expand the concept of protecting legitimate expectations into domestic law beyond where the administrative courts are applying EU law directly. ${ }^{57}$ Nevertheless, the same decision brought into French law an idea from EU law that the validity of an administrative decision should depend on the availability of transitional provisions. ${ }^{8}$

\subsubsection{European Convention on Human Rights}

As was mentioned in Chapter 1, Section 6, France ratified the European Convention on Human Rights in 1974 to be applied before French courts, and it allowed individual action before the Strasbourg court in 1981, contrary to the UK, which did it the other way round. Its status in domestic law comes from art. 55 of the Constitution, which gives a ratified treaty a superior status to domestic laws made by Parliament. As a result, it is a significant part of French public law. It creates obligations on public authorities not to interfere unduly with a range of fundamental rights. The use of the Convention as a part of the test for the legality of administrative decisions will be discussed in Chapter 7 , Section $3 \cdot 3$.

When discussing the controversy over the role of the commissaire $d u$ gouvernement in Chapter 1, Section 6, it was seen that the Convention can set alternative standards to those current in French administrative law. The Conseil d'Etat acceded reluctantly to the position adopted by the European Court of Human Rights only after trying to test whether the European Court was prepared to review its earlier decision, which had not been unanimous.

But, as in the United Kingdom, the major role of the Convention is in interpretation. Domestic legislation and case law are read in such a way that is consistent with the Convention. A good example is the Diop case. ${ }^{59}$ Diop was a Senegalese citizen. When Senegal was a colony, he joined the French army in 1937 and left in 1947 to join the police force, acquiring his pension in 1959. Having served the French state, he was entitled to a French pension, which the French state continued to pay after Senegal's independence. That pension was revalued annually until a law of 1979 applied art. 71 of the Finance Law for

F. Train, 'L'influence du droit communautaire sur le droit administratif français en matière du droit transitoire', AJDA 2010, 1305.

59 CE Ass. 30 November 2001, Ministre de la Défense c Diop, no. 212179, Rec. 605 concl. Courtial. This is a part of a long saga of legislation on the use of nationality and residence as criteria for discrimination in public service pensions that has involved decisions of the Conseil constitutionnel and the Conseil d'Etat ensuring that the principles of equality in the Constitution and the prohibition on discrimination in the Convention are respected: see Grands Arrêts, pp. 762-6. 
1960 of 26 December 1959 to Senegalese citizens. Under this law, the pension was replaced by an annual payment which did not come under revaluation. Diop wrote to the Minister of Defence, who rejected his request that the pension be revalued. Agreeing with the cour administrative d'appel of Paris, the Conseil d'Etat held that the pension was a debt which, consistent with the case law of the European Court of Human Rights, was a property right under art. 1 of Protocol 1 to the Convention of which the law on revaluation had deprived Diop. Furthermore, the rule on revaluation discriminated between former French public employees on the ground of their nationality - a French national former soldier living in Senegal would have a revaluated pension and a Senegalese one would not. This was unjustified discrimination contrary to art. 14 of the Convention. Accordingly, the minister should have assessed Diop's right to a pension without regard to art. 71 of the 1959 law and should have revalued his pension.

The approach in the case reflects that suggested by commissaire du gouvernement Labetoulle in Debout in $197^{6 .}{ }^{60}$ He suggested that domestic law should be interpreted to be consistent with the Convention 'as far as possible with two preoccupations: on the one hand to avoid any solution which is radically incompatible with the case law of the [European] Court [of Human Rights]; on the other hand, to avoid a solution which on a specific point would mark a departure from previous domestic law'.

Article 6 of the Convention is very significant within the provisions applied by the Conseil d'Etat in the interpretation of its own case law. For example, it was used by the Conseil d'Etat to require professional and other disciplinary bodies to conduct their proceedings in public. ${ }^{61}$ It also uses that article to control the imposition of administrative sanctions. In Didier, it applied the European Court's approach to the bodies which art. 6 covers to include the disciplinary panel of the Financial Markets Authority, even though this would not count as a 'court' within French domestic law. ${ }^{62}$ As a result, the principle of impartiality applied to its proceedings in relation to the presence of the investigating judge in the decision-making panel.

The Convention not only plays a role in acting as a guide to the interpretation of domestic legislation and case law, it may also serve as an encouragement for the French administrative courts to enhance their protection of fundamental rights. Chapter 7 , Section 3.2 gives the example of freedom of

$6 \circ$

CE Sect. 30 October 1998, Lorenzi, no. 159444, RFDA 1999, 633; CE 23 February 2000, L'Hermite, no. 192480, AJDA 2000, 363.

62 CE. Ass. 3 December 1999, Didier, no. 207434. 
the press. Whereas before the Convention was ratified, the administrative courts would only interfere with restrictions on the freedom of the press on public interest grounds where the decision was manifestly wrong, in Ekin, the Conseil d'Etat decided that no restriction would be allowed unless the public authority demonstrated a clear case of necessity, a requirement more in line with the Convention. ${ }^{6}$ Effectively, the burden of proof of necessity has shifted.

\subsubsection{General Principles of Law}

After the Vichy period, the Conseil d'Etat sought to clarify the 'republican constitutional tradition'. Even though the courts could not then strike down legislation, they could limit executive acts and they could interpret legislation restrictively. A series of general principles were elaborated by the administrative courts, drawing both on the specific declarations of rights and on more general principles. In 1951, Rivero identified four sources of general principles of law: (i) the traditional principles of 1789 , such as equality, freedom of trade and conscience and the secular character of the State, (ii) general principles derived by analogy with private law and private law procedure (bindingness of decisions, rights of due process), (iii) principles drawn from 'the nature of things', the logic of institutions, such as continuity of public service, and (iv) necessary ethical principles, such as the administration seeking to serve the common good. ${ }^{6}$ These thus include constitutional values such as freedom of education and religion and freedom of commerce, as well as procedural safeguards like the right to a hearing and the right to challenge decisions of the administration in the courts. Even rules of procedure, such as the right of appeal, might be included. Commissaire du gouvernement Gentot stated in Dame David: ${ }^{65}$

If the general principles of law express - or reflect - commonly accepted ideas which are at the base of our legal system, they have to be consecrated by history and traditions, and be characterised by a certain permanence and a certain appeal to universality.

63 CE Sect. 9 July 1997, no. 151064, AJDA 1998, 374 note Verdier.

64 D. ${ }_{1951}$ Chr. 21 at 22 . See generally B. Jeanneau, Les principes généraux du droit dans la jurisprudence administrative (Paris: Sirey, 1954), and id., 'La théorie des principes généraux du droit à l'épreuve du temps', Etudes et Documents du Conseil d'Etat 1981-2, 33.

65 CE 4 October 1974, no. 88930, Leb. 464; D. 1975, 369, note Auby; JCP 1975.II.19967, note Drago. Although the case only concerned civil procedure, the commissaire took the view that the finding of a general principle of civil judicial procedure might lead to the rules of administrative court procedure being called into question. 
Letourneur linked this with statutory interpretation:

When the legislator of a specific nation votes a particular text, he does so within the framework of the political, social and economic organization existing at the period in question, a framework determined by a certain number of principles which represent the state of the evolution and civilization which that nation has reached; when the judge does not find in a written text the solution to the litigation which is submitted to him, he is necessarily led to apply the same principles that the legislator is accustomed to take as his guide. $^{66}$

Although the general principles have an important status, not all of them are of constitutional status. As Chapus suggested in 1966, some are binding on the legislature, which eventually became true when the Conseil constitutionnel upheld some of them as constitutional principles, while others merely bind the administration in its legislative and administrative functions. ${ }^{6}$ Both types also have some importance in the interpretation of the Constitution. All general principles are of importance in defining the scope of the executive's power to legislate under art. 37 of the Constitution. Furthermore, only Parliament may alter general principles of law under art. 34 of the Constitution. But some general principles, though unwritten, may also bind the legislature in that they constitute fundamental principle recognised by the laws of the Republic or objectives of constitutional value, such as the continuity of public services, and these Parliament cannot alter. The point was well made by commissaire du gouvernement Fournier in Syndicat Géneral des Ingénieurs Conseils in 1959:

There are the general principles of law properly so-called, laid down by the declarations of rights or deduced by judges from them. Among these fundamental principles, which are at the foundation of our political system, one must undoubtedly place the equality of citizens, the guarantee of essential freedoms, the separation of powers and the finality of judicial decisions, the nonretroactivity of the decisions of public authorities and the inviolability of acquired rights, the right of citizens to challenge administrative decisions, a right which has a passive form (the right to a hearing) and an active form (the right to bring an action for judicial review). Equally should be included, as a counterbalance, the continuity of public services, essential to the life of the nation. ${ }^{68}$

M. Letourneur, 'Les principes généraux du droit dans la jurisprudence du Conseil d'Etat', Etudes et Documents du Conseil d'Etat 1951, 19 at p. 20.

67 R. Chapus, 'De la valeur des principes généraux du droit et des autres règles jurisprudentielles de droit administratif D. 196699 at p. 104.

68 CE Sect. 26 June 1959, no. 92099, Leb. 394. See further G. Morange, 'Une catégorie juridique ambiguë: les principes généraux du droit', RDP 1977, 761. 
Among the important general principles of law of infra-constitutional status are that administrative silence is tantamount to a decision to reject a request from a citizen, ${ }^{69}$ that only laws and not administrative decrees or decisions can have retrospective effect, ${ }^{7 \circ}$ and that of audi alteram partem (le principe $d u$ contradictoire $).{ }^{71}$

\subsubsection{Case Law (La jurisprudence)}

Set up in 1799 and soon with a duty to provide reasons for its decisions, the Conseil d'Etat published judgments from 1806. Even under the Restoration (1814-30), it was producing on average 400 judgments a year. The first commercial collection of judgments was in 1819 and the official series began in 1831, the Recueil Lebon, which continues to this day to publish the main cases selected by the Conseil d'Etat itself. So there were official law reports in France many years before the Incorporated Council of Law Reporting began its series in 1865 in England. Unlike in England, administrative law was a clearly defined subject as the product of a distinct court. Having no code, the Conseil d'Etat naturally referred to its own case law even if precedents were not cited as authority in judgments as in England. The major turning points in the development of administrative law have mainly come through judicial decisions. It is clear in the arguments of the commissaire du gouvernement (as the office was then called) as well as from textbooks since the 1830 s that constant reference was made to cases. Indeed, it could be argued that French administrative law was a kind of common law system. As Bernard Schwartz commented,

The development of a system of administrative law to help minimize [the danger of arbitrariness] has been, in France as in the common law world, largely the handiwork of the judge. In this respect the droit administratif, unlike most other branches of French law, bears a resemblance to the kind of law prevalent in the Anglo-American system. The French administrative lawyer, like his confrere in the common law world is accustomed to derive the basic principles of his system inductively from the decided cases ... [But] in the common law world the basic principles of administrative law have been worked out by the ordinary courts by analogy from the principles of private law. In France, on the other hand, the law courts concerned with the

69 See CC decision no. 69-55 L of 26 June 1969, Protection of Monuments Rec. 27; CE Ass. ${ }_{27}$ February 1970, Commune de Bozas, no. 76380 .

$7 \circ$ CC decision no. 69-57 L of 24 October 1969, Repayment of Fees at the Ecole Polytechnique, Rec. 32.

${ }^{71}$ CC decision no. 72-75 L of 21 December 1972, Administrative Procedure, Rec. 36. 
dispensation of justice between individuals have played only a minor part in the field ... The droit administratif is based on the existence of a special law for cases involving the administration and of special courts to decide them. ${ }^{72}$

Dicey made the same point in his lectures (which were unpublished until the remarkable work of John Allison): 'Droit administratif is in its contents utterly unlike any branch of English law, but in the method of its formation it resembles English law far more closely than does the codified civil law of France. For droit administratif is, like the greater part of English law, "caselaw", or "judge-made law". '73

Under the Third Republic, the lack of a constitution made it necessary for judges to develop the principles of public law. In more recent times, it is not merely the diversity of the sources of the domestic Constitution that require the judges to take the lead in developing public law principles. The administrative courts are responsible for giving effect to the priority of European Union law and the European Convention on Human Rights over domestic law. Articles 55 and 88-1 of the Constitution give that priority, but without setting up a mechanism to achieve the alignment that is legally required. So, as was seen in Chapter 1, this task has fallen to the administrative and civil courts. As a result, case law has a major significance in public law.

The difficulty of the case law has always been the style of decision. The laconic style, beginning 'Considering that ...', and the syllogistic organisation of the argument made the judgments difficult to interpret and understand. But the format of the decision of an administrative court was deductive in style and exiguous in justification, which might suggest a timidity in the exercise of judicial lawmaking power. As Gaudemet suggested, "The drafting of the decision cannot be simply the written transposition of the work of reflection and reasoning of the administrative judge. ${ }^{74}$ The explanation lies in considering the function of the text of a judgment. That style was changed in 2019 and the administrative courts have adopted a style that is short by common law standards, but is more like the judgments of the European courts in Strasbourg and Luxembourg. The judgments need to be read in conjunction with the conclusions of the rapporteur public and any annotations. Although the drafting of leading decisions is undertaken with great care, the production of a decision by a very large group of people will often be brief, the lowest

72 French Administrative Law and the Common-Law World (New York: New York University Press, 1954), pp. 2-3.

73 A. V. Dicey, Lectures on Comparative Constitutionalism (edited by J. W. F. Allison) (Oxford: Oxford University Press, 2013), pp. 311-12.

74 Ibid., p. 95 . 
common denominator necessary to achieve the decision. ${ }^{75}$ Occasionally, there may be 'authorised commentary' by members of the Service de documentation of the Conseil, who have published a regular review of recent decisions in the AJDA since 1962, and this can serve as a kind of briefing for the wider public, since they attend the délibéré of the commented cases, although never breaching its secrecy. Rather than relying on the format of reasons, the skilled interpreter is forced to rely on certain institutional practices. Le Berre notes that the internal practices of the Conseil may be a good indicator - if a decision is taken by the chambres réunies, then it will not be intended to overturn established case law, since that function is reserved to the more solemn formations of the Section du contentieux or the Assemblée. ${ }^{7}{ }^{6}$ Since the Conseil controls the publication of its own decisions, this process is also used to signal whether the decision is making an important development in the law, or merely is a routine decision or one confined to its facts. The absence of publication of a decision can minimise its importance, as well as if not commented by the members of the Conseil d'Etat after the judgment. ${ }^{77}$

\subsubsection{Legal Scholarship (La doctrine)}

The term 'administrative law' has been shaped by legal scholarship, but in much closer relationship with the judiciary in France than in England. ${ }^{78}$ The term first appears in 1807 , and the very first course was offered in $1808 .{ }^{79}$ The appointment of a professor in Paris in 1819 (Gerando) was the real starting point for legal education in administrative law. ${ }^{80}$ From the 1830 , there was regular teaching in the universities, leading to the permanent foundation of

75 See J. Bell, 'Reflections on the Procedure of the Conseil d'Etat', in G. Hand and J. McBride, eds., Droit sans frontières (Birmingham: Birmingham Faculty of Law, 1991) (hereafter Bell, 'Reflections'), 211 at p. 226.

${ }^{76}$ H. Le Berre, Les revirements de jurisprudence en droit administratif de l'an VIII à 1998 (Conseil d'Etat et Tribunal des Conflits) (Paris: LGDJ, 1999), p. 297; Bell, 'Reflections', p. 229.

77 Le Berre, Les revirements de jurisprudence en droit administratif de l'an VIII à 1998, pP. 298-9, citing as an example CE Sect 7 July 1982, Commune de Guidel c Mme Courtet, no. 30533, RDP 1983, 1439 which allowed a recours pour excès de pouvoir against a contract, but which was sidelined by non-reporting in Lebon.

$7^{8}$ See generally J. Bell, 'La contribution de la doctrine à la formation du droit administratif : perspectif britannique’, in Le Service Public: Mélanges Long (Paris: Dalloz 2015), pp. 41-54.

79 As part of the proposals drawn up by the inspectors of the Faculties: J.-L. Mestre, 'Aux origines de l'enseignement du droit administratif: le Cours de législation administrative de Portiez de l'Oise (1808)', RFDA 1993, pp. 244-6.

so M. Touziel-Divina, La Doctrine Publiciste 180o-1880 (Paris: La Mémoire du Droit, 2009), p. 263 . 
administrative law chairs in all universities in $1838 .{ }^{81}$ A national programme for university courses in administrative law was imposed by decree in $1862 .{ }^{82}$ From 1855, there was a national recruitment of university professors of law (the agrégation de droit). Administrative law was thus taught to students from an early date. ${ }^{83}$ So there was demand for textbooks and a body of teachers across the country required at least to produce their courses, often in printed form. In addition, the training of senior civil servants started after 1830. Teaching in administrative law was established in 1831 at the École des Ponts-et-Chaussées, the leading college for the administration's engineers. The teachers were leading members of the Conseil d'Etat, such as Cotelle, Aucoc and E. Laferrière. ${ }^{84}$ After 1872 , the École libre des Sciences Politiques followed the same pattern for generalist administrators with leading members of the Conseil d'Etat as teachers such as Romieu, Odent and Braibant during the following century. The written versions of the courses taught in those institutions became the major texts of administrative law scholarship (and the work of their successors remains such today). ${ }^{85}$ Furthermore, commissaires $d u$ gouvernement (as they were then known) would not only teach, but would also develop legal doctrine in their conclusions in judicial proceedings. These would provide the court with a dispassionate and extensive survey of the law, together with clear recommendations as to its development. Their role in negotiating the listing of cases for hearing enabled them to plan the grouping of decisions favourable to dealing with important issues of law and thus in shaping legal doctrine. ${ }^{86}$

University professors not only wrote textbooks at the turn of the twentieth century, but they also shaped the subject by their case notes, a genre serving judges would not be able to use. The great principled content of administrative

81 T. Fortsakis, Conceptualisme et empiricisme en droit administratif français (Paris: LGDJ, 1987), pp. $44^{-8}$.

82 Touzeil-Divina, La Doctrine Publiciste, pp. 237-40.

83 Students were required to obtain a law degree in order to become an avocat from 1810.

84 Touzeil-Divina, La Doctrine Publiciste, pp. 116-20; P. Gonod, Edouard Laferrière, un Juriste au Service de la République (Paris: LGDJ, 1997), pp. 38-9.

85 See P. Gonod, 'Les membres du Conseil d'Etat, auteurs de manuels de droit administratif, in J. Caillosse, ed., Le Conseil d'Etat et l'Université (Paris: Dalloz, 2015), p. 127. She states that the three 'Bibles' of administrative law are all by Conseillers d'Etat: Les grands arrêts de la jurisprudence administrative, the course of Odent (1970) and the treatise of Laferrière (1887). As Rivero put it, 'le juge écrit et le juge enseigne': 'Jurisprudence et doctrine dans l'élaboration du droit administratif, Etudes et Documents du Conseil d'Etat 1955, 27 at p. 29.

86 See B. Stirn, 'Les commissaires du gouvernement et la doctrine', in La Revue Administrative 1997 numéro spécial: Le Conseil d'Etat et la Doctrine, p. 41. The nearest equivalent in the English common law was the lengthy judicial decision which, unlike the French judicial decision, is discursive and fully argued. 
law and judicial review came with the work of Laferrière in 1887 and with academics such as Hauriou and Duguit who wrote at the turn of the twentieth century. The contribution of Laferrière's Traité (1887) and Hauriou's Précis was to present a much greater and more principled systematisation of administrative law and judicial review. ${ }^{87}$ That has continued through the work of university professors such as Chapus and members of the Conseil d'Etat such as Braibant, Stirn and Guyomar. In addition, after 1870, there was a programme for doctoral students in public law which encouraged original research. Indeed, the course for about forty doctorate students which he gave in $1883-4$ was the basis for Laferrière's Traite..$^{88}$

The function of doctrinal writing is to provide structure which is missing in the absence of a code, but also the kind of principled content which the Code civil provides.

The early development of legal scholarship in France contrasts with England. Even as late as 1964, only fourteen of nineteen law schools offered an option in administrative law, and Professor Wilson noted that this reflected the rapid rise of a subject which would generally have been regarded as unsuitable for study at [the] undergraduate level a few years ago'. ${ }^{89}$

\subsection{CONCLUSION}

The context of French administrative law is distinctive, but not exceptional. The organisation of government is distinctive in that the French President is the head of the executive and commands personal political authority more similar to the President of the United States than to the heads of state in most of Europe. The fact that ministers are not members of Parliament and Parliament formally has limited powers reinforces the power of the President. Parliament has less investigative power than in the United Kingdom. In practice, the formal weakness of the French Parliament in the face of the executive is matched by the practical weakness of many parliaments in other countries of Europe. The formally centralised character of French governmental institutions is also matched by de facto centralisation in other countries. France does not have the strong decentralised powers in regional governments that are found in Germany, Belgium and Spain. But reforms

\footnotetext{
Fortsakis, Conceptualisme et empiricisme, Part 1, chapter 2.

88 G. Richard, 'Enseigner le droit public à Paris sous la Troisième République' (Thesis Paris IX, 2013), pp. 64-6, 742; Gonod, Edouard Laferrière, p. 39. This contrasts with England, where doctorates in administrative law date from only after 1945 .

89 J. F. Wilson, 'A Survey of Legal Education in the United Kingdom' (1966) 9 JSPTL (NS) 1 at p. 46.
} 
since the 1980s have given more power to regions and to local government at a time when traditionally strong local government in England has become weaker. The roles of the prefect and the rector of the Académie symbolise central control over local government and public education in a more visible way than in other countries, thereby reinforcing the image of the centralised state since, as Odilon Barrot put it, with 'deconcentration', 'it is the same hammer which hits but with a shorter handle'. French institutions have evolved either from the Revolution of 1789 and the reforms of Napoleon Bonaparte or from an even earlier period. Adaptation has often reflected the path dependency of how institutions were initially created, especially in the relationships of central and local government. But France is also capable of major change, such as in the institutions of the Fifth Republic.

France's legal sources of administrative law also reflect a gradual development driven by distinctive institutions, particularly the Conseil d'Etat and the education of students and administrators in the universities and in the grandes écoles. The pattern of development is distinct from that in Germany or in the United Kingdom. Indeed, it has been influential beyond its borders. At the same time, French law operates in an international and supranational environment to which it not only contributes, but from which it learns. As was seen in Chapter 1 and will be seen in the remaining chapters, supranational influences from within Europe are integral to the way French administrative law now operates. Almost half of the claims before the Conseil d'Etat make some appeal to the European Convention on Human Rights. European Union law is directly applicable. French law thus shares sources of law with other countries in a way which is more profound than in the post-Brexit United Kingdom or in the United States.

Although France has distinct institutions and procedures, it has followed international trends in many ways in which government has developed in the past forty years. It adopted the ombudsman from Scandinavia in a distinctive manner and then turned the institution into the 'Defender of Rights', as had already been done in Spain. In this way, the ability of the citizen to complain has been enhanced. France has followed trends in regulating aspects of the private sector, especially financial markets, through independent administrative authorities. It has also followed trends to control public bodies through independent agencies. French administrative law continues to adapt in ways that maintain a certain French distinctiveness, but with a willingness to adapt to both domestic pressures and international trends. 


\section{3}

\section{Courts and Judges}

\subsection{HISTORICAL CONTEXT}

As has been noted, one of the distinctive features of the French administrative justice system is that it has general courts that are separate from the general courts dealing with civil and criminal matters, and that the judiciary working in them is also separate. Indeed, it has become more separate in the past one hundred years. Whereas the great founder of administrative law scholarship, Edouard Laferrière, was first Vice President of the Conseil d'Etat and later Procureur-Général at the Cour de cassation, such a career in both judiciaries would be very rare today. ${ }^{1}$

The separateness of administrative justice has its roots in the battle between the French kings and the Parlements. The unification of France under Henry IV beginning in 1589 was carried through by measures that centralised power. In the 1620 , Louis XIII and his minister Richelieu appointed royal officials as intendants to represent the king in local areas and, among other things, to receive complaints from citizens on taxation and later on public works. Appeals from his decisions lay with the Conseil du Roi, renamed the 'Conseil d'Etat' around the end of the sixteenth century. The king also legislated by way of decrees, which were also challenged in the Conseil du Roi. These actions brought about a conflict with the twelve regional Parlements which, like the English House of Lords at the time, both voted legislation (lois) and were courts adjudicating on (regional) law. At that stage, before the Revolution of 1789 , there was no uniform French private law, but a set of regional laws made and adjudicated upon by the regional Parlements. As the Stuart kings found at the same period, unifying a country with different laws, different parliaments and different courts generated conflict. But,

1 See P. Gonod, Édouard Laferrière, un juriste au service de la République (Paris: LGDJ, 1998). 
whereas the British outcome was victory for Parliament, the French victory (if there was one) was for the king, and the persistence of distinct administrative courts and judiciaries is testimony to the distinctive political history of France.

The separate character of administrative justice was definitively set out in the Edict of St Germain-en-Laye of 1641, building on the edicts of earlier kings. In it, Louis XIII set out the claims of absolute monarchy and reserved the right to take the advice of the Parlements as and when he thought it good for his service. As part of this, he prohibited the Parlements from judging matters other than those between subjects and in relation to all matters which concern our state, administration and government, we reserve to our person alone and to our successors as king'. ${ }^{2}$ Even if it created a new start with new institutions of government, the Revolution of 1789 fundamentally continued this approach. It abolished the Parlements as enshrining the privileges of the aristocracy and replaced them with a body of national courts, headed by the Tribunal de cassation. But the law of 16-24 August 1790 set out the separation of powers in such a way as to prohibit the civil judges from interfering with the administration. Article 13, which is still in force alongside arts. 10 and 12, provides:

Judicial functions are distinct and will always remain separate from administrative functions. It shall be a criminal offence for the judges of the ordinary courts to interfere in any manner whatsoever with the operation of the administration, nor shall they call administrators to account before them in respect of the exercise of their official functions. ${ }^{3}$

This prohibition was reinforced by the law of 7-14 October 1790 regulating conflicts between the civil courts and the administration, which gave the final say to the king and is the origin of the main remedy before the administrative court, the recours pour excès de pouvoir. The Constitution of An III (1795) repeated this prohibition. During the Revolution, the task of handling complaints was left to the administration itself, giving rise to many concerns about its fairness. ${ }^{4}$ The creation of the Conseil d'Etat in 1799 and of the conseils de préfecture in 1800 did mark a significant step towards judicial handling of complaints against the administration. But it was a slow process. At first, a complaint was referred by a minister to the Conseil d'Etat and the decision

2 On the history of administrative law, see J.-L. Mestre, Introduction historique au droit administratif français (Paris: Presses Universitaires de France, 1985) and id., 'France, the Vicissitudes of a Tradition' in P. Cane, H.C.H. Hofmann, E.C. Ip and P.L. Lindseth (eds), Oxford Handbook on Comparative Administrative Law (Oxford: Oxford University Press, 2021), pp. 23-51.

3 Translation from M. Weston, An English Reader's Guide to the French Legal System (Oxford: Berg, 1991), p. 141.

4 G. Bigot, Introduction historique au droit administratif depuis 1789 (Paris: Presses Universitaires de France, 2002), nos. 21 and 22. 
on the handling of a complaint was formally made by a head of state. Only in 1806 was a formal separation of judicial and administrative functions made within the Conseil d'Etat. Napoleon recognised the need for this: 'I wish to create a corps that is half administrative and half judicial, which will regulate the use of that portion of necessary arbitrariness in the administration of the State. 5 The result was a decree of 11 June 1806 which divided the Conseil d'Etat into sections, with one specifically identified with the task of adjudication, the Commission du Contentieux (relabelled Section du Contentieux in 1849), although decisions still required a signature by the head of the state. However, the Commission rapidly gained de facto independence to a point that Napoleon once declared 'I am only a signature' ('je ne suis qu'une griffe'). From then on, the citizens addressed their complaints against a minister directly to the Conseil d'Etat. The distinctiveness of the litigation function was emphasised by the reform of 1849 under which the decisions of the (then) Section du Contentieux did not require approval by the Assemblée Générale of the Conseil in the same way as decisions of the administrative sections. That would otherwise give the impression that the administrators would be able to outvote the judicial members of the Conseil on the outcome of individual cases. This law was also the response to the criticism raised in the 183 os by prodemocratic thinkers against the Conseil d'Etat to a point which could jeopardise its very existence. So its members managed to spread the idea that the Conseil d'Etat was a result of the French conception of separation of powers such that ordinary courts cannot have jurisdiction over the executive. The idea was so deeply rooted in the twentieth century that in 1987, the Conseil constitutionnel endorsed it, despite the demonstration made in the 1970s by Professor Jacques Chevallier that it was largely a rewriting of history. ${ }^{6}$

The two limiting features of this process on the judicial character of the Conseil needed to be addressed. First, justice was delivered at the instigation of the administration - the idea of la justice retenue that harked back to Louis XIII. The other feature was that the decision was rendered in the name of the minister, retaining the idea that the minister was judge (the concept of the ministre juge). Like the British Privy Council, the judicial decision used to be in the form of advice to the head of state, rather than a judicial decision. Despite the gradual movement towards the de facto independence of the administrative courts, only in the Third Republic (1870-1940) were these relics of the past abandoned, and administrative justice became more apparently

\footnotetext{
Quoted in ibid., no. 35.

J. Chevallier, L'élaboration historique du principe de séparation de la juridiction administrative et de l'administration active (Paris: LGDJ, 1970).
} 
independent. Indeed, it was in the Third Republic that administrative law as a distinct legal discipline really took off.

The Law of 24 May 1872 empowered the Conseil d'Etat to make decisions in relation to complaints against the administration in its own name and without recourse to the form that it was merely offering advice to the head of state. But the requirement of a request first to a minister to rectify a problem which would then be challenged took longer to change. There were allegations that complaints which might compromise senior officials or politician were rejected without judicial investigation. ${ }^{7}$ The idea became no longer necessary in some areas of litigation, such as the recours pour excès de pouvoir. Finally, this formality was removed altogether by the Conseil d'Etat's decision in Cadot in ${ }_{1889 .}{ }^{8}$ In that case, the town council of Marseille abolished the post of technical director of highways and waterways. The post holder brought a damages action in the civil courts, but they rejected the complaint because it was an administrative contract. The conseil de préfecture rejected the complaint because it had no competence over employment contracts. The Minister of the Interior rejected the complaint because it was a matter for the Marseille council. Cadot then appealed against the decision of the minister to the Conseil d'Etat, which accepted jurisdiction even though the case had not been referred to it by the minister. It was the existence of a dispute between the citizen and the state, not the prior decision from a minister, that gave the Conseil jurisdiction.

Other aspects of a judicial character to the work of the administrative courts came earlier under the July Monarchy. In 1831, the Commission du Contentieux of the Conseil d'Etat began to hold a public hearing at which the parties were represented and after which the Commission published its decision. As we will see in Chapter 4, the procedure is largely written and the formal, public hearing is largely perfunctory compared with a common law judicial hearing. Nevertheless, the principle of public justice was established. The waiver of court fees for certain types of litigation, notably judicial review of decisions (the recours pour excès de pouvoir), in 1864 was a marker that administrative justice was genuinely available to all, alongside the gradual extension of standing for action.

So, by the last quarter of the nineteenth century, a structure that is very recognisable as an administrative law judicial system was established in France, well ahead of other European countries. By contrast, the United Kingdom had no coherent shape to its administrative law judicial system

See E. Poitou, La liberté civile et le pouvoir administratif (Paris: Charpentier, 1869), chapter 9.

8 CE 13 December 1889, Cadot, no. 66145, Leb. 1148 concl. Jagerschmidt. 
much before the last quarter of the twentieth century. But the contemporary structure of courts and judicial careers in France has evolved markedly since then, in both the range and the numbers of institutions and personnel.

\subsection{ADMINISTRATIVE COURTS}

Administrative courts have a long history in France. But, unlike the private law courts, it has been easy to restructure them to meet contemporary needs. As a result, today they are located regionally in convenient centres of population. The present three-tier structure of the general administrative courts dates from 1987 , but a number of additional courts have also been created over the years. In particular, some specialist administrative courts have been created to deal with some of the largest areas of judicial work. Most of these are called commissions and they deal with particular types of litigation. If we compare the distribution of work between the general courts and the specialist courts, then there is clearly far more work undertaken by general courts in France than by the High Court in England and Wales. That is because the latter is concerned with only a small, supervisory element of administrative court work. Firstinstance work and appeals relating to the facts of complaints against the administration are heard in the United Kingdom by tribunals. Complaints about the liability of public authorities and public contracts are heard by the ordinary civil courts. It is therefore very difficult to compare the work of French administrative courts with judicial work in the United Kingdom, and this will generally be avoided here.

\subsection{GENERAL COURTS}

The general administrative courts started with the creation of the Conseil d'Etat in 1799. At that time, it was the principal body to which complaints against the administration were brought. The creation of the local tribunaux administratifs in 1953 and the creation of the regional cours administratives d'appel in 1987 were designed to reduce the workload of the Conseil d'Etat. In large part, the reforms have been successful in that they have allowed for a large increase in complaints brought to the courts without the Conseil d'Etat being swamped. In 2018, the tribunaux administratifs decided 209,618 cases. The average time for a decision was nine months and fifteen days. The cours administratives d'appel decided 32,854 cases. The average time for a decision was ten months and twenty-three days. The Conseil d'Etat 
decided 9,583 cases. The average time for a decision was six months and seventeen days. ${ }^{9}$

The way the courts work is shown in videos which have been produced for the general public and which are available from the websites of the different administrative courts. This is part of a long effort to explain how citizens can make complaints against the administration.

\subsubsection{Tribunaux administratifs}

The tribunaux administratifs were created as general courts in 1953. Previously, the conseils de préfecture had been established in 1800 to assist the prefect of the département with litigation on specific matters. The Law of 26 pluviôse An VIII (17 February 1800) gave them competence in relation to claims by individuals on direct taxation, the maintenance of public works (including roads and canals) and matters relating to the highway and public property. The first two areas of competence had been given to the directorates of départements when these were created by the Law of 6, 7-11 September 1790 (and, even earlier, this had been the competence of the intendants in the 1620 , the pre-Revolutionary predecessors of the prefects). Especially in the later years of Napoleon I, further areas of jurisdiction were added. These conseils of limited jurisdiction were composed of three to five officials sitting without the presence of the prefect, and their decisions were treated as executory without the prefect's intervention. As a result, there was already a clear separation of judicial and the administrative activities. ${ }^{10}$ In 1865 , the jurisdiction of the conseils de préfecture was extended to cover all matters within the competence of the prefect (which obviously excluded, inter alia, education and matters under the direct control of the national government). The qualifications of the members of the conseils were also professionalised to require either a law degree or long administrative experience. ${ }^{11}$ So, at this point, the conseils were effectively local courts of limited jurisdiction with a professional judiciary. Reforms of 1926 then regrouped the existing eighty-six conseils de préfecture at the level of a département into twenty-six conseils covering several départements.

Despite the increasing workload taken on by the conseils de préfecture, the Conseil d'Etat faced overload. The task of 'purifying' the administration after the Liberation in 1944 (l'épuration) led to a surge in appeals which went

9 Conseil d'Etat, Rapport d'activité 2019 (Paris, 2019), pp. 31-2.

10 See Bigot, Introduction historique, nos. 18, 36-8.

11 Ibid., nos. 93-4. 
directly to the Conseil d'Etat. By 1953, the Conseil d'Etat had a backlog of twenty-six thousand cases awaiting decision. The solution was to turn the conseils de préfecture from courts of limited jurisdiction into courts of general jurisdiction (juridictions de droit commun) - to become the first tier in a judicial hierarchy and thus the normal judge of more than 80 per cent of the caseload that was then starting in the Conseil d'Etat. It was at this point that they were relabelled 'tribunaux administratifs'. ${ }^{12}$ This reform cemented the place of local administrative justice and the existence of a separate corps of lower-tier administrative judges.

Looking at the tribunaux administratifs today, they are the principal administrative court for most complaints against the administration. Indeed, there are a large number of matters on which they are judge at first and last instancefor example, social assistance to the unemployed or in relation to housing, access to public documents, local taxes, the removal of driving licences and civil service pensions (see generally art. R811-1 CJA). They are locally based much more than the 'tribunals' in the United Kingdom, which are still not general courts. As will be seen in Section 3.1 of this chapter, they are staffed by a large body of specialist judges. In addition, there is a body of support staff in the court office (le greffe). To take an example, the tribunal administratif of Montpellier has six chambers, each with a senior judge as president. Each chamber then has two or three less senior judges as assessors and a rapporteur public. The President of the whole court sits as juge des référés, deciding alone on urgent matters, a process discussed in Chapter 4. The court is middle-sized with 6,551 cases decided in 2018 . There a number of very big courts, such as Paris with 19,954 cases, more than ninety judges and eighteen chambers. There are also some small ones, like Limoges with 2,126 cases, nine judges and two chambers. This enables justice to be delivered locally, but also for specialisations to be developed. There are thirty-one tribunaux administratifs in metropolitan France and eleven in the overseas territories and départements, which have very small numbers of cases and which often share judges.

Because the court is very local, parties can often attend hearings in person, and this gives a different dynamic to the hearing of cases compared with the regional or national courts higher up the hierarchy. Judges themselves are likely to be familiar from personal knowledge with local areas, problems and administrations. In many cases, they will have chosen to be assigned to

12 See generally Bigot Introduction historique nos. 215-16; L. N. Brown, "The Reform of French Administrative Courts' (1959) 22 M.L.R. 357. Brown pointed out that the label 'tribunal administratif was taken from the conseil de préfecture in Strasbourg which had jurisdiction over Alsace-Lorraine and had carried over its name from its period under German rule before 1924. 
a particular court because of personal connections with a particular area of the country. In this sense, they might be seen as more similar to circuit and district judges in England and Wales than to tribunal judges. However, there are incentives to move regularly from one court to another in order to progress in a judicial career.

It is noted in Section 2.4 in relation to specialist courts that some of their work has been integrated into that of the tribunaux administratifs in recent years. In significant part, this has been to ensure that the appearance of an independent adjudication of claims against the administration is maintained. Only within the general administrative courts would an adequate body of judges be found, without needing to resort to the use of current administrators as members of an adjudicatory panel.

In addition to the judicial work, the conseils de préfecture also had an important advisory role. The significance of the advisory function declined considerably in the twentieth century and is now rare. ${ }^{13}$ It is retained in Art. L212-1 CJA, but the number of requests from a local prefect may be as few as one a year. For example, it was reported on an official website that in the area of the cour administrative d'appel of Lyon, which has fourteen départements and four tribunaux administratifs, there were only five such consultations in 2016. ${ }^{14}$ This low number is probably due to the importance of the prefect's prior request to abide by the law, which is usually respected.

\subsubsection{Cours administratives d'appel}

Although the reforms of 1953 brought considerable relief to the Conseil d'Etat, the increased activity of the state in the 1960 and the increase in the supervisory role of the Conseil en cassation over administrative courts of special jurisdiction, notably the (then) Commission des Réfugiés, gradually brought the Conseil d'Etat back to a position of overload. Indeed, on 31 December 1987, it had a backlog of 25,392 cases awaiting decision, a position very similar to that in 1953 - equivalent to more than three years' work. This time the solution was to create a new tier of courts, the cours administratives d'appel, by the Law of 31 December 1987. ${ }^{15}$ Initially, there were five regional cours and, at the time of writing, there are eight: Bordeaux, Douai, Lyon, Marseille, Nancy, Nantes, Paris and Versailles. But a ninth

13 See Y. Ladié, 'Les fonctions consultatives des tribunaux administratifs', in CURAPP, ed., La loi du 28 pluviôse An VIII (Paris: Presses Universitaires de France, 2000), pp. 249-67.

14 P. Gérard, La Juridiction Administrative (Paris: La Documentation Française, 2017), p. 138.

15 See L. N. Brown and J. Bell, 'Recent Reforms of French Administrative Justice' (1989) 8 C.J.Q. 71. 
Cour administrative d'appel will soon be put in place in Toulouse. Their jurisdiction was initially limited to le plein contentieux (decisions on law and fact, predominantly contract, liability, civil service and tax). But in 1995 this was extended to cover all matters, except the legality of legislation.

The French legal system normally recognises a right to an appeal (le principe du double dégré de juridiction). So litigants do not need leave to appeal. The existence of the cours administratives d'appel at the regional level implements this. The eight cours administratives d'appel decided 32,854 cases in $2018 .^{16}$ The workload is more evenly divided between the different cours with most having 3,000 or 4,000 decisions a year, with the largest in Marseille (nearly 5,000 ) and the lowest in Nancy (just below 2,500). In a big cour like Marseille, there are nine chambers and forty-nine judges. In a small cour like Nancy, there are only four chambers and twenty-four judges. So the dynamics within the cours are different. At least being regional, they offer the possibility of litigants coming in person to hearings, though this is less likely than before the tribunal administratif, especially as we shall see in Chapter 4 that the proceedings are predominantly written, so there is less the parties or their lawyers can contribute to the public hearing. The requirement to have a lawyer is quite generalised at the cours administrative d'appel level.

In terms of workload, nearly half of the appeals lodged in 2018 related to immigration (49.4 per cent), and that is despite the existence of a specialist court dealing with refugees (see Section 2.2). The next highest areas were tax cases (14.1 per cent), civil service employment (8.9 per cent) and planning (6.8 per cent).

Art. L212-1 CJA gives the cours administratives d'appel the possibility of being consulted by prefects of their region. But such consultations are very rare. ${ }^{17}$

\subsubsection{Conseil d'Etat}

The Conseil d'Etat was created in 1799. In the pre-Revolutionary period, like in many European kingdoms, the French king's Privy Council received complaints against his administration which were resolved within the administration, but there was no system of administrative courts. The Conseil decided on complaints against its own legal regulations and against appointments to royal offices, and it heard complaints against intendants. It is contested in the literature how far these practices constitute true roots of post-1799

16 Figures from the Conseil d'Etat, Rapport d'activité 2019, p. 44.

17 Gérard, La Juridiction Administrative, p. 147 found none in 2016. 
French administrative law. ${ }^{18}$ The creation of the Conseil d'Etat in 1799 by the constitution of 22 Frimaire An VIII (13 December 1799) was designed to provide a better structure for advice to the government and adjudication of complaints against it.

Like the English Privy Council before 1641 and even in its modern UK form, the Conseil d'Etat had advisory sections and an adjudication section. Judges will usually be assigned both to the judicial section (Section du Contentieux) and to an administrative section (Public Finances, Interior, Public Works, Social and Administration), or to the Section du Rapport et des Etudes, not to mention the participation of members of the Conseil d'Etat in various administrative commissions. The integration of administrative and judicial functions is seen traditionally as the distinctive key to the effectiveness of the administrative judge. Odent, President of the Section du Contentieux, commented that, in the Conseil d'Etat:

The interpenetration of administrative and litigation functions is fortuitous: if administrative judges were isolated from the active administration, if they ceased to be in constant contact with the needs and constraints of administrative life, they would lose their specific character: instead of building a law adapted to the necessities of the public service, they would be inspired by a fossilised law bearing no relationship to the realities of active administration. Administrative judges must have an administrative training, and they have to sustain it to retain an understanding of administrative life. ${ }^{19}$

As will be noted when talking of the careers of members of the Conseil in the next chapter, most judges have experience of working in the 'active' administration.

\subsubsection{The Judicial Role}

These days, the Conseil d'Etat is largely an appellate court dealing with points of law. Its function is to decide difficult cases and also to maintain the unity of approach within the body of administrative courts. Since it is the only national court in the hierarchy of general administrative courts, it has a distinctive place.

The jurisdiction of the Conseil d'Etat is threefold. First, it is the judge in relation to appeals on a point of law (en cassation) in relation to decisions of

R. Odent, Contentieux administratif, 6 volumes (Paris: Les Cours du Droit, 1981), pp. 746-7. The point is repeated by Mme Questiaux [1995] P.L. 247 at P. 255 that the generality of powers conferred on the administration requires that judges who review the exercise of discretion 'do not drift too far away from the experience of the administration'. 
the cours administratives d'appel, of certain specialist administrative courts, and of the tribunaux administratifs judging in first and last instance like they do regarding most of référés (emergency interim proceedings - see Chapter 4, Section 3). This covers about 70 per cent of the work of the Conseil. Secondly, it is judge of appeal on law and fact in relation to decisions of the tribunaux administratifs on local elections (municipalities and cantons) and référéliberté, emergency interim decisions affecting fundamental liberties. Thirdly, it is judge in first and last instance over questions concerning the legality of governmental decrees and other regulatory acts, and of regulatory acts of certain major public agencies, and it deals with litigation in relation to regional and European elections as well as the recruitment and discipline of senior civil servants. ${ }^{20}$ This third category is about 25 per cent of its work. Over and above this, the Conseil may receive references from the lower administrative courts, the tribunaux administratifs and the cours administratives d'appel on points of law in much the same way as the Court of Justice of the European Union receives references from the courts of Member States. So, although there are some matters of fact involved in certain types of litigation before the Conseil, its overwhelming function is now as a judge of questions of law. As we will see in Chapter 4, the jurisdiction in relation to référés does often involve findings of fact and some of that involves findings of fact by the Conseil itself. But this can never be very complex fact-finding.

The Conseil d'Etat operates internally at a number of levels. The basic level is the chamber (previously called a sous-section). This will be composed of a president, a number of senior members of the Conseil (conseillers), midcareer members (the maîtres des requêtes) and a permanent trainee (auditeur). The titles of roles are recognisable from the medieval Privy Council in both England and France. This is the body which will undertake the instruction or investigation of a case and produce an initial judgment (for this process see Chapter 4, Section 4). The cases are prepared by one of the maitres des requêtes (or occasionally by a conseiller) as rapporteur and the draft judgment will be reviewed by a senior member of the chamber as 'revisor' (réviseur) before being discussed by the whole chamber in a weekly meeting before and after the hearing. As explained in Chapter 4, another member of the Conseil will act as rapporteur public, presenting at the hearing a more general legal perspective on a problem than would come from the parties. The rapporteurs publics are a distinct body of members of the Conseil d'Etat and may work closely with more than one chamber. As noted in Chapter 1, the rapporteur public was

20 National elections to Parliament or to the presidency are judged by the Conseil constitutionnel. 
called commissaire du gouvernement until the decree of 7 January 2009, which was adopted as a response to the sustained criticism addressed to it by the European Court of Human Rights case law in Kress, discussed in Chapter 1, Section 6.

When it comes to judging cases, decisions are taken in varying formations. The most straightforward decisions (typically rejections of cases as totally unfounded called procédure d'admission) are made by the President of a chamber acting alone by way of ordonnances but only for 'cassation', that is to say quashing on a point of law. In 2018, 32 per cent of the Conseil d'Etat's decisions were made in this way. ${ }^{21}$ Relatively unproblematic cases are resolved by the instruction chamber on its own. In 2018, 3,590 (37.5 per cent) of the Conseil d'Etat's decisions were made in this way. More difficult cases or ones where a chamber is going to reverse a line of previous case law will be sent to two or more chambers sitting together - in 2018, there were 1,309 such decisions (13.5 per cent of cases). The most difficult cases will go to the plenary of the Section du Contentieux ( 15 cases (1.6 per cent of decisions in 2018)) or to the Assemblée du contentieux, which involves presidents of the administrative sections (13 cases (1.4 per cent of decisions in 2018)). The choice between the last two really depends on the degree of legal and constitutional principle that a decision involves. It is clear from this account that the Conseil d'Etat has an internal hierarchy of decisions, and this is true for most large supreme courts. In Chapter 4, the different rules of composition will be explained. This difference in composition has implications for the authority of decisions. The higher the formation within the court, the greater the authority that attaches to its decision. It is also clear that the decision within the Conseil is a collegial decision. Not every member will have read the papers to the same extent, but they take collective responsibility for the decision which emerges since dissenting opinions are not allowed.

\subsubsection{The Consultative Role}

The consultative work of the Conseil d'Etat is substantial. It is the primary legal advisor to the government. It does not advise on policy, but it ensures that proposed legislation conforms to the Constitution and is well drafted, intelligible, coherent and consistent with existing legal rules.

The consultative role of the Conseil d'Etat is divided into two main blocks of activity. On the one hand is advice on proposed legislation. On the other

${ }^{21}$ See Conseil d'Etat, Rapport d'activité 2019, p. 55. 
hand, the Conseil advises on the legal issues involved in problems facing the government.

Scrutiny of Draft Legislation: Most of the legislation work comes from the government, but Parliament may also refer texts for scrutiny. Since 1945 and now under art. 39 of the Constitution, all government bills are submitted to the Conseil for scrutiny before they are debated in Parliament. In practice, it will often be the case that a member of the Conseil is invited to be involved in the government department's drafting team that produces the text, since French government departments do not generally have their own in-house legal service. In recent years, a few members of the Conseil d'Etat have been seconded to ministries to head up an in-house legal service. The Prime Minister's office has published a long guidance note on the preparation of legislation, and the role of the Conseil d'Etat is to see how far this good practice has been followed. ${ }^{22}$ The text of the bill will be submitted to the appropriate section of the Conseil and a senior member will be assigned the task of producing an initial scrutiny report. ${ }^{23}$ The section will then interview representatives of the sponsoring department and any related departments, such as the Ministry of Finance. The discussion takes place in one of the grand rooms of the Palais Royal (facing the Louvre Museum) with about a dozen members of the section and half a dozen representatives of the government present. It may well go on for several sessions. The discussion will examine whether the department has complied with the pre-legislative procedures required by the Constitution. Under art. 39 of the Constitution, all bills (with a few exceptions) must be submitted with an impact assessment. But certain types of bill are subject to additional requirements. For example, a bill on education must be submitted for the opinion of the Conseil économique, social et environnemental (CESE) before it is presented to Parliament. The discussion will also examine the compatibility of the proposed text with the Constitution - not only on matters of fundamental rights, but also with respect to the legislative competences of Parliament and government, particularly when a bill authorises further legislation by decree. The discussion on the clarity of the aims of a bill and of the language used is more rigorous than would be expected in the UK Parliament, even if Parliament still manages to introduce some fuzzy concepts into legislation. The result is a report agreed in private by the members of the section, which is then submitted to the agreement of the whole Conseil which meets in the Assemblée Générale. The

22 Guide de légistique (Paris: Documentation française, 2017).

23 See generally J. Bell, 'What Is the Function of the Conseil d'Etat in the Preparation of Legislation?' (2000) 49 International and Comparative Law Quarterly 661-72. 
opinion (avis) of the Conseil d'Etat is not automatically publicly accessible. It is specifically excluded from the right of access to public documents by art. L 311-5 of the Code of Relations between the Public and the Administration. In practice, since 2015 , most of the avis are made publicly available on the government website Légifrance. But the text of the bill in the form the Conseil d'Etat approved is not made public.

A special advisory role was created in 1999 for local laws (lois du pays) from New Caledonia. This is the nearest the French have got to devolved legislation.

Since 2009, it has been possible for Parliament to request the opinion of the Conseil d'Etat on bills proposed by members of either chamber of Parliament (propositions de loi). Once a bill has been presented for consideration, then the President of the relevant chamber, with the consent of the proposer, can send the bill for consideration before it is sent to scrutiny in a parliamentary committee. The procedure is similar to that for government bills, but with the difference that the people interviewed are the proposer and the result of the process is not a revised text, but merely a note on the legal issues that need to be addressed.

In 2018, the Conseil d'Etat examined 973 legal texts. The average for the preceding eight years was $1,167 .{ }^{24}$ Of these, 69 were government bills and 7 were bills proposed by members of Parliament. In addition, it examined 27 draft ordonnances and 822 draft decrees. The Conseil likes to work fast and managed to review most texts within two months in 2018 .

In addition to bills which are then submitted to Parliament for enactment, the government produces a large body of legislation which it enacts on its own authority. Under art. 38 of the Constitution, draft ordonnances (a form of delegated legislation) have to be submitted to the Conseil. These forms of legislation are used heavily when a new government comes into power and is given authority by Parliament to act quickly on particular issues. In recent years, such legislation has been used to deal with emergencies. In addition, a number of important decrees also have to be submitted to the Conseil under art. 37 of the Constitution, but there are not many of these each year. (Unlike in the United Kingdom, decrees are not subject to resolutions in Parliament before enactment.) Decrees are not normally submitted to the Assemblee Générale because they are usually more precise and technical.

Because some bills need to be examined quickly, given the urgency of the subject matter or the government's timetable for passing particular legislation, the Conseil d'Etat has developed a 'fast-track' review through the Commission

24 Conseil d'Etat, Rapport d'activité 2019, p. 195. 
Permanente. This procedure replaces the consideration by the relevant section and by the Assemblée Générale. The Commission Permanente is composed of the Vice President, the President of the relevant section for the matter in question, two members nominated from each section of the Conseil, and two others nominated by the President of the section and the Vice President for their special expertise in the matter. Presidents of other sections may attend. In 2018, only four bills were considered by the Commission Permanente. That said, it does prove a useful device. For example, a bill to deal with the Covid-19 crisis was introduced on 17 March 2020 and reported on by the Commission Permanente on 18 March, leading to a law passed by Parliament on 23 March and the postponement of elections on 22 March. $^{25}$ A slightly slower timescale was followed in May 2020 when it took five days to consider a bill postponing the decision on the timing of municipal elections then due to be made by 27 May at the latest, which eventually took place on 28 June. $^{26}$

How does one measure whether this system works well? It is not sufficient to have details of the procedure followed and the number of pieces of legislation scrutinised. One way of measuring it would be to follow the bills as they go further in the legislative process. For example, of the seven bills from Parliament considered in 2018 , four became law and three were subjected to constitutional review by the Conseil constitutionnel before they were enacted (since the Constitution allows for such a request from only sixty members of either the National Assembly or the Senate). In all three cases, the bill was declared consistent with the Constitution, subject to one reservation of interpretation. Similarly of the twenty-six government bills listed as having been scrutinised by the Conseil d'Etat in 2018, seventeen were enacted subsequently by Parliament and three were ratifications of ordonnances which take effect, even if not actually enacted by Parliament. ${ }^{27}$ Of those seventeen enacted lois, thirteen were referred for review by the Conseil constitutionnel. Of these, in nine cases the only provisions struck down were those introduced into the bill in Parliament after the Conseil d'Etat had given its advice and for which the Conseil d'Etat could not be blamed. In two cases, the whole loi was declared compatible with the Constitution. In two other cases, the Conseil constitutionnel struck down provisions in the bill which the Conseil d'Etat had also criticised in its advice, including one both declared unintelligible to the citizen. By contrast, where the government had adopted the suggestions of

25 Conseil d'Etat, avis no. 399873 of 18 March 2020.

26 Conseil d'Etat, avis no. 400229 of 26 May 2020 (the bill was submitted on 21 May).

27 Conseil d'Etat, Rapport d'activité 2019, pp. 200-1. 
the Conseil d'Etat, they were upheld as compatible with the Constitution by the Conseil constitutionnel. ${ }^{28}$ These examples suggest that, at the very least, the Conseil d'Etat is well able to anticipate the approach of the Conseil constitutionnel to what is constitutionally acceptable. It is well placed to give the government good advice on how to draft legislation, although this not a full guarantee, as shown by the 2010 law forbidding the concealment of the face in public which was criticised on constitutional grounds by the Conseil d'Etat but largely upheld by the Conseil constitutionnel.

The other category of advice is on more general legal issues which concern an administration. The Conseil d'Etat lists ten opinions given in 2018. An example is the set of legal questions arising from the decision to cancel the large expansion of a small airport at Notre-Dame-des-Landes, an environmentally sensitive area which was the subject of a lengthy illegal occupation by protestors. The legal issues included whether the government could resile from its concession contracts involved in the construction in the light of the circumstances. ${ }^{29}$ Many legal principles first articulated by the Conseil in its avis then are used as the basis for its judicial decisions. As was seen in Chapter 1, this dual function raised concern on the impartiality of the Conseil d'Etat after the European Court of Human Rights ruling in the 1995 Procola, which considered that the same organisation both advising the government and deciding an issue judicially was contrary to art. 6 in relation to the Luxembourg Conseil d'Etat. But the French Conseil d'Etat convinced the European Court of Human Rights that the much larger number of its members enabled it to comply with the objective impartiality principle whilst also recusing members involved in the advisory process from the judicial activity of the Conseil.

\subsubsection{Section du rapport et des études}

Founded in 1963 as the Commission du Rapport with the task of reporting to the government on the activity of the Conseil d'Etat and current problems that they identified, this body became the Section du Rapports et des Etudes in 1985. Its current missions are set out in Art. R123-5 CJA.

The first of those missions is to be the vehicle through which the Conseil d'Etat draws the attention of public authorities to the legislative or

28 These were provisions on fixed penalty fines and the equivalent of cautions (composition pénale) in the Law on Justice of 23 March 2019, see CC decision no. 2019-778 DC of 21 March 2019.

29 See Rapport d'activité 2019, pp. 246-50. 
administrative reforms which it considers necessary in the public interest under Art. L112-3 and develops a study on these at the request of the Prime Minister or its own Vice President. In this role, it goes beyond being a law reform commission and is much closer to what Neville Brown described as a 'think tank'. ${ }^{\circ}$ Some of these issues identified by the Conseil itself are developed into a full study as part of its annual report. A full list is given on the Conseil d'Etat's website, but important examples include France and the European Union (1993 and 2007), rights to housing (2009), the role of independent agencies in public law (2012) and the simplification and the quality of legislation (2016). Examples of studies commissioned by the Prime Minister include reform of the law on bioethics (2009 and 2018), compulsory recourse to the administration before beginning litigation (2008) and taking account of risk in public decision-making (2018). These studies will be worked on by members of the section together with others in the Conseil, and they will solicit such outside expertise as they find useful. The report is then approved by the section and by the Assemblée Générale.

The second task is to identify difficulties which arise in the execution of judgments from the administrative courts. As will be seen in Chapter 4.8 , the administrative courts have been given extra powers in the past forty years to enforce their decisions. So most of the effort in securing enforcement now lies with them. The reforms of 2017 have simplified the process of enforcing administrative court decisions. In relation to the Conseil d'Etat, any litigant who is having difficulty in obtaining implementation of its judgment may apply to the Section du Rapport et des Etudes and it will seek to discover the problems of the relevant administration and seek to facilitate compliance. If this administrative phase fails to secure the required action, the matter passes to the judicial phase and the President of the Section du Contentieux is empowered to issue enforcement orders of the kind explained in Chapter 4.8. These orders may be backed by a penalty fine (astreinte) for persisting in non-compliance. These are rare events. The judicial phase of enforcement took place in only eleven cases in 2018 and only one of these led to an astreinte. This compares with eighty-seven applications which were made to begin the administrative phase in the same year. ${ }^{31}$

In relation to this second role, the section may also be asked by the administration involved in a case to clarify parts of the judgment, so that it knows precisely what to do. These demandes d'éclaircissement under art. 931-1 CJA again are fairly rare events. The Conseil d'Etat issued two of these in 2018 .

30 Brown and Bell, 'Recent Reforms of French Administrative Justice', p. 79.

31 Conseil d'Etat, Rapport d'activité 2019, p. 181. 
The third role is to produce an annual report for the Conseil d'Etat, outlining its activity and bringing attention to any problems in the law or encountered in the enforcement of judicial decisions. The report of activity is a rich mine of information about the work of the administrative courts, in terms of statistics, but also in terms of examples. It is here that the Conseil can comment on its own decisions with a view to highlighting to the government where the law is inadequate or where administrative practice needs to be improved. In that way, its annual report is more like that of the UK Supreme Court than that of the English and Welsh Lord Chief Justice.

A fourth task not mentioned in the CJA is the maintenance of the Conseil d'Etat's important and numerous international relations. Within the Section du Rapport et des Etudes is a unit dealing with international relations and a unit dealing with European law. The special place of French law in the world and its diffusion is assisted by the first unit and the many visits it arranges and receives in the course of the year. The more specific task of the European unit is to ensure that the Conseil is briefed on norms which are developed inside the institutions of the European Union.

Within this area, the section is also responsible for a number of conferences and workshops organised by the Conseil on topics of interest, such as alternative dispute resolution in 2019. ${ }^{32}$ It is also responsible for organising exchanges, including the exchanges with the British judiciaries which have been going on since the 1980 .

\subsubsection{Cour nationale du droit d'asile}

Claims for refugee status are among the largest body of cases brought to administrative courts. In 2018, the Office français de protection des réfugiés et apatrides (OFPRA) received 123,625 claims for asylum and refugee status. ${ }^{33}$ It granted 26.6 per cent of requests, a figure which rose to 35.9 per cent after appeal to what is now called the Cour nationale du droit d'asile. It is thus clear that the administrative side of refugee work is both substantial and significant. Challenges on other immigration matters are taken through the generalist administrative courts.

The Commission des recours des réfugiés started work in 1953 and had a steady caseload of about 300 cases a year until 1979. But subsequently the number of refugee applications increased very substantially to reach 16,515 by 1989. Its function is to hear appeals from the decisions of the OFPRA. The

32 See Chapter 4, Section 2.3.

33 OFPRA, Rapport d'activité 2018. 
Commission operated initially with just three members. As cases increased, more staff were added. A radical reform was made in 2007 which transformed the Commission into the Cour nationale du droit d'asile (CNDA) and attached it to the Conseil d'Etat. It heard 47,314 cases in $2017 .{ }^{34}$

Whereas presidents are full time, assessors are part-time. Presidents are judges appointed by the Vice President of the Conseil d'Etat, the President of the Cour des Comptes or the Minister of Justice. Assessors are appointed by the Conseil d'Etat and by the UNHCR and are required to serve at least thirty sessions in each of the three years of their appointment. They need to show an appropriate expertise in the field and are of French nationality, but they are not necessarily judges in their main job. In 2019, the CNDA had 24 full-time presidents (including a member of the Conseil d'Etat as its president). In addition, there were 176 fee-paid presidents and 291 assessors. ${ }^{35}$ Cases are prepared by judicial assistants, as rapporteurs, who do not sit with the judge in the deliberation.

The CNDA sits either in a collegial formation or (more normally) with single judges. The collegial formation consists of a president, an assessor appointed by the Vice President of the Conseil d'Etat, and an assessor appointed by the United Nations High Commissioner for Refugees. This decides within five months of the application. Presidents sit as single judges and decide within five weeks of an application. Since 2013 , there has been a Grand Chamber made up from nine judges (three presidents, three assessors appointed by the UN High Commissioner for Refugees and three assessors appointed by the Vice President of the Conseil d'Etat). In 2019, there were twenty-two chambers, each with its own full-time president, and the chambers are grouped into six sections. An average of ten fee-paid presidents and ten assessors are then assigned to each chamber. Each judgment formation deals with an average of 364 cases in a sitting day! ${ }^{36}$ The Cour held 691 sittings in 2019 , including 223 by videoconference. ${ }^{37}$

In 2019, the CNDA decided 66,464 cases, of which 66.5 per cent were decided with a hearing and the rest by ordonnance (typically because they were inadmissible). Seventy per cent were decided in a collegial formation and 30 per cent by a single judge. ${ }^{3}$ The Cour has its own legal aid department which dealt with 51,891 requests in 2019, of which 48,789 were granted.

\footnotetext{
Conseil d'Etat, Rapport d'activité 2019, p. 71.

CNDA, Rapport d'activité 2019 (Paris, 2019), p. 41.

Ibid., p. 35.

Ibid., p. 36.

Ibid., p. 13.
} 
Appeal on a point of law (recours en cassation) lies from the CNDA to the Conseil d'Etat. Few cases are challenged in this way (1.4 per cent in 2019) and only 0.1 per cent were quashed. ${ }^{39}$

\subsubsection{Cour des comptes and Other Financial Courts}

The idea of a 'court' of accounts may seem strange to a British lawyer who is used to a parliamentary official, the comptroller and auditor general as head of the National Audit Office, supervising national government accounts and reporting to the House of Commons Public Accounts Committee. The Cour des comptes dates from 1807, but shares common ancestors in medieval administration with the comptroller and auditor general. The early, judicial role of the Cour des Comptes is to judge accounting officers in government bodies and to sanction them for irregularities in accounts. Accounting officers are usually appointed by the Ministry of Finance and are accountable in the first instance to it. But their independent role within departments is secured by their accountability to the Cour des Comptes. It receives and signs off more than a thousand accounts a year and gives a discharge to the accounting officer.

Apart from judging accounts, there are three other roles for the Cour - to supervise, to certify and to evaluate. The supervisory role is to ensure the appropriateness, the efficiency and the effectiveness of the management of public money. Is the administration following proper procedures, is it wasting resources, and is it achieving the results for which the money was given? In its mission created in 2000, the Cour certifies the accounts of the state and, since 2005, those of social security. Here the Cour ensures the accuracy, comprehensibility and transparency of public accounts, thus enabling the government to be held to account for spending. Finally, in its mission created in 2008 of evaluation, the Cour des comptes looks at the fitness for purpose of expenditure in terms of the objectives which were required to be achieved. This is very similar to a 'value for money' study by the National Audit Office. In terms of benchmark standards, the OECD, also based in Paris, provides research and ideas for many public auditors, including the French and the British.

The Cour des comptes has six chambers which specialise in different sectors of the public service. There is also a prosecutor section which is responsible for leading investigations into irregularities. As will be seen in 
what follows, being a financial judge is a high-status position for a public official and one in which a person may make a career.

The Cour des comptes is responsible for national bodies (1,027 in 2019). It is assisted by 13 regional chambres régionales des comptes responsible for 15,646 bodies. ${ }^{40}$ The judicial activities arise because accounting officers are liable personally and financially for the deficiencies in their accounts. Investigations are undertaken on site and examine the audit trails of expenditure and income. The accounts are initially examined by the officials of the Cour or relevant chambre régionale. Where the accounts are in order, then the Cour or the relevant chambre issues an order to that effect, which discharges the accounting officer. Where the accounts are not in order, the Cour or chambre issues a débet, identifying money which is owed. In 2019, the sums in question amounted to $€_{19.55}$ million. ${ }^{41}$ If any irregularity appears, the procureur of the court is informed and she will requisition information. If there is a problem, she may simply inform the public body and make recommendations. If there has been a significant failing by an accounting officer, she may investigate further. As a result of investigations, the Cour or chambre may impose a fine on the accounting officer which he or she has to pay personally. In 2019, these fines amounted to $€_{45,147}$. It is clear that these fines are in no way comparable to the surcharge which may be imposed for the misuse of public funds in the United Kingdom, which is an obligation to make good the money lost by wilful misconduct. In 2019, the Cour des comptes handed down 95 judgments at first and last instance in relation to state accounting officers and heard 73 appeals. The chambres régionales des comptes heard 339 cases at first instance. Where very serious wrongdoing has been identified, the procureur may refer the matter to the criminal authorities, which was done in 71 instances in 2019. Alternatively, she may begin proceedings before the Cour de discipline budgétaire et financière (CDBF). This is a purely sanctioning body which penalises any public official, not just accounting officers, especially in matters of remuneration, public procurement and awarding grants. It is presided over by the President of the Cour des comptes and includes the President of the Section des Finances of the Conseil d'Etat and is composed of equal numbers of judges from the two courts. It dealt with 12 cases in 2019 , which took an average of 41.2 months. ${ }^{42}$ An example was the prosecution of the director general and several other senior officials of Radio France for signing building contracts without following the required rules on public procurement. The

\footnotetext{
Cour des comptes, Rapport d'activité 2019, p. 8.

Ibid., p. 9 .

$4^{2}$ CDBF, Rapport d'activité 2020 (Paris, 2020), p. 22.
} 
adjustments to the original contracts amounted to more than 40 per cent of the original contract price for the refurbishment of a major public building. The whole case took a total of 1,509 days and led to a fine of $€_{1,000}$ for the director general and $€_{500}$ for each of two senior officials. Another case involved the payment of grants to farmers' associations without adequate detail of the purposes for which the money was given. This led to a fine of $€_{2,500}$ against the chair of the regional agriculture board. ${ }^{43}$

\subsubsection{Other Administrative Courts}

A large number of administrative tribunals or commissions are specialist courts. Similar to British tribunals in the past, the membership of these bodies has sometimes included current officials with expertise in the subject matter of the commission. Usually, they would also be members from among judges of the civil, administrative or financial courts. But inevitably questions arose about the independence of any officials appointed to these courts. In 2000, the Cour de cassation ruled that one social security tribunal, the Cour nationale de l'incapacité et de la tarification de l'assurance des accidents du travail, breached Art. 6 of the European Convention by having members who were officials who could be moved to other roles at any point. ${ }^{44}$ Similarly in 2002, the Conseil d'Etat ruled that having officials as members of the Commission centrale d'aide sociale who did not enjoy any guarantees of independence breached the European Convention..$^{45}$ In two decisions of 2011 and 2012, the Conseil constitutionnel ruled that the composition of two bodies of welfare courts breach constitutional provisions (notably in art. 16 DDHC) on judicial independence. It first ruled on the commissions départementales d'aide sociale $(\mathrm{CDAS})^{4^{6}}$ and decided that the presence of departmental official appointed by the minister breached judicial independence. This then led it to rule that the similar composition of the appeal body from these commissions, the Commission centrale d'aide sociale (CCAS), was also unconstitutional. ${ }^{47}$ Their jurisdiction and that of other social security and social welfare commissions was transferred to the general civil and

43 Ibid., pp. 41-3 (Président de la chambre départementale d'agriculture de la Gironde).

44 Cour de cassation, assemblée plénière, 22 December 2000, nos. 99-11303 et 99-11615.

45 CE Ass, 6 December 2002, Trognon, no. 240028.

$4^{6}$ CC decision no. 2010-110 QPC, 25 March 2011, M. Jean-Pierre B (Composition de la commission départementale d'aide sociale).

47 CC decision no. 2012-250 QPC, 8 June 2012, M. Christian G (Composition de la commission centrale d'aide sociale). 
administrative courts from 1 January 2019, as part of a general reorganisation of first-instance courts.

Many administrative bodies exercise professional discipline. A number of these relate to medical professions (e.g. doctors, dentists, pharmacists and nurses). There are often different levels of court. For example, in the case of doctors, there are twenty-five first-instance disciplinary chambers at regional level with appeal to a national disciplinary chamber of the professional

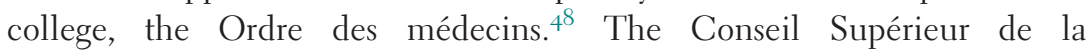
Magistrature when it sits on disciplinary matters concerning professional civil and criminal judges (who are civil servants) is also treated as an administrative court and subject to review by the Conseil d'Etat. These cover a range of professions. For example, the Conseil national de l'enseignement supérieur et de la recherche is an appeal body on university discipline which hears just over one hundred cases a year. It is chaired by a member of the Conseil d'Etat and is comprised of teachers or researchers of the same grade or higher to the person under investigation and it also has student members (Art. L232-3 Code de l'Education).

The Commission du contentieux du stationnement payant is an administrative court responsible for appeals on parking fines after they were decriminalised. There is a single court in Limoges for the whole country. ${ }^{49} \mathrm{It}$ is presided over by an administrative judge from the tribunaux administratifs or the cours administratives d'appel with assessors appointed on a part-time basis. It is the busiest of all the specialist administrative courts. In its first year, 2018, it received a total of 69,478 appeals but was only able to deal with 11,508 , creating a huge backlog. Its problems were compounded by being created around an IT platform which did not work properly.

\subsection{ADMINISTRATIVE JUDGES}

Administrative judges belong to one of two corps or groups. The first is the corps of the judges of the tribunaux administratifs and the cours administratives d'appel, which dates from 1980. The second and more ancient is the corps of

$4^{8}$ La justice administrative, chapter 19. See also www.conseil-national.medecin.fr/lordremedecins/linstitution-ordinale/juridiction-ordinale. For statistics, see Chambre disciplinaire de l'ordre des médecins, Rapport annuel d'activité de la juridiction ordinale 2018 (Paris, 2019). In $2018,1,402$ cases were decided, involving 370 public hearings. The report notes at p. 9 that the normal length of time for a first-instance decision is ten months and nineteen days compared with the norm of six months laid down in legislation. The national chamber dealt with 334 appeals in 2018 .

49 Gérard, La Juridiction Administrative, chapter 21. 
the members of the Conseil d'Etat. Their administration is combined within the Conseil d'Etat, notably through its vice president and its secretary general. But they are distinct bodies of civil servants and special procedures apply to the transfer between them - it is not a simple promotion as within the judiciaries of the United Kingdom.

\subsubsection{Corps of Judges of the Tribunaux administratifs and the Cours administratives d'appel}

The most numerous administrative judges belong to this corps - about twelve hundred in 2020. About three-quarters of the members of this corps work in the tribunaux administratifs. Their activity is predominantly judicial, although they do have some advisory functions.

Their career structure is governed by the Conseil supérieur des tribunaux administratives et des cours administratives d'appel. This body is responsible for overseeing senior appointments, such as presidents of courts. The supervising role regarding careers of administrative judges in courts below the Conseil d'Etat lay on the shoulder of the home office (Ministère de l'intérieur) until the law of 31 December 1987. Parliament was reluctant to apply the same principle as for civil, commercial and criminal courts - that is, giving the supervision to the Ministry of Justice - and this role was eventually allocated to the Conseil d'Etat itself through this Conseil supérieur.

There are four routes of entry. The first is nomination directly from the ENA (art. R233-1 CJA). There were eight appointments by this route in 2019. The second is by examination either from among civil servants of at least four year's standing (concours interne) or from outside the civil service - for example, from among avocats and those qualified to enter ENA (concours externe) (arts. $\mathrm{R}_{233-4}, \mathrm{R}_{233-8}$ to $\mathrm{R}_{233-14}$ CJA). In 2019, 38 candidates were successful (20 women and $18 \mathrm{men}$ ) out of 480 who sat the exams. ${ }^{50}$ Their average age was thirty, but the average age of external candidates was twentyfive, while that of internal candidates (existing civil servants) was thirty-six. This is obviously the route chosen by those who were not successful in the ENA exams. The third is by secondment to the tribunaux administratifs (détachement) from either civil servants or university professors or lecturers. This recruitment takes the form of advert and application (Art. R233-5 CJA). In 2019, 7 judges were appointed by this route ( 4 women and 3 men). The fourth is by appointment from outside the corps to senior positions as conseiller or premier conseiller (tour extérieur, i.e. political nominations based on

50 Procès-Verbal of the Jury 2019 (from Conseil d'Etat website). 
experience). In 2020, the recruitment for this category was 10 posts. This means that, like members of the Conseil d'Etat, those conseillers are not trained with future members of civil, commercial and criminal courts who are trained in the Ecole Nationale de la Magistrature based in Bordeaux, the city of Montesquieu.

In March 2020, 45 per cent of the magistrats of this corps were women. Only 37 per cent of the presidents of the cours administratives d'appel are women and 35 per cent of the presidents of the tribunaux administratifs..$^{1}$

\subsubsection{Corps of the Conseil d'Etat}

At the time of writing, there were 231 members of the Conseil d'Etat, about two-thirds of whom carry out its current business in the Palais-Royal in the heart of Paris. The membership of the Conseil d'Etat is different from that of the superior courts of the United Kingdom. To begin with, the members of the Conseil are younger than judges in the jurisdictions of the UK - the average age of entry is thirty-five. But this average is made up from at least three different categories - those who are initial entrants from the National Civil Service College (ENA) and who make up three-quarters of its members, those who enter by way of competitions from within the public service especially the tribunaux administratifs and cours administratives d'appel, and those who are appointed from outside (the tour extérieur), including a small number of people appointed to senior roles for a four-year period from universities or public positions. Those appointed by the tour extérieur are more likely to have a legal qualification than those recruited directly through ENA. Those who enter the Conseil directly from ENA are typically aged twenty-seven, whereas the tour extérieur entrants would be forty-nine.

The second difference is that most of recruits are not lawyers. Rouban noted that in the fifty years from 1958 to 2008 , the proportion of members of the Conseil d'Etat with a law degree fell from 87 per cent to 48 per cent..$^{52}$ Indeed, he noted that the decline was greatest amongst those entering directly from ENA (in 2000 only 31 per cent of maitres de requêtes and 25 per cent of auditeurs - the two most junior career stages - were lawyers). ${ }^{53}$ It was more likely that the recruits from the other categories would be lawyers. The direct

${ }^{11}$ Journée Internationale des Droits des Femmes: Conférence-débat du Conseil d’Etat, interventions of Vice-President Lasserre and Secretary-General Bobo, 6 March 2020 on Conseil d'Etat website (visited 6 June 2020).

52 L. Rouban, Le Conseil d'Etat 1958-2008. Sociologie d'un grand corps, Les cahiers du CEVIPOF no. 49 (Paris: CNRS, 2008), p. 33.

53 Ibid., p. 50. 
entrants, who will usually go on to occupy the most senior positions in the Conseil, are more likely to have attended one of the grandes écoles (66 per cent of direct entrants) - for example, Ecole Polytechnique or Ecole Normale Supérieure, or one of the business schools followed by Sciences-Politiques and ENA than to have been to a law school. All the same, Rouban argued, 'It would be difficult to say that the increasing rarity of lawyers has led to a lowering of the legal quality of decisions. ${ }^{54}$ This may be explained by the importance of law courses in Sciences-Politiques and ENA. A third difference that arises from the fact that administrative judges are public servants and not simply lawyers. Membership of the Conseil d'Etat as a career is that members will not devote their whole career to judicial activities. Very many will spend a number of years as advisors or administrators in a ministerial office or in some other public body. In addition, just over 20 per cent will go into a career in business. Rouban states that, among those he studied, only half the women and a quarter of the men spent their whole career within the Conseil d'Etat. Taking a job on the outside is the typical route to advancement, and nearly all the vice presidents of the Conseil d'Etat have had major role in public administration. The current vice president, Bruno Lasserre, was director general of posts and telecommunications and also head of the competition authority for years. His predecessor, Jean-Marc Sauvé, served as a senior administrator in the Ministries of Justice and the Interior before becoming secretary general of the government (equivalent of the cabinet secretary in the UK). Sauvé's predecessor, Renaud Denoix de Saint Marc, had also been secretary general of the government, as well as administrator of Radio France, and served in a number of administrative roles in ministries. In 2020, both the French judge at the Court of Justice of the European Union and the French judge at the European Court of Human Rights came from the Conseil d'Etat, as did the secretary general of the Conseil constitutionnel.

Rouban calculated that between $195^{8}$ and 2002, 12 per cent of the members of the Conseil held political office, including one president of the Republic and thirty-three ministers. ${ }^{55}$ Throughout the twentieth century, at least 10 per cent of members of the Conseil were politically active.

A fourth difference is that more of them are women. The first women were appointed to the Conseil in 1953 . Whereas in 1958 , women made up only 3 per cent of its members, by 2007 this had risen to 24 per cent, and in March 2020 it was 33 per cent. But there is still some work to be done. In 2020 , only 28 per cent of the sections of the Conseil and 30 per cent of the

54 Ibid., p. 53 .

55 Ibid., p. 105. 
chambers of the Section du Contentieux were presided over by women. ${ }^{56}$ The number of women presidents of sections is no greater than in 1986, when the first women entrants to the Conseil (Mmes Grévisse and Questiaux) had reached that grade. As in the private law courts (and in the private sector), the large number of women entrants does not translate into an equal proportion in the most senior positions.

A fifth difference is the idea of a career. Because they often start at a young age (particularly if they are direct entrants from ENA), members of the Conseil d'Etat will seek to build a career. They will move through the ranks from auditeur to maître des requêtes and then to rapporteur public. Rapporteurs publics are usually in their thirties and this position lasts around ten to twelve years. Not all the judges in the Conseil d'Etat have to perform this role at some time in their career, but most if not all the presidents within the Conseil d'Etat were rapporteurs publics before becoming réviseurs and eventually - if a position was available - president of one of the ten chambers of the Section du contentieux.

There is a concern about elitism. The candidates for entry direct from ENA are within the top fifteen of the eighty-five or so graduating from ENA each year. In 2019, among the eighty-two members of the 'Promotion Molière' from ENA, eight went to the tribunaux administratifs and cours administratives d'appel and four to the Conseil d'Etat. In other respects, the members of the Conseil d'Etat are part of a social élite. Although there are very few dynasties within the Conseil, nearly half come from public sector families and more than 75 per cent come from upper-class families, including a majority from the Paris region. ${ }^{57}$ This makes them far more exclusive than those recruited by the English judiciary from Oxford and Cambridge..$^{5}$ An ordonnance of 2 June 2021 addressed this issue by transforming the ENA into an 'Institut national du service public'. One of the aim of this reform is to diversify the recruitment of high civil servants. Members of the Conseil d'État, the Cour des comptes, the tribunaux administratifs, the cours administratives d'appel and the chambres régionales et territoriales des comptes will, in addition, be liable to be transferred to other roles and will be subject to performance appraisal.

${ }^{6}$ See Vice President Lasserre, Allocation for International Women’s Day, 6 March 2020.

57 Rouban, Le Conseil d'Etat 1958-2008, pp. 23-4.

$5^{8}$ Even if one notes that the three 2019 appointments to the Supreme Court were all people who had come first in their year in the law degree at Oxford and Cambridge, they had each come through a cohort of about 230 students for whose places there were more than 1,000 applicants. 


\subsubsection{Corps of Financial Judges}

Alongside the 'ordinary' (civil and criminal) judges and the judges of the general administrative courts, the next major group of judges are those in the financial courts. In 2019, there were fifty judges and rapporteurs in the Cour des comptes and forty judges and vérificateurs in the chambres régionales des comptes. ${ }^{59}$ Of the senior personnel in these courts (including judges), 45 per cent were women in 2018, and the courts had never had so many women. Three of the seven presidents of chamber in the Cour des comptes were women, as was the procureure générale and one of her assistants. Three of the thirteen presidents of the chambres régionales were also women. ${ }^{60}$ The status of financial judge is high. This was shown by the choices made at the exit from ENA in 2019. The 'Promotion Molière' had eighty-two students, four of whom chose to enter the Cour des comptes and four the chambres régionales des comptes. As with the general administrative courts, there is also a competition among existing civil servants and avocats for entry into the financial judiciary.

The career pattern of the members of the Cour des comptes is very similar to that of the Conseil d'Etat. The entrant from ENA becomes an 'auditeur' grade 2 for eighteen months before passing to grade 1 and then as a conseiller référendaire after three years from entry. In 2019, there were 417 judges, including 16 auditeurs ( 36 per cent women), 168 conseillers référendaires (33 per cent women), 203 conseillers maitres (22 per cent women), and 12 presidents 33 per cent women). ${ }^{6}$ Some serve elsewhere in public office, and one president of the Republic in recent years was a member (Chirac). In 2020, the competition for conseillers (judges) of the chambres régionales aimed to make eight appointments. There is also scope for the appointment of external reporters (rapporteurs) to the Cour des comptes. These are experienced civil servants who are appointed for up to two three-year terms, and they work at the same level as members of the Cour. In 2019, there were 75 of these, of whom 40 were women. As with the Cour nationale du droit d'asile, the court is assisted by officials (vérificateurs) who prepare the early stages, notably reading carefully the accounts and highlighting deficiencies. There were about 400 of these officials in 2020.

\subsection{CONCLUSION}

The structure of the French administrative courts and the career pattern of their judiciaries are the most distinctive features of the French administrative

59 Cour des comptes, Rapport d'activité 2019, pp. 28-9.

6o Ibid., p. 30.

61 Cour des comptes website (visited 30 June 2020). 
law system. As Odent pointed out, the close involvement of judges with the active administration whom they control is a particularly distinctive feature. ${ }^{62}$ It is perhaps the most difficult feature for the outside observer to understand, and it clearly has been difficult for the European Court of Human Rights to see how this fits with an independent judiciary, as was seen in Chapter 1, Section 6, when discussing the role of what was then called the commissaire du gouvernement. Yet the values that underpin the institutions and the people who operate within them are shared with other countries. The French administrative courts did act independently since the beginning of the Third Republic and this was formalised by the removal of the ministre-juge concept in the Cadot decision of 1889. ${ }^{6}$ The independence of 'commissions' has been reinforced in recent years, and Sections 2.2 and 2.4 of this chapter have shown the way the judicial character of these bodies has been more fully formalised in the twentyfirst century. The United Kingdom has had similar experiences with the role of the Lord Chancellor and the judicial character of its tribunal system. They also have had to respect judicial independence more obviously and formally. For systems which have adapted over long periods of time to democracy and to expectations of standards of justice, the process has not always been easy. Although there is a danger that the European Convention on Human Rights is interpreted as a Procrustean bed onto which every legal system has to fit, the Strasbourg court has rightly allowed different legal systems a margin of appreciation in adapting their historical institutions and practices to contemporary shared values. Thus French administrative law remains distinctive, but not exceptional.

62 Note 19.

63 Note 8 . 


\section{4}

\section{The Procedure for Making Claims against Public Authorities}

Claims in administrative law cases are called a request (la requête) or recours. English lawyers familiar with the Privy Council before 1642 will recognise the name from its judicial activity in the Court of Requests. There are a number of important differences from the application for judicial review in English law and their equivalents in Scots and Northern Irish laws. In the first place, a claim or request is not limited to an action seeking to annul an administrative decision. That is the recours pour excès de pouvoir (the remedy for misuse of power), which is concerned with the legality of administrative action. But a request can also include claims for breach of contract or administrative liability, or for appeals against administrative decisions (such as on certain social benefits or certain taxes), and the remedy is granted more than merely annulment. This is the recours de pleine juridiction, which is dispersed in a variety of different ways in English law. ${ }^{1}$ So the request is a one-stop place for all kinds of action brought against the administration. For ease of understanding, this book refers to a 'request' as a 'claim'.

\subsection{PRINCIPLES OF THE ADMINISTRATIVE COURT PROCESS}

French administrative court procedure is governed by seven principles, some of which are of greater importance than others. Four are fundamental values (the right to effective redress, the principle of contradiction, the principle of openness and the principle of a decision within a reasonable time) and three are operational principles based on experience (principally the written, the collegial and the inquisitorial character of judicial proceedings). These last three are the

1 For completeness, Guyomar and Seiller also add le recours en declaration (covering matters such as a request that a court clarify its decision) and le contentieux de la repression (where fines are imposed for administrative infringements such as blocking the highway): M. Guyomar and B. Seiller, Contentieux administrative, th $^{\text {th }}$. (Paris: Dalloz, 2019), section 1 \&2. 
distinctive features of the French system. They are inherited from pre-Revolution practices, originally canonist procedure. To a great extent, there is a path dependency in these aspects of the French administrative law tradition of a fair trial. By contrast, the first four principles have been shaped in recent years by the shared tradition of liberal democracies represented by the European Convention on Human Rights.

\subsubsection{The Right to Effective Redress (Le droit au recours)}

France recognises a 'right to effective redress'. This is traced back to art. 16 of the DDHC. ${ }^{2}$ As the Conseil constitutionnel put it in 1989, 'the good administration of justice requires that the exercise of an appropriate remedy ensures the effective guarantee of the rights of those affected'. ${ }^{3}$ The principle was also recognised by the Conseil d'Etat in 1998 as a general principle for any kind of claim (where in 1950 it was done for the recours pour excès de pouvoir only). ${ }^{4}$ It is a principle found in art. 13 of the European Convention on Human Rights and was considered a general principle underlying the constitutional traditions of Member States by the ECJ in 1986.5 The Conseil d'Etat brought this thinking together in Bayrou in 2006, when it stated that 'the possibility of seeking an effective redress before a judge has the character of a fundamental right'. 6 This principle shapes the structure of the right to bring a claim either for judicial review of a decision or for an appeal or for damages. It also secures a number of other rights, such as the right of the asylum seeker to remain in France until his claim has been assessed by the OFPRA. ${ }^{7}$

\subsubsection{The Principle of Contradiction (Le principe du contradictoire)}

The idea that a party should be able to challenge points raised by the other party or by the judge is a consideration of both fairness and efficiency of

2 'Any society in which the guarantee of rights is not assured ... has no constitution.'

3 CC decision no. 89-261 DC of 28 July 1989, Rec. 81, para. 29.

4 CE 29 July 1998, Syndicat des avocats de France, no. 188715, Leb. 313. The right to obtain judicial review was recognised as a general principle of law in CE Ass. 17 February 1950, Minister of Agriculture c Lamotte, no. 86949, Leb. 110, which admitted the recours pour excès de pouvoir against administrative decisions that a law from the 'Régime de Vichy' had said were not subject to any review.

5 Case 222/84, Johnston v Chief Constable of the Royal Ulster Constabulary [1986] ECR I-1615. See now art. 47 of the EU Charter of Fundamental Rights.

6 CE 13 March 2006, Bayrou and Association de défense des usagers des autoroutes publiques de France, no. 291118, Leb. 1017.

$7 \mathrm{CE}_{4}$ December 2009, Minister of Immigration c Hammou, no. 324284, Leb. 781. 
proceedings. English lawyers would tend to describe it as the adversarial principle'. But it is not so much about giving two parties a say as it is about ensuring that the citizen is able to challenge points relating to their claim. The principle is now laid down in art. L5 CJA: "The investigation of cases is contradictory. The requirements of contradiction are modified by urgency, the secrecy of national defence and by the safety of persons.' This reflects prior case law of the Conseil d'Etat which had held that there was 'a general principle applicable to all administrative courts according to which procedure should have a contradictory character. ${ }^{8}$. The content of the principle was explained in the Conseil d'Etat's decision in Esclatine: 'The principle of contradiction, which aims to ensure the equality of the parties before the court, implies the communication to each of the parties of the totality of the documents in the file, as well as, where applicable, the grounds raised ex officio [by the judge].'9

As this quotation suggests, the right to contradict includes the right to contradict the judge if she raises a point of law ex officio. Article R611-7 CJA requires that the judge notify the parties when she considers that her decision may well be based on a point she wants to raise ex officio. This is treated as a general principle and applies to other administrative courts, such as the Cour nationale du droit d'asile. ${ }^{10}$ Guyomar and Seiller suggest this rule is based on the idea of equal treatment of the parties (the 'equality of arms') and also on loyalty to the litigation process. ${ }^{11}$ Since this ex officio power is widespread before administrative courts due to the numerous moyens d'ordre public (grounds of public policy which the judge is bound to raise even if they have not been pleaded by the parties), the principle of contradiction has a significant impact on the courts' process.

The principle that documents submitted by one party should be communicated to the other dates back to the ordonnance of Chancellor d'Aguesseau in 1738. The result is that the judge is not allowed to base the decision on material which the parties have not seen. ${ }^{12}$ The other party must be given adequate time

8 CE Sect. 12 May 1961, Société La Huta, no. 40674, Leb. 313. The Conseil constitutionnel would see this as part of the right of defence: CC Decision no. 89-268 DC of 29 December 1989, Finance Law for 1990, Rec. 110.

9 CE 29 July 1998, no. 179635 , Leb. 320. The particular application of the principle in that case (that the conclusions of the commissaire du gouvernement (now rapporteur public)) do not have to be communicated in advance to the parties) no longer applies, but the principle stated remains valid.

10 CE 14 March 2011, Ahmad, no. 329909, Leb. 83.

11 Guyomar and Seiller, Contentieux administratif, no. 765 .

12 CE Sect. 23 December 1988, Banque de France c Huberschwiller, no. 95310, Leb. 464 ; CE ord. 23 December 2016, Section française de l'observatoire des prisons, no. 405791. 
if a new document or argument is raised. On the whole, this avoidance of surprise is now solved by allowing both parties access to the same folder within the Télérecours platform and does not need much manual communication. But, if one party is allowed to submit a new document, then the other has to have reasonable time in which to respond. For example, in Texier c Le Bail, three days was judged too short to respond to substantially new points raised by one of the parties. ${ }^{13}$ For that reason, apart from emergency procedures, it is often prudent for the judge to close the investigation period some time (usually two weeks) before the hearing of the case, since art. R613-3 CJA provides that documents submitted after this time do not have to be communicated to the other side. Originally, the principle of contradiction had one important limit, which was that the facts put forward by public authorities could not be challenged. In other words, the facts on which an administrative decision was made were deemed true without the possibility for a claimant to challenge the assessment made by public authorities. This changed with the 1916 case of the Conseil d'Etat known as Camino. ${ }^{14}$

As art. L5 CJA identifies, there are exceptions to the requirement of the right to contradict - urgency, legally protected secrecy and the safety of persons. The most difficult of these is national security. The exceptions are narrowly construed. In principle, the judge cannot take account of materials legally protected by defence secrecy which are submitted, but not communicated to the other party. ${ }^{15}$ So in Moon sun myung, a woman was prevented from continuing her journey to Spain on her arrival into France on the basis of data held in the Schengen database which were not given to her. ${ }^{16}$ She complained to the CNIL, which refused her access to the relevant documents, and she challenged that decision. The Conseil d'Etat held that it could not make a decision on her complaint without access to the information on her in the database and that the CNIL was obliged to provide the court with it. In its view, if, consistent with the principle of the contradictory character of investigation, the administrative judge is bound only to decide on the basis of those documents in the file which have been communicated to the parties, it is incumbent on him in the exercise of his general powers of directing the procedure to obtain for himself, by legal means those elements of the type which will permit him to come to an informed decision on the litigated issues'. In rare cases, a court will read materials not available to the parties. Legislation

13

14

15

16

CE 28 December 2007 no. 282309.

CE 14 January 1916, Camino, no. 51619, Leb. 15, RDP 1917, 463 concl. Corneille, note Jèze.

CE 11 March 1955, Coulon, no. 34036, Leb. 149, dealing with the dismissal of an employee.

CE Ass. 6 November 2002, no. 194246, Leb. 380. 
on terrorism of 2015 enshrined in art. L773-2 CJA permits the appointment of a special panel of the Conseil d'Etat which is allowed to see defence secrets, but these documents are not available to the parties. Article L $773-3$ provides for the adaptation of the requirements of contradiction to these circumstances. The Conseil d'Etat considers that these arrangements do not excessively interfere with the requirements of a fair trial under art. 6 of the European Convention on Human Rights. ${ }^{17}$

\subsubsection{The Principle of Openness (Le principe de la publicité)}

Justice is rendered in the name of the French people (art. L2 CJA). In addition, litigation is one of the mechanisms by which public authorities are held to account to show that they have acted within their legal powers. For both these reasons, it is important that litigation is public - it is not simply the resolution of a private dispute between a citizen and an administration. As has been seen, this was established as a matter of practice by the Conseil d'Etat in 1831. Accordingly, art. L6 CJA provides that there be a public hearing of all cases. In addition, art. Lio requires that judgments are rendered publicly and contain the names of the judges. Article 20 of Law $n^{\circ} 2016-1321$ of 7 October 2016 added that the public can have access to them for free, and art. 33 of Law n ${ }^{\circ}$ 2019-222 of 23 March 2019 mandated that it should be done by electronic means. The same law and decree $n^{\circ} 2020-797$ of 29 June 2020 introduced exceptions to the naming of courts' members (judges as well as clerks for both administrative and civil courts) when its disclosure is likely to affect the security or privacy of these persons or their entourage, which raised concerns. ${ }^{18}$ As we will see, much of the important work in administrative litigation is conducted privately by judges in the stages preceding the formal hearing. Furthermore, it is very common that parties will not attend the formal hearing or will make little contribution to it. All the same, the parties need to be given notice of the hearing date and their right to attend. ${ }^{19}$ Obviously, there are a few exceptions, notably in terrorism cases where a special panel is created

See Prof. Thomas Perroud, quoting J. Bentham, 'Where there is no publicity there is no justice', https://blog.juspoliticum.com/2019/o3/11/lanonymisation-des-decisions-de-justice-estelle-constitutionnelle-pour-la-consecration-dun-principe-fondamental-reconnu-par-les-lois-d e-la-republique-de-publicite-de-la-justice (accessed 27 April 2021).

19 Article R712-1 states that lawyers are told four days before a hearing, but this can be reduced to two in urgent cases. A late notice to the parties can lead to the nullity of the judicial decision: CE 30 November 1904, Allarousse, Leb. 746. 
to examine matters that involve national security. Here the hearing of the case can partly be in private (art. L773-4).

\subsubsection{The Principle of a Decision within a Reasonable Time (La durée raisonnable de la procédure)}

The length of proceedings has been a constant complaint about administrative justice in France, and it has prompted many reforms. It is also the commonest complaint before the European Court of Human Rights for breach of art. 6 of the Convention and also an area where state liability can take place on the basis of a simple fault and not of a serious fault as usually required for the misfunctioning of the justice system (see Chapter 8). In 2002, drawing on art. 6, the Conseil d'Etat declared that it results from the general principles which govern the operation of administrative courts that litigants have the right that their claims should be judged within a reasonable time'. In this Magiera case, a routine public works case took seven and a half years to decide before the tribunal administratif of Versailles. ${ }^{20}$ The failure to decide in good time does not affect the validity of the decision, but it does lead to a right to compensation, as in the Magiera case.

\subsubsection{The Principle of the Written Nature of Proceedings (Le caractère principalement écrite de la procédure)}

By long tradition, French administrative court procedure is essentially written. That implies that parties will submit their main arguments and evidence in writing. That remains the underpinning structure of the Télérecours platform. Parties set out their main claims in writing and upload relevant documents. That is not to say that there are not significant moments which are oral. In ordinary proceedings, either the parties or their lawyers are allowed to speak to make observations during the public hearing. In practice, they will say little or nothing at all at that moment in particular before the Conseil d'Etat. Except for matters which involve more the facts of a case than checking the legal arguments, the rapporteur public will often give her opinion (conclusions) orally and may, at her discretion, give the written version if asked or deposit them in the Service de diffusion des conclusions where anyone can have access to them. As a result of the Kress case discussed in Chapter 1, Section 6, it is now common practice, with the exception of the Conseil d'Etat, that parties or their lawyer again take the floor after the rapporteur public has given her

20 CE Ass. 28 June 2002, Garde des Sceaux c Magiera, no. 239575, Leb. 247 concl. Lamy. 
opinion to 'respond' to her. Importantly, as will be seen later, during the interim or référé procedure, it is very common for parties to make substantial oral observations because there is insufficient time for the parties to exchange written documents when the matter is urgent and because the instruction stage is not closed. More generally, two areas were in the vanguard of increased oral hearings. In 1990, a law provided for a judicial review of the removal of a person refused entry into France within forty-eight hours and, as a consequence, provided for an oral hearing to facilitate the speed of this decision-making. In 1992 and 1993 legislation on public procurement provided for an oral hearing where a person was not permitted to participate in the awarding process. Both of these are the commonest occasions for an essentially oral procedure. ${ }^{21}$ But the reform of référés by the Law of 30 June 2000 increased the importance of oral hearing in many interim procedures.

\subsubsection{The Principle of the Inquisitorial Character of Proceedings (Le caractère inquisitoire de la procédure)}

The inquisitorial character of administrative litigation has as its principal idea that the judge directs the investigation and decides when a case is ready to be judged. In part, this follows as a way of addressing the essential inequality between the citizen and the administration. For example, it was stated in 1936 in Couespel de Mesnil that the court may 'require the relevant administration to produce all the documents needed to convince the court and verify the allegations of the claimant'. ${ }^{22}$ A further important example is the Barel decision of 1954 in which the failure of the administration to provide the documents explaining a decision involving appointment to the civil service led to the Conseil d'Etat deciding that it had acted unlawfully. ${ }^{23}$ In relation to discrimination in civil service appointments, the Conseil d'Etat balanced the need to sanction discrimination and the difficulty of the administration's complex processes. It held that first the claimant must demonstrate sufficient facts that raise a presumption that a breach of the principle of equality before the burden of proof shifts to the defendant administration to disprove any unlawful discrimination. ${ }^{24}$

${ }^{21}$ See A. Monod, 'Le dévéloppement de l'oralité du point de vue d'un avocat aux Conseils', in C. Teitgen-Colly, ed., Pouvoir et devoir d'instruction du juge administratif (Paris: Institut des sciences politiques et juridiques de la Sorbonne, 2017), p. 117.

22 CE Sect. 1 May 1936, no. 44513 , Leb. 485.

23 See text at note 65 .

24 See CE Ass. 30 October 2009, Mme Perreux, no. 298348, AJDA 2009, 2385. 
More recently, the Conseil d'Etat has repeated that it is up to the administrative judge, in the exercise of his general powers to direct the proceedings, to take any measures he thinks fit through legal means of a kind that permit him to be convinced about issues that are being litigated'. ${ }^{25}$ In that case, the court insisted correctly that the redacted documents and the reasons for secrecy be included in the case file, even if defence secrecy itself was not breached thereby. The consequence of the judge being in charge of the proceedings is that the reporter judge decides when a case is ready for decision. It is up to the judge to be satisfied with the outcome of the case. All the same, the burden of proof remains on the claimant.

\subsubsection{The Principle of Collegiality (Le principe de la collégialité)}

Article $\mathrm{L}_{3}$ CJA provides that judicial decisions are made collegially unless the law provides otherwise. This principle is said by Odent to be associated with the impartiality and independence of judges: 'A serious deliberation leading to a judgment offering the litigant guarantees of independence and impartiality implies necessarily that several persons are consulted, discuss their respective points of view and come to a majority decision. ${ }^{26}$ As will be seen, this principle minimally requires that a judicial decision is reached by a series of individual inputs - at least, those of the reporter judge, the rapporteur public and the president of the court. Many court panels will consist of other members who have not read the full file, but whose role is to consider the proposals made for the decision in the case and to decide whether they are broadly consistent with administrative law principles and whether the solution is adequately justified. The decision is the result of the work of more than one individual. His prejudices and weaknesses become less influential in a collective decision. In that way, impartiality of the result is secured. If the decision is the result of a collegial procedure, then there is less scope for putting pressure on the judge to decide in a particular way.

In part, the practice of collegial decision-making is a way of ensuring effective justice. One person may easily be mistaken, but a collegial court is less likely to be mistaken. But there need to be exceptions to be efficient and to avoid delay. Article L222-1 CJA allows for exceptions relating to the subject matter of the litigation or the issues to be tried. The Code then lists a number of types of cases which may be tried by a single judge in the tribunal administratif.

25

26

CE 20 February 2012, Ministre de la défense et des anciens combattants, no. 350382, Leb. 54 . Odent, Cours, cited in Guyomar and Seiller, Contentieux administratif, no. 721. 
More importantly, a collegial decision in France does not mean that all judges deciding a case are involved in all stages of the court process. Indeed, much of the process is managed by a single judge. In the first place, we will see that the hearing and the decision-making which follows is prepared by a single judge, the reporter judge. He or she will oversee the whole file and then draft a judgment for decision. The reading of the evidence of facts and the statements of the law that form the background to that draft judgment will not necessarily be read by all the judges who take part in the decision. Rather like in a committee, the presenter is in full possession of the information and the decision makers ask for such information as is necessary to satisfy them that the decision is right. So the final decision is collective, but, unlike British collective court processes, the earlier parts of the process are individual. We will also see that the interim decisions process (le référé) is typically the work of a single judge in both preparing the decision and in taking the decision.

In practice, a lot of decisions are taken by single judges. ${ }^{27}$ As will be seen in Section 4.4, the president of a court or chamber may resolve a case by ordonnance where the result is obvious or where a party has desisted. Nearly all decisions of the juge des référés described in Section 4.3 are taken by a single judge. In addition, there are a significant number of areas of litigation where the tribunal administratif may decide through a single judge. In 2018, these first two categories accounted for 26.7 per cent and the last accounted for 38.2 per cent of the cases resolved by the tribunaux administratifs - nearly twothirds of cases. ${ }^{28}$ Decision by ordonnance accounted for 48.5 per cent of all the decisions of the Conseil d'Etat and for 39.3 per cent of the decisions of the cours administratives d'appel. It is neither necessary nor efficient for collegial decisions to be taken in very many cases, even if a collegial decision remains the default approach of French administrative law.

\subsection{HOW IS A CLAIM MADE?}

Most importantly, the right to an effective redress entails that no permission is required from the court in order to bring a claim, even a claim to annul an administrative decision. The court must come to a formal decision on the merits of all claims submitted to it. Some decisions will be brief, but some form of reason has to be given.

Another way of implementing the right to an effective redress is that bringing a claim against the administration requires limited formality and is free. The most 
common form, which is used by citizens and companies and is obligatory for lawyers and all but the smallest public authorities, is the online Télérecours citoyens. Once registered, the litigant completes a note of the complaint about the administrative decision and attaches a copy of the decision and additional documents if necessary such as proof of residence. Alternatively, private parties (individuals and companies) can simply use the post or leave their claim at the court. There is no formal structure to the content of a claim, but it must have the essential elements. Thus it must have the name and details of the claimant, a clear statement of what is being claimed (nullity of a decision, damages for breach of a contract, etc.), what are the facts of the case and what are the legal arguments on which the claimant relies to justify the claim. The claimant can upload documents electronically to the site or send them subsequently by post. This 'dematerialised' system enables the claimant to communicate electronically with the court and to monitor easily the progress of a claim, since she will be notified by email of any new procedural act. Whereas judicial review in England is expensive, the cost is free in France. ${ }^{29}$ Since 1 January 2014, the droit de timbre (stamp duty), amounting to $€_{35}$ and imposed some years before, is no longer required.

So how is a potential flood of claims prevented? First, there is the possibility of administrative redress. Second, in some cases, there is need for legal representation.

\subsubsection{Prior Administrative Redress}

The person affected by any administrative decision has a right to request the decision maker or her superior to review it (art. L411-2 Code des relations entre le public et l'administration (CRPA)). Whilst such a request is being considered, the time limit is interrupted against any claim brought to the courts until the request has been rejected or accepted (art. L410-1 CRPA), which means that the time limit starts again entirely after the rejection, contrary to what happens when the time limit is simply suspended. There are obvious advantages of speed, cost and simplicity in encouraging the administration to correct its mistakes. For that reason, the law provides that, in a large number of cases, the citizen is required to bring a request for administrative review before commencing litigation (the so-called recours administratif préalable obligatoire (RAPO)). Such a request must be made within the time limit for bringing the claim or sometimes in a reasonable time. ${ }^{30}$ In this case, taxpayers sought in

29 Public Law Project, An Introduction to Judicial Review (London, 2019), p. 3.

30 CE Sect. 31 March 2017, Ministre des finances et des comptes publics c Amar, no. 389842, Leb. 105. 
2011 to have reviewed their tax for the years 1987 and 1989, which had been the subject of discussion with the tax authorities in 1992 and 1993. It was held that such administrative decisions could not be reopened indefinitely. Normally, the time limit is two months from the date when the administrative decision was properly notified to the claimant. But if it was not properly notified - that is, with no mention of the timing for bringing a claim against it and the necessity of a RAPO, if ever, the Conseil d'Etat ruled that by principle the time limit is one year. ${ }^{31}$ But the citizen does not suffer prejudice whilst an administrative review is going on because the time limit for bringing a claim in the courts only starts to run from the decision in relation to the request for an administrative review. This is different from alternative dispute mechanisms, but it is the simplest for avoiding litigation.

\subsubsection{Alternative Dispute Resolution}

There have been efforts over many years to set up mechanisms for alternative dispute resolution, but with limited and patchy success. The tribunaux administratifs were given the power to encourage conciliation in 1986. The Conseil d'Etat produced reports in 1980, 1988 and especially in 1993 when it was the theme of its annual report. A circular from the Prime Minister in 1995 encouraged the administration to resolve disputes before they become court cases and, especially, to respond to complaints in good time. Many complaints are based on the implied rejection of a request for redress. There was a rule that silence by the administration for more than four months (then, since 2000 , two months) amounts to a rejection of the request. Since the Law of 12 November 2013, the principle is reversed with many exceptions laid down in decrees. $^{32}$ But it has really taken until the Law of 18 November 2016 and its implementing decree of 18 April 2017 for a more systematic approach to develop. The results of this so far are more experimental than embedded. There are three distinct areas for the focus on alternative dispute resolution: within the administration itself, within the court process and on settlement agreements made by the administration.

(i) Solutions within the administration: As the Prime Minister's circular of 1995 made clear, the largest scope for alternative dispute resolution is

31 CE Ass. 13 July 2016, M. Czabaj c Ministre de l'Economie, no. 387763 , AJDA 2016, 1479.

32 According to a Senate report, the 2013 law extended the number of administrative procedures where silence amounts to an agreement from four hundred to twelve hundred, but there are still twenty-four hundred administrative procedures where silence amounts to a rejection of the request (www.senat.fr/rap/r14-62g/r14-6293.html). 
within the administration, once it receives a complaint from a citizen. Certain branches of the administration have long had schemes for trying to settle complaints amicably before litigation begins. This is particularly true for areas of administrative action that are subject to RAPO. A major area is tax. The French tax authorities receive 3.5 million complaints per year, relating to about 2.8 million contested assessments. About 96 per cent of these are handled within three months and 82 per cent are (wholly or in part) in favour of the taxpayer. ${ }^{33}$ For those cases in which the taxpayer is not satisfied, there is an internal conciliation system which deals with some 65,000 complaints a year, giving a 60 per cent success rate to the taxpayer. There is then an institutional mediator for the tax service who receives about 1,500 cases, again with a 60 per cent success rate for the taxpayer, and the Défenseur des droits (the national mediator) also receives some 600 cases. Tax cases account for 8.4 per cent of the claims made to the tribunaux administratifs, and these were 10 per cent down in 2018 compared with the previous year. ${ }^{34}$ Conciliation has also been obligatory since 1996 in medical negligence cases, but it is used more widely in the hospital sector to include employment cases. For example, the large Paris Hospital receives 800 claims a year and resolves 130 to 180 through mediation..$^{35}$ Other areas include education and public service, especially personnel issues.

(ii) Solutions within the court process: Article R213-5 CJA permits the tribunal administratif to propose the parties resort to mediation. The initiative may also come from the parties under the supervision of the court (art. R213-4 CJA). Since 2017, there have been some experiments with compulsory mediation (médiation préalable obligatoire (MPO)). But the numbers involved have been small $-1,500$ out of the 300,000 claims presented in a year. All the same, there is a high rate of settlements resulting from these interventions $(80$ per cent in the experiments). ${ }^{36}$ So this may be a line of direction to pursue in the future. For the moment, mediation is normally conducted with the consent of both parties. In addition, art. R621-72 CJA provides

Conseil d'Etat, Assises nationales de la médiation administrative (Paris, 2019), p. 51. See also S. Boyron, 'Mediation in Administrative Law: The Identification of Conflicting Paradigms' (2007) 13 European Public Law 263; and Boyron, "The Rise of Mediation in Administrative Law Disputes: Experiences from England, France and Germany' (2006) Public Law 320. 
that an expert can try to conciliate the parties during the litigation process.

Certain fields lend themselves particularly to mediation. Public service employment is a large area and one where mediation has proved successful, covering 23 per cent of cases in the experiments. ${ }^{37}$ It involves issues such as bullying and sexual harassment, as well as incapacity for work.

(iii) Settlement agreements (la transaction): French administrative law has traditionally been wary of private agreements between the administration and private parties, even to resolve disputes. As the Conseil d'Etat ruled in Mergui in 1971, 'a public body should never be condemned to pay a sum which it does not owe'. ${ }^{3}$ In other words, the liability of the public body must be clear, unlike in private law where a settlement might be reached even where the defendant does not accept liability. ${ }^{39}$ Furthermore, arbitration clauses are not accepted by law in contracts with the administration and more generally for public authorities (art. 2060 of the Civil Code), except for certain établissements publics considered public enterprises (such as EDF until it was transformed into a private company), in international agreements or in publicprivate partnership contracts. For example, the contract to create Eurodisney at Marne-la-Vallée was permitted to contain arbitration clauses (avis of the Conseil d'Etat, 6 March 1986). But the ban, on principle, of arbitration for public bodies is considered to avoid the risk of parties evading administrative courts and administrative law. In 2007, a commission led by Président of the Section du Contentieux Daniel Labetoulle suggested reversing the principle, but no government dared to endorse the proposal since an arbitration between a public company and a famous businessman hit the headlines and ended in its annulment by a civil court. Furthermore, the Minister of the Economy, who had given her consent to it, was found guilty of a criminal offence. ${ }^{40}$ In cases where arbitration is permitted, the Conseil d'Etat allows for its review by administrative courts. ${ }^{41}$

37 Ibid., pp. 69 and 77.

$3^{8}$ CE Sect. 19 March 1971, Mergui, no. 79962, Leb. 235.

39 See A. Lyon-Caen, 'Sur la transaction en droit administratif, AJDA 1997, 48; Brown and Bell, p. 30.

40 Ultimately Christine Lagarde was dispensed from criminal sanction and this permitted her to stay as the head of the International Monetary Fund and then as head of the European Central Bank.

41 CE Ass. 9 November 2016, Société Fosmax, no. 388806. 
The change in the attitude of French law towards mediation was influenced by way of a 'spillover effect' from Directive 2008/52/EC on mediation in civil and commercial matters. Although the Directive was limited to cross-border disputes and specifically excluded state agreements (art. 1(2)), it provided a momentum for reconsidering France's approach to mediation not only in civil and commercial law (by way of a 2010 law), but also in relation to public law. But since 2017, art. L213-4 CJA gives legal force to agreements resulting from mediation, but requires the settlement agreement to be registered by the public body with the tribunal administratif and the tribunal administratif can refuse its consent to this homologation. ${ }^{42}$ Such a settlement can be refused registration, for example, where the undertakings by the public body are unclear or where the contract breaches rules of public policy, such as the rules on public procurement. ${ }^{43}$ The courts do not take a narrow view of what is an acceptable settlement. As long as it is genuinely designed to put an end to litigation, the courts will not insist that there is a reciprocity in the concessions provided by each side, which is the rule for settlements in private law under art. 2044 of the Civil Code. For example, if a public employee has already withdrawn his complaint as a result of the mediation but before the settlement agreement was approved by the court, the agreement is sufficiently justified to be approved. ${ }^{44}$ The Conseil d'Etat has made clear that such settlements can not only relate to contractual or public employment claims or claims for compensation, but they can include the withdrawal of a claim for the judicial review of a decision on the ground that it is illegal. ${ }^{45}$

\subsubsection{Obligatory Legal Representation}

In certain types of litigation, notably those where the claimant seeks to recover money from a public body for a wrong done or a contract breached, the claimant is required to be represented by a lawyer (art. R431-2 CJA). But for many important types of litigation, such as the recours pour excès de pouvoir and immigration, there is no such requirement, especially in the first instance. The counterpart of this requirement is the obligation on the state to make available legal aid. The Conseil d'Etat has ruled that, because legal aid is a mechanism which contributes to the constitutionally protected right to

$4^{2}$ This power to refuse homologation was already recognised in case law: see CE Ass. avis 6 December 2002, Syndicat intercommunal des Etablissements du second cycle du second degré du District de L'Hay-Les-Roses, no. 249153.

43 For example, TA Bordeaux 15 July 2019, Bordeaux Métropole, no. 1902219, AJDA 2019, 2381.

44 TA Lyon 27 March 2019, B, no. 1704535, AJDA 2019, 1296 concl. Lacoste Lareymondie.

45 CE 5 June 2019, Centre hospitalier de Sédan, no. 412732. 
effective redress, any application for legal aid suspends time limits within administrative litigation proceedings. ${ }^{46}$ The Conseil d'Etat has also widened the scope of what counts as administrative litigation covered within legal aid to include the refusal of asylum or entry into France. ${ }^{47}$

\subsection{INTERIM MEASURES (LE RÉFÉRÉ)}

The juge des référés is, in principle, the judge of interim orders. As art. L511-1 CJA states, he 'decides by means of measures which have a provisional character'. But this simple description does not give the full picture. Some decisions are genuinely provisional - a stay of execution in a deportation, interim payments in a contract action for damages where the outcome is not seriously contestable. For example, art. L521-1 CJA empowers the judge to order the suspension of an administrative decision where there is urgency and serious doubt about the legality of the administrative decision in question, this référésuspension being the main weapon to act urgently before administrative courts, and the claimant must lodge an ordinary claim simultaneously. If suspended, the court must rule on the ordinary claim within one year in order to avoid blocking the administrative action for too long. But a significant number of decisions will, in practice or in law, be final. This applies especially in cases concerned with fundamental rights but not only with them. Article L522-1 CJA provides that in the référé-liberté the judge may make an order to safeguard a fundamental freedom which the decision of a public body or a private body carrying out a public service has seriously and manifestly unlawfully infringed or in case of référé précontractuel for breach of public procurement and concession award rules where the courts are granted power of annulment by law.

The Covid-19 crisis in 2020 illustrated the use that can be made of this procedure to undertake a definitive and not merely a provisional challenge to government decisions. During the first twelve months of the pandemic, the Conseil d'Etat handed down 647 decisions, quashing central and local government measures in 51 of them..$^{8}$ In a further 200 cases, the government withdrew or altered measures related to the 'confinement' (the more elegant French term for 'lockdown'). In Bicycles, at the beginning of the period of 'confinement', different local administrations interpreted the rules laid down

$4^{6}$

47

$4^{8}$

CE 6 May 2009, Khan, no. 22713.

CE ord. 8 February 2012, Ministre de l'Intérieur c Koné, no. 355884, Leb. 29.

Conseil d'Etat, 'Communiquée de Presse', 21 April 2021 (from Conseil d'Etat website). www .conseil-etat.fr/actualites/actualites/covid-19-retour-en-chiffres-sur-un-an-de-recours-devant-le -conseil-d-etat-juge-de-l-urgence-et-des-libertes (accessed 11 October 2021). 
in the government decrees in different ways. The prefects and police in various parts of the country interpreted art. $3 \mathrm{n}^{\circ} 5$ of the decree of 23 March 2020 as excluding cycling and closed cycle lanes, and a number of cyclists were fined for breaching the decree. That article provided, inter alia, that, until 11 May, people should stay in their homes except for brief excursions, limited to one hour a day and within a maximum of one kilometre around their home, connected with individual physical activity'. Other parts of the article talked about 'walks' with others in their household or with animals, so local officials considered that 'excursions' should be of the same kind. This was challenged by the national cycling federation on 21 April, which sought an order directed to the Prime Minister that he issue an interpretative circular clarifying the scope of the rule so as to include cycling. The competence of the juge des référés under art. L521-2 CJA was based on interference with a 'liberty', the freedom of movement. After an oral hearing on 29 April, the President of the Section du Contentieux ordered on the following day that the Prime Minister issue a clarification to be disseminated widely on conventional and social media within the next twenty-four hours that people were free to use their bicycles for their daily exercise. ${ }^{49}$ This ruling was consistent with the interpretation agreed at an inter-ministerial meeting on 24 April, but had not been widely publicised and was only given to the court on the day of the hearing. Although satisfying the cycling federation for the future, the Conseil had no power under art. L521-2 CJA to quash any fines imposed on cyclists, who were left to appeal through the normal channels of the criminal process. Nor could the court, in this case, direct public authorities to reopen cycle routes.

Enforcement of the very strict rules imposed in France from 4 March 2020 was obviously a problem, especially the very restricted movements permitted to people outside their homes, which came into force on 17 March before the law of 23 March 2020, based on the general power to protect public order recognised by the Conseil d'Etat to the head of the executive since a famous case related to the first driving licenses regulation before the First World War. ${ }^{50}$ On 18 March, the prefect of Paris decided to use drones fitted with CCTV cameras to assist in enforcement of confinement rules, especially to identify possible group gatherings. Although not fitted with recording equipment, the cameras on the drones were fitted with zoom lenses and could transmit pictures enabling police units to be despatched to potential trouble spots. They were also fitted with a loudspeaker which could warn people to disperse or go home. This use of drone surveillance became publicly discussed

49 CE ord. 30 April 2020, Fédération française des usagers de la bicyclette, no. 441079.

$5 \circ$ CE 8 August 1919, Labonne, no. 56377, Leb. 737. 
on 25 April and was challenged by civil liberties groups as unauthorised in law. The claim was rejected on 5 May by the juge des référés of the TA Paris, but the appeal was allowed by the juge des référés of the Conseil d'Etat on 18 May. ${ }^{51}$ In light of police explanations of the use made of the drones, the Conseil d'Etat found that the purpose of law enforcement was legitimate and that the surveillance without recording as such was not manifestly unlawful. But the drones did enable the collection of personal data in the form of images of people observed. The lack of prior authorisation of this activity by regulation breached the EU General Data Protection Regulation of 2016 and domestic French legislation of 1978 . Accordingly, the state was ordered to stop the use of drones forthwith in Paris. The decision was of more general significance as the Ministry of the Interior had already launched a tendering process for 650 drones for police purposes on 12 April. ${ }^{52}$

Once 11 May 2020 was reached, the government issued a number of 'deconfinement' measures. Various Catholic organisations and their leaders, including the President of the Christian Democrat Party, immediately challenged the decision not to allow churches to reopen for religious services. ${ }^{53}$ After an oral hearing on Friday, 15 May 2020, the Vice President of the Conseil d'Etat quashed the outright ban on services in religious buildings (other than funerals), but not with immediate effect and issued an ordonnance on Monday, 18 May, requiring the Prime Minister within a week to amend the

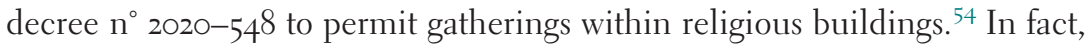
a new decree was issued on Friday, 22 May, setting out restrictions within which such religious events could take place, and church services began the following day. The interferences with freedom of the individual were related to the freedom of religion under the European Convention, but also to the rights protected under the Concordat with the Pope of 26 Messidor An IX (which still applies in Alsace-Lorraine) and arising from the law of 1905 on the

CE ord. 18 May 2020, Association 'La Quadrature du Net', nos. 440442 and 440445, AJDA 2020, 1552.

52 See 'Drones: une ombre chinoise derrière l'appel d'offres du ministère de l'intérieur', Le Monde, 16 April 2020, which specifically mentions the use of drones in enforcing the confinement. See also 'Le Conseil d'Etat ordonne à la Préfecture de police de Paris de laisser ses drones au sol', Le Monde, 18 May 2020.

53 Churches had been allowed to remain open, but without services, except for funerals: see art. 8 IV of decree no. 2020-293. The 'deconfinement' rules were set out first in decree no. 2020-545 of 11 May 2020 and were altered later that day by decree no. 2020-548. A number of claims filed too quickly with the Conseil d'Etat were declared inadmissible because they only challenged decree no. 2020-545, which had been replaced in certain relevant particulars by decree no. $2020-548$ !

54 CE ord. 18 May 2020, W and others, no. 440366 (and seven other decisions), AJDA 2020, 1733. 
separation of church and state (which relates to the rest of France with the exception of some overseas territories). Basically, the court found the continuing outright ban on religious services disproportionate in its interference with a fundamental freedom. The disproportion in the balance between risk and interference with freedom was shown by comparison with other permitted activities which were riskier than meetings in religious buildings. For example, travel on public transport could not be limited to ten or fewer people in the same way as other permitted public gatherings. People were to be allowed to go to shops, schools and libraries where they were able to operate allowing a personal space of at least four square metres. Other activities which remained prohibited did not involve the same kind of fundamental freedom as the freedom of the practice of religion. Furthermore, there was inadequate evidence to support the view that religious gatherings would cause serious harm. The main reason the government offered for the ban was that rules could not be designed for social distancing nor they could not be enforced effectively by the authorities in question, or that decontamination measures could not be taken. There had been no investigation of whether these concerns were sufficiently justified by the evidence to support the absolute ban on gatherings, other than funeral services for twenty persons or fewer. The Minister of the Interior had pointed to an outbreak which had followed a religious gathering of more than a thousand people in Mulhouse from 17 to 24 February. But the evidence that this was a cause of the outbreak was insufficient.

There was a clear attempt in these cases to challenge the decisions of the government by means of rapid judicial review, rather than relying on political means to determine the right way forward. In the Church Gatherings case, the juge du référé-libertés had to reject an attempt to challenge the political declaration made by the Prime Minister on 28 April 2020 and the reasons he gave to the Assemblée Nationale for not opening churches for services. Only actual decisions such as the decrees of 11 May could be challenged. But the juge du référé-libertés is limited to interfering where the administrative decision seriously and manifestly infringes fundamental freedoms or there are serious doubts about its legality. This is a high threshold, but it may apply to the exercise of discretionary powers. For example, the claim by the union of junior doctors that the state should take additional steps to provide personal protective equipment to medical staff in hospitals failed. ${ }^{5}$ Very detailed evidence was provided by the Ministry of Health that it had acquired and made available large stocks of such equipment. As a result, the court 
concluded that, although there were problems in the availability of equipment in some locations, there was not a serious and manifest failure to act to prevent a threat to the lives of the medical staff. But a claim to challenge the adequacy of the protection of public health at the very beginning of the Covid-19 outbreak did succeed in relation to decisions to impose rules which still permitted jogging and open markets. ${ }^{56}$

The other high threshold is 'urgency'. The interpretation of this concept is often influenced by the substance of the case. For example, the 2016 case on the 'burkini' in which the Conseil d'Etat considered a local ban of showing religious belief by the attire worn when bathing in the sea at Cagnes-sur-mer was urgent enough to allow a référé-liberté.$^{57}$ It is clear that the discriminatory nature of the ban encouraged the court to accept that there was an urgence caractérisée. (This term is found in the case law whereas the law itself only requires urgence sufficient to require that the judge decide the matter within forty-eight hours (art. 521-2 CJA).) This is more stringent a standard than the urgency required in practice for référé-suspension, which sometimes allows suspension by the judge within three or four weeks.

Indeed and by contrast, in the case of the référé-suspension, the standing for action is closer to recours pour excès de pouvoir. But it is also to be noted that this référé-suspension action may be taken not only to challenge legislation, but also to challenge 'any document of general application issued by a public authority, in physical or other form', 'when these are capable of having serious effects on the rights or situation of people other than those who have to implement them'..$^{8}$

All these cases illustrate the way the interim decision procedure effectively enabled definitive decisions to be reached. In none of these cases would there be a later, final decision on the matter in hand. At the same time, the court respects the legitimate freedom of the executive by giving the administration time to produce new rules.

Although the decision of the juge des référés is normally taken individually by the president of the court or other senior judges, the judge can refer the matter to a full court because of the seriousness of the issue in question. The clearest example of this is Lambert. ${ }^{59}$ Vincent Lambert had a motor accident in 2008 which left him tetraplegic. After investigation and various attempts at treatment, it was concluded in 2011 that he was in a vegetative state with minimal

56 CE ord., 22 March, Syndicat Jeunes Médecins, no. 439674.

57 CE ord., 26 September 2016, Association de défense des droits de l'homme - Collectif contre l'islamophobie en France c Commune de Cagnes-sur-Mer, no. 403578.

$5^{8}$ CE Sect. 12 June 2020, GISTI, no. 418142.

59 CE Ass. 24 June 2014, Mme Lambert, no. 375081, AJDA 2014, 1669. 
consciousness. His parents and some members of the family wished for care to continue. His wife, other members of the family and the hospital wanted the treatment ended and hydration stopped. In the absence of an agreement within the family, the authorised consultant exercised powers under art. 1110-5 of the Code de Santé Publique on 11 January 2014 to bring his treatment to an end two days later. His parents requested judicial review of this decision and the suspension of its implementation from the juge des référés of the TA of Châlons en Champagne. That court granted the suspension on 16 January on the grounds that the decision would be irreversible. Lambert's wife challenged this to the Conseil d'Etat. The juge des référés remitted the matter to the Assemblée du Contentieux in view of the significance of the issue. The judge ordered a group of experts to report on Lambert's physical condition under art. R621-1 CJA. He also commissioned the Académie nationale de médecine, the Comité consultatif national d'éthique and the Conseil national de l'Ordre des médecins, as well as Jean Leonetti, rapporteur in Parliament on the 2005 law on the rights of sick people and the end of life under which the doctor's decision in this case was taken to produce written observations as amicus curiae under art. R 625-3 CJA. They were asked to report generally on the scientific, ethical and moral questions arising from the litigation, in particular on the interpretation of the concept of 'unreasonable obstinacy' and artificially keeping someone alive within the meaning of art. L1110-5 of the Code de la santé publique. Given Lambert's vegetative state and the way the legislative provision should be interpreted, the Conseil concluded that the steps the doctor had taken in coming to the decision did not demonstrate that, on the facts of this case, the doctor had reached an illegal decision. Although technically an interim decision on whether an administrative decision should be suspended, the practical reality was that this was a substantive hearing of the issue of whether the doctor acted lawfully in deciding to stop medical treatment. The matter continued through the European Court of Human Rights and back through the French courts until Lambert died on 11 July 2019 due to the stopping of treatment. ${ }^{60}$ This included a decision in référé on 24 April 2019, seeking to quash the repeated decision to end treatment taken by the doctors. The whole saga of decisions in the courts was conducted by way of interim decision. There are many similarities with the Bland case in England, not least the resort to amicus curiae briefs to clarify the moral issues at stake. ${ }^{61}$ But there it was the doctors who were seeking judicial approval for their decision, rather than relatives contesting it.

60 Decision 5 June 2015. See generally www.lemonde.fr/societe/article/2019/04/24/affaire-vincent -lambert-le-conseil-d-etat-juge-legale-la-decision-d-arret-des-traitements_5454289_3224.html (accessed 11 October 2021).

61 Airedale NHS Trust v Bland [1993] A.C. 789. 


\subsection{THE INVESTIGATION (L'INSTRUCTION)}

The French procedure is essentially written. The documents uploaded by the litigant are then supplemented by the administration and form a file (le dossier). Traditionally, the file was a cardboard folder into which were put the various documents from the parties and assembled by first by the greffe of the court and then by the reporter judge. These days, it is an electronic folder shared on the Télérecours platform. In this way, the litigant is able to follow the progress of his or her case. There are specific rules about when communications are deemed to have been made on this system. As has been said, the investigation phase (l'instruction) is managed by the judge. ${ }^{62}$ The purpose of the instruction is to clarify the facts and to research the applicable law with a view to preparing the case for hearing. Because the hearing (l'audience), as we shall see, is often so short, the preparation phase is far more significant than in common law systems.

The instruction is carried out differently in different administrative courts. In the tribunal administratif or the cour administrative d'appel, the file is first sent by the greffe, the court office, to the president or delegate responsible for assigning work to members of the court (art. R611-9 CJA). Unlike in Germany, which has a very strict rule that cases simply go to the next qualified judge, the president does enjoy discretion in the choice of the reporter judge (juge rapporteur) entrusted with the preparation of the file for the hearing. The reporter judge may be chosen because of particular expertise in a field, or because he or she has already a number of similar files on the same topic. In practice, the reporter judge will be responsible for liaising with the parties and determining a timetable for a decision, as well as identifying measures to be taken.

In the Conseil d'Etat, the instruction is carried out by a collegial chamber of the court which will review the file and potential draft judgment before recommending in which formation of the court the case should be decided. This more elaborate process is started only when the file has been completed by the parties (art. 611-20 CJA). This stage is called the mise en état, and whether a file is ready is determined by the president of the chamber to which the case is assigned. The President of the Section du Contentieux of the Conseil determines which subject matter is assigned to each chamber (chambre jugeant seule) or to two chambers (chambres réunies). The president of the chamber may order investigatory steps to be taken, such as requiring the parties to provide further documents, before the file is judged ready. Only

62 See generally Teitgen-Colly, Pouvoir et devoir d'instruction. 
where the case is 'good for a reporter' (bon pour rapporteur) does the president of the relevant chamber appoint one of its members as a reporter judge. The chamber will review the case collectively at the end of the instruction phase.

In the case where a claim is obviously inadmissible or otherwise the solution to the case is obvious, the president of the court or chamber can decide that there will be no instruction phase and that he or she can proceed to decide the case by way of ordonnance (art. R611-8). He or she can also require one of the parties to provide a summary of the arguments contained in the submitted documents, which will clarify the nature of the complaint or defence. The ordonnance is not delivered in public.

The procedure before the lower administrative courts, which hear the bulk of cases at first instance, is more inquisitorial than before the Conseil d'Etat. ${ }^{63}$

A number of investigatory steps might be taken in order to get the file ready to be decided. Most of these involve clarifying the facts beyond the detail provided by the parties in their initial submissions and complementary documents. Although it is for the reporter judge to decide what measures are necessary, the parties play a significant role in the procedure, but rarely themselves ask for particular measures to be taken. ${ }^{64}$

\subsubsection{Request for Information}

A request for information can be addressed either to one of the parties or to an administration, depending on who is likely to hold it. As the Conseil d'Etat explained in Erden: ${ }^{65}$

It is incumbent on the administrative judge in the exercise of his general powers of directing the procedure to order any investigatory measure which he considers necessary for the solution of litigation submitted to him, and especially to require the parties as well as, in appropriate circumstances, third parties and especially competent administrative authorities to communicate documents which enable him to verify the allegations of the claimant and that will permit him to come to an informed decision.

One party will be given a deadline to produce a response to the allegations of the other. If the claimant fails to respond in time, he or she is deemed to have desisted in their claim (art. R612-5 CJA). If the defendant fails to respond in time, he or she will be taken to have accepted the claimant's version of the facts

63 See Guyomar and Seiller, Contentieux administratif, nos. 838 and 839 .

64 See L. Poupot, 'Le rôle des parties dans la prescription des mesures d'instruction', in TeitgenColly, Pouvoir et devoir de l'instruction, pp. 63-4.

65 CE Sect. 1 October 2014, Erden, no. 349560. 
(art. R612-6). A request for information may be addressed to a public administration other than one of the parties. A famous example is the Barel decision, in which it was alleged that a number of applicants for the civil service college (ENA) were being rejected on grounds of their political beliefs, especially their relationship to the Communist Party. ${ }^{66}$ The Conseil d'Etat requested the files on a number of candidates, not just the claimants. When the administration refused to provide these, the Conseil inferred they had been refused for unlawful reasons. More recently, two employees of private companies were refused permits to enter a naval dockyard on the ground that, as a result of a security inquiry, their behaviour was incompatible with defence interests. The employees challenged this non-renewal of their security passes and the tribunal administratif sought the documents relating to these individuals. The matter was referred to the Commission consultative du secret de la défense nationale (CCSDN), which recommended in favour of partial declassification of the documents. But by a curt letter to the court the Ministry of Defence simply stated that it would not be following the advice of the CCSDN and would not hand over the documents. In the absence of a proper explanation, the tribunal administratif quashed the refusal by the head of the naval dockyard (run by a private-sector company) to renew the claimants' security passes. ${ }^{67}$ In the absence of access to the documents setting out the complaints against the claimants, the administration had failed to satisfy the court about the reality of the complaints against them. ${ }^{68}$

\subsubsection{Expert Report (L'expertise)}

The principle of the inquisitorial nature of the proceedings has the consequence that the judge is responsible for appointing an expert (art. R621-1 CJA). The parties may suggest that this happen and they are allowed to comment on the suggested names of experts, but it is the judge's decision. The expert reports to the court. This contrasts with the way common law experts are appointed by the parties and, unless they agree to a common expert, then the judge is left to arbitrate. An example is the Lambert case, where the hospital and the wife considered the injured man in a vegetative state and his parents 
disagreed and argued that he should continue to receive treatment. ${ }^{6}$ To determine whether to uphold the doctor's decision to cease treatment, the Conseil d'Etat appointed its own panel of experts to determine the state of Lambert's health.

Experts are used particularly in the assessment of damages. For example, in the liability of public hospitals, an expert will be used typically to report on the extent of the injury of the claimant and the likely cost of future medical treatment. But they can also be used for searching for the cause of any damage, such as in public contracts, where the questions relate to the technical methods used.

In one sense, the presence of the expert reduces the adversarial nature of the proceedings - the parties are not responding to the arguments of the other side, but feeding into an independent process. But, at the same time, the parties have a vital role in providing the expert with information, sometimes meeting with the expert under judicial supervision, and in responding to the findings the expert presents to the judge.

\subsubsection{Site Visit (La visite des lieux)}

Under art. R622-1, the judge may order a site visit. This process is frequently undertaken in areas such as planning, where the configuration of a site is under dispute. But it can occur in other cases. For example, in a case concerning the compatibility of the compulsory retirement age of air traffic controllers with age discrimination law, the Conseil d'Etat arranged for the judges of the relevant chamber to visit an air traffic control centre so as to understand the work the controllers undertook and why an age limit might be relevant to their performance. ${ }^{70}$ In another case, dealing with the creation of a racing circuit in the Cevennes area as part of a conversion from coal mines, the judges made the trip to assess the level of noise made by cars and motorcycles and eventually quashed the decision authorising the opening, although the regulations insisted merely on assessments of safety but not of the potential for private nuisance. ${ }^{71}$ Eventually, the race circuit was reopened after public works mitigating the noise were done (to limited effect, as one of the authors can tell from his home).

69 See note 59.

70 CE Ass. 4 April 2014, Ministre de l'Ecologie, du développement durable et de l'énergie, no. 362785 (and eight others), Leb. 83 .

${ }^{71}$ CE Sect. 1 July 2005, Abgrall, no. 256998. 


\subsubsection{Witness Hearing (L’enquête)}

Only since 2001 has the witness hearing (l'enquête à la barre) revived in significance. ${ }^{72}$ In a case concerning tariffs for prescription drugs, the ministry presented details of the way in which the tariff had been calculated. The soussection of the Conseil d'Etat did not find the ministry's explanation for reducing the tariff sufficiently clear and it arranged for an oral hearing before the sous-section in its instruction formation to hear the representatives of the ministry with the participation of representatives of the claimants. ${ }^{73}$ They were then able to comment on the minutes of that meeting produced by the reporter judge. In the end and on the basis of this information, the Conseil did not find that the ministry had committed an error of law in basing its tariff on actual expenditure in the preceding year. This form of oral hearing of the parties or witnesses is of particular significance in urgent proceedings. Where decisions have to be made quickly in relation to removal on refusal of entry into France, then the court can benefit from information particularly from the claimant. It has been suggested that such an oral hearing can be a speedy way of assisting the court to clarify the facts and the areas in dispute between the parties, as well as helping the litigants to understand how the judge is approaching the question. ${ }^{74}$

\subsubsection{Amicus Curiae}

A 2010 decree created the opportunity for a court to invite any external person to provide written or oral information (now contained in art. R625-3 CJA). A good example is the Lambert decision. The law also provides for a court to consult specific external bodies in their areas of competence, such as the Haute Autorité de la Concurrence. For instance, the Conseil d'Etat in the Société Lacroix Signalisation case sought the opinion of the Autorite de la concurrence before ruling on a request to annul a public procurement contract which was concluded by a département after a collusion between firms. ${ }^{75}$ It ruled not entirely in conformity with the views of the latter, which was claiming the contractor should reimburse the entire payment made upon the public procurement contract but decided it should be deprived of any

72 See Guyomar and Seiller, Contentieux administratif, no. 848; Guyomar in Teitgen-Colly, Pouvoir et devoir de l'instruction, p. 123.

73 CE 16 February 2001, Centre du château de Gleteins, no. 220118, AJDA 2001, 296.

74 Note by Claire Landais in AJDA 2001, 296; also Guyomar, in Teitgen-Colly, Pouvoir et devoir d'instruction, p. 123.

75 CE 10 July 2020, no. 420045. 
profits as a consequence of the retroactive effect of the annulment, the termination of the contract for the future having no sense under the contract as entirely executed. Mainly the opinion sought from an amicus is on a legal issue. It may well be a matter for a specialist legal historian. For example, in one case, an amicus was appointed to explain whether an aveu et dénombrement (a recognition of seigneury accompanied by a list of the property involved) on 1 May 1542 could be considered as creating title to a property before the Edict of Moulins of February 1566, thereby blocking a ruling that the property could not be alienated because it was public property. ${ }^{76}$ The court must form its own judgment on the issues before it and cannot simply servilely follow the view of the amicus curiae. ${ }^{77}$ Without appointing officially an amicus curiae, the Conseil d'Etat and, less often, lower administrative courts, may take the advice of experts in the field, including professors of law, as in the Société Lacroix Signalisation case.

\subsection{RAPPORTEUR PUBLIC}

In Chapter 1, Section 6, it was noted that the operation of the rapporteur public (previously called the commissaire $d u$ gouvernement) has undergone significant change as a result of decisions by the European Court of Human Rights. This section considers the current functions of the rapporteur public in administrative litigation.

Once the reporter judge has completed the instruction and has the case ready for hearing, the file is passed to the rapporteur public. The file will contain the reporter judge's draft judgment. The ability of the rapporteur public to view the draft judgment before the hearing when the parties could not was challenged unsuccessfully before the European Court of Human Rights, which found that the practice was not contrary to the equality of arms in court proceedings, since the rapporteur public was not a party to the case. ${ }^{78}$ The intervention of the rapporteur public can be dispensed with in a number of cases. Some are laid down in specific legislation, such as was the case in relation to the Covid-19 crisis. More generally, art. R732-1-1 CJA provides that the opinion of the rapporteur public can be dispensed with in a number of routine cases (challenges to removal of driving licences, to the refusal by the police to assist in enforcing court judgments, to the rejection of naturalisation, to immigration cases on refusal of entry or removal (other than

\footnotetext{
76 See H. Muscat in Teitgen-Colly, Pouvoir et devoir d'instruction, p. 140.

77 CE 6 May 2015, Association tutélaire d'Ille-et-Vilaire, no. 375036, Leb. 163.

$7^{8} \mathrm{ECHR}_{4}$ December 2013, Application no. 54984/o9, Marc-Antoine v France.
} 
deportation), and to decisions on certain property taxes or on certain social welfare payments to private-sector employees), as these cases are mainly dealing with fact-checking rather than legal reasoning. ${ }^{79}$ The rapporteur public does not produce an opinion on ordonnances except in the case of some référé matters. He may also suggest that it is not necessary to express an opinion on a specific case, and the president of the court or chamber may accept this (art. R776-13 CJA). In any case, even if the conclusions of the rapporteur public have to be given, they do not need to be written, but can be oral. In practice, most of the conclusions in all but the most straightforward cases are written and available, when it comes from rapporteurs publics of the Conseil d'Etat, at the Service de diffusion des conclusions of the Conseil d'Etat or directly at the official website of the Conseil d'Etat called ArianeWeb. It may not always be the case because the rapporteurs publics may reserve them for publication in legal journals or not publish opinions for decisions of lower importance such as those decided by a single chamber.

The purpose of the rapporteur public's intervention is to view the solution proposed by the reporter judge from a broader legal perspective than that offered by the parties and to do so in public, unlike the private pleadings (art. L7 CJA). These conclusions provide a kind of counterpart to the relative brevity of the judgments. The rapporteur public examines the individual case in the context of the law as a whole. She expresses her view independently, which marks her out from the collegial decision makers in the formation of judgment. The common law reader will find the style both more detailed and more personal than the judgment of the court. But the style is not really that of a common law advocate, but much more that of the Advocate General of the Court of Justice of the European Union, which was based on the rapporteur public in the first place. Like the Advocate General, the rapporteur public will give greater detail about the facts of the case and will also provide the broad legal framework in which the issues in the case belong. This opinion will help the court to avoid being misled by the particular facts of a case or by the way it has been argued by the parties.

Both the style and the function of the opinion of the rapporteur public make it more of a scholarly dissertation than a judicial judgment. French administrative law has been shaped by a series of conclusions of famous commissaires du gouvernement, especially David, Romieu and Léon Blum in the early period and Letourneur, Braibant and Genevois in the second half of the twentieth century. For that reason, Deguergue considered the commissaire

79 This compares with the earlier idea that the commissaire du gouvernement should offer an opinion in all cases: CE Sect 13 June 1975, Adrasse, no. 93747, AJDA 1975, 477; N. Rainaud, Le Commissaire du gouvernement près le Conseil d'Etat (Paris: LGDJ, 1996), pp. 52-6. 
du gouvernement (now rapporteur public) similar to a doctrinal legal writer. ${ }^{80}$ Indeed, former President of the Section du Contentieux Bernard Stirn stated that the function of the rapporteur public was to make the link between the work of the administrative judge and legal scholarship, although the reality of the assessment may vary from one rapporteur public to another depending on her ability to read and quote academics. ${ }^{81}$ At the same time, the argument has to be focused on the case at hand and cannot range as widely as the scholarly writing which many rapporteurs publics have published in extrajudicial writings. As Guyomar and Seiller remark, there is no prescribed length for these conclusions. In a simple case, the oral presentation can last a couple of minutes. In other cases, it can last up to forty-five minutes or an hour. 'But it is recommended to know how to be brief or at least not too long, so that you do not exhaust the attention span of the members of the formation of judgment. ${ }^{82}$

In the Conseil d'Etat, the instruction is completed by a meeting of the chamber to which the case has been assigned. Here the reporter judge will introduce the case. His report will have already been seen and discussed with another senior member of the chamber as réviseur. Other members of the chamber can contribute to the discussion, and the rapporteur public will also take part in this debate and sometimes invited experts will do the same. Particularly where the reporter judge and the rapporteur public disagree, there may be a lively discussion and even a change of initial positions. The purpose of this meeting is to produce a draft judgment (not two, in contrast to the practice of the Cour de cassation) to be taken forward to the hearing and the decision-making formation of the Conseil. In the tribunal administratif or a cour administrative d'appel which does not operate the instruction through chambers, there is no formal mechanism for the reporter judge and the rapporteur public to discuss their disagreements, especially since rapporteurs publics have a very limited time to write their conclusions (generally two weeks for several cases), in contrast to the rapporteurs publics before the Conseil d'Etat who have a say on the timing of instruction. But this may well happen informally. They will often have offices in the same building and eat in a common canteen, so it becomes natural to discuss the work they share.

The opinion of the rapporteur public is delivered orally at the hearing. In advance of the hearing, the parties are given 'the sense of the conclusions'

8o M. Deguergue, Jurisprudence et doctrine dans l'élaboration du droit de la responsabilité administrative (Paris: LGDJ, 1994), pp. 729-32 and 738. See also D. Fairgrieve and F. Lichère, 'Style and Form of Judgments in France: enter the Rapporteur public' in Liber Amicorum for Mads Andenas (forthcoming Springer, 2022).

81 B. Stirn, 'Les commissaires du gouvernement et la doctrine', La Revue Administrative 1997: numéro spécial: Le Conseil d'Etat et la Doctrine, p. 41.

82 Guyomar and Seiller, Contentieux administratif, no. 860. 
(arts. R711-3 and R712-1 CJA). They are not given the full text in advance, but the outcome, which is proposed. As a guide to good practice, the Conseil d'Etat has suggested that the rapporteur public explain the main reasons for the proposed solution, without necessarily going into great detail. ${ }^{83}$

Since 2006, the rapporteur public in the tribunal administratif and the cour administrative d'appel does not retire with the judges to be present at their deliberations (and, indeed in the past, to take an active part in their discussion but not in the voting). But art. $\mathrm{R}_{733-3}$ CJA retains the possibility for the rapporteur public to be present during the deliberations in the Conseil d'Etat as he or she is considered to be building up the case law of the supreme administrative court. The parties are advised that they can ask for him not to be present since the rapporteur public, although not a party per se, has become the objective ally of one party in public. But, in practice, they very rarely do so. ${ }^{84}$ So, even today, the rapporteur public will learn why the judges came to their decision, though he is no longer allowed to speak in the deliberation stage. ${ }^{85}$ This specific organisation of functions was eventually ruled as compatible with the European Convention of Human Rights after the 2001 Kress decision led to the conclusion that the presence in the deliberation of the commissaire du gouvernement was probably incompatible with art. 6 of the Convention (see the discussion on the change from the commissaire $d u$ gouvernement to the rapporteur public in Chapter 1, Section 6). ${ }^{86}$

\subsection{PRELIMINARY REFERENCES}

There are five different situations in which an administrative court may suspend its consideration of a case and refer an issue to a preliminary decision of another court.

Reference for an opinion of the Conseil d'Etat: The tribunal administratif or the cour administrative d'appel may refer a preliminary question for the opinion (avis) of the Conseil d'Etat under art. L113-1 CJA. The request for such an opinion is restricted to questions of serious difficulty which will apply in a number of cases. In 2019, twenty-eight of these were submitted to the Conseil d'Etat. ${ }^{87}$

Conseil d'Etat, Rapport public: L'activité juridictionnelle et consultative des juridictions administratives en 2019 (Paris, 2020), p. 54 (hereafter: 'Rapport public 2019'). 
Public law and private law: Because of the clear separation between administrative and ordinary courts, the most established category of reference is a conflict of jurisdiction between administrative and civil courts. This is discussed at length in Chapter 5. In brief, art. R771-2 CJA provides that where litigation in an administrative court raises a serious question lying within the competence of the ordinary courts, the court should suspend proceedings and refer the relevant question for a ruling by the civil court. In addition, since 1960, there has been a procedure to allow the Conseil d'Etat (as well as the Cour de cassation) to obtain a preliminary ruling from the Tribunal des Conflits where there is a serious question about the jurisdiction of the administrative or ordinary courts over a case before it. This is explained further in Chapter 5, Section 6.3.

European Union law: Since the Treaty of Rome of 1957, there has been a procedure for national courts to refer questions of $\mathrm{EU}$ law by way of the preliminary reference to the CJEU. Article (now) $267 \mathrm{TFEU}$ provides that any court of a member state may refer a question necessary for the decision in a case to the CJEU, but that courts with final jurisdiction must refer such a case. Initially, the Conseil d'Etat was reluctant to send preliminary references, but this reluctance ended the year after the Nicolo decision ${ }^{88}$ in Fédération nationale du commerce extérieur des produits alimentaires. ${ }^{89}$ More recently, the CJEU criticised the Conseil d'Etat for failing to make a reference. In Commission v France, a number of issues had arisen before the Conseil d'Etat in relation to the taxation of companies with receipts from subsidiaries abroad..$^{\circ}$ The Conseil d'Etat decided that it did not have to apply a recent CJEU decision to the case in hand on the ground that the arrangement between the companies was not the same. The CJEU did not consider that the law was clear and decided the issue in a different way, although it agreed with the Conseil d'Etat on other points of interpretation. The CJEU held that the Conseil d'Etat was obliged to make a reference in such a situation where it was a final court and the point of European law was not clear. ${ }^{91}$

In 2019, the Conseil d'Etat made eleven references to the CJEU and the tribunaux administratifs made one. In turn, the CJEU handed down three decisions on French references in that year, leaving a significant stock of seventeen pending cases. ${ }^{92}$

\footnotetext{
Discussed in Chapter 1, Section 5.

CE Ass. 26 October 1990, no. 69276, Leb. 294.

Case C-416/17, ECLI:EU:C:2018:811.

Ibid., paras. 105-14.

Conseil d'Etat, Rapport public 2019, p. 39.
}

88 
Constitutional law: As noted in Chapter 1, Section 4, since 2010 the Conseil d'Etat has been able to refer a question préalable de constitutionnalité (QPC) to the Conseil constitutionnel. The request that a question be sent to the Conseil constitutionnel is often raised at first instance. In 2019, the tribunaux administratifs received 662 such requests and they decided 572 . But they only referred 25 (4.4 per cent) to the Conseil d'Etat for consideration. The cours administratives d'appel decided 97 such requests and referred 9 (9.3 per cent) to the Conseil d'Etat. The Conseil d'Etat received 123 requests directly (because it has jurisdiction over legislative acts of the administration). Of all the requests received directly or from the lower courts, it referred 44 (28 per cent) to the Conseil constitutionnel. ${ }^{93}$

European Convention: With the entry into force of Protocol 16 of the European Convention on Human Rights in 2018, it has become possible for national courts to make a preliminary reference to the European Court in Strasbourg. The first reference was made by the Conseil d'Etat in 2021. ${ }^{94}$

\subsection{THE HEARING}

The hearing before the decision-making panel of the court (a single judge or several) takes place in public. But because of the written preparation, it is usually shorter than comparable hearings in the common law or even before the Court of Justice of the European Union. It is not uncommon for thirty cases to be scheduled for a morning in front of the tribunal administratif. The purpose of the hearing in ordinary cases is to give a formal presentation of the issues to be decided and to garner any final observations from the parties that are not already in the file (which they have seen). Except in urgent cases where there may be oral questions, there will rarely be surprises. But they do occur. The presence of an unrepresented applicant may be particularly valuable. Given that the initial claim will often not be clearly structured around the legally pertinent issues, the oral hearing may give the judges the chance to ask a few questions and to form a clearer picture of what happened. In one case that one of the authors observed in a tribunal administratif, a schoolgirl complained that she had been asked questions in an oral exam for the baccalaureate which were off the syllabus and sought the quashing of her examination failure. The oral hearing enabled the court to understand more

93 Ibid., pP. 36-7. The number of requests for a QPC before the tribunaux administratifs is a mere 3 per cent of all cases they receive.

94 CE 15 April 2021, Fédération Forestiers privés de France (Fransylva), no. 439036, concerning the conventionality of rules governing the withdrawal of land from compulsory local hunting area plans. 
clearly what had gone on in the viva and enabled the judges to form an impression of the truthfulness of the applicant. In the end, her case was believed.

Since 2011, the hearing of a case begins with the reporter judge reading the summary of issues to the court. The rapporteur public then presents his opinion orally in full. It then falls to the parties (or their lawyers) to make any final comments (see art. R732-1 CJA). Often, they will just refer the court to the written submissions. But they may wish to add comments on the opinion of the rapporteur public. Comments can be oral or can be written in the form of a note en délibéré, a hastily written comment which the judges can read at the beginning of their deliberations. In major cases, the arguments may be longer. In many cases, particularly on appeal to the cour administrative d'appel or to the Conseil d'Etat, the parties may not attend and may not decide to send a legal representative. After all, why go to the expense of travelling to a regional centre or to Paris when you have little, if anything, to add? If no parties are present, the case is postponed to the next hearing date.

The judgment panel is drawn from within the court. Particularly in the cour administrative d'appel or the Conseil d'Etat, the court may sit in different formations, depending on the difficulty of the case. A straightforward case may well be heard by a single chamber consisting of at least three judges. A more complex case or one where there is going to be a departure from established case law will often be heard by two or more chambers sitting together and involving at least two members of each chamber, an external member of the court and, as president, one of the assistant presidents of the Section du contentieux - at least five judges. A more plenary formation of a court can involve more judges. In the Conseil d'Etat, there are two plenary formations. The Section du Contentieux will have fifteen judges consisting of all the presidents of the chambers together with the President of the Section du Contentieux and his three assistant presidents, and the reporter judge (art. R122-18 CJA). The Assemblée du contentieux is reserved for the most difficult cases of principle. In this case, the presidents of each section of the Conseil will sit, together with the three assistant presidents and the four most senior presidents of chamber in the Section du Contentieux, the president of the chamber in which the instruction took place and which is proposing a draft judgment, and the reporter judge. It is then presided over by the Vice President of the Conseil - a total of seventeen judges (art. R122-20 CJA). The decision to refer a case to the Section or the Assemblée is taken by the President of the Section du contentieux depending on the importance of the case, the necessity to ensure harmony between chambers and the likelihood to overrule an established case law. He is assisted by the three assistant presidents, 
and this informal committee created in 1959 is internally called the 'Troïka' in spite of their number (four), so named at a time when the assistant presidents were only two. There is thus a hierarchy of decision-making panels, and this has an impact on the authority of the decision as a precedent. Decisions handed down by the Section or the Assemblée du contentieux have very great authority, even if they are not formally binding on lower courts.

\subsection{THE DELIBERATION}

The deliberations of the court take place in private and all present have to respect the secrecy of deliberations. In the Conseil d'Etat, its members, including the rapporteur public, have a right to attend the deliberation in order to learn how decisions are taken. They are spectators, but it is often a useful learning experience, especially for the auditeurs who are in formation. Exceptionally external members are invited, such as professors of law, and they may be invited to give their opinion on the case at this stage too.

It is often suggested that common law and French judges reason differently. That might appear to be true if you simply look at the style of the justifications produced for decisions. But, as one of us has written, actually you can find all the forms of reasoning used by common law judges in the debates between French administrative judges as they come to their decisions. ${ }^{95}$ For example, they may not cite previous decisions in their formal judgment with the exception of the 2014 Dieudonné case ${ }^{96}$ ), but the dossier prepared by the reporter judge will be full of copies of previous decisions and the rapporteur public will make extensive use of such cases in his opinion. As one of the authors wrote elsewhere, ${ }^{97}$

The practice of drafting judgments shows a special respect for precedent. The French style of judgments is very precise in its formulations. Rapporteurs are told to reproduce a precedent word for word unless they intend to depart from it. There is no question of following the common law judicial habit of paraphrasing a precedent but meaning the same thing. If an expression different from the precedent is used, this indicates a change in the case-law. sans frontières (Birmingham: Birmingham Faculty of Law, 1991), p. 211. 
Similar remarks can be made about the use of policy arguments and consequentialist reasoning. Examples can be found in the preparatory materials made by the reporter judge and the rapporteur public or in the oral debates, but they do not find their way into the judgment.

At the end of the deliberation, the reporter judge drafts the final version of the judgment which reflects the decision taken and this is signed off by the president of the court before it is published and sent to the parties and to the relevant ministry or public authority. A minute of the deliberation is also kept for the internal files of the court. It is possible for members of the court to consult these minutes at a later date in order to understand the decision more clearly.

The style of French judgments has long been a subject of comment and puzzlement by both common law and French lawyers. The canonist form of writing the text as a single sentence with each main idea being expressed in the form of a recital beginning 'Considering that ...' has long bemused French litigants and foreign observers alike, although the style of the Cour de cassation (starting each paragraph with 'attendu que') appeared to be even more obscure for non-lawyers. It was with relief that the working group headed by Bernard Stirn, the President of the Section du contentieux, steered through a reform which led to a major change in the style adopted by the administrative courts from 1 January 2019. Gone is the 'Considérant que ...' formula and also writing the judgment as a single sentence..$^{98}$

The Vade-mecum produced by the Stirn working group in 2018 now provides detailed guidance on the drafting of administrative court judgments. ${ }^{99}$ The booklet advises those drafting a judgment that it should be 'readable, intelligible, and convincing' for the parties. ${ }^{100}$ It also notes that there are other audiences for a judgment: citizens and journalists, those interested in the development of legal doctrine, as well as the judges involved in earlier stages of the case.

\subsection{ENFORCEMENT}

The judgment is sent to the parties and their representatives. The judgment has an executory formula which orders the ministry or other relevant public authority (and huissiers if measures are to be taken against private persons) to ensure the enforcement of the decision (art. R751-1 CJA).

$9^{8}$ See Vade-mecum, note 99, and C. de Montecler, 'Adieu considérant', AJDA 2018, 2420.

99 Conseil d'Etat, Vade-mecum sur la rédaction des décisions de la juridiction administrative (Paris, 2018), accessible on the Conseil d'Etat website.

100 Ibid., p. 4. 
In the case of orders against the administration to pay money, the judgment itself constitutes authority to pay (an ordonnancement) (art. L911-9 CJA). As long as the judgment is final and specifies the exact sum to be paid, then the claimant who has not been paid within two months of the decision by the state can take the judgment to the accounting officer of the relevant public authority and request payment. If the public body in question is a local authority or other non-state body, the claimant addresses herself to the prefect or the supervisory body for that authority. That supervisory authority has power to substitute their decision for the authority in question and to use its resources to pay the judgment. Thus, a prefect in Corsica claimed he had no power to sell property of the commune of Santa Maria Poggio in order to satisfy a judgment debt resulting from a decision of the tribunal administratif of Bastia in favour of the claimant. He committed an error of law and his refusal was quashed by the Conseil d'Etat. ${ }^{101}$

When a decision requires the administration to act or refrain from acting, the court may issue an injunction (injonction) to act which, as a matter of principle, must be requested by the claimant. For example, in the Church Gatherings case discussed in Section 4.3, the Prime Minister was required to produce a new set of regulations within a week which dealt with the question of religious organisations holding services and other activities in their buildings. As in England, there was a long reluctance to allow the courts to issue injunctions against the administration. But this was permitted by legislation in 1995 (now enshrined in arts. L911-1 and L911-2 CJA) and it has become commonplace. Interestingly, such a power injunction did exist in until the Law of 24 May 1872 when the justice retenue was abandoned. A former President of the Section du Contentieux explained that, within the system of the justice déléguée, since judgment did not have the signature of an executive body anymore, the courts refrained from issuing injunctions since they did not have a means to enforce them. As Rivero famously wrote, "le juge ne saurait brandir la hache de guerre contre l'autorité qui la porte à la ceinture'. ${ }^{102}$ But things have evolved due to two pieces of legislation enacted at the end of the twentieth century.

Since 1980, the Conseil d'Etat has been able to attach a monetary penalty, an astreinte, to any order for the enforcement of a judgment (art. L911-4 CJA) after the inexecution of a judgment is established. The Law of 8 February 1995 gave similar powers to lower administrative courts and also gave the possibility

101 CE Sect. 18 November 2005, Société fermière de Campoloro, no. 271898.

102 J. Rivero, 'Le Huron au Palais-Royal ou réflexions naïves sur le recours pour excès de pouvoir', D. 1962 , chr. 37 . 
to give injunction at the time of the ruling (and not only once the inexecution is established) and eventually astreintes if the injunction does not come into effect, which is quite rarely the case since the injunctions (the function of which is also to enlighten parties about the consequences of a court decision) are generally respected. Regarding astreintes, they usually take the form of a sum of money for each day on which the judgment is not enforced. At the end of the process, the court then converts this into a final sum of money due, and it determines how much of the money is paid to the parties and how much is paid to the state (arts. L911-6 to L911-8 CJA). The penalty can be substantial. For example, the tribunal administratif of Polynesia quashed the implicit refusal by the local administration to approve an operator of mobile telephony in its territory. It then required the administration to grant it an operator's licence within a month subject to an astreinte of $€_{1}$ million a day for noncompliance. ${ }^{103}$ The number of astreintes ordered for the enforcement of decisions is small. In 2018, the tribunaux administratifs ordered seventy-four astreintes, the cours administratives d'appel ten, and the Conseil d'Etat sixteen. These are out of a total of 3,555 complaints of non-enforcement. ${ }^{104}$ That said, half of these complains concern cases which the administration is appealing against the finding in favour of the complainant and so these are not proper instances of non-enforcement of judgments by the administration. Threequarters of the complaints are resolved at an administrative stage in the courts, and these do not require judgments. ${ }^{105}$ In the end, only fifteen astreintes were liquidated (i.e. confirmed) by the administrative courts in 2018 , which shows ultimately a low level of non-enforcement. ${ }^{106}$

As is illustrated by the Church Gatherings case and the Polynesian mobile telephony case, a court order may specify a time period within which the administration must act to rectify the situation. ${ }^{107}$ In order to protect legal certainty, the Conseil d'Etat in the Church Gatherings case did not annul the existing regulation banning gatherings in churches and religious buildings. It just gave the government time to produce a rule which better reflected the proper balance between the protection of health and the freedom of religious practice. In some cases, the result will be different from the quashed decision, but where there has been a procedural irregularity, it will allow the administration to reach the same result by a proper process. This technique of

103 TA French Polynesia, 12 June 2018, SAS ViTi, no. 1700414, Conseil d'Etat Rapport d'activité 2019, p. 141.

104 Ibid., pp. 178-9, 180-1.

105 Ibid., p. 179 .

106 Ibid.

107 See notes 54 and 95, respectively. 
adjusting the effects of a decision in time can meet concerns of legal certainty. This is easiest in the plein contentieux, where the decision examines the legal situation of the parties at the day of judgment. In the case of the recours en annulation, the court examines the issue of legality at the date of the administrative decision and so any annulment should have retrospective effect. But this might upset the interests of third parties as well as of the administration.

In the Association AC!, administrative rules implementing a collective agreement relating to employment law had been taken having consulted a committee some of whose members had not been properly appointed. ${ }^{108}$ As a result, the new rules were invalid, but were being implemented by the administration. The Conseil d'Etat quashed the invalid rules, but only gave the annulment prospective effect, as is done sometimes by the CJEU but without a text as a legal basis. As it said, the court had to exercise a balancing judgment:

Considering that the annulment of an administrative act implies in principle that this act is deemed never to have been made; that, however, if it appears that this retroactive effect of the annulment is such as to cause manifestly excessive consequences both in relation to the effects it could produce and to the situations which could have arisen whilst it was in force so that the public interest might lie in the temporary maintenance of its effects, it is proper for the administrative judge ... to take into account on the one hand the consequences of the retrospective nullity for the various public or private interests in the case and, on the other hand, the disadvantages which would arise from a limitation of the temporal effects of the nullity with regard to the rule of law and the right of litigants to an effective remedy.

In this case, it was declared that some rules should only be annulled prospectively. But, even if other rules were to be annulled retrospectively, this should not affect the validity of payments already made by the administration to individuals in application of the invalid rules.

A similar protection of the situation of individuals from the effects of a nullity operating retrospectively applies in areas like civil service appointments and promotions. If a competition for promotion is annulled for an irregularity, then the civil servants who have been assigned already to new posts do not automatically lose their new jobs.

Very occasionally, the administration may ask a court to clarify its judgment. This enables the administration to determine what it has to do in order to comply with the judgment. It is not a different route to contest the outcome.

108 CE Ass. 11 May 2005, Association AC! and others, no. 255886, Leb. 917 concl. Devys; RFDA 2004,438 . 
One suspects that most such problems are resolved informally. But in 2018, fourteen such decisions were rendered - two by the Conseil d'Etat, one by the cours administratives d'appel and eleven by the tribunaux administratifs. ${ }^{109}$

\subsection{CONCLUSION}

The procedure of French administrative courts is a distinctive approach to doing justice to the parties, particularly to the citizen who wishes to complain about an administrative decision. The written procedure in particular is a distinctive mode of dealing with a case. It has advantages in focusing any oral hearing on precise issues, and making it less expensive for litigants at a distance to obtain justice. But, as has been seen, this process may result in considerable delay. France is not alone in having a mainly written procedure. Indeed, the common law procedures are becoming more similar in their requirements of written submissions. All the same, the common law procedures are more oral. Most systems now have interim decision procedures which are more oral, simply as a matter of practicality. Particularly in controversial policy areas, there is pressure to use the interim procedure to achieve results which would matter far less if they waited for a full hearing - for example, the decisions on restrictions of public liberties during the Covid-19 epidemic. ${ }^{110}$ As has been seen, the rules of procedure have developed in the light of the European Convention on Human Rights and in the light of changes in technology. Social expectations have also changed with greater demands for transparency and accountability. The process of change has been one of organic development rather than radical change.

109 See Conseil d'Etat, Rapport d'activité 2019, pp. 181-2.

110 Compare the Church Gathering decision (note 54) with Rev. Dr J.U. Philip and others [2021] $\mathrm{CSOH}_{32}$ (Lord Braid). 


\section{The Distinction between Public Law and Private Law}

The separation of administrative courts from the ordinary civil and criminal courts is a constitutional principle in France. In the Competition Law decision of 1987 , the Conseil constitutionnel ruled: ${ }^{1}$

Considering that the provisions of articles 10 and 13 of the Law of 16 and 24 August 1790 and of the decree of 16 Fructidor Year III, which laid down in general terms the principle of the separation of administrative and ordinary judicial authorities, do not, in themselves, have constitutional value; as, nevertheless, consistent with the French conception of powers, there figure among the 'fundamental principles recognised by the laws of the Republic' one by which, except for matters reserved by their nature to the ordinary courts, there belong to the administrative courts in final instance the nullity or rectification of decisions taken in the exercise of the prerogatives of public power by authorities exercising executive power, their agents, local authorities or, public bodies placed under their authority or control.

France is unusual in considering that the separation of administrative and ordinary courts is a constitutional requirement, rather than just a matter of tradition or administrative convenience. In other European countries such as Germany and Italy, separate administrative courts are staffed by members of a common judiciary. ${ }^{2}$ In Spain, England and Wales and Scotland, the

1 CC decision no. 86-224 DC of 23 January 1987, Competition Law, Rec. 8, para. 15. The reason the Conseil constitutionnel had to reject the key texts it mentions as a basis for its decision was that the first was a law of a monarchy and the second was a mere decree, as was the decree of 31 July 1945, which then set out the current rules on the Conseil d'Etat. Implicitly, the decision relied on the Law of 24 May 1872 on which its decision on the independence of administrative judges had already relied: CC decision no. 80-119 DC of 22 July 1980, Validation of Administrative Decisions, Rec. 46.

2 J. Bell, Judiciaries in Europe (Cambridge: Cambridge University Press, 2005), chapter 3, sections 2 and 3 . 
administrative courts are merely a division of the common court system. ${ }^{3}$ To have distinct administrative courts with their own distinct judiciary is unusual in Europe. France is unique in having this distinctiveness entrenched as a constitutional requirement.

The French position is a clear example of path dependency. The requirement that the ordinary courts should not seek to review administrative decisions was already laid down by the edict of St Germain-en-Laye of February 1641, which prohibited the Parlements from being concerned with litigation "concerning the State, administration or government which we reserve to ourselves alone and to our successor kings'. This arose out of conflicts in the recently unified French state between the king and the aristocrats who were the judges in the Parlements. A similar wariness of those ordinary court judges was reflected in the early legislation of the Revolution. The Law of 16 and 24 August 1790 provided that the judicial functions are distinct and shall always remain distinct from administrative functions; judges may not, on pain of forfeiture of office, interfere in any manner whatsoever with the activities of administrative bodies nor summon before them administrators for reasons of their office' (art. 13). ${ }^{4}$

This antagonism between the ordinary judiciary and the administration no longer provides a justification for the separation of ordinary and administrative courts. So French jurists of the past 150 years have sought to rationalise and justify the continued distinction. The declaration by the Conseil constitutionnel in 1987 illustrates that process of reinterpretation. Although many authors have tried to propose one, it will be seen in Section 5 that there is no single criterion by which the distinction is made adequately. The declaration of the Conseil constitutionnel offers three dimensions which can usefully serve as a framework for our consideration of the question: (1) the subject matter of any decision before the court ('the nullity or rectification of decisions') discussed in Sections 1 and 2; (2) the body that took those decisions ('authorities exercising executive power, their agents, local authorities or, public bodies placed under their authority or control') discussed in Section 4; and (3) the nature of the administrative decision challenged before the court ('decisions taken in the exercise of the prerogatives of public power') discussed in Section 5. The Conseil constitutionnel decision did not need to mention that actions of the administration which constitute a flagrant illegality (the so-called voie de fait) fall within the jurisdiction of the ordinary courts. This will be discussed in

3 Ibid., chapter 4, section 3 .

4 For a useful short summary of the history, see M. Guyomar and B. Seiller, Contentieux administratif, 5th ed. (Paris: Dalloz, 2019), nos. 13-28. 
Section 3. Apart from this competence set out by the Conseil constitutionnel in order to safeguard a minimum jurisdiction to administrative courts from encroachment by the legislator, it is for the ordinary courts and their supreme courts (Conseil d'Etat, Cour de cassation and where conflicts arise, the Tribunal des Conflits) to interpret the legislative principle of the separation of administrative and ordinary judicial authorities and decide on the criteria which illustrate it. Each area of administrative has its own criteria (administrative contracts, unilateral administrative act, public works, public agent, domaine public etc.) laid down by the case law, but there is often either simply a reference of prerogative of public power (prérogatives de puissance publique) or of public service (service public) or to both. Indeed, the question of which criterion should prevail opposed at the beginning of the twentieth century two deans who were also professors of public law (and their followers): the dean of Toulouse Maurice Hauriou, who claimed the jurisdiction of administrative courts should be limited to the use of prerogative of public powers, whereas the dean of Bordeaux Léon Duguit took the view that it should extend to any public service mission - that is, every time the administration acted in the general interest. Although the case law did not decide in favour of one or another theory, this distinction remains a landmark in the case law when constitutional competence is not at stake.

\subsection{THE SUBJECT MATTER OF LITIGATION AT THE CONSTITUTIONAL LEVEL}

The Conseil constitutionnel decision focuses on the issue of the legality of administrative decisions as the core of the distinctive competence of the administrative courts at the constitutional level. This, indeed, was the most obvious way in which the ordinary courts could interfere with the administration. But, as Laferrière noted in 1887 , actions for damages against the administration could impose burdens on the public treasury and thereby impede the work of the administration. ${ }^{5}$ So it is necessary to consider not only judicial review, but also actions relating to contracts, compensation and property.

\subsubsection{Illegality}

The legality of administrative decisions involves the analysis of whether there is a legal source of authority for the decision, and whether the bounds of the

5 E. Laferrière, Traité de la juridiction administrative et des recours contentieux, 1st ed. (Paris: Berger-Levrault, 1887), p. 13. 
legal authority have been respected. It is here that an understanding of both the body of law relating to the administration and the way the administration works is valuable in coming to a ruling on whether the administration has acted lawfully.

The issue of the legality of an administrative decision arises most straightforwardly when the claimant seeks to annul an administrative decision affecting her. The procedures for bringing such an action are only found in the Code de Justice Administrative (CJA), and they can only be brought in the administrative courts. Indeed, in Entry and Residence of Foreigners in 1989, the Conseil constitutionnel went so far as to strike down a law which transferred competence over the administrative expulsion of foreigners to the ordinary courts. ${ }^{6}$

\subsubsection{Exceptions to the Separation of Administrative and Ordinary Judicial Authorities}

There are a number of exceptions to the principle that it is for the administrative courts to rule on the legality of administrative decisions. The Conseil constitutionnel decision of 1987 refers to 'matters reserved by their nature to the ordinary courts' and, in addition, the decision permitted legislation to make exceptions 'in the interests of the good administration of justice'.?

\subsubsection{The Defence of Illegality before the Civil Courts}

The legality of an administrative decision may arise not as the ground of action, but as a defence. At this point, the court hearing the case has to determine whether it is competent to adjudicate on the matter, or whether this particular issue needs to be referred for decision by the administrative courts. The principle was laid down by the Tribunal des Conflits in Septfonds. ${ }^{8}$ In this case, a merchant sent forty-three bags of sugar by train, and they were lost. The merchant sued the (private) railway company before the commercial courts for breach of contract. A ministerial order made under war powers set a short time limit for bringing such claims. The prefect objected that the court was not competent to interpret this order. The Tribunal des Conflits held that the order was an administrative decision which was legislative in character, since it applied to all rail freight contracts.

6 CC decision no. 89-261 DC of 28 July 1989, RFDA 1989, 691 note Genevois.

CC decision no. 86-224 DC of 23 January 1987, Rec. 8, para. 16.

TC 16 June 1923, Septfonds, no. 00732, S. 1923.3.49 note Hauriou. 
The legality of the order could be decided only by the administrative courts. But the ordinary courts were competent to interpret its meaning when applying the legislation in question when there was a contested issue of interpretation during the course of litigation properly brought before them. Interpretation is part of the process of application, rather than challenging the validity of the order. But since the Septfonds case, the Tribunal des Conflits introduced four exceptions to the duty of civil courts to send a preliminary question to administrative courts: when they have to assess the legality of an administrative regulation which constitutes a voie de fait ${ }^{9}$ and when tax law is at stake. ${ }^{10}$ Two other exceptions can be claimed as a consequence of the good administration of justice (see Section 2.4).

Two possible solutions could be applied to this situation. The first is to apply the maxim 'the judge of the action is the judge of the defence' (le juge de l'action est juge de l'exception). This would breach the principle of the separation of courts, but would be efficient from the point of view of litigants. Alternatively, the civil court seised of the case would have to suspend proceedings in order to send a preliminary question (question préjudicielle) to the administrative court for a ruling. Both of these alternative solutions are reflected in art. 49 of the Code of Civil Procedure, which provides that the civil courts are competent to decide all issues raised by way of defence except those which belong to the exclusive jurisdiction of another court - for example, the administrative courts. Where a serious question is raised falling within the jurisdiction of the administrative courts, the civil court must submit the question to the relevant administrative court. But the administrative court is restricted to answering the preliminary question put to it by the civil court. An example is where a purchaser of land sought to have the contract annulled when she discovered that the local mayor claimed one of the property's walls was public property. The cour d'appel submitted to the tribunal administratif the question of whether the wall separating the property from the road was public property. The Conseil d'Etat ruled that it was public property. ${ }^{11}$ But it also ruled that the lower tribunal administratif to which the case was originally referred was wrong to answer a separate question - namely, whether the repair of the wall was a public work for which the mayor could claim a contribution from the landowner. Similarly, art. R771-2 CJA provides that where litigation in an administrative court raises a serious question lying within the

9 TC 20 October 1947, Barinstein, Leb. 511.

${ }_{10} \quad \mathrm{TC}_{7}$ December 1998, District urbain de l'agglomération rennaise c Société des automobiles Citroën, no. 03123, D. 1999, 179, concl. Sainte-Rose.

11 CE 23 January 2012, no. 334360. 
jurisdiction of the ordinary courts, the court should suspend proceedings and refer the relevant question for a ruling by the civil court.

\subsubsection{Criminal Proceedings}

The need for justice to be speedy is important when criminal penalties are at stake. Criminal courts may always determine the legality of administrative decisions. The principle was affirmed in Avranches et Desmarets: ${ }^{12}$

It follows from the nature of the mission assigned to the criminal court that it has, in principle, full competence over all issues on which the imposition or non-imposition of penalties depends; as it may, for this purpose, not only interpret ... administrative regulations, but also assess their legality when they serve as the basis for a prosecution or are invoked as a ground of defence.

In this case, the son and son-in-law of a tenant were prosecuted for poaching on neighbouring land. Their defence was that a standard clause in the tenant's lease inserted by order approved by the prefect of the département permitted such hunting. The criminal court declared the clause illegal as, in its view, the parent legislation only allowed such a clause to permit hunting on the land leased, but not more widely. The prefect raised the objection that the legality of an administrative rule should be decided by the administrative courts, but the Tribunal des Conflits rejected this objection and upheld the right of the criminal court to decide the matter. However, the Avranches et Desmarets case implicitly made an exception to the competence of criminal courts for the assessment of legality of individual administrative decisions.

The principal solution the Tribunal des Conflits adopted is now contained in art. 111-5 of the Penal Code of 1992, which no longer provides for any exception:

Criminal courts have competence to interpret administrative decisions, whether regulatory or individual, and to determine their legality when the outcome of the criminal case submitted to them depends on such a determination.

This entails that the criminal court is bound to rule on any defence. Thus, the cour d'appel of Pau was wrong to deny its competence to consider a defence which alleged that the decree under which a company was prosecuted was unconstitutional. ${ }^{13}$ In the case, the company sold foie gras containing

12 TC 5 July 1951, no. 01187 , S. 1952.3.1 note Auby.

13 Crim. 29 January 2019, no. 17-84366, D. $2019,257$. 
reconstituted by-products of the deveining process. The defendants alleged that the decree breached the principle of equality before the law in requiring national products to meet standards different from those that were lawful in other Member States of the European Union (EU). Because this affected whether their actions were unlawful, the criminal court was bound to determine the matter. Article 111-5 of the Penal Code also empowers the criminal judge to rule on the legality of searches authorised during a criminal investigation. ${ }^{14}$

\subsubsection{Protection of Civil Liberties and Private Property}

Article 66 of the Constitution provides that the ordinary judge is 'guardian of individual liberty'. In particular, that article focuses on preventing arbitrary detention, but this traditional competence also covers personal status and interference with property. As the Tribunal des Conflits put it, there is a general principle that the protection of individual liberty and the protection of private property belong essentially to the attributes of the ordinary courts. ${ }^{15}$

The issues related to personal status cover civil status (name, paternity, marriage), legal capacity and nationality, as well as qualification as an elector. There are some exceptions, most notably the change of name which, under arts. 60 to $61-4$ of the Civil Code is determined by the Conseil d'Etat in its administrative capacity. Decrees of naturalisation are also within the domain of the administrative courts.

The scope of 'the protection of individual liberty' has been the subject of substantial litigation before the Conseil constitutionnel. ${ }^{16}$ The core is the role of the criminal judge controlling the detention of individuals before trial and imprisoning them after conviction. In this work, the judge (often the procureur or the juge d'instruction) is assisted by the judicial police (police judiciaire). Article 136 of the Code of Criminal Procedure provides that in all cases of an interference with individual freedom, the administrative authorities may never raise a conflict and the ordinary courts always have exclusive competence'. But the Tribunal des Conflits has held that this does not give competence to the ordinary courts to rule on the legality of the decision on the basis of which the administration is interfering with an individual's liberty. ${ }^{17}$ It held

14 Crim. 13 December 2016, no. 16-84794, D. 2017, 275 note Pradel.

15 TC 18 December 1947, Hilaire, no. o0976, D. 1948, 62.

16 For a survey, see G. Eveillard, 'Les matières réservées par nature à l'autorité judiciaire', AJDA 2017, 101, esp. pp. 106-11.

17 TC 12 May 1997, Préfet de police de Paris c Tribunal de grande instance de Paris, no. 03056, RFDA 1997, 514 concl. Arrighi de Casanova. 
in that case that the ordinary court could not consider the legality of the order made by the prefect in relation to Moroccan migrants neither to enter French territory nor to leave the ship on which they had arrived in France.

On the one hand, the Conseil constitutionnel has held that a number of restrictions on the individual do not constitute infringements of individual liberty within the meaning of art. 66 of the Constitution. Administrative decisions authorising tax or customs searches, ${ }^{18}$ restricting a person to their residence ${ }^{19}$ or stopping and searching vehicles ${ }^{20}$ are not considered within its scope, nor are detention of seriously mentally ill people ${ }^{21}$ and holding illegal migrants in waiting areas. Indeed, in Entry and Residence of Foreigners in 1989, the Conseil constitutionnel went so far as to strike down a law which transferred competence over this administrative expulsion of foreigners to the ordinary courts. ${ }^{22}$ That decision limits 'liberty of the individual' to detention, criminal penalties and civil status. But where the detention has to be extended because the immigrant could not be expelled immediately, then the ordinary courts have competence to determine the terms under which the person is held. ${ }^{23}$

On the other hand, France has been aware of the requirements of the European Convention on Human Rights to provide adequate protection against detention. ${ }^{24}$ Created by a law of 2000 , the juge des libertés et de la détention has jurisdiction over a wide range of interferences by the state into individual liberty. In such situations, the judge authorises detention, rather than just reviewing the legality of actions by the police or the administration. In this way, the separation of powers is respected, but the role of the ordinary judge as the protector of civil liberties is enhanced. In criminal matters, under art. 137-1 of the Code of Criminal Procedure, the judge deals with preventive detention during the investigation of a criminal offence, as well as authorising searches and telephone or electronic surveillance. Since 2011, the judge has had jurisdiction concerning the detention of the mentally ill (Public Health Code, arts. R3211-10 and following), and of migrants rejected entry into France and detained beyond a short period of forty-eight hours (Code on the Entry and Residence of Foreigners and Asylum, art. L552-1). The judge is also

18

19

20

21

22

23

24 
responsible since 2017 for administrative visits to homes as part of antiterrorism legislation. Effectively, this judge has become a major person responsible for protecting liberty, thereby limiting the role of the administrative courts. Although the role is not to review the legality of administrative decisions, it has a major impact by transferring competence to make decisions away from the administration and giving it to a civil judge.

In relation to interference with property rights, the Conseil constitutionnel has recognised a general principle of law that competence in such matters lies with the ordinary judges. In TGV Nord, a law allowed the administration to expedite the expropriation process for the construction of a TGV line by taking possession of the property by a decree after a favourable opinion of the Conseil d'Etat. ${ }^{25}$ The normal procedure for an expropriation order had then to be begun before the civil judge within a month for fixing the amount of compensation. The Conseil did not disapprove of this but set out a new principle:

as, thus, in any case, the importance of the functions conferred on the judicial authority in relation to immovable property by the fundamental principles recognised by the laws of the Republic is not disregarded.

Commentators have some difficulty in discerning which laws of the Republic are referred to, but it seems clear from this that the traditional functions of the judiciary in expropriation of immovable property are to be treated as of constitutional value. The competence of an ordinary judge to order the transfer of property and to determine the compensation for expropriation had been settled since a Law of 8 March 1810 (a Law of an Empire). Numerous laws since then have given the determination of compensation for decisions on matters such as requisitioning private property. In the case of administrative servitudes over private property, some laws have given jurisdiction to the ordinary judges, but in the Eiffel Tower Amendment decision, the Conseil had held further that 'no principle of constitutional value requires, in the absence of dispossession, that compensation for harm caused lies within the jurisdiction of the civil judge'. ${ }^{26}$ In that case, the Law permitted Télédiffusion de France to install and use equipment for transmitting radio and television programmes on roofs, terraces, and the superstructure of buildings. The building principally envisaged was the Eiffel Tower, owned by the City of Paris. The installation had to be approved by the president of a tribunal de grande instance. The Conseil took the view that creating an administrative

25 CC decision no. 89-256 DC of 25 July 1989, TGV Nord, RFDA 1989, 1009 note Bon. Local farmers were selling off their land in very small units in order to make the expropriation process more difficult.

26 CC decision no. 85-198 DC of 13 December 1985, D. 1986, 345 note Luchaire. 
easement of this kind did not amount to the deprival of a property right. The conclusion would have been different, it continued, if the effect of the easement had been to empty the property right of all content or had affected persons occupying the property.

\subsubsection{The Good Administration of Justice}

The good administration of justice is a recognised constitutional objective. ${ }^{27}$ In addition, as seen earlier, general principles of law establish that a litigant has a right to a decision within a reasonable time, a principle influenced by the European Convention on Human Rights. ${ }^{28}$ The Tribunal des Conflits has used these values to add flexibility to the allocation of competences set out in Septfonds. In joined cases INAPORC and CNIEL, it decided that a civil court need not transmit a preliminary question where it appears clearly, on the basis of established case law, that the matter can be resolved by the civil court. ${ }^{29}$ This is a French version of the acte clair doctrine in EU law. ${ }^{30}$ The Tribunal des Conflits also held in that case that, in order to ensure an effective remedy as required by EU law, the civil court could refer a preliminary question to the Court of Justice of the European Union (CJEU) without first referring the case to the administrative courts. In this case, the question at issue was the validity of compulsory contributions to inter-professional associations in the light of EU rules on state aid. This more flexible approach was picked up by the Conseil d'Etat in Fédération Sud Santé Sociaux and represents a focus on the value of expertise in other courts being used when needed, rather than a more doctrinaire distinction between public and private law. ${ }^{31}$ In that case, it ruled that, where the good administration of justice and, in particular, the right of litigants to a judicial decision within a reasonable time so require, the court initially seised of the case may rule on all the matters involved in the case. In that specific case, the private law issue was a novel and complex matter concerning collective agreements and so the issue was referred to the private law courts for an opinion. Overall, it would appear that courts on either side of the divide may be willing to rule on relatively settled issues of law from the

27 CC decision no. 2006-545 DC of 28 December 2006, Rec. 138.

28 See Chapter 4, Section 1.4.

29 TC ${ }_{17}$ October 2011, SCEA de Chéneau v Interprofessional nationale porcine (INAPORC) and Centre national interprofessionnel de l'économie laitière (CNIEL), no $\mathrm{C}_{3} 828$, RFDA 2012,122 concl. Sarcelet, note Seiller.

30 The phrase used by the Tribunal des Conflits - 'well established case law' - is the same as that of Protocol 14 to the European Convention on Human Rights, which came into force in the previous year and justified remitting cases to smaller panels of judges.

31 CE 23 March 2012, Fédération Sud Santé Sociaux, no. 331805, Leb. 102. 
other branch of the law in order to ensure a speedy resolution of a dispute on which the court is otherwise competent. But references will be made on complex issues, as will be explained further in Section 7.3.

\subsubsection{Legislative Exceptions}

The Conseil constitutionnel in 1987 made clear that

Where the application of specific legislation or regulation could give rise to a variety of litigation which would be distributed according to the normal rules on competence between the administrative courts and the ordinary courts, it is lawful for the legislator, in the interests of the good administration of justice to unify the rules of judicial competence within the judicial body principally affected. ${ }^{32}$

Thus, in that case, on the application of the normal rules on competence, litigation on competition could arise before administrative courts, criminal courts and commercial courts. So it was permissible for the legislator to bring all the competition litigation into the ordinary courts and give the Cour de cassation the role of ensuring a unified interpretation of the legal rules.

This approach has been followed in relation to other economic legislation. So the cour d'appel of Paris, acting exceptionally as a court of first instance, has been given jurisdiction to examine the decisions of the Financial Markets Authority (the Autorité des marchés financiers), the authority regulating electronic communications and La Poste, and the commission regulating energy. ${ }^{33}$

\subsection{OTHER CATEGORIES OF LITIGATION}

Apart from questions of legality dealt with by the constitutional principle, the administrative courts have jurisdiction over other types of litigation concerning the administration, especially contracts and commercial activities, public property and the liability of public bodies. But this jurisdiction is concerned with the interpretation of the principle of the separation of administrative and ordinary judicial authorities, not with the fundamental principle recognised by the laws of the Republic quoted earlier in this chapter and discovered in 1987 by the Conseil constitutionnel.

32 CC no. 86-224 DC, note 1, para. 16.

33 See M. Lombard, G. Dumont and J. Sirinelli, Contentieux administratif, 13th ed. (Paris: Dalloz, 2019), no. 663 . 


\subsubsection{Contracts and Commercial Activities}

As will be seen in Chapter 9, there is a substantial body of law relating to administrative contracts which fall within the jurisdiction of the administrative courts. Unlike classic administrative decisions, contracts made by the administration do not impose obligations on another, but are the result of agreement in which the other party may be in a stronger bargaining position. The Proposal for a Regulation on a Common European Sales law did not differentiate between public and private contracts, except to exclude contracts in the exercise of public authority (such as rights of pre-emption under legislative authority). ${ }^{34}$ French law, on the other hand, adheres to its differentiation between public contract law governed by public law rules and adjudicated by the administrative courts and private contract law governed by private law and adjudicated by the ordinary courts. It therefore becomes important that contracting parties know which is the relevant governing law.

In very broad terms, a French administration can enter into both administrative contracts (contrats administratifs) and private law contracts (contrats de droit privé). The two traditional criteria for identifying the former are that the administrative contract relates to a public service and that it reserves exceptional powers to the administration (it contains clauses exorbitantes du droit commun). Either criterion may suffice to make a contract 'administrative' in character, but the involvement of the contract in the provision of a public service is the primary criterion. The classic example is Terrier, discussed in Section 5, in which an advert made to the public offering a reward for catching vipers was held to be a public contract. ${ }^{35}$ A further example would be that a contract with a constructor to build a school is a public contract because it is a way of providing a public service or education. But a contract with a dairy to provide milk for the school canteen would be private, since it is merely about supplies, rather than the actual provision of the public service. Despite their apparent simplicity, these criteria give rise to a complex case law which will be explained more fully in Chapter 9 .

\subsubsection{Property}

Just as public bodies may make either public or private contracts, depending on the issue in question, so public bodies (like the Queen in England) may have a public and a private domain. Article L2111-1 of the General Code on the

\footnotetext{
$\mathrm{COM} / 2011 / 0635$ final.

35 CE 6 February 1903, Terrier, no. 07496, Leb. 94, D. 1904.3.65 concl. Romieu.
} 
Property of Public Persons provides that property belonging to a public person (as listed in art. Li of the Code) is public domain if it is dedicated to use by the public or in a public service, provided it has been adapted in a way indispensable to performing the public service. An example of the former is a public park. An example of the latter might be a garage specially designed for public service buses. Movable property may be included - for example, art or archaeological objects. Special rules govern the disposal of public property and the administrative courts have jurisdiction to determine disputes on such matters.

Since the Law of 28 pluviôse An VIII, special rules govern public works such as canals or roads. As has been seen, the status of something as a public work is a matter for the administrative courts. ${ }^{36}$ Interferences with public works are also a disciplinary matter for the administrative courts, imposing fines for such acts (the contentieux de la répression).

\subsubsection{Liability of Public Bodies}

Chapter 8 will explain that there are special rules on the liability of public authorities. These special rules of liability are applied by the administrative courts. The Tribunal des Conflits made the point in Blanco in 1873 that ${ }^{37}$

the liability which may be incurred by the state for the loss caused to individuals by the actions of persons whom it employs in the public service cannot be governed by the principles laid down in the Civil Code to regulate the legal relationships of individuals.

The consequence of separate rules was a separate jurisdiction to administer them. As will be seen in Chapter 8, these rules govern both fault-based and nofault liability. All the same, for the good administration of justice, Parliament has legislated to group litigation on certain matters within the ordinary courts, even when they relate to public law activities.

Among the earliest areas was accidents at work. Compensation for such accidents was introduced in 1898 and it provided that litigation on the matter would belong in the ordinary courts, whether the employer was a public or a private body. This enabled a coherent development of the law relating to a substantial number of physical injuries.

36 CE 23 January 2012, no. 334360 , note 9.

37 TC 8 February 1873 , Blanco no. o0o12, D. 1873.3.17, translated by D. Fairgrieve, State Liability in Tort. A Comparative Law Study (Oxford: Oxford University Press, 2003), p. 288. 
This approach was extended to motor vehicle accidents by the Law of ${ }_{31}$ December 1957. It made little sense for separate rules to govern the victim's injuries depending on whether she was knocked over by the mayor's official car driven on official business or by his personal car driven on a personal errand. The same arrangement has carried over into the compensation arrangements under the no-fault scheme established in 1985 .

Harm arising from nuclear accidents was reserved by the Law of 1968 to the civil courts. The special compensation scheme for acts of terrorism introduced in 1986 gives litigation competence to the civil courts. In 1991, the cour d'appel of Paris was similarly given jurisdiction over litigation against decisions of the compensation commission set up to deal with AIDS-infected blood. This was necessary because blood transfusion might be conducted by public or private institutions.

\subsection{VOIE DE FAIT}

Voie de fait (literally an 'assault' or perhaps better a trespass) identifies a flagrant illegality and is not so much an exception to the rules on the jurisdiction of the administrative courts as the point where the justification of distinct treatment for the administration runs out.

Where the administration interferes seriously and unlawfully with individual freedoms or property, then the individual affected can challenge the legality of the action before the administrative court, especially using the référé-liberté procedure discussed in Chapter 4, Section 3. But where the action is flagrantly illegal, the administration is considered to have departed so far from its functions that its action is considered a mere fact lacking any legal justification at all. The action has lost all its administrative character and does not merit any special treatment, so it falls within the jurisdiction of the ordinary courts, civil or criminal.

A voie de fait involves a physical operation and a flagrant legal defect affecting the freedom of the individual or the extinction of a property right. The requirement of a physical operation involves not just the making of a decision, but also its implementation or the threat of its implementation. That implementation must interfere with the rights of an individual. In its decision in Bergoend, the Tribunal des Conflits held that ${ }^{3^{8}}$

there is no voie de fait on the part of the administration justifying, as an exception to the separation of the administrative and judicial authorities, the

$3^{8}$ TC 17 June 2013, Bergoend c Société ERDF Annecy Léman, no. C3911, RFDA 2013, 1041 note Delvolvé. 
courts of the ordinary judiciary to order it to cease or to be compensated unless either the administration has proceeded to the use of force in unlawful circumstances to implement a decision, though lawful, which interferes with freedom of the individual or leading to the extinction of a property right, or has taken a decision which has the same effects on the freedom of the individual or the extinction of a property right and is flagrantly incapable of being related to a power belonging to an administrative authority.

This restricted voie de fait to the unlawful use of force or to implementing a decision which is not just unlawful, but also is flagrantly not something the administration could claim to do. In that case, the company in charge of the electricity grid erected a pylon in 1983 on the claimant's land without following the requisite procedures to obtain authority to do so. In 2009, the claimant brought an action before the civil courts to order its removal. The action did not extinguish a property right, because it was a mere servitude, and it was not flagrantly something the administrative body could not do, because EDF (by then ERDF) had statutory power to erect pylons on private land.

The decision continued the long-standing case law that identifies two types of flagrant illegality: the unlawful use of force to implement a lawful decision affecting the freedom of the individual or a property right, and the making of a flagrantly unlawful decision to the same effect. But it did restrict the interference with property to where the property right is extinguished, not just where it is interfered with, as previous case law had done. ${ }^{39}$ The Tribunal des Conflits confirmed this in another decision of 2013 , Panizzon. ${ }^{4 \circ}$ In that case, a commune contracted to use adjoining land as part of its sports facility. At the end of the contract term, it did not return the land. The landowners brought an action for the return of the land before the civil courts. Because this was not a total extinction of their title (indeed the commune was trying to buy the land from them), the Tribunal des Conflits held that the civil court was wrong to claim jurisdiction over the matter.

In Bergoend, the Tribunal des Conflits also restricted voie de fait to 'freedom of the individual', not to other rights, and in this it brought this exception into line with the scope of art. 66 of the Constitution discussed in Section 1.2.3. In the past, leading cases of voie de fait had included flagrantly unlawful interference with the freedom of the press $^{41}$ or the withdrawal of a passport from an

39 For example, the unlawful taking possession of an individual's property: TC 24 June 1954, Société Trystram, no. o1434, Leb. 716.

$4^{\circ} \quad$ TC 9 December 2013, Panizzon c Commune de Saint-Palais-sur-Mer, no. C3931, Leb. 376. The Cour de cassation has aligned itself to this position: Cass. 3 civ., 11 March 2015, Société de l'Avenir, no. 13-24133, AJDA 2015, 1301.

${ }^{41} \quad$ TC 8 April 1935, Action française, no. o0822, S. 1935.3.76 concl. Josse. 
individual who owed large sums in taxes and appeared not to be sufficiently solvent to pay them. ${ }^{42}$ Now, the mere retaining of a foreigner's identity papers longer than necessary to check their validity does not constitute a voie de fait, even if it is a restriction on the freedom of movement. ${ }^{43}$ The freedom of the individual is narrowly construed as connected with personal safety and the right not to be arbitrarily detained, and not as including wider freedoms of the person, such as the freedom to marry or the right of privacy.

Since the introduction of the référé procedure in 2000 , the administrative court has had a speedy method for handling complaints against unlawful administrative actions and issuing injunctions to make them stop. Even before these two decisions of the Tribunal des Conflits, the Conseil d'Etat had declared that the administrative court had jurisdiction to declare a voie de fait illegal and to grant a remedy against the administration. ${ }^{44}$ The Tribunal des Conflits in Panizzon specifically referred to this competence of the administrative courts in justifying the restriction of voie de fait and removing the doctrine of emprise from the range of matters which fell within the jurisdiction of the civil courts. Given these changes to the procedures before the administrative courts and the scope of the legal concept of voie de fait, jurisdiction in matters of the flagrant illegality of administrative decisions is likely in practice to lie with the administrative courts.

The distinction between a flagrant and an ordinary illegality was always going to be a fine one. A classic illustration is Carlier..$^{45}$ The claimant was a strong critic of the Administration of Fine Arts for its neglect of France's monuments. When photographing Chartres Cathedral, he was arrested on the order of the prefect and had his photographs confiscated. Soon afterwards, whilst queuing with tourists, he was refused entry to the belfry of the cathedral. The Conseil d'Etat held that his arrest was a flagrant illegality which was incapable of being connected to administrative functions, and so it constituted a voie de fait over which it had no jurisdiction. But the refusal of entry to the belfry was merely an unlawful way of performing the administrative task of giving users access to a public monument, and so that was an ordinary illegality for which the administrative courts were able to award compensation. In those situations where the vestiges of voie de fait remain, such subtle distinctions between degrees of illegality will stay relevant.

42 TC 9 June 1986, Commissaire de la République pour la région d'Alsace, no. 02434, RFDA 1987, 37 concl. M.-A. Latournerie.

43 TC 12 February 2018, Guyue c Agent judiciaire de l'Etat, no. C4110, Leb. 612.

44 CE 12 May 2010, Alberigo, no. 333565, Leb. 694; CE ord. 23 January 2013, Commune de Chirongui, no. 365362 , AJDA 2013, 788 .

45 CE Ass. 18 November 1949, no. 77441, S. 1950.3.49 note Drago. 


\subsection{PUBLIC PERSONS}

Public law can generally be considered to concern public persons. The Conseil constitutionnel decision of 1987 specifically mentions 'authorities exercising executive power, their agents, local authorities, or public bodies placed under their authority or control'. By this are clearly covered ministries and local authorities, as well as their executive agencies. But the category of public bodies is vaguer and there is also the question of whether private bodies are also included when they are running public services.

Organisations such as regulatory agencies are generally public bodies. As mentioned in Chapter 2, Section 4, many regulatory agencies are so-called independent administrative authorities (autorités administratives indépendantes (AAIs)) such as the CNIL. They are clearly governed by public law and challenges to their decisions are brought in the administrative courts. This was established in a very early case, Association syndicale du Canal de Grignac. ${ }^{4}$ Regulations approved by ministers obliged adjoining landowners to join a private association set up to maintain the Grignac Canal and its surroundings. Its creditors had to sue in the administrative courts. Some regulatory agencies are autorités publiques indépendantes (APIs), and they have legal personality. As mentioned in Section 2.5, legislation establishing such bodies regulating the commercial sector often stipulates that litigation against them is brought before civil courts.

Some publicly owned enterprises run public services in a commercial manner. While creation and control of the public service in question is a public law matter, the enterprise running the public service is governed by private law. This applies whether the enterprise in question is purely private in nature (a public limited company) or has the status of a public body, an entreprise public industriel et commercial (EPIC).

In La Bergamote, the Tribunal des Conflits made clear that the ordinary courts had jurisdiction over all matters concerning EPICs, 'except those relating to their activities which, such as regulation, policing and monitoring, belong by their nature to the prerogatives of public power'. ${ }^{47}$ In that case, a bridge over a canal connecting the Marne and the Rhine at Nancy was under the control of an EPIC created by a law, Voies Navigables de France. It collapsed and blocked the river. As a result, a floating restaurant and cruise ship could no longer ply its trade. Its owners sued Voies Navigables de France

$4^{6} \quad$ TC 9 December 1899, no. o0515, S. 1900.3.49 note Hauriou.

47 TC 12 December 2005, EURL Croisières lorraines 'La Bergamote' c Voies Navigables de France, no $\mathrm{C}_{3455}$, Leb. 671. 
for compensation in the administrative courts. Because the maintenance of the bridge was not an exercise of public power, the Tribunal des Conflits upheld the view of the tribunal administratif that it did not have jurisdiction to deal with the claim.

Private bodies may still be governed for part of their activities by public law and thus come within the jurisdiction of the administrative courts. It was clearly established in Aide et Protection in $1938^{48}$ that 'a body charged with the performance of a public service, even if this body has the character of a "private enterprise", can still be governed by public law. That case concerned the caisses (funds) set up under the legislation establishing schemes for compensation for industrial injuries in both public and private employment. These bodies were private. The litigation concerned whether their employees were governed by rules prohibiting the accumulation of pensions and remuneration from different sources. Given that the provision of social insurance was a public service, it was legitimate to include the employees of these caisses in the ban on additional sources of income.

Whether a private body is performing a public service depends on an interpretation of the whole context of its activity. Three criteria are of particular relevance as set out in the Narcy decision: ${ }^{49}$ whether a public service mission has been conferred on the body; whether the body is given the exercise of public power to achieve this mission; and the control exercised over the body by the administration. In relation to the first, the conferral of a public service mission can be express or implied. The Aide et Protection case is a good example of an express legislative mission. But this can be implied from the other two features. Prerogatives of public power could involve the power to impose requirements on those who use a service, or to impose an obligation to belong to an association or to pay a contribution, or to enjoy a monopoly over an activity. In Montpeurt, litigation by a manufacturer against a wartime organisation set up to manage the use of resources in the glass industry was held to be within the jurisdiction of the administrative courts..$^{50}$ The organisation was performing a public service at a time of resource scarcity and challenges to its refusal to give a particular person the quota he desired were a public law matter. Many professional disciplinary bodies also have an ability to control membership and conduct. For example, in Bouguen, the claimant was able to challenge the refusal by the Conseil supérieur de l'ordre des

$4^{8}$ CE Ass. 13 May 1938, Caisse primaire 'Aide et Protection', no. 57302, D. 1939.3 .65 concl. Latournerie, note Pépy.

49 CE Sect. 28 June 1963, Narcy, no. 72002, Leb. 401.

$5 \circ$ CE Ass. 31 July 1942, Montpeurt, no. 71398 , D. 1942, 138 concl. Ségalat. 
medecins, a private body governing the medical profession, to allow him to open a practice before the Conseil d'Etat. ${ }^{51}$ As will be seen, the cases on national professional sporting bodies also show how these perform a public service in regulating their sports and athletes.

Even without a clear legal basis to establish that a private body is performing a mission of public service, its organisation and activities may, taken together, suggest that it is engaged in such a mission, and thus its activities are within the jurisdiction of the administrative courts. In Ville de Melun, a private law association was created by the council to support cultural and leisure facilities in the town..$^{2}$ It received half of its money from the council and the rest from private sources, and it spent most of its money on activities within the town. The mayor was its ex officio president, and several councillors were on its committee. In the light of all these features, it was held to be performing a public service under the control of the council. Therefore, its accounts were public documents and the administrative courts had jurisdiction over litigation concerning them.

Professional bodies are typically private law institutions. They do perform regulatory functions and, in this work, they are considered to be performing a public service. This public service is underpinned by some form of ministerial or legislative authorisation. Under art. 131-8 of the Sporting Code, national sporting bodies are approved by a minister. Their statutes have to contain certain compulsory provisions and a disciplinary code which is consistent with a standard form. As a result, such professional sporting bodies are governed by public law in performing their specially authorised functions. For example, in Peschaud, the suspension of the vice president of the French football association pending a disciplinary inquiry was held to be within the jurisdiction of the administrative courts. ${ }^{53}$ The situation is different if the body is simply 'agrée', but does not hold any legal monopoly to run a given sport, as was the case with the aerobic and stretching federation. In that case, a disciplinary measure was the normal business of the association and the case belonged in the civil courts. ${ }^{54}$

51 CE Ass. 2 April 1943, no. 72210, S. 1944.3.1 concl. Lagrange, note Mestre.

52 CE 20 July 1990, Ville de Melun et Association 'Melun-culture-loisirs' c Vivien, nos. 69867, 72160, AJDA 1990, 320. See also CE Sect. 6 April 2007, Commune d'Aix-en-Provence, no. 284736 , RFDA 2007,812 : the association organising an international music festival was undertaking a mission of public service.

53 TC 7 July 1980, Peschaud c Groupement du Football professionnel, no. o2165, RDP 1981, 483 concl. Galabert.

54 CE 19 December 1988, Pascau, no. 79962. 
An industrial or commercial public service established as a private company, as opposed to an EPIC, may take administrative decisions. This was established in Air France c Barbier. ${ }^{55}$ The case concerned staff regulations under which air hostesses who got married were required to leave the service. Although Air France was a private company, its organisation was subject to ministerial regulation under legislation and its terms of employment were not governed by collective agreements with unions. In those circumstances, the administrative law courts were judged to have jurisdiction to deal with this issue as it relates to the assessment of legality of an administrative regulation of a public service.

\subsection{GENERAL CRITERIA FOR IDENTIFYING PUBLIC LAW MATTERS}

The account just given of the way the jurisdiction of public and private law courts is differentiated involves complex and subtle distinctions. There is no schematic framework, but a large number of specific decisions made by legislators and the courts during the past two hundred years. Authors have tried to make sense of this picture. Many have tried to distil organising principles to provide a sense of direction.

Laferrière sought the organising principle in the idea of 'public power'. In his view, the exercise of public power was administrative by nature and fell within the jurisdiction of the administrative courts. ${ }^{5}$ These were acts of authority and this conception was endorsed by Dean Hauriou, as seen earlier. In addition, their jurisdiction included the administration of public services (actes de gestion) as attributed by legislation. Dean Vedel, who was the reporter judge in the 1987 decision, also found public power (la puissance publique) to be the most useful guiding idea in the allocation of jurisdiction between the public and private law courts. ${ }^{57}$ This idea does find its way into the Conseil constitutionnel decision of 1987. But the administration does not always use its unilateral authority in order to achieve its purposes. The illustrations in the previous sections of this chapter also show the use of contracts, of funding and of influence. The exercise of public power is but one aspect of government and administration.

TC 15 January 1968, Compagnie Air France c Barbier, no. o1908, Leb. 789 concl. Kahn. The specific case law no longer applies because Air France was moved to the private sector in 2004. See Laferrière, Traité de la juridiction administrative, pp. 5-8.

57 See G. Vedel, Droit administratif, 7th ed. (Paris: Presses Universitaires de France, 1981), preface. 
Other writers, notably leading members of the Conseil d'Etat who taught at Sciences-Politiques in Paris Odent and Braibant, ${ }^{58}$ drew on the ideas in the earliest case law, such as Blanco, and considered that the performance of a 'public service' provided a key criterion in line of what Dean Duguit had previously said. ${ }^{59}$ When running a tobacco factory, the state was not exercising power or authority, but it was merely operating what it considered to be a public service. The same can be said for activities of education, health, roads, canals, transport and the many other things the modern state undertakes. The idea of public service captures the basic ethic around which public law activity operates.

The concept of 'public service' is, however, elusive. A public service exists where there is a public need, carried on under the aegis of a public authority. Such a 'public need' arises when it is identified by a public authority. Not all public needs are defined as such under legislation, as is the case of education or health care. A classic example is Terrier. ${ }^{60}$ The conseil départemental decided to rid its area of vermin. It offered a quarter of a franc for every viper killed by members of the public. The campaign was so successful that the fund set aside for these payments was exhausted and the conseil refused to pay the claimants for the vipers they had killed. The claimants brought an action in the local conseil de préfecture, which disclaimed jurisdiction. The Conseil d'Etat, however, found that this was a legitimate action to bring in the administrative courts, even though it was implicitly a contract claim. As has been noted in particular in Section 4 of this chapter, the identification of an activity as a public service has been important in giving jurisdiction to the administrative courts over private activities, such as, in Ville de Melun, supporting leisure and cultural activities, which in no way demonstrate the exercise of public power. ${ }^{61}$

The case of Ville de Melun illustrates the problem of the second criterion for a public service - that it is conducted under the aegis of a public body. Section 4 has already shown the wide variety of private bodies considered to be delivering public services and thus come within the scope of public law. Many these days are private companies, including major utilities such as electricity, gas and rail services. The special involvement of a public authority is not just in exercising command and direction, but also in exercising influence in

58 R. Odent, Cours de contentieux administratif (Paris: Les Cours de droit, 1965-6), p. 288 (the author maintained his approach in his last edition of 1977, p. 482); G. Braibant and B. Stirn, Le droit administratif français, $4^{\text {th }}$ ed. (Paris: Economica, 1997), p. 135.

59 See note 41.

6o CE 6 February 1903, Terrier, no. 07496, Leb. 94, D. 1904.3.65 concl. Romieu.

61 See note 56. 
a privileged way, for example in giving a special status to a professional or sporting body and how it is required to operate. On the whole, these special relationships of public law apply to dealings between the public authority and the operator of the service, whereas the dealings between the provider and users of the service are within the jurisdiction of the ordinary courts. But if this triangle of relationships may be fairly clear, the jurisdiction over relationships with third parties is less clear. For example, where Gaz de France (then a public enterprise) caused poisoning by fumes, the client had to sue in private law courts (because he had a contract with the company), but the neighbour had to sue in public law courts for harm caused by a public work. ${ }^{62}$

The distinctive French conception of public service has come under increasing pressure within the EU. The Treaty of Maastricht included public activities within competition rules and, despite French lobbying, did not recognise 'public services' as an exception. Article 106(2) of the Treaty on the Functioning of the European Union (TFEU) now only makes special provision for 'services of general economic interest', which is a narrower concept. European Union directives on rail transport and the postal service, in particular, have had significant effects on how these services are organised in France. This has important implications for how far the very broad concept of public service with its special powers and protection can be maintained, particularly in the face of the requirement to open the market to providers lawfully established in other Member States. ${ }^{6}$

Even if neither of these classic criteria is fully satisfactory, that does not justify a descent into existentialism, even if some contemporary authors describe the situation as 'a mosaic of judicial solutions'. ${ }_{4} 4$ The solutions adopted are not random, but there is no simple pattern. Rather there is a bundle of indicia, reflecting the variety of considerations which have to be borne in mind, of which the exercise of public power and the provision of a public service are two dominant features. Increasingly, the recent trend of legislation and judicial decisions in all the courts has been to focus on the expertise of specific courts in the matters under dispute and to ensure that the procedures adopted enable the most expert judges to rule on the issues.

62 TC 1 July 2002, Labrousse c Gaz de France, no. 03289, AJDA 2002, 689.

63 See for example J. Bell, "The Concept of Public Service under Threat from Europe? An Illustration from Energy Law' (1999) 5 European Public Law 189.

64 Lombard, Dumont and Sirinelli, Contentieux administratif, no. 634 with an echo to B. Chenot, 'L'existentialisme et le droit' (1953) Revue française de science politique at p. 57. 


\subsection{MECHANISMS FOR HANDLING CONFLICTS OVER JURISDICTION}

Conflicts between the ordinary and the administrative courts arise occasionally. In 1872, the Tribunal des Conflits was established to resolve them, a task previously given to the Conseil d'Etat itself (and for this very reason the judges of Tribunal des Conflits still meet in the Palais-Royal). The institution revived a short-lived body which existed during the Second Republic. It has the role of deciding issues of jurisdiction but may (on rare occasions) decide the substance of a case.

The membership of the Tribunal des Conflits was modified by the Law of ${ }_{17}$ February 2015. It currently is composed of four members appointed by the Conseil d'Etat and four members by the Cour de cassation, all appointed for a three-year term, renewable once. Each court also appoints two supplementary members for a similar period. The Tribunal des Conflits is presided over by one of its members chosen by the others. There is an understanding that the presidency will rotate between the members from the Conseil d'Etat and the members from the Cour de cassation. In the case of a tied vote, the 2015 law makes provision for a rediscussion of the case before an enlarged panel. In this case, the two supplementary members chosen by each court join the original members and it is hoped this will enable a decision to be reached. Until 2015, the Minister of Justice had the casting vote in the case of a tie. But this was considered incompatible with judicial independence. In practice, such tied votes are rare. Most estimates suggest that there were no more than a dozen such cases between 1872 and 2015. The last tied vote was in 1997 in Préfet de police de Paris. ${ }^{65}$ As in the Conseil d'Etat, the procedure is essentially written, which makes it possible to reassemble the panel with additional members without having to rehear the submissions of the parties. There are four forms of process by which conflicts can be raised.

\subsubsection{Positive Conflict}

A positive conflict arises when the ordinary courts hear a case which the administration considers should be heard by the administrative courts. In this case, the local prefect may raise an objection, a déclinatoire de compétence, setting out the reasons why the ordinary court does not have jurisdiction. The ordinary court then decides whether it has jurisdiction. It can either decline its jurisdiction or continue to assert it. In the latter case, it suspends hearing the 
case to give the prefect time to decide whether to abandon the objection or to refer the case to the Tribunal des Conflits. After the decision of the Tribunal, the case may either be allowed to continue before the ordinary courts or must be terminated and a new case started before the administrative courts.

As was shown in Radiodiffusion Française, the prefect may use this procedure to argue that neither court has jurisdiction. ${ }^{66}$ In this case, the prefect successfully claimed that the jamming of Radio Andorra by Radiodiffusion Française on the orders of a minister was an acte de gouvernement over which neither body of courts had jurisdiction.

There is no equivalent procedure whereby a litigant can object to the administrative court has entertained a case. In this case, all the litigant can do is to appeal the eventual decision on the ground that the lower court was not competent to hear the case. Only ministers before the Conseil d'Etat could decide to seise the Tribunal des conflits if the latter confirmed its jurisdiction, but it never happened, so this right was abolished in 2015 .

\subsubsection{Negative Conflict}

A negative conflict arises when neither an ordinary court nor an administrative court considers itself to have jurisdiction to hear a claim. There is obviously a risk of a denial of justice in this case. In order to speed up the handling of such cases, a decree of 25 July 1960 established a procedure of reference by which the rule is that the second court seised which also thinks it is not competent must seise the Tribunal des conflits before judging it is not competent in order to avoid the first court declining jurisdiction to an appropriate court in the other judicial order. Despite this, examples can be found where the resolution of the question about which court system has jurisdiction takes a significant number of years. ${ }^{67}$

\subsubsection{Preliminary Reference by a Court}

The decree of 1960 permitted the Cour de cassation or the Conseil d'Etat to request a preliminary ruling from the Tribunal des Conflits where there is a seriously difficult question of jurisdiction that involves the separation of ordinary and administrative courts. Such references are not frequent, but

66 TC 2 February 1950, no. 01243 , Leb. 652.

67 Lombard, Dumont and Sirinelli, Contentieux administratif, no. 673 cites the case of TC 20 October 1997, Paris Racing I c Fédération française de football, no. 03074, where a claim in relation to the payment on the transfer of a footballer took eight years between the TGI Paris declining competence and the TC coming to a decision on which court had jurisdiction! 
average at more than one a year. Article 35 of the decree of 27 February 2015 extended this possibility to any court where the solution to the case depends on such a question of jurisdiction. This process does make a serious attempt to speed up the decision on competence, because it does not require a final decision in the case. As noted in Section 1.2.1, art. 49 of the Code of Civil Procedure and art. R771-2 CJA implement this reference process.

\subsubsection{Conflict of Decisions}

As a result of the Law of 20 April 1932, it is possible to submit final judgments of administrative and ordinary courts to the Tribunal des Conflits in 'litigation having the same subject matter' (des litiges portant sur le même objet) and these are contradictory, thereby constituting a denial of justice. This arose as a result of litigation on a vehicle accident in which the claimant was a passenger. ${ }^{68} \mathrm{He}$ sued the driver of the private car in which he was travelling, and the ordinary court found him not liable. He sued the state for the driving of the other vehicle in the accident, an army truck, and the administrative court held that driver was not at fault. The Law of 1932 allows the Tribunal des Conflits to resolve the case itself. Such cases are rare because they require the identity of the subject matter and decisions by each court system. It has been invoked in only about ten cases since it was enacted. ${ }^{69}$ The Tribunal des Conflits has interpreted the rules more liberally in recent years to include not only where there are two final decisions, but also where one court has declined jurisdiction and a court from the other system has handed down a judgment, leading to a denial of justice. ${ }^{70}$

\subsection{CONCLUSION}

The division of jurisdiction between administrative and ordinary courts is an integral feature of the French conception of justice. The rationale for the system has evolved over time and the operational details have also changed. This way of delivering justice inevitably throws up difficult cases, but the remarkable thing is that there are so few. The Tribunal des Conflits handed down 24 decisions in 2019 , this contrasts with 2.25 million cases before the civil courts and more than 250,000 decisions handed down by the tribunaux administratifs. Difficulties in deciding on the appropriate court are rare.

69 Lombard, Dumont and Sirinelli, Contentieux administratif, no. 675.

70 TC 6 July 2009, Mario Bonato c APELIOR, no. C3692, RFDA 2009, 1229. 
Although the criteria for determining which is the appropriate court may be difficult to state succinctly, French lawyers basically know how they work. If we seek an explanation of the current rationale, it seems to lie in the expertise of the different courts. Just as lawyers are used to the special expertise of the CJEU and of the European Court of Human Rights, so lawyers are used to the special areas of expertise of administrative and ordinary courts. As far as the administrative courts are concerned, it is their knowledge not just of administrative law, but also of how the administration works. On the other hand, the ordinary courts are better placed in commercial matters and dealing with criminal matters. The Constitution now provides the basic framework within which the questions of jurisdiction between the administrative and ordinary courts is decided by the legislator, but the case law decides on its own criteria when the legislator has not taken a view on a particular litigation. This adds a layer of principle to what might otherwise appear to be pragmatic solutions to particular problems. 


\section{6 \\ Judicial Review of Administrative Action}

Procedure

Judicial review of administrative action is a major part of the work of the administrative courts. As was pointed out in Chapter 4, the role of the Conseil d'Etat is most typically as the review court for the work of the cours administratives d'appel and the tribunaux administratifs. In French terminology, it is the court of cassation (quashing) rather than the court of appeal. But, like the civil and criminal Cour de cassation in private law, it sets the approach the other courts are to follow, and it interprets the major points of law either by way of avis or by review after the lower courts have decided a matter.

Judicial review is about ensuring the legality of the actions of the administration. Unlike supreme courts in some parts of the world, such as the Indian subcontinent, French administrative courts are essentially reactive - they cannot begin proceedings of their own initiative (suo moto). The French judge is required to confine herself to the claim made and cannot judge outside it (ultra petita). Thus, the judge cannot annul a decision in its totality when only certain parts are challenged in the claim. ${ }^{1}$ The main exception here are the moyens d'ordre public, grounds which exist in the public interest, and which the judge can raise of her own initiative, provided she then submits these to the observations of the parties.

The extent to which the administrative courts are a major forum in which the decisions of the administration are challenged depends on the ease with which actions can be brought and the character of the remedies that can be granted, as well as their enforcement.

1 CE 27 July 2005, Département d'Essonne, no. 267499: the lower court annulled the whole decision placing the claimant on leave from December 2000, when she only challenged its effects from April to December 2001. 


\subsection{WHO CAN CHALLENGE AN ADMINISTRATIVE DECISION?}

The basic principle in French law is that anyone with a direct and certain interest can challenge an administrative decision which affects him or her. Individuals can bring an action which affects them as individuals, as members of a group, as users of a public service or for a collective interest. In a number of situations, associations can bring challenges. Because actions in the courts are not just the defence of rights, as in private law, but are designed to maintain the legality of public decision-making, the requirements for having a legitimate interest in bringing an action are much less than in private law. On the other hand and contrary to other jurisdictions, the action has no suspensive effect until the court rules on the case.

Interests as an individual can arise either because you are the person to whom the administrative decision is addressed - for example, the refusal of planning permission - or because your personal situation is affected. To be affected, there must be something in the decision which changes your legal situation. A simple example is where your neighbour is given planning permission. So giving planning permission for building a cinema complex to a rival was not a sufficient interest to justify other cinema owners challenging the permission. ${ }^{2}$ But the standard went so low that actions against planning permission became a lucrative sport to gain money for withdrawing a claim - so lucrative that the legislator decided in 2018 to set for this area a stricter standing for action. Article 6oo-1-2 of the Planning Code (Code de l'urbanisme) provides that an individual may only challenge the award of planning permission to another if it is liable to affect directly the conditions of his occupation, use or enjoyment of the property. On the other hand, civil servants are entitled to challenge the appointment of someone else to a category to which they belong or who might advance into that category. Thus, in Lot in 1903, appointment to the grade of archivist-palaeographer was limited to the holders of particular diplomas. ${ }^{3}$ It was held that Lot was entitled to challenge the appointment of someone else as director of the archives for breach of the rules on appointments (though in the end no breach was found on the facts). Similarly, in Rodière, it was held that a civil servant could challenge the appointment of others to posts in grades below his, because their appointment to those grades entitled them to compete with him in future promotions. ${ }^{4}$ Financial interests can also be sufficient to give a person an

2 CE Sect. 13 March 1987, Société albigeoise de spectacles, no. 55525, Leb. 97.

3 CE 11 December 1903, Lot, no. 10211, S 1904.3.113 note Hauriou.

4 CE 26 December 1925, Rodière, no. 88369, S. 1925.3.49 note Hauriou. 
interest. For example, in Cook, a firm of travel agents was able to challenge successfully a municipal by-law which subjected excursion charabancs to the same (stringent) regulations as taxis. ${ }^{5}$ A simple camper had standing for action against a mayoral ban to camp even though he had never set foot in the city at stake. $^{6}$

Interests as member of a group arise where several individuals are affected by the same decision of a public body. Art. L 77-10-3 CJA provides that one person may sue on behalf of a group to annul a decision or to bring an action for state liability.

Interests as users of a public service are a kind of group action. The individual is personally affected as a user, but he or she is really one of a group. In Croixde-Seguey-Tivoli, a leading public lawyer, Léon Duguit, formed his neighbours into an association to protect the interests of his neighbourhood in Bordeaux. ${ }^{7}$ They then complained that the private company running the tramway concession had decided to withdraw the service to their area in the reorganisation of the service from horse-drawn to electric trams. The prefect rejected their complaint. The association was allowed standing, even though it was unsuccessful in its challenge to his interpretation of the terms of the concession. A good example of a user successfully challenging the costs of a public service is Wajs. ${ }^{8}$ Here Mme Wajs, a motorway user, challenged the Minister's approval of toll charges imposed as a result of a concession to run a motorway. These included an obligation for the toll road company to pay for policing, which was held to be unlawful, and so the decree was annulled.

Interests of associations are less readily accepted because the Conseil d'Etat has not wanted to permit an actio popularis, but it does see the advantage of more orderly and competent challenges brought by associations, rather than by a series of random individuals. Reformed in 2017, art. L77-10-4 CJA provides that associations which have been registered for at least five years may bring actions to protect interests identified in their statutes. This is narrower than the situation of users of a public service in Croix-de-SegueyTivoli, where the association was set up to challenge the changes in tram services, but it was the first time French law introduced class actions. It applies to claims in relation to discrimination, the environment and public health, where there are special rules. The purpose of the rules in the CJA are to ensure an orderly use of litigation and to prevent series of cases being introduced.

\footnotetext{
CE 5 May 1899, Cook et Fils, nos. 91926, 91927, D. 1900.3.218.

CE, 14 February 1958, Abisset, no. 9999.

7 CE 21 December 1906, Syndicat des propriétaires et contribuables du Quartier de Croix-deSeguey-Tivoli, no. 19167, D. 1907.3.41 concl. Romieu.

8 CE Ass. 30 October 1996, Mme Waijs et Monnier, no. 136071, 142688, Leb. 327.
} 
A frequent example of actions by associations is the challenge by public-sector trade unions to civil service appointments and promotions. For example, in Syndicat de la Magistrature, Molins, the head of the Minister of Justice's private office, was appointed to the rank of avocat général at the Cour de cassation, but he never exercised his functions before he was appointed two years later as prosecutor at the TGI Paris. ${ }^{9}$ The arrangement was designed to qualify him for the position he took up when he left the Minister's office. The association was able to protect its interest in the legality of the appointment process in that it affected the interests of its members which it was formed to defend. More generally, professional associations can bring actions to protect the interests of their members. But it was explained in Syndicat des PatronsCoiffeurs de Limoges that the association must bring an action that relates to its collective interests and cannot bring an action relating to an individual, except by authorisation. ${ }^{10}$ So it could challenge a regulatory decision affecting its members, but it could not challenge the refusal of the prefect to grant the workers in hairdressers' salons Mondays as their weekly day off because the law made such a decision an individual matter and not a regulatory matter.

Collective interests may also justify actions by individuals. In Casanova, local taxpayers were able to bring an action to challenge the refusal by the prefect to annul the decision of their commune to pay for a municipal doctor to provide free medical care for poor people. ${ }^{11}$ The Conseil found that there was no need for this appointment, as two doctors already provided adequate care. In line with this case, the Conseil d'Etat eventually allowed local taxpayers to challenge not only decisions which increase local taxes, but also decisions which suspend taxes and diminish a city's income. ${ }^{12}$ The courts have not wished to allow people to bring actions where their interests are only secondary. They have insisted that claimants be affected in a sufficiently particular way. Illustrations of statuses which have not been held sufficient for standing include a national taxpayer challenging a government publicity campaign, ${ }^{13}$ a 'French citizen' concerned about state support for religion in Alsace-Lorraine, ${ }^{14}$ a consumer challenging a ban on a pharmaceutical product ${ }^{15}$ and a television viewer concerned for children and complaining about the lyrics of a broadcast pop video. ${ }^{16}$ The peculiar treatment

\footnotetext{
CE Sect. 18 January 2013, no. 354218, Leb. 5 .

CE 28 December 1906, no. 25521, S. 1907.3.23 concl. Romieu.

CE 29 March 1901, Casanova, no. 94580, S. 1901.3.73 note Hauriou.

CE 1 July 2009, Kohumoetini, no. 324206.

CE 23 November 1988, Dumont, no. 94282, Leb. 418.

CE 17 May 2002, Epoux Hofmann, no. 231290, Leb. 943.

CE 29 December 1995, Beucher, no. 139530, Leb. 480

CE 16 January 2002 Stiegler, no. 230386, Leb. 10.
} 
of local taxpayers is paralleled by art. L2132-5 CGCT, which allows the tribunal administratif to allow a local taxpayer to bring an action on behalf of the commune (at his own expense) when the commune itself has neglected to bring the action. The small size of many communes perhaps explains the concern that corruption may prevent challenges being brought by elected offcials, a concern that is not as prevalent at the national level.

\subsection{WHAT KINDS OF DECISIONS CAN BE CHALLENGED?}

The discussion of standing has already brought out that there is a distinction between individual decisions (actes individuels) and rules or regulatory decisions (actes réglementaires). On the whole, it is easier for associations to challenge regulatory decisions and for individuals to challenge individual decisions affecting them.

\subsubsection{The Need for a Prior Decision}

French law insists that there be a prior administrative decision to be challenged. This is a legacy of the nineteenth century, when the administrative courts only dealt with litigation and were not the general judges of the legality of administrative decisions. ${ }^{17}$ There can be no hypothetical actions and French law does not have the equivalent of a declaratory action, such as was used in the litigation prior to the withdrawal of the United Kingdom from the European Union. ${ }^{18}$

The rule requiring a prior decision (la règle de la decision préalable) allows a challenge to unilateral decisions - ones which are an exercise of authority. Such a decision must have legal consequences - either establishing a norm of conduct in the case of a regulatory decision or changing the legal situation of an individual in the case of an individual decision - for example, requiring them to pay money. The case law is quite flexible about the existence of a decision as shown by the 1986 Cusenier case. Mrs Cusenier challenged the decision of the Ministry of Culture to build the famous 'colonnes de Buren' in the front of both the Ministry of Culture and the Conseil d'Etat. The commissaire du government stated he had not found any formal decision, but that there must be a decision prior to a public expense. ${ }^{19}$ The requirement is now laid

See M. Guyomar and B. Sellier, Contentieux administratif, 5 th ed. (Paris: Dalloz, 2019) \& 646.

18 See R (on the Application of Miller) $v$ Secretary of State for Exiting the European Union [2017] UKSC 5 .

19 CE 12 March 1986, Ministre de la culture c Mme Cusenier, no. 76147, Leb. 661. The picture on the cover of this book shows the colonnes de Buren. The Ministry of Culture is in the foreground to the left, and the Conseil d'Etat lies at the back. 
down in art. R421-1 CJA, and since 2014, there is no exception for public works. That provision lays down that a challenge seeking the payment of money must be preceded by a request for payment. The existence of such a decision is established at the date that the claim is made to the court. Where the administration has simply failed to respond to a complaint, then its silence for two months used to be treated as a rejection. Since 2014 for state bodies and 2015 for local government, art. L231-1 CRPA lays down that the silence of the administration after two months constitutes acceptance. Numerous exceptions are made to this, and so a list of those decisions to which this rule applies is kept on the government website. Although this list does not have legal status as such, the claimant can always rely on the general principle in the absence of a specific exception. ${ }^{20}$

\subsubsection{Circulars and Soft Law}

In terms of general measures, some such as decrees and by-laws clearly have legal effect. But it has taken French law longer to recognise the legal effect of soft law measures such as circulars (circulaires) and guidelines (directives) and various 'grey literature' through which the wishes and understandings of higher organs of the administration are communicated to lower officials and to the public.

\subsubsection{Circulars}

Circulars are internal measures by which ministers advise officials how to apply the law. Typically, these are more detailed and try to ensure discretion is exercised more uniformly. In practical terms, these may become the documents of reference for officials, rather than the parent laws and decrees. There is a distinction between circulars that simply provide information and those that provide new instructions. In the past, a distinction used to be made between circulars that interpreted existing rules and those creating new rules, but that really failed to grasp the creative power of new 'interpretations' of existing rules. The Conseil adapted its approach in Duvignères by adding another possible situation. ${ }^{21}$ In this case, the claimant challenged both a decree of 1991 and a circular of 1997 governing legal aid in that neither excluded a personal housing allowance benefit from the calculation of resources determining the eligibility to legal aid. The law on legal aid of

20 See Chapter 4, note 32.

${ }^{21}$ CE Sect. 18 December 2002, Mme Duvignères, no. 233618 , Leb. 463 concl. Fombeur. 
1988 had excluded family housing allowance from such a calculation, but left it to the administration to determine what other social welfare benefits to exclude. The different treatment of the two types of housing allowance breached the principle of equality, and so the provision in the decree was annulled. As regards the circular, the Conseil distinguished between circulars interpreting laws and decrees and imperative circulars with general application. The latter would be subject to review. But as long as they did not contain imperative elements, the former would not. A circular would be imperative if either it imposed a rule where the legislation was silent or it misapplied the legislative provision which it purported to explain or it repeated a legislative rule which was, in itself, unlawful. This last was the case of the 1997 circular. But importantly, there is a distinction drawn between the faithful interpretation of a decree and a misguided one. Legality is the central feature which determines whether the circular can be challenged. Those which are imperative can always be challenged, but those that are not imperative in the ways described cannot. All the same, inadequate interpretation can be sufficient to cause provisions in a circular to be annulled. For example, the Conseil d'Etat annulled paragraphs of the official commentary on the tax code which failed to mention clearly the interpretation given by the Conseil constitutionnel to provisions on dividends. ${ }^{22}$ Since the 2020 GISTI case (see Section 6.2.2.3), case law has evolved to adopt a common approach to what is usually called in French 'soft law' or droit souple, including circulars and guidelines.

\subsubsection{Guidelines}

Guidelines (formerly called directives and now lignes directrices in French so as not to be confused with European directives) are further examples of 'soft law'. 23 They guide the conduct of officials and ensure uniformity, but obviously this affects those dealing with the administration in that the guidelines will be typically applied to them. So there is no objection in principle to the administration producing guidelines where the legal texts do not set out all the conditions necessary for their application, but they cannot add new rules. Unlike legal rules, the administration is at liberty to depart from the guidelines in individual cases. Indeed, it is necessary for the administration to consider both the requirements of the public interest and the totality of the facts of the individual case before applying

22 CE 8 June 2016, Association française des entreprises privées, no. 383259, Leb. 230.

23 Following the Rapport Public of 2013 on Le droit souple. This usage is borrowed from EU law: see, for example, Case 17/99, France v Commission [2001] ECR I-2481. 
the guidelines. ${ }^{24}$ Accordingly, in Cortes Ortiz, an applicant for a residence permit could not rely on the guidance alone to complain that the prefect had refused him a permit on a full examination of his particular case. ${ }^{25}$

\subsubsection{Other Soft Law and Information}

Such guidance is often produced by regulatory bodies. They may also issue other forms of soft law: 'advice', 'recommendation', 'position statements' or 'warnings' which may have an effect on individuals. In Fairvesta, the financial markets authority (Autorité des marchés financiers) issued a 'warning' notice about the activities of the claimant and its products retailed in France as a result of complaints by investors. ${ }^{26}$ The claimant company sought judicial review to quash the warnings and sought compensation for losses incurred. The Conseil accepted that this was the kind of administrative action which could be challenged in this way. In line with the case law we have just seen on guidelines, it held that general and imperative soft law provisions or individualised provisions which could later be used to sanction non-compliance could be challenged. In addition, challenges could be made to measures which are capable of having a significant economic or other effect, or are designed to influence the behaviour of those to whom they are addressed. In this case, there had been a significant drop in investments in the financial products of the claimant, and this justified permitting a legal challenge to the legality of the measure. But, on the merits, the claim failed since no manifest error in assessment was shown.

For a general measure to be reviewable, it must traditionally have a normative effect. ${ }^{27}$ The Conseil d'Etat clarified this in relation to what the French call 'grey literature' (la literature grise):

Documents of a general character put out by public authorities, whether in physical form or not, such as circulars, instructions, recommendations, notes, presentations or interpretations of positive law may be submitted for judicial review when they are capable of having significant effects on the rights or situations of people other than the officials charged with implementing them in a relevant case.

24 CE Sect. 4 February 2015, Ministre de l'Intérieur c Cortes Ortiz, no. 383267, Leb. 17.

25 Ibid.

26 CE Ass. 21 March 2016, Société Fairvesta International GmbH, no. 368082, Leb. 77; AJDA 2016, 717; also Société NC Numéricable, no. 390023, Leb. 89. Once a recommendation is made, it must be kept up to date in the light of scientific advances: see CE 23 December 2020, Association Autisme Espoirs vers l'Ecole, no. 428284, AJDA 2021, 11 and 948.

27 CE Ass. 29 January 1954, Institution Notre-Dame du Kreisker, no. 07134, Leb. 54. 
The phrase 'significant effects' (effets notables) is more wide-ranging than simply requiring that the measure be of normative effect. In the case in hand brought by GISTI, the information update (note d'actualité) drew the attention of officials to possibly fraudulent documentation coming out of Guinea (Conakry). ${ }^{28}$ It did not require officials to act in a particular generalised way. Since it encouraged attention to potential fraud on a case-by-case basis, then the document in question was not reviewable. All the same, this is a significant advance in ensuring legal certainty.

\subsubsection{Internal Measures}

Many circulars and guidance notes are for the internal use of members of the public service, and that is why the control exercised by the courts was originally very limited. Judicial review was intended to protect citizens from the administration. Internal matters would usually have their own schemes of redress - for example, in public service employment or in the military - or would be of minor significance - for example, the opening hours of post offices. Measures of internal organisations of the public service (mesures d'ordre intérieur administratives) are generally not subject to judicial review, whereas in the past, public service organisations such as the army, prisons and schools were considered closed institutions where internal discipline should not be weakened. This has become untenable, at least where individual rights are affected. The leading decisions are now Hardouin and Marie. ${ }^{29}$ In Hardouin, a sailor was found drunk on shore leave in the Canaries and he refused to take a breathalyser test. He was punished by ten days in jail. In Marie, a prisoner complained he was being refused dental treatment and was punished by the governor with eight days in a punishment cell. The lower courts rejected their claims against these decisions on the ground that such decisions were internal measures, applying the then consistent case law of the administrative courts. But the Conseil d'Etat overruled that case law and declared the claims to quash the decisions admissible. In Hardouin, the Conseil noted that the punishment had direct effects on the freedom of movement of military personnel outside their hours of duty and also on promotion and the renewal of their contracts of service. For these reasons, the sailor was allowed to challenge the decision. His various grounds of appeal were, however, rejected. By contrast, in Marie, the claimant was able to show

CE Ass. 17 February 1995, Hardouin and Marie, nos. 107766 and 97754, Leb. 82 and 85 concl. Frydman; AJDA 1995, 379. 
successfully that his punishment was not justified. His letter complaining of the medical services in the prison might have been intemperate, but it was not outrageous, threatening or insulting. The seriousness of the penalty imposed justified him being given the right to bring a complaint and the lack of factual basis for the governor's decision justified the quashing of his decision. To encourage the Conseil to reverse its case law, the commissaire du gouvernement relied on the European Convention on Human Rights and the development of case law on such matters in countries comparable to France. The principles laid down in this decision are that the courts will entertain complaints which either affect fundamental rights or which have serious consequences. For example, where legislation permitted prisoners to use their own computers, the refusal to allow a prisoner to acquire a particular operating system for computer was not significant enough to be reviewable. But the seizure of his equipment did constitute a measure interfering significantly with his right. ${ }^{30}$

The availability of judicial review in relation to school discipline was recognised earlier. In Chapou in 1954, the Conseil d'Etat refused to quash a Paris school headmistress's rule that girls were forbidden to wear ski trousers as a purely internal matter of discipline. ${ }^{31}$ But in Kherouaa in 1992, parents of pupils were allowed to challenge the exclusion by the headmaster of female pupils who wore a Muslim headscarf within the school. ${ }^{32}$ At the time, this was a highly controversial topic and in 1989 the Conseil d'Etat had issued advice to the Minister of Education that pupils had a right to freedom of conscience and were entitled to express their religious beliefs, provided this was not done in an ostentatious or provocative manner. That advice was put into a ministerial circular to schools and was followed by the Conseil d'Etat in this case. This school's ban on wearing a headscarf was too broad. It was general and absolute, rather than an appropriate response to particular identified problems with how the girls were behaving, and did not show proper consideration of the right of the pupils to freedom of conscience and expression. Again, the concern for fundamental rights, especially those recognised in the European Convention, influenced a change of approach by the Conseil d'Etat and justified allowing challenges to internal rules of the public service. Eventually the legislator banned in 2004 any ostensible religious signs in state schools, allowing only discreet ones.

\footnotetext{
CE 9 November 2015, D and B, nos. 380982 and 383712, AJDA 2016, 53.

CE 20 October 1954, Chapou, no. 15282, Leb. 541.

2 CE 2 November 1992, Kherouaa, no. 130394, AJDA 1992, 788.
} 


\subsubsection{Actes de gouvernement}

The immunity of the state attaches to sovereign acts (actes de gouvernement) what English lawyers refer to as 'acts of state'. To begin with, this was a wide category. In 1875 in Prince Napoleon, the cousin of the former Emperor Napoleon III was omitted from the annual army list of 1873 by the Minister of War as a result of the change of regime in 1870 . The Conseil d'Etat refused his claim to annul the decision. But the decision already marked a step towards a modern understanding of the rule of law in that it implicitly rejected the idea that all politically motivated decisions were not susceptible to judicial review. At that time, a wide range of discretionary decisions taken by ministers or by the head of state were considered to fall within the category of actes de gouvernement. But the list has reduced over the years. Prerogatives of the head of state, such as declarations of amnesty or pardon, ${ }^{33}$ decisions to extradite foreigners ${ }^{34}$ or decisions of the Prime Minister to nominate a member of Parliament for a mission ${ }^{35}$ are not included. Following the view of the European Court of Human Rights, the courts no longer defer to the interpretation of the Ministry of Foreign Affairs when interpreting a treaty. ${ }^{36}$ There are, however, a small number of topics on which the administrative courts will not permit claims to be brought because they are actes de gouvernement. Decisions in relation to the legislative process and the relationships between government and Parliament are not amenable to review, such as whether to submit a draft bill for consideration by Parliament or whether to refer a matter to the Conseil constitutionnel. The use of constitutional powers is similarly not amenable - for example, the use of art. 16 of the Constitution to declare a state of emergency or the use of art. 11 to submit a legislative proposal to a referendum. Both of these were controversial at the beginning of the Fifth Republic. The decision to invoke art. 16 is subject to prior advice of the Conseil constitutionnel, even if that advice does not have to be followed, and so in Rubin de Servens no challenge could be brought to the use of this procedure after the attempted military coup in Algeria in 1961 to establish special courts which punished the officers involved, ${ }^{37}$ nor could the use of a referendum to change the Constitution and establish the direct election of the President. ${ }^{8}$ Similarly the dissolution of the National

33 CE 30 June 2003, Section française de l'observation internationale des prisons, no. 244965 , Leb. 296.

34 CE Ass. 30 May 1952, Dame Kirkwood, Leb. 291.

35 CE Sect. 25 September 1998, Mégret, no. 195499.

36 CE Ass. 29 June 1990, GISTI, no. 78519, AJDA 1990, 621 concl. Abraham.

37 CE Ass. 2 March 1962, Rubin de Servens, no. 55049, Leb. 143.

$3^{8}$ CE Ass. 19 October 1962, Brocas, no. 58502 , Leb. 553. 
Assembly is not reviewable. ${ }^{39}$ In the Fifth Republic, referendums and parliamentary elections are scrutinised by the Conseil constitutionnel (and it has an abundant caseload after each election). So these matters fall outside the competence of the Conseil d'Etat, which deals merely with local elections. On the other hand, implementing decisions will be subject to review. For example, the decision of the Conseil Economique Social et Environnemental to reject a reference made to it was capable of review. ${ }^{4}$

Government actions in relation to defence and foreign affairs are also not susceptible to review. Thus, in 1995, the President decided to resume the testing of nuclear weapons in French Polynesia. A challenge brought by Greenpeace was unsuccessful because the President's decision could not be separated from the conduct of international relations. ${ }^{41}$ The doctrine was successfully invoked to shelter from review a ministerial circular cancelling the registrations of Iraqi students at French universities after the outbreak of the First Gulf War. ${ }^{42}$ Similarly, the failure of the French government to do enough to repatriate its citizens from the civil war in Syria could not be challenged. ${ }^{43}$ The use of powers in relation to a treaty are not subject to review. For example, the vote by a French minister in the Council of the European Union (as it is now called) could not be reviewed, ${ }^{44}$ nor could the decision to suspend the implementation of a treaty. ${ }^{45}$

Two limits apply in any case to the unreviewable character of actes de gouvernement. First, under art. 55 of the Constitution, treaties that have been duly ratified have a higher status than laws, decrees and regulations in French domestic law. As a result, a litigant can challenge a decision that is contrary to a ratified treaty. ${ }^{46}$ Second, the exclusion of foreign affairs only applies to sovereign acts. Many decisions, such as signing a treaty, are distinct from sovereign acts, and these separable decisions (actes détachables) are subject to review. For example, the decision to negotiate and sign an extradition treaty is a sovereign act. But the decision to make use of a power in such a treaty to request the extradition of an individual is a separable decision and is thus subject to

39 CE 20 February 1989, Allain, no. 98538 , Leb. 20.

$4^{\circ}$ CE 15 December 2017, Brillault, no. 402259, AJDA 2018, 491.

$4^{1}$ CE 29 September 1995, Association Greenpeace France, no. 171277, Leb. 348. See also CE 30 December 2003, Comité contre la Guerre en Iraq, no. 255904, Leb. 707.

$4^{2}$ CE 23 September 1992, GISTI and MRAP, no. 120437, AJDA 1992, 752 concl. Kessler.

43 CE ord. 23 April 2019, Mme C and Mme D, no. 429668, AJDA 2019, 907.

44 CE Ass. 23 November 1984, Association 'Les Verts', no. 54359, Leb. 382.

45 CE Ass. 18 December 1992, Préfet de la Gironde c Mahmedi, no. 120461, RFDA 1993, 333 concl. Lamy.

46 CE Ass. 20 October 1989, Nicolo, no. 108243, AJDA 1989, 756 and 788. 
review. ${ }^{47}$ Indeed, the Conseil d'Etat has accepted that it can review the refusal to extradite an individual at the request of a foreign government. In Colonie Royale de Hong Kong, the French government rejected a request by the United Kingdom and the Governor of Hong Kong (then a British colony) to extradite a Malaysian businessman, Sanimam, to Hong Kong on charges of fraud and corruption. ${ }^{4}$ The Conseil accepted the claim by the United Kingdom and the Governor of Hong Kong to quash the refusal on the ground that the French Minister of Justice had committed errors of law in coming to his decision, which was contrary to the favourable advice given by the chambre d'accusation of Versailles. ${ }^{49}$

As the authors of the Grands Arrêts suggest, there is no longer a general theory of actes de gouvernement. Rather, there is a natural reluctance of the judicial branch to interfere with the special prerogatives of the legislative and executive branches, including the diplomatic function. ${ }^{\circ}$

\subsection{IS JUDICIAL REVIEW INAPPROPRIATE?}

Because of the availability of other routes to redress, judicial review may be inappropriate either for the administration or for a particular litigant. The courts do not wish to receive unnecessary litigation. In the case of the administration, it may well already have powers to deal with a situation. After all, the privilège du préalable (the right to act first and be questioned later) gives the administration a strong position. For example, a département had the power on its own authority to withdraw a subsidy for a health centre in a local commune. Accordingly, it did not need to obtain a court order that it had lapsed. ${ }^{51}$ Similarly, a municipal authority was entitled to issue an order to pay to the co-owners of property which the authority had repaired because of its dangerous state. The lower court was wrong to insist that it wait until a court order to pay had been issued. ${ }^{52}$ The case law went even further by dismissing an action in court if it has power to act itself.53 There is only one exception for public contracts, as will be seen in Chapter 9, Section 3.2.

47 CE Sect. 21 July 1972, Legros, no. 82147, Leb. 554 (but in that case only subject to challenge in the extradition proceedings in the criminal court).

$4^{8}$ CE Ass. 15 October 1993, Royaume-Uni et Gouverneur de la Colonie Royale de Hong Kong, no. 142578 , Leb. 267 concl. Vigouroux.

49 The French government then ordered the extradition of Sanimam and the Conseil d'Etat rejected his challenge to this decision: CE 29 July 1994, Sanimam, no. 156288, Leb. 368.

$5 \circ$ P. Delvolvé, M. Long, P. Weil, G. Braibant and B. Genevois, Les Grands Arrêts de la Jurisprudence Administratif, 22nd ed. (Paris: Dalloz, 2019), p. 28.

${ }^{51}$ CE 21 July 1989, Commune de Noisy-le-Grand, no. 88120, Leb. 866.

52 CE 18 May 1988, Ville de Toulouse, no. 39348, Leb. 939.

53 CE 9 May 1913, Préfet de l'Eure, no. 47115, Leb. 583. 
In the case of a private individual, there may be an alternative remedy that he or she should pursue before seeking judicial review of an administrative decision. For example, if a company considers it has paid too much value-added tax (VAT) because France was slow in implementing an EU Directive, it must challenge this by way of the normal appeal on tax matters and not pay - one of the rare remedies having a suspensive effect ${ }^{54}$ - and then seek to obtain an 'indemnity' for the wrong done to it by the illegal request for tax. ${ }^{55}$ Similarly, those who have a priority right to housing should make use of the special procedure to enforce this right under the Housing Code, rather than seeking a judicial order in judicial review proceedings under the general CJA.$^{56}$ Where special procedures have been designed by the legislator, judicial review cannot be used to evade their procedural and other requirements and safeguards.

\subsection{TIME LIMITS}

As in many countries, the need for certainty has led French administrative law to insist on short limitation periods for bringing proceedings against the administration. If a challenge is brought a long time after an administrative decision is made, this may upset both the effective implementation of policies and the interests of other citizens. The basic principle is that the litigant has two months in which to challenge an administrative decision. Special rules apply to particular decisions. For example, a member of the public potentially affected can challenge permission to make use of works for the protection of the environment up to four months after notice of the permission was posted on the building (and thus when she might reasonably learn about it). ${ }^{57}$ On the other hand, some time limits are very short. For example, a candidate wishing to contest the results of a local election has only five days in which to present a claim..$^{58}$

In order to make it reasonably possible to bring a claim, the time limit runs from the date a decision was made public, rather than from the day on which it was made. Some decisions, such as planning permissions, have to be presented in a certain manner so that the attention of interested parties is drawn to their essential content. Article R421-5 CJA requires the administration to inform the affected person of the time limit for action and competent court when informing

54 However, this suspensive effect is not permitted in case of illegal state aid as contrary to the principle of effectiveness of EU law: see ECJ 5 October 2006, Case C-232/05, Commission v France ECLI:EU:C:2006:651 (aid granted to Scott Paper SA/Kimberly Clarke).

55 CE Ass. 30 October 1996, SA Dangeville, no. 141043, Leb. 399.

56 CE 3 May 2016, Lourdjane, no. 394508, Leb. 155.

57 Art. R514-3-1 Code de l'environnement.

$5^{8}$ Art. Ri19 Code électoral. 
her of an individual decision to the interested person. If it fails to do so, the time limit does not run. But the Conseil d'Etat set out a time limit for the reason of legal certainty: if it is established that the affected person was aware of the decision, she must act within a reasonable time, which is 'in principle' one year after the decision was taken, unless particular circumstances justify another time limit. ${ }^{59}$ In that case, Czabaj, a retired policeman, challenged the decision that set his pension twenty-two years after this decision on the ground that the decision had failed to mention the competent court. The Conseil d'Etat dismissed his claim on the ground that there were no special circumstances to allow the action.

\subsection{CAN JUDICIAL REVIEW BE EXCLUDED?}

In the past, there have been debates in France and among foreign commentators about whether the right to challenge an administrative decision could be excluded by the legislator. The current position is neatly summarised by the editors of Grands Arrêts: ${ }^{60}$

Under the double influence of the increasing place of international agreements in domestic law and the expansion of constitutional review of laws exercised by the Conseil constitutionnel, it seems possible to assert that a legislative provision which sought to remove an administrative decision from all judicial control would clash both with the international norm as well as with the constitutional norm.

That remark is made as a comment to a decision of 1950, Dame Lamotte, in which a Vichy Law of 1943 provided that the decision to award a unilateral concession, a sort of licence, could not be challenged by any administrative or judicial means. ${ }^{61}$ All the same, the Conseil d'Etat allowed a challenge by a landowner against a decision to grant a concession over her land to another person for nine years on the ground that it had been uncultivated for two years. It ruled that the law 'had not excluded judicial review before the Conseil d'Etat against the concession decision, a review which is available even without any (specific) provision against any administrative decision and which has the effect of ensuring respect for legality in conformity with the general principles of law'. This 'general principle of law' was converted into a 'principle of constitutional value' by the Conseil constitutionnel in $1994 .{ }^{62}$ The Conseil constitutionnel will

59 CE Ass. 13 July 2016, Czabaj, no. $3^{87763}$, Leb. 340.

6o Delvolvé et al., Grands Arrêts, p. 368.

61 CE Ass. 17 February 1950, Minister of Agriculture c Lamotte, no. 86949, Leb. 110. See Chapter 4 , note 4 .

62 CC decision no. 93-335 DC of 21 January 1994, Rec. 40. 
strike down not only a total exclusion, but also an effective exclusion. For example, where a law provided that a foreign national held in detention could only challenge an order for his expulsion from France within five days, the Conseil struck down the provision as breaching his right to a legal remedy. ${ }^{6}$ The principle of a right to recourse to the courts is recognised as a general principle recognised by the constitutional traditions of the Member States of the EU. ${ }^{64}$ It is also recognised by art. 47 of the European Charter of Fundamental Rights and art. 13 of the European Convention on Human Rights.

\subsection{REMEDIES}

The French administrative law on remedies is simpler than the array of orders in English law which still bear the marks of their origins in the prerogative writs and the remedies of Chancery. In France, there are basically orders to nullify or quash a decision or orders to require a person to act or to refrain from acting. In Chapter 4, Section 3, it was explained that interim remedies can be requested as a matter of urgency. In that chapter, the illustrations, particularly the handling of Covid-19 cases, showed how the interim procedure, particularly the référé-libertés, can effectively be the disposal of a specific problem. The problem of whether churches would be open for public worship during the pandemic would have disappeared if the normal process and time period were followed before the courts came to a decision. ${ }^{6}$ The range of remedies is available in interim cases as well as in final cases.

\subsubsection{Nullity}

In relation to the illegality of an administrative decision, a common remedy is nullity, which in England is known as a quashing order. Nullity declares that the administrative decision never took place, and it brings the situation back to where it was before the decision was taken.

\subsubsection{What Is the Effect of Nullity?}

Putting things back to where they were is not always easy or desirable. It is not always easy because time has elapsed since the original decision was made. In the case of a public employee, the lapse of time may mean a loss of opportunity

63 CC decision no. 2018-709 QPC of 1 June 2018, AJDA 2018, 1131.

64 Case 22/84, Johnston v Chief Constable of Northern Ireland [1984] ECR I-1651.

65 See Chapter 4, note 53, and text thereto. 
for experience or promotion. For a century, the French administrative courts have linked the nullity of promotions or lists of promotions with the power to reconstitute the careers of those affected in the light of typical patterns of advancement. In Rodière, the claimant had successfully brought an action to quash the list of promotions which the Minister for the Liberated Regions had drawn up for 1921 in which a number of individuals appeared. ${ }^{66}$ In 1925, the Minister then regraded them back to the grade they occupied in 1921 and then gave them the typical promotion they would have had in the intervening period. The claimant was unsuccessful in challenging this as a misuse of power. The effect of a nullity should not be to set everything back to the beginning and make the civil servants start again to earn their promotion. Rather, the individuals should have the guarantee of the continuity of career which they expected at the time of the original unlawful decision.

As noted in Chapter 4, the Conseil d'Etat has accepted in this century to permit the practice of prospective nullity as a way of safeguarding legal certainty. The decision in Association AC! demonstrates the value of a prospective nullity of legal rules which thereby protects the acquired rights of those appointed under them. ${ }^{67}$ The alternative for a court is to grant a suspensive effect to a nullity which allows an orderly transition back to legality. For example, in the Church Gatherings case discussed in Chapter 4, Section 3, provisions in the Prime Minister's Covid-19 decree were quashed, but the effect was suspended for a week to enable the Prime Minister to make a new decree to regulate the situation. This permitted there to be some rules in place during the interim to deal with the serious health crisis in question.

\subsubsection{Can Nullity Be Avoided?}

The courts have adopted four techniques to avoid declaring an administrative decision null whilst restoring a lawful situation. These are interpretation, substituting a proper legal basis to the decision, correction and declaring an error not to be substantial.

Interpretation constrains the meaning of a provision and 'extracting its venom'. For example, in Sueur, the loi d'habilitation had given power to make an ordonnance in order to introduce PPP contracts, but had required the government to ensure fair access to small and medium-sized enterprises in

6 CE Ass. 11 May 2005, Association AC! and Others, no. 255886, Leb. 917 concl Devys; Chapter 4, Section 9. 
the award of component parts of contracts. ${ }^{68}$ The Conseil d'Etat refused to nullify the ordonnance because it did not require small and medium-sized enterprises to be included in all public contracts awarded. But it did interpret the provisions in question so as to maintain the powers of a public authority to intervene if the potential participation of small and medium-sized enterprises was being neglected, and so as to maintain the effect of specific rules which guaranteed payment within a reasonable period to subcontractors. This avoided the danger that small and medium-sized enterprises would be excluded without declaring null rules that had been applied in relation to many public contracts.

Substituting a legal basis for an administrative decision enables the court to find a valid legal basis, even if it was not the one cited in the challenged decision. In Préfet Seine-maritime c El Bahi, the Conseil d'Etat declared: ${ }^{69}$

When it ascertains that the decision challenged before it could have been taken by a similar exercise of discretion on the basis of a legal text different from the one whose breach is alleged, the court in judicial review may substitute this legal basis for the one which served as the basis for the challenged decision, provided that the person affected has had available the safeguards relating to the application of the text on the basis of which the decision ought to have been made.

In this case, the prefect expelled a Moroccan from France on the basis of art. 22 (1) of the ordonnance of 1945 relating to foreign residents. However, he was able to show that he did not enter France unlawfully because he had a valid Italian residence card and was validly exercising free movement within the EU. But the Conseil d'Etat found that he had breached art. 22 (2) in that he had not obtained a French residence card within three months of his entry into France. By substituting this legal basis for the one mentioned in the prefect's order of expulsion, the prefect's decision was upheld. The court is allowed to come to this substitution decision in the light of all the evidence on file, as long as the parties have been given an opportunity to make observations on these issues. Indeed, a lower court commits an error of law if it fails to proceed on its own motion to make such a substitution of legal basis. In Nassiri, claimant children sought to change their surname from that of their father, who had abandoned them and taken no further interest in them, to that of their mother. ${ }^{70}$ The lower court simply reviewed the Minister's refusal to see whether there had been a manifest error in evaluation. But the Conseil

68 CE 29 October 2004, no. 269814, AJDA 2004, 2383.

69 CE Sect 3 December 2003, no. 240267, Leb. 479 concl. Stahl.

70 CE 31 January 2014, Ministre de l'Intérieur c Nassiri, no. 362444 , Leb. 698. 
d'Etat substituted a normal control assessment and concluded that the Minister had failed to take account of the legitimate interest the children had on these exceptional facts to be rid of any association with their father. Obviously, such a correction of legal basis may simply involve selecting among the reasons offered by the administration and disregarding those which are illegal. But that only works if the court is sure the official would have taken the same decision on the basis of the other facts mentioned in its reasons for the decision. $^{71}$

The court may refuse to annul a decision on the ground that the illegality found in the decision was not substantial. For example, a decision declaring a project of public utility was not quashed where errors in the notice of a public inquiry did not appear to have prevented a significant number of people making representations to it, and errors in required information did not significantly alter the scale of the cost. ${ }^{72}$ Here the court is avoiding requiring the administration to take back a decision and remake it with the same result. Consistent with but going beyond this case law, the Conseil d'Etat now asserts that

If administrative acts must be taken in accordance with the forms and procedures provided for by the laws and regulations, a defect affecting the conduct of a prior administrative procedure, whether compulsory or optional, may render the decision taken unlawful only if it is clear from the documents on file that it was likely to influence the meaning of the decision taken in the case in question or that it deprived the persons concerned of a guarantee. $^{73}$

\subsubsection{Injunctions (Injonctions)}

In Chapter 4, Section 9, it was noted that there was a long reluctance to allow the courts to issue injunctions against the administration. But this was permitted by legislation in 1995 (now enshrined in arts. L911-1 and L911-2 CJA), and it has become commonplace. Article L911-1 allows the court, when requiring a decision to be made with particular content, to require that the decision is made within a specified time. Article L911-2 provides that where the public

${ }^{71}$ CE Ass. 12 January 1968, Ministre de l'Economie et des Finances c Perrot, no. 70951, AJDA 1968, 179 concl. Kahn. (In that case, the Conseil d'Etat was not convinced the same decision would have been made.)

${ }^{22}$ CE 3 July 1998, Association de défense et de protection de l'environnement de Saint-Come-d'Olt, no. 162464 , Leb. 283 .

73 CE Ass. 23 December 2011, Danthony, no. 335033, Leb. 649. 
body has to remake a decision in the light of a review of the facts, then it can be required to act within a specified time. This power was used effectively in the cases relating to gatherings in places of worship during the Covid-19 crisis. In two decisions, the Conseil d'Etat in référé-liberté decisions annulled the provisions relating to the numbers permitted to gather for worship in churches and ordered the Prime Minister to produce new rules within a week. ${ }^{74}$

Injunctions may thus not only be to refrain from acting, but also may require action. In this way, they cover what are described in English law as mandatory orders, prohibiting orders and injunctions. For example, it may accompany the nullity of planning permission with an injunction requiring the landowner to demolish a car park being constructed on the basis of that planning permission. ${ }^{75}$ It may also be used in conjunction with a référé suspension. In that case, the order can also require actions but only as long as they are reversible. For instance, the suspension of a university decision refusing a student progression to a superior academic year is possible only if this admission is temporary - that is, valid until the court takes a position on the substance of the claim.

French law does not have a procedural equivalent to the English contempt of court in order to enforce such injunctions. Instead, it uses the procedure of astreinte discussed in Chapter 4, Section 8. This financial penalty is set at a level to encourage action. It is either a lump sum or a penalty fixed for a short period - for example, an amount per week. This idea of a financial penalty awarded against the administration has found its way since 1993 into EU law, where it features among the sanctions the CJEU can apply under art. 260 TFEU.

\subsubsection{Declaratory Judgments}

French administrative law does not have a category of 'declaratory judgments'. There is no real place for the equivalent of the procedure which exists in English law. In the first place, as has already been seen, there must be a prior administrative decision. There is no place for an action brought in anticipation of an administrative decision as was done in $R$ (on the Application of Miller) $v$ Secretary of State for Exiting the European Union. ${ }^{76}$ At the very least, there must be a circular which has an impact on individual situations. Second, French courts do not deal with hypothetical cases, but concrete situations. On

\footnotetext{
4 See Church Gatherings, Chapter 4, and Association Civitas, Chapter 7.

5 See CE Sect. 14 October 2011, Commune de Valmeinier, no. 320371, AJDA 2011, 2226.

76 See note 18.
} 
the whole, the French administration is allowed to act and, if it acts unlawfully, it pays.

That said, there are a few instances of judgments which have a declaratory effect. The first is when a court is invited to clarify its previous decision. This will often be a request by the administration to make more explicit the consequences of a previous court ruling. Clearly, there is no new decision here, as there would be in an appeal, so the new decision is merely declaratory in nature.

\subsubsection{Correcting a Decision}

Where an administrative decision comes to the court by way of appeal, the court is able not just to quash the decision, but also to correct it. In principle, such a power can be exercised in the plein contentieux rather than in the recours pour excès de pouvoir, though some of the techniques noted for avoiding the nullity of a decision may have a similar effect. Correction will often happen in tax matters. Where the claimant establishes an error in the basis on which he has been taxed, then the court may be in a position, on the basis of the facts on file, to come up with the correct amount of tax the claimant owes. For example, where the tax authorities applied an inappropriate rule to calculate the value of an option the taxpayer had exercised so as to treat it as the transfer of a business, the Conseil d'Etat simply reassessed the tax due on a basis which excluded the wrongly applied rule and treated it merely as a transfer of empty property. ${ }^{77}$

Similarly, election litigation may lead the court to alter the results. For example, in relation to local elections in French Guyana, the ballots in one commune had been wrongly rejected. The court simply recalculated the results including these ballots. ${ }^{7}$

\subsection{COSTS}

Orders in relation to costs have to distinguish between the costs incurred by the court (les dépens) and those incurred by the parties (les frais liés à l'instance). Under art. R761-1 CJA, the administrative court can make a ruling of its own motion in relation to court costs (les dépens), which will include the costs of court experts, of any investigation or of other measures ordered by the court to inquire into the facts of the case. The only exception

77 CE 28 December 2002, Société Valeo équipements électriques, no. 362444, Leb. 844.

$7^{8}$ CE 20 February 2020, Elections municipales Saint-Elie, no. 235473, Leb. 755. 
are expenses which are part of the running costs of the court, including the cost of site visits. That article provides that normally the court costs are to be borne by the losing party, but the court may order them to be borne by the state. It is up to the parties to make submissions that their costs should be met by the other side. Their own costs will typically be the costs of their avocat, the cost of the huissier who has produced a formal record of the state of premises at a key moment and any other costs the party has incurred in conducting the litigation. These frais will be borne by the party on whom the court costs are imposed or, by default, on the party who loses the case. The judge exercises a discretionary power with regard to these party costs. In the light of the justice of the case and the economic situation of the party in question, the court may order all or part of the costs to be borne by the losing party but with no correlation to the actual costs. (Typical amounts are from $€_{1,000}$ to $€_{5}, 000$.) Where the losing party has been allowed legal aid, the state will bear the party costs awarded against the losing party. Although the court has a discretion, it cannot award party costs against the winning party. Where a public body has not employed an external lawyer, but has conducted the litigation through its in-house staff, it may only recover any additional costs it can identify that are attributable to this specific litigation. It may not claim a proportion of the general costs of running the in-house service which deals with litigation. ${ }^{79}$

\subsection{PENALTIES}

Under art. R741-12 CJA, the administrative court is empowered to fine a claimant for making an abusive claim. This is a power which belongs to the court and cannot be requested by the other party. The level of the fine is for the court to determine, but it is rare that the maximum (at the time of writing) of $€_{10, \infty}$ is imposed. ${ }^{80}$ This fine may be the subject of appeal. The imposition of this fine does not prevent the other party to the case bringing a distinct claim for abusive proceedings. Before the administrative courts, the party wishing to make a claim that the other party's claim is abusive can only do so by way of counterclaim in pleine juridiction proceedings. It is not possible within judicial review proceedings. Exceptionally, planning law provides that, where a claim challenging planning permission also seeks the demolition of

$79 \mathrm{CE}_{3}$ October 2012, Ministre de la Défense et des Anciens combattants, no. 357248, AJDA 2012, 2178 concl. Dacosta.

8० For a rare case of a maximum penalty, see CE 10 July 2006, Jacques A, no. 294971. Here a judge dismissed after a disciplinary decision of the Conseil supérieur de la magistrature sought to challenge his dismissal on the (spurious) ground that such an administrative decision breached the principle of the independence of the judiciary. 
what has been constructed by the beneficiary of the planning permission, that party may be able to ask the court to award damages from the claimant for abusive proceedings (art. L6oo-7 Planning Code).

Article $741-2$ CJA provides that a court may order a litigant to suppress any insulting or defamatory remarks contained in his pleadings or in any report of the proceeding. This replicates powers that exist in private law in the press law of 1881 . In a sense, this is merely a power to curb the effects of an abuse of process, which in English law would be contempt of court.

\subsection{CONCLUSION}

France has distinctive administrative law procedures that have developed within its distinctive institutions. The distinction between public and private law has enabled procedures and remedies to be adapted to the context of relations between the administration and those it administers. That said, a number of procedures have been borrowed from private law. For example, administrative law adopted the astreinte after it had been successful in private law, and the injonction was another borrowing. It is notable that recent reforms, such as the Law of 23 March 2019 simplifying civil and administrative court procedure, view both branches of law together.

The distinctiveness of administrative law procedure has worked in two ways. On the one hand, especially in the early years, it has protected the administration. The requirement of an actual administrative decision that was either individual or normative restricted the range of administrative actions that could be challenged. In particular, it limited challenge to the range of soft law instruments which the administration uses to guide low-level decision makers and which are publicised to potential users of administrative services. There was no opportunity to challenge instructions before they were implemented. ${ }^{81}$ It protected the administration against hypothetical claims, but allowed it to act first and be challenged later (the so-called privilège $d u$ préalable). The administration was protected for a long time against hard-edged remedies such as injunctions. The availability of the combined remedies of injunction and astreinte in more recent years has changed the character of much litigation against the state. On the other hand, the distinctive administrative law procedures have helped the citizen, especially where the interests of the citizen overlap with the interests of good administration in maintaining the

81 Cf. Gillick v Norfolk and Wisbech AHA [1986] A.C.112, where a challenge was permitted against a circular from the Ministry of Health to general practitioners about the prescription of contraceptives to girls under the legal age of consent. 
legality of actions by officials. For example, the early availability of the standing of associations allowed the pooling of resources and collective redress.

Recent procedural developments have led more often to an expansion of the scope of judicial review. The broadening of the standing rules in relation to interest groups has been of particular importance. The availability of the référé-liberté and the power of injunction have enabled interest groups to have speedy redress against administrative decisions. Single-interest pressure groups now find judicial review an important political weapon, particularly in protecting minorities against policies which may be popular with the majority. The long-standing role of GISTI in protecting the interests of migrants is an obvious example. But, during the Covid-19 pandemic, administrative law litigation provided churches with an avenue to challenge limitations on the freedom of religion. Pressures for broader uses of judicial review have been helped by the movement towards recognising fundamental rights, especially through the ratification of the European Convention on Human Rights in 1974. The use of that Convention to challenge administrative actions against prisoners or in schools or even in the military has provided minorities a forum in which to voice concerns about the actions of the majority. Though procedural reforms often appear technical, they have the potential for major impacts on the way protest is conducted in society. 


\section{7 \\ Maintaining Legality \\ The Grounds of Review}

The fundamental purpose of judicial review in France is to secure the rule of law. French terminology is different from English terminology. The concept of l'Etat de droit or le règne du droit focuses on legality. ${ }^{1}$ The administration must have legal authority for its actions and must comply with the requirements of the law. In this, the sovereignty of the people is ensured - the people make the law through their representatives in the legislature and the courts ensure the law is obeyed. ${ }^{2}$ This differs from the common law conception of Dicey, which includes statute and common law within the concept of 'law' and is focused on subjecting officials to the ordinary law of the land. ${ }^{3}$ It is also different from more modern international conceptions which include the enforcement of fundamental rights as an integral element of the rule of law. ${ }^{4}$ The French concept is much closer to the German Rechtsstaat. As was mentioned in Chapter 2, the protection of fundamental rights has become an important feature of French public law since the Liberation of France in 1944. But the framework of French judicial review of administrative action was already established. In more recent years, there has also been a wider concern that the executive respects principles of good administration, especially those laid down in the Code des relations entre le public et l'administration (Code on the Relations between the Public and the Administration, CRPA) of 2015. It is best to explain contemporary judicial review first in terms of the formal

1 J. Rivero, 'Etat de droit, Etat du droit', in L'Etat de droit Mélanges en l'honneur de Guy Braibant (Paris, 1996), p. 6o9.

$=$ See J.-L. Autin, 'Illusions et vertus de l'état du droit administratif, in D. Collas, ed., L'Etat de droit (Paris, 1987), p. 149: 'Sovereignty of la loi and sovereignty of the people are inseparable in French public law.'

3 See A. V. Dicey, Lectures Introductory to the Study of the Law of the Constitution, edited by J.W.F. Allison (Oxford: Oxford University Press, 2013), p. 188.

4 See the Delhi Declaration of 1959 and T. Bingham, The Rule of Law (London: Allen Lane, 2011). 
grounds of review and then in terms of the values judicial review is now seeking to ensure the administration respects.

\subsection{GROUNDS OF REVIEW}

The formal grounds of review in French law are lack of competence, breach of an essential procedural requirement (or of a required formality), breach of the law and abuse of power. Indeed, lack of competence was the only ground at the creation of judicial review by the Law of $7-14$ October 1790. These four grounds found their way into art. 263 (2) of the Treaty on the Functioning of the European Union as the grounds of review of the institutions of the European Union. This illustrates the importance of French administrative law in shaping the European Union. As in European Union law, it is necessary to add a fifth ground of review, the declaration of the non-existence of the administrative decision in question in the case of a material inexistence or of a very serious illegality. Each of these grounds is connected to the idea of legality. Lack of competence, breach of a procedural requirement and breach of required formality relate to the external legality of a decision (légalité externe) in that they relate to the external circumstances in which the decision was made. The court here seeks to ensure that the proper person made the decision according to the proper procedure. Breach of law and abuse of power relate to the internal legality of a decision (légalité interne), which is seen from the terms of the decision itself, especially the reasons given for it. The court here is checking that legally valid reasons are given to justify a decision and that it was made for the purposes laid down by law and not for an improper purpose. French judicial decisions will frequently focus first on the external legality and then on the internal legality. The difference has a practical impact. Each category is called a cause juridique distincte. Therefore, if ever the judicial review was founded on grounds belonging to one sole category, the claimant will not be able to develop a new legal argument after the timing for action has expired in the name of the cristallisation du contentieux principle, unless it is a moyen d'ordre public.

\subsubsection{Non-existence (Inexistence)}

If what is claimed as an administrative decision never actually happened, then it is treated as never having existed. If a court intervenes, it will declare the non-existence of the decision, but it cannot annul it since there is nothing to deprive of its legal effect. In Anticor in 2016, the Conseil d'Etat succinctly set out the conditions for holding a decision as non-existent: 'A decision can only 
be held to be non-existent if it lacks physical existence or if it is so seriously vitiated that this affects not merely its legality, but its very existence. ${ }^{5}$

In that case, a claim failed that rules governing the treatment of former Presidents of the Republic did not exist because they were contained in a private letter written by the Prime Minister and were not published in the Journal Officiel de la République. The leading case is Rosan Girard. ${ }^{6}$ Here in April 1953, Dr Rosan Girard, the communist mayor of a commune in Guadeloupe, declared the results of the elections on the basis of counting the votes of only three of four ballot boxes, the fourth having being seized by the police after disturbances. Rather than referring the matter to the Conseil de préfecture, the prefect simply declared the election non-existent and ordered new elections for July. In those elections, the non-communists obtained a majority. In 1957, the Conseil d'Etat declared the prefect's decision non-existent. Due to the seriousness of his failure to leave the decision on the validity of the elections to the Conseil de préfecture, the election judge, the prefect's decision was void and non-existent. Despite subsequent attempts by the government to get around the effects of the decision, Rosan Girard and his communists were eventually elected as the majority party.

As the statement in Anticor makes clear, the decision should exist materially. That does not always mean there should be a record, but any evidence must show a decision, not merely a discussion. For example, Commune de Lavaur $v$ Lozar concerned a claimed agreement signed by the mayor to acquire a local château and its park for $850,000 \mathrm{~F} .7$ The tribunal administratif heard witnesses and decided that the commune council's meeting had debated the acquisition of the château, but it had not passed a resolution to buy it and authorising the mayor to sign a contract. Accordingly, the claimed decision was non-existent.

Where an actual physical decision is taken by an apparently authorised person, it is more difficult to determine when it is non-existent or merely unlawful. The Rosan Girard case shows a situation where the wrong person was making a decision about the validity of the local election. Often nonexistent decisions will constitute a voie de fait, a topic discussed in Chapter 5 , Section 3. For example, in Auger, the police ordered the closure of premises used by the claimant on the ground that they were being used for immoral purposes. ${ }^{8}$ They then engaged a contractor to block the entrance to the

5 CE 28 September 2016, Association pour la prévention de la corruption et pour l'éthique en politique (Anticor), no. 399173.

6 CE Ass. 31 May 1957, nos. 26188, 26325, Leb. 355 concl. Gazier.

7 CE 9 May 1990, no. 72384 , Leb. 115.

8 CE 11 March 1998, Ministre de l'intérieur c Mme Auger, no. 169794, Leb. 676. 
premises. The claimant succeeded in showing that the police had no authority to block the entrance because such powers were limited to emergency situations. This was such a flagrant breach of her right to property as to be both null and void and a voie de fait. But this is not always the case. Some implementing actions may be voies de fait without having an underlying decision - for example, a wilfully wrong police operation. Other decisions may be voies de fait but be the result of a merely illegal decision.

\subsubsection{Lack of Competence (Incompétence)}

A decision maker must have the legal authority to make the decision or to take the action affecting a person. Sometimes an official is too eager to achieve a policy objective and acts beyond his authority. This is shown by Mann Singh in which a minister was delegated the power by legislation to enact rules which determined the granting of driving licences. ${ }^{9}$ By circular the Minister of Transport required that a driver's photograph had to show him with a bare head. The claimant was a Sikh. He challenged the prefect's refusal to issue him with a driving licence on the ground that he was not bareheaded on his photograph. Adult Sikhs wear turbans as part of their religious practice. Although he challenged the decision on the basis of failure to respect his freedom of religion, the Conseil d'Etat quashed it on the ground that the rule the prefect applied was contained in a circular and the Minister was not legally authorised to issue rules in that way. In a more recent case, the mayor of Sceaux issued an order requiring face masks in public places during the early days of the Covid-19 pandemic. His decision was quashed on the ground that he did not have authority to make such orders. ${ }^{10}$ The emergency legislation on Covid-19 had given powers under the Public Health Code to the national government to order measures to combat the spread of the infection. At that point, the Prime Minister had decided not to require face masks in public due to a lack of masks. The Conseil d'Etat ruled there can be exceptions to the competence of the national government entrusted with special public health powers, based on the general power of mayors for ensuring public order in their communes 'when imperative reasons linked to local circumstances make their enactment indispensable and provided that, in so doing, they do not compromise the coherence and effectiveness of those taken for this purpose by the competent State authorities', but that the mayor was not empowered to impose face masks in his area in the absence of special circumstances.

9 CE 5 December 2005, no. 278133 , Leb. 545.

10 CE ord. 17 April 2020, Commune de Sceaux, no. 440057, AJDA 2020, 1013. 
Of course, wearing face masks in public did become compulsory some three months after this ruling, but the decision to require them was taken by the Prime Minister.

Officials can show lack of competence not only by taking action, but also by failing to take action. In Syndicat des médecins de l'Ain, the government used its power to make an ordonnance under which social sickness insurers were to issue electronic cards to their members. ${ }^{11}$ But the ordonnance left the details to a decree. The Conseil d'Etat held that the government had failed to exercise its competence because it failed to make provision for consent to and limits on the storage of the insured's medical data.

Only material breaches of the rules on competence will lead to nullity of the decision. $^{12}$

\subsubsection{Breach of an Essential Procedural Requirement (Vice de procédure} et vice de forme)

A lawful decision must be made not only by the authorised person, but also by following the required procedure. Procedure ensures the recording and publicity of decisions, as well as the opportunity for interested parties to contribute to the decision-making process. Procedural requirements may relate to formality and to process. Some requirements are essential (les formes substantielles), and some are non-essential (les formes non substantielles). Only failures to comply with essential requirements vitiate a decision. For example, the failure to mention the favourable opinion of the Architect des Bâtiments de France in a demolition permit was not such as to invalidate the decision to authorise a building's demolition when its approval was uncontested. ${ }^{13}$

Breach of formality may well be significant. If a decision has not been authorised by an appropriate person, then it may not simply be irregular, but non-existent. There are frequent cases where decisions are challenged because the power to sign them off has been delegated too far down the administrative hierarchy. Formalities not only ensure that the hierarchy of authority is respected, they also provide guarantees that affected individuals are allowed some participation in decisions that affect them before they are made. Whilst lawyers and bureaucrats may appreciate the value of formality, this is not always the case among policymakers and citizens. As a result, often formalities

11 CE Ass. 3 July 1998, no. 188004.

12 CE Ass. 21 December 2012, Groupe Canal Plus, no. 362347, AJDA 2013, 215 on the collegiality of the Competition Authority.

13 CAA Paris 6 February 1996, Société de Promotion et de Distribution Touristique, no. ${ }_{94} \mathrm{PA} 02130$. 
are not scrupulously respected, and the court is left to sort out the situation. Respect for the law might suggest that the decision should be quashed and taken again respecting the proper formalities in full. On the other hand, decisions may have been implemented and it would be against legal certainty to undo the new situation. A compromise has to be made to avoid excessive formalism, but also to ensure that the values are respected for which the formalities have been created.

The leading case on this issue is Danthony. ${ }^{14}$ In this case, the merger of two higher education institutions in Lyon was planned. The legal rules stated the governing bodies of the two institutions needed to meet separately and request the merger. The legal rules also required consultation with the staff liaison committees (comités techniques paritaires) before the governing bodies made their decision. In this case, the governing bodies made their request at a joint session with a single chairperson. A joint meeting of the staff liaison committees of both bodies then approved the merger. The staff liaison committee of the merged establishment gave its approval to the enlarged powers of the new organisation only after it had been created. Staff from one of the colleges challenged the legality of the ministerial decree approving the merger and the granting of wider powers to the new establishment. Clearly, the procedure preceding the decree was irregular. The Conseil d'Etat considered that the purpose for consulting the staff liaison committee protected a constitutional value - the right of workers to participate in decisions governing their conditions of work set out in paragraph 8 of the preamble to the 1946 Constitution. Therefore, the prior consultation of the staff representatives was an essential procedural requirement because it provided them with an important safeguard. Its omission invalidated the deliberations of the governing bodies and the ministerial decree. The requirement that each governing body approve a merger was a fundamental safeguard for the autonomy of each establishment. This was also an essential procedural requirement. The problem for the administrative courts was that the merger had been agreed in May and June 2009, concluding with a ministerial decree in December 2009 setting up the new college on 1 January 2010. By the time the Conseil d'Etat was deliberating in December 2011, the new structures had become embedded. Accordingly, although there had been breaches of essential procedural requirements, an annulment with retrospective effect was not appropriate. The Conseil d'Etat therefore ordered the nullity of the decision with effect

14 CE Ass. 23 December 2011, Danthony, no. 335033; CE Sect. 23 December 2011, Danthony, no. 335477, AJDA 2012, 195 and 1684 comment Mailot. 
from 30 June 2012, giving time for the situation to be regularised through new, lawful procedures.

Article 70 of the Law of 17 May 2011 provided that a factor vitiating a preliminary administrative procedure is not such as to affect the legality of a decision taken unless it is clear from the evidence on file that it was capable of having an influence, in the case at hand, on the outcome of the decision taken or unless it deprived the person affected of a safeguard. The Section du Contentieux of the Conseil d'Etat expanded its application to the omission of procedures. ${ }^{15}$ But in this case, it was clear that the procedures omitted did provide essential safeguards. It was therefore necessary for the Assemblée plénière of the Conseil d'Etat to consider moderating the application of the ruling in time:

If it appears that the retroactive effect of a nullity is capable of having manifestly excessive consequences by reason of the effects the decision has produced and the situations which have arisen whilst it was in force that it is in the public interest to keep in place its effects for a time, it is for the administrative judge ... to take into account, on the one hand the consequences of the retroactivity of the nullity for the various public and private interests at stake, and on the other hand the disadvantages which would arise with regard to the principle of legality and the rights of litigants to an effective remedy of a limitation in time of the effects of a nullity.

There are thus two ways of attenuating the effects of a procedural irregularity. First, it may be declared not substantial enough to affect the validity of the decision. Second, even if it is substantial, its effects may be moderated by delaying the nullity pending rectification by the administration.

The ability for the administration to regularise procedural errors is frequently necessary. An example is Commune de Sempy. ${ }^{16}$ Here a commune adopted a planning scheme which involved greater house building and a reduction in agricultural land within its area. Planning legislation required it to obtain the opinion of two bodies, the committee on the use of agricultural spaces and the chamber of agriculture. The commune obtained the opinion of neither body before it decided in 2012 to adopt the planning scheme. The tribunal administratif duly annulled the decision in 2014. The commune appealed and, before the cour administrative d'appel, it then presented opinions given by the two bodies, one favourable and one not. All the same, the appeal was rejected on the ground that the decision could not be regularised.

15 The legislator was content with this and repealed art. 70 by art. 51 of the Law of 10 August 2018, leaving the matter to the case law of the Conseil d'Etat.

16 CE Sect. 22 December 2017, Commune de Sempy, no. 395963. 
The Conseil d'Etat disagreed with this point as a matter of law. But, in order to regularise the decision, it was still necessary for the commune to meet and reaffirm its approval of the planning scheme in the light of the observations it had now received from the bodies who had finally been consulted. So the Conseil d'Etat ordered the decision on the appeal by the commune to be suspended for three months to see if a new decision by the commune could be made which might regularise the original approval of 2012 .

That decision also repeated the principle used in Danthony and originally based on art. 70 of the Law of 2011 setting out the limits for regularisation. It is now applied as a general principle. So a procedural irregularity in the levying of taxes will only be annulled if it deprives the taxpayer of a legal safeguard and if it would have had a material influence on the decision to impose a tax. ${ }^{17}$

A decision which provides inadequate reasons will also be procedurally defective. For example, Lars von Trier's film Antichrist was very controversial. The Minister granted it a film certificate for viewing by people over sixteen years of age. The Minister simply repeated the reasons given by the film certification board, which were held to be inadequate, stating that the film was too violent, but not explaining how this justified the age restriction. The decision was therefore quashed. ${ }^{18}$

\subsubsection{Abuse of Power (Détournement de pouvoir)}

Détournement de pouvoir enables a court to review not the formalities of an administrative decision, but its content. In particular, this ground of review examines the purposes and motives for which a power has been used. Until the ground of illegality (violation de la loi) was expended in the twentieth century, this was a significant control of power. But rather like the English tort of malicious abuse of office, it has tended to fall out of favour. Litigants frequently allege a détournement de pouvoir, but it is rarely found as substantiated by the courts. In the four years from 2017 to 2020 , some two hundred cases before the Conseil d'Etat alleged this ground of review, and not one was substantiated. That is not to say that abuse of power is not happening. In the past decade, two Presidents of the Republic and one presidential candidate have been convicted for abuse of their public office. Rather, it is that the ground of détournement de pouvoir is difficult to prove and it is easier to use illegality as a ground of review when a decision has been made for an improper purpose. Moreover, the case law tends to admit that a decision is lawful if

17 CE Sect. 16 April 2012, Epoux Meyer, no. 320912, AJDA 2013, 1733.

18 CE 25 November 2009, Association Promouvoir, nos. 328677 and 328769. 
grounded on a lawful motive despite the existence of another unlawful motive, at least when the latter is not of private nature. For instance, an expropriation might be lawful if motivated by a financial interest as long as there is also a general interest. ${ }^{19}$

Détournement de pouvoir is, in many ways, like the French civil law abuse of power or the English abuse of trust. It involves a decision being made for a purpose other than that for which it is authorised by law. In most cases, the abuse of power will be intentional. The French case law recognises three typical situations.

First and most extreme, the decision is taken for a purpose different from any public interest. For example, in Fabrègue the mayor was authorised by law to suspend a rural guard for up to a month from his post. ${ }^{20}$ The mayor of Cotignac decided to suspend the claimant by ten successive orders each lasting one month as an act of vengeance. The orders were accordingly quashed. Similarly, the decision of a bodybuilding association to refuse to allow an athlete to participate in a European championship team because of her public criticism of one of the directors of the association was quashed. ${ }^{21}$ The decision was not motivated by any sporting consideration, but only by a desire to punish her for unwarranted criticism.

Abuse of power occurs not only in personnel matters, but also in powers such as on public order and planning, which are taken by the mayor of a commune. As we have seen, many communes are small and so personal rivalries can spill over into policy decisions. For example, in Rault a mayor used public order powers to limit the hours for balls and dancing. ${ }^{22}$ The hours chosen favoured his two establishments and disadvantaged the inn of the claimant. The orders on the timing of balls and dancing were quashed for abuse of power. In France, the local communes have a right of pre-emption in certain circumstances when landowners put their property up for sale. In Guillec, the local council of Tignes (Savoy) claimed to exercise that right when the claimants put their property up for sale. ${ }^{23}$ It emerged that the council did this for the sole purpose of preventing people from outside the local area acquiring property in the municipality. The Conseil d'Etat ruled that a local authority could only exercise powers of pre-emption for the public interest and the purpose in this case was not of that kind. Similarly in Baron, the local

19 CE 11 January 1957, Louvard, Leb. 27.

20 CE 23 July 1909, nos. 33151, 33335, 33336, Leb. 727; S. 1911.3.121 note Hauriou.

${ }^{21}$ CE 25 May 1998, Fédération française d'haltérophilie, musculation et disciplines associées, no. 170752, JCP 1999.II.10001 note Lapouble.

22 CE 14 March 1934, no. 22256, Leb. 337.

23 CE 1 February 1993, M et Mme Guillec, no. 107714, JCP 1993.II.22088 concl. Vigoroux. 
commune sought to expropriate a property recently bought by a local businessman when he applied for planning permission to build a hotel and commercial complex on the site. ${ }^{24}$ The commune argued that it wanted to protect the rural character of the neighbourhood. But this was not a recognised public interest and so the power of expropriation had been abused.

Second, détournement de pouvoir may be used where the administrative decision is taken for a different public interest than the one for which the power is authorised. In the leading case of Pariset, a law was passed in 1872 creating a state monopoly on the production and sale of matches. ${ }^{25}$ The law provided for the expropriation of existing factories with resultant compensation. The Ministry of Finance decided that where a factory merely had a permit of limited duration to manufacture matches, the permit need not be renewed. The factory would then have to close under dangerous factories legislation (and thus no compensation was due). Following the Ministry's guidance, the prefect issued an order to close the factory. The Conseil d'Etat quashed the decision on the ground that the prefect's power had been used for a purpose which was different from that for which it was conferred. In another case, Bes, the mayor used his public order powers covering public health to prevent the claimant landowner damming his part of a canal, thereby ensuring that waste water continued to flow away from land further up. ${ }^{26}$ The principal reason for this measure was not public health, but to save the commune the expense of dredging its part of the canal. This amounted to an abuse of power and the mayor's order to the claimant was annulled.

Attempts to use powers to evade the consequences of a judicial decision are common. A flagrant example was Bréart de Boisanger. ${ }^{27}$ The Minister sought to terminate the claimant's role as administrator of the Comédie française before the end of his term of office. This was annulled by the administrative courts. The Minister then passed a general decree amending the rules on that post and a new appointment was made to this position which was identical to one that had been annulled. The claimant was able to obtain the annulment of the general decree because it was not promulgated in the general interests of culture, but to get around a judicial decision.

A third and common issue is the abuse of procedure. Here the administration hides the real content of its decision through a false appearance of a lawful procedure. Often this will occur where the administration does not have the

24 CE 16 February 1973, Ministre de l'équipement et du logement c Baron, nos. 82689, 82765, Leb. 139.

25 CE 26 November 1873 , no. 47544, Leb. 934.

26 CE 24 June 1987 , no. 4726o, Leb. 568.

27 CE Ass. 13 July 1962, Bréart de Boisanger, nos. 57498 et 57499, Leb. 484. 
powers it wishes to have. For example, in Guillemet, the administration used powers to expropriate a business's goods because it did not have the power to punish it for breach of economic legislation. ${ }^{28}$ In Keddar, the power to requisition people and limit their freedom of movement in the interests of public order was used to intern them in camps. ${ }^{29}$ In both cases, the decisions were quashed.

$$
\text { 7.1.5 Illegality }
$$

Illegality, based on the content of decision, is a common ground of review. It represents the heart of legality review - the administration must abide by the law. At the same time, if the administration has legal competence to make a decision, a court should not challenge its assessment of the merits of a case. Conceptually at least, there is an important distinction between review of legality and review of the merits (opportunité). This distinction leads both to the categories of grounds of review (error of fact, error of law and so on) and the degree of scrutiny to which a decision is subjected (the so-called sliding scale of review).

\subsubsection{Error of Fact}

In principle, facts are to be assessed by the decision maker. It is here that judicial review is different from appeal. Where an appeal lies to a court in the contentieux de pleine juridiction, then it can consider the facts and come up with its judgment. For example, in tax matters, the question before a court is whether the taxpayer owes tax on income for a particular tax year and that depends on the facts underpinning the assessment. In judicial review (the recours pour excès de pouvoir), the decision about the facts is a matter for the decision maker, and the court intervenes rarely.

All the same, the court does examine the existence or materiality of facts which give rise to the competence of an administrator to take a decision. This was stated by the Conseil d'Etat in Camino in 1916: ${ }^{30}$

Whereas the Conseil d'Etat cannot assess the merits of the measures submitted to it by way of judicial review, it is its role on the one hand to verify the existence if the facts which justify the decision and, on the other hand, in the 
case that the facts do exist to see if they could legally justify the application of the sanctions provided for [by law].

In this case, the mayor of Hendaye, Dr Camino, was suspended by the prefect for not ensuring the decency of a funeral where he was present. It was alleged that he had required the coffin to be brought into the cemetery by a hole in the wall, rather than through the gate, and that the grave he had arranged for the body was not deep enough. The Conseil d'Etat rejected the allegations on the ground that the documents in the case file demonstrated that they were wrong in fact. This shows the source of evidence on which the court relies the material submitted on file. The second set of facts in that case also shows the issue of the burden of proof. It was alleged that Dr Camino had caused problems for a private ambulance on the beach at Hendaye. Here the Conseil found the facts not to have been fully established in the file and, in any case, these were matters which were not connected with his official functions as mayor, and so they did not justify the sanction imposed by the prefect. This decision marked a change from the established approach of not treating errors of fact as justifying judicial review.

Apart from examining the materiality of facts, administrative courts may also review the classification of facts (qualification juridique des faits). In Gomel, legislation permitted the prefect to refuse planning permission where a proposed construction affected an existing view of architectural value (une perspective monumentale). ${ }^{31}$ The claimant's application for planning permission was refused for a building in Place Beauvau (opposite the Elysée Palace, the official residence of the President of the Republic). The Conseil d'Etat quashed the refusal on the ground that 'taken as a whole, the Place Beauvau could not be considered as forming a view of architectural value'. This approach to facts giving rise to competence to make a decision is applied today. For example, in Société Edilys, a very similar planning rule (then contained in art. R 621-21 of the Code du patrimoine) was used by the prefect to refuse planning permission in another part of central Paris, the Place Vendôme. ${ }^{32}$ His argument was that the planned alterations would change the character of the building from its state when it was classified in 1862. The Conseil d'Etat held that the rule was not designed to protect the character of a building at the moment of classification, but to protect the public interest and the place of the building in French architectural heritage. The prefect should have examined the changes as they affected the perspective of the building as originally constructed at the beginning of the eighteenth century.

${ }^{31}$ CE 4 April 1914, Gomel, no. 55125, S. 1917.3.25 note Hauriou.

32 CE 5 October 2018, Société Edilys, no. 410590, Leb. 365, AJDA 2019, 184. 
In examining documents from this period, the cour administrative d'appel had concluded that no harm to architectural heritage could be shown in relation to the proposed alterations to the claimant's clock shop, and the Conseil d'Etat upheld its quashing of the prefect's decision.

The courts will quash decisions based on a fundamental error in assessing facts. For example, in Bouhanna the claimant foreign national was applying for naturalisation. ${ }^{33}$ To qualify, he had to show he was 'resident' in France. Under judicial interpretation, this term meant he must establish that France was his 'centre of interests'. He had been living in France with his family since 1979, but his principal source of revenue came from work abroad. The Minister declared his application inadmissible on the ground that he was not resident in France and this was quashed.

Although the administration does not have to provide a full set of facts justifying its decisions, it needs to provide enough to demonstrate that there was enough evidence on which it was possible to conclude that the necessary facts were established. This was shown very firmly by the Conseil d'Etat in Barel. ${ }^{34}$ In that case, students applied to the Ecole Nationale d'Administration. Under the legal rules, the Minister was required to draw up a list of candidates allowed to take part in the competitive entrance examination on grounds of their suitability for the civil service. The claimants were rejected on grounds of their political opinions (communist leanings). To deal with their claim for review of the decision, the Conseil d'Etat requested the file of information on which the decision was taken. The Minister refused, and so the Conseil quashed the decision. The Conseil accepted that the Minister had discretion in assessing candidates, but it rejected the idea that the Minister could escape any review simply by keeping silent about the reasons for his decision.

\subsubsection{Error of Law (Erreur de droit)}

Error of law is a basic failure of a judge or decision maker and needs to be sanctioned by a court in order to maintain the principle of legality. As in English law, an error of law can take several forms. Three particularly merit attention. The first is an error of law concerning the powers the decision maker has. The second is applying a rule which does not relate to the facts. For example, in Tabouret et Laroche, a Law of 1940 required the prefect to approve sales of land. ${ }^{35}$ Prefects frequently refused approval to industrialists who

33 CE Sect. 28 February 1986, Bouhanna, no. 57464, Leb. 53.

34 CE Ass. 28 May 1954, Barel, no. 28238, Leb. 308 concl. Letourneur.

35 CE Ass. 9 July 1943, nos. 71607, 71720, Leb. 182; D. 1945, 163 note Morange. 
wished to buy agricultural land. The Conseil d'Etat quashed a prefect's decision for error of law on the ground that the legislation was intended to avoid speculation and not to prevent a change from agricultural to industrial uses. The third error is failing to apply a rule relevant to the facts. An example of failing to apply a relevant legal provision is Mann Singh, where the administration failed to take account of a person's right to religious belief and expression in designing the rules on photographs for driving licences. ${ }^{36}$ An error of law may also arise from taking into account irrelevant considerations. For example, in Université de Dijon c Picard et Brachet, the university disciplinary panel found two students guilty of misconduct in the examination. ${ }^{37}$ Appeal lay with the national panel of the Conseil supérieur de l'éducation nationale, which acquitted them on the ground that the exams had taken place under poor conditions and the assessments were more continuous assessment than end-of-course exams. The university successfully appealed to the Conseil d'Etat, which quashed the decision of the national panel on the ground that its decision was based on the irrelevant consideration of how the exams were conducted, rather than on the relevant consideration of the conduct of the students. Error of law is different from violation directe de la loi, which is a direct breach of a law.

\subsubsection{Manifest Error in Evaluation (Erreur manifeste d'appréciation)}

Most difficulties with administrative decisions arise not because of mistakes about the meaning of the legal text or the evidence for the existence of essential facts but because of assessments made by the administration about whether those facts meet the legal requirements. Because legal texts are often deliberately couched in vague or general language, the administration inevitably has considerable latitude in assessing how the legal terms apply to facts. The concept of manifest error in evaluation recognises both the latitude for judgment by the administration and the limits of any exercise of power..$^{38}$ The term 'manifest error' suggests that little fact-finding is needed. But, as was clear in Barel, the fact that the French administrative courts can require the decision file of the administration to be made available does enable serious scrutiny of the basis for the decision taken.

This ground of review was developed in litigation about measuring 'equivalence'. In Lagrange in 1961 , for budgetary reasons a commune decided to

\footnotetext{
See note 9 .

CE Sect. 17 January 1992, nos. 68756, 68757, Leb. 24.

S. Rials, Le juge administratif français et la technique du standard (Paris: LGDJ, 1980), p. 249.
} 
abolish the post of rural policeman and create a second post of road mender. ${ }^{39}$ Under the law, Lagrange, the rural policeman, was only entitled to compensation if he was not offered equivalent employment. He refused to accept the job of road mender and claimed compensation, but the Conseil d'Etat rejected this because there was no manifest lack of equivalence between the two roles. On the other hand, in the area of the reorganisation of rural landholdings, the Conseil d'Etat in Achart was willing to declare there had been a manifest error in offering the claimant one plot of land in replacement for the agricultural land taken from her. ${ }^{4}$

The distinct character of this ground of review was recognised in Société de la Plage de Pamplonne. ${ }^{41}$ The prefect had given planning permission to the claimant for the building of two hotels close to a natural beach. The local residents challenged the decision, and the Minister withdrew the planning permission. The law entitled him to do this if the decision of the prefect was illegal. The Conseil d'Etat ruled the prefect was entitled to award planning permission on the merits of an application, but 'the decision which he makes must not be based on materially inaccurate facts, on an error of law, on a manifest error of evaluation or be vitiated by a misuse of power'. Here the prefect had failed to take appropriate account of the character of the neighbouring properties which would be affected by the building of the hotels. Accordingly, the Minister was right to quash the prefect's decision.

The delicate balancing act of the Conseil d'Etat represented by this ground of review is seen in the 'theory of the balance sheet' (le bilan) developed in the leading case Ville Nouvelle Est. ${ }^{42}$ The case concerned a new development for the University of Lille on the outskirts of the city. As experience had shown that segregating students from the rest of the population had serious disadvantages, the proposed development included a new town alongside the university campus. A local defence association was formed of residents and property owners, and they contested the decision to declare this a "public interest development' and to expropriate the land needed for the project. The relaxation of the procedure for expropriation in the late 1950 s had been controversial but had been approved by the Conseil d'Etat in legal advice in $1957 .{ }^{43}$ That approach see CE 13 November 1953, Denizet, no. 8304, Leb. 489.

$4 \circ$ CE 13 July 1961, Demoiselle Achart, no. 50609, Leb. 476.

41 CE Ass. 29 March 1968, Société du Lotissement de la Plage de Pamplonne, no. 59004, Leb. 211 ; AJDA 1968, 341 .

42 CE Ass. 28 May 1971, no. 78825, Leb. 409 concl. Braibant, RDP 1972, 454 note Waline.

43 See generally T. Perroud, J. Caillosse, J. Chevallier and D. Loschak, Les grandes arrêts politiques de la jurisprudence administrative (Paris: LGDJ, 2019), pp. 367-9. 
relaxation had left the decision to the government and not to Parliament. But the extent of the judicial control over such decisions remained to be clarified until Ville Nouvelle Est. Whereas the judges had been reluctant to intervene, the decision shows that the availability of judicial review was a necessary counterbalance to greater executive power in this area. Guided by the commissaire du gouvernement Braibant, the Conseil ruled:

An operation cannot be legally declared as of public utility unless the interference with private property, the financial cost and, where it occurs, the attendant inconvenience to the public is not excessive having regard to the benefits of the operation.

This theory of the balance sheet (le bilan coût-avantages) provided a framework for assessing whether the concept of public utility had been properly applied. At the same time, Braibant made clear this was not an attempt by judges to rule on the merits of a project:

There is no question that you should exercise discretions that belong to the administration; questions such as whether the new airport for Paris should be built to the north or the south of the capital, or whether the eastern motorway should pass close to Metz or close to Nancy remain matters of opportunité. It is only above and beyond a certain point, that is, where the cost, whether in social or financial terms, appears abnormally high, that you ought to intervene. What matters is that you should be able to review decisions which are arbitrary, unreasonable or ill-considered, and that you should compel local authorities to put before the public in the first place (and later, if need be, before the court) solid and convincing reasons for their proposals. ${ }^{44}$

The balance sheet was to be drawn up by the administration and the role of the court was merely to see that the costs to private individuals were not excessive in relation to the public interest. The claimants here had not shown that the decision to build the new town was excessive. The decision marked an important change in approach to expropriation which deferred less to the administration than earlier decisions had, but the actual result in the case favoured the administration.

It is important to stress that erreur manifeste is not seen as an intrusion into merits or into the qualification juridique des faits. ${ }^{45}$ So the courts will not engage in the comparison of the action proposed by the administration with other alternatives which the claimant alleges have less cost associated with them. This point was made by commissaire du gouvernement Braibant in the

44 Translation in L. N. Brown and J. Bell, French Administrative Law, $5^{\text {th }}$ ed. (Oxford: Oxford University Press, 1998), p. 264.

45 M. Guyomar and B. Seillier, Contentieux administratif, 5th ed. (Paris: Dalloz, 2019), \$123. 
quotation just given. In Adam, commissaire du gouvernement Gentot clearly regretted the choice of route for a motorway chosen by the administration, but he was clear that it was not the role of the court to interfere unless the choice was manifestly unfounded in relation to the evidence. ${ }^{4}$

In the area of expropriation, few decisions have been quashed for failing the balancing test. The courts have been willing to examine whether the declaration of an expropriation to be of public utility is justified. A clear example of an unjustified expropriation was Grassin. ${ }^{47}$ Planning permission was given for an aerodrome for a local flying club. It failed to find land it could buy, and the council moved to expropriate land. Despite the views of local industry and property owners, the prefect declared the project to be of public utility as a category D airport. The Conseil d'Etat quashed this decision on the ground that little potential use had been shown other than the use by the flying club. The cost of 700,000 F was disproportionate for a commune of only a thousand inhabitants. The Conseil d'Etat was also willing to consider annulling an expropriation where its necessity was not shown since the public authority already possessed property of its own with which to deliver the project in an equivalent way. ${ }^{8}$ The court thus proceeds in two stages: first to examine the necessity of the expropriation in terms of public utility, and then to examine the balance between the different interests to ensure the costs are not excessive relative to the gain from the proposed project in the public interest. ${ }^{49}$

Subsequent decisions have amended the list of factors included in the balance of interests to include other public interests, as well as social disadvantages other than those to the people expropriated, including effects on the environment assessed through the principle of precaution..$^{\circ}$

The formulation of the balance of interests in more recent decisions confirms the analysis of leading scholars that the control over the balance [of interests] amounts to a control over manifest error'..$^{1}$ The point was also

$4^{6}$ CE Ass. 22 February 1974, Adam, nos. 91848, 93520, Leb. 145, RDP 1975, 486 concl. Gentot; see also CE Ass. 28 March 1997, Fédération des comités de défense contre le tracé de l'autoroute A 28, no. 165318, Leb. 123, RDP 1997, 1433 note Waline.

47 CE Sect. 26 October 1973, Grassin, no. 83261, AJDA 1974, 34.

$4^{8}$ See CE 20 November 1974, Epoux Thony and Epoux Hartman-Six, nos. 91558, 91559; CE 19 October 2012, Commune de Levallois-Perret c Boyer, no. 343070, AJDA 2012, 1982; CE 11 May 2016, Commune de Levallois-Perret, no. 375161, AJDA 2016, 2015 note Hostiou.

49 See CE 19 October 2012, note 48, point 3.

50 See CE Ass. 12 April 2013, Association coordination interrégionale Stop THT, no. 342409, RFDA 2013, 610 concl. Lallet, para. 43.

${ }^{51}$ P. Wachsmann, 'Un bilan du bilan en matière de l'expropriation. La jurisprudence Ville Nouvelle Est trente ans après', in Gouverner, administrer, juger. Liber amicorum J. Waline (Paris: Dalloz, 2002) p. 744 at p. 745. 
made by rapporteur public Lallet in 2013 that 'As far as the control over the balance [of interests] is concerned, when there is a declaration of public utility, an examination of your case law shows that only a marked imbalance, if not to say a manifest one, is capable of leading to a nullity.' As long as the relevant interests have been considered, then the court will only interfere with an obvious misjudgment, and such cases are rare. Although this might appear to be an interference with the merits of decisions, it is actually very cautious. ${ }^{52}$

There are a few examples of a court quashing decisions due to the balance being manifestly wrong. For example, the case of Ste Marie de l'Assomption involved the building of a slipway which would render an important mental hospital unusable as well as depriving it of all its green space. ${ }^{53}$ Only once has the Conseil d'Etat quashed a governmental motorway project where the cost and the number of properties expropriated exceeded the public interest. Here the Swiss had cancelled building a motorway on the other side of the border. ${ }^{54}$ On the whole, however, the main influence has been on the decision-making process, which is more careful to avoid successful challenge. ${ }^{55}$ It encourages a management style of decision-making which is perhaps less in tune with contemporary concerns over matters such as the environment, where a more holistic approach is needed to what is 'excessive'. This concept is close to proportionality, to which we now turn.

\subsubsection{Proportionality}

In 1974, Guy Braibant wrote that French judges were using the concept of proportionality without knowing it. ${ }^{5}$ He attributed its origins to the administrative tribunal of the International Labour Organization. ${ }^{57}$ He suggested the idea lay behind the review of public order measures which affected an

52 P. Janin, 'Principe de précaution et contrôle de l'utilité publique', RFDA 2017, 1068. J.-M. Pontier, 'La balance des intérêts' AJDA 2021, 1309.

53 CE Ass. 20 October 1972, no. 78829 , RDP 1973, 843 concl. Morisot.

54 CE Ass. 28 March 1997, Association contre le projet autoroute transchablaisienne, no. 170856, AJDA 1997, 645. Also CE 28 June 2021, Département des Alpes Maritimes, no 434150, AJDA 2021, 1356 .

55 See Perroud et al., Les Grands arrêts politiques, pp. 390-4. Also Delvolvé et al., Grands Arrêts, p. 556 , para. 14, which notes how often the administrative sections of the Conseil d'Etat refer to this principle.

${ }_{56}$ G. Braibant, 'Le principe de proportionnalité', in Mélanges offertes à Marcel Waline : Le juge et le droit public, 2 vols. (Paris: LGDJ, 1974), vol. 2, p. 297 at p. 302. Essentially, this line of argument is carried forward by $\mathrm{S}$. Roussel in her more recent review of the topic in which the explicit character of the concept is made clear: S. Roussel, 'Le contrôle de proportionnalité dans jurisprudence administrative', AJDA 2021, 780.

57 See the conclusions of R. Latournerie, CE 5 July 1929, Ministre de travail, RDP 1931, 319. 
individual's civil liberties. In Benjamin (discussed in Section 7.1.5.5), the Conseil d'Etat quashed a mayor's ban on a public lecture on the ground that the facts showed that 'the likelihood of disorder did not show the degree of seriousness such that [the mayor] could not maintain order without banning the lecture'..$^{5}$ Indeed, others see this idea shown in the much earlier case of Abbé Olivier. ${ }^{59}$ Here the mayor of Sens banned clergy wearing vestments to accompany a funeral cortège along a public road on the ground that this would cause problems of public order at a time when feelings about the separation of church and state were high in the town. But the Conseil d'Etat held that customs and local traditions could only be interfered with where it was 'strictly necessary for the maintenance of order', which was not evidenced in this case.

Similarly, the idea that disciplinary penalties needed to be proportionate was found in civil service matters - for example, whether a finding that a nurse 'lacked tenderness towards patients' justified her dismissal, especially when the idea of manifest error of evaluation was extended to this area. ${ }^{60}$

Although there are elements of proportionality thinking contained in erreur manifeste cases, the full adoption of proportionality has only come in the past ten years or so, under the influence of both European courts and also of the Conseil constitutionnel. The leading case was Association pour la promotion de l'image. ${ }^{61}$ The case involved the French implementation of an EU policy on adopting biometric passports. The French decree authorised the automatic collection and storage of digital photographs and the imprints of eight fingers. The justification for this storage of personal data was that it enabled replacement of passports and also the combatting of fraud. The Conseil d'Etat set out the principle of proportionality:

The interference with the right of any person to respect for his private life which is constituted by the collection, storage and processing by a public authority of nominate personal information can only be justified legally if it fulfils legitimate purposes and that the choice, collection and processing of the data are carried out in a manner appropriate and proportionate in relation to these objectives.

In this case sufficient safeguards were in place to protect the data from misuse, but not for the number of fingerprints, which was deemed excessive. The case

58 CE 19 May 1933, nos. 17413, 17520, S. 1933.3.1, note 83.

59 CE 19 February 1909, no. 27355, D. 1909.3.34 concl. Chardenet.

6o Conclusions of Kahn, CE 22 November 1967, AGAP de Paris c Chevreau, no. 6866o, Droit ouvrier 1968, 113. See earlier Latournerie in note 57.

61 CE Ass 26 October 2011, no. 317827, Leb. 506, AJDA 2012,35. 
shows clearly the influence of the case law of the European courts for which the concept of proportionality has been used regularly for many years. ${ }^{62}$ The Conseil constitutionnel has adopted the triple test of necessity, appropriateness and proportionality since $2008 .{ }^{63}$

This approach was followed in Canal Plus, which involved injunctions by the Competition Authority to deal with the dominant position of Canal Plus. ${ }^{64}$ The Conseil d'Etat rejected the complaints of the company by examining in detail the proportionality of the injunctions relative to the purpose of opening up the market in matters such as the distribution of films.

The level of intensity involved in contemporary proportionality reasoning can be seen from decisions in relation to Covid-19. The Church Gatherings case, discussed in Chapter 4, Section 3, involved a decree of 28 April 2020 on relaxing the confinement restrictions in France. ${ }^{65}$ The Prime Minister decided not to relax the rules, which permitted individual prayer in places of worship but did not permit gatherings, except for funerals, until 2 June. The necessity to restrict the freedom of civil liberties because of the health emergency was accepted given its gravity. But the claimants contested that an outright ban was needed. The Minister of the Interior drew attention to an outbreak of Covid-19 which had followed a large religious gathering in Mulhouse in February 2020. But the Conseil d'Etat challenged the relevance of this on the ground that social distancing measures were not being applied at that time. Furthermore, it pointed to the measures taken in other parts of the contested decree dealing with other activities. Public transport was limited to a gathering of ten people on the street and shops and education establishments could receive the public respecting social distancing measures defined as four square metres of space per person. The evidence did not show that places of worship presented a greater risk than these places and that safety measures could not be developed for them to received groups of people. As a result, the total ban on gatherings in the decree represented a disproportionate interference with the freedom of religion, and the Prime Minister was ordered to draw up new rules within a week of the Conseil d'Etat's decision. The decision shows how far the evidence of necessity and the possibility of a lesser

62 See ECHR 4 December 2008, App. Nos. 30562/04 and 30566/04, S and Marper v UK [2008] ECHR ${ }_{15} 81$ on the use and storage of digital fingerprints. Also see CJEU, Cases C-465/0o, C-138/o1 and C-139/o1, 20 May 2003, Osterreichischer Rundfunck, ECLI:EU:C:2003:294 on storage of data.

63 CC decision no. 2008-562 DC of 21 February 2008, Detention for Security, Rec. 89, para. 13.

64 CE Ass. 21 December 2012, Société Groupe Canal Plus et Société Vivendi, no. 362347, Leb. 430, esp. paras. 108-13.

65 CE ord. 18 May 2020, W and Others, no. 440366, AJDA 2020, 1733 note Rambaud. 
interference with fundamental rights is now taken. Weaknesses in the justification offered by the government are probed. The Conseil constitutionnel took a similar approach to subsequent legislation on deconfinement. ${ }^{66}$

As mentioned at the beginning of this section, it is clear that the reasoning of administrative courts in relation to human rights has long involved proportionality between the administrative measure and the consequences for the person affected (see the cases of Abbé Olivier and Benjamin). A similar approach was adopted when considering the application of the European Convention after it was ratified and took effect in domestic law in 1974, even if decisions were formally based on the ground of manifest error in evaluation. ${ }^{67}$ The Conseil constitutionnel had long examined the necessity and proportionality between the criminal penalties imposed and the offence committed in the light of art. 8 of the Declaration of the Rights of Man of 1789, starting with the Security and Liberty decision of 1981, but formally referred to the concept of manifest error in evaluation. ${ }^{68}$ But in more recent years it has moved explicitly to using proportionality. ${ }^{69}$ The administrative courts make decisions in both of these areas, and it is natural that the use of proportionality by these courts would influence the reasoning of the administrative courts as well. The area of competition law involves both national and European Union courts, and, again, it is natural that there will be an alignment of reasoning.

French commentators, like Roussel, ${ }^{70}$ would not see anything revolutionary in the assessment of the appropriateness of the measures for the objective to be achieved, of the necessity of a decision and the proportionality between the benefits and the burdens imposed. In her view, each of these has been found in decisions of the Conseil d'Etat for many years, especially in the control of police powers, of the bilan and of disciplinary sanctions. The 'principle of proportionality' brings these elements together in a structured way. It would be fair to say that all the French supreme courts have now adopted the principle as of general application and that they use it to

See CC decision no. 2020-803 DC of 9 July 2020, Deconfinement Law, ECLI : FR : CC : 2020 : 2020.803.DC, paras. 20-6.

67 See CE Ass. 19 April 1991, Babas and Belgacem, nos. 117680 and 107470, Leb. 152 and 162 on the balance between the expulsion of a migrant and the right to family life under art. 8 of the Convention. See generally E. Bjorge, Domestic Application of the ECHR. Courts As Faithful Trustees (Oxford: Oxford University Press, 2015), pp. 157-60.

68 CC decision no. 80-127 DC of 19 and 20 January 1981, Security and Liberty, Rec. 15, paras. 7-12.

69 CC Decision no. 2008-562 DC of 21 February 2008, Indefinite Sentences, Rec. 89, para. 22. See further Bjorge, Domestic Application of the ECHR, pp. 160-2.

70 S. Roussel, 'Le contrôle de proportionnalité dans jurisprudence administrative', AJDA 2021,780 . 
structure decisions. ${ }^{71}$ All the same, the intensity of review is not the same in every branch of law, even within the concept of proportionality, since the courts sometimes refer to 'disproportion manifeste'.$^{72}$ Proportionality is best used as a framework for the balancing of incommensurable interests - for example, the interests of the public and the consequences for private individuals where a significant element of subjective judgment must come into the decision. It enables questions to be examined in sequence: whether a measure is appropriate to achieve the legitimate objective, whether it is necessary to take this measure and whether the benefits outweigh the harms. The question of necessity includes an element of comparison between options that was not allowed in the ground of the manifest error in evaluation, so that already increases the intensity of review. On the whole, this ground will be used in relation to the interference with vested rights and interests and, increasingly, in relation to the environment.

\subsubsection{The Sliding Scale for Review}

When dealing with the review of the administration's exercise of discretion in the legal classification of facts, French authors distinguish between intensities of scrutiny. The significance of some decisions is such that they should be examined more carefully than others. The intensity of scrutiny depends on the nature of the discretion given and the subject matter about which decisions are taken.

Courts will exercise self-restraint in relation to some subjects. An obvious example is a very technical subject on which the administration will have undoubted expertise. Here the court will intervene only where there is a very obvious error in evaluation. For example, the courts will normally be very reluctant to intervene with assessments of whether a product is toxic. But the Conseil d'Etat did quash a decision where a total ban on a product was imposed, but the toxic effects were rare and occurred when the product was used with other products. ${ }^{73}$ No study was included in the file to justify a total

${ }^{71}$ See the dossier 'Actualité du contrôle de proportionnalité', AJDA 2021, no. 14, especially Roussel, note 70, and V. Goesel-Bihan, 'Le contrôle de proportionnalité au Conseil constitutionnel', AJDA 2021, 786 .

72 See CE 26 July 1991, Fédération nationale des syndicats de producteurs autonomes d'électricité, no. 91956 , for the first use of the expression by the Conseil d'Etat.

73 CE 15 May 2009, Société France conditionnement, no. 312449, AJDA 2009, 1668 note Markus; cf. CE Ass. 27 April 1951, Toni, Leb. 236 where the court refused to intervene with the classification of a product as toxic. 
ban. Other powers existed to require labelling or other measures to deal with the identified harms.

A second area for restrained scrutiny is public service promotion and discipline. These involve assessment of performance and are best undertaken by those within the service. For example, the decision by a university committee that an applicant for a post in Italian studies was more suited to a post in Corsican studies could only be quashed if there was a manifest error in evaluation. Since the committee had carefully examined his research record, he could not successfully challenge its decision. ${ }^{74}$ Similarly, a civil judge was unsuccessful in challenging the negative assessment made by the Conseil supérieur de la magistrature of his qualifications for being appointed a vice president at the cour d'appel of Paris, since no manifest error had been shown in that assessment. ${ }^{75}$ But in Syndicat Parisien des Administrations Centrales, the Conseil d'Etat quashed a decision by a minister to appoint a person from outside the civil service to the corps of the Inspection général des finances. ${ }^{76}$ The advisory committee on such external appointments had examined his experience and interviewed him, but it had concluded that he was not appropriately qualified for the role. Nonetheless, the Minister had appointed him. Given the evidence on file, especially from the advisory committee, which the Minister had not contradicted, the Conseil d'Etat concluded the Minister had committed a manifest error in evaluation in using his discretion to appoint the senior executive of an airline company to a role in financial audit. On the other hand, dismissal from a position will be more carefully scrutinised to see that the facts justifying the dismissal actually exist. In SAFER d'Auvergne c Bernette, the head of a farming support service had been accused by his superiors of running his service at a deficit and was sacked. ${ }^{77}$ Because he was a union representative, his dismissal required the approval of the board of the service and the works inspector, neither of which gave it. On representations by his superiors, the Minister approved the dismissal. But the administrative courts quashed the Minister's decision on the ground that the faults alleged against him were not sufficiently serious to justify dismissal. This stricter scrutiny applies where vested interests or rights are affected.

A third area traditionally for restrained scrutiny has been public order measures because these are matters of policy. But in more recent years, there has been an increased emphasis on human rights. As a result, public

74 CE 9 February 2011, Piazza, no. 317314, Leb. 956.

75 CE Ass. 8 June 2016, Prats, no. 382736 , Leb. 236 concl. von Coester.

$7^{6} \mathrm{CE} 23$ December 2011, Syndicat Parisien des Administrations centrales, économiques et financières, no. 346629, AJDA 2012, 607 note Dord.

77 See CE Ass. 5 May 1976, SAFER d'Auvergne c Bernette, nos. 98647, 98820, D. 1976, 563. 
order decisions which affect human rights will be subject to full scrutiny, as is shown in the Napol case. ${ }^{78}$ The same is true for public order measures to expel a person from the country or to refuse a residence permit. ${ }^{79}$

Finally, where the administration is given a broad and vague discretion, then the court will typically leave a wide area for discretion (un large pouvoir discrétionnaire). That is what we have already seen in Section 1.5.3 in relation to the application of the concept of 'public utility' in expropriation. A clear example where rights are not involved is the decisions of the Ministry of Education over the school curriculum. The Conseil d'Etat rejected a challenge to the refusal of the Minister to change the history curriculum in relation to the topic of the Armenian genocide of 1915. The complainants suggested the framing of the topic in the current curriculum was contrary to the duty of neutrality in teaching, but this was not considered to demonstrate a manifest error in evaluation. ${ }^{80}$

In rare cases, there will be minimal scrutiny which involves restricting scrutiny to an error of law, material error of fact or détoumement de pouvoir. This is limited to decisions which are both sensitive and involve broad discretion such as the award of honours ${ }^{81}$ and the decisions of juries in competitive examinations - which court would dare to review thousands of student exam scripts? - or the awarding of degrees. ${ }^{82}$

A normal intensity of scrutiny (contrôle normal) involves an examination of the materiality of facts and the absence of error of law or détournement de pouvoir. There is some latitude in the assessment of facts, but they must be capable of justifying the decision reached. The approach adopted by the Conseil d'Etat in Gomel illustrates this very clearly. ${ }^{83}$ It required that the decision of the administration be based on correct facts and interpretation of

78 CE Ass. 6 July 2016, Société Napol et autres, no. 398234, Leb. 320 concl. BourgeoisMachureau; AJDA 2016, 1635, Chapter 8, Section 4.4.

79 CE 12 February 2014, Ministre de l'Intérieur c Barain, no. 365644, Leb. 30 (insufficient evidence of the circumstances surrounding the convictions for sexual assault to amount to a serious threat to public order); CE Sect. 17 October 2003, Bouhsane, no. 249183, Leb. 413 (the court found the claimant's convictions for drug trafficking and use of false identity justified considering him a serious threat to public order and expelling him).

so CE 4 July 2018, Association pour la neutralité de l'enseignement de l'histoire turque dans les programmes scolaires, no. 392400, AJDA 2018, 1894.

81 CE 10 December 1986, Lorédon, no. 78376, Leb. 516 (claim to be granted the Légion d'honneur).

82 CE 20 March 1987, Gambus, no. 70993, Leb. 100 (refusing to review the decisions of an exam board for legal studies); CE 26 September 2018, Joublot, no. 405473, Leb. 709 (rejecting a challenge to questions in a university oral exam in history).

83 Note 31 . 
the law such that the application of the legal classification of a 'view of architectural value' was justified.

A maximum intensity of scrutiny gives little latitude for the assessment of facts by the administration. It examines how far the measures adopted by the administration are appropriate. This is used particularly where public order measures interfere with fundamental rights. The leading case is Benjamin, a case dealing with a version of no-platforming of speakers. ${ }^{84}$ A notorious rightwing speaker was banned from addressing a public meeting organised by a literary society on the ground that left-wing groups had threatened public disorder if he spoke. The Conseil d'Etat quashed the mayor's decision to ban the meeting on the ground that there was no evidence that the threated public disorder would be sufficiently serious to justify such a ban nor was it shown that a ban was the only way of dealing with the problem. The idea of maximum scrutiny is contested. Many scholars consider it identical to normal intensity. ${ }^{85}$ What is certain is that sometimes a decision maker is said to have no room for discretion (what is called compétence liée). For example, if the President of the Republic wants to dismiss a member of an independent administrative agency, this can only be done for the reasons set by the law and strictly interpreted. ${ }^{86}$

There has been a significant movement of areas that, in the past, were subject to minimum to normal control. A good example is civil service discipline. This was traditionally seen as an internal measure over which very limited review was exercised. For example, in 1978 in Lebon, a teacher's claim against a disciplinary penalty imposed for indecent acts with children was upheld simply on the ground that the facts alleged on file were 'material'. ${ }^{87}$ But in 2007 in Arfi, a motor vehicle expert assessor was struck off the list of approved experts by a public disciplinary panel on the ground that he had certified repairs had been made to three vehicles when this was not the case. ${ }^{88}$ He had been an expert for sixteen years and none of the vehicles was dangerous when it went back on the road. Given that the panel had available to it a range of sanctions and had chosen the most draconian, the Conseil d'Etat struck down the decision for manifest error in evaluation. Finally, in 2013, the Conseil d'Etat applied normal control to disciplinary matters. In Dahan, the Conseil d'Etat declared that in the discipline of public officials, ${ }^{89}$

\footnotetext{
CE 19 May 1933, nos. 17413, 17520, S. 1933.3.1.

See Guyomar and Seillier, Contentieux administratif, $\$ 249$.

CE 19 October 2020, M. B., no. 438620.

CE Sect. 9 June 1978, Lebon, no. 05911, Leb. 245.

CE Sect. 22 June 2007 , no. 272650 , Arfi, Leb. 263.

89 CE Ass. 13 November 2013, no. 347704, AJDA 2432; RFDA 2013, 1175 concl. Keller.
} 
it is the role of the court in judicial review ... to examine whether the facts alleged against a public official that are the subject of a disciplinary penalty constitute faults of a kind that justifies a penalty and whether the penalty imposed is proportionate to the seriousness of the faults.

In this case the findings of sexual harassment against an ambassador justified his forced retirement from office. This extent of control has subsequently been applied to prison discipline, where it was held insufficient for a lower court to limit its review to manifest error and that it should have considered whether the penalty imposed was proportionate..$^{\circ}$

\subsection{VALUES ENFORCED THROUGH JUDICIAL REVIEW}

Judicial review is concerned with enforcing legality. In most cases, this will involve ensuring that the powers and procedures laid down in specific legislation are respected. But there are some more generally applicable values which serve to interpret legislation and to act as benchmarks for the way the administration should act. This section will deal with two groups of provisions. First, it will deal with values connected with the protection of fundamental rights. Second, it will deal with principles of good administration. The need for general principles arises from the very nature of administrative law. Laferrière wrote that decisions of the Conseil d'Etat were inspired by 'traditional principles, written or unwritten, which are in some sense inherent in our administrative public law'. ${ }^{91}$ These days, many such principles are codified, but they remain a significant part of judicial review.

\subsection{FUNDAMENTAL RIGHTS}

Chapter 2, Sections 6.1, 6.4 and 6.5 considered the place of fundamental rights within public law. These days, there are rights recognised as of constitutional value identified predominantly by the Conseil constitutionnel. Indeed, the question préalable de constitutionnalité will ensure that the Conseil constitutionnel plays a dominant role in determining the standards to be applied by the administrative courts. Not all fundamental rights are constitutional rights. In particular, the European Convention on Human Rights contains some different rights to those in the French constitution. The general principles of (administrative) law provide additional protections to individuals.

$9 \circ$ CE 1 June 2015, Boromée, no. 380449 , Leb. 105 concl. Bretonneau.

$9^{1}$ Preface to the Traité de la juridiction administrative, 1st ed. (Paris: Berger-Levrault, 1887), p. xiii. 


\subsubsection{Constitutional Rights}

Since the Conseil constitutionnel undertook the review of laws enacted by Parliament on the ground of their compatibility with fundamental rights, the role of the administrative courts in the application of general principles of law has been less significant. That is even more the case since the question préjudicielle de constitutionnalité (QPC) was introduced, allowing the compatibility of enacted laws to be challenged in the course of litigation. So, on the whole, it is not the place of the administrative courts these days to define new fundamental liberties. That said, the administration makes many decisions which affect fundamental rights, and this requires the administrative courts to trace the detailed boundaries between the freedom of the administration to implement policies in the public interest and the fundamental rights of those whom their action affects. The contemporary work of the administrative courts is thus closely linked to the decisions of the Conseil constitutionnel.

The important background to any study of the work of the administrative courts in judicial review is the consultative role of the administrative sections of the Conseil d'Etat in advising on legislation (both draft laws and draft decrees or ordonnances), which was discussed in Chapter 3, Section 3.3.2. In this consultative role, the Conseil d'Etat's advice has to draw attention to any possible incompatibility of legislation with the Constitution alongside other superior norms. It will thus read attentively the case law of the Conseil constitutionnel. When it comes to judging cases on the application of such laws and decrees, the judicial section of the Conseil d'Etat will have available the advice given to the government by its administrative sections, as well as any rulings on a law by the Conseil constitutionnel.

In broad terms, when faced with a challenge to an administrative decision, the administrative courts will be looking not so much at the existence of a right as at its scope and at how far the requirements of the public interest justify interference with those rights. Furthermore, in relation to decrees, the Conseil d'Etat has the responsibility to ensure that the government has competence to make rules which interfere with individual rights. In principle, under art. 34 of the Constitution, legislation affecting the fundamental freedoms of the individual must be made by Parliament and not by the executive.

In Chapter 2, Section 6.1, it was explained that there is no single consolidated statement of fundamental rights. Instead, these are gleaned from the four written documents: the Constitution of 1958 , the Declaration of the Rights of Man and of the Citizen of 1789 , the Preamble to the 1946 Constitution, and the Charter of the Environment of 2005. In addition, fundamental principles are recognised by the laws of the Republic and other 
'principles of constitutional value'. It is not possible here to summarise all the different rights recognised in the past fifty years by the Conseil constitutionnel. Other works attempt this, and the reader interested in a particular fundamental right is advised to look on the Conseil constitutionnel's own website with translations of major cases into English, German and Spanish. ${ }^{92}$ This section will merely illustrate some of the ways in which the administrative courts serve to define fundamental rights.

The imposition of criminal penalties was an early topic in the Fifth Republic in which the authority of the Conseil constitutionnel made itself clear. Article 8 of the Declaration of the Rights of Man and of the Citizen provides "no one may be punished except according to a loi passed and promulgated prior to the offence'. The Conseil d'Etat took the view that this applied only to serious criminal offences (crimes and délits) but did not apply to minor criminal offences (contraventions) and regulatory offences. But the Conseil constitutionnel decided subsequently that a loi was required for any offence that led to imprisonment. ${ }^{93}$ In a contrasting example, the Conseil d'Etat has a well-established principle that reductions in the sentences for any crime or regulatory offence would be applied immediately, even to offences committed before the rule establishing the lower sentence came into force. ${ }^{94}$ The Conseil constitutionnel later considered that this was actually a constitutional principle inherent in art. 8 of the 1789 Declaration. ${ }^{95}$ The influences are thus reciprocal in terms of which court takes a lead, even if the Conseil constitutionnel has the final say on constitutional matters.

The freedom of association was recognised as a fundamental principle recognised by the laws of the Republic by the Conseil d'Etat in 1956. In Annamites de Paris, the Conseil d'Etat annulled a decree of the Minister of the Interior declaring unlawful an association formed by Vietnamese citizens because it breached this principle. ${ }^{96}$ The principle was then recognised famously by the Conseil constitutionnel in its path-breaking decision in 1971, the Associations Law. ${ }^{97}$ It was in this decision that the Conseil

See S. Boyron, The Constitution of France (Oxford: Oxford University Press, 2012) and, earlier, J. Bell, French Constitutional Law (Oxford: Oxford University Press, 1992).

93 Compare CE 12 February 1960, Société Eky, no. 46922, Leb. 101 with CC decision no. 73-80 L of 28 November 1973, Criminal Penalties (Rural Code), Rec. 45; D. 1974, 269; Bell, French Constitutional Law, Material 6 and Decision 10.

94 See CE 23 July 1976, Secrétaire d'Etat aux Postes et Télécommunications, no. 99520.

95 CC decision no. 80-127 DC of 19 and 20 January 1981, Security and Liberty, Rec. 15, para. 71.

96 CE Ass. 11 July 1956, Amicale des Annamites de Paris, no. 26638, Leb. 317.

97 CC decision no. 71-44 DC of 16 July 1971, Associations Law, Rec. 29; Bell, French Constitutional Law, Decision 1. 
constitutionnel declared the principles recognised by the laws of the Republic enforceable as law in a kind of Marbury $v$ Madison moment.

Freedom of religion (liberté du culte) remains very contested in France. On the whole, French public law adopts a privatised conception of freedom of religion - it is a permissible activity undertaken in private. But when people wish to express themselves in public, then concerns of public order and secularism constrain it without suppressing it. The principle of secularism tends to trump it, especially in the public service. So public employees are banned from wearing clothing or insignia that demonstrate their adherence to a religious belief. ${ }^{8}$ Indeed, volunteers, such as parents accompanying children on a school outing, must also respect these requirements, but can only be sanctioned for breaching public order, which is rarely the case. ${ }^{99}$ The Conseil d'Etat also did not find a 2004 law banning the wearing of religious signs in state schools contrary to the European Convention, ${ }^{100}$ which was an outcome similar to the European Court of Human Rights decision in Leyla Şahin a few months earlier. ${ }^{101}$ That law was subsequently upheld directly by the European Court of Human Rights. ${ }^{102}$

The administrative courts have the role not merely in enforcing the freedom of religion, but also in defining its scope. A good illustration is Association Civitas in 2020. ${ }^{103}$ Regulations made to deal with the Covid-19 crisis restricted church services to thirty participants irrespective of the size of the building. This was challenged by a Catholic association and by the French Catholic bishops. The Conseil d'Etat emphasised that freedom of religion was not only an individual right but included as an essential component the right to participate collectively in 'ceremonies', especially in places of worship. But the individual and collective aspects of the right had to be reconciled with the public interest, in this case the constitutionally recognised value of the protection of public health. But the government was found to have acted disproportionately to the risk in imposing a blanket ban, rather than permitting a limit to

98 CE avis 3 May 2000, Mlle Martaux, no. 217017, RFDA 2001, 146 concl. Schwartz.

99 TA Nice, 9 June 2015, D, no. 1305386, AJDA 2015, 1933.

$100 \mathrm{CE} 8$ October 2004, Union française pour la cohésion nationale, no. 269077, RFDA 2004, 977 concl. Keller.

101 ECHR (Grand Chamber), App. no. 44774/98, Leyla Şahin v Turkey [2004] ECHR 299.

102 ECHR (Grand Chamber), App. no. 43835/11, SAS v France [2014] ECHR 695. Further: J. Bell, 'Secularism French Style' [2017] European Public Law 237, and Ilias Trispiotis, "Two Interpretations of "Living Together" [2016] C.L.J. 580.

103 CE ord. 29 November 2020, Association Civitas, Conférence des Evêques de France, no. 446930, AJDA 2021, 632. The commentary in that report suggests that the decree reflected a misstatement by the Minister in a press conference and that the limit should have been up to 30 per cent of the capacity of the building, not thirty people. 
be set in relation to the size of the building, as was set out in the decree in relation to other premises open to the public, such as shops. In this respect, the decision in this case followed the approach on proportionality seen in the Church Gatherings case earlier in the same year. ${ }^{104}$

The definition of rights may not be clearly based on a constitutional text and therefore the Conseil d'Etat may appeal to 'general principles of law', as was noted in Chapter 2, Section 6.5. The leading example is GISTI (1978). ${ }^{105}$ A decree of 1976 gave the right for families of foreign workers to come to France and to obtain a residence permit except in limited circumstances. Eighteen months later, given rising unemployment as a result of an economic crisis, the rights under the 1976 decree were suspended for three years except for those who did not seek to work in France. The decree was challenged by an immigration non-governmental organisation, GISTI, on the ground that it breached the right to a normal family life found in the tenth paragraph of the preamble to the 1946 Constitution: "The Nation shall ensure the individual and the family the conditions necessary for their development.' The commissaire du gouvernement argued that a general principle of law giving a right to a normal family life could be found in that text, especially in the light of a number of international agreements France had signed, notably the European Social Charter of the Council of Europe which France had ratified in 1973. By reading the preamble broadly, a right to a normal family life could be found not only for French citizens, but for foreign workers also. The Conseil d'Etat found that the government had failed to respect this principle by enacting a general ban on foreign workers bringing their families. It did, however, hold that the government had the role of defining the way in which this right could be exercised as long as it complied with international agreements France had signed (particularly EU law) and concerns of public policy and the social protection of foreigners, but always subject to the control of the courts. In this way, the government enjoys a margin of appreciation in determining the rights of families, as in many other rights. The case also shows clearly that constitutional rights cannot be seen in isolation from the international treaties on rights France has signed. Since both constitutional rights and treaties are binding on the Conseil d'Etat, it is not surprising it seeks to ensure interpretations of both that are consistent with each other.

The GISTI decision effectively shows how the Conseil d'Etat has been able to contribute to the recognition (if not the creation) of constitutional norms.

104 See note 65 .

105 CE Ass. 8 December 1978, Groupe d'Information et de Soutien des Travailleurs Immigrés, no. 10097 , D. 1979, 661 note Hamon. 
This was shown even more sharply by Koné in 1996, where the Conseil d'Etat declared a new 'principle recognised by the laws of the Republic'. ${ }^{106}$ In this case, courts in Mali sought the extradition of the claimant for a variety of offences involving complicity in diverting public funds and unlawful enrichment from them. The extradition treaty between France and Mali contained an exclusion for political and connected offences. The Conseil d'Etat stated this provision must be read in the light of a general principle recognised by the laws of the Republic that extradition must not be sought for a political purpose. This was a principle the Conseil d'Etat had expressed in its administrative capacity in the previous year. ${ }^{107}$

\subsubsection{European Convention on Human Rights}

As noted in Chapter 1, the European Convention on Human Rights has been a major reference point on fundamental rights in the past fifty years. Since French lawyers were among the major authors of the Convention, there is a natural continuity between the Convention and French law, though the Convention has encouraged a greater focus on the rights of the citizen, rather than the need to promote the public interest represented by the administration. As an illustration, freedom of the press has been protected by administrative law for a long time. But the state is given broad scope to restrict it in the public interest. In 1973 (before France ratified the European Convention) in Librairie François Maspero, the Minister of the Interior banned the Revue Tricontinental. Edition Française on the ground that it essentially reproduced the content of a journal published in Cuba which the Minister had already banned. ${ }^{108}$ The journal was a French translation and so could come under powers to ban journals of foreign origin, even though the French edition was totally produced in France. The Conseil d'Etat moved from reviewing on ground of error of material fact to announcing it would review manifest error in evaluation. On the facts of this case, no such error was found. But, under the influence of the European Court of Human Rights, it decided to increase its level of scrutiny. In Société Ekin in 1997, the claimant company published a French-language version of a Basque journal under the title Euskadi en guerre. ${ }^{109}$ The Minister of the Interior banned it using the same powers as in the François Maspero case. But here, noting the provisions on the freedom of

106 CE Ass. 3 July 1996, Koné, nos. 394399, 400328, Leb. 355.

107 Etudes et Documents du Conseil d'Etat 1995, p. 395.

108 CE Ass. 2 November 1973, Librairie François Maspero, no. 82590, Leb. 611.

109 CE Sect. 9 July 1997, no. 151064 AJDA 1998, 374 note Verdier. A further example is CE 10 June 2021, Syndicat national des journalistes, no. 444849, AJDA 2021, 1791 and 1803 where 
the press in the European Convention, the Conseil d'Etat decided it would 'examine whether the banned publication is of a nature to harm [the public interest] in such a way as to justify the interference with civil liberties'. In that case, the Minister did not sufficiently demonstrate the harm caused and his decision was quashed. The structure of this later judgment shows clearly how the Convention has altered the approach to review of decisions on the freedom of press. Whereas François Maspero basically upheld the decision of the administration to invade a basic liberty unless it was obviously wrong, the Société Ekin decision only upheld the decision of the administration if it has shown a sufficiently strong case to justify the interference with a basic liberty.

The cases on clothing reflecting religious beliefs discussed in the previous section show the relationship between French administrative law and the European Convention. The French judge at the Strasbourg court was questioned by the French Parliament before it voted on the 2004 law, and his view on the likely approach of the European Court of Human Rights was then reflected in the Leyla Şahin judgment a few months later, in which he took part. ${ }^{110}$ As Bjorge points out, that case and the subsequent SAS case in relation to France relied on the margin of appreciation doctrine which gave a wide discretion to national authorities. ${ }^{111}$ But he also explains that this scope extends to the right to life. In the Lambert case, ${ }^{112}$ the Conseil d'Etat was asked to rule on whether a public hospital should be allowed to end treatment for a tetraplegic in a total state of dependence. The doctors had followed the procedure laid down in French law and so had done nothing unlawful. On careful examination of the Strasbourg case law, it concluded that the Convention left the French authorities a significant margin of appreciation in such circumstances and that it was the Conseil d'Etat's role to examine the French law in detail. It carefully reviewed the legally authorised procedures and was satisfied that they provided safeguards to protect the rights to life and privacy. Having carefully examined the facts, including specially commissioned expert evidence, the Conseil d'Etat concluded there was no reason to question the decision taken by the doctors and the public hospital. The decision was not found incompatible by the European Court of Human Rights. ${ }^{13}$ The case shows the close interaction between the

public order considerations were held not to be sufficiently strong to justify restrictions on giving public information to journalists.

11 See note 101.

111 Bjorge, Domestic Application of the ECHR, pp. 26, 30, 190.

112 CE Ass. 24 June 2014, Mme Rachel Lambert, M. François Lambert \& Centre hospitalier de Reims, nos. 375081, 375090, RFDA 2014, 657; Bjorge, Domestic Application of the ECHR, pp. $187-90$.

${ }^{113}$ ECHR (Grand Chamber) 5 June 2015, App. no. 46013/14, Lambert v France [2014] ECHR 605. 
French administrative courts and the European Court in trying to apply the European Convention to specific situations.

\subsubsection{General Principles of Law}

As seen in Chapter 2, Section 6.5, the general principles of law emerged as an idea during the Third Republic and at the Liberation in 1944-6. Unlike most French regimes since the Revolution of 1789 , the Third Republic had no written constitutional text. When legality was restored after the Vichy period in August 1944, it took until October 1946 for a new constitution to be adopted and no legal effect was given to the provisions on fundamental rights contained in the preamble, which also referred to the Declaration of the Rights of Man and of the Citizen of 1789 . In particular, in dealing with the problems related to the Vichy regime and its aftermath, it was necessary to formulate French republican legal values more precisely. As Batailler explained,

The 'republican constitutional tradition' permits the consecration of the principles of political organisation, whereas the general principles of law reflect the principles of individual civil rights (such as equality, individual and public liberty). ${ }^{114}$

The term formally appeared first in Aramu in 1945 when the Conseil d'Etat talked of 'general principles of law applicable even in the absence of a text' in relation to the actions of the Liberation administration. ${ }^{115}$ In his substantial thesis on the topic, Jeanneau argued that the general principles articulated in the 1940s and 1950s could be traced in Conseil d'Etat decisions since before the First World War, but it was during the Vichy regime that they needed to become more explicit, since the Conseil d'Etat was the sole constraint on the government of that time. ${ }^{116}$ All the same, during the Vichy period the control exercised over government decisions was limited. ${ }^{117}$

The status of general principles is important in the Fifth Republic because they constrain the executive both in its decisions and in its legislation. As the

114 F. Batailler, Le Conseil d'Etat juge constitutionnel (Paris: LDGJ, 1966), pp. 151-2.

115 CE Ass. 26 October 1945, no. 77726, Aramu, S. 1946.3.1 concl. Odent (the right of a civil servant to present a defence to a commission d'épuration).

${ }^{116}$ See B. Jeanneau, Les principes généraux du droit dans la jurisprudence administrative (Paris: Sirey, 1954), p. 3 ; G. Morange, 'Une catégorie juridique ambiguë : les principes généraux du droit', RDP 1977, 761 at pp. 764-5. See also the conclusions of Letourneur in Barel RDP 1954, 509 at p. 526 where he argued that the Declaration of 1789 'serves as the basis for many of your decisions'.

${ }^{117}$ Notwithstanding the valiant effort to give a positive account in T. Bouffendeau, 'Le juge de l'excès de pouvoir jusqu' à la libération du territoire métropolitaine’, EDCE 1947, 23. 
Conseil d'Etat made clear in 1959, 'the general principles of law ... as they follow especially from the Preamble to the Constitution, are binding on every regulatory authority even in the absence of legislative provisions'. ${ }^{118}$ They bind the decree-making power of the administration, including when the government is empowered to legislate by ordonnances before they become a law. The idea of general principles as a supplement to legal texts was adopted early on by the European Court of Justice. ${ }^{119}$ The approach of using international treaties to establish general principles of (domestic) law was shown in the GISTI (1978). It was also shown in Bereciartua-Echarri, which recognised the non-constitutional general principle that a political refugee could not be extradited to his original country. ${ }^{120}$ It derived the principle from the definition of a refugee in the Geneva Convention on Refugees of 1951. So the sources of general principles these days can be varied. Since the Conseil constitutionnel can only base constitutional principles on domestic constitutional documents, there is scope for the Conseil d'Etat to establish a wider range of non-constitutional principles incorporating the full range of sources of law applicable in French law.

In 1951, Rivero identified four sources of general principles of law. ${ }^{121}$ First, there were the traditional principles of the Revolution of 1789 , such as equality, freedom of trade, freedom of conscience and the secular character of the state. Second, there were principles drawn by analogy with private law basically to make up for the absence of written texts in administrative law. These included the binding nature of judicial decisions and the right to be heard in your defence. Third, there were principles derived from the nature of things, the logic of institutions, such as the need to ensure the continuity of public services. Fourth, there were the necessary ethical principles, such as the requirement that the administration serve the common good. Certainly, the last three sources and some elements of the first typically do not give rise to constitutional principles and so remain very much to be developed by the administrative courts.

Traditional principles are mainly laid down in the Declaration of the Rights of Man of 1789 . In particular, the principle of equality has been a major source of general principles. These general principles are additional to specific treaty or legislative rights to equality contained, for example, in art. $21 \mathrm{TEU}$, which

118 CE Sect. 26 June 1959, Syndicat général des ingénieurs-conseils, no. 92099, RDP 1959, 1004 concl. Fournier.

119 See ECJ Cases 37, 38, 39 \& 40/59, 15 July 1960, Präsident Ruhrkolen-Verkaufsgesellschaft mbH ECLI:EU:C:1960:36, para. 2.

120 CE Ass. 1 April 1988, no. 85234, RFDA 1988, 499 note Genevois.

${ }^{121}$ J. Rivero, 'Le juge administratif français : un juge qui gouverne’, D. 1951 Chr. 21 at p. 22. 
prohibits discrimination of a wide variety of kinds, such as sex, race, disability or age. Three main areas for the use of general principles can be identified within public services: equality among the providers of public services (the civil servants or procurement contractors), equality among the recipients of public services (the users), and both for the access and in the treatment given by public service. The basic idea of equality before the law is that those who are in the same situation have to be treated equally without preference or favour, but that different situations may be treated differently. ${ }^{122}$ To take a simple example, all road users should be treated equally. It is not legitimate to discriminate between religious processions on the highway and other processions. ${ }^{123}$ By contrast, it is permissible to have different arrangements for parking on the highway for different kinds of transport. ${ }^{124}$ This is very different from ensuring equal treatment in practice. For example, uniform restrictions on the production of a specific kind of cheese may affect differentially those who can diversify and traditional cheesemakers who could not. ${ }^{125}$ The typical formulation is:

The principle of equality neither prevents the legislator (or the regulatory power) regulating different situations differently nor derogating from equality for reasons of public interest, provided that the difference in treatment resulting in each case is directly related to the purpose which the law authorises.

Put in this way, differences are fine provided there is an objective difference in situation related to what the law is trying to achieve.

Equality takes various forms which are presented here in terms of classic headings found in French administrative law texts.

Equal access to public office was a key principle of the Revolution (art. 6 DDHC). In 1912, this was extended by the conclusions of commissaire du gouvernement Heilbronner to include equal access to the civil service, which was no longer to be at the discretion of ministers. ${ }^{126}$ This was formally recognised in the Barel case in 1954, where discrimination on grounds of political allegiance was rejected as a relevant ground for excluding candidates to ENA. ${ }^{127}$ Judicial interpretation enabled the equality of women for access to

\footnotetext{
122 CE 27 July 1928, SA des usines Renault, no. 79735, Leb. 969.

123 CE 4 December 1925, Charton, no. 77765, Leb. 972.

124 CE 4 May 1945, Syndicat des entrepreneurs des transports de la Riviera, no. 38517, Leb. 94.

125 CE 27 April 1987, Comité interprofessionnel du Gruyère de Comté, no. 49854, Leb. 146 ; also CE 22 February 1950, Société des ciments français, nos. 87957, 87958, Leb. 175.

126 CE 10 May 1912, Bouteyre, no. 46027, D. 1914.3.74 concl. Heilbronner.

127 See note 34 .
} 
central government employment well before they were given the vote in $1944{ }^{128}$ In more recent times, this gives rise to a way of interpreting legal rules in the absence of a specific text so as to ensure civil servants are treated equally. For example, rules on work accidents allowed compensation for a second work invalidity happening to a civil servant to take account of a previous work injury which had caused an invalidity when she was in a different civil service position. Despite the absence of a specific provision, the rule was applied to a case where a second invalidity resulted during work in a civil service and a previous invalidity occurred on military service. ${ }^{129}$ A similar example occurred when the rules of the SNCF pension scheme allowed parents of a severely handicapped child to retire within three years of the birth of the child and to receive an immediate pension payment. It was held that there was no justification in the public interest that justified the three-year limit and so discriminated between those who retired within three years of the birth of the child and those who retired later in the life of the child. $^{130}$

Equality in taxation (égalité devant l'impôt) is something the Revolution was very keen to secure, rather than the different tax obligations of the different estates of society (aristocrats, clergy and others). It found its expression in art. 13 DDHC. It was recognised by the Conseil d'Etat in 1922 and confirmed in $1936 .{ }^{131}$ Where taxes are set by a law, then the Conseil constitutionnel has a very rich case law on equality in taxation. ${ }^{132}$ In its view, equality before taxation does not at all mean tax rules should be the same for everyone. Different taxes or tax rates for different people is perfectly constitutional. For example, the taxation of private individuals and companies can legitimately differ. ${ }^{133}$ As long as the difference is justified by a difference in situation or by a different reason of public interest, then a difference is justified, but not where having an arbitrary date for the treatment of those benefiting from a usufruct could not justify different treatment. ${ }^{134}$ Equally, different rates of tax on

${ }_{128}$ See CE 3 July 1936, Bobard, no. 43239, D. 1937.3.38 concl. Latournerie.

129 CE 20 November 2020, no. 431508.

130 CE 9 October 2019, no. 428634 .

${ }^{131}$ See CE 5 May 1922, Sieur Fontan, Leb. 386 (tax on vehicles in Hanoi); CE 23 November 1936, Abdouloussan, Rec. 1015 (differential taxation).

${ }^{132}$ See Bell, French Constitutional Law, chapter 6, section C 3; L. Ayrault, 'Le principe d'égalité en matière fiscale’ (April 2020): www.conseil-constitutionnel.fr/publications/titre-vii/leprincipe-d-egalite-en-matiere-fiscale (visited 15 March 2021).

133 See CC decision no. 2014-425 QPC of 14 November 2014, Special Tax on Fire Insurance, ECLI : FR : CC : $2014: 2014 \cdot 425$. QPC.

134 See CC decision no. 2017-758 DC of 28 December 2017, Finance Law for 2018, ECLI : FR : CC : $2017: 2017 \cdot 758$.DC, para. 59. 
alcoholic beverages depending on whether the premises had signed an agreement with the local tourist agency was held to be an excessive interference with the public health purpose of the tax measure. ${ }^{135}$ By contrast, it is not required that companies in different situations should be taxed at different rates. Thus, in Société Baxter pharmaceutical companies complained about special taxes introduced to balance the social security budget. ${ }^{136}$ The tax rates did not distinguish between companies that had signed agreements with the government about the supply of pharmaceutical products (and thus their price) and those that had not. But this was held not to be an unjustifiable inequality of treatment. The non-constitutional features of equality in taxation focus on equality in the application of tax rules and equality in the recovery of taxes. ${ }^{137}$

Equality before public services (égalité devant les services publics) is not found in the Declaration of 1789 at all. But the idea was already found earlier in the eighteenth century. Thus, the courts of Marseille argued that 'The letter post is an institution created for the public and for the utility of all the subjects of the King. They all contribute to the costs of the institution according to their means and from the product of general taxation. They should thus all equally receive its fruits. ${ }^{138}$ Accordingly, no preferential treatment could be given to the chamber of commerce in Marseille in the distribution of letters.

The first case in which this principle was discussed before the Conseil d'Etat was Chomel in 1911, where a postmistress objected to delivering post to the complainant on the ground that he had a dog and to delivering to his valet, because he had an even more ferocious dog. ${ }^{139}$ The matter was referred to the Minister in Paris who decided Mr Chomel should not receive letters or telegrams at home until he installed either a post box or a bell at the perimeter of his property. Chomel sought judicial review and the decision was quashed on the ground that only exceptional circumstances could justify refusing him the application of the general rules of the public service. The decision of the

135 CE 22 March 2006, no. 288757.

${ }_{136}$ CE Ass. 28 March 1997, nos. 179049, 179050, 179054, RFDA 1997, 450 concl. Bonichot, note Melin-Soucramanien.

137 CE 4 February 1944, Guiyesse, no. 62929, RDP1944, 169 concl. Chenot (a claim that tax rates were different between goods produced in Senegal and those imported there).

${ }^{13^{8}}$ See J.-L. Mestre, Introduction historique au droit administratif français (Paris: Presses Universitaires de France, 1985), pp. 270-1.

139 CE 29 December 1911, Chomel, reported in RDP 1912, 26 at Pp. 35-8, note Jèze. The first explicit reference to the principle was in CE 10 February 1928, Chambre synodical des propriétaires de Marseille, Leb. 222 (division of water services into two tariff zones where there was only a single source). 
Minister was quashed because he was unable to establish the existence of such a reason.

The principle had its classic application in Société des concerts du conservatoire. $^{140}$ In this case, the orchestra company had sanctioned two members for taking part in a concert organised by the national radio broadcaster, Radiodiffusion française. Radiodiffusion française responded by suspending the broadcasting concerts given by the orchestra. The orchestra company was successful in challenging this decision. The Conseil d'Etat held that Radiodiffusion française had failed to respect the principle of equality in public services and had used its powers for an extraneous purposeto punish the orchestra for its treatment of its members. This decision established the idea of equality in the functioning of public services, even if it had earlier roots.

This principle continues to be recognised both in legislation and in judicial decisions. For example, in 2021 a decision concerned the application of a legal obligation on communes to provide a connection for drinking water to properties. In this case, the commune refused to connect a group of new houses on its boundaries. When this decision was challenged, the tribunal administratif annulled the decision, but the cour administrative d'appel reversed it. The Conseil d'Etat quashed the cour administrative d'appel and remitted the case to be considered in the light of whether the commune had examined the need to make provision for access to water, and if so, whether its decision was vitiated by a manifest error in evaluation. ${ }^{141}$

The principle does not always require the same treatment for all users of a public service. Indeed, the failure to respect actual difference of situations will often be a breach of the principle in very specific circumstances. A good example is Commune de Chalons-sur-Saône, where the mayor announced by a press release that primary school canteens would only have one menu option and no substitute menu would be available when pork was served. ${ }^{142}$ The decision was endorsed almost unanimously by the council on the ground that it was required by the principle of secularism (laïité) and the neutrality of public services. This was challenged by a Muslim organisation and parents for its failure to make provision for their children. This was an optional public service, but once it had been set up, it had to be operated taking account of the public interest and the interests of all users. Secularism did not prevent or

140 CE Sect. 9 March 1951, no. 92004, Leb. 151; S. 1951.3.81. The commentary in Grands Arrêts,

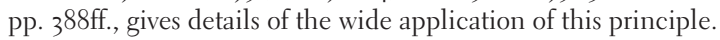

141 CE 26 January 2021, no. 431494.

${ }^{142}$ CE 11 December 2020, Commune de Chalons-sur-Saône, no. 426483. 
oblige the commune to provide meals which respected the religious beliefs of children, but the commune had failed to prove that a substitute meal was not practically possible, and so the decision was quashed.

On the whole, the administration is left with a wide latitude for its own assessment of how equality should be applied, and the courts will sanction only manifest errors in evaluation.

Principles borrowed from private law are particularly important in public law contracts, liability law and employment law (including the civil service). For example, in CCI de Meurthe et Moselle, the Conseil d'Etat identified a general principle of law illustrated by the (private law) Labour Code under which an employee who became physically unable to continue in her present work should be found suitable alternative activity within the organisation by her public employer and only be dismissed if this could not be found. ${ }^{143}$ Earlier public employment cases had also borrowed from private law to establish basic terms and conditions. For example, in Peynet, a nurse was dismissed at a public hospital while pregnant. ${ }^{144}$ Drawing on a general principle of law illustrated in the Labour Code, the Conseil d'Etat held that no employer could dismiss a pregnant employee, except in special circumstances, such as public service emergencies, which did not apply here. Similarly, in Ville de Toulouse c Mme Aragnou, the Conseil d'Etat found that there was a general principle of law illustrated in the Labour Code that any employee should not be paid less than the minimum wage, and that this applied to public employment, even in the absence of a text. ${ }^{145} \mathrm{~A}$ more significant general principle was established in Berton, where it was held that the alteration of the essential terms and conditions of employment in the public sector could only occur with the agreement of both the employer and the employee. ${ }^{146}$ This general principle was found illustrated in the Civil Code and the Labour Code, which held that collective agreements are binding. The old model of unilateral power on the part of the administration was limited to exceptional circumstances. Accordingly, the SNCF could not introduce a new rule into the collective agreement allowing it to demote an individual in the case of proven lack of competence in his role without the agreement of the unions. On the whole, the Conseil d'Etat is reluctant to economic and social rights on the ground that they are more specific and changing. That is particularly the case

\footnotetext{
143 CE 2 October 2002, CCI de Meurthe et Moselle, no. 227868 , AJDA 2002, 1294.

144 CE Ass. 8 June 1973, Dame Paynet, no. 80232, Leb. 406 concl. Suzanne Grévisse.

145 CE Sect. 23 April 1982, no. 36851, Leb. 152 concl. Labetoulle, AJDA 1982, 440.

${ }_{146}$ CE Ass. 29 June 2001, no. 222600, AJDA 2001, 648 chr. Guyomar and Colin.
} 
in economic matters where the boundaries of what remunerative activities public bodies can undertake changes over time.

The nature of things is a label used to describe principles necessary for the public service to work. On the one hand, this may justify certain prerogatives of the administration to act in the public interest. For example, in Films Lutetia, legislation of 1945 established a national system of film certification, characterised as a public order special power. ${ }^{147}$ Despite certification by the Minister that they were permitted to be shown, the mayor of Nice banned several films on the ground that they were contrary to decency and good morals. Various organisations had campaigned against the laxity of the national certification. The Conseil d'Etat upheld the power of the mayor to use his public order general powers under a law of 1884 in this way. It held that the local situation described in evidence could legally justify the use of this power to protect public order in his locality. Although not appealing to any general principle, the powers of the President of the Republic to manage national public order, even in the absence of an express power, had been recognised in Labonne. ${ }^{18}$ Although the law of 1884 gave express general powers on public order to the mayor and the prefect, the President of the Republic was held to have the power to introduce a national system of driving licences in order to maintain public order on the roads, even without any specific text. This power included setting out the circumstances justifying the removal of the driving licence which the claimant contested.

The Conseil constitutionnel has suggested that there are some public services 'whose necessity follows from principles and rules of constitutional value'. 49 The extent of this remains debated. The idea is mainly used to determine whether a particular activity is a public service. For example, it has been held that horse racing is a public service as an implicit consequence of a law of 1891 and so the discipline of trainers is governed by principles of public law. ${ }^{150}$

The continuity of the public service was first a general principle of law. The right to strike was recognised in the preamble to the Constitution of 1946, but in an ambiguous way, stating that this right exists "in the framework set by the law'. In Dehaene, six heads of section in a prefecture were sanctioned as a result of taking part in a strike of civil servants in $1948 .^{151}$ They challenged

147 CE 18 December 1959, nos. 36385, 36428, D. 1960, 171 note Weil.

$14^{8}$ CE 8 August 1919, no. 56377 , Leb. 737.

149 CC decision no. 86-207 DC of 25 and 26 June 1986, Privatisations, Rec. 61; Bell, Constitutional Law, Decision 30, para. 53. See further J. Waline, Droit administratif, 28th ed. (Paris: Dalloz, 2020), para. 393.

150 CE 12 October 2018, Boutin, no. 410998, AJDA 2018, 2338 concl. Odinet.

${ }^{151}$ CE Ass. 7 July 1950, no. o1645, JCP 1950.II.5681 concl. Gazier. The notes in Grands Arrêts, pp. 371-2, explain the strong case law of the Conseil d'Etat against strikes in the public sector during the Third Republic. 
the sanction on the ground that it breached the right to strike recognised by the Constitution. The Conseil d'Etat rejected the claim on the ground that, even in the absence of a specific text, the government's responsibility for public services entitled it to determine the limitations on the right to strike necessary for public order. The Conseil d'Etat then went on to uphold the right of a minister to prescribe the terms of a minimum service to be maintained in public services (in this case, the national radio and television stations). ${ }^{1.2}$ This restriction on the right to strike to protect continuity in the public service was recognised as a constitutional principle by the Conseil constitutionnel in 1979, also in relation to national radio and television stations. ${ }^{153}$

A different principle is the duty of the public service to provide protection in their functions to civil servants. In a case in 2019 , the French army in Afghanistan employed an Afghan as an interpreter. ${ }^{154}$ When the French army withdrew, he faced threats as a result of his work for the French and sought a visa for himself and his family. The Conseil d'Etat held that there was a general principle requiring the state to offer protection to civil servants who were the subjects of litigation or threats relating to their service and that this might, in some cases, include the duty to provide a visa for him and his family to reside in France.

Ethical principles would include the obligation to serve the common good. This idea is reflected in the decisions we have seen already on détournement de pouvoir where decisions of public officials were quashed because they were seeking to obtain a private advantage rather than to promote the public good.

Another major ethical principle is the neutrality of the public service. That requires that the public service is not attached to any particular political, religious or ethical movement within society. For example, in Fédération des parents d'élèves de l'enseignement public, a decree required all associations providing sporting activities for primary state school pupils to belong to an association which was avowedly secular. ${ }^{155}$ This requirement had no necessary connection with the good functioning of the public service and was contrary to the neutrality of the public service. This principle is often invoked so as to prevent support for religious bodies. In a series of decisions in 2011, the Conseil d'Etat concluded that the principle did not prevent the grant of public funds to support the maintenance or even the construction of a religious building. But

\footnotetext{
${ }_{152}$ CE 12 November 1976, Syndicat unifié de radiodiffusion et de télévision CFDT, no. 98583, Leb. 484 .

153 CC decision no. 79-105 DC of 25 July 1979, Strikes in Radio and Television, Rec. 33; Bell, French Constitutional Law, Decision 23.

154 CE 1 February 2019, L, no. 421694, Leb. 13 concl. Henrad.

155 CE Ass. 21 October 1988, no. 78462, RFDA 1989, 124 concl. Faugère.
} 
the support had to be given to an association constituted under a law of 1905 which held the property of building rather than promoted religious services and activities. So a commune could construct a multipurpose building and then lease it out to an association for use as a place of Islamic religious worship, or it could acquire and hire out equipment to be used in a temporary abattoir for the festival of Eid, or to fund a lift to help disabled people gain access to a Catholic basilica, or to fund an organ which would be placed in a church and be used both for religious services and public concerts. ${ }^{156}$ The French conception of the neutrality of the public service can lead to strange results. For example, it has been held that a priest might not teach in a school as this is incompatible with neutrality, ${ }^{157}$ but that it is perfectly compatible for a Minister of Religion to be the head of a university. ${ }^{1{ }^{8}}$ The difference is explicable by the fact that the latter case took place in the Alsace region and that the cornerstone principle of secularism, though not all the rules, were laid down by a law of 9 December 1905, which came into force at a time when Alsace (and the département of Moselle) was German. As a result, when the region was returning to France after the First World War, the 1905 law was not introduced and is still not applicable.

The principle of neutrality requires civil servants to abstain from any partisan comment when they perform their functions, to show loyalty to state institutions and to obey their political superiors. ${ }^{159}$ But this does not prevent civil servants belonging to political parties outside their duties. Indeed, many leading civil servants and judges have become prime ministers, Presidents of the Republic and members of Parliament. On the contrary, since their position is secure once they return to civil service, it naturally leads to an overrepresentation of civil servants among politicians which is often criticised.

\subsubsection{Modern Emerging Principles}

Rivero was right in 1951 to emphasise the place of traditional principles drawn from the 1789 and 1946 declarations of rights or found in principles recognised in the laws of the Republic, especially the Third Republic from 1870 to 1940.

156 CE Ass. 19 July 2011, Commune de Montpellier, no. 313518; Communauté urbaine du Mans no. 309161; Fédération de la libre pensée du Rhône, no. 308817; Commune de Trélazé, no. 308544 , Leb. 372 concl. Geffray; RFDA 2011, 967.

157 CE 10 May 1912, Abbé Boutèyre, no. 46027, Leb. 553 concl. Heilbronner; S.1912.3.145 note Hauriou (rejecting a claim by a priest excluded for the competitive examination to teach philosophy in a secondary school).

${ }_{158}$ CE 27 June 2019, SNESUP-FSU, no. 419595 (rejecting a claim that a Minister of Religion could not be appointed president of the University of Strasbourg).

159 CE Sect. 3 March 1950, Jamet, no. 98284 , Leb. 247. 
But society has evolved a lot since 1946. The Constitution of 1958 did not add many new principles and international treaties are necessarily limited, notwithstanding the 'living instrument' approach of the European Court of Human Rights. The question arises whether further fundamental principles can be identified that deal with contemporary problems. The approach of the administrative courts is often innovative. It is often called upon to declare something a fundamental freedom in the context of the référé-liberté procedure. As discussed in Chapter 2, Section 3, under art. L 521-2 CJA, the judge is empowered to make an order to safeguard a fundamental freedom which the decision of a public body or a private body carrying out a public service has seriously and manifestly unlawfully infringed. The scope of 'fundamental freedom' is interpreted very broadly and goes beyond constitutional liberties or those recognised by the European Convention on Human Rights or by the European Charter of Fundamental Rights. The use of contemporary legislation as the source of fundamental rights can be illustrated in two areas: the rights of the handicapped and the right to housing.

There is no explicit constitutional right of disabled people, as the issue was not salient before 1946. Instead, it has fallen to the legislature to enact a law of 2005 on the equality of those with disabilities, thereby improving on a law of 1975. The Conseil d'Etat has also used its interpretation of general principles to recognise this development. For example, in Pehrilhé, the Conseil d'Etat held that the failure to provide any schooling or adapted schooling could constitute a serious breach of a fundamental freedom, in this case the right of equal access to education. ${ }^{160}$ But such a breach was not found where the teaching assistant had resigned and had not been replaced for several months.

The right to housing was created by legislation, in particular by a law of 1990 which the Conseil constitutionnel upheld. ${ }^{161}$ The Conseil constitutionnel then went on to recognise the right to housing as 'an objective of constitutional value'. In a decision of 2004, it declared that the principles laid down in paragraphs 10 and 11 of the preamble of the 1946 Constitution guaranteeing individuals and families the conditions necessary for existence led to the constitutional objective of 'the possibility for every person to have available decent lodging. ${ }^{162}$ The Conseil d'Etat then turned this 'objective' that the administration should legitimately pursue into the right of an individual. In a référé-liberté case of 2012, the Conseil d'Etat found, contrary to the judge at

\footnotetext{
160 CE ord. 15 December 2010, Ministre de l'Education Nationale c Pehrilhé, no. 344729, AJDA 2011, 858 note Prélot.

161 CC decision no. 90-274 DC of 29 May 1990, Housing Law, Rec. 61.

162 CC decision no. 2004-503 DC of 12 August 2004, Law on the Freedoms and Responsibilities of Local Authorities, Rec. 144, para. 21.
} 
first instance, that the failure to provide emergency accommodation as required by several provisions of the Code of Social Action and Families could constitute a breach of a fundamental freedom where the breach caused serious consequences for the person in question. ${ }^{163}$ In this case, the state argued that it had taken adequate measures to meet the need for emergency accommodation and gave a large amount of detail to the court, but in the end the court did not need to rule on the matter. It did, however, rule against the state in a later case involving homeless failed asylum seekers. ${ }^{164}$ Here the tribunal administratif of Clermont-Ferrand ordered the prefect to find accommodation for an Albanian couple and their three children within fortyeight hours. The state objected they were failed asylum seekers and it did not have to accommodate them. The Conseil d'Etat upheld the order of the lower court on the ground that, even if there was no general duty to house those required to leave French territory, the failure to provide accommodation could amount to a serious breach of a fundamental right to decent lodging in exceptional cases. On the facts, this was an exceptional case because it involved very young children and the social services had not been able to find a more suitable alternative arrangement for them than to be housed with their parents. So the principle of a right to decent housing combined with the rights of the children to justify the lower court's order.

Thus the combination of national legislation and international treaties is expanding the fundamental rights which the administrative courts recognise to be at a level lower than constitutional rights.

\subsection{PRINCIPLES OF GOOD ADMINISTRATION}

The concept of 'good administration' has long underpinned the decisions of the administrative courts. After all, the Conseil d'Etat has an important hierarchical role within the administration in its advisory capacity. But principles of good administration have not been systematised until recently. Most clearly, the Code on the Relations between the Public and the Administration (Code des relations entre le public et l'administration (CRPA)) sets out both principles and rules to guide the diverse parts of the administration. It brings together rules from various pieces of prior legislation and government circulars. The CRPA now sets out the main rules in this aspect of how the

163 CE ord., 10 February 2012, Fofana, no. 356456, AJDA 2012, 716 note Duranthon. The claimant was provided with accommodation just before the hearing of the case and so the Conseil d'Etat did not need to decide whether there had been a manifest breach of the right in this situation.

${ }^{164}$ CE Sect. 12 July 2016, Ministre des affaires sociales c Rumija, no. 400074, Leb. 363. 
administration should deal with citizens by codifying different texts and the case law with slight adjustments. Over the years, the Conseil d'Etat has also developed principles that govern how the administration should deal with the public. France is not alone in thinking about these matters. The right to good administration is laid down in art. 41 of the Charter of Fundamental Rights of the European Union, which acquired legal force with the Treaty of Lisbon in 2009. The European Commission adopted the Code of Good Administrative Behaviour in 2000, and it was adopted by the Parliament in 2001. ${ }^{165}$ Several academic studies have sought to identify principles of good administration across the states of the Council of Europe. ${ }^{166}$ Looking just at the European Union Code, in brief, the principles cover how officials will behave, how they will handle requests from the public and how they will make decisions. Officials should act lawfully (art. 5), impartially and independently (art. 8), objectively (art. 9), fairly (art. 11), courteously (art. 12) and with respect for data privacy (art. 21). In handling requests from the public, they will reply in the language of the recipient (art. 13), acknowledge receipt (art. 14), transfer misdirected requests to the competent official (art. 15), give the affected person an opportunity to be heard (art. 16), take decisions within a reasonable time (art. 17) and set out the avenues for appeal (art. 19). The decisions will be made without discrimination (art. 6), without abuse of power (art. 7), respecting the legitimate expectations of the public (art. 10), with outcomes that are proportionate (art. 6), giving reasons for a decision (art. 18). In addition, the European Ombudsman set out in 2012 a number of principles in its Code of Public Service: commitment to the European Union (loyalty), integrity, objectivity, respect for others and transparency. Many of these principles are found in French expectations of public servants and public decision-making, but not all of them are considered legally enforceable.

\subsubsection{The Conduct of Public Officials}

As far as the conduct of public officials is concerned, we have already seen that respect for legality is essential and neutrality is the focus of attention in the area of impartiality and independence. Art. Lioo-2 CRPA expresses the core values thus:

The administration acts in the public interest and respects the principle of legality. It is bound by the duty of neutrality and to respect for the principle of

165 See European Ombudsman, The European Code of Good Administrative Behaviour (Strasbourg, 2013).

166 See U. Stelkens and A. Andrijauskaite, Good Administration and the Council of Europe: Law, Principles and Effectiveness (Oxford: Oxford University Press, 2020), esp. chapter 1 and Emilie Chevalier's chapter 5 on France. 
secularism. It complies with the principle of equality and guarantees each person impartial treatment.

The principle of legality is reinforced by the duty to withdraw or repeal decisions which are or have become illegal. This duty was laid down in modern terms in Compagnie Alitalia. ${ }^{167}$ The company asked the Prime Minister to repeal provisions in the tax code enacted by decree in 1967 and 1979 on the ground that they were incompatible with the Sixth VAT Directive of the European Union dated 17 May 1977. His refusal was quashed because there was a principle under which the competent public authority is bound to repeal an illegal decision or decree, whether it was illegal when signed or has become so subsequently. This principle was reflected in a decree of 28 November 1983 on relations between the administration and users of public services, which explicitly laid down that the administration should withdraw an illegal regulation. The duty to withdraw or replace an illegal rule or decision is now contained in art. L243-2 CRPA. It requires the withdrawal of any illegal rule. It also requires the withdrawal of non-regulatory decisions which have not created a vested right. This principle of legality does not, however, withdraw rights acquired on the basis of the validity of the legal provision in question. As was decided in Ternon, the withdrawal of an order must not affect vested rights, unless adopted within a period of four months and only if the order is unlawful. ${ }^{168}$ Here an individual working for the regional government was originally entitled to become a civil servant, but a later decree appointed him merely as a contractual employee. When he was subsequently dismissed, he claimed the dismissal was unlawful because it failed to respect the procedure for dismissing civil servants. The region was ordered to reinstate him and to reconstitute his career on the basis of the original nomination order. The principle in this case is now codified in art. L242-1 CRPA. Ternon illustrates the importance of the principle of legal certainty, which will be discussed in what follows. Where an unlawful decision can be rectified applying the Danthony principle, ${ }^{169}$ then it cannot be revoked, but where the defect in the decision cannot be rectified, then the decision has to be withdrawn and the individual is left to obtain compensation against the administration, rather than insisting the decision be maintained. ${ }^{170}$

167 CE Ass. 3 February 1989, no. 74052, RFDA 1989, 391 concl. Chahid Nourai. The date for assessing whether a decision is unlawful is the date of the court judgment, not when it was originally taken: see CE Ass. 19 July 2019, Association des Américains accidentels, no. 424216; CE, 28 February 2020, Stassen, no. 433886.

168 CE Ass. 26 October 2001, no. 197018, Leb. 497 concl. Séners.

169 Note 14 .

170 CE 7 February 2020, B, no. 428625, AJDA 2020, 1795. 


\subsubsection{Transparency and Data Protection}

The Vice President of the Conseil d'Etat remarked in 2011 that 'transparency and secrecy are both features of public action' ${ }^{171}$ In his view, transparency has to be balanced against efficiency and effectiveness of the administration. It is for that reason that it is not a general principle of law. In the case law of the Conseil constitutionnel, attention is paid particularly to the intelligibility and comprehensibility of legislation.

Respect for data privacy has been a long-standing concern in France and predates European developments. The Commission nationale de l'informatique de des libertés (CNIL) was created in 1978. A key aspect of transparency has been the access to public documents. The Commission d'accès aux documents administratifs (CADA) was also set up in 1978. Its work is now governed by the provisions set out in Book 3 Title IV of the CRPA. But powers of these bodies to impose sanctions on the administration only came in 2004 and 2005, respectively. These are supervisory bodies which set standards for how public bodies handle data and how far documents are made available. Data privacy is driven far more by EU requirements, notably the GDPR, rather than by agreements within the Council of Europe. ${ }^{172}$

Transparency is not, as such, a general principle of administrative action. Rather, Book 3 of CRPA sets out a basic duty of the administration to place administrative information online and to communicate documents to interested persons on request, subject to a number of detailed conditions. Any large administration is required to place most of its general information and policies online (art. L312-1-1 CRPA). Circulars and instructions from ministers which interpret the law or set out administrative procedures should also be made public (art. L312-2 CRPA). Subject to data protection and security law, a person has a right to know the information a public body holds in relation to them (art. L311-3 CRPA). She also has the right to know if a decision is taken on the basis of an algorithm. A large number of exceptions to accessibility are laid down in arts. L311-5 to 311-8 CRPA, often relating to the nature of the information or the nature of the agency holding it (e.g. health information and security information). Some administrative information may be licensed for use and the administration may charge for this. This is especially true for statistical information the administration gathers.

Data protection is not a general principle, but is ensured by a number of specific rules. For example, different administrative bodies should only share

${ }^{171}$ J. M. Sauvé, Discours (2011): www.conseil-etat.fr/actualites/discours-et-interventions/transpar ence-valeurs-de-l-action-publique-et-interet-general (accessed 18 March 2021).

172 See Chevalier, note 166, at paras. 5.27-5.29. 
data when it is strictly necessary, and the public are informed about the data held on them and are given the right to correct them (art. L114-8 CRPA).

\subsubsection{The Handling of Requests from the Public}

The CRPA sets out principles for the handling of requests and complaints from the public. Book 1 Title II deals with the procedure for electronic communication. It sets out when this procedure may be used and for what purposes. It deals with the practical matters identified in the European Code of Good Administration such as the acknowledgement and dating of receipt, and the duty to transmit misdirected correspondence to the correct addressee (art. L114-2). Given the French administration's preoccupation with proving identity and other matters which it considers necessary before considering a request, the Code helpfully clarifies which pieces of information satisfy requests for information (art. L113-4 and following CPRA), thus saving a hapless citizen from a relentless paper chase in order to satisfy the bewildering requirements of the administration.

The right to a hearing (droit à une procedure contradictoire préalable) was established as a general principle of law in Trompier-Gravier in $1944 .{ }^{173}$ In this case, the prefect withdrew Mme Trompier-Gravier's permit to sell newspapers from a kiosk on the streets of Paris on the ground that she had committed a wrong against her manager. This was not a matter of public interest, and she was not given the opportunity to give her account of what had happened before the licence was withdrawn. The decision of the prefect breached her rights to a defence (droits de la défense). Under the Code, such a right is guaranteed for individual decisions (art. L121-1 CPRA). Exceptions are made for urgency or public order and international relations reasons, or where a specific procedure is laid down under which the decision is to be taken. Art. L122-1 CPRA makes clear that normally representations are written, but may be oral in some cases. The right to be represented is also specified. In the cases of sanctions or discipline, the right to know the charges and to have access to the file of information is a prerequisite for the validity of any decision again the person in question (art. L122-2 CPRA).

This communication of information may then lead the citizen to correct their request by specifying a different legal provision or by supplying more information. This process of correcting errors is specifically permitted (art. L123-1 and following). The right of the citizen to receive and provide

173 CE Sect. 5 May 1944, Dame Veuve Trompier-Gravier, no. 69751, D. 1945, 110 concl. Chenot, note de Soto. 
information is balanced against the right of the administration to conduct checks and use the information gained in making decisions, providing this is legally authorised (art. L 124-1).

The advantage of the codified provisions is that they are more detailed than general principles such as the right to contradict evidence (le droit au contradictoire: the equivalent of audi alteram partem) and avoid litigation.

When it comes to more general or group decisions, the rights of citizens change from being able to challenge information that mentions them to being able to participate in the decision-making process and express a view. The general principle laid down in the CRPA goes further than any judicial principle on participation. Article L131-1 CPRA states:

Outside cases governed by provisions of law or decree, when the administration decides to involve the public in drawing up a reform or in developing a project or a decision, it shall publicise the details of this procedure, make available to the people concerned the necessary information, give them a reasonable time to participate and ensure that the results or follow-up envisaged are made public at an appropriate moment.

The Code then goes on to provide detail on consultation by the Internet, by consultative committees and by public inquiries. There is much to be said for the provision that consultative committees cannot go on for longer than five years (art. $R_{133-2}$ ). These sets of rules provide for written and sometimes oral submissions. These rules do not govern inquiries into expropriation or the environment, which are governed by special rules. In the case of the environment, the Charter of the Environment of 2004 includes in art. 7 the right of every citizen to participate in the development of any project which has an effect on the environment. The CPRA thus broadens the scope of the right to participate.

Nothing in these provisions or in the equivalent provisions governing expropriation and the environment can avoid the controversy to which many large projects give rise. The story of the proposed airport at NotreDame-des-Landes exposes the limits of the legal process. The building of a new airport near Nantes was conceived in 1963 when it was expected that air travel would increase. The airport and transport links covered a substantial area of natural beauty and scientific interest, and it was expensive. Examination of sites and costs carried on until a final site was chosen in 1992. The plan was relaunched in 2000 with a public consultation in 2002-3 and the confirmation of the site by a minister in 2003. Following approval after a public inquiry, the expropriation was declared to be of public utility in 2008 . The concession was then made to an airport operator. But by this time the 
environmental impact, as well as that on agriculture, became more prominent. In 2016, the government used its powers to conduct a local plebiscite to gather opinion, a procedure not provided for specifically in planning law. Opponents challenged this procedure and sought an interim order suspending the consultation. This was rejected by a collegial formation of the Conseil d'Etat. In the end, the government appointed 'mediators' to re-examine the options. They reported in December 2017, and the government abandoned the project the following month. So, after nearly fifty-five years and no fewer than 179 cases brought at various times before the courts, the project came to nothing. Those decisions and especially the Conseil d'Etat decision of 2016 rejecting the objections of the opponents to the government's procedure did not calm the acrimonious controversy associated with the project. ${ }^{174}$

\subsubsection{Time Limits and Appeals}

We have already seen that there is a general principle that courts will decide cases in a reasonable time, a principle laid down in Magiera, following case law of the European Court of Human Rights. ${ }^{175}$ There is also the obligation to bring a challenge to the decision of the administration in a reasonable time, but the Code of Administrative Justice (art. R421-1 CJA) specifies that this is two months from the decision. The general principle of a right to appeal is limited to judicial decisions. But the right to bring judicial review was firmly established in Lamotte in 1950, as seen in Chapter 6, Section $5 \cdot{ }^{176}$ In that case, a law of 1943 provided that the award of a concession of uncultivated land by a prefect was not susceptible of any judicial or administrative redress. But the Conseil d'Etat held that this did not exclude judicial review. The right to judicial review was a general principle of law which is part of respect for legality.

The Code provides that the acknowledgement should state whether the decision is governed by the rules that entitle a person to a decision in their favour unless the administration responds within two months, and sets out the ways of challenging a decision (art. R112-5 CRPA).

\footnotetext{
${ }_{174}$ CE 20 June 2016, Association citoyenne intercommunale des populations concernées par le projet d'aéroport de Notre-Dame-des-Landes, no. 400364, Leb. 838. See commentary by M. Torre-Schaub in Grands arrêts politiques, pp. $526 \mathrm{ff}$.

175 CE Ass. 28 June 2002, Garde des Sceaux c Magiera, no. 239575, Leb. 247, concl. Lamy; Chapter 4, Section 1.4.

${ }_{176}$ CE Ass. 17 February 1950, Ministre de l'Agriculture c Dame Lamotte, no. 86949, Leb. 110.
} 


\subsubsection{Principles Governing the Decision Taken}

The European principles on how decisions are taken reflect French law in many respects, not least because French advocates general and judges were very influential in the creation of the European Court of Justice (as it then was). The principles of judicial review were drawn heavily from French and German laws.

The traditional French principles excluding discrimination and abuse of power have already been seen. The imported German principle of proportionality has already been discussed. The two other European principles of good administration involve respect for legitimate expectations and the duty to give reasons. Both of these have met resistance from the French administrative courts.

\subsubsection{Legitimate Expectations and Legal Certainty}

French administrative law has been willing to accept legal certainty as a general principle, but not the protection of legitimate expectations. The basic argument is that legal certainty is objective. As the Conseil d'Etat wrote in its annual report for 2006:

Without it requiring impossible efforts on their part, citizens should be able to determine what is permitted and what is prohibited by the law. To reach this result, the norms enacted have to be clear and intelligible, and must not be subject to changes over time that are too frequent nor above all unpredictable. ${ }^{177}$

Legitimate expectations are subjective, based on individual expectations and reliance on what the administration has said or done. Each tries to ensure a degree of stability and predictability in the relations between the citizen and the state. Both principles have their origins in German law and have been accepted by both the Court of Justice of the European Union and the European Court of Human Rights. Legal certainty (sécurité juridique) was accepted first. ${ }^{17}$ The protection of legitimate expectations (confiance légitime) came later. ${ }^{179}$ Because EU law is directly applicable and the European Convention has priority over national legislation, the French courts became familiar with applying these standards when giving effect to the supranational

177 Conseil d'Etat, Rapport Annuel 2006: La Sécurité Juridique (Paris, 2006), p. 281.

${ }_{17} 8$ See Case 13/61, Kledingverkoopbedriff De Geus en Uitdenbogerd v Bosch Gmbh [1962] ECR 74 and ECHR, 13 June 1979, App. no. 6833/74 Marckx and Marckx v Belgium (1980) 2 EHRR 330.

179 See Case 112/80, Firma Anton Dürbeckv Hauptzollamt Frankfurt am Main-Flughafen [1981] ECR-I 1096 and ECHR, 15 June 2006, App. no. 33554/o3, Lykourezos v Greece [2006] ECHR 1179 . 
systems. But, when they applied purely domestic law, they have adopted different concepts. The Conseil constitutionnel also came to recognise that the accessibility and intelligibility of the law were 'objectives of constitutional value' but did not thereby accord legal certainty the status of a constitutional principle. $^{180}$

The clarity and predictability of the law is essential for the citizen to plan her life. Legal certainty requires that the rule be intelligible and comprehensible, that it is accessible, and the citizen must be able to determine whether it is valid. Legitimate expectations arise more often from the practices and assurances of the administration. Both are features in allowing the individual to plan their lives, but they constrain the ability of the administration to change policies in the light of emerging public interests. It is the way that particularly protecting the legitimate expectations of citizens potentially privileges these over the public interest that has led the French to be wary of giving this goal the status of a general principle of law. ${ }^{181}$

The position of the Conseil d'Etat was made clear in KPMG. ${ }^{182}$ In this case a French law of 2003 implemented a European Union Directive of 1984 dealing with the authorisation of accountants. A decree of 2005 then gave effect to the provisions of the law by enacting a code of conduct for accountants which was to come into effect immediately. In the wake of accountancy scandals in the United States, the code of conduct provided that accountants were not to audit the accounts of firms to whom they provided other professional services. An accountancy firm challenged this on the ground that it breached both legal certainty and legitimate expectations. The Conseil d'Etat gave the latter point short shrift. It stated that the principle of legitimate expectations, which is a general principle of European Community law, only applies in domestic law in the situation where the case before the French administrative court is governed by Community law', which was not the case in KPMG. But it then went on to decide that the absence of transitional provisions in the decree breached the principle of legal certainty. The code applied to contracts already in progress and the disturbance of such arrangements was excessive in relation to the objective of ensuring the independence of accountants. There was no imperative need to affect existing

180 See CC decision no. 99-421 DC of 16 December 1999, Codification, Rec. 136 and CC decision no. 2010-102 QPC of 11 February 2011, AJDA 2011, 303. But some of its decisions come close to accepting the importance of respecting established legal situations: see CC decision no. 2013-682 DC of 19 December 2013, Rec. 1094.

${ }_{181}$ See B. Bonnet, 'L'analyse des rapports entre administration et administrés au travers du prisme des principes de sécurité juridique et confiance légitime', RFDA 2013, 718.

182 CE Ass. 24 March 2006, no. 288460, AJDA 2006, 1028; Grands Arrêts, no. 104. 
contracts. A few days before this decision, the annual report of the Conseil d'Etat was published in which it wrote that 'legal certainty is one of the foundations of the rule of law'. ${ }^{183}$ But if there are transitional arrangements, then it is unlikely that the courts will require greater protection. ${ }^{184}$

\subsubsection{Duty to Give Reasons}

The Conseil d'Etat never required the administration to provide reasons for its decisions. For example, in Lang it stated that a committee certifying whether a person was qualified to be a finance officer of companies did not have to provide reasons for its refusal to include the claimant on the approved list of qualified individuals. ${ }^{185}$ The decision showed, all the same, that the Conseil d'Etat itself would look at the decision file to see if improper factors had been taken into account, and this follows the approach adopted in Barel. But it did require that professional bodies justify their decisions, for example, in allocating shipping routes. ${ }^{186}$ But a law of 1979 listed decisions for which reasons had to be given, but without laying down a general principle.

The duty to give reasons was enshrined in the treaty creating the European Coal and Steel Community in 1951 and is now found in the Charter of Fundamental Rights, art. 41, written in 2000 . The inclusion of a formal principle in the CRPA of 2015 reflects both domestic and European influences. Article L211-2 CRPA asserts the right of any person to be informed without delay of administrative decisions which are adverse to them. That article then lists the types of decision in which this duty applies. The list covers decisions which restrict civil liberties, impose sanctions, impose conditions on authorisations, withdraw or repeal a decision that has created right, raise an objection that an application is out of time, refuse a right-creating benefit to someone, refuse an authorisation or reject an appeal against a decision. The CPRA thus goes further than previous legislation and further than the administrative courts.

As far as the content of the duty to give reasons is concerned, art. L211-5 CRPA provides that the reasons must list the considerations of law and fact which constitute the basis of the decision. This broadly repeats the approach of the Conseil d'Etat in Maison Genestal, where it was said that the Minister's refusal to give a tax concession on the ground that the project put forward by

\footnotetext{
183 See note 177 , p. 227.

184 See CE Ass. 18 May 2018, Louvion, no. 400675, Leb. 168 concl. Dutheillet de Lamothe.

185 CE Sect. 26 January 1973, no. 8789o, D. 1973, 606 note Pacteau.

186 CE Ass. 27 November 1970, Agence maritime Marseille-Fret, nos. 74877, 75123, RDP 1971, 987 concl. Gentot.
} 
the claimant did not offer sufficient economic advantages provided reasons which were too general to enable the court to verify compliance with legality. ${ }^{187}$ The Minister had to provide the reasons of law and fact which demonstrated that it did not offer the necessary economic benefits to justify the tax concession.

Exceptions to the duty to give reasons are limited. The CRPA does provide exceptions for security. For example, in a decision of 2019, the cour administrative of Versailles upheld a refusal by the prefect to explain why an individual involved in logistics was refused authorisation to have access to Charles de Gaulle Airport. ${ }^{188}$

\subsection{CONCLUSION}

French administrative law began as a very French development. It was driven by the practice of the Conseil d'Etat and the textbooks used in university and civil service courses. ${ }^{189}$ By the end of the nineteenth century, that domestic product was seen as a model for others of how to exercise control of the administration in a democracy. The Strasbourg professor Otto Mayer wrote a long book on the subject which made available French ideas as a reference point for the development of a German administrative law. ${ }^{190}$ Dicey specifically wrote and lectured on French administrative law, whilst not wishing to have the equivalent in England. He wrote, 'On the whole it appears to be true that if administrative law is to exist it is seen at its best as French droit administratif. ${ }^{191}$ It continued to be a major point of reference even in common law countries well into the 1960 s. ${ }^{192}$ As has been mentioned, it had a clear influence on the judicial structure of European Union law. So French administrative law, despite its distinct roots, was exported quite widely.

Some of the approaches of the early French administrative law reflected both the particular deference of courts to the administration as the arbiter of the public interest and the role of the administrative judge as part of the public service and thus a kind of hierarchical superior of lower administrative bodies, prepared to correct their mistakes. This reflected the role of organs of central

187 CE Sect. 26 January 1968, Société Maison Genestal, no. 69765, Leb. 62 concl. Bertrand.

188 CAA Versailles, 3 December 2019, no. 16VE03652, AJDA 2020, 964.

189 See J. Bell, "The Role of Doctrinal Writing in Creating Administrative Law: France and England Compared' (2018) 15 Glossae 141 at p. 15 o.

$19 \circ$ See M. Stolleis, Public Law in Germany (trans. T. Dunlap) (Oxford: Oxford University Press, 2017), pp. 70-1. Strasbourg was a German territory at that time.

191 A. V. Dicey, Lectures on Comparative Constitutionalism, edited by J. W. F. Allison (Oxford: Oxford University Press, 2013), p. 314.

192 See Bell, 'The Role of Doctrinal Writing', at p. 149. 
government, such as the Conseil d'Etat and the prefects, in keeping the large number of dispersed communes and administrations in order.

French administrative lawyers were significant in the early days of the European Court of Justice and have regularly been the judges on the Court. But the European influence has been a two-way involvement. The ideas developed in European courts have found their way into French law firstly and directly because European Union law or the European Convention have been directly applicable on a particular matter. Secondly and less directly, those systems have developed grounds of scrutiny and legal standards which have inspired developments in French law as a kind of 'spillover' effect. French judges do not consider that they can apply one set of standards in European cases and lesser standards in purely domestic cases. In terms of grounds of review, manifest error and proportionality are particular influences. As stated in Chapter 6, the scope of judicial review, especially in relation to institutions such as schools and prisons, has widened. In terms of values, fundamental rights in France have been developing at much the same time as the European Union developed its Charter of Fundamental Rights and the European Convention has been interpreted broadly by the European Court of Human Rights. Throughout this chapter, there have been illustrations of where fundamental rights have been shaped by understandings emerging from Strasbourg. But Strasbourg takes its ideas from the laws of the members of the Council of Europe. It leaves a significant margin of appreciation on many issues. Issues remain, such as secularism, the fight against terrorism and immigration, where many of the standards applied are developed primarily in France. In the area of principles of good government, there has clearly been a sharing of ideas and good practice at the European level, if not more broadly within the Organisation for Economic Co-operation and Development. It is not surprising that the current synthesis in the Code of Relations between the Public and the Administration reflects both French experience and the lessons from other European countries. It is not worth attempting to suggest how far European supranational law has influenced French administrative law. It is best to see European law as a regular factor in shaping the thinking and practice of French law. 


\section{8}

\section{State Liability}

\subsection{INTRODUCTION}

The French term responsabilité covers a number of English-language concepts 'liability' (a duty to pay), 'responsibility' (a duty to take charge) and 'accountability' (a duty to explain). An action brought by a citizen against the state may be trying to perform one or more of these functions. The notion of liability is our primary concern in this chapter: when does the state have to pay a citizen for losses she has incurred as a result of state activity? In order to find the state under a duty to pay, it will be necessary to find that the state should have taken charge of a situation or its consequences. But in many cases, the motivation of the claimant is to make the state explain why harm happened and to apportion blame. This last function is clearly detachable from any claim to compensation and could be carried out by criminal proceedings or by an inquiry. The uses of tort law to perform these different functions differ between England and France. Whereas in England, it is not uncommon that a tort action is seen as almost a proceeding of last resort to force the state to explain how harm occurred, ${ }^{1}$ in France, this is more likely to arise in criminal proceedings. ${ }^{2}$ In English law, Dicey noted that trespass actions had an important place in vindicating fundamental rights against infringement by public officials. ${ }^{3}$ These established liability without proof of loss. In France, the creation of means of redress to challenge the legality of the actions of public authorities made the use of state liability as a vindication of right unnecessary. The French law of state liability is therefore about compensation.

1 See C. Harlow, State Liability. Tort Law and Beyond (Oxford: Oxford University Press, 2004), pp. 49-51.

2 Although the scope for these is more limited.

3 The first principle of the rule of law: see A. V. Dicey, Lectures Introductory to the Study of the Law of the Constitution, edited by J.W.F. Allison (Oxford: Oxford University Press, 2013), especially p. 188. 
There has been a long debate about why the state should have to pay compensation for its activities. The most useful summary is found in the Recommendations of the Council of Europe in $1984:^{4}$

1. Reparation should be ensured for damage caused by an act due to a failure of a public authority to conduct itself in a way which can reasonably be expected from it in law in relation to the injured person.

2. Reparation should be ensured if it would be manifestly unjust to allow the injured person alone to bear the damage, having regard to the following circumstances:

- the act is in the general interest;

- only one person or a limited number of persons have suffered damage; and

- the act was exceptional or the damage was an exceptional result of the act.

Those two principles distinguish between fault on the one hand and the collective sharing of losses on the other. As we will see, French administrative law sees both of these issues as part of its law on state liability (responsabilité de l'administration). By contrast, English law would see the first principle as concerned with the grounds for liability, but the second as concerned with the grounds for compensation. Harlow has argued that these two issues should be kept separate, and that tort law should only be concerned with liability. In her view, compensation is a matter for legislative schemes, such as those on vaccine damage, or for non-legal processes, such as ex gratia payments. ${ }^{5}$

\subsection{THEORIES OF LIABILITY}

There has been long debate in France about the basis of state liability. The principle set out in Blanco in 1873 is that

Whereas the liability which may be incurred by the state for the loss caused to individuals by the actions of persons whom it employees in the public service cannot be governed by the principles laid down in the Civil Code to regulate the legal relationships of individuals. ${ }^{6}$

4 Recommendation no. R (84)15 on Public Liability, adopted by the Council of Ministers of the Council of Europe on 18 September 1984 (Strasbourg 1985).

5 Harlow, State Liability, pp. 61 and 116-22.

6 TC 8 February 1873, Blanco no. 00012 , D. 1873.3.17, translated by D. Fairgrieve, State Liability in Tort. A Comparative Law Study (Oxford: Oxford University Press, 2003), p. 288. For the historical background to this case, see F. Rolin, 'Elle s'appelait Ignacia' RFDA 2021, 413. 
The starting point is thus that state liability requires its own justifications. It is not like the liability of a private employer for the harm he causes directly or indirectly through his employees. In the past, as in England in relation to the Crown, the special position of the state acting in the public interest justified an immunity from suit. ${ }^{7}$ But this is no longer considered acceptable. As we will see, there may be some areas of state activity requiring special protection from suit, but these are exceptional and increasingly few in number.

France is unusual in having a completely distinct set of both substantive and procedural rules that govern the liability of public bodies. Countries such as Germany and Italy have common procedural rules and some common substantive rules. The French approach could simply be seen as the effect of path dependency - France started on this route in the seventeenth century if not at the Revolution of 1789 and has just carried on accumulating solutions to problems within this framework. That would not require any deep philosophical justification. But there are at least some philosophical reasons.

If the state is acting in the public interest, one response might be to give it greater protection than is afforded to private individuals who act for their own selfinterest. The good motivation of public bodies could justify greater indulgence towards them, especially if the spectre of liability were to make them overcautious. This kind of reasoning is found in the arguments of French scholars and judges, especially when arguing that the state should only be liable where gross fault (faute lourde) is proved. On the other hand, the fact that the state is acting for the collective good when a single individual suffers loss could be an argument in favour of the collective sharing of the harm - one individual should not be sacrificed for the good of the whole community. Duguit went so far as to argue that the rationale of state liability was 'the idea of social insurance provided by the central budget and compensating those who have suffered a loss arising from public services ... So if the intervention of the State creates a special loss for some people, the Government must compensate it, whether there is a fault of the public officials or not. ${ }^{8}$ His argument was that, though private law (then) was wedded to subjective fault, fault in public law had long been objective, the failure of a public service to perform its function, and to this were now added liability for risk and for abnormal losses. In his view, 'the liability of the state can never have any other basis than national solidarity and equality before public burdens'. ${ }^{9}$ In this Duguit

7 On the comparative place of state immunity in tort see J. Bell and A. W. Bradley, Government Liability: A Comparative Study (London: UKNCCL, 1991), chapter 1.

8 L. Duguit, Traité de droit constitutionnel, 3rd ed., 4 vols. (Paris: Fontemoing, 1928), vol. 3, pp. $466 \mathrm{ff}$. , quoted by R. Errera, 'The Scope and Meaning of No-Fault Liability' [1986] Current Legal Problems 157 , at p. 171. The discussion is already in Duguit's second edition of 1923 (see note 9), $\$ 81$.

9 L. Duguit, Traité de droit constitutionnel, 2nd ed., 4 vols. (Paris: de Boccard, 1923), vol. 3, p. 466. 
was following one of the other founders of modern French administrative law, Hauriou. For Hauriou, the foundation (or cause) of state liability was the mutual insurance run by the state against administrative accidents. Fault was not the cause of the obligation to compensation, but merely one of the conditions that had to be satisfied before an obligation arose; in contemporary terms it was a fait générateur (a fact giving rise to liability). ${ }^{10}$ Some recent authors would support this approach. ${ }^{11}$ Most authors do not go so far. English commentators tend to limit the differences between French and English law by emphasising that fault is the primary basis of liability of the state and no-fault liability is an exception. ${ }^{12}$ This is stated by many French authors as well. ${ }^{13}$ All the same, Fairgrieve helpfully remarks that 'French theories all have in common a shift in emphasis from the individual to the collective in bearing the burden of public service activity. ${ }^{14}$ So, whether or not there is one overarching value or several within the rules governing state liability, French administrative law is less concerned with vindicating individual rights than with providing compensation from the community where individuals have suffered from activities undertaken in the public interest.

The presentation here will reflect the two broad categories of fault and nofault liability found within the Recommendations of the Council of Europe. As Errera pointed out, these two categories often blur into each other. ${ }^{15}$ Objective conceptions of fault, a focus on fault of the institution (faute de service) rather than of individual civil servants and presumptions of fault draw fault liability away from values of blame and subjective fault. The clear distinction between liability and compensation for which Harlow argued does not really fit French law, where both fault-based and no-fault-based claims lead to entitlement to reparation from the courts.

\subsection{LIABILITY FOR PUBLIC WORKS (RESPONSABILITÉ POUR LES TRAVAUX PUBLICS)}

As was stated in Blanco, the French law on the liability of public authorities is not based on the Civil Code. It is based on principles developed by the courts and on specific rules laid down by statute in relation to specific activities. As

M. Hauriou, 'Les actions en indemnité contre l'Etat pour les préjudices causés dans l'administration publique', RDP 1896, 51, 53 .

${ }^{11}$ See the authors cited in Fairgrieve, State Liability in Tort, p. 144, note 71.

12 See Fairgrieve, State Liability in Tort, pp. 265-6, Harlow, State Liability, p. 60.

13 Notably R. Chapus, Responsabilité publique et responsabilité privée: Les influences réciproques des jurisprudences administrative et judiciaire (Paris: LGDJ, 1954); see note 25.

14 Fairgrieve, State Liability in Tort, p. 266.

15 Errera, 'The Scope and Meaning of No-Fault Liability', p. 172. 
such, the structure is much like English law. The basic ideas were laid down in the Law of 28 pluviôse An VIII (17 February 1800). This was a general law on local government within which the rule on the liability of the local commune for harm caused by public works was laid down. It consolidated and improved previous laws of the Revolution withdrawing competence for litigation in relation to public works from the ordinary courts, giving it to the new conseils de préfecture. ${ }^{16}$ Although this was a specific law dealing with a specific problem, it summarised principles of liability which had been recognised before the Revolution and it has served as an inspiration for the development by analogy of rules of liability in relation to other activities and other public bodies.

A public work is an immovable object created in the public interest to fulfil a public objective, typically by or on behalf of a public body. ${ }^{17}$ The case law drew from the Law of An VIII rules for two types of situation, fault and no fault. Where harm is caused to the participant in the public work - for example, the workman - then proof of fault is necessary. Where harm is caused to the user of the public work, then there is a presumption of fault. The public body is liable unless it can show that it did not commit any fault in the construction or maintenance of the public work. Where harm is caused to a third party - for example, to a neighbour - then the public body is liable without proof of fault. If the harm is permanent - for example, loss of amenity - then the neighbour recovers by showing that the loss is specific to him or a small group and it abnormally exceeds what can be expected between neighbours. If the harm is accidental and temporary, then his loss is covered without needing to show that it is abnormal or special. ${ }^{18}$ In cases of no fault, the public body pays unless it shows that harm has resulted from an external cause or from the fault of the victim. In case of fault, the case law adds as exceptions to payment the fault of a third party and the unknown cause (cas fortuit). In these provisions, the principles of fault and no-fault liability of public bodies were articulated. In short, the user as beneficiary of a public work has to take some burdens and inconveniences arising from the way it is designed but does not accept fault. By contrast, the neighbour does not accept to suffer an abnormal burden in order to benefit someone else. These principles have been a reference point

16 See G. Bigot, Introduction historique au droit administratif depuis 1789 (Paris: Presses Universitaires de France, 2003), paras. 18 and 41.

17 It can include motorways built and run by private bodies as long as these are part of a public service: TC 8 July 1963, no. o1804, Société Entreprise Peyrot, Leb. 787.

18 On the distinction between accidental and permanent harms, see $\mathrm{P}$. Ferreira in his note to CE 10 April 2019, Cie nationale du Rhône, no. 411961, AJDA 2019, 1821. 
ever since. In many ways, they resemble the liability for public nuisance in English law.

An example of the interaction of the two bases of liability is the Syndicat intercommunale case dealing with the riverbank of rivers in the region between Narbonne and Perpignan. ${ }^{19}$ Dykes constructed in the seventeenth century proved inadequate to prevent serious flooding in 1999. In 2006, the prefect ordered the intercommunal board responsible for the maintenance of the dykes to undertake substantial works, changing their level, dredging the river and reinforcing banks. These works proved inadequate to prevent flooding of the neighbouring land of a semi-wild animal reserve in 2011 and 2013. The intercommunal board was found liable to the neighbour. The work on the dykes was undertaken in the public interest by a public body in order to prevent flooding, and so was a public work, even though the dykes themselves belonged to the private owners of the riverbank. The Conseil d'Etat upheld two distinct bases of liability. First, the lower court found the intercommunal board at fault in failing to dredge the existing course of the river, which was still partially blocked with debris, and this fault in maintenance contributed to the flooding. Second, without fault, the work of rebuilding the dykes had left them lower than before and this permanent state of the public work had contributed to the subsequent flooding. But these grounds of liability accounted for only 30 per cent of the loss. The rest was due to natural causes arising from the preexisting susceptibility of the neighbouring land to flooding. In recent years, injunctions to prevent harm have been awarded along the lines of quia timet injunctions in England. ${ }^{20}$

\subsection{FAULT LIABILITY}

It is usually stated that the primary liability of the state in France is based on fault: the state acts, but if it acts badly, it pays. This emphasis on fault might give the impression that public law liability, at least in this respect, is similar to private law or English law. But there are significant differences. First, public law fault is essentially institutional fault, a fault of the service (faute de service), rather than the fault of individual public servants. Second, the standard of fault is not that of the bon père de famille, but a failure to fulfil a mission. That standard is much closer to maladministration as understood by the ombudsman in England. In other respects, it does share much in common with

19 CE 13 March 2019 Syndicat intercommunale pour l'aménagement hydraulique du bassin de la Berre et du Rieu, no. 406867, AJDA 2019, 1243 concl. Dutheillet de Lamothe.

20 CE 18 March 2019, Commune de Chambéry, no. 411462, AJDA 2019, 2002 note Ferreira. 
French private law, not least in relation to the range of losses which may be compensated and the vagueness of the approach to causation.

\subsubsection{The Nature of Fault}

Fault in public law was developed independently from notions in private law. Deguergue points out that the conception of fault in administrative law has its origins in the liability of the state for failure to maintain public works under the law of 28 pluviôse An VIII (17 February 1800), discussed in Section 3. The public authority was liable either for a failure to construct the public work correctly or for a failure to maintain it. ${ }^{21}$ Liability for other public activities developed by analogy from this, not from a general principle as articulated in art. 1382 (now art. 1240) of the French Civil Code of 1804 and paraphrased by the Conseil constitutionnel decision of $1982 .{ }^{22}$

All the same, there are similarities between fault in public and in private law. The classical statement of the meaning of fault in French law was that of Planiol. Planiol wrote in 1905 that fault was a failure to conform to a preexisting duty established by law, honesty or professional skill. ${ }^{23}$ Leading administrative law scholars have taken this to be a common point of reference for both public and private law. Certainly, the Conseil constitutionnel has ruled, 'Considering that, since no one has the right to harm another, in principle every human act which causes loss to another, obliges him by whose fault it occurs to make reparation. ${ }^{24}$ Fault liability is thus a general principle of constitutional value applicable to both public and private law. Scholars have noted that, in both public and private law, the courts have been reluctant to identify categories of fault, but rather they assess facts in a holistic way to determine fault. In comparing public law and private law liability, Chapus wrote in 1954 that the approach of civil and administrative judges to determining fault is exactly comparable, for they "both pay attention very attentively to all the circumstances of the case in order to decide whether there has been a breach of an obligation'. ${ }^{25}$ In more recent years, scholars in England and France have confirmed this case-by-case approach. Borghetti

${ }^{21}$ See M. Deguergue, Jurisprudence et doctrine dans l'élaboration du droit de la responsabilité administrative (Paris: LGDJ, 1994), pp. 148-59.

22 See note 24 .

23 M. Planiol, 'Etudes sur la responsabilité civile', Revue critique de législation et de jurisprudence $1905,277$.

24 CC decision no. 82-144 DC of 22 October 1982, Trades Union Immunity, Rec. 61; J. Bell, French Constitutional Law (Oxford: Oxford University Press, 1992), Decision 24.

25 R. Chapus, Responsabilité publique et responsabilité privée: Les influences réciproques des jurisprudences administrative et judiciaire (Paris: LGDJ, 1954), p. 357. 
suggests that the majority of private law scholars accept the idea that fault is the objective failure to conform to a pre-existing standard. ${ }^{26}$ But he also notes that the required standards are not set out in any detail and so much of the precision comes from the detailed analysis of the circumstances of each case. Fairgrieve also pointed out that in French administrative law fault requires a detailed focus on the circumstances of the case. ${ }^{27}$ He helpfully explained that, in English law, the categorisation of types of fault arises because of the importance of the striking-out procedure to defeat claims as a matter of law. By contrast, French decisions will always be based on the facts in the file read as a whole.

Despite these important similarities between fault in private law and fault in administrative law (and, indeed, in English law), there are also important differences. Private law (and indeed the statement of the Conseil constitutionnel) is about protecting rights. If the defendant owes a pre-existing duty, as Planiol held, then it would be correlative to a right in a claimant. But public bodies owe duties to the public in general to carry out the mission they have been given. Jacquemet-Gauché argued that the distinctive feature of French administrative law is that it focuses on the functioning of the administration and so it does not need to ask whether individual rights are affected, as German law does. ${ }^{28}$ The amorphous concept of faute de service suffices and does not require a correlative duty. ${ }^{29}$ This allows for compensation to be provided for disappointed expectations - for example, when the state fails to provide schooling. Rather than focusing on whether an unlawful act by a public body is a breach of a duty owed to the claimant, the question is rather whether the loss suffered by the claimant is causally connected to the unlawful act of the administration. Despite Planiol, the concept of 'duty' is really redundant as it does not feature in the reasoning process of the French administrative courts.

\subsubsection{Faute de service}

In French public law, fault is defined as the fault of an institution, not of a person. The state is not vicariously liable for the acts of its servants, as under

26 J.-S. Borghetti, 'The Definition of la faute in the Avant-projet de réforme', in J. Cartwright, S. Vogenauer and S. Whittaker, eds., Reforming the French Law of Obligations (Oxford: Hart, 2009), chapter 12 , at pp. 278-9.

27 Fairgrieve State Liability in Tort, pp. 125-6.

28 A. Jacquemet-Gauché, La responsabilité de la puissance publique en France et en Allemagne (Paris: LGDJ, 2013), p. 481.

29 See B. Delaunay, La Faute de l'administration (Paris: LGDJ, 2007), paras. [57]-[59] and at p. 178 . 
the German Civil Code $\$ 839$. Rather, it is liable for its own organisational failings, what the English lawyers often describe as 'non-delegable duties'. Unlike $\int_{31}$ of the German Civil Code, French private law has (at the time of writing) no specific provision on corporate liability for fault, though it has gradually developed the concept through case law. ${ }^{30}$ Proposed reforms of 2017 would introduce an article in the French Civil Code to this effect. By contrast, French administrative law has long made use of institutional liability as its principal focus. Laferrière wrote in 1887 that 'The liability of the state is not the liability for others envisaged by article 1242 [former article 1384] Cc, but direct liability: the public service is deemed to be author of the fault; it is it, that is to say the state, which compensates. ${ }^{31}$

This concept was articulated in Pelletier in 1873 to distinguish the jurisdiction of the private law courts from that of the public law courts. ${ }^{32}$ Following the abolition of the immunity of civil servants from suit in 1870 , an action was brought in the civil courts against the military officer in charge of the state of siege of the département de l'Oise who confiscated a newspaper. The Tribunal des Conflits held that the action was ill founded because the complaint was simply about an action related to public order without alleging any personal wrongdoing. So the concept started life as a determinant of the compétence of the administrative courts - they decided on faute de service, rather than the personal wrongs committed by public officials against members of the public.

The key feature about the idea of faute de service is that it is not necessary to identify any specific public official who has committed a wrong before the state is liable. It is sufficient that the state organisation is responsible for the act in question. This was clarified in Feutry in 1908. ${ }^{33}$ In this case, a mentally handicapped adult escaped from an asylum run by the département of Oise and set fire to hayricks of a neighbouring farmer. No fault on the part of any of the asylum staff was alleged, but the case was still held to fall within the functioning of the public service for which the département was liable under public law.

'Fault' in the service does not necessarily mean that there is a fault committed by the administration, but merely a fault for which it is responsible. For

30 G. Viney, P. Jourdain and S. Carval, Traité de droit civil : Les conditions de la responsabilité, $4^{\text {th }}$ ed. (Paris: LGDJ, 2013), para. 854, citing a legal person answers for the faults for which it is made liable by its organs without it being necessary to show that it is liable under art. [1242] para. 5 [of the Civil Code] for the organs as its employees' (Cass. $2^{\mathrm{e}}$ civ., 17 July 1967, Bulletin civil II, no. 261, p. 182; obs. Durry, Revue trimestrielle de droit civil 1968, 149).

$3^{31}$ E. Laferrière, Traité de la juridiction administrative et des recours contentieux (Paris: BergerLevrault, 1887), vol. 2, 178 .

32 TC 30 July 1873 , Pelletier, no. 00035 , D. 1874.3 .5 concl. David.

33 TC 29 February 1908, Feutry, no. 00624, D. 1908, 349 concl. Teissier. 
example, the state was held responsible where the school bursar was subjected to bullying by administrative and teaching staff in her school. ${ }^{34}$ In this case, legislation provided that no civil servant should suffer repeated bullying, and this gave rise to state liability without her having to prove fault in allowing the bullying to occur.

\subsubsection{Faute personnelle}

The principle established in Pelletier is that claims based on the personal fault of a civil servant or official should be brought in the ordinary courts. Of course, this is unattractive since the individual rarely has the funds to satisfy a judgment. An argument that the claimant's harm resulted from the personal fault of a civil servant or official will be made by the state either as a defence to a claim by the victim or a reason for disciplining the author of the harm. The difficulty in distinguishing faute personnelle from faute de service is similar to the attempts by English employers to show that they are not vicariously liable for harm caused by their employee.

The classic example of the reluctance of French administrative courts to accept that a fault is purely personal is Anguet. ${ }^{35}$ Here a customer arrived at a Parisian post office in the evening to cash a money order. When he wanted to leave, he found that the public exit was already shut. An official directed him to leave by a passageway normally reserved for post office employees. Two employees seeing him leaving mistook him for a wrongdoer and pushed him so forcefully out of the post office and into the street that he fell and broke his leg. Although the Minister of Posts and Telegraph claimed that this was a purely personal fault of the employees, the Conseil d'Etat found that their actions resulted from the poor performance of the public service and so the state remained liable to compensate Mr Anguet. Despite the view of scholarly writing at the time, the Conseil decided that it was possible for there to be a cumulation (cumul) of the faute personnelle of the state employees and the faute de service of the organisation - two distinct faults leading to a single loss. This was taken further in Epoux Lemonnier. ${ }^{36}$ The commune of Roquecourbe held its annual fête and included a shooting range with targets floating on the river. A bullet from one of the guns struck Mme Lemonnier as she and her husband were walking along the footpath along the river. The bullet lodged in her spine and pharynx. Initially, the Lemonniers sued the commune in the

34 CE 28 June 2019, no. 415863.

35 CE 3 February 1911, Anguet, no. 34922, S 1911.3.37 note Hauriou.

36 CE 26 July 1918, Epoux Lemonnier, no. 49595, S 1918-19.3.41 concl. Blum, note Hauriou. 
civil courts and the claim was rejected at first instance based on Feutry. They then asked the commune for compensation and, on its refusal, they brought a claim before the Conseil d'Etat. In the meantime, their appeal of the civil judgment was heard by the cour d'appel of Toulouse, which awarded them damages against the mayor for his personal fault in organising the shooting range. Notwithstanding this, the Conseil d'Etat awarded them damages for a faute de service by the commune. The fact of the civil judgment did not deprive them of their right to compensation for a fault in the management of a public service and the appropriate measure of damages for that (which might be different from the amount found by the civil court). Here the same fault could be seen as both a faute personnelle and a faute de service. The two judgments were distinct, but the public authority was then subrogated to the claimants and could obtain reimbursement from the mayor as awarded by the civil court.

In both Anguet and Lemonnier, the acts of the officials were clearly within their public roles as employees or mayor. The Conseil d'Etat went further in Mimeur, Defaux et Besthelsemer to find that there might be state liability even where the state employees were acting contrary to their official duty. ${ }^{37}$ In each of the three cases under consideration, road accidents were caused by officials using official cars for private journeys. For example, in Mimeur, a soldier driving a petrol tanker made a detour to his home village and crashed into the wall of the claimants' house. The claimants in the cases were able to recover. The commissaire du gouvernement Gazier noted that private law held the keeper of a car liable for the unauthorised journeys of the driver and administrative law needed to follow suit. Accordingly, the Conseil d'Etat held that the accidents had resulted from vehicles entrusted to drivers for the performance of a public service and, on the facts of each case, the accident could not be considered without any link to the service in question..$^{8}$ This case law continues to apply. For example, the commune of Saint-Paul was held liable for a mayor who used his office to issue false documents recognising debts owed by the commune which were used as evidence of solvency of a company by the claimant bank. ${ }^{39}$

Where there has been a personal fault of a public official, the question arises whether a contribution can be expected from the official. In Laruelle, a soldier took away an army vehicle without authorisation for a private journey in the

37 CE 18 November 1949, Mimeur, Defaux et Besthelsemer, no. 91864, JCP 1950. II. 5286 concl. Gazier.

$3^{8}$ Litigation in relation to road accidents caused by public service vehicles was moved to the civil courts by the Law of 31 December 1957 and is now governed by the Law of 5 July 1985 .

39 CE 2 March 2007, Société Banque française commerciale de l'Océan Indien, no. 283257. 
course of which he knocked down a pedestrian. ${ }^{40}$ The pedestrian successfully sued the state. The Conseil d'Etat found that there was inadequate supervision in the garage which had allowed Laruelle to remove the vehicle, and this amounted to a faute de service. The administration paid the victim but then issued an order to pay a contribution for the whole amount from the soldier, which he challenged. The Conseil d'Etat upheld the contribution claim because the harm had been caused by personal fault. In Delville, a civil court awarded damages against a government lorry driver who injured a third party whilst drunk. He sought to recover the damages from the state on the ground that the accident was caused by defective brakes on the lorry. The Conseil d'Etat upheld his claim to a 50 per cent contribution by the state. Thus the decision in the two cases established the right of the state to seek contribution from a public employee to the extent that their personal fault had caused the harm to the victim.

The scope of this principle was set out in Papon in 2002. ${ }^{41}$ In this case, a Vichy official was convicted in 1998 of crimes against humanity in ordering the arrest and detention of Jews between 1942 and 1944 whilst he was the secretary general of the département of Gironde. Apart from a lengthy prison sentence, the cour d'assises ordered him to pay a sum of $€_{720,000}$ in costs and damages to relatives of his victims. He sought reimbursement by the state on the ground that his acts were undertaken in his official capacity. The Conseil d'Etat found that, notwithstanding the declaration of the unlawfulness and nullity of the acts of the Vichy regime made at the Liberation, the policies and decisions in question were a fault on the part of the state. It then was a question of determining the appropriate portion that the state should bear and the Conseil d'Etat decided that this was half the amount of damages ordered by the criminal court, because his eagerness to have Jews detained went beyond what was required of him as an official at the time. The decision sets out clearly three possible situations. In the first, the harm for which the public official has been sanctioned in the civil court is wholly attributable to a faute de service. Here the official is entitled to a full reimbursement from the state. In a second situation, the harm results exclusively from a personal fault of the official which is separable from the performance of his functions. In such a case, the official cannot obtain any reimbursement for the damages awarded against him because there is no faute de service committed by the administration. In a third situation, like in Papon or Delville, the harm is caused both by a personal fault and by a faute de service. Here the victim can seek redress for

$4^{\circ}$ CE Ass. 28 July 1951, Laruelle and Delville, no. 04032, Leb. 464.

41 CE Ass. 12 April 2002, Papon, no. 238689, Leb. 139 concl. Boissard. 
the totality of the harm done either from the administration or from the individual. Where the official pays, the administration is only obliged to reimburse him for that part of the harm attributable to the faute de service and this is a matter of assessment by the administrative court in the light of the seriousness of the respective faults of the service and the official.

\subsubsection{Faute simple and Faute lourde}

Laferrière, the father of modern French administrative law, wrote in 1887 that article 1240 (former article 1382) of the Civil Code did not apply in administrative law. On the one hand, it was too broad since the state is not liable to compensate for every act of fault, and on the other, the state can be liable to compensate without fault. ${ }^{4^{2}}$ The first of those two exceptions related to the rules requiring proof of gross fault (faute lourde) for a significant number of state activities. Faute lourde is not necessarily a standard of liability that is prejudicial to the victim. The authors of the Grands Arrêts argue that the use of this standard has permitted the courts to remove many activities from a previous total immunity whilst being able to balance the needs of the service and the interests of users of a service. ${ }^{43}$ It constitutes a halfway house between total immunity and total liability for fault.

In the course of the twentieth century, there was a gradual decline in the number of areas in which faute lourde is required to establish liability. In particular, the areas in which the state is only liable for faute lourde (gross negligence) have diminished: hospitals, prisons and public order activities have all moved to faute simple. As late as 1954, Chapus noted that there were two areas in which ordinary fault had been heightened to faute lourde: where a service was gratuitous (gratuitous passenger or a beneficiary of a public service) and difficult activities, especially medical cases, recovery of taxes and supervision of others (particularly the mentally ill). ${ }^{44}$ Chapus already identified that the faute lourde requirement was out of line with the current climate of wishing to compensate victims as much as possible. ${ }^{45}$ Consequently in 1992, the Conseil d'Etat in Époux $V$ abandoned the restriction of hospital liability to faute lourde..$^{6}$ For a long time, the administrative courts had distinguished between medical treatment and hospital care. Public hospitals were liable for ordinary fault (faute simple) where they were careless in looking

$4^{2}$ Laferrière, Traité de la juridiction administrative, vol. 2, p. 176.

43 Grands Arrêts, 22nd ed. 2019, p. 636.

44 Chapus, Responsabilité publique et responsabilité privée, pp. 360-6.

45 Ibid., p. 371.

$4^{6}$ CE Ass. 10 April 1992, no. 79027, Leb. 171, concl Legal. 
after a patient. But in the case of medical interventions such as operations or prescribing drugs, they were liable only in the case of gross fault (faute lourde). In this case, a woman had a caesarean operation in which the risks of hypertension and cardiac problems were known. She was given an excessive dose of a drug which caused hypertension and a cardiac arrest. Fortunately, another hospital saved her life, but she was left with severe after-effects. The commissaire du gouvernement argued that the distinction between those medical treatments subject to requirements of faute lourde and those for which faute simple sufficed was incoherent. The Conseil d'Etat followed, noting the facts and holding that they 'constitute a medical fault of a kind giving rise to the liability of the hospital'. This approach was enacted in art. 1142-1 of the Code of Public Health from 2002. ${ }^{47}$ The approach was also followed in relation to emergency medical treatment. ${ }^{8}$ In prisons, immunity was replaced in 1958 by faute lourde and then by faute simple in $2007 .{ }^{49}$ Public regulation and safety (police in the French meaning) was immune from liability until 1905 , then replaced by faute lourde. Now emergency services are liable merely for faute simple, despite the difficulty of the task. ${ }^{\circ}$ More significant, in the Napol case in 2016, the Conseil d'Etat gave the advice that prefects issuing search warrants in hot pursuit of terrorists would be liable for ordinary and not gross fault. ${ }^{51}$ The regulation of dangerous premises, phytosanitary measures and the urgent removal of driving licences all now give rise to liability where there has been simple fault. ${ }^{2}$ Equally, tax authorities protected by immunity until 1962, then subjected to liability only for faute lourde until this was all replaced by faute simple in 2011 in the Krupa case. ${ }^{53}$

Frier and Petit comment that "without being totally abandoned [faute lourde] tends to retreat before the increasingly strong requirements of social solidarity'. ${ }^{54}$ Three areas in particular seem resistant to this trend of abandoning the requirement of faute lourde: judicial decisions, internal security and regulatory authorities. The main area for faute lourde is shared with private Machureau; AJDA 2016, 1635.

52 See respectively, CE 27 September 2006, Commune de Baalon, no. 284002, AJDA 2007, 385 note Lemaire; CE 7 August 2008, Ministre de l'agriculture et de la pêche, no. 278624, AJDA 2008, 1572; and CE 2 February 2011, M Gérard A, no. 32776o, RFDA 2011, 451.

53 CE Sect. 21 March 2011, M Christian Krupa, no. 306225, AJDA 2011, 1278 note Barque.

54 L. Frier and J. Petit, Droit administratif, 1oth ed. (Paris: LGDJ, 2018), para. [958]. 
law - the operation of the justice system. The Law of 5 July 1972 (art. L141-1 Code de l'organisation judiciaire) imposes liability of the state for 'faute lourde or déni de justice'. Although not directly applicable to administrative law, the Conseil d'Etat followed suit in Darmont in 1978, reversing a decision in 1969 setting out the immunity of the state for judicial decisions. ${ }^{55}$ But, when the state is sued for excessive delay in dealing with a case in breach of art. 6 (1) of the European Convention on Human Rights, liability is based on ordinary fault. Thus, in Magiera, the proceedings at first instance were allowed to drag on for seven years and six months with the expert's report alone taking four years and four months to be produced..$^{56}$ The Conseil d'Etat followed the lower courts in finding this an excessive delay. Basing itself both on art. 6 (1) and on 'the general principles governing administrative justice', it found that litigants had the right to have their case decided in a reasonable time. The calculation of the reasonable time is assessed through a holistic view of the proceedings. Litigation on this matter is brought normally directly before the Conseil d'Etat under art. $\mathrm{R}_{311-1} 5^{\circ}$ of the CJA. But the complexity of the split between public and private law can lead to the Tribunal des Conflits judging the case. For example, in a case in $2019,{ }^{57}$ the Tribunal decided that a case involving the dismissal of an employee which had taken nine and a half years was excessively delayed and non-pecuniary loss of $€_{7,500 \text { was awarded. }}$ Here, the dismissal action against the employer lay before the tribunal des prud'hommes, but the challenge to the refusal by the labour inspector to permit the dismissal of a protected employee lay before the administrative courts. The case involved two decisions at first instance, three in appeal courts, two in the Cour de cassation before the parties eventually settled, and the damages claim against the state was brought to a further court of first instance and the Tribunal des Conflits!

More recently, Wachsmann has argued that the requirement of faute lourde has unjustifiably been retained in cases such as terrorist surveillance. ${ }^{5}$ Since Epoux $\mathrm{V}$ and Napol, major bastions of this requirement had crumbled. $\mathrm{He}$ considered it a legacy of the ancient immunity of the state amounting to a denial of justice in the modern era. For him, the difficulty for the administration in undertaking a task can be handled within the idea of fault without resorting to requiring proof of faute lourde.

\section{L'Etang, no. 7248 o, Leb. 388.}

56 CE Ass. 28 June 2002, Garde des Sceaux c Magiera, no. 239575, Leb. 248, concl. Lamy.

57 TC 9 December 2019, C, no. C4106, AJDA 2020, 1186.

$5^{8}$ P. Wachsmann, 'A quoi sert la faute lourde en matière de police administrative ?', AJDA 2018, 1801 . 
In the cases Wachsmann criticised, it was held that public authorities exercising surveillance of terrorist suspects would only be liable for gross fault for failing to prevent the harm the suspects caused to the claimants. Traditionally liability to third parties for policing responses to terrorism has been based on faute lourde. ${ }^{59}$ This was applied in two cases in 2018 . In one case, relatives of those killed by terrorists at the Bataclan nightclub in 2015 sued the security services for failing to apprehend the killers based on information available to them. The tribunal administratif of Paris rejected the claim on the ground that no faute lourde had been alleged against the services. ${ }^{60}$ The terrorist plans were conceived outside France and the terrorists were only in France for a short period before the attack. In a case before the Conseil d'Etat, Chennouf, the family of a victim of a terrorist killings in Nice sued the state for failures of the security services in monitoring Merah, a suspect whom the services failed to follow up. ${ }^{61}$ It was held that there was no faute lourde and so no liability. In this case, the Minister of the Interior himself admitted mistakes, so it was hard to see why there was no liability. It is possible that the problem of the secrecy of security information would make it impossible for documents to be released to the court.

\subsubsection{Fault and Unlawfulness}

Until the 1970s, there was a debate in France about whether an unlawful decision was necessarily a fault giving rise to liability. But that was resolved by the Conseil d'Etat in Ville de Paris c Driancourt. ${ }^{62}$ In that case, the police commissioner banned the use of gaming machines in a posh part of Paris as a result of complaints from the residents' association. That decision was annulled subsequently by the tribunal administratif of Paris which awarded the owner of the premises $85,745 \mathrm{~F}$ in damages. The decision was upheld by the Conseil d'Etat, which held that 'unlawfulness, even if it is attributable to a mere error of assessment, constitutes a fault which is capable of giving rise to the liability of public authorities'. In the view of the commissaire du gouvernement Gentot, 'subjects have a genuine right to legality and can claim damages

59 CE 22 October 1975, Bergon, no. 92865, Leb. 521: a traffic accident resulting from tear gas fired onto the highway during May 1968 riots.

6o TA Paris 18 July 2018, V,W,X, no. 16121238/3-1 AJDA 2019, 130 note Blandin.

61 CE 18 July 2018, Chennouf, $\mathrm{n}^{\circ}$ 411156, AJDA 2018, 1915 concl. Marion. The commentary notes that liability for the failure of the security services to stop children joining jihadists abroad has been held to be based on faute simple: CE 9 Dec 2016, $n^{\circ} 386817$, AJDA 2016, 332 concl. Domino; CE 26 April 2017, $n^{\circ}$ 394615, AJDA 2017, 1469 concl. Domino.

62 CE Sect. 26 January 1973, no. 84768, Leb. 78 concl. Gentot, translated in Fairgrieve, State Liability in Tort, pp. 297-8. 
for the harmful consequences of the breach of this right'. This point was reinforced by an avis of the Conseil d'Etat in 2016, Société Napol. ${ }^{63}$ The question in this case was liability for illegal searches undertaken within the state of emergency declared following the terrorist attacks at Bataclan and other locations in Paris in November 2015. On subsequent days, prefects ordered searches of private accommodation under powers granted under the Law of 3 April 1955. In a decision in February 2016, the Conseil constitutionnel ruled that search warrants had to be accompanied by reasons. ${ }^{64}$ Those subject to searches sought the nullity of the warrants for lack of reasons and damages. The Conseil d'Etat responded to a request for an opinion by the tribunal administratif of Cergy-Pontoise that 'any illegality affecting a decision ordering a search amounts to a fault capable of giving rise to the liability of the state'. But, as Fairgrieve had already pointed out, the extent of this scope for liability is limited by the requirements of causation - that is, the cause of illegality in the present case. In particular, the Conseil d'Etat noted 'the direct character of the causal link between the illegality committed and the alleged harm cannot be established where the decision ordering the search is only vitiated by an irregularity in formality or procedure and where the court considers, in the light of all the facts presented to it by the parties, that the decision ordering the search could have been taken legally by the administrative authority in the light of the facts available to it at the time the search was authorised'. This follows established case law which refuses compensation when the court considers that the administration could have taken the same decision lawfully at the time and so the illegality has had no real impact on the situation of the citizen. ${ }^{65}$

A particularly important area of unlawfulness is the incompatibility of legislation and judicial decisions with EU law. In Gestas, despite its reluctance to allow to use a damages action as a means to remake a final judgment, the Conseil d'Etat held that 'the liability of the state can be found where the content of a court judgment is affected by a manifest breach of community law having as its purpose the conferral of rights on individuals' ${ }^{66}$ But that was not

63 CE Ass. 6 July 2016, Société Napol et autres, no. 398234, Leb. 320 concl. BourgeoisMachureau; AJDA 2016, 1635.

64 CC decision no. 2016-536 QPC of 19 February 2016, Ligue des droit de l'homme, ECLI: FR: CC:2016:2016.536.QPC.

65 See CE Sect. 19 June 1981, Carliez, no. 20619, Leb. 274 concl. Genevois; Fairgrieve, State Liability in Tort, pp. 184-5. On the importance of causation generally, see C. Malverti and C. Beaufils, 'Les causes perdus' AJDA 2021, 966.

66 CE 18 June 2008, Gestas, no. 295831, Leb. 230. The claimant teacher did, however, recover $€_{14,000}$ in damages for the delay in dealing with his challenge to a civil service employment decision taken against him, which had taken fifteen years and eight months to decide. TA Paris, 21 April 2021, no. 1823994/2-2, AJDA 2021, 1345. 
found in that case, nor in Lectalis Ingredients. ${ }^{67}$ It is to be noted that, in these cases, liability of courts is grounded on gross fault (faute lourde). This standard matches the requirements of EU law that the state is responsible for sufficiently serious breaches of EU law by its courts. ${ }^{68}$

\subsubsection{Fault in Regulation}

Fault in regulation (supervision and control) is controversial in all countries. When a citizen sues the state for the failure to regulate a private body, she is effectively making the state a guarantor of the good behaviour of a private person and is usually suing for a failure to act to prevent harm being caused, rather than for a positive act done by the regulatory body. The problem in France is similar to that in England as it may entail a risk of disempowerment. ${ }^{69}$ After the Liberation in 1944, the liability of state regulatory or supervisory bodies was established on the basis of faute lourde. The justification lay in the particular difficulties of the task. ${ }^{7 \circ}$ For example, in the supervision of banks, faute lourde is required before the supervisory body was liable, even if there irregularities in the information provided by the bank over several years and criminal offences were being committed by its directors. ${ }^{71}$ This line of case law was maintained in Kechichian. ${ }^{72}$ The Conseil d'Etat rejected the ruling by the lower court that a finding of liability could be based on simple fault, but found gross fault on the facts. In this case, depositors claimed that the Commission Bancaire had committed fault in supervising a Saudi-Lebanese bank. An inspector's report to the Commission that the Bank needed urgently to make provision against large unpaid debts, but it noted the goodwill of the managers. In view of all the facts, gross fault was found on the part of the Commission Bancaire in following up the inspector's report. It had delayed too long in ensuring that the finances of the bank were secured, and it had not acted in accordance with prudential principles in ensuring sufficient funds were held by the bank.

67 CE 9 October 2020, Lectalis Ingredients SNC, no. 414423, AJDA 2020, 1935, but was found by a lower court in a case involving an erroneous decision by the Conseil d'Etat. Case C-224/o1, Köbler v Austria, ECLI:EU:C:2003:513 [51]-[59].

69 See generally M. Andenas and D. Fairgrieve, 'To Supervise or to Compensate?', in M. Andenas and D. Fairgrieve, eds., Judicial Review in International Perspective. Liber Amicorum for Lord Slynn of Hadley (The Hague: Kluwer, 2000), chapter 24.

70 See Deguergue, Jurisprudence et doctrine, pp. $231 \mathrm{ff}$.

${ }_{71}$ See CAA Lyon, 28 December 1990, Fauvry, no. 89LYo1299.

72 CE Ass. 30 November 2001, Kechichian, no. 219562, AJDA 2002, 136, translated in Fairgrieve, State Liability in Tort, pp. 321-3. 
A similar approach was adopted in relation to the supervisory role of the prefect in referring actions of a public authority to the administrative courts. ${ }^{73}$

\subsubsection{Types of Fault}

Fault may take various forms. The first is the failure to provide a public service. For example, the law provides that the state has a duty to provide education for a handicapped child that is appropriate to his or her needs. Where the state had failed to provide such education for a handicapped girl, it was held liable to her. The duty was not one of best efforts and the state could not escape liability by claiming that there were no available facilities for her. ${ }^{74}$ Similarly, where the state was unable to provide all the teaching on its prescribed curriculum throughout an academic year because of insufficient staff, the father of the child was able to obtain damages for the disruption to his child's schooling. ${ }^{75}$ This is the equivalent of a breach of a statutory duty.

Fault may occur in the performance of a perfectly lawful and careful policy. Thus, in Blanco, the girl was injured by the careless use of a public service cart from a tobacco factory. ${ }^{76}$ Similarly, in $M D$, there was a policy on the frequency of checks by prison officers on vulnerable prisoners. ${ }^{77}$ In this case, a routine check was not carried out, which permitted a young offender to commit suicide.

Fault may occur not only by action but also by inaction. This is shown in the case of precautions with regard to health, especially in the medical case M.D. ${ }^{78}$ Here, the risk of transmission of HIV through contaminated blood transfusions was only established scientifically in November 1983. Already in June 1983, the Minister of Health issued a circular warning of the suspicion of such transmission. The effectiveness of heating blood to deal with this risk was proved scientifically in October 1984 and this was communicated to the administration in a scientific report in November 1984. Advice on using this treatment through products, readily available internationally, was not disseminated until a ministerial circular of October 1985. The failure of the Minister to act

73 CE 6 October 2000, Ministre de l'Intérieur c Commune de St-Florent, no. 205959, Leb. 395.

74 CE 8 April 2009, Laruelle, no. 311434, AJDA 2009, 1262 concl. Keller. The principles were reaffirmed in CE 8 November 2019, BA, no. 412440, AJDA 2020, 1109, but no liability was found on the facts.

75 CE 27 January 1988, Giraud, no. 64076, Leb. 39, translated in Fairgrieve, State Liability in Tort, p. 303. Only 1,000 F (about $€_{150}$ ) was awarded for the loss of seven hours of teaching a week.

${ }^{6} 6$ See note 1.

77 See note 48 .

$7^{8}$ CE Ass. 9 April 1993, M.D., no. 138653, AJDA 1993, 344; D. 1993, 312 concl. Legal. 
promptly in preventing the possibility of infection led to the state being found liable for fault to all those harmed by infected blood between November 1984, when the Minister should have acted, and October 1985, when action was finally taken. On the criminal side, both the Prime Minister and the Minister were found not guilty ten years later, confirming the statement of the Minister in which she had said she felt 'responsible but not guilty', an assessment badly received by the public as the symbol of non-accountability of politicians. The first issue is thus whether the risk to health was known. For example, in Cohen, there was no-fault liability for harm caused to a surgeon treating a patient with infected blood in May 1983. ${ }^{79}$ The second issue is whether there are means of avoiding the risk. The third issue is whether the state failed in adopting those means. The existence of such means and the failure to act promptly to ensure they were adopted led the Conseil d'Etat to find the state liable for fault in the medical case, M.D. Where the risk was not known or could not be prevented, the state may still be liable, but only on the basis of no-fault, as was the case in Cohen where the risk of contracting HIV during surgery was considered abnormal in that public service.

\subsection{NO-FAULT LIABILITY}

No-fault liability of the state predates the Revolution. The idea of compensation for actions taken to protect the community, such as demolishing buildings in the path of a fire, and for actions to help the community, such as the billeting of troops or the expropriation of property for defences, goes back to medieval times. ${ }^{80}$ The underlying principle is that burdens borne for the common good should be shared. It is conventional in France to distinguish between liability for risk and the principle of equality before public burdens. That will be followed here, though the two are fundamentally connected.

\subsubsection{Liability for Exceptional Risks}

At the end of the nineteenth century, no-fault liability was introduced into public and private law on the basis of risk. But, as the idea of Hauriou cited earlier made clear, the fundamental justification was social solidarity and that

79 CE 10 October 2003, Cohen, no. 197826, AJDA 2003, 2390 concl. Chauvaux, note Deguergue. The case is a good example of the division of responsibilities between public and private law. The surgeon's loss of earnings was a matter for social security law and thus for the ordinary courts. The claims of his children as ricochet victims was for public law.

$8 \circ$ J.-L. Mestre, Introduction historique au droit administratif français (Paris: Presses Universitaires de France, 1985), pp. 28-32, 137-40. 
is directly connected to the principle of equality before public burdens. ${ }^{81}$ This is even more the case today when the idea of liability for risk has gone out of fashion in France. ${ }^{82}$

The classic example of liability for exceptional risk is Regnault-Desroziers. ${ }^{83}$ From 1915 a large quantity of grenades was stored in a fort to the north of Paris, close to a heavily populated area. In March 1916, there was a huge explosion in the fort, killing fourteen soldiers and nineteen civilians and injuring eightyone others. It was found that the army had placed this large cache of weapons destined for the Front against the Germans without undertaking the precautions necessary to avoid harm to neighbours. Whereas the commissaire du gouvernement Corneille argued for liability based on fault, the Conseil d'Etat preferred to base its decision in favour of the victims on no fault. In its view, the operations, undertaken under the pressure of military necessity, "involved risks exceeding those which normally apply to a neighbourhood, and ... such risks were capable of incurring the liability of the state without [proof of] fault'. ${ }^{84}$ The principle applied here of no-fault liability for harm exceeding the normal inconveniences between neighbours had previously only applied to public works, as explained in Section 3. The decision broadened the scope of liability beyond public works. Subsequent decisions stressed the importance of the dangerousness of the public work in that it justifies compensating not only third parties to the public service, but users as well. Thus, in Dalleau, there was a rock fall onto a road which damaged the claimant's car and injured himself and his passenger; the state was held liable to compensate him. ${ }^{85}$ The risk of landslips in that part of the island of Réunion had been increased by cutting down trees in order to construct the road and several had occurred since it was built. The exceptional dangerousness of the public work justified a finding of liability without fault in favour of a user of the road and without proof of a defect in design or maintenance. However, a few years later, due to improvements of the prevention of rocks falling, the Conseil d'Etat ruled that the presumption of fault should apply again to users of this road and no other example of no fault in case of users of public works had been found since then. The road should be soon closed once the autoroute de la mer, an artificial road seven miles long, is built to the sea.

$81 \quad$ See note 10.

82 See G. Viney, P. Jourdain and S. Carval, Traité de droit civil. Les conditions de la responsabilité, $4^{\text {th }}$ ed. (Paris: LGDJ, 2013), para. 854.

83 CE 28 March 1919, Regnault-Desroziers, no. 62273, S. 1918-19.3.25 note Hauriou.

84 Translation by Fairgrieve, State Liability in Tort, p. 293.

85 CE Ass. 6 July 1973, Ministre de l'équipement et logement c Dalleau, no. 82406, Leb. 482. 
This ground of liability was expanded beyond harm in a neighbourhood to dangerous activities in general. So, in Lecomte a bar owner sitting in his doorway was shot by a municipal police officer in an operation trying to stop a car which contained suspects. ${ }^{86}$ Whereas, because of the special difficulty of policing, the City of Paris would only have been liable for faute lourde, the Conseil d'Etat held that the state would be liable without proof of fault for the use of firearms. The exceptional risk of harm by ricochet bullets here exceeded the ordinary risks of life an individual would expect to bear. Similarly, the husband of Mme Daramy was able to recover for her death caused by bullets fired by a municipal police officer who was chasing men who had knifed a taxi driver. ${ }^{87}$ As the authors of the Grands Arrêts point out, this decision talks about risk, but also relies on the abnormal character of the harm, which typically is a feature of liability for equality before public burdens. ${ }^{88}$ So the case shows how the two bases of no-fault liability are connected where the harm is to third parties to a public service. The pattern of liability is repeated in numerous other cases. For example, in Sadoudi, the family of a claimant was able to recover when a policeman's service revolver went off accidentally, killing his flatmate. ${ }^{89}$ The risk to the public of the obligation to keep his service revolver at home justified the liability of the police authority. Indeed, subsequent cases such as Napol invoke equality before public burdens in order to provide a remedy to third parties (such as neighbours) who suffer harm as a result of lawful police searches. ${ }^{90}$

The debate about whether risk is a determinant part of the justification for liability has become more acute in relation to liability for the acts of those whom the state controls or supervises. An ordonnance of 1945 replaced imprisonment for juvenile offenders with a more liberal institution where offenders lived under supervision but could more easily escape. In Thouzellier, several inmates of such a re-education centre and committed burglary in the claimant's villa. ${ }^{91}$ He successfully sued. The Conseil d'Etat based its decision on the special risk the institution posed for those in the neighbourhood. This was followed in Banque Populaire de Strasbourg, in which three prisoners robbed

CE Ass. 24 June 1949, Lecomte, no. 87335, Leb. 307.

CE Ass. 24 June 1949, Daramy, no. 90163, Leb. 308. These days the liability for most such policing activities lies with the ordinary courts where exactly the same principles apply: Cass. ıre civ. Consorts Pourcel c Pénier et Agent judiciaire du Trésor public, JCP 1986.II.20683 rapport Sargos.

22nd ed. (2019), p. 967.

CE Ass. 26 October 1973, Sadoudi, no. 81977, RDP 1974, 936.

See note 62 .

CE Sect. 3 February 1956, Leb. 49; D. 1956, 596 note Auby; C. J. Hamson, 'Escaping Borstal Boys' [1969] C.L.J. 273, at pp. 279-80. 
a bank a significant distance from their prisons. ${ }^{92}$ One prisoner was on leave but had failed to return. A second was on a special regime of semi-liberty, working out of prison during the day, but returning at night. The third was on parole. The scheme of penalties was established in the public interest, but it caused a special risk for third parties and so the bank was able recover its losses without proof of fault.

In the case of other children in the care of public authorities, this used to be based on fault, not on risk. In 1990, the Conseil d'Etat adopted the idea of a presumption of fault. In Ingremeau, a seven-year-old child placed by a local authority with foster parents was playing in a friend's garden. ${ }^{93}$ He accidentally injured his friend's eye with an arrow fired from his bow. The département of Charente was held fully liable because it failed to show it could not have prevented the injury. But this solution soon became inconsistent with the liability in private law of those supervising children and adults lacking mental capacity. The Conseil d'Etat responded by establishing no-fault liability without any mention of the concept of risk. In GIE Axa Courtage, a child was under the care of a child and family institution as a result of a court order. ${ }^{94}$ The child set fire to a building, for which the claimant insurer compensated the building owner and sought indemnification from the state. Using the same terminology as the civil courts, the Conseil held that the transfer by the judge of the power to 'organise, direct and control the life of the minor' to a public body made the state liable for the harm he caused unless the harm was caused by force majeure or fault of the victim. This principle has since been applied to young offenders placed under the care of an association by a public authority.

In Garde des Sceaux c Mutuelle des instituteurs de France, where a fire was caused by a young offender placed with the association Igloo, it was held that the state could be sued for the special risk of the policy of limited surveillance, as well as the association being liable in private law. ${ }^{95}$ This combination of grounds of liability shows that, as in private law, this is not liability based on risk, but on social solidarity..$^{6}$

CE 29 April 1987, Garde des Sceaux c Banque Populaire de Strasbourg, no. 61015, RFDA 1987, 831 concl. Vigoureux, [1987] P.L. 465.

CE Sect. 19 October 1990, Ingremeau, no. 76160, AJDA 1990, 869.

CE Sect. 11 February 2005, Cie Axa Courtage, no. 252169, RFDA 2005, 594 concl. Denys. For the similar liability of those who are not permanently resident with a public body, see CE Sect. 1 July 2016, Société Groupama de Grand Est, no. 375076, Leb. 310 concl. Decout-Paolini.

CE Sect. 1 February 2006, no. 268147, Leb. 42 concl. Guyomar.

See J. Bell, 'Tort Law and the Moral Law: Anglo-French Divergences' (2021) 80 ( $\left.\mathrm{S}_{1}\right)$ Cambridge Law Journal $\mathrm{S}_{33}$ at pp. $\mathrm{S}_{4} 8-\mathrm{S}_{55}$. 
The connection between risk and social solidarity was even clearer in the medical field. For example, in Bianchi, a patient was injected with a contrasting fluid as part of a diagnostic test. ${ }^{97}$ He suffered a severe reaction to it, leading to tetraplegia and pains which were not responsive to pain relief. Although this was a known risk of the treatment, there was no indication that the patient was susceptible to it. The Conseil d'Etat decided that, even if no fault could be found, the state was liable. Where a medical treatment involved a known risk whose occurrence was exceptional and there was no reason to think the patient would suffer from it, the hospital is liable where the harm to the patient is directly connected with the treatment and is of extreme seriousness. The subsequent legislation on no-fault medical liability of 2002 most clearly moves this kind of situation into the category of collective responsibility.

\subsubsection{Assistance to the Public Service}

The earliest of the decisions on no-fault liability outside public works came in Cames..$^{8}$ In 1895 , Cames was a worker in a munitions factory in Tarbes. He was injured by a piece of metal which flew into his left hand under the pressure of a pneumatic drill. He sued for his injuries, which made him unable to work. Commissaire du gouvernement Romieu based his argument in favour of no-fault liability on fairness in the relations between the state and its workers that the state should guarantee them against the special risks of their work in the public service. Although the statutory scheme for industrial injuries was adopted a few years later and there are statutory arrangements for most other public service employees, ${ }^{99}$ this remains a basis for claims made by those assisting in the public service. ${ }^{100}$ In Cohen, it provided compensation to the employee's children for their pain and suffering at their father's illness. ${ }^{101}$ It also provides a remedy for occasional or voluntary helpers of the public service. Thus, in Commune de Saint-Priest-La-Plaine, two men volunteered to help the mayor in setting off the fireworks at the local fête. ${ }^{102}$ They were injured by the premature explosion of the fireworks. They were able to

97 CE Ass. 9 April 1993, no. 69336, Leb. 126 concl. Daël, AJDA 1993, 344.

$9^{8}$ CE 21 June 1895, Cames, no. 82490, S. 1897.3.33 concl. Romieu, note Hauriou; translated by Fairgrieve, State Liability in Tort, p. 289.

99 For example, art. L62 of the Code du service national.

100 See a repetition of this principle in CE Ass. 4 July 2003, Moya-Caville, no. 211106, AJDA 2003, 1598.

101 See note 79.

102 CE Ass. 22 November 1946, no. 74725 , Leb. 279. 
recover against the commune on the basis that they were assisting in the performance of a public service. There is abundant case law applying this principle to voluntary work in the public service. Indeed, it may also apply where there is no actual public service, but where a private initiative makes up for what should have been a public service. For example, in Commune de Batz-sur-Mer c Tesson, there was no lifeguard on a stretch of beach for which the local commune had a duty to prevent accidents. ${ }^{103}$ A citizen drowned trying to rescue a child who was being carried out to sea. His widow was able to recover against the commune for his death, and its lack of resources did not justify the absence of the public service which he effectively provided.

\subsubsection{Equality before Public Burdens}

Under the principle of equality before public burdens, the state is liable to compensate the victim of (a) a serious harm that is (b) special to him or her or to a small group and which (c) is abnormal in the sense that it exceeds what citizens generally should expect to bear as the result of the lawful action of public authorities. It is ancient. Deguergue argues that it was seen first as a principle governing taxation. ${ }^{104}$ Only with the writings of Hauriou in 1896 and then Jèze in 1910 did it become articulated as a principle of state liability. ${ }^{105}$ The Conseil d'Etat moved gradually to recognise the principle after the First World War, leading to the decision in Couitéas in $1923 .{ }^{106}$ In this case, Couitéas owned large areas of land in southern Tunisia, then still a French colony, which became occupied by eight thousand nomadic tribesmen. He obtained a court order for their eviction but the military authorities refused to enforce the order on the ground that this might provoke a rebellion, a decision upheld by the government in Paris. He claimed compensation from the government and the Conseil d'Etat upheld his claim. It held that a citizen in possession of a court order had a right to rely on the assistance of public force to secure its enforcement. The government was entitled to refuse on grounds of public security, in which case the refusal imposed a burden that exceeded what a citizen should normally bear and, in that case, the state should provide compensation. There was a substantial case law applying this

103 CE Sect. 25 September 1970, no. 73707, D. 1971, 55 concl. Morisot; see also CE Sect. 22 March 1957, Commune de Grigny, no. 33431, Leb. 524.

104 Deguergue, Jurisprudence et doctrine, pp. 138-9.

105 M. Hauriou, 'Les actions en indemnité contre l'Etat pour les préjudices causés par l'administration publique', RDP 1896, 51.

106 CE 30 November 1923, no. 38284 , D. 1923.3 .59 concl. Rivet; S. 1923.3.57 note Hauriou; RDP 1924, 75 and 208 note Jèze; Deguergue, Jursprudence et doctrine, pp. 140-2. 
principle to the refusal of public authorities to help with the enforcement of court orders before it was enshrined in statute. ${ }^{107}$

The principle has been applied to other state inaction which causes abnormal loss to an individual. This is well illustrated by two cases on the illegal blockade of Channel ports by French fishermen in late August 1980. In Sealink U.K. Ltd., the fishermen had blockaded the Boulogne, preventing ferries taking passengers and vehicles between England and France at the busy end of the summer holiday period. ${ }^{108}$ The length of the failure of public authorities to remove the illegal blockade (six days and then two and a half days) caused an abnormally severe loss of trade. The specific character of this trade and its timing made this a special loss exceeding the normal inconvenience suffered by all port users. By contrast, in Société Jokelson et Handstaem, the loss to a local forwarding firm of having to divert two ships in order to unload and of having an office inactive was not sufficiently special and serious as to justify compensation. ${ }^{109}$

As in English law, there has been special statutory liability for riot damage since 1795. Article L211-10 of the Code de la sécurité intérieure provides that the state is liable for the damage caused by criminal offences committed by demonstrations or gatherings. The losses covered here can include commercial losses. For example, in COFIROUTE demonstrators occupy a toll bridge and let vehicles through for free, then the toll bridge company can recover for its loss of revenue. ${ }^{110}$ The text speaks of 'damage and harms' ('dégâts et dommages') and that was interpreted widely enough to include all business harms.

Liability will lie not only for inaction, but also for the actions of public bodies. For example, in Commune de Gavarnie, public order rules prohibited pedestrian access along a road which had previously attracted many tourists taking excursions with donkeys or horses from the local circus. ${ }^{111}$ Although there was no fault, the commune was held liable to the owner of a tourist souvenir shop on that road which the tourists would no longer frequent. Equally in Lavaud, the public housing body for Lyon decided to close ten tower blocks after disturbances in the area. ${ }^{112}$ The Conseil d'Etat held that it

\footnotetext{
107 Now art. L153-1 of the Code des procedures civiles d'exécution. See also CC decision 98-403 DC of 29 July 1998, Rec. 276 upholding the right of the state to refuse its assistance.

108 CE 22 June 1984, no. 53630, Leb. 246; also CE 30 September 2019, Compagnie méridionale de navigation, no. 416615 .

109 CE 22 June 1984, no. 53924, Leb. 247.

11 See CE Ass. (avis) 6 April 1990, Compagnie financière et industrielle des autoroutes (COFIROUTE), no. 112497 , Leb. 95 concl. Hubert.

11 CE Sect. 22 February 1963, Commune de Gavarnie, no. 50438, Leb. 113.

112 CE Sect. 31 March 1995, Lavaud, no. 137573, Leb. 155 concl. Bonichot.
} 
was obliged to pay compensation to a pharmacist whose clientele had been very substantially reduced as a result of the closure.

The liability of the state will even lie for harm caused by legislative acts. In 1838 , it had been decided that the state was immune from suit for losses imposed by legislation. ${ }^{113}$ This was justified on the ground that legislation was a sovereign act. But in La Fleurette, a Law of 1934 banned the use of the word 'cream' for any product not entirely sourced from milk. ${ }^{114}$ As a result, the claimant company had to cease production of a product sold under the label 'Gradine', which posed no danger to public health. Although the law did not make provision for compensation, the Conseil d'Etat concluded that there was no evidence that the legislator intended to impose an abnormal sacrifice on people in the claimant's position. Accordingly, it ordered that this burden, imposed in the public interest, should be borne by the state.

The key to this case law is the intention of the legislator. If the legislator intends effects on private individuals, as established through the travaux préparatoires preceding the law, that will not give rise to liability unless the Conseil constitutionnel strikes down the legislative provision. Many pieces of legislation passed in the public interest, such as to protect endangered species, may have effects on particular individuals which the legislator fails to think about and for which it is appropriate therefore to compensate for abnormal and special losses in the administrative courts. ${ }^{115}$ This liability for the effects of lawful legislation applies also to the effects of treaties. For example, in Ministre des affaires étrangères c Burgat, ${ }^{116}$ landlords who tried to evict a tenant after the expiry of notice and for non-payment of rent were met with a claim of diplomatic immunity under the UNESCO treaty signed with France in 1954 on the part of her partner who had joined her after the tenancy began. The landlords successfully sued the state for compensation for this abnormal and special consequence of a lawful treaty.

In 2019, the Conseil d'Etat declared as a principle that the state was liable for the effects of unconstitutional statutes. Since the procedure of the question préalable de constitutionnalité was introduced in 2010, it has been possible for the Conseil constitutionnel to declare an enacted law unconstitutional. The effect of such a decision is typically to make the law inapplicable to the

113 CE 11 January 1838 , Duchâtellier, no. 13059, Leb. 16.

114 CE 14 January 1938, S.A. des Produits Laitiers 'La Fleurette', no. 51704, D. 1938.3 .41 concl. Roujou, note Rolland.

115 See, for example, CE Sect. 30 July 2003, Association pour le développement de l'aquaculture en région Centre, no. 215957, RFDA 2004, 114 concl. Lamy, note Bon, where protecting cormorants would have deleterious effects on fish farming.

116 CE Sect. 29 October 1976, no. 94218, RDP 1977, 213 concl. Massot. 
claimant. That obviously raises the question of compensation for losses sustained by the implementation of that law. In two decisions, the Assemblée of the Conseil d'Etat declared that the state could be liable not only for the abnormal losses caused by valid laws, but also for any losses caused by unconstitutional laws.

By reason of the requirements of the hierarchy of norms, [state liability can be required] to compensate for the totality of harms which result from the application of a law breaching the Constitution or the international agreements of France.

It stated that such a liability only arises if the Conseil constitutionnel specifically declares the relevant provisions of the law unconstitutional and does not let their effects subsist in such a way as to maintain the validity of the effects for which the claimant seeks compensation. In addition, the claimant has to prove causation. In both the cases in which this principle was declared, the claimants failed to demonstrate that their losses were the direct effect of unconstitutional provisions of a law. In Paris Eiffel Suffren, an ordonnance of 1986 authorised a decree to specify the rules by which employees of privatised public enterprises would be entitled to a share of company profits. ${ }^{117}$ In 2013 , the Conseil constitutionnel ruled that these provisions of the law were unconstitutional to the extent that they delegated the determination to the relevant rules to a decree. ${ }^{118}$ In 2011, the Cour de cassation had ruled that the Paris Eiffel Suffren company had failed to comply with the ordonnance (and its subsequent statutory re-enactments) and ordered it to pay more than $€_{2}$ million to its employees covering the period 1986 to 1999. Having complied with that judgment, the company sued the state for the cost of applying an invalid law. The claim failed. The ruling of the Conseil constitutionnel did not find that the requirement for companies to make such payments to their employees was against fundamental rights, but it was unconstitutional only on the procedural ground that the rule should have been made in a law and not in a decree, a defect the legislator corrected in 2004. The only direct loss was the lost opportunity of building up a reserve for such a liability before it became validly required in 2004 (a claim the claimant did not present). This decision

117 CE Ass. 24 December 2019, no. 425983 and similarly CE Ass. 24 December 2019, Société Paris Clichy, no. 425981 , AJDA 2020, 509. In the third case, no. 428162 Laillat, a claim of a worker for compensation was rejected in relation to litigation for a claim to a share in profits of an applicable company that was pending at the moment of CC decision and was then stopped. The approach of the Conseil d'Etat in these cases was upheld by the Conseil constitutionnel in CC decision no. 2019-828/829 QPC of 28 February 2020, AJDA 2020, 1307. 
applied the restrictive principles on causation discussed in Section 8.4.5 in relation to illegal administrative decisions.

This case law on liability for unconstitutional legislation follows the line adopted in relation to legislation which breached the European Convention on Human Rights. In Gardedieu, a decree establishing a pension contribution for dentists was declared illegal by the Conseil d'Etat and the legislator passed a law validating the provisions of that decree except for judicial decisions which had already been handed down. ${ }^{119}$ The claimant's challenge to the validity of the state's claim for pension contribution against him was pending when the validation law was passed. The Conseil d'Etat did not consider that a sufficiently serious public interest justified denying the claimant his right to a fair trial and he was able to reclaim the pension contributions he had made. In Société Métropole Télévision (M6), breaches of general principles of European Union law were held to be included within international agreements of France', thereby providing a basis for Francovich liability. ${ }^{120}$ That decision was interesting in that it rejected liability based on fault, but retained liability for the unlawful effects of laws. In all three decisions, a distinction was made between the narrow ground for compensation under equality before public burdens and the wider ground for laws in breach of the Constitution or of a treaty. Though some have seen liability for breach of the Constitution or treaty as fault, the Conseil d'Etat has never said this explicitly. The rapporteur public Sirinelli described the liability in Paris Eiffel Suffren as 'a regime of fault which does not dare to speak its name'. ${ }^{121}$ Essentially, the judge does not like to say that the sovereign legislator has committed a fault! She prefers 'manquement' to 'faute' as the latter has a moral and negative connotation. But since this is strict liability in the sense that illegality is automatically fault, then the line between fault and no-fault liability is not great.

\subsubsection{Other No-Fault Compensation}

In addition to the general principles of no-fault liability, there are a number of statutory schemes. Some are general in nature. For example, the scheme to compensate the victims of compulsory vaccination was first set up in 1964 and is now part of the Code of Public Health (Code de la santé publique), art. L3111-9. The scheme is run by the Office national d'indemnisation des

119 CE Ass. 8 February 2007, no. 279522, Leb. 78 concl. Derepas.

$120 \mathrm{CE} 22$ October 2014, no. 361464, AJDA 2014, 2433.

121 See Chronique Malverti et Beaufils, AJDA 2020, at p. 514. 
accidents médicaux (ONIAM) and it undertakes the medical assessment of a claimant.

In 2002 legislation was passed to unify the substantive law governing liability for private and public health care. ${ }^{122}$ Generally, the legislation provided that doctors, dental surgeons, midwives and 'any establishment, service or bodies in which individual acts of prevention, diagnosis or care take place are liable for the harmful consequences of acts of prevention, diagnosis or care only in the case of fault'. ${ }^{123}$ Two important exceptions were made for liability in respect of the supply of defective products (owing to the impact of the EU Product Liability Directive) and in respect of hospital-acquired infections or the intervention of medical practitioners in exceptional circumstances, where liability was imposed on the hospital or other institution unless they show cause étrangère (i.e. force majeure). ${ }^{124}$ These liability provisions were coupled with an obligation on all those providing medical services, whether private or public, to insure against their liability, with the exception of the state itself. ${ }^{125}$ It also set up a special fund, based on national solidarity, to compensate those suffering very serious harm as a result of contracting a hospital-acquired infection or a medical accident where liability was not established. ${ }^{126}$ The law made the significant changes to the procedure for compensation. The medical institution has to provide the victim (or relatives) with an explanation of harm within fourteen days of its discovery. The matter is then referred to the regional Conciliation and Compensation Commission which will determine responsibility and compensation. If fault is established, then the insurer of the hospital or professional is required to make an offer of compensation. The idea was to avoid litigation. In practice, there is still a significant amount of litigation now against the compensation agency ONIAM in the administrative courts for rejecting claims of victims, rather than suing for doctors and private hospitals for fault under the Civil Code or suing public hospitals under administrative law principles.

Subsequent health problems resulting from particular drugs have also given rise to compensation schemes - for example, in the case of Mediator (the brand name for benfluorex, a treatment for diabetes, also used for diet, which led in 2021 to the pharmaceutical firm being criminally sanctioned for

${ }^{122}$ Loi no. 2002-303 of 4 March 2002; see S. Taylor, "The Development of Medical Liability and Accident Compensation in France', in E. Hondius, ed., The Development of Medical Liability (Cambridge: Cambridge University Press, 2010), pp. 93-8.

123 Art. L1142-1 al. $11^{\circ} \mathrm{C}$. santé pub.

124 Art. Li142-1 al. $12^{\circ} \mathrm{C}$. santé pub.

125 Art. L1142-2 C. santé pub.

126 Art. L. 1142-1 al. II C. santé pub. 
forgery), legislation provided for full indemnity and prevented conflicts of interests in the drug sector ${ }^{127}$ and in the case of Dépakine, a drug for epilepsy and bipolar disorder. ${ }^{128}$

In these areas, the principle of national solidarity is explicitly invoked. The complexity of making appropriate administrative arrangements to handle claims and ensuring the budget to pay makes this a better area for legislative intervention than for judicial expansion of general public law principles of liability, even if the first steps in many of the areas have been made by the administrative courts. ${ }^{129}$

\subsection{CONTROLS ON LIABILITY}

Although the scope of liability in French administrative law is very wide, this does not necessarily result in greater recovery for citizens against the state than in other countries. As Fairgrieve pointed out, rather than limit liability through the framework of duties, controls are effected, especially through causation and rules on the measure of damages.

\subsubsection{Categories of Harm}

Because French law does not have special rules on liability for different types of loss - economic, emotional or ecological loss - there are, in principle, no limits on the harm for which recovery is possible. Indeed, a number of the cases mentioned in this chapter have been examples of such harms. For example, many of the cases just discussed under equality before public burdens relate to economic loss - the loss of the ability to sell a product ( $\mathrm{La}$ Fleurette), the payment of pension contributions (Gardedieu), the distribution of profits to employees (Paris Eiffel Suffren). In relation to faute lourde, Kechichian is an example of recovery for economic loss. An example of recovery for economic loss in the case of ordinary fault (faute simple) would be Driancourt. Damages can be substantial. In Nice Hélicoptères, based on incorrect facts about the ability of the company to comply with the requirements of control over helicopters, the Ministry of Transport unlawfully refused to renew a licence to operate helicopters. ${ }^{130}$ This led to the collapse of the business, for which the company was awarded 10 million F. It was also

127 Loi no. 2011-900 of 29 July 2011.

${ }_{128}$ Loi no. 2016-1917 of 29 December 2016.

129 See J.-M. Pontier, 'La notion de la réparation intégrale', AJDA 2018, at p. 853.

130 CE 24 March 1995, no. 129415. 
awarded 50,000 $\mathrm{F}$ for the unlawful interception and grounding of flights by the police.

For a long time, the administrative courts refused damages for nonpecuniary loss. But in Letisserand, a man and his seven-year-old son were killed when their motorbike collided with a lorry belonging to a public authority. ${ }^{131}$ The father of the man recovered 1,000 $\mathrm{F}$ as a pretium doloris and the man's widow recovered for the emotional effects of losing her young son as a then more established category of troubles dans l'existence de la vie (disturbance in her way of life). This second category is frequently used to provide non-pecuniary damages. Particularly in medical cases, the Conseil d'Etat has since expanded categories of recoverable loss to include anxiety at a potential illness resulting from medicine a patient had taken ${ }^{132}$ or breaches of human dignity arising from detention in unacceptable prison conditions. ${ }^{133}$ Such préjudice moral is recoverable in liability for fault and liability without fault.

In recent years, the legislator has encouraged the recognition of ecological harm, harm to the environment. In private law, this was achieved through an amendment to the Civil Code (art. 1246). Administrative law followed suit through case law, influenced also by the Charter on the Environment and the Conseil constitutionnel. ${ }^{134}$ This was accepted by an administrative court of first instance in $2021^{135}$ at the request of associations and was preceded by a 2020 case where the Conseil d'Etat, at the request of a city under sea level, asked the government to prove it has done enough against climate change. ${ }^{136}$

\subsubsection{Causation}

As in French private law, in French administrative law the scope of liability is kept in check not by limiting categories of loss, as in English law, but by the doctrine of causation. Unlike German scholars and judges, French scholars and courts do not pay attention much to theories of causation. Causation is a matter of fact for the lower court judges, and the Conseil d'Etat these days is merely the review court (juge de cassation). The Conseil will only interfere where the lower court has clearly misinterpreted the facts. For causation to be established, the claimant must show that his or her loss is the direct and certain

${ }^{131}$ CE Ass. 24 November 1961, Epoux Letisserand, no. 48841, Leb. 661.

${ }^{132}$ CE 9 November 2016, Mme Bindjouli, no. 393108, Leb. 496 concl. Lessi.

133 CE Sect. 3 December 2018, Bermond, no. 412010, AJDA 2019, 279.

134 CC decision no. 2011-116 QPC of 8 April 2011, Rec. 183.

135 TA Paris, 3 February 2021, no. 1904968, para. 10.

${ }^{136}$ CE 19 November 2020, Commune de Grande-Synthe, no. 427301. 
consequence of the action of the administration. In part, this will be established by the expert's report, but the final assessment of the facts is for the judge, and that is more a matter of intuition than logic. ${ }^{137}$ The concept of 'certainty' is used to restrict the amounts recovered for loss of profits.

In cases of unlawful acts, then it has already been noted in Section 8.4.5 that errors in procedure or failure to follow formalities may not be held to have a sufficient causal connection between the unlawfulness and the harm suffered by the victim. As the Assemblée of the Conseil d'Etat pointed out in Napol, where the same decision could have been taken validly on the basis of facts known at the time, then there is no direct connection between the unlawful decision and the loss. ${ }^{13^{8}}$ The loss would have happened in any case. A similar approach was adopted in Paris Eiffel Suffren in relation to unconstitutional laws. ${ }^{39}$ In that case, the ground of unconstitutionality was a failure of the legislature to make the rule itself, rather than delegating the task to the executive. The procedural irregularity was not the cause of the loss. On such matters, the law on liability is consistent with the provisions of the Law of 17 May 2011, which only allows a decision to be quashed for a procedural irregularity where it would have affected the decision taken. ${ }^{140}$ Causation is the basis for denying liability in such cases.

Causation is harder to establish in the case of omissions, especially omissions in supervision.

There is no liability where the public authority is able to show an alternative cause, either force majeure or act of the victim. Force majeure or act of nature was shown in the Syndicat intercommunale case. ${ }^{141}$ Although the repair to dykes and failures of dredging the river caused loss to the claimants, most of the loss was due to natural flooding after heavy rain.

The act of a third party will also exonerate the public body if it breaks the causal link in whole or in part. For example, in Kechichian, although the state was held liable for the gross fault of the Commission Bancaire, the loss to the claimant had principally resulted from fraud committed by the directors of the bank in which it had invested and which the Commission had failed to supervise. $^{142}$

137 See Fairgrieve, State Liability in Tort, p. 170 and references. And see also note 64.

${ }_{13}^{8}$ See note 62.

139 See note 116.

140 Loi 2011-525 of 17 May 2011, art. 70 and CE Ass. 23 December 2011, Danthony, no. 335033, RFDA 2012, 284. See Chapter 7, note 14.

141 See note 19.

$14^{2}$ See note 71 . 
The act of the victim is often a proximate cause of loss. For example, in one case, a mayor in Réunion designated a particular stretch of beach as unsafe for bathing. The claimant was a long-standing resident and an experienced surfer. ${ }^{143}$ He was injured by a shark attack in the waters close to that area of the beach. Although the claimant argued that the mayor had provided an inadequate warning of the dangers of sharks, the lower court had concluded that the claimant knew the area and it was his lack of care for his own safety that caused his injuries.

A way of avoiding questions of causation is for the claimant to seek compensation for loss of a chance. ${ }^{144}$ In such a case, the amount awarded is generally related to the probability that the outcome would have been different, rather than as a contribution to the loss actually suffered. In Centre hospitalier de Vienne, a patient presented himself at a hospital with a postoperative problem in his eye. ${ }^{145}$ Because of incorrect treatment, he lost the use of the eye. The lower court found that, if he had been treated correctly, he might have saved his sight. The loss of the chance was estimated at 30 per cent and so the claimant recovered that proportion of the harm caused by the loss of his sight. All the same, the loss of a chance must still be direct and certain, so that a serious probability is required. Loss of a chance is not the way to evade dealing with doubts. In the case of damages for loss of a chance to win a public procurement contract or a contract, the likelihood of winning the award had the illegality occurred is not correlated to the amount awarded. If the claimant had a high chance to get the contract, he will be fully compensated for his loss, as we will see in Chapter 9.

\subsubsection{Measure of Damages}

The basic principle of French law is the full recompense for all losses (reparation intégrale). ${ }^{146}$ As a result, there is no ceiling on the amount of damages, as there would be in a lump-sum system. All the same, the full compensation principle may lead in some cases to a lump sum, rather than to regular payments. The determination of the amount is inevitably difficult. Fairgrieve is among a number of authors who point out that the compensation recovered through French state liability is often lower than comparable cases in England. ${ }^{147}$

\footnotetext{
143 CE 22 November 2019, no. 422655, AJDA 2020, 1867.

144 See Fairgrieve, State Liability in Tort, pp. 205-10.

145 CE Sect. 21 December 2007, Centre hospitalier de Vienne, no. 329328, AJDA 2008, 135.

146 See generally J.-M. Pontier, 'La notion de la réparation intégrale', AJDA 2018, 848.

147 Fairgrieve, State Liability in Tort, pp. 222-4.
} 
In the case of personal injury, the administrative courts follow closely the heads of damage recognised in private law, the Dintilhac categories (named after a Cour de cassation judge), which are included in the Code of Social Security. The court assesses the full range of harms the victim has suffered and assigns them to appropriate categories (medical expenses, loss of capacity, loss of salary, effect on future employment, etc.). It then becomes possible to make deductions for social security and other payments received under these headings in order to avoid overcompensation. ${ }^{148}$ The close following of social security and private law ensures a greater consistency of approach than before when Fairgrieve was writing in 2003. ${ }^{149}$ That said, the Conseil retains the possibility of extending the scope of recovery in new areas, such as problems of anxiety about potential future illness or death. ${ }^{150}$

Fairgrieve notes that it is often the case that financial loss is assessed with great strictness. ${ }^{151}$ He notes in particular the low percentage of turnover used to estimate loss of profits resulting from the refusal of planning permission. The Gestas case shows a very low payment for the delay in a court dealing with his civil service employment claim $\left(€_{14}, 000\right.$ for a delay of more than fifteen years). ${ }^{152}$

Fairgrieve also notes that amounts awarded in the French courts are often less than those awarded by the ombudsman in England for similar harms - for example, the failure of a public authority to provide educational support. ${ }^{153}$ But this is very difficult to substantiate on a significant basis of comparable facts.

In the past, for example, in Letisserand, amounts for non-pecuniary loss were much lower than those in the civil courts. It is true that the willingness to preserve public funds as long as the risk of public inaction in case of damages' threat may drag the courts to adopt a restrictive approach of financial compensation. But it is now considered that the administrative courts award sums in line with those in civil courts. ${ }^{154}$ All the same, there are questions about whether the amounts are appropriate, especially where no comparison can be

${ }_{148}$ See CE avis 4 June 2007, Lagier, Consorts Guigon, nos. 303422, 304214, AJDA 2007, 1800.

149 See Pontier, 'La notion de la réparation intégrale', AJDA 2018, at p. 850.

150 See Mme Bindjouli, note 131.

${ }^{151}$ Fairgrieve, Strict Liability in Tort, pp. 198-201.

152 See note 65.

153 Fairgrieve, Strict Liability in Tort, pp. $197^{-200}$ and $247^{-8}$. It is difficult to have exact comparisons, but the differences may not be that great. Compare two cases on failure to provide education support to children with special needs: Local Government Ombudsman, Isle of Wight Council (no. o8001991 of 12 June 2009) awarding £17,000 with CAA Paris, 11 June 2007, no. o6PA01579, awarding $€_{33}$,000.

154 See Grands Arrêts, p. 504. 
made with private liability - for example, $€_{3}, 000$ for the detention of a person in inhumane prison conditions over four years. ${ }^{155}$

Because state liability is often funded by insurance companies or special funds, they are typically subrogated to the rights of the successful claimant.

\subsection{CONCLUSION}

The trend in the French law of state liability over the past 150 years since Blanco has been to diminish very significantly state immunity, both in terms of its absolute refusal of liability and in the limitation of liability to gross fault. Although state liability is not based on the Civil Code, the two systems tend to work in tandem. The rapporteurs publics frequently refer to private law as a benchmark, especially in the measure of damages. But the two still work on parallel lines. The notion of faute de service makes it easier to invoke an objective character of fault, especially in that the state will not seek recourse to an indemnity from the wrongdoing official, unless there is also a faute personnelle. But the ubiquity of insurance has reduced the difference with private law over the past forty years. All the same, fault is a more expansive concept in public law, covering the failure to meet expectations, rather than just the interference with an individual's protected rights and interests. It is in the area of no-fault liability that the biggest difference lies. In both public and private law, the notion of risk has diminished in importance and the ideas of social solidarity have increased. In private law, parents are now liable strictly for their children and associations are liable for the acts of handicapped adults whose lives they organise and control. The rationale for this is that they take responsibility for people under their charge without necessary benefit to them. But it is rare to expect private individuals to take on themselves burdens for the whole community. The no-fault liability of the state for burdens falling on particular individuals which benefit the community has a more intuitive appeal in relation to the state. This was long established in relation to expropriation, billeting of troops and riot damage, and has become increasingly important in relation to policing actions in relation to strikers, squatters and demonstrators. It is in the area of ill health that the line between judicial intervention and legislative intervention has been most blurred. In cases such as Epoux $V$ or Bianchi, the administrative courts have leapt in to provide a remedy for unfortunate victims, but the legislator has subsequently provided

155 H. Belrhali-Bernard, 'La responsabilité administrative au service de la protection des droits de l'homme', in Martial Mathieu, ed., Droits naturels et droits de l'homme (Grenoble, 2010), 359, at pp. $377-8$. 
a more structured and efficient solution. In both cases, the philosophical basis of intervention is national solidarity as proclaimed in the Preamble to the 1946 Constitution.

Inevitably the European dimension has been of some importance. It has undoubtedly led to liability for unlawful legislative acts. But the narrow scope for liability of the state under art. 340 of the Treaty on the Functioning of the European Union has not been the model the French have followed. Their approach is more generous. The existence of rights under the European Convention has encouraged expansion of the areas in which the state is liable, such as for prisoners and security and policing forces. ${ }^{156}$ But on the whole most of the trends have been influenced by internal trains of thought within France. Public opinion encouraged by the media has given rise to demands for compensation, and that has had some influence on the judges. ${ }^{157}$

${ }^{156}$ See Belrhali-Bernard, note 154 .

157 See Pontier, 'La notion de la réparation intégrale'. 


\section{Claims Relating to Public Contracts}

As pointed out elsewhere, public contracts in Western countries tend to be governed by specific rules with the main objective of awarding specific powers to public contractors, even in common law countries such as the United States and England and Wales where those rules derive from statutory regulations or standard terms. ${ }^{1}$ Nonetheless, situations may vary to a certain extent from one country to another. Contrary to common law countries, civil law countries such as France, Spain, Portugal and Finland reproduce the public and private law divide when it comes to public contracts. Other civil law countries such as Germany, Denmark, Poland and Sweden, even those with distinct administrative courts, would consider public contracts a common legal transaction and therefore adjudicate those contracts in civil courts with the consequence that they are governed by (private) contract law. France is an interesting example of the second category in relation to most public contracts - that is, contracts signed by the administration are public law contracts (contrats administratifs) subject to specific rules, set most of the time by the case law of the Conseil d'Etat, whose aim is to protect the public interest. Another consequence of the jurisdiction of the administrative courts lies in the existence of specific remedies, but both consequences follow from the contract's characterisation as a contrat administratif.

\subsection{WHAT IS A PUBLIC LAW CONTRACT?}

The predominance of the criterion of intérêt public (public interest) in French administrative law drove the Conseil d'Etat to build its case law upon the

1 P. Craig, 'Specific Powers of Public Contractors', in R. Noguellou and U. Stelkens, eds., Droit comparé des contrats publics/Comparative Law of Public Contracts (Bruxelles: Bruylant, 2010), p. 173 . 
public and private law divide even for contracts. Indeed, the unilateral act was never the only way for public authorities to act (administrer). Unlike most civil law countries, which tend to consider contracts as transactions relating to private law, French law put in place specific rules for public contracts long before the creation of the 'new' Conseil d'Etat in $1799 .{ }^{2}$ Even today, public authorities are free to decide whether to contract out or to arrange in-house services and act unilaterally, and this principle initially set by the case law is now enshrined in the Code de la commande publique (CCP), which consolidates rules applicable to public procurement contracts and to concessions since its creation by Ordinance of 26 November 2018 and Decree of 3 December $2018 .{ }^{3}$ So it is very unlikely that the French parliament would introduce a system equivalent to the compulsory competitive tendering used in the 1980s and the 199os in the United Kingdom for the reason that it is contrary to the tradition and spirit of French administrative law. In addition, although public contracts have been fostered during the second half of the twentieth century as a way to promote citizens' acceptance of public policies and often replace unilateral acts, the Conseil d'Etat has sometimes re-characterised those so-called contrats as unilateral acts when the contract is just a façade. ${ }^{4}$

However, the Conseil d'Etat also considers that not every public contract serves the public interest and distinguishes between those having a sufficient link with the public interest whose adjudication is assigned to administrative courts and subject to public law rules and those with no such a link which are assigned to civil courts and subject to private law rules.

Therefore, in practice, public contracts must often first be characterised as contrats administratifs - that is, public law contracts - in order not only to know the competent court in case of litigation, but also the applicable rules. The exception is where there are written legal rules applicable independently of this characterisation, for instance on transparent award rules.

However, the legislator sometimes intervenes to assign adjudication for specific types of public contract to either administrative or civil courts regardless of the criteria set by the case law.

2 J.-L. Mestre, Introduction historique au droit administratif (Paris: PUF, 1985), esp. nos. 49, 97 and 151.

3 Art. Li CCP: "The concessionaries and the authorities granting a concession may choose freely, to meet their needs whether to use their own methods or to have recourse to a public procurement contract.'

4 CE 20 March 2000, Mayer et Richer, no. 202295, AJDA 2000, 756, note Jegouzo, regarding the charte des thèses and the relationships between $\mathrm{PhD}$ students and their supervisors. 


\subsubsection{Criteria Laid Down by Administrative Courts}

Modern criteria were set by the Conseil d'Etat at the beginning of the twentieth century and are twofold: some criteria relate to the existence of a public service mission, whereas others relate to the presence of a clause which involves a regime going beyond private law.

\subsubsection{Criteria Linked to a Public Service Mission}

The case law refers to service public ('public service' meaning a service in the public interest) in different ways. The most obvious example is when the execution of a public service by the contractor of the administration is the very subject matter of the contract, as was the case in Thérond. ${ }^{5}$

The city of Montpellier and Mr Thérond entered into a contract for the capture and impounding of stray dogs and the removal of dead animals. A dispute arose and Thérond tried to obtain the termination of the contract and damages. The Conseil d'Etat confirmed the jurisdiction of the administrative courts on the ground that by contracting out 'the city of Montpellier acted with a view to the hygiene and safety of the population and therefore had the aim of providing a public service'. On the substance, it ruled in favour of Thérond. Since the monopoly created by the contract was illegal, the contract had to be terminated and damages awarded to Thérond. Soon after, the service public criterion was discarded in favour of another criterion based on the presence of a clause going beyond private law (the clause exorbitante; see Section 1.1.2). But the service public criterion saw a revival in the mid-1950s. In October 1944, Mr and Mrs Bertin were asked by the administration to take care of Russian refugees. The Conseil d'Etat in 1956 considered this as the implementation of a contrat administratif, in spite of the absence of any written contract, on the ground that they were fulfilling a public service mission. ${ }^{6}$

The very same day, the Conseil d'Etat issued a second example of identifying a public law contract by reference to a public service mission, although the contract did not entrust the contractors with the mission itself, but they were a means of delivering a public service. The government had undertaken by contract to carry out reforestation work on land belonging to private owners, which led to a fire on several properties, including those of the Grimouards. The Conseil d'Etat had jurisdiction since the contract was of a public law

5 CE $_{4}$ March 1910, no. 29373, Leb. 193.

6 CE Sect. 20 April 1956, Epoux Bertin, no. 98637, Leb. 167. 
nature in that the contract did entrust public works to the administration. ${ }^{7}$ This idea was later extended outside the scope of public works. ${ }^{8}$

Finally, the public service notion is also used to identify a public law contract when it comes to contracts made with employees of the administration. In principle, public agents have a status rather than a contract. But for reasons of flexibility, the legislator regularly adds exceptions. The question arises whether those contracts are of public law nature, subject to limited rights and obligations set by decrees ${ }^{9}$ and by the case law of the Conseil d'Etat concerning general principles of law such as the ban on sacking a pregnant woman unless she committed a serious fault and the duty to pay a minimal wage, ${ }^{10}$ or of private law nature and therefore subject to the Labour Code. Case law makes a distinction between the participation of the agent in a service public administratif, which is the normal nature of national or local public services such as public universities or public hospitals, and in a service public industriel et commercial, which is similar to private economic activities - for example, public transportation, water distribution or sewage. In the first case, the contract of the agent is of public law nature ${ }^{11}$ and the agent called an agent public contractuel; in the second, the contract is of a private law nature unless it concerns the head of the service or the public accountant. ${ }^{12}$

\subsubsection{Criteria Based on a Clause Unusual in Private Law}

The second alternative criterion was set in 1912 by the Société des granits porphyroides des Vosges case, which was decided on the conclusions of the commissaire du gouvernement Léon Blum twenty-four years before he became the first socialist Prime Minister (or Président du conseil as the position was then called). The Conseil d'Etat dismissed the claim as brought before the wrong court and ruled the following:

The contract between the city and the company was exclusive of any work to be carried out by the company and had as its sole object supplies to be

7 CE Sect. 20 April 1956, Consorts Grimouard, no. 33961, Leb. 168.

8 TC 24 June 1968, Société Distilleries bretonnes, no. o1917, D. 1969, 116.

9 Decree of 17 January 1986 for agents of the State or its public establishments, decree 15 February 1988 for agents of local authorities or their public establishments and decree 6 February 1991 for agents of public hospitals.

10 Respectively CE Ass. 8 June 1973, Peynet, no. 80232, Leb. 406 and CE Sect. 23 April 1982, Ville de Toulouse c Aragnou, no. 36851 , Leb. 152.

${ }^{11}$ TC 25 March 1996, Préfet de la région Rhône-Alpes, no. 03000, Leb. 535, which abandoned the previous distinction between direct and indirect participation in the service public administratif.

12 CE 26 January 1923, De Robert Lafrégeyre, no. 62529, Leb. 67; CE Sect. 8 March 1957 , Jalenques de Labeau, no. 15219, Leb. 158. 
delivered in accordance with the rules and conditions of contracts between individuals.

The ruling made no reference to the absence of a public service mission, which was interpreted as an abandon of this criterion. The 'rules and conditions of contracts between individuals' reference was later interpreted as meaning the absence in the contract of any clause exorbitante du droit commun (droit commun meaning private law). In other words, every time a court can spot a clause going beyond what is permissible in a private law contract, the contract is deemed of a public law nature and administrative law applies. For a long time, the case law did not define precisely what this meant. But scholars referred to it either giving exceptional powers to the administration or more generally as unusual in private relationships. It is true that most of those clauses illustrate the former - for instance, a clause which allows the administration to terminate a contract for reasons of public interest ${ }^{13}$ or which imposes strong powers of control over the private party. ${ }^{14}$ But the case law also illustrates a wider concept: a tax-exemption clause is exorbitante ${ }^{15}$ just as is a clause which secures to local inhabitants the benefit of preferential conditions for using a ski lift service. ${ }^{16}$ On the contrary, a clause is not exorbitante either where a company commits to exporting local products and creating jobs, ${ }^{17}$ or where the public owner is allowed to take back the use of a leased building without compensation at any time and for any reason, only subject to one month's notice. ${ }^{18}$

The broader concept of clauses unusual in private relationships means that such clauses are not absent in contracts signed between private parties. This is the reason the Tribunal des Conflits decided to change the formulation: it does not refer to them anymore as 'clauses derogating from private law' but as clauses 'which, in particular by virtue of the prerogatives granted to the contracting public entity in the performance of the contract in the public interest, imply that it falls within the regime of public law contracts'. ${ }^{19}$

Having such a clause or, alternatively a link with a public service mission, contrats administratifs must, in principle, also include at least one public authority as a party to the contract. But it may happen that such a public law contract is characterised by the courts as 'private'. This is the case when one

\footnotetext{
TC 16 January 1967, Société du vélodrome du Parc des Princes, no. o1895, Leb. 652.

TC 22 June 1998, Agent judiciaire du Trésor c Miglierina, no. 03003.

TC 2 July 1962, Consorts Cazautets, no. 1776, Leb. 823.

TC 6 June 2016, Commune d'Aragnouet, no. C4051.

TC 11 May 1992, Société Office Maraîcher fruitier, no. o2696, Leb. 485.

TC 20 February 2008, Verrière, no. $\mathrm{C}_{3} 623$.

TC ${ }_{13}$ October 2014, Société Axa France IARD, no. $\mathrm{C}_{39} 6_{3}$, Leb. 471.
} 
party acts on behalf of a public authority because it previously signed an agency $\operatorname{contract}^{20}$ or when one of the private parties acts on behalf of a public authority, a blurred concept which encapsulates several particular hypotheses where the private party appears to be a sort of tool in the hand of a public authority albeit with no proper agency contract. ${ }^{21}$

The Société des granits porphyroïdes des Vosges case also implicitly ruled as shown by the conclusions of Léon Blum - that a simple decree could not be opposed to the criteria set by the Conseil d'Etat. ${ }^{22}$ By setting the criteria of a public law contract, the Conseil d'Etat interprets the principle of separation of administrative and judicial authorities laid down by law and no decree can overturn this interpretation. Of course, the legislator can undo what it has laid down in a previous law. As we have seen previously, public contracts are not in the field of the jurisdiction of administrative courts guaranteed by the Constitution as interpreted by the Conseil constitutionnel. ${ }^{23}$

\subsubsection{Criteria Laid Down by the Legislator}

It is sometimes difficult to identify the reason the legislator assigns contracts either to administrative courts or to civil courts. This is because either some of the relevant decisions were made a long time ago or by way of secondary legislation (ordonnances) with no trace of the travaux préparatoires. A chronological order offers greater simplicity and clarity than would a logical one, which would be hard to find.

The Law of 28 pluviôse An VIII (17 February 1800) assigned two types of public contracts to the administrative courts (or more precisely to the conseils de préfecture which were created simultaneously): public procurement contracts related to public works and selling of real estate by the government. The former may be explainable by the willingness to allocate litigation, already allocated to the Conseil du Roi before the Revolution, to local administrative courts because they were very numerous. ${ }^{24}$ The latter is explained by the desire to avoid the risk that ordinary judges - that is, civil courts, would declare void contracts selling real estate formerly owned by the Catholic Church on the ground that they were illegally acquired by the government during the French Revolution. ${ }^{25}$ The former was repealed 'by accident' when the latter was

20 CE 27 May 1957, Artaud, no. 32818, Leb. 350.

${ }^{21}$ See F. Lichère, 'L'évolution du critère organique du contrat administratif, RFDA 2002, 341.

22 CE 31 July 1912, no. 30701, Leb. 909.

23 CC decision no. 86-224 DC of 23 January 1987, Competition Law, Rec. 8, Chapter 5, note 1.

24 Mestre, Introduction historique, p. 198.

25 K. Weidenfeld, Histoire du Droit administratif (Paris: Economica, 2010), p. 129. 
included in 2006 in art. L3331-1 of the newly published Code de la propriété des personnes publiques (CGPPP) but the Conseil d'Etat still applies the rule without any legal text since the content of the notion of travaux publics derives only from its case law. ${ }^{26}$

Décret-loi 17 June 1938, now codified in art. L2331-1 CGPPP, allocated to administrative courts litigation in relation to the occupation of the domaine public permitted by public authorities or their concessionaries. As was seen in Chapter 5, Section 2.2, this public domain includes real estate owned by public authorities which is dedicated to public use or to public service missions. It is subject to rules protecting them from third parties - for example, it is inalienable - or from public authorities themselves - for example, there are no legal possibilities to sell them unless a formal decision to decommission them is adopted. The idea of the décret-loi was to unify litigation since private use of the public domain might also take the form of a license which can only be granted by a public authority and litigation over this belongs to administrative courts. ${ }^{27}$ For obscure reasons, the Tribunal des Conflits ruled that the term concessionaries should be interpreted restrictively as meaning concessionnaires de service public and such a position, constantly reaffirmed, is still often criticised as contrary to the initial intent. ${ }^{28}$

The Law of 11 December 2001 extended the jurisdiction of administrative courts to litigation involving a public authority (with the exception of établissements publics industriels et commerciaux) and dealing with public procurement contracts of any sort, and not just public works as under the Law of 28 pluviôse An VIII. It appears that simplification by way of unification was the reason for this law, which now extends to all public procurement contracts signed by any public authorities since the Ordinance 23 July 2015 and also to concessions signed by public authorities since the Ordinance 29 January 2016, both of them now codified in the Code de la commande publique.

Article L442-5 of the Education Code, resulting from the Law of 5 January 2005, considers that teachers attached those private educational establishments which entered into contract with the government are bound to the state by a public law contract.

The Energy Code assigns two types of litigation to administrative courts. Article L314-7, resulting from art. 88-III of the Grenelle II Law of 12 July 2010, categorises mandatory electricity purchase contracts as public

E. Glaser in his conclusions on CE, 7 August 2008, SAGEP, no. 289329, Bulletin juridique des contrats publics 2009, no. 62, p. 41 .

27 P. Blanquet, 'Le sous-contrat. Étude de droit administratif (Thesis Paris 2, 2020), p. 385.

28 See, for example, N. Foulquier, Droit administratif des biens, 5th ed. (Paris: Lexisnexis, 2019), p. 394 . 
contracts. $^{29}$ Such a categorisation was clearly made as a way to avoid civil courts in a particular context. In autumn 2009, the government announced that the price of the electricity produced from renewable energy would be reduced in January, which led to a rise in projects of 500 per cent compared to the precedent autumn. To combat this windfall (effet d'aubaine) phenomenon, the government in January 2010 issued an order stating that the new price would be applicable when the contract was signed and not when the prior request for connection was made. The latter would have meant that the former high price applied for twenty years. The government feared that civil courts would undermine this order by application of art. 1583 of the Civil Code according to which the sale is complete as soon as the thing and the price have been agreed upon. However, the Tribunal des Conflits was able to rule in 2010 that this categorisation could not apply to contracts signed before the law was passed without infringing the European Convention on Human Rights (ECHR). ${ }^{30}$ This was and is still the only application of the ECHR by this court. For the contracts signed after the law, the Conseil d'Etat rejected a question préalable de constitutionnalité (QPC) on the grounds that 'these provisions have neither the object nor the effect of modifying the economy of the contracts in question, the legal regime of which being entirely determined by the law'.31 In addition, art. 104 of the Law of 17 August 2015 introduced into the Energy Code art. L314-24, which also provides that remuneration supplement contracts concluded by Electricité de France (EDF) with renewable energy producers who sell their electricity on the wholesale market and not to EDF are public law contracts.

Finally, the transformation of the Société Nationale des Chemins de fer français (SNCF) into a private company (as a public capital company) by the Ordinance of 3 June 2020, which came into force on 1 January 2021, maintained the jurisdiction of administrative courts to rule on public procurement contracts litigation and also on contracts related to the occupation of domaine public (art. L2111-9-1 of the Code des transports). It is assumed that the government wishes the SNCF to keep its prerogative powers attached to public law contracts. By contrast, it could still be the case that civil courts are competent for certain litigation and this may affect the normal jurisdiction of administrative courts.

\footnotetext{
29 Electricité de France is obliged to buy electricity produced from renewable energy.

30 TC 13 December 2010, Société Greenyellow, no. C3800, Leb. 592.

${ }^{11}$ CE 5 June 2013, Société MSO Sablirot, no. 366671.
} 
The Rural Code entrusts the judicial courts with the contractual litigation of rural leases, including leases concluded by public authorities.

Under art. L7121-2 of the Labour Code, 'any contract by which a natural or legal person secures, for remuneration, the assistance of a performing artist with a view to its production, is presumed to be an employment contract'. It is therefore a private law contract even if it is concluded by a public person to fulfil a public service mission. ${ }^{32}$

The two examples mentioned earlier aimed at creating homogeneous litigation arrangements whatever the status of the employer, similar to those discussed in Chapter 5, Section 2.5. The situation of the last exception regarding établissements publics industriels et commerciaux created by a law is different. The Tribunal des Conflits interprets such a creation as a willingness to submit those public persons to private law, because the public enterprises are often subject to competition law, and it recognises very limited exceptions. A recent formulation of the exceptions widens them a little bit:

Unless otherwise provided for by law, when a public establishment has the status of an industrial and commercial establishment, contracts concluded for the needs of its activities fall within the jurisdiction of the civil courts, with the exception of those containing clauses derogating from private law or falling under a regime derogating from private law as well as those relating to those of its activities which by their nature fall under the prerogatives of public authorities. 33

9.2 SPECIFIC RULES APPLICABLE TO PUBLIC LAW CONTRACTS

\subsubsection{Rules Applicable to the Formation of the Contract}

The so-called transparency principle is the underlying principle of the award rules now set at an EU level by specific directives regarding competitive open tendering, which have had some effect on French law, as we will see in the conclusion of this chapter. But the scope of those rules diverges from the scope of contrats administratifs. For one thing, despite the expansion of the principle beyond its traditional scope that is, public procurement contracts signed by the administration - not all public law contracts are bound to respect such a duty of transparency. The duty certainly extends to concessions and to occupation of the public

32 TC 17 June 2013, Olteanu, no. C3910.

33 TC 7 April 2014, Société Services d'édition et de ventes publicitaires, no. C3949, and compare TC 16 October 2006, Caisse centrale de réassurance, no. $\mathrm{C}_{35}$ o6, Leb. 640. 
domain ${ }^{34}$ but, for instance, neither to the occupation of domaine privé, nor to the sale of real estate belonging to public authorities, except for property belonging to the state. ${ }^{35}$ By contrast, due to the influence of $\mathrm{EU}$ law the transparency rules do not apply only to public law contracts, as seen in the conclusion to this chapter. So, the peculiarities of the formation of contrats administratifs lie very much more in the case law of the Conseil d'Etat than in the rules regarding the award of some of them.

Unlike the rules applicable to the performance of the contract, the Conseil d'Etat tries here to follow the Civil Code as much as possible. As put by several rapporteurs publics, the idea is to copy and paste the Civil Code as long as public interests do not force the courts to diverge from it. This is the case to large extent when it comes to the validity of the consent and to a certain extent to the validity of the content of the contract. Article 1128 of the Civil Code states:

The following are necessary for the validity of a contract:

1. the consent of the parties;

2. their capacity to contract;

3. content which is lawful and certain.

Their decisive character is assessed in the light of the person and of the circumstances in which consent was given.

We will focus on the validity of the consent and the validity of the content. The capacity of public authorities is similar to their competence when they adopt unilateral administrative acts, as was discussed in Chapter 7 , Section 1.2.

\subsubsection{Validity of the Contractual Consent}

The civil law insists on the free will to consent. The Civil Code states in art. 1129 that 'one must be of sound mind to give valid consent to a contract' which is then expressed by the need to identify any defects in consent (vices $d u$ consentement). Article 1130 adds that 'Mistake, fraud and duress vitiate consent where they are of such a nature that, without them, one of the parties would not have contracted or would have contracted on substantially different terms.' This formulation comes from the reform of the (private) law of contracts introduced in 2016, which made clear what was disputed for a long

34 Art. R2122-1 Code général de la propriété des personnes publiques (CGPPP) introduced by Ordinance 19 April 2017 as a consequence of the decision of the CJEU 14 July 2016, Case C-458/14, Promoimpresa Srl., ECLI:EU:C:2016:558. On the concept of domaine public see Chapter 5, Section 3.2.

35 Art. R $3211-2$ CGPPP, with exceptions in art. $\mathrm{R}_{3211-7}$ CGPPP. 
time - namely, that defects in contracts apply not only where contracts would have not been signed had the defect not occurred, but also where parties would have alternatively contracted on substantially different terms. Many civil law scholars argued that only the former should lead to the contract being declared void and never to damages. But this was disputed, other scholars claiming that the former should lead to annulment, the latter to damages and yet others that it should be for the victim to decide. ${ }^{36}$ Indeed, one cannot reconstruct what a party would have done had the defect not occurred. For instance, in a case of asbestos in a building illegally hidden by the vendor, which is fraud, would the party not have entered into the contract or instead agreed to buy it at a reduced price?

Interestingly, the case law regarding contrats administratifs was not unaware of those concerns even before the 2016 reform. The Conseil d'Etat made reference to the fraud $(d o l)$ in a $1923 \mathrm{case}^{37}$ and ruled in 2007 that illicit collusion for the award of a public procurement contract - a very important one regarding the building of high-speed railways from Paris to the north and to the south-east of France - was deemed a fraud and could lead the victim to choose between the annulment of the contract or damages. ${ }^{38}$ Recently it even went further by adding that the victim could choose annulment even if the contract is entirely performed and when choosing annulment, he could seek restitution, the contractor in breach being then able to claim damages on the grounds of unjust enrichment, something not yet decided by the civil courts. ${ }^{39}$ In practice, it means that the contractor is deprived of any benefits, whereas in case of damages, the private contractor must only reimburse the extra costs incurred by the public authority due to the illicit collusion.

Mistake (erreur) can be a defect of consent where it affects the substance of the contract or the person of the contractor. When it concerns the substance, it may regard the identity of the thing or its substantial qualities, ${ }^{40}$ the Conseil d'Etat being quite demanding for the latter: the sale of a stallion incapable of reproducing is not void since the contract only stipulated that it had to be 'straight and in good shape'. ${ }^{41}$ By contrast, the Conseil d'Etat ruled

$3^{6}$ F. Moderne, 'Une illustration exemplaire de la théorie du dol dans le contentieux des contrats administratifs', RFDA 2008, 109.

37 CE 14 December 1923, Société des grands moulins de Corbeil, no. 242323, Leb. 852.

$3^{8}$ CE 19 December 2007, Société Campenon-Bernard, no. 261918, Leb. 507.

39 CE 10 July 2020, Société Lacroix signalisation c Seine-Maritime, no. 420045; see F. Lichère, 'Le nouveau régime contentieux des pratiques anticoncurrentielles dans les contrats administratifs', Contrats et marchés publics, November 2020, p. 7.

$4^{\circ}$ Respectively CE 10 January 1912, Ville de Saint-Étienne, no. 34708, Leb. 22 and CE Sect. 13 October 1972, SA de banque 'Le Crédit du Nord', no. 79499, Leb. 630.

${ }^{41}$ CE 28 December 1917, Belmont, no. 58000, Leb. 878. 
in favour of a contracting authority where there was a mistake as to the person of the contractor when an administration representative thought a person was acting in his capacity of representative of a firm when it acted on his own behalf. ${ }^{42}$

Finally, duress (violence) is explicitly mentioned by the case law of the Conseil d'Etat very rarely as it seems unlikely that an administration's representatives would use such threats and that private parties would do the same towards civil servants. Furthermore, the case law is strict on the degree of duress. An assertion by a civil servant that the administration would apply strictly' the terms of the current contract if the other party did not sign another contract was not deemed duress. ${ }^{43}$ However, duress can originate from a third party when the contractor is under excessive economic dependence to another undertaking. ${ }^{4}$

One may notice that cases are rare before administrative courts regarding the validity of consent. It is certainly explained by the fact that public contracts are made by professionals and maybe because claimants tend to focus on the procedural award rules when they exist.

Apart from the remedies available for fraud, the way the Conseil d'Etat applies the defect of consent to contrats administratifs seems to be more or less in conformity with the case law of the Cour de cassation. ${ }^{45}$

\subsubsection{Validity of the Contractual Content}

The peculiarities of public law contracts are more striking in this area because of the way the Conseil d'Etat interprets the lawfulness and certainty of the content of a contract and because of many specific public principles to take into account.

Article 1128 of the Civil Code now requires that the content must be lawful and certain. It is the result of the reform by Ordinance 10 February 2016, which deleted a well-known and much debated concept of cause du contrat which had to be certain and lawful and was covering two different aspects: the counterpart of the contract (cause objective) and the motive of contractors (cause subjective). However, the former can still be spotted in the requirement of a certain content and the latter in the new art. 1162, which reads that 'a contract cannot derogate from public policy either by its

$4^{2}$ CE 26 April 1950, Domergue, no. 83931, Leb. 813.

43 CE 4 May 1900, Héritiers du sieur Gouy, no. 81356, Leb. 319.

44 CE 21 May 1971, La cellulose d'Aquitaine, no. 79962, RDP 1973, 275.

45 B. Plessix, 'La théorie des vices du consentement dans les contrats administratifs', RFDA 2006, p. 12. 
stipulations or by its purpose, whether or not this was known by all the parties'. In addition, the previous version of the Civil Code also required a certain and lawful subject matter which seems to be included in the same articles 1128 (certain content) and 1162 (lawful content).

The case law of the Conseil d'Etat did refer to both traditional civil law concepts and still does but with some specificities. It sees an absence of 'cause' in the case of a public person who signs a contract with a company for work that has already been the subject matter of a previous contract between the same parties, a generous solution for the contracting authority which was able to claim damages. ${ }^{46}$ The Conseil d'Etat was even more generous when declaring an absence of cause where a stipulation agreed by public blood transfusion services with their insurers had the effect of excluding any compensation for the occurrence of risks during part of the term of the insurance contract. ${ }^{47}$ This somewhat wide approach seems to extend to the unlawfulness of a 'cause'. The Conseil d'Etat assimilated it to the détournement de pouvoir in judicial review ${ }^{48}$ but went beyond the traditional civil concept by declaring void a contract whose purpose was to implement a regulation that was itself illegal. ${ }^{49}$ In that case, such voidness benefited the private contractors. Another interesting example regards a case brought before administrative courts by the state's representative against the amendment of a concession for public car parks by which the city of Aix-en-Provence and its concessionary removed from the concession the underground car parks in order to sell them to the concessionary. ${ }^{50}$ The Conseil d'Etat referred to the explicit aim of the operation, clearly claimed on the city's website, that the city was trying to avoid the transfer of competence to the Métropole of Marseille by simply deleting the very object of the competence (the underground car parks!). The Conseil d'Etat ruled out the amendment on the grounds that the subject matter was illicit. One may argue that it was more a question of cause subjective, but since the motive was so explicit it somewhat contaminated the lawfulness of the subject matter itself.

\footnotetext{
CE 26 September 2007, OPDHLM du Gard, no. 259809.

CE 29 December 2000, Beule, no. 212338, Leb. 655.

$4^{8}$ CE 15 February 2008, Commune de La-Londe-lès-Maure, no. 279045 AJDA 2008, 575. See Chapter 7, Section 1.4.

49 CE 20 February 2008, Office National de la Chasse et de la faune sauvage, no. 302053, Leb. 54.

50 CE 15 November 2017, Commune d'Aix-en-Provence, no. 409728.
} 
Regarding the lawfulness of the subject matter (objet illicite), the Conseil d'Etat rarely refers to it. Apart from the Aix-en-Provence case law, it uses it only with one purpose:

[T]he principles governing the action of public authorities and persons entrusted with a public service mission preclude an authority vested with regulatory power, which is responsible for exercising that power in the general interest with regard to the various interests for which it is responsible, from undertaking, by means of a contract, to use the regulatory power conferred on it in a specific manner..$^{1}$

But even without referring to the objet illicite (unlawful subject matter), administrative courts regularly check the lawfulness of the subject matter of a contract with regard to many other public law principles. As the Conseil d'Etat often rules, public authorities may not entrust to third parties those functions which, by nature or by the will of the legislator, are not susceptible to delegation. Therefore, a contract cannot delegate the exercise of public teaching functions, including the supervision of pupils during lunchtime in state schools, ${ }^{52}$ nor administrative police functions such as the recording of parking offences. ${ }^{53}$ Apart from the principles set by the case law, it may happen that a law forbids the administration from making certain contracts. This is notably the case regarding arbitration which is by principle banned to public authorities (art. 2060 of the Civil Code) as a way to protect the competence of administrative courts and administrative law, with few exceptions for établissements publics industriels et commerciaux, PPP contracts (marchés de partenariat) or international contracts. These exceptions are under the potential supervision of administrative courts which may check whether the arbitration infringes public policy. ${ }^{54}$

In other words, if a public law contract 'cannot derogate from public policy' as it is said for private law contracts in art. 1162 of the Civil Code, public policy has its own meaning in the area of administrative law.

\subsubsection{Rules Applicable to the Performance of the Contract}

One must bear in mind the importance of standard terms and conditions, especially with public procurement contracts. Although not compulsory, they

${ }^{51}$ CE 9 July 2015, Football Club des Girondins de Bordeaux, no. 375542.

52 CE Avis, 7 October 1986 in Y. Gaudemet, B. Stirn, T. Dal Farra and F. Rolin, Les grands Avis du Conseil d'Etat, 3rd ed. (Paris: Dalloz, 2008), no. 24.

53 CE 1 April 1994, Commune de Menton, no. 144152.

54 CE Ass. 9 November 2016, Société Fosmax, no. 388806. 
are adopted by arrêtés ministériels and most of the time incorporated into public procurement contracts. ${ }^{55}$ In such cases, they have the simple status of contractual clauses, but their importance is so high in practice that the Conseil d'Etat eventually decided to review their interpretation by lower courts even when seised as a juge de cassation..$^{56}$ Other clauses - that is, specific clauses of public law contracts, are interpreted by ordinary administrative courts and this will only be quashed in case of dénaturation (gross distortion) by them. However, the striking point of French administrative law when it comes to public law contracts lies in the existence of different rules set by the Conseil d'Etat. It calls these règles générales applicables aux contrats administratifs (general rules applicable to administrative contracts). They diverge from the binding force of contracts, the French equivalent of the sanctity of contract principle. Some of them may benefit contracting authorities, others private contractors.

\subsubsection{Exceptions to the Binding Force of Contracts Benefiting Public} Authorities

The exceptions to the binding force of public contracts can be summed up by the recognition of several unilateral powers to contracting authorities without any legal texts or contractual clauses. Furthermore, the contracting public authorities cannot renounce them by contract. ${ }^{57}$ The rationale behind these exceptional powers is that public authorities have responsibility for the public interest which sometimes must prevail over contracts. Four sets of unilateral powers are at stake: modification, suspension, sanction and termination.

The unilateral power of modification is certainly the most striking example when one compares it to the sanctity of contract principle under English law or the principle according to which contracts are the law of the parties under French private law. The very existence of this power has been disputed by several authors because they considered that the power in the founding case was actually laid down by a regulation..$^{5}$ However, the Conseil d'Etat eventually made clear that it was a règle générale applicable aux contrats administratifs in $1983 .{ }^{59}$ Contrary to what is sometimes feared, such a power should not

See the last version of the six Cahiers des clauses administratives générales des marches publics issued by the arrêtés 30 March 2021.

56 CE Sect. 27 March 1998, Société d'assurances la Nantaise et l'Angevine réunies, no. 144240, Leb. 109 .

57 CE 6 May 1985, Association Eurolat, no. 41589, RFDA 1986, p. 21, concl. Genevois.

$5^{8}$ CE 11 March 1910, Compagnie générale française des tramways, no. 16178, Leb. 216.

59 CE 2 February 1983, Union des transports publics urbains et régionaux, no. 34027, Leb. 33. 
be detrimental to the other contracting party, because it has a right to financial compensation in order to restore the financial balance of the contract (l'équation financière du contrat). ${ }^{60}$ Under this principle, the unilateral modification cannot concern only financial clauses. ${ }^{61}$ Furthermore, such power is nowadays framed, for public procurement contracts and concessions, by the European directives, as we will see in the conclusion of this chapter.

Case law also permits the administration to suspend its performance of the contract if the other party does not fulfil its contractual duties. This application of exceptio non adempleti contractus is peculiar since it is not applicable to the other party, unlike in civil law, and the underlying idea is the preservation of the continuity of the public service. ${ }^{62}$

The power of sanction varies depending on the nature of the sanction. For a long time, the administration has been allowed to impose sanctions on a defaulting contractor short of terminating the contract, and this is often enriched by the case law. Indeed, the Conseil d'Etat recognised in 2016, without any legal text or clause, the power of mise en régie by which a contracting authority takes over the contractor in case of deficiency of the performance of the contract by the latter who shall pay the extra expenses (if any). ${ }^{63}$ The power of sanction was so strong that for a long time the Conseil d'Etat refused to reduce excessive penal clauses benefiting public authority contractors. Since 2008, it allows such a reduction (or to raise them if derisory) 'by application of the principles underlying art. 1152 (now art. 1231-5) of the Civil Code', but only when requested by a party, contrary to the Civil Code, which allows civil courts to raise the question of their own motion. ${ }^{6}$ Regarding the termination of a public law contract as a sanction, there were two limitations. For all public law contracts, the fault must be serious (faute grave), and this is still the case. The administrative courts apply the proportionality principle and provide compensation only for equipment not amortised when returned to the public authority. ${ }^{65}$ At the same time, the Conseil d'Etat also sought to offer security for private investments for public equipment. The power to terminate was not recognised without any specific clause when a concession or any other contract involved investment in fixed

60 Craig, 'Specific Powers of Public Contractors', p. 175.

61 CE 16 May 1941, Commune de Vizille, no. 58205, Leb. 93.

62 CE 27 March 1957, Carsalade, no. 21919, Leb. 216.

63 CE Ass. 9 November 2016, Société Fosmax, no. 388806, quoted in note 54. The two parties were private, but the contract was signed at a time when Gaz de France was a public authority and the contract kept its original nature.

64 CE 29 December 2008, OPHLM de Puteaux, no. 296930, Leb. 479.

65 CE 20 March 1957, Société des Établissements thermaux d'Ussat-les-Bains, no. 33114, Leb. 182. 
equipment to be amortised over the duration of the contract. ${ }^{66}$ However, since the contractor has now an effective remedy against such termination thanks to the Béziers II case law (see Section 3), the Conseil d'Etat admits the power to terminate any public law contract for serious fault including concessions, as it has done for a long time for the power to terminate for public interest. ${ }^{67}$

The power to terminate the contract in the public interest was stated as a régle générale applicable aux contrats administratifs in 1958, but existed earlier in the case law. ${ }^{68}$ The public interest reason is widely interpreted: technical difficulties, the reorganisation of a service or the refusal to modernise public street lighting are enough. ${ }^{69}$ Even a change in the capital assets of the concessionary (a mixed capital company) of the city of Chamonix which led the neighbouring city of Saint-Gervais to gain the majority of the capital assets was admitted as such. ${ }^{70}$

The counterpart of this wide acceptance of termination is the full compensation of the contractor, which includes damnum emergens and lucrum cessans. ${ }^{71}$ The Conseil d'Etat recently set an exception but about a peculiar public interest: serious illegality of a contract (grave irrégularité) can now justify a unilateral termination of the public law contract by the public authority. In such a case, the indemnification is based on the same principles set when the contractor or a third party obtains the voidness of a contract before an administrative court: the other party must at least be compensated in order to avoid unjust enrichment and can be fully compensated where it had no part in the illegality of the contract..$^{72}$ Regarding the unilateral termination of the contract by a private party, it is only possible when a contractual clause so provides and with strong limitations set in 2014 by the Conseil d'Etat. Such termination is never possible for contracts whose subject matter is the performance of a public service mission and, for other contracts, the public authority can always oppose the termination on grounds of public policy. ${ }^{73}$

CE 20 January 1905, Compagnie départementale des eaux, no. 08248 , Leb. 55.

CE 12 November 2015, Société Le Jardin d'acclimatation, no. 387660.

CE Ass. 2 May 1958, Distilleries de Magnac-Laval, no. 32401, Leb. 246.

See CE Sect. 22 January 1965, Société des établissements Michel Aubrun, no. 59122, Leb. 50, CE Ass. 29 April 1994, Colombani, no. 105401, Leb. 209 and CE 10 January 1902, Compagnie nouvelle du Gaz de Deville-lès-Rouen, no. 94624, Leb. 5.

70 CE 31 July 1996, Société des téléphériques du massif du Mont-Blanc, no. 126594, Leb. 334.

${ }^{71}$ Ibid.

72 CE 10 July 2020, Société comptoir Négoce Equipement, no. 430864.

73 CE 8 October 2014, Société Grenke location, no. 370644. 


\subsubsection{Exceptions to the Binding Force of Contracts Benefiting Private Contractors}

Some exceptions benefit private contractors. The theories at stake set by the case law ensure some right to damages in spite of the absence of any legal text or clause which could support them. One may notice nonetheless that the underlying basis of those rights is not public generosity but the continuity of the public service - so they are a sort of win-win.

Imprévision comes first to mind. As stressed by Paul Craig, it is similar to frustration but with notable differences, the main one being that in principle it does not lead to the termination of the contract. ${ }^{74}$ Introduced in 1916 by the famous case of Gaz de Bordeaux, it is a landmark of the differences between public law contract and private law contract, the latter being totally reluctant to this idea until the Ordinance 10 February 2016 introduced in art. 1995 of the Civil Code as a pale copy of the administrative law theory of imprévision. ${ }^{75}$ The 1916 case was related to a concession, but the case law extends the concept to other contrats administratifs such as public procurement contracts. It remains uncertain whether it should apply to contracts with no link at all with a public service mission such as conventions d'occupation du domaine public. The Gaz de Bordeaux case stated

In principle, the concession contract regulates the respective obligations of the concessionary and the grantor in a definitive manner until its expiry ... The increase which has occurred during the present war in the price of coal, which is the raw material for the manufacture of gas, has reached such a proportion that not only is it exceptional in the sense usually given to this term, but that it entails an increase in the cost of the manufacture of gas which, to an extent which defies all calculations, certainly exceeds the extreme limits of the increases which could have been envisaged by the parties at the time of the conclusion of the concession contract; that, as a result of the combination of the above-mentioned circumstances, the economic substance of the contract has been completely overturned.

The latter concept, called bouleversement de l'économie du contrat ('overturning the economy of the contract'), is the core element of the theory. For concessions, it means that an unforeseeable event causes a deficit. For public procurement contracts, it means extra costs which go beyond the normal prediction, the threshold of which varies in the case law between approximately 7 per cent and 12 per cent of the agreed price. The unforeseeable events are not limited to wars,

74 Craig, 'Specific Powers of Public Contractors', p. 175.

75 CE 30 March 1916, Compagnie générale d'éclairage de Bordeaux, no. 59928, Leb. 143. 
but have extended to the German occupation during Second World War, the events of May 1968 in Paris, the 1973 oil crisis, exceptional storms or new regulations, etc., as long as they are external to the parties. ${ }^{76}$ Imprévision has not played an important role in recent decades because most public contracts added clauses to limit the impact of economic turmoil. But the Covid-19 pandemic will probably give this theory a rebirth. Another underlying condition was made explicit in 1982: the contractor must continue the performance of the contract which confirms that the basis of the theory is the continuity of the public service. ${ }^{77}$ The consequence of imprévision for the contracting authority is a duty to pay damages which amount between 80 and 95 per cent of the loss, depending on the behaviour of the contractor and its past and future benefits. ${ }^{78}$ The idea is to keep the contractor at risk to a certain extent. For this reason, the case law admitted in 1932 that, if the imbalance of the contract becomes permanent because of this unforeseen event, both parties are entitled to ask the competent administrative court to terminate the contract (with no damages), which is sometimes called force majeure administrative. ${ }^{79}$ This must not to be confused with force majeure, which, like in private law, entitles any contractor to get rid of its contractual obligations either temporary or permanently. Like imprévision, force majeure involves an unforeseeable event, external to the parties but which is also compelling (événement irresistible).

The situation is different regarding the fait du prince theory in administrative law, in terms of both the conditions and the consequences. The consequences are straightforward. The duty of the contracting authority is to compensate its contractor fully. The conditions are quite simple: the event is not exterior to the party because the source of the damage lies in the action of the contracting authority, but in its capacity of a public authority - that is, in its public interest role and not as a contractor. For instance, the state must pay damages for the land of which a company was deprived despite the contractual expectations, due to a modification of the urban planning regulation made by the state. ${ }^{80}$ If the shift in regulation causing harm comes from another public authority, the victim can turn to the imprévision theory but will have lower damages for the reason explained previously.

$7^{6}$ Regarding the potential use of this theory in the Covid-19 context, see F. Lichère, F. Akoka, A. Meynier-Pozzi and V. Lamy, 'Crise sanitaire et contrats publics, une approche de sociologie juridique' AJDA 2021, 1425.

77 CE Sect. 5 November 1982, Société Propétrol, no. 19413, Leb. 381.

$7^{8}$ A. De Laubadère, F. Moderne and P. Delvolvé, Traité des contrats administratifs, 2 vols. (Paris: LGDJ, 1984), vol. 2, p. 624 .

79 CE 9 December 1932, Compagnie des tramways de Cherbourg, no. 89655, Leb. 1050; CE 14 June 2000, Commune de Staffelfelden, no. 184722, Leb. 227, for permanent pollution.

8o CE 29 December 1997, Société civile des Néo-Polders, no. 146753. 
Finally, the case law introduced two other theories challenging the binding force of contracts, but applicable to public procurement contracts only, probably because concessions imply more risks on the concessionary's part. The unforeseen situations (sujétions imprévues) are

material difficulties encountered in the performance of the contract, of an exceptional nature, unforeseeable at the time of conclusion of the contract and whose cause is external to the parties. ${ }^{81}$

This is notably the case where exceptionally difficult terrain is discovered in the course of public works.

The last theory concerns works (or services) which are essential for the proper execution of the works included in the public procurement contract plan. ${ }^{82}$ Compensation can be provided for oral instructions which were never confirmed in writing or, more frequently, for works which follow from the nature of the activity (règles de l'art). ${ }^{83}$ However compensation cannot be awarded if the contracting authority is clearly opposed to them. ${ }^{84}$

\subsection{REMEDIES FOR PUBLIC LAW CONTRACTS}

As seen in Chapter 4, remedies before administrative courts are mainly either annulment in judicial review (the recours pour excès de pouvoir), or a variety of powers entrusted to the courts in the recours de plein contentieux or de pleine juridiction. Contract litigation belonging to the latter prevails, since the case law lays down as a strong principle the impossibility to exercise a judicial review in relation to a contract. Two exceptions were laid down in the 1990s and survived the introduction of new remedies of plein contentieux in the twenty-first century. The first one is more of an exception which confirms the principle rather than being a real exception. In the 1996 case Cayzeele, the Conseil d'Etat held that regulatory clauses - that is, clauses which have an effect on third parties - can be challenged by interested third parties. ${ }^{85}$ In the case, a landowner was able to challenge a clause in a rubbish collection concession which required the concerned owners - who were third parties to the concession - to buy specific containers. This case is in line with a case decided eighty years earlier where the Conseil d'Etat allowed judicial review

\footnotetext{
CE 30 July 2003, Commune de Lens, no. 223445, Leb. 862.

CE 9 September 2010, Société Babel, no. 319481.

CE Sect. 17 October 1975, Commune de Canari, no. 93704, Leb. 516.

CE 27 March 2020, Société Géomat, no. 426955.

CE Ass. 10 July 1996, Cayzeele, no. 138536, Leb. 274.
} 
against a unilateral act on the grounds that it was contrary to a regulatory clause contained in a concession. ${ }^{86}$

In the 1998 Ville de Lisieux case, the Conseil d'Etat allowed the recours pour excès de pouvoir of third parties against contracts for the recruitment of public agents. However, the standing for this action is higher than usual, since the third party must have a 'sufficient interest' which is the case for members of a city council against the recruitment by contract decided by the mayor. ${ }^{87}$ Recours pour excès de pouvoir from third parties was also admissible against a separable unilateral administrative act from a contract (whether of public law nature or not). But nowadays this is rarely used since the Conseil d'Etat introduced a new remedy for third parties. In this matter, one must distinguish between contracting parties and third parties.

\subsubsection{Remedies for Third Parties to Public Law Contracts}

Administrative contracts may be concerned with remedies available to third parties introduced as a result of the transposition of the EU review directives, which give important powers to the courts including setting aside decisions regarding the award of public procurement contracts or concessions (référé précontractuel, art. L551-1 CJA) or the contract itself (référé contractuel, art. L551-13 CJA). But civil courts are also concerned with the same remedies, since the relevant EU directives apply to contracts considered private law contracts under French law and subject to the jurisdiction of the civil courts. Moreover, those remedies are open only to public procurement contracts and concessions and not to other contrats administratifs, even if subject to an open award procedure such as the contracts for the occupation of public property (conventions d'occupation du domaine public). ${ }^{88}$ As a consequence, we will focus on the other remedies which are all recours de plein contentieux, whether they concern damages or other powers attributed to the courts.

In France, damages for a wrongfully rejected bidder in administrative award procedures are quite generous when compared with other jurisdictions. ${ }^{89}$ Three situations are envisaged. If the bidder had no chance of winning the contract (lack of capacity, for instance), he will not be compensated. If he was not deprived of any chance to win the contract (a valid bid but badly ranked), he will have its bid costs compensated. If he had a serious chance of winning

86

87

88

89

CE 21 December 1906, Syndicat des propriétaires et contribuables du Quartier de Croix-deSeguey-Tivoli, no. 19167, D. 1907.3.41 concl. Romieu.

CE Sect., 30 October 1998, Ville de Lisieux, no. 149663, Leb. 375.

CE 30 April 2019, Société Total Marketing France, no. 426698.

D. Fairgrieve and F. Lichère, eds., Damages as an Effective Remedy (London: Hart, 2011). 
the contract (he was very likely to win had the illegality not occurred), he will be compensated for the loss of profits. ${ }^{9}$

But the most notable recours de plein contentieux is the judge-made remedy created in 2007 and extended in 2014, sometimes called the recours Tropic/ Tarn et Garonne. ${ }^{91}$ Any interested third party can challenge the validity of a public law contract, but two sets of rules secure the contract to a limited extent. Unlike local state representatives, the prefects, and members of the local assemblies for local public contracts, third parties must prove that they have suffered or are likely to have suffered from a breach of law. Moreover, any illegality would not force a court to order annulment or termination, because it can decide whether to maintain the contract, to terminate it or to annul it, depending on the seriousness of the unlawfulness, the possibility to regularise it and the public interest in maintaining the contract.

Finally, the Conseil d'Etat transformed in 2017 a recours pour excès de pouvoir into a recours de pleine juridiction regarding a refusal to terminate a public law contract. ${ }^{92}$

A third party to a public law contract likely to be prejudiced in a sufficiently direct and certain way by a decision refusing to grant his request to terminate the performance of the contract, shall be entitled to bring before the contract judge an action of full jurisdiction seeking the termination of the contract.

The reason for this change is to preserve legal certainty since there are strong limitations on the admissible legal arguments. Not only must the invoked unlawfulness prejudice the claimant, but only three legal arguments may be invoked: the contract must be terminated because of new legislative provisions applicable to current contracts, or the contract is vitiated by irregularities which are of such a nature as to preclude its continued performance and which the court should raise of its own motion, or that continued performance of the contract is manifestly contrary to the public interest.

\subsubsection{Remedies for Parties to Public Law Contracts}

Damages are the main remedy regarding contractors and the reason for this is in line with the privilège d'action d'office (the state's privilege to act as it thinks

$9 \circ$ CE 18 June 2003, Groupement d'entreprises solidaires ETPO Guadeloupe, no. 249630, Leb. 865 .

91 CE Ass. 16 July 2007, Société Tropic Travaux Signalisation, no. 291545, Leb. 360 concl. Casas; CE Ass. 4 April 2014, Département du Tarn-et-Garonne, no. 358994, Leb. 70 concl. Dacosta.

92 CE Sect. 30 June 2017, Syndicat mixte de promotion de l'activité transmanche (SMPAT), no. 398445 . 
necessary). For a long time, the Conseil d'Etat considered that damages were the only remedy available for private contractors who cannot challenge decisions taken by public authority contractors in the course of the performance of the contract, because this would block public action. By way of exception, the private contractor can now challenge the decision to terminate the contract since the 2011 Béziers II case and even asks for its suspension (art. L521-1 CJA), the latter being rarely granted because suspension requires the matter to be urgent. ${ }^{93}$ But it has not gone further - and one may even challenge the idea that termination relates to the performance of a contract. The Conseil d'Etat has so far not allowed a challenge to other decisions concerning performance, including a unilateral change of contract. ${ }^{94}$

Most damages actions concern bad performance of the contract, including against contracting authorities when they manage the contract poorly in a manner that delays the works to be done. ${ }^{95}$

If the contract is declared void, two damages actions are available to the private contractor. The contractor can seek damages for the unjust enrichment of the public contractor (responsabilité quasi-contractuelle) which does not require any proof of a fault. In addition, where the unlawfulness was the consequence of a fault of the public authority, the contractor may seek full compensation, including the loss of profits (responsabilité quasi-délictuelle). ${ }^{6}$ If the private contractor contributed to the illegality or could not reasonably ignore it, the fault is mutual, and the courts tend to split the liability, but exceptionally it leads to the full liability of the private contractor. ${ }^{97}$

As for public contractors, since they can use their own powers to secure performance (pouvoir d'exécution d'office), they can order their contractors to pay a sum (à titre exécutoire) as soon as they consider themselves creditors. However, the Conseil d'Etat made an exception to the principle by which a public authority cannot bring an action in an administrative court if it itself has the power to act unilaterally if brings an action for damages against a private contractors. ${ }^{98}$ In addition, the Conseil d'Etat tends to extend the jurisdiction of administrative courts regarding damages sought by the administration against a private person on a non-contractual basis, despite the ment (réparation en nature) awarded to a contractor against a public body: CE Sect. 6 December 2019, Société des copropriétaires de Montecarlo Hill, no. 417167, RFDA 2020, 121 concl. Pellisier and 333 note Petit.

96 CE 23 May 1979, Commune de Fontenay-le-Fleury, no. o0o63, Leb. 226.

97 CE Sect. 10 April 2008, Société Jean-Claude Decaux, no. 244950, Leb. 152.

$9^{8}$ CE 24 February 2016, Département de l'Eure, no. 395194. 
principle of jurisdiction of civil courts, every time there is a link with public law contracts. We have seen this tendency regarding damages for illicit collusion, but its scope is wider. ${ }^{99}$

The other remedy available concerns the challenge to the validity of the contract by contractors. Until 2009, it was widely accepted that a party could seek the annulment of a public law contract from an administrative court for almost any illegality but the Conseil d'Etat reduced its scope in the name of the newly created principles of contractual loyalty and contractual stability in the so-called Béziers I case. ${ }^{100}$ Since then, the courts apply the same reasoning as in Tarn-et-Garonne with regard to the consequence of an illegality and take into consideration the seriousness of the breach, the possibility to regularise it and the public interest in maintaining the contract. When the validity is challenged in the course of contractual litigation already brought before a given court, the contractors can only seek annulment for illicit content or very serious unlawfulness. This is a high bar which requires more than the simple illegality of the award. The award must have been made on purpose clearly to favour a bidder in such a way that it is similar to a criminal offence. ${ }^{101}$ One may notice that French law created in 1991 a specific criminal offence for favouritism in the course of awarding a public procurement contract or a concession (art. 413-14 of the Criminal Code).

It should be recalled that since the 2020 Société comptoir négoce équipements case, the public contractor may decide to terminate the contract in case of serious unlawfulness of the contract but can still ask the judge to annul the contract or to terminate it. ${ }^{102}$

On the whole, remedies available to third parties and remedies available to public authority contractors are currently converging - though not merging. The common trend lies in the balance between redressing unlawfulness and maintaining public law contracts. The development of several recours de plein contentieux in this area by the Conseil d'Etat gives the core role of setting the right balance in the hands of the administrative courts themselves.

\subsection{CONCLUDING REMARKS}

Contemporary French administrative law on public contracts is a product of history and tradition. However, the rules set by long-standing case law are

99 See note 38.

100 CE Ass. 28 December 2009, Commune de Béziers, no. 304802, Leb. 509.

101 CE 11 January 2011, Manoukian, no. 338551, Leb. 5.

102 See note 72. 
nowadays challenged by academic writings and by European and international laws.

The academic challenges started with concerns about the modernity of specific powers to contractors and more generally doubts the compatibility of the exceptions to the binding force of contracts with the very essence of contract. The power to change public law contracts unilaterally led one author to ask the following: can public law contracts be deemed the 'law of the administration', a reference to the Civil Code rule according to which contracts are the law of the parties? ${ }^{103}$ Asking the question was already giving the answer. One famous author even suggested assigning all public contracts to civil courts. ${ }^{104}$ No such debates happen today. But there are tensions between keeping the specificities of public contracts as much as possible and reducing the differences with private law contracts when possible. One example of this tension may be seen in the implementation of good faith to public contractors which is challenged by a rapporteur public and a professor on the ground that civil courts use the principle of good faith (bonne foi) to sanction the abuse of the exercise of contractual prerogatives and to guarantee the principle of equality between parties, which is contrary to contrats administratifs. ${ }^{105}$ However, the Conseil d'Etat now seems to accept to verify whether a contracting authority acted in good faith during the performance of the contract. $^{106}$

Moreover, French law is now shaped by European and international trends which produced some effects on public contracts law. At the international level, if the Organisation for Economic Co-operation and Development (OECD) does not play a great deal in this field, the World Trade Organization (WTO) Agreement on Government Procurement (GPA) was signed in 1994 as part of the Marrakech agreements, as a plurilateral agreement by all the EU Member States and by nineteen other states and was approved by Council Decision 94/80o/EC. The aim of the GPA is to establish a multilateral framework of balanced rights and obligations relating to public contracts with a view to achieving the liberalisation and expansion of world trade. In concrete terms, it has an impact on which public procurement contracts are opened to firms originated from the signatory states and

\footnotetext{
103 J. L'Huillier, 'Les contrats administratifs tiennent-ils lieu de loi à l'administration?', D. 1953, chr. 87 .

104 Roland Drago, 'Le contrat administratif aujourd'hui', Droits 1990 no. 12, p. 117

105 G. Pellissier, conclusions on CE 7 December 2015, Syndicat Mixte de Pierrefonds, no. 382363 ; see also J.-F. Sestier, 'La loyauté dans l'exécution des relations contractuelles: un standard juridique commode?', in Mélanges Richer (Paris: LGDJ, 2013), p. 451.

106 CE 10 February 2020, SAEM, no. 422063.
} 
encourages the application of EU public contracts directives to economic operators of third countries that are signatories to the agreements. It also affects the thresholds above which public contracts award notices must be published in the Official Journal of the EU. Those thresholds are expressed as special drawing rights, a combination of the main currencies. The thresholds laid down by the European directives on public contracts are aligned to ensure that they correspond to the euro equivalents of the thresholds of the GPA and periodic reviews of the thresholds expressed in euros are made by means of a purely mathematical operation so as to adjust them to possible variations in the value of the euro in relation to those special drawing rights.

But in terms of influence over public contracts, WTO rules cannot compete with EU law. European Union directives on public procurement contracts, adopted in the 1970 o for works and supplies (and in 1992 for services) and amended in 1989, 2004 and 2014, has had a direct effect on French public contracts law albeit largely inspired by the French Public Procurement Code. ${ }^{107}$ The main effect has been on the scope of the award procedures rules. Limited to public authorities under the 1964 Code des marchés publics (with the exception of those with industrial and commercial activities which do not handle public money), rules on the award now extend to any bodies governed by public law or associations formed by one or more such authorities or one or more such bodies governed by public law as laid down in the directives. These include many entities considered of private law nature under French law such as mixed capital companies. Moreover, certain contracts deemed as excluded from those rules in relation to the importance of the individual characteristics of the contractor (the principle of intuitu personae) now fall into their scope because of EU law. This is notably the case in agency contracts whose exclusion from the Code des marchés publics by a 2001 decree was overruled by the Conseil d'Etat as contrary to EU directives. ${ }^{108}$ Even more topical was the case of public procurement contracts between public authorities. For the Conseil d'Etat those contracts were possible without award procedures under traditional practice, explicitly allowed by a 1974 guideline on the implementation of the 1964 Code. But EU law made it impossible to sustain this position, so the Conseil d'Etat deemed those contracts public procurement contracts when they are above the European thresholds but not

107 P. Terneyre, 'L'influence du droit communautaire sur le droit des contrats publics', AJDA, 1996, 84; F. Lichère, 'L'influence du droit communautaire sur le droit français des contrats publics', in J. Dutheil de la Rochère and J.-B. Auby, eds., Droit administratif européen (Bruxelles: Bruylant, 2007), p. 945.

108 CE 5 March 2003, UNSPIC, no. 233372, Leb. 108. 
when they are below. ${ }^{109}$ This peculiar reasoning was abandoned by the government with the adoption of the 2001 Public Procurement Code which defined economic operators as of private or public nature whatever the amount of the contract was. But it revealed that the rationale of applying award procedural rules shifted, because of EU law, from an approach in favour of contracting authorities, with the aim at protecting them from firms which may abuse the lack of knowledge of civil servants, to one in favour of economic operators - with the aim at securing in practice the free movement principles by extending formal rules which render difficult the temptation to buy nationally (or locally). Bearing this in mind, EU law influences to a certain extent not only the scope but also the substance of the rules. For instance, French law used to deal with abnormally law offer in a flexible manner. Contracting authorities had the power to set aside such offers but it was not made mandatory since it was for them to decide whether they take the risk of bad performance of the contract - or even non-performance in case of insolvency. The Court of Justice of the European Union (CJEU) made it obligatory by considering that, if a tenderer offers an abnormally low price, the contracting authority must ask in writing to clarify its price proposal.

That authority must treat the various tenderers equally and fairly, in such a way that a request for clarification cannot appear unduly to have favoured or disadvantaged the tenderer or tenderers to which the request was addressed, once the procedure for selection of tenders has been completed and in the light of its outcome. ${ }^{110}$

Regarding concessions, the influence is even more prominent. Nonetheless, France had anticipated the EU directive 2014/23/EU on concessions many years prior to its adoption on the 26 February 2014 with the Loi Sapin of 29 January 1993. The latter put in place obligations of transparency which left contracting authorities with a wide margin of appreciation for choosing their concessionaires. But the transposition of the directive 2014/23/EU clearly assimilates the award of concessions to that of public procurement contracts, which may compromise the implicit idea that concession awards are to be made upon the intuitu personae principle. ${ }^{11}$

109 CE 20 May 1998, Communauté de communes du Piémont de Barr, no. 188239, RFDA 1998, 6o9, concl. Savoie.

11 CJEU 29 March 2012, Case C-599/10, SAG ELV Slovensko a.s. ECLI:EU:C2021:191. The same solution was adopted just before by the Conseil d'Etat on the ground of equality albeit the Code clearly stated that the contracting authority 'may' reject an abnormally low offer, CE 1 March 2012, Département de la Corse du Sud, no. 354159.

111 On this particular issue, see F. Lichère, 'La passation des concessions', AJDA 2016, 1000. 
European Union rules may produce an indirect effect on specific powers granted to public authorities. This is notably the case concerning the unilateral power of modification which, for public procurement and concessions contracts, must now fulfil the limits set by the case law of the European Court of Justice (ECJ) in 2008 and subsequently framed in art. 72 of directive 2014/24/ EU. ${ }^{112}$ The new Code de la commande publique (CCP) makes clear that these rules apply to any amendment (avenant) and, when it comes to contrats administratifs, both for consensual and unilateral modifications. ${ }^{113}$ It is even probably the case for financial compensation for imprévision, sujétions imprévues and fait du prince. Often considered as extra-contractual damages which may or may not lead to an amendment, they should be considered as a modification if one takes a thorough look at the Finn Frogne case: ${ }^{114}$

A material amendment cannot be made to that contract without a new tendering procedure being initiated even in the case where that amendment is, objectively, a type of settlement agreement, with both parties agreeing to mutual waivers, designed to bring an end to a dispute the outcome of which is uncertain, which arose from the difficulties encountered in the performance of that contract. 'Material' must be understood here as 'significant' since in the French version the adjective used is 'substantiel', which may therefore include amendments which are purely financial ones as may be indemnification of imprévision for instance.

Interestingly, an example of 'gold plating' - that is, of over implementation, may, on the contrary, reinforce the powers of contracting authorities. ${ }^{115}$ Article 57 , para. $4 \mathrm{~g}$ of directive $2014 / 24 / \mathrm{EU}$ states that contracting authorities may exclude from participation in a procurement procedure any economic operator 'where the economic operator has shown significant or persistent deficiencies in the performance of a substantive requirement under a prior public contract, a prior contract with a contracting entity or a prior concession contract which led to early termination of that prior contract, damages or other comparable sanctions'. When transposing the directive, the French government decided to add to this potential exclusion during the award phase the possibility to terminate the contract if the contractor had faced or

112 ECJ 19 June 2008, Case C-454/o6, Pressetext Nachrichtenagentur, ECLI:EU:C:2008:351.

113 Articles L2194-1 CCP for public procurement contracts and L3135-1 CCP for concessions.

114 CJEU 7 September 2016, Case C-549/14, Finn Frogne A/S, ECLI:EU:C:2016:634.

115 F. Lichère, "The Transposition of the Public Procurement Directive in France: Between Over Implementation and Questionable Implementation', in S. Treumer and M. Comba, eds., Modernising Public Procurement: The Approach of EU Member States (London: Elgar, 2018), pp. 93-111. 
even faces this situation during the performance phase. Obviously, such a power may represent an important threat to private contractors.

However, it remains uncertain whether in practice the EU rules led to significant changes in the habits of public authority contractors regarding the use of their unilateral powers.

More generally one may think that the insistence of legal scholars on extracontractual powers of public contractors may not represent the reality of contractual relationships which are probably shaped on a daily basis around the contract terms. If parties to public law contracts are unequal, this also stems from the unilateral formation of the contract and from the content of those contracts which ensures strong powers to public contractors especially through the use of standard terms and conditions, as it is the case in common law countries. ${ }^{116}$ Contrats administratifs are agreements of the will between unequal parties, but the source of this inequality is certainly diverse in France. ${ }^{117}$

116 N. Gabayet, L'aléa dans les contrats publics en droit anglais et droit français (Paris: LGDJ, 2015).

${ }^{11}$ L. N. Brown and J. Bell, French Administrative Law, $5^{\text {th }}$ ed. (Oxford: Oxford University Press, 1998), p. 192. 


\section{Conclusion}

The overview of French administrative law in this book has shown that it is currently shaped by multiple influences. This short conclusion will draw out four of those influences: path dependence, the constitutional turn, the European environment and social change. No legal system remains the same, nor does it remain distinctive in the same ways as in the past. What UK scholars like Dicey or Hamson saw as distinctive in 1885 and 1954 is not the same as what will strike the reader of 2021. This is particularly true for the UK reader of 2021, since her administrative law has changed radically in the intervening years and so the vantage point for comparison is different. But this will also be the case for the Dutch or German or Scandinavian reader of this work.

\subsection{PATH DEPENDENCE}

Bell has suggested that

established legal approaches from the past to the solution of issues will determine the way in which new situations or new problems are handled in the present and in the future. Legal development is explained not simply by the effect of social and economic pressures operating on the law from the outside at the current time, but also by the internal dynamic of the law, the pressure of established ways of dealing with issues. ${ }^{1}$

This is very clear in French administrative law. A number of features of current French administrative law are only explicable by reference to the historical tradition of French institutions.

1 J. Bell, 'Path Dependence and Legal Development' (2013) 87 Tulane Law Review 787. 
The most obvious example is the separation between public law and private law. As explained in Chapter 5, Section 1, France has distinctive historical reasons why there is a clear separation between administrative courts and ordinary courts. That separation as a matter of policy was established even before the Revolution and was restated at the beginning of the 1789 Revolution, of the 1799 consulate and of the Third Republic. It has now been confirmed as a constitutional value in a way that is very unusual in Europe. The consequences have affected both institutions and substantive law. As was seen in Chapter 3, Section 3, there are distinct judicial institutions from those involved in judging criminal and civil matters. They are staffed by individuals whose training has become more and more distinct, especially since the creation of Ecole Nationale de l'Administration distinct from the Ecole Nationale de la Magistrature since 1945. Whereas once administrative judges had degrees from law faculties, now they have a different profile. The subsequent career is different because of another distinctive feature of the French system - the close connection between the judges of the administration and administrators. The fact that individual civil servants can move between administrative, judicial and political activities in the course of a career is very different from the career of ordinary judges and even more different from the experience of judges in other career judiciaries in Europe, let alone from the common law countries. These different judicial institutions have developed their own distinct procedure for deciding cases. This has some similarities with the procedure in the ordinary courts and there is an attempt to align the two. But all the same, there are distinct features, such as the power to order the administration to produce information.

Path dependence is shown especially in two aspects of substantive law. In judicial review, the grounds of review were broadly established by Laferrière in 1887 and they have remained very similar ever since. The influence of the Law of 28 pluviôse An VIII in relation to public works on the ideas behind state liability in France put French administrative law on a path different from that of private law and also from other countries. That is not to say that there are not similarities and cross-influences, but the framework of concepts is distinct.

This distinctiveness of substantive law is reinforced by the distinctiveness of French public law scholars. Those who have written on and shaped French administrative law have been either members of the Conseil d'Etat giving courses preparing students for entry into the civil service or have been professors at universities in specialist public law chairs. The separateness of the competition for public law professorships in France, especially since the rules of the agrégation established in 1895 ensures the distinctiveness of scholarly 
thought enshrined in the law faculties having distinctive paths after two years of common studies. Those who teach public law do not teach or research subjects in private law.

These aspects of path dependency have reinforced the special character of French administrative law for more than two hundred years. This did not arise at once, but the features just mentioned show how French administrative law has accumulated distinctive features particularly in the course of the nineteenth century. But although French public law has been set on a distinctive path, the dimensions of the Constitution and of Europe have radically altered its course during the Fifth Republic and have created new path dependencies arising out of new existential commitments.

\subsection{THE CONSTITUTIONAL TURN}

Core French public law teaching used to be divided between a rather doctrinal course on droit administratif and a course on droit constitutionnel et institutions politiques (as it was called from 1954). Since it was re-established as a first-year subject in law faculties in 1889 , the focus has been on the description of constitutional institutions and the principles underpinning them. But it was very much a droit politique, not really hard law. This was reflected in the status of the Comité consultatif constitutionnel of the Fourth Republic of 1946, which was effectively a committee reporting to Parliament on constitutional issues. But the decision by the Conseil constitutionnel in 1971 to treat fundamental rights as legally enforceable and the change in those who could make references to the Conseil constitutionnel to include members of Parliament in 1974 altered the situation. The emphasis in the courses and in the scholarship moved to the legal character of constitutional law, with a particular focus on the case law of the Conseil constitutionnel. ${ }^{2}$ This led in 1997 to a relabelling of the basic course as simply droit constitutionnel. This reflected the emerging place of constitutional law within public law, a position entrenched by the constitutional reforms of 2008 , especially the introduction of QPC.

The legal character of constitutional law and its status in relation to administrative law can be seen especially in the work of the Conseil constitutionnel. Its members do not have to have a legal qualification, but this has become increasingly the case. Its judicial workload is significant. The Conseil

2 See J. Chevallier, 'Droit constitutionnel et institutions politiques: les mésaventures d'un couple fusionnel', in M. Amellier, P. Ardant and J.-C. Bécane, eds., La République. Mélanges en l'honneur de Pierre Avril (Paris: Montchrestien, 2001), pp. 183-99, esp. p. 190. 
constitutionnel gave 319 decisions on electoral matters in a major electoral year (2017-18) and had 160 cases pending at the end of that year. ${ }^{3}$ It deals with disputes on referendums and presidential and parliamentary elections, whereas the administrative courts deal with local and European elections. Not only can it prevent laws being signed by the President and annul existing laws, the Conseil constitutionnel can lay down how laws are to be interpreted both by the administration and by the courts. Since the 1980 , these réserves d'interprétation have become a very significant part of the decisions the Conseil constitutionnel has handed down in relation to challenges to the validity of legislation. ${ }^{4}$ It was, of course, a technique borrowed from the Conseil d'Etat. ${ }^{5}$ As was seen in Chapter 4, Section 6, the administrative courts deal with many requests to refer an issue to the Conseil constitutionnel by way of QPC. Nearly half of the references for a QPC come from the Conseil d'Etat. So, although the administrative courts are a major filter for requests, the Conseil constitutionnel is the lead decision maker on major questions of public law concerning the validity and interpretation of legislation passed by Parliament. The Conseil d'Etat has a complementary if less glamorous role in relation to legislation made by the government. Particularly in the area of fundamental rights, the Conseil constitutionnel has become the pace setter.

Even if the administrative courts are no longer the lead institution in relation to constitutional matters, it is worth remembering that this has come about by the expansion of public law. Situations treated as legal issues in 2021 are more numerous and important than what was considered a legal matter in 1958. The administrative courts have not lost any powers in that period. Indeed, they have gained them. The illustrations throughout this book from the Covid-19 pandemic, especially in Chapter 4, Section 3, show just how far the administrative courts are now able to give orders to the Prime Minister to change legislation within a very short deadline. Their work is at the operational level of the Constitution, but in terms of ensuring that powers are exercised and fundamental rights are protected, their actions are very

3 Conseil constitutionnel, Rapport d'activité 2018 (Paris, 2018), p. 14.

4 A. Viala, Les réserves d'interprétation dans la jurisprudence du Conseil constitutionnel (Paris: LGDJ, 1999).

5 On the retrait du vénin, see, for example, CE 4 January 1957, Syndicat autonome du personnel enseignant des Facultés de droit, RDP 1957, 673 note Waline: a ban on the holding of international conferences without the permission of the Minister was upheld provided it was interpreted as applying only to conferences requiring financial support from the administration. 
powerful. In many ways, the prestige of the Conseil constitutionnel has been reflected onto the other courts.

Fundamental rights are not the only values enforced in public law. As seen in Chapter 7, Section 4, principles of good administration have been developed significantly in the past fifty years both by the legislator and by the administrative courts. This is not an area in which the Conseil constitutionnel plays a major role, but is part of the overall operation of constitutional institutions in France.

\subsection{THE EUROPEAN ENVIRONMENT}

In the course of the Fifth Republic and unlike the United Kingdom, France made two existential and not merely instrumental commitments to Europe. After De Gaulle's hesitancy, France became a fully committed member of the European Union. A few years later, it ratified and embraced the European Convention on Human Rights. Those two commitments have led French administrative lawyers to treat Europe as both a natural partner in dealing with issues of administration and as a benchmark for the best standards of administrative law. These two dimensions of current French administrative law have created their own path dependence within French law.

The significance is shown by the fact that the words 'Europe' and 'European' occur nearly three hundred times in the Conseil d'Etat's annual report in relation to its work and that of the administrative courts for $2020{ }^{6}$ The major administrative law journals regularly have updates on EU law and the European Convention and their presence in discussions in articles is pervasive. Significantly, these aspects of French law give a new status to both administrative and ordinary courts, since they, not the Conseil constitutionnel, are the primary institutions enforcing the laws of the EU and of the Convention. They are the institutions which can strike down domestic legislation because it is incompatible with these supranational norms.

As was seen in Chapters 1 and 4 , the Convention affects procedure, especially through the requirements of art. 6 on a fair trial. As seen especially in Chapter 7, Section 3.2, the Convention affects the understanding of fundamental rights. There are topics, such as privacy and the right to a family life, which are not clearly covered in the formal French constitutional texts, so the Convention is the primary source of certain fundamental rights. Bjorge suggests that, until the 2000s, the Conseil d'Etat's interpretation of the

6 Conseil d'Etat, Rapport public 2020 (Paris, 2020). Most of the uses relate to the European Union. 
Convention was rather restrictive, but that, since then, it has adopted the 'living instrument' approach of the Strasbourg court. ${ }^{7}$ In that way it has not only decided to follow the interpretation of that Court in relation to specific provisions, but to embrace its approach to the Convention as a whole.

European Union law affects large amounts of substantive administrative law - for example, tax law, environmental law and immigration law, among others. Chapter 9 showed how radically the French law on administrative contracts has been altered by EU legislation, changing not just its scope and content, but also its ethos. The Conseil d'Etat's annual report has sections specifically on the EU in relation to both its judicial and its consultative work. Certainly since the 1990s, EU principles have been hard-wired into the whole administrative law system.

The influence of the $\mathrm{EU}$ on French administrative law is not limited to the specific rules and principles which originate in EU law. The place of European partners as benchmarks for best practice is seen very clearly in the influence of the European ombudsman on principles of good administration, which culminated in the enactment of the CRPA in 2015. That is not to say that Europe was the only influence. Indeed, the French experience fed into the deliberations of the European ombudsman. France administrative law had been moving in this direction since the late 1970s. But the climate created by the European developments provided extra stimulus and reference points for French developments. This is but one example of the 'spillover' phenomenon by which domestic law changes beyond the requirements of EU law. All the same, French developments have been selective. As was seen in Chapter 7 , Section 4.6, French administrative law has not adopted the concept of 'legitimate expectations', preferring to keep with the idea of legal certainty and its reduced scope. Similarly, in Chapter 8, Section 4.5, it was seen that French law on compensation for unlawful actions is more generous than that under art. 340 TFEU. For the most part, the identification of spillover is complex. There are French developments and European developments which merge into an overall 'mood music'. The use of proportionality is a good example (see Chapter 7, Section 1.5.4). It is clear that the European concept provides a common language for dealing with issues for which French law previously used different terminology. All the same, there is a clear movement of French administrative law towards the greater level of scrutiny which the concept of proportionality represents.

7 E. Bjorge, Domestic Application of the ECHR. Courts as Faithful Trustees (Oxford: Oxford University Press, 2015) Pp. 126-30. 
The development of French administrative law in line with the two European laws is facilitated by informal mechanisms of genuine dialogue, as well as by the more formal communication that comes through references from French courts to the European courts and their responses. Not only are members of the Conseil d'Etat judges in the courts, but they are also référendaires in the Luxembourg court. Members of the courts hold regular informal meetings where ideas can be exchanged on key topics (and the authors have been present at such meetings). These links between people reinforce the sense that enforcing Convention rights and EU law is a collaborative effort, rather than an external imposition, despite differences of opinion about specific topics.

Overall, it is impossible to think of French administrative law today independently of its involvement in the enterprises of the European Convention and European Union Law.

\subsection{SOCIAL CHANGE}

France is not an island, and French society is deeply involved in global enterprises at the political, economic and community levels. French society is cosmopolitan. According to French statistics, 8.355 million people (12.85 per cent, out of a population of 65.130 million) living in France in 2019 were born elsewhere, which is very similar to the UK (13.4 per cent). ${ }^{8}$ France is a consumer economy drawing in goods and services from across the world. As a consequence, its social expectations of public administration are not defined totally by what France traditionally has on offer.

French society after 1968 has been less deferential to authority and more consumerist in its approach to public services. There has also been a decline in belief in centralised planning and a greater reliance on the market. These trends have changed what is run as a public service and how far people are able to complain. Chapter 7, Section 4 noted that the changes in France are mirrored in other countries in the developed world. Reforms of public administration and the organisation of public services is a common theme of studies by the OECD.

That said, there are distinct dynamics within France. France has a very distinctive approach to secularism (laicité). ${ }^{9}$ It also has a specific approach to

8 Statistica website: www.statista.com/statistics/548869/foreign-born-population-of-france (visited 6 May 2021).

9 See M. Hunter-Hénin, Why Religious Freedom Matters for Democracy: Comparative Reflections from Britain and France for a Democratic 'Vivre Ensemble' (Oxford: Hart, 2020), chapter 2 . 
terrorism. As noted in Chapter 1, Section 5, the decision of the Conseil d'Etat in La Quadrature du Net carefully negotiated the French policy of wishing to have access to mobile telephony data in the fight against terrorism with the EU legislation on data retention. ${ }^{10}$ Guided by a reference to the CJEU, it found lawful most of what the government wished to ensure for its antiterrorism policy, but required the retention to be reviewed more frequently than the government planned.

The dynamics of contemporary public law are shown by the case in that the administrative courts are coming to the final decision under the influence of both domestic constitutional law and EU law.

France also has a distinctive balance between centralised power and local administration. Much of the structure of this balance has been laid down for centuries, but, as Chapter 2 explained, changes in the past forty years have moved France to a different set of arrangements than are found in the United Kingdom, Belgium, Germany or Italy. In many ways, globalisation has led to greater attention to the way power and influence can be exercised at the local level. In this topic, as in many others, France has a distinctive way of handling issues which are common to many developed countries.

\subsection{RENVOI}

This book has provided an introduction to French administrative law. The dynamics identified in this chapter explain why that law is always on the move, whilst retaining much of its distinctive and recognisable shape. Enduring elements were laid down by the Revolution and Napoleon's legal and administrative reforms, by the early years of the Third Republic, and by France's more recent commitments to the EU, to the European Convention and to legal constitutionalism. At the same time, society and ideas about public administration change, and the law will reflect these movements. 


\section{Index}

abuse of power, 179, 185-8, 222, 228

the state and, 5

Académie, 31, 60

accountability (a duty to explain), 22-3, 80, 127,233

acte clair doctrine, 137

actes de gouvernement, $164-6$

administration

basic duty of, 224

modernisation programme and, 22

reform of, 21-4

Administration of Fine Arts, 143

administrative act, 10, 47, 126, 130, 279, 290

administrative action, 43, 46, 66, 143

judicial review procedure and, 154

administrative contracts (contrats

administratifs), 64, 130, 139, 284,

290, 304

amendment (avenant), 297

administrative courts, $65,82-3,90-8$,

$$
\text { 272-8, } 303
$$

and fines for abusive claims, 175

exceptions to separation of ordinary judicial authorities, 131-8

good administration and, 221-31

judicial review of, 154

penalities and, $175-6$

proportionality and, 198

religious freedoms and, 206-7

separation from ordinary courts, $128-30$,

$$
147-9,151
$$

administrative decisions, 139, 147, 177

and assessments of legal requirements, 191

appeals against, 90

challenging, 155-8

correcting, 174 criminal courts and legality of, 133

declaratory judgments, $173-4$

delay of, 230

duty to withdraw, 223

exceptions to legality of, 131-8

grounds of review of, 185

illegality of, 143, 169, 261

incompatible, 49

legality of, 23, 51, 130, 136, 158

non-existence and, $179-81$

request for review of, $5,99,100,128$

right to challenge, 53, 54, 168

techniques of avoiding null decisions, 170

administrative judges, $1,6,18,20,67,70,83-8$

creation of, 5

independence of, 45

administrative law, 1, 9

Conseil constitutionnel and, 8

context of, 26

fait du prince theory, 288

procedures, 176

sources of, $43-59$

administrative law cases, claims in, 90

administrative redress, 227

prior, 99-100

administrative regulations, 132, 133, 147

adversarial principle, the, 92

agent public contractuel, 273

AIDS-infected blood, compensation and, 141

Algeria, military coup in, 164

Allison, John W. F., 1, 56

alternative dispute resolution, $43,78,100-3$

amicus curiae, 17, 109, 114-15

Anglo-American system, 55

anti-terrorism legislation, 136 
appeals

Conseil d'Etat and, 70

immigration-related, 69

in the United Kingdom, 65

the Commission and, 78

time limits and, 227

to the European Convention on Human

Rights, 60

to the king, 61

Architect des Bâtiments de France, 182

Armenian genocide, 201

Assemblée Nationale, 107

astreintes, 77, 124-5, 173, 176-7

authority, legal source of, 130

Autorité de la concurrence, 114

balance sheet, theory of (le bilan coût-avantages), 192-5

Barre, Raymond, 28

Barrot, Odilon, 60

Batailler, F., 210

Bell, J., 299

biometric passports, 196-7

Bjorge, E., 209, 303

black people, false accusations against, 33

Blum, Léon, 116, 273

Bonaparte, Napoleon, 33, 63, 306

bouleversement de l'économie du contrat, 287

Boulogne, blockade of the port of, 258

Braconnier, S., 20, 21

Braibant, Guy, 58, 59, 116, 148, 193, 195

British lawyers, droit administratif and, 1

Brown, Neville, 2, 41, 67, 77

burkini, local ban of, 108

CADA (Commission d'accès aux documents administratifs), 40, 224

care homes, breaches in, 42

case citation, 24

case law (la jurisprudence), $55-7$

cases, public hearing of, 94

Catholic Church, real estate owned by, 275

causation, 263, 264-6

cause juridique distincte, 179

centralised power and local administration, 306

Chancellor d'Aguesseau, 92

Chancery, remedies of, 169

Chapus, R., 54, 59, 239, 245

Charter of Fundamental Rights of the European Union, 49, 169, 230, 232 article 41 of, 222

Charter of the Environment, 204, 226

Chartres Cathedral, 143

Chirac Government, 21

Christian Democrat Party, 106

circulars, 159-60

and guidance notes, 162-3

and soft law, 159

public access to, 224

Civil Code, 285, 294

article 1128 of the, 279, 281

article 1129 of the, 279

article 1162 of the, $281-2,283$

article $1231-5$ of the, 285

article 1240 of the, 239,245

article 1242 of the, 241

article 1583 of the, 277

article 2044, 103

contractual consent and, 279

exceptions under, 134

liability and, 268

civil courts, 56, 64, 94, 119, 294

annulment by, 102

defence of illegality before, 188-203

ordinary, 65

regulation on conflicts in, 62

civil law countries, 270

civil liberties, 230

protection of, 134-7

civil servants

protection against suit, 217

civil service appointments, discrimination in, 96

civil service college. See École nationale de l'administration (ENA)

claims

making, 98

procedure for making, 90

clause unusual in private law, 273-5

CNIL (Commission nationale de

l'informatique de des libertés), 40, 93, 144, 224

Code Civil. See Civil Code

Code de Justice Administrative (CJA), 46, 131

article $111-5,133$

article $741-2,176$

article L111-5, 134

article L212-1, 68

article $\mathrm{L} 213-4,103$

article $\mathrm{L}_{3}, 97$

article L521-1, 104-5, 292 
article $\mathrm{L}_{521-2,105,108}$

article L522-1, 104, 220

article L6, 94

article L773-4, 95

article L911-1, 124

article L911-4, 124

article L911-9, 124

article R122-18, 121

article $R_{311-1,} 247$

article $\mathrm{R}_{421-1, ~ 159,} 227$

article $\mathrm{R}_{421-5,} 167$

article R621-1, 109

article R621-7-2, 101

article R622-1, 113

article R625-3, 114

article $\mathrm{R}_{711-3}, 118$

article $\mathrm{R}_{712-1,118}$

article $\mathrm{R}_{732-1,121}$

article $\mathrm{R}_{732-1-1,115}$

article $\mathrm{R}_{741-12,175}$

article $\mathrm{R}_{751-1,123}$

article $\mathrm{R}_{7} 61-1,174$

article $\mathrm{R}_{771-2,132,152}$

Code de l'entrée et du séjour des étrangers et du droit de l'asile (Ceseda), 46

Code de la commande publique (CCP), 46 , 271, 276, 297

Code de la propriété des personnes publiques (CGPPP), 276

Code de la santé publique, 109

Code de la sécurité intérieure, 258

Code de Santé Publique, article 1110-5, 109

Code des marchés publics, 295

Code des relations entre le public et

l'administration (CRPA), 23, 24, 46, 74, 99, 159, 178, 221, 222-3, 224-5, 226, 227, 230-1, 304

article L122-1, 225

article L211-2, 230

article L211-5, 230

article L242-1, 223

article L243-2, 223

Code des transports, 277

code général des collectivités territoriales

$$
\text { (CGCT), } 46
$$

code général des impôts, 46

Code of Civil Procedure, 132, 152

Code of Criminal Procedure

and individual freedoms, 134

article $137^{-1}$ of, 135

Code of Good Administrative Behaviour, 222
Code of Public Health, 261

Code of Relations between the Public and the Administration, 232

Code of Social Action and Families, 221

Code of Social Security, 267

codes and legislation, 46

cohabitation, 27

collegiality, principle of, $97-8$

Comité consultatif national d'éthique et le Conseil national de l'Ordre des médecins, 109

commercial activities, and categories of litigation, 139

commissaire du gouvernement, 6, 7, 11, 12, 14, 55,58 , See also rapporteur public

Commission centrale d'aide sociale (CCAS), 82

Commission consultative du secret de la défense nationale (CCSDN), 112

Commission de contrôle des assurances, 38

Commission des recours des réfugiés, 78

Commission des Réfugiés, 68

Commission du Contentieux. See Conseil d'Etat

Commission du contentieux du stationnement payant, 83

Commission du Rapport et des Etudes, 76-8

commission for access to public documents (CADA), 39

Commission Permanente, 75

commissions départementales d'aide sociale (CDAS), 82

commune, the, $32,3^{6-7}$

big cities in, 33

elected local authorities in, 34

services provided by, 37

compensation, 252, 289

no-fault, $261-3$

state liability and, 234

competence, lack of, 181-2

competition law, $47,198,278$

compulsory competitive tendering process, 271

concessionaires, 276, 296

Conciliation and Compensation

Commission, 262

conflicts

handling, 150-3

negative, 151

of decisions, 40

positive, $150-1$ 
Conseil constitutionnel, 6, 129, 134, 168, 217, 275, 302

constitutional principles, 211

equality in taxation and, 213

Conseil constitutionnel decision, 130

Conseil d'Etat, 2, 6, 8, 12, 13, 47, 63, 69-70, 94, $111,125,137,192,201,248$

annuling of an expropriation and, 194

consultative role of, $72-6$

decision of, 64

droit administrative and the, 3

equality in taxation, 213

judicial role of, $70-2$

Prince Napoleon and, 164

reference for an opinion of the, 118

renaming of, 61

scrutiny of draft legislation and, 73-4

Section du Contentieux, 184

Service de diffusion des conclusions, 116

time limits and, 167

Conseil du Roi, 61, 275

Conseil économique, social et environnemental régional (CESER), 35

Conseil national de l'enseignement supérieur et de la recherche, $8_{3}$

Conseil national de l'informatique et des libertés (CNIL), 39

Conseil regional, 35

Conseil Supérieur de la Magistrature, 83

Conseil, the, local authorities and, 34-5

conseils de préfecture, 62, 66, 68, 237, 275

consent, contractual, 279

Constitution

article 55 of the, 165

article 66, 134, 135, 142

the guardian of, 7

Constitution (1946), 3

Preamble, 44, 183, 204, 207, 217, 220, 269

Constitution (1958), 3, 6, 204, 220

legislative powers and, 8

preamble to, 7

Constitution French, 44-6

Constitution of An III (1795), 62

Constitutional law, 120

influence of, 7-10

constitutional rights, 204-8

constitutional turn, the, 301-3

contentieux de pleine juridiction, 188

contracts

and categories of litegation, 139 binding force of, 284-6

consent, validity, 279-81

content, validity, $281-3$

formation of, $278-9$

illegality of, 286

performance of the, $283-9$

remedies for parties to public law contracts, 291-3

remedies for third parties, 290-1

scope of, 278

unilateral termination of, 286

contradiction, principle of, 91-4

contrats administratifs, 270, 271, 280, 287, 290, 294, 298, See also contracts

scope of, 278

corporate liability, for fault, 241

corps of financial judges, 88

corps of judges of the tribunaux administratifs, 84-5

corps of prefects, membership of, 33

corps of the Conseil d'Etat, 85-7

costs, court, 174-5

Council of Europe, 224, 232

state liability and compensation, 233

Cour d'appel of Paris, 141

Cour de cassation, 150, 151, 247

in private law, 154

Cour de discipline budgétaire et financière

$(\mathrm{CDBF}), 81$

Cour des comptes, $80-2$

Cour nationale du droit d'asile (CNDA), $78-80,88,92$

Cours administratives d'appel, 68-9, 84-5

court costs (les dépens), 174-5

Court of Justice of the European Union

(CJEU), 6, 13, 86, 137, 153, 296, 305

Advocate General, 15, 17, 19, 116

and principles of decisions taken, 228

article 260 TFEU, 173

French administrative law and, 232

general principles and, 211

legitimate expectations, 228

Court of Requests, 90

court office (le greffe), 67

court processes, article R213-5 CJA, 101

courts, 138

administrative, 65

Cours administratives d'appel, 68-9

criminal courts, $84-5,128,133$

general, 65

reference by, 151 
tribunaux administratifs, 66-8

Covid-19 pandemic, 37, 75, 115, 173, 177, 288, 302

church services and, 206

complaints received by the Défenseur during, 42

emergency legislation, 181

handling of, 28, 169

interim measures and, 104

Prime Minister's decree and, 170

principle of proportionality and, 197-8

the prefect and, 34

Craig, Paul, 287

criminal offences (crimes and délits), 205

criminal penalties, 133, 135, 205

and offences, 198

criminal proceedings, 133-4

and state liability, 233

cristallisation du contentieux principle, 179

cross-border disputes, 103

CRPA. See Code des relations entre le public et l'administration (CRPA)

customs and local traditions, interference with, 196

Czabaj, M., 168

d'Aguesseau (Chancellor), 92

d'Estaing, Giscard, 3

damages, measures of, 266-8

damnum emergens, 286

data privacy

EU requirements and, 224

respect for, 224

data protection, and transparency, 224-5

decisions

administrative, 169

conflict of, 40

correcting, 174

emergency interim, 71

individual, 158

kinds to be challenged, 158-66

legality of, 179

principles governing, 228

prior, 158-9

regulatory (actes réglementaires), 158

Declaration of the Rights of Man and of the

Citizen, 8, 44, 204, 210

article 8 of, 205

declaratory judgments, 173-4

deconfinement measures, 106

decree of 1960, 151 defective products, liability and supply of, 262 defence secrecy, documents protected by, 93

Défenseur(e) des droits, 23, 38, 41-3, 101 independence of, 42

Deguergue, M., 116, 239, 257

deliberation, the, $122-3$

demandes d'éclaircissement article 931-1 CJA, 77

dénaturation (gross distortion), 284

Département de la Sarthe, 36

département, the, 32,36

elected local authorities in, 34

détoumement de pouvoir (abuse of power), $185-8,201,282$

Dicey, A.V., 1, 4-5, 56, 178, 231, 233, 299

Dintilhac categories, 267

direct and certain consequence, 265

Directives of the European Union

2000/78/CE, 12

2008/52/EC, 103

2014/24/EU, 297

VAT, 11, 50, 223

disabled people, constitutional right of, 220

disciplinary penalties, 196

discrimination, 228

documents, sharing of, 92

Donoughmore Committee, 2

draft legislation, Conseil d'Etat and, 73-4

driving licences, granting, 181

droit administratif, 1, 2, 3, 301

as a benchmark, 2

shaping of, 5-6

what it is, 4-5

droit politique, 301

Duguit, Léon, 2, 59, 130, 148, 156, 235

duress (violence), 279, 281

École des Ponts-et-Chaussées, 58

Ecole libre des Sciences Politiques, 58, 86

École nationale de l'administration (ENA), 33 , $85-6,112,212,300$

Ecole Nationale de la Magistrature, 13, 300

Ecole Normale Supérieure, 86

Ecole Polytechnique, 86

Education Code, 276

effective redress, right to, 91

Eisenmann, C., dispute with Vedel, 7-9

electronic communication, 225

emergency interim decisions, 71

emerging principles modern, 219-21

emprise, doctrine of, 143 
Energy Code, 276

article L314-24 of, 277

enforcement, $123-7$

English Privy Council, 70

Equal Opportunities Commission, 42

Errera, R., 236

erreur manifeste cases, 193

proportionality in, 196

error of fact, $188-90$

error of law, 192, 201

absence of, 201

error of law (erreur de droit), 190-1

essential procedural requirement (vice de procédure et vice de forme), 182-5

essential procedural requirement, breach of, $182-5$

ethical principles, 218

EU General Data Protection Regulation (2016), 106

EU law. See European Union law

Eurodisney at Marne-la-Vallée, 102

European Charter of Fundamental Rights, 220

European Coal and Steel Community treaty, 3,230

European Commission Code of Good

Administrative Behaviour, 222, 225

European Community law, 229

European Convention on Human Rights, 3 , 51-3, 91, 118, 127, 208-10, 220, 232, 261, 269, 303

appeals to, 60

article 6 (1) of, 82, 94, 247

article 13 of, 169

danger of, 89

domestic law, influence on, 14-21, 56

fair trial, rights to, 14

freedom of individuals and, 106

French administrative law and, 306

French Constitution and, 203

participation of France in, 3

Protocol 16 of, 120

ratification of, 6, 177

right to redress and, 91

wearing of religious signs and, 206

European Court of Human Rights, 18, 86, 89, 109, 153, 206, 209, 232

and actes de gouvernement, 164

and the rapporteur public, 115

complaints about length of proceedings, 95

impartiality principle and, 76

interference and, 20 living instrument approach, 220, 304

Vice President Genevois and decision of, 19

European Court of Justice. See Court of Justice of the European Union (CJEU)

European Directives, on public contracts, 295

European Economic Community

France entry to, 10

European law, environment of, 303-5

European Ombudsman, 304

Code of Public Service

commitment principles, 222

European principles, and decisions taken, 228

European Social Charter of the Council of

Europe, 207

European supranational law, 232

European Union

breaches of law of, 261

competition law and courts of, 198

Court of Justice, 86

development of Charter of Fundamental

Rights, 232

France membership in, 303

French administrative law and, 179

membership in, 6

participation of France in, 3

treations on, 47

European Union Directives, 149, See also

Directives of the European Union

European Union law, 47-51, 119, 137, 207, 228, 279, 296, 303-5

acte clair doctrine in, 137

effect on administrative law, 304

influence of, 10-14

unlawfulness and, 249

WTO rules and, 295

evaluation, manifest error in, 161, 171, 191-2, 198-9, 200, 201, 208, 215

ex gratia payments, 234

exceptional risks, liability for, $252-6$

Executive, the central organ of the State, 27-8

expert report (l'expertise), 112-13

expropriation, 194

facts

error of, $188-90$

evaluation of, 191-2

material error of, 201

fair trial, the right to, 14-21

Fairgrieve, D., 236, 240, 249, 263, 266, 267

fait du prince theory, 288, 297

fault, 236 
and unlawfulness, 248-50

by inaction, 251-2

failure to provide a public service, 251

faute de service, 240-2, 243, 244

in regulation, 250-1

liability, 237, 238, 239

nature of, 239-40

no-fault liability, 252

ordinary, 263

types of, 251-2

faute lourde, $245-8,250,254$

faute personnelle, $242-5,268$

differentiating from faute de service, 242

faute simple, 245-8, 263

Fifth Republic, 3, 8, 164

Constitution of, 7, 26, 30

finance laws, 28, 44, 45, 51

financial courts, $80-2$

financial judges, corps of, 88

Financial Markets Authority (Autorité des marchés financiers), 52, 138, 161

First World War, 8, 210, 257

flagrant illegality (voie de fait), 129

force majeure administrative, 288

foreigners, expulsion of, 131, 135

Fourth Republic, 3, 8

France, social change in, 305-6

Franks inquiry, control of ministers' powers, 2 fraud, 281

freedom of movement, interference with, 105

freedom, scope of fundamental, 220

French academics, and the droit administratif, 3

French administration, 22, 41, 49, 174, 225 types of contracts and, 139

French administrative courts, 88, 154 and promotions, 170 procedure of, 127

French administrative justice system, background to, 61-5

French administrative law, 176, 271, 299, 306 change and, 3

development of, 231

European Convention and, 3, 305

European influences on, 232

influence of the European Union on, 304

legal certainty and, 228-30

liability and, 263, 264

public contracts and, 293

public law contract and, 270

remedies and, 169 state liability and, 234

French Civil Code, 239, 241

French law

as a source of EU law, 47

state liability and, 268

French Ombudman (Médiateur). See also Défenseur(e)

Frier, L., 246

frustration, 287

fundamental rights, 203, 220

constitutional rights as, 204-8

European Convention on Human Rights and, 208-10

public law and, 303

Gambetta, Léon, 27, 28

Garner, Jack, 2, 6

General Code on the Property of Public Persons, 140

general courts, 61-5

General Tax Code, 11

Geneva Convention on Refugees (1951), 211

Genevois, Bruno, 11, 19, 46, 116

German Civil Code $\$ 839,241$

German occupation, 288

globalisation, 306

good administration, principles of, 221-31

good faith, principle of (bonne foi), 294

gouvernement, actes de, 164-6

Government website (Légifrance), 74

Grands Arrêts, 166, 168, 245, 254

grey literature (la literature grise)

soft law and, 161

gross fault (faute lourde), 235, 245, 250

guidelines, case of, 160

Guyomar, M., 12, 59, 92, 117

Hamson, C. J., 2, 3, 19, 299

harm, categories, 263-4

Hauriou, M., 2, 59, 130, 147, 236, 252, 257

Haute Autorité de la Concurrence, 114

HCERES, 39

hearing, the, $120-2$

right to a, 225

Hédon, Claire, 42

Heilbronner, 212

Henry IV, 61

HIV transmission, 251-2, See also AIDSinfected blood, compensation and

homologation, 103

Hood, Christopher, 21 
House of Commons Public Accounts

Committee, 80

Housing Code, 167

human rights, proportionality and, 198

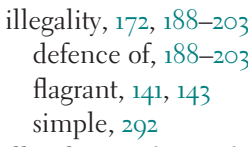

illegality (violation de la loi), 185

imprévision, 287, 288, 297

administrative law theory of, 287

inaction, liability for, 258

Incorporated Council of Law Reporting, 55

Independent Administrative Authorities

(AAIs), 38, 144

independence of, $40-1$

rule-making powers of, 39

Independent Office for Police Conduct, 42 individual decisions (actes individuels), 158

individual freedoms, 40, 107, 204

information, handling of, 225-7

injunctions (injonction), 172-3

inquisitorial character, principle of, 90, 96-7

institution of the Ombudsman, 41

intérêt public (public interest), 270

interim decisions process (le référé), 98

interim measures (Le référé), 104-9

international contracts, 283

International Labour Organisation, 195

international treaties, and general principles of (domestic) law, 211

intuitu personae principle, 296

investigation (L'instruction), 110-11

judges, impartiality and independence of, 97

judgments, public access to, 94

judicial review

exclusion of, $168-9$

grounds of, 179

inappropriateness of, 166-7

purpose of, 178-9

sliding scale for, 199-203

values enforced through, 203

juge de cassation, 284

juge des référés, 98, 104, 105

juge du référé-libertés, 107

jurisdiction

division of, 152

handling conflicts over, $150-3$ justice déléguée, 124

justice, denial of, 152

Labetoulle, Daniel, 102

Labour Code, 216, 273

article L $7121-2$ of the, 278

Laferrière, E., 58-9, 61, 147, 203, 241, 245, 300

Laski, H., 2

Lasserre, Bruno, 86

law/laws

breach of, 179

error of, 190-1, 192, 201

general principles of, 8, 21, 45, 53-5, 210-19

Law (1790), 62, 129, 179

Law of 22 Frimaire An VIII (1799), 70

Law of 28 Pluviôse An VIII (1800), 140, 237, $275,276,300$

Law (1872), 46

Law (1905), 106, 219

Law (1957), 141

Law (1979), 23

Law (1995), 124

Law (2000), 24

Law (2011), 183, 265

Law (2016), 94

Law (2019), 94

lawfulness, 283

legal certainty, legitimate expectations of,

$$
\text { 228-30 }
$$

legal representation, obligatory, 103-4

legal scholarship (la doctrine), 57-9

legality

enforcing, 203

maintaining, $178-9$

principle of, 222

Légifrance (Government website), 74

legislative acts, liability of the state and, 259

legislative exceptions, 138

legislative powers. See Constitution (1958)

legislative principle, 130

categories of litigation and, 138-41

Legislature, the, 54 central organ of the State, 28-30

legitimate expectations, 51, 304

legal certainty and, $228-30$

public and, 222

Leonetti, Jean, 109

liability

controls on, $263-8$

exceptional risks and, 252-6

for public works, $236-8$ 
no-fault, 140, 236, 237

state, $233-4$

theories of, 234-6

Liberation (1944-1946), 210

litigation, categories of, 138-41

living instrument approach, 220, 304

local administration and centralised power, 306

local authorities, elected, 34-5

Local Government Ombudsman, 42

local languages, the French and, 35

loss of profits, 292

losses, recompense for, 266

Louis XIII, 61

absolute monarchy and, 62

lucrum cessans, 286

Luxembourg Conseil d'Eta, 16

Luxembourg Court. See Court of Justice of the European Union (CJEU)

Maastricht Treaty, 12

MacMahon, 27

manifest error in evaluation, 161, 171, 191-2, 198-9, 200, 201, 208, 215

control over, 194

Marrakech agreements, 294

material error of fact, 201

Mayer, Otto, 231

Médiateur (the French Ombudsman), 23, 41

mediation, Directive 2008/52/EC on, 103

Mediator, case of, 262

mental capacity, lacking, 255

Métropole of Marseille, 282

Minitel, 22

minor criminal offences (contraventions), 205

mistake (erreur), 280-1

Mitchell, J. D. B., 2

mobile telephony data, access to, 306

modern French administrative law, 236

money penalty, 124

Moroccan migrants, 135, 171

Moulin, Jean, 33

moyen d'ordre public, 179

Muslim headscarf, exclusion of students with, 163

Napoleon. See Bonaparte, Napoleon

Napoleon III (emperor), 164

National Assembly, dissolution of, 165

National Audit Office, 80
National Conference of Local

Administration, 31

National Health Service, 42

negative conflict, 151

New Public Management, 22

no-fault compensation, other, 261-3

no-fault liability, 140, 236, 237, 252, 261-3

non-existence (inexistence), 179-81

note en délibéré, 121

Notre-Dame-des-Landes, airport at, 226

nuclear accidents, 141

nullity, 169

can it be avoided, 170-2

effect of, 169-70

objet illicite (unlawful subject-matter), 283

obligatory legal representation, 103-4

Odent, R., 58, 70, 89, 97, 148, 210

OFPRA (Office français de protection des réfugiés et apatrides), 78 , 91

ONIAM (Office national d'indemnisation des accidents médicaux), 262

openness, principle of, 94-5

oral hearings, use of, 96

ordinary fault (faute simple), 263

ordinary judicial authorities

separation from administrative courts, 147-9

ordonnance (1945), 46, 254

Ordre des médecins, 83

Organic Laws, 41, 43, 44

Organisation of Economic Co-operation and Development (OECD), 22

pantouflage, 46

Paris Lyon Marseille (PLM), 33, 37

Parliament, 59

adoption of Code of Good Administrative Behaviour, 222

Parliamentary and Health Ombudsman

(UK), 42

path dependence, 299-301

Pays de la Loire, 36

Penal Code (1992), 133, 134

penalties, $175^{-6}$

criminal, 198

disciplinary, 196

pension contributions (Gardedieu), 263

Petit, J., 246

pharmaceutical companies, 214

Planiol, M., 239, 240

Planning Code, 155 
plein contentieux, 126, 174, 289

pleine juridiction proceedings, 175

point of law (en cassation), 70

political refugee, general principle and, 211

Poniatowski, 41

Pope, 106

Port, F. J., 2

positive conflicts, $150-1$

Posts and Telecommunications, 86

power, abuse of, 185-8, 222, 228

powers, separation of, 9, 54, 62

PPP contracts (marchés de partenariat), 170,283

prefect, the, 33

préfet de police de Paris, 150

préjudice moral, 264

preliminary references, 118-20

pretium doloris, 264

principle of contradiction, the (le principe du contradictoire), 90, 91-4

principles, and decisions taken, 228

prior decision, need for, $158-9$

private bodies, 145

private contractors, exceptions to binding force and, 287-9

private law

clause unusual, 273-5

Cour de cassation in, 154

principles borrowed from, 216-17

private law contracts (contrats de droit privé), 139, 241, 264

private law relations, 1

private property, protection of, 134-7

privilège d'action d'office, 291

privilège du préalable, 166

Privy Council, British, 70

Privy Council, French King's, 69

proceedings

inquisitorial nature of, 112

length of, 95

time limits and, $167-8$

written nature of, 95-6

prohibition, 42, 62

Promotion Molière, 87, 88

property, ownership of, 139

proportionality, 195-9

principle of, 228

Proposal for a Regulation on a Common

European Sales law, 139

public action, transparency and, 224
Public and the Administration (Code des relations entre le public et l'administration (CRPA)), 221

public authorities, 94

exceptions to binding forces of contracts, 284-6

liability and, 236

making claims against, 90

real estate owned by, 276

state liability and, 233

termination of contract and, 286

public bodies

decision-making powers of, 40

public bodies, liability of, 140-1

public burdens, equality before, 257-61, 263

public contractor, 292

public contracts

claims relatind to, 270

French administrative law and, 293

public law

and private law, 119, 239, 252, 300

distinction between private law and, 128-30

identifying matters, 147-9

separation between and private law, 300

public law contracts ('contrats adminitratifs'), 270-1, 281, 298

legislator and, 275-8

remedies for, 289-93

remedies for third parties to, 290-1

specific rules and, 278-89

public law matters, 147

public office, equal access to, 212-13

public officials

conduct of, 222-3

public persons, 144-7

Public Procurement Code, 296

public procurement contracts, 266, 271, 276, $278,287,294,295,296$

annulment of, 114

collusion and, 280

concessions and, 285, 287, 289, 290

EU Directives and, 295

favouritism and, 292

litigations and, 277

performance and, 283

public works and, 275

public property, occupation of, 290

public requests, handling of, 225-7

public service mission, 272-3

public services

administrative regulation, 147 
assistance to, 256-7

continuity of the, $217-18$

equality before, $214-15$

failure to provide, 251

internal measures, $162-3$

neutrality of, 215

neutrality of the, 218-19

public works, liability for, 236-8

public, legitimate expectations of the, 222

quangos (Executive Non-Departmental Public Bodies (ENDPBs)), $3^{8}$

question préjudicielle de constitutionnalité

(QPC), 204

rail track company (RFF), 38

rapporteur public, 6, 19, 25, 56, 67, 71, 87, 95, 195, See also commissaire du gouvernement

reasonable time, decisions in, 95, 227

reasons, duty to give, 230-1

Rechtsstaat, 178

Recommendations of the Council of Europe, 236

and state compensation, 234

recompense for all losses (réparation intégrale), 266

recours (request), 90

recours administratif préalable obligatoire (RAPO), 99

recours de plein contentieux, 289, 291, 293

recours pour excès de pouvoir, 62, 64, 90, 103, 108, 174, 188, 289, 290, 291

redress, right to, 91

référé procedure, 71, 96, 141, 143, 220

référé-liberté, 71, 104, 107, 108, 169, 173, 177, 220

refugee status, claims for, 78

Region of Pays de la Loire, $3^{1}$

region, the, 35-6

elected local authorities in, 34

regional administration, 30-2

regulation, 144, 206

AAIs and, 39

administrative, 132, 133

EEC, 10

fault in, 250-1

General Tax Code and, 11-12, 50

prefect and implementation of, 34

public, 246

regulatory decisions (actes réglementaires), 158

regulatory offences, 205 religion, freedom of (liberté du culte), 206-7

religious beliefs, 209

remedies, 169

for fraud, 281

for public law contracts, 289-93

nullity and, 169

parties to public law contracts, 291-3

third parties to public law contracts and, 290-1

renvoi, 306

reparation, 234, 239

entitlement to, 236

recompense for all losses, 266

request (la requête), 90

request for information, 111-12

réserves d'interprétation, $3 \mathrm{O} 2$

responsibility (a duty to take charge), 233

Restoration (1814-30), 55

review

grounds of, 179

sliding scale for, 199-203

review court (juge de cassation), 264

Revolution (1789), 60, 61, 129, 210, 211, 237, 300,306

before the Conseil du Roi, 275

départements and, 32

equal access to public office, 212

equality in taxation and, 213

equality of public burdens and, 5

state officials and, 30

theories of liability and, 235

Richelieu, 61

rights

against direct or indirect discrimination, 41 constitutional, 204-8

fundamental, 203

rights of the child, 41, 221

to a fair trial, 3, 14-21, 261

riot damage, statutory liability, 258

Rivero, J., 53, 124, 211, 219

Robson, W. A., on Dicey's approach, 2

Rocard, M., 23, 29

Romieu, 58

Rouban, L., 85, 86

rule of law, British, 1

Rural Code, 48, 278

Saint Marc, Renaud Denoix de, 86

Sauvé, Jean-Marc, 86

Schengen database, 93

Schwartz, Bernard, 55 
Sciences-Politiques. See Ecole libre des

Sciences Politiques

scrutiny

intensity of, 201

maximum intensity of, 202

restrained, 200

Section du Contentieux, 117, 124, 184

Section du rapport et des études, 76

secularism (laïcité), 215

Seiller, 92, 117

serious criminal offences (crimes and délits), 205

Service de diffusion des conclusions, 116 service public administratif, 272, 273

Single Market, 12

site visit (la visite des lieux), 113

SNCF. See Société Nationale des Chemins de fer français (SNCF)

social change, France and, 299, 305-6

social et environnemental (CESE), 73

Société Nationale des Chemins de fer français (SNCF), 38, 213, 216, 277

soft law, 160, 161-2

circulars and, 159

sovereign acts, decisions and, 165

Sporting Code, 146

St. Germain-en-Laye, edict of, 129

state liability, $233-4$

foundation (or cause) of, 236

French law and, 268

theories of liability and, 234-6

State, the

Executive, 27-8

Legislature, 28-30

local organs of the, 30

Stirn, Bernard, 8-9, 59, 117, 123

Strasbourg Court. See European Court of Human Rights

Stuart kings, 61

tax authorities, 101

Tax Code, 223

taxation, equality in, 213-14

taxpayers, requests for review of, 99

Télérecours platform, 93, 95, 99, 110

terrorism

compensation scheme for acts of, 141

legislation on, 94

surveillance of suspects, 248

theory of appearances, 17 theory of the balance sheet (le bilan coût-avantages), 192-5

third parties, remedies and public law contracts, 290-1

Third Republic, 8, 44, 300

time limits, $167-8$

and appeals, 227

tort action, in England, 233

Toubon, Jacques, 41

traditional principles, 53, 203, 211-12, 219

transparency, data protection and, 224-5

transparency principle, 278

travaux préparatoires, 275

Treaty on the Functioning of the European Union (TFEU), 47, 179

tribunal administratif, 11, 19, 34, 69, 97, 98, 101, $110,112,117-18,120,132,145,180,184$, 215,249

homologation and, 103

local taxpayers and, 158

of Bastia, 124

of Clermont-Ferrand, 221

of Montpellier, 67

of Paris, 248

of Polynesia, 125

of Versailles, 95

preliminary question and, 118

Tribunal des Conflits, 119, 131-2, 133, 134-5, $137,140,141,144,150,151,152,241,247$, 277,278

concessionaries and, 276

unlawful administrative actions and, 143

tribunaux administratifs, 66-8, 152

reconcilliation and, 100

Troïka, 122

troubles dans l'existence de la vie (disturbance in a way of life), 264

UNESCO treaty, 259

unforeseen situations (sujétions imprévues), 289

unilateral termination, 286

United States, Administrative Law Procedure Act (1945), 2

unlawfulness, 265, 291, 292-3

fault and, 248-50

under acts of the Vichy regime, 244

unreasonable obstinacy, 109

VAT. See Directives

Vedel, G., 8, 9, 147

dispute with Eisenmann, 7-9 
Vichy Law (1943), 168

voie de fait, 129, 132, 141-3, 180

Wachsmann, P., 247

Wildhaber, L., 18

Wilson, J. F., 59 witness hearing (l'enquête), 114

World Trade Organization

(WTO)

Agreement on Government Procurement

('GPA'), 294

rules, 295 
